SUOMEN EKSEGEETTISEN SEURAN JULKAISUJA 109

JEESUS, SEKSI JA HARHAOPPISET sekä muita kirjoituksia varhaisesta kristinuskosta

ISMO DUNDERBERG 
Jeesus, seksi ja harhaoppiset 
Suomen Eksegeettisen Seuran julkaisuja

Julkaisusarjan päätoimittaja: Antti Marjanen

Toimitus ja taitto: Susanna Asikainen

Kansi: Kirsi Valkama

Kannen kuva: Kirsi Valkama

ISSN: 0356-2786

ISBN (painettu): 978-951-9217-64-2

ISBN (pdf): 978-951-51-5022-6

DOI: $10.31885 / 9789515150226$

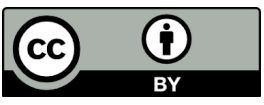

Tämä teos, jonka tekijä on Ismo Dunderberg, on lisensoitu CC BY 4.0 -lisenssillä (Creative Commons Nimeä 4.0 Kansainvälinen) 
SUOMEN EKSEGEETTISEN SEURAN JULKAISUJA 109

\section{Jeesus, seksi ja harhaoppiset}

sekä muita kirjoituksia varhaisesta kristinuskosta

ISMO DUNDERBERG

Suomen Eksegeettinen Seura

Helsinki 2015 



\section{Sisällysluettelo}

Lukijalle

1. Jeesus, seksi ja harhaoppiset......

Jeesuksen sanojen traditioista imperiumin tutkimukseen

2. Mitä Jeesus opetti naisista?....................................................33

3. Martta ja Maria Uudessa testamentissa .................................. 41

4. Marian evankeliumi - Johanneksen evankeliumin

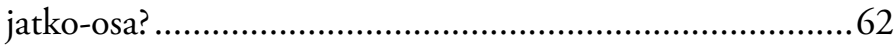

5. Jeesuksen oppilaat kirjureina................................................79

6. Viimeiset tapahtumat ja Jeesuksen sanojen perimätieto.......87

7. Synnin sosiologiaa Ensimmäisessä Johanneksen kirjeessä .134

8. Nöyrä auttaja vai välikäsi? Varhaiskristillisen diakonia-

käsitteen uudelleenarviointia............................................... 150

9. Halusiko Johannes korvata muut evankeliumit?.................162

10. Johannes, synoptikot ja Ockhamin partaveitsi ................169

11. Uusi testamentti antiikin maailmassa............................... 190

Varhainen kristinusko ja "gnostilaisuus"

12. Gnostilaisuus ja kristinusko

13. Gnostilaisuus uskontojen ja uskonnonfilosofian risteyksessä 208

14. Gnostilaisuus kristinuskon "toisena":

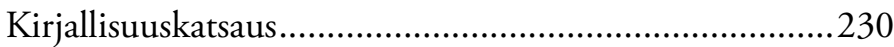

15. Puhuiko Mooses totta? ......................................................244

16. Vainot ja vainojen välttely varhaiskristillisenä aikana......257

17. Hengellinen johtajuus ja sen kritiikki: varhaiskristillisiä

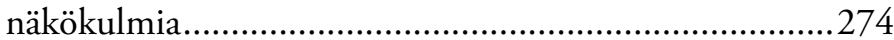

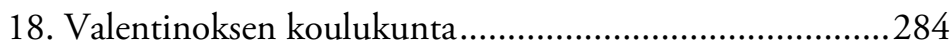

19. Tunteet ja maailman synty ..................................................306

20. "Te olette alusta asti kuolemattomia" ................................327

Kirjallisuus 



\section{Lukijalle}

Käsillä oleva kirja on kokoelma vuosien varrella syntyneitä kirjoituksia tutkimusaiheestani, Uudesta testamentista ja varhaisesta kristinuskosta. Mukana on myös pari aikaisemmin julkaisematonta esitelmää. Suurin osa kirjan luvuista liittyy teemoihin, joita olen käsitellyt laajemmin kansainvälisissä julkaisuissa, mutta kirjassa on mukana myös kotimaisia "tilaustöitä" aiheista, joista en ole muuten kirjoittanut kovinkaan paljon.

Kirjan pääotsikko on sama kuin ensimmäisessä luvussa. Toivottavasti lukijalle ei ole ylitsepääsemätön pettymys, että muissa luvuissa on puhetta seksistä vain paikoitellen. Jeesusta koskevia traditioita (niin Uudessa testamentissa kuin sen ulkopuolella) ja harhaoppisia käsitellään useammassakin tämän kirjan luvussa.

Näin pitkän ajan kuluessa syntyneet tuotokset herättävät monenlaisia ajatuksia tekijässäänkin. Näkemykseni tutkimusaiheistani ja -metodeistani ovat vuosien varrella ainakin muuttuneet ja toivottavasti myös kehittyneet. Nostan esiin kaksi mielestäni keskeisintä esimerkkiä.

Varhaisin artikkelini Martasta ja Mariasta (luku 3) perustuu pitkälti pääainetutkielmaani, jossa pyrin erottelemaan hyvinkin tarkasti erilaisia toimitusvaiheita Johanneksen kertomuksessa Lasaruksen kuolleistaherättämisestä (Joh. 11:1-46). Jatkoin samalla metodilla myös väitöskirjassani, jonka tulosten yhteenvetoa teen luvussa 9 (vrt. myös luku 10). Tällaisen lähdekriittisen työskentelyn huippukausi on epäilemättä takanapäin. Pidän edelleen todennäköisenä, että nykyinen Johanneksen evankeliumi on syntynyt useassa vaiheessa.

Se että teksteistä tehtiin erilaisia versioita ei ollut tavatonta antiikin maailmassa, ei edes se, että "valmiisiin" teksteihin tehtiin laajojakin lisäyksiä. Hyviä esimerkkejä löytyy koptinkielellä säilyneistä varhaiskristillisistä teksteistä: Johanneksen salaisen kirjan versiot ovat paikoitellen hyvinkin erilaisia, Eugnostos-nimisestä tutkielmasta tehtiin Jeesuksen ja opetuslasten välinen dialogi Jeesuksen Kristuksen viisaus ja Tuomaan evankeliumin kreikankieliset fragmentit osoittavat, että tästä Jeesuksen 
sanojen kokoelmasta oli liikkeellä myös selvästi lyhyempiä versioita kuin Nag Hammadin kirjastoon kuuluva teksti. Myös Uuden testamentin teksteihin tehtiin käsikirjoituksissa lisäyksiä. Tunnetuimpia esimerkkejä ovat Markuksen evankeliumin myöhemmin lisätty lopetus (Mark. 16:8-20), Johanneksen evankeliumiin joissain käsikirjoituksissa lisätty kertomus avionrikkojanaisesta (Joh. 7:53-8:11) ja Apostolien tekojen käsikirjoitus D, jossa on noin $20 \%$ enemmän tekstiä kuin muissa varhaisissa käsikirjoituksissa.

Ei ole siis periaatteellista estettä olettaa, että Johanneksen evankeliumi syntyi vaiheittain, toimitustyön tuloksena. Ongelma on käytännöllinen: millaisilla perusteilla myöhempiä lisäyksiä voidaan paljastaa silloin, kun eri toimitusvaiheista ei ole "kovaa" evidenssiä, toisin sanoen toisistaan poikkeavia käsikirjoituksia? Tekstissä esiintyvät omituisuudet, kuten oudot katkot ja ristiriidat juonenkulussa tai merkittävät teologiset jännitteet, voivat olla viitteitä toimitusprosessista, mutta niillä voi olla muitakin selityksiä, esimerkiksi huolimaton kirjoittaja tai epäjohdonmukainen ajattelu.

Tutkimustyöni alkuvaiheessa olin kohtuullisen luottavainen, että tekstin syntyvaiheita voi paljastaa riittävän yksityiskohtaisella eksegeettisellä analyysillä. Työskentely Nag Hammadin tekstien kanssa on pakottanut minut pohtimaan, pystyisinkö lähdekriittisellä metodillani paljastamaan edellä kuvatun kaltaisia toimitusvaiheita, jos mainitsemistani teksteistä olisi ollut vain yksi käsikirjoitus. Erityisesti Tuomaan evankeliumin osalta voi hyvin ajatella, että tällaiseen Jeesuksen sanojen kokoelmaan on helppo lisätä yksittäisiä lausumia tai ottaa niitä pois. Kun siirryin väitöskirjani jälkeen tutkimaan Tuomaan evankeliumia, kiinnostuksen kohteeni olivat muuttuneet siinä määrin, etten edes yrittänyt rakentaa mallia evankeliumin kirjallisista kerrostumista.

Kun katson taaksepäin vanhaa artikkeliani Martasta ja Mariasta, minusta siinä kiinnostavammilta kuin lähdekysymykset näyttävät nyt kertomushahmojen karakterisointiin liittyvät pohdinnat. Minusta on edelleen kiinnostava ongelma, onko Martta Johanneksen kertomuksessa (Joh. 11:1-46) positiivinen vain negatiivinen hahmo, ja minusta näyttää edelleen, ettei Martta ole tässä kertomuksessa erityisen esikuvallinen hahmo. Myöhemmissä tutkimuksissani olen kiinnittänyt huomiota siihen, että Martta ei ole tässä suhteessa erityistapaus. Johannek- 
sen evankeliumissa on hyvin vaikeaa löytää yhtään selkeästi positiivista hahmoa Jeesuksen lisäksi. Evankeliumissa kaikki, sekä seuraajat että vastustajat, ymmärtävät Jeesuksen väärin. Nähdäkseni tämä koskee myös salaperäistä "opetuslasta jota Jeesus rakasti” (Joh. 13:23; 20:2-10; 21:7, 20-23).

Toinen aihepiiri, jossa ajatukseni ovat vuosien varrella muuttuneet, on gnostilaisuuden määritelmistä käytävä keskustelu. Muutos näkyy myös tämän kirjan luvuissa. Varhaisemmissa lähden liikkeelle gnostilaisen ajattelun keskeisistä tuntomerkeistä, joita ovat ajatus kahdesta jumalasta - Kaikkeuden isästä ja alemmasta luojajumalasta - ja näkemys, että ihminen on sisimmässään sukua korkeimmalle Jumalalle.

Tällaiset tuntomerkit ovat hyödyllisiä esimerkiksi silloin, kun pohditaan, onko Tuomaan evankeliumi tai joku muu varhaiskristillinen teksti "gnostilainen" vai ei. Gnostilaisuuden tutkijat ovat kuitenkin käyneet keskustelua, onko itse termi "gnostilaisuus" perusteltu vai ei. Termi ei esiinny antiikin lähteissä lainkaan, vaan se on peräisin 1600luvulta. Tämä ei kuitenkaan ole ylitsepääsemätön ongelma. Vaikka termi "gnostilaisuus" ei ole varhainen, varhaisissa lähteissä kuvataan kristittyjä, jotka kutsuivat itseään "gnostilaisiksi" tai "gnostikoiksi," ja joiden opetukseen kuului samanlaisia elementtejä (esimerkiksi ajatus kahdesta jumalasta) kuin monissa Nag Hammadin teksteissä.

Vakavampi ongelma on, millaisia mielikuvia tutkijat synnyttävät varhaisen kirkon historiasta käyttäessään termiä "gnostilaisuus." Kaikki hyväksyvät nykyisin, ettei "gnostilaisuus" kuvaa tiettyä varhaiskristillistä ryhmää. Tämän termin alle luokitellut varhaiset kristityt olivat yhtä mieltä, että maailman on luonut alempi luojajumala, mutta he eivät olleet yhtä mieltä kovin monesta muusta asiasta. Heidän käsityksensä esimerkiksi siitä, millainen hahmo tämä alempi luojajumala on, poikkesivat toisistaan huomattavasti. Vain osassa "gnostilaisiksi" luokitelluista teksteistä luojajumala kuvataan Saatanan kaltaiseksi, ihmisiä kadehtivaksi ja kiusaavaksi hahmoksi. Toisissa "gnostilaisissa" lähteissä luojajumala on tietämätön, mutta muuten myönteinen hahmo. Kun tutkijat kuvaavat "gnostilaista" käsitystä luojajumalasta, he lähes säännönmukaisesti valitsevat näistä kahdesta vaihtoehdosta ensimmäisen. Miksi? Siksi että näin gnostilainen teologia saadaan erottumaan mahdollisimman kirkkaasti muusta varhaiskristillisestä teologiasta. 
Ja juuri tässä on koko ongelman ydin. "Gnostilaisuus" on terminä ongelmallinen, sillä siihen liittyy väistämättä ajatus toiseudesta suhteessa kristinuskoon. Näin syntyy diskurssi, jossa "kristinusko" on normi ja "gnostilaisuus" poikkeama siitä. Joskus sanotaan ääneen, että "gnostilaisuutta" on kaikki, mikä poikkeaa varhaisen "valtakirkon" tai "kristinuskon valtauoman" opetuksista. Vielä useammin tämä oletus paljastuu rivien välistä - aina silloin kun tehdään vertailua "varhaisen kirkon" ja "gnostilaisuuden" välillä. Kun tutkijat käyvät keskustelua termiin "gnostilaisuus" liittyvistä ongelmista, kyse ei siis ole vain tarpeettomasta sofisteriasta tai terminologisesta pilkunviilauksesta, vaan kysymys on siitä, millaisilla välineillä hahmotetaan kuva varhaisen kirkon historiasta ja kuinka asianmukainen tällainen kuva on (vrt. luku 14). Itse olen tämänkaltaisten ongelmien seurauksena luopunut vähin erin gnostilaisuus-terminologian käytöstä silloin, kun se on suinkin mahdollista. Minusta paras vaihtoehto on pyrkiä kuvaamaan varhaiskristillisiä opettajia yksilöinä, ei jonkun ryhmän - eikä varsinkaan "oikean" tai "väärän" opin - puhemiehinä. Näillä opettajilla oli kannattajia ja vastustajia, mutta rintamalinjat näiden ryhmien välillä eivät mene yksi yhteen "ortodoksian" ja "heresian" välisen jaon kanssa. Tämä ongelma on erityisen keskeinen Valentinoksen koulukunnan osalta, joka on ollut yksi tärkeimmistä tutkimuskohteistani. Monet "gnostilaisuuteen" liittyvät yleistykset, kuten jyrkkä vastakkainasettelu muiden kristittyjen kanssa, sopivat erittäin huonosti tähän ryhmään. Kuitenkin tällaiset yleistykset vaikuttavat käsityksiin valentinolaisista opettajista. Kun heidän opetuksensa esimerkiksi näyttävät samankaltaisilta kuin muidenkin oppineiden kristittyjen näkemykset, heidän epäillään vain salailevan, mitä he oikeasti ajattelevat. (Tämä varhaisten vastustajien poleeminen näkemys on siirtynyt muitta mutkitta modernien tutkijoiden kuvauksiin valentinolaisista.)

Tällaisen kokoelman voi järjestää monella tavalla. Päätin koota ensimmäiseen osaan Uutta testamenttia ja siihen liittyviä tekstejä (kuten eikanoniset varhaiskristilliset evankeliumit) koskevat luvut ja toiseen 
varhaista kristinuskoa käsittelevät. Raja näiden osien välillä ei ole lainkaan selvä. Esimerkiksi Marian evankeliumia koskeva artikkeli voisi olla kummassa tahansa osiossa.

Kirjan luvuista ei synny selkeää temaattista kokonaisuutta, jossa edettäisiin yhdestä aiheesta toiseen. En myöskään laittanut kirjan lukuja kronologiseen järjestykseen, sillä en usko ajatteluni kehittyneen siinä määrin, että kronologialla olisi suurta merkitystä kirjan lukijalle. Olen järjestellyt luvut kahden pääotsikon alle hyvin subjektiivisesti arvioituun kiinnostavuusjärjestykseen. Olen sijoittanut jaksojen alkupäähän sellaisia lukuja, joiden teemojen kuvittelen olevan yleisesti kiinnostavia, ja loppupäähän sellaisia, jotka liittyvät oman tutkimukseni erityisteemoihin ja (minusta edelleen kiinnostaviin) yksityiskohtiin. Erityisesti gnostilaisuutta käsittelevissä luvuissa on jonkin verran päällekkäisyyttä, sillä olen eri yhteyksissä lähtenyt liikkeelle kuvauksella, mitä gnostilaisuus on tai mitä sen on ajateltu olevan. Esimerkiksi luvut 12 ja 13 tarjoavat tiiviin ja laajemman johdatuksen samantyyppisiin aiheisiin. Luvun 13 aiemmasta versiosta pudotettiin alaviitteet julkaisuvaiheessa pois; tähän versioon olen ne sisällyttänyt.

Aivan kaikkia suomenkielisiä akateemisia artikkeleitani en ole ottanut mukaan. Olen jättänyt pois muun muassa pitkähkön johdatuksen Johanneksen evankeliumiin (Dunderberg 1997c), sillä siinä ei ollut varsinaista kysymyksenasettelua, ja kaksi Teologisessa aikakauskirjassa julkaistua kirjallisuuskatsausta. Otin kuitenkin mukaan kuitenkin gnostilaisuutta "toisena" käsittelevän kirjallisuuskatsauksen, sillä pidin sitä olennaisena edellä kuvaamani keskustelun kannalta.

Kiitollisuudenvelkaa on ehtinyt syntyä moneen suuntaan niiden yli 20 vuoden aikana, jona tämän kirjan luvut ovat syntyneet. Haluan tässä yhteydessä mainita erityisesti ne, jotka ovat johtaneet minut akateemisen tutkimuksen pariin. Lukionaikainen uskonnonopettajani Pirkko Tavio ja kotiseurakuntani nuorisopastori Tapani Markkula avarsivat ajatuksiani ja maailmankuvaani niin, että pystyin seuraamaan akateemisen teologian opetusta Helsingin yliopistossa kohtuullisen avoimin mielin. Raija Sollamo ja Anne-Marit Enroth-Voitila perehdyttivät minut tekemään Uuden testamentin tutkimusta pääaineseminaarissa. Tosin tutkijanurani alkoi takellellen, ja vasta opiskelijatoverini Ari Ahokkaan seminaarityöstä pääsin jyvälle, miten eksegeettisessä tutki- 
muksessa edetään. Heikki Räisänen ei koskaan opettanut minua perusopintovaiheessa, mutta hänen palautteensa tutkimustyöni eri vaiheissa 1980-luvun lopulta, jolloin hän luki pääainetutkielmani, tähän päivään asti on ollut korvaamattoman tärkeä tuki. Markku Kotila perehdytti minut Johanneksen evankeliumin tutkimukseen, ja hänen esikuvansa innostamana lähdin tekemään jatko-opintoja Kielin yliopistoon Jürgen Beckerin opastuksella. Risto Uro ja Antti Marjanen kouluttivat minusta tutkijan Tuomaan evankeliumin tutkimusprojektissa ja ovat tämän jälkeen useaan otteeseen antaneet palautetta töistäni. Raimo Hakola on ollut läheinen ystävä nuoruudesta asti ja opintoajoistaan asti tärkeä keskustelukumppani, jolta olen oppinut paljon näinä vuosina Johanneksen evankeliumista, eksegetiikan metodeista, juutalaisuudesta ja arkeologiasta. Simo Knuuttila ja Petri Järveläinen saivat minut kiinnostumaan antiikin filosofien tunneteorioista ja tätä myöten laajemminkin antiikin filosofiasta. Helsingin yliopiston eksegeetit ovat muodostaneet hienon yhteisön, jossa on ollut ilo työskennellä ja aika ajoin juhliakin.

Perheeni (puolisoni Päivi Salmesvuori ja lapsemme Fanni, Linus ja Olga) on ollut korvaamattoman tärkeä tuki kaikkina näinä vuosina, Päivi myös tutkimusteemoihin, metodeihin, akateemiseen opetukseen ja yliopistomaailmaan liittyvissä pohdinnoissa.

Kiitän lämpimästi Suomen Eksegeettistä Seuraa kirjani julkaisemisesta. Erityisesti kiitän kirjan nimetöntä lausunnonantajaa, joka luki käsikirjoituksen ja teki siihen tarkkanäköisiä ehdotuksia, ja Susanna Asikaista kirjan asiantuntevasta taittamisesta. 


\section{Alkuperäiset julkaisut}

Luku 1: Sivut 31-36 kirjassa Taivaallista seksiä: Kristinusko ja seksuaalisuus. Toimittaneet Minna Ahola, Marjo-Riitta Antikainen ja Päivi Salmesvuori. Helsinki: Tammi, 2006.

Luku 2: Vartija 106 (1993): 161-167.

Luku 3: Sivut 59-83 kirjassa Viisaus ja rakkaus: Naisia Raamatussa. Toimittaneet Raija Sollamo \&Ismo Dunderberg. Helsinki: Yliopistopaino, 1992. Luku 4: Teologinen Aikakauskirja 117/2 (2012): 110-119.

Luku 5: Vartija 112 (1999): 104-109.

Luku 6: Sivut 11-58 kirjassa Ismo Dunderberg et alii, Aikojen taite: Kirkko kolmannen vuosituhannen vaihteessa. Helsinki: Kirjapaja, 1998.

Luku 7: Sivut 277-293 kirjassa Johdatus sosiaalitieteelliseen raamatuntutkimukseen. Toimittaneet Petri Luomanen, Jutta Jokiranta \& Outi Lehtipuu. Suomen Eksegeettisen Seuran julkaisuja 105. Helsinki: Suomen Eksegeettinen Seura, 2013.

Luku 8: Diakonian tutkimus 2005/2 (2005): 5-15.

Luku 9: Teologinen Aikakauskirja 99 (1994): 513-516.

Luku 10: Teologinen Aikakauskirja 98 (1993): 102-112.

Luku 11: professorin virkaanastujaisluento 27.5.2009, aikaisemmin julkaisematon.

Luku 12: Sivut 73-78 kirjassa Suomalainen Tiedeakatemia Vuosikirja / Finnish Academy of Science and Letters Year Book 2005. Toimittanut Matti Saarnisto. Helsinki: Suomalainen tiedeakatemia, 2006.

Luku 13: Sivut 100-118 kirjassa Uskontojen risteyksessä: Välimeren uskontojen juurilla. Toimittanut Jaakko Hämeen-Anttila. Helsinki: Gaudeamus, 2001.

Luku 14: Teologinen aikakauskirja 110 (2005): 553-560.

Luku 15: Studia Generalia -luento Helsingin yliopistossa 9.2.2012, aikaisemmin julkaisematon.

Luku 16: Esitelmä Suomen Eksegeettisessä Seurassa 16.2.2006, aikaisemmin julkaisematon.

Luku 17: Vartija 123/4 (2010): 128-134.

Luku 18: Teologinen aikakauskirja 107 (2002): 568-579.

Luku 19: Teologinen Aikakauskirja 103 (1998): 387-398.

Luku 20: Teologinen Aikakauskirja 102 (1997): 138-149. 



\section{Jeesus, seksi ja harhaoppiset}

(2006)

\section{Seksi kiinnostaa aina}

Martin Scorsesen elokuvassa Kristuksen viimeinen kiusaus (1988) Jeesuksen kuvattiin miettineen ristillä, millaista olisi ollut tavallinen elämä, johon olisivat kuuluneet avioelämä ja jälkeläiset. ${ }^{1}$ Ajatusta kuvitettiin hienovaraisilla, verhon takaa kuvatuilla seksikohtauksilla. Vaikka kyse oli vain Jeesuksen ohimenevästä kiusauksesta elää samanlaista elämää kuin muut ihmiset, pelkkä visio hänestä rakastelemassa naisen kanssa oli monille liikaa: elokuva herätti valtavan protestien aallon ja sen esittämistä vastustettiin monissa maissa.

Samanlaista kohua on herättänyt Dan Brownin menestysromaani Da Vinci -koodi. Siinä ei kuvata Jeesusta harrastamassa seksiä, mutta siinä keritään auki suuri salaisuus, että Jeesus oli naimisissa Magdalan Marian kanssa. Kirjan mukaan heidän lapsestaan, Saara-nimisestä tyttärestä, polveutui meidän päiviimme asti ulottuva sukupuu. ${ }^{2}$ Kristil-

\footnotetext{
${ }^{1}$ Elokuva perustui kreikkalaisen Nikos Kazantzakiksen romaaniin Viimeinen kiusaus (suom. Elvi Sinervo; Helsinki: Tammi, 1957).

2 Baigent, Leigh ja Lincoln (1982, 350-352) esittävät vielä mielikuvituksellisemman ratkaisun: Barabbas, Jeesuksen sijasta vapautettu kapinallinen (Mark. 15:6-15), oli hänen poikansa! Minun on vaikea uskoa, että tätä väitettä on tarkoitettu otettavaksi vakavasti; sen täytyy olla tehty kieli poskessa. Baigent ym. esittävät nimittäin näkemyksen tueksi seuraavan laskelman: jos Jeesus oli kuollessaan noin 30-vuotias ja jos hän olisi mennyt naimisiin 16vuotiaana, hänellä olisi voinut juuri ja juuri olla 13-vuotias poika, jota juutalaisen käytännön mukaan olisi voitu kutsua jo "mieheksi" (Mark. 15:7). Melkoinen saavutus 13-vuotiaalta tässä tapauksessa: hän oli jo ehtinyt osallistua kapinaan ja sen yhteydessä tehtyyn murhaan
} 
linen kirkko on kuitenkin halunnut pimittää totuuden Jeesuksesta ja on vuosisatojen kuluessa pyrkinyt järjestelmällisesti tuhoamaan hänen veriperillisensä. Siksi heidät on pidetty piilossa julkisuudelta, ja asia on pysynyt salassa.

Da Vinci -koodin henkilöhahmot esittävät vaihtoehdon kirkon perinteiselle opille Jeesuksesta. Kirjan keskeinen väite on, että Jeesus oli vain ihminen ja että hänestä tehtiin Jumala vasta 300-luvulla keisari Konstantinuksen vaatimuksesta. Jeesuksen avioliitto ja lapsi Magdalan Marian kanssa edustavat romaanin mukaan hänen inhimillistä puoltaan, josta kirkossa on vaiettu. Tosin aivan tavalliset ihmisgeenit eivät ilmeisesti olleet pelissä tämänkään teorian mukaan. Jeesuksen jälkeläisistä nimittäin syntyi varhaiskeskiajalla merovingien kuningassuku Ranskassa. ${ }^{3}$ Saman sukuhaaran edustajaksi paljastuva Sophie Neuve, kirjan toinen päähenkilö, on sekä poikkeuksellisen kaunis että "selvästikin hiton paljon älykkäämpi" kuin kirjan miespäähenkilö Robert Langdon. ${ }^{4}$

Metoditietoisten kirjallisuuden- ja historiantutkijoiden harmiksi suuri yleisö on Da Vinci -koodista käydyn keskustelun yhteydessä ollut ennen kaikkea kiinnostunut siitä, miten asiat todella olivat ("wie es eigentlich gewesen ist"). Postmodernin kirjallisuuden- ja historiantutkimuksen keskeinen väitehän on, ettei tähän kysymykseen pystytä lainkaan vastaamaan, sillä kaikki tekstit ovat fiktiota. Tekstit eivät kuvaa maailmaa sellaisena kuin se on, vaan niissä luodaan tietynlainen kuva maailmasta, ja ainoastaan tällaisia kuvia pystytään tutkimaan, ei niiden takana olevaa todellisuutta. Brownin kirjan synnyttämä keskustelu on osoittanut, että tällainen näkemys tekstien ja historian suhteesta on auttamattoman elitistinen. Lukijoiden valtaosaa ei kiinnosta lainkaan Brownin luoma kirjallinen maailma tai se millaisia merkityksiä kirjasta

(Mark. 15:7)! (Baigent ja kumppanit vaikenevat tietenkin visusti ja tarkoitushakuisesti siitä, miksi Barabbas oli vangittuna.)

3 Tämäkin ajatus Brownin romaanissa perustuu Baigentin, Leighin ja Lincolnin teoriaan (1982, 234-270).

${ }^{4}$ Brown 2004, 107. 
voidaan nostaa esiin. Heitä askarruttaa se, onko kirjassa esitetyissä väitteissä perää vai ei.

Olisi helppoa leimata nykyisen kiinnostuksen Jeesuksen seksuaalielämään heijastavan länsimaista näkökulmaa, jossa kaikki asiat - etenkin massaviihteen saralla - tavalla tai toisella kiedotaan seksin ympärille. Seksi ja sen kuvaaminen ovat kuitenkin kiinnostaneet ihmisiä kaikkina aikoina. Varhaisin kuvaus Jeesuksesta harrastamasta seksiä naisen kanssa on peräisin 300-luvulta. Sen rinnalla Kristuksen viimeisen kiusauksen seksikohtaukset näyttävät kovin kesyiltä. Kyseisessä tekstissä kerrotaan, kuinka Jeesus loi kyljestään naisen, rakasteli tämän kanssa, nautti siemennestettään ja siunatuksi lopuksi vielä veisteli: "Näin meidän pitää tehdä, jotta saisimme elää.” Kaikki tämä tapahtui Magdalan Marian seuratessa hämmentyneenä sivusta.

Lähinnä hard core -pornoksi luokiteltava kertomus tunnetaan Salamiksen piispa Epifanioksen (315-403) kirjoittamasta teoksesta Lääkelaukku. Epifanioksen mukaan hänen vastustamillaan harhaoppisilla kristityillä oli käytössään teksti nimeltä Marian suuret kysymykset, jossa kyseinen kohtaus esiintyi. Epifanios väittää lisäksi, että nämä harhaoppiset toimivat kertomuksen antaman esikuvan mukaisesti: he antoivat vaimonsa vapaasti uskonveljien käyttöön, harjoittivat kokoontumisissaan keskeytettyä yhdyntää ja nauttivat sekä siemennestettä että kuukautisverta. Näitä tapoja he perustelivat lainauksilla Uuden testamentin evankeliumeista. ${ }^{5}$

Tutkijat kiistelevät siitä, tapahtuiko tällaisia orgioita todella vai ainoastaan Epifanioksen mielikuvituksessa. Niin tai näin, kiinnostus Jeesuksen seksuaalielämää kohtaan ei selity pelkästään nykyajan seksikeskeisyydestä käsin, vaan siitä on merkkejä jo paljon varhaisemmalta ajalta. Samalla teksti kertoo myös, kuinka varhaisen kirkon aikana toisinajattelevia kristittyjä vastaan ei taisteltu ainoastaan teologisin asein, vaan myös levittämällä huhuja heidän moraalittomasta elämäntavastaan.

${ }^{5}$ Epifanios, Lääkelaukku (Panarion) 26.8.1-26.9.3; tekstistä ja sen tulkinnasta ks. Marjanen 1996, 191-202. 


\section{Jeesuksen jumaluus, ihmisyys ja likainen seksi}

Vaikka kristillinen kirkko opettaakin Jeesuksen olleen yhtäaikaisesti sekä ihminen että Jumala, hänen inhimillistä puoltaan ei yleensä ole liitetty seksuaalisuuteen. Osoituksina Jeesuksen ihmisyydestä on pidetty toisenlaisia piirteitä, esimerkiksi sitä että hän itki (Joh. 11:35; Hepr. 5:7), söi tavallista ruokaa (Luuk. 24:41-43), tunsi uupumusta ja janoa (esim. Joh 4:6-7) ja oli muiden ihmisten tavoin kiusausten kohteena (Hepr. 5:8).

Seksuaaliset toimet, tarpeet ja toiveet edustavat sellaista ihmisyyden osa-aluetta, jota ei ole helppo yhdistää ajatukseen Jeesuksen pyhyydestä ja jumalallisuudesta. Jeesus on monille ihmisille erityinen, pyhä hahmo, jonka yhteydessä seksistä puhuminen koetaan sopimattomaksi ja uskoa loukkaavaksi. Seksiin yhdistyy mielikuvia, jotka eivät sovi synnittömään ja viattomana kuolleeseen Vapahtajaan. Seksiin liittyy erottamattomasti himo, joka tuomitaan Uudessa testamentissa. Niin ikään toisiinsa yhdistetään seksi, saastaisuus ja synti. Tämä epäpyhä kolminaisuus näkyy arkisessa kielenkäytössämmekin. Alapään huumori kertoo "likaisesta mielikuvituksesta," eroottinen paritanssi on "dirty dancing", ja "syntiset ajatukset" liittyvät nimenomaan seksuaalisiin fantasioihin ja haluihin.

Ilmaukset nousevat pitkästä juutalaiskristillisestä perinteestä. Vanhassa testamentissa seksiin ja suvunjatkamiseen tosin suhtaudutaan myönteisesti ("lisääntykää ja täyttäkää maa," 1. Moos. 1:28) ja jopa ylistetään seksuaalista halua (Laulujen laulu!). ${ }^{6}$ Jo Vanhassa testamentissa seksiin liittyvät kuitenkin myös synti, epäpuhtaus ja saastaisuus. ${ }^{7}$ Ihmisen syntisyyteen kuuluu tekosyntien lisäksi tapa, jolla hän sai alkunsa (Ps. 52:7): "Synnissä äitini tuli raskaaksi."

Ajatus synnissä sikiämisestä liittyy epäilemättä seksuaalisen aktin aiheuttamaan epäpuhtauteen. Seksin ja epäpuhtauden välinen yhteys

\footnotetext{
${ }^{6}$ Myönteisestä suhteesta seksuaaliseen haluun ks. myös Sananl. 5:18-20; Saarn. 9:9; 5. Moos. 24:5 (Veijola 1988, 181).

${ }^{7}$ Puhtaudesta ja saastaisuudesta Vanhassa ja Uudessa testamentissa ks. Uro 1998a.

${ }^{8}$ Uuden kirkkoraamatun käännös kyseisestä kohdasta ("synnin alaiseksi olen siinnyt äitini kohtuun") häivyttää seksuaalisen aktin ja synnin välisen yhteyden, johon jakeessa epäilemättä viitataan.
} 
näkyy erityisesti Vanhan testamentin puhtauslaeissa. Niiden mukaan siemensyöksy tekee miehen epäpuhtaaksi saman päivän iltaan asti (3. Moos. 15:16); yhdynnän jälkeen sekä mies että nainen ovat epäpuhtaita saman päivän iltaan asti (3. Moos. 15:18); mies ei yöllisen siemensyöksyn jälkeen saa osallistua pyhään sotaan seuraavana päivänä, vaan hänen on mentävä sotaleirin ulkopuolelle (5. Moos. 23:10-12); nainen on epäpuhdas kuukautisten vuoksi viikon ajan, ja saman ajan epäpuhdas on myös mies, joka makasi kuukautistilassa olevan naisen kanssa (3. Moos. 19:19-24). ${ }^{9}$ Näiden lakien mukaan ihmisten on puhdistauduttava peseytymällä siemennesteen ja kuukautisveren aiheuttamasta epäpuhtaudesta, ja niiden tahraamat vaatteetkin on pestävä (3. Moos. 15:17-22).

Vaikka seksin aiheuttama epäpuhtaus onkin näiden lakien mukaan pääosin lyhytaikaista ja helppohoitoista, se sopii huonosti yhteen Jeesukseen perinteisesti yhdistettyjen mielikuvien, pyhyyden, puhtauden ja viattomuuden kanssa: "Hän on pyhä, viaton ja tahraton, hänet on erotettu syntisistä ja korotettu taivaita korkeammalle” (Hepr. 7:26.) Siksi erityisesti konservatiivikristityt kokevat rienaukseksi jo pelkän ajatuksen, että Jeesuksella olisi ollut seksuaalisia fantasioita - esimerkiksi sellaisia, joita Scorsesen elokuvassa kuvattiin. Vaikka Jeesuksen ajatellaan olevan ihminen, hänen ihmisyytensä uskotaan olevan jollain tavalla erityislaatuista.

Torjuva asenne ei kuitenkaan ole koko totuus konservatiivisten kristittyjen suhteesta Jeesuksen seksuaalisuuteen. Evankelikaalisiin amerikkalaisiin kristittyihin kuuluva raamatuntutkija Ben Witherington toteaa: "Ei ole mitään syytä, miksi Jeesus ei olisi voinut olla naimisissa. Koska hän ei opettanut, että seksi saastuttaa ... ei ole mitään syytä miksi avioituneella Jeesuksella ei olisi voinut olla seksisuhteita ja jopa jälkeläisiä.” Jeesuksen avioliitolle ei siis ole teologisia tai periaatteellisia esteitä. Witheringtonin mukaan Jeesus tosin ei solminut avioliittoa,

9 Toisen, jyrkempää kantaa edustavan lain mukaan yhdyntä kuukautistilassa olevan naisen kanssa oli rikos, joka johti karkotukseen pyhän kansan joukosta (3. Moos. 20:18). 
vaan "päätti pysyä selibaatissa tuodakseen maan päälle Jumalan pelastavan hallintavallan." 10

Witheringtonin päätelmät osoittavat, etteivät konservatiiviset kristityt suhtaudu torjuvasti seksiin sinänsä - mikäli se tapahtuu miehen ja naisen välillä avioliitossa. ${ }^{11}$ Tarkemmin tarkasteltuna ne kuitenkin paljastuvat ongelmallisiksi. Jos Jeesus nimittäin ajatteli, että seksin harrastaminen $e i$ saastuta, hänen näkemyksensä poikkesi jyrkästi edellä kuvatuista Vanhan testamentin puhtauslaeista ja oman aikansa juutalaisuuden päälinjasta, jonka mukaan seksi saastuttaa ja vaatii puhdistautumista. Siitä, ajatteliko Jeesus todella näin, ei ole säilynyt todisteita puolesta tai vastaan. Hänen ei tiedetä opettaneen, että seksi saastuttaa, mutta hänen ei myöskään tiedetä opettaneen, että se ei saastuta.

Jeesus hyväksyi avioliiton ja katsoi sen perustuvan Jumalan käskyyn (esim. Mark. 10:2-9). Tästä ei kuitenkaan voi päätellä (kuten Witherington tekee), ettei hän olisi pitänyt seksuaalista aktia sinänsä saastuttavana. On hyvin mahdollista, että hän ajatteli asiasta samoin kuin muutkin oman aikansa juutalaiset: yhdynnän jälkeen ihminen on määräajan saastainen, ja hänen täytyy sen vuoksi erikseen puhdistautua.

Ja toisaalta, jos seksi ei Jeesuksen mielestä millään tavalla saastuttanut, miksi ihmeessä hänen piti valita selibaatti tuodakseen Jumalan hallintavallan maailmaan? Eikö se olisi toteutunut, jos hän olisi mennyt naimisiin? Ehkä Jeesus todella ajatteli näin. Tähän viittaa seuraava lauselma niistä, jotka ovat valinneet naimattomuuden Jumalan valtakunnan tähden (Matt. 19:12):

On sellaisia, jotka äitinsä kohdusta saakka ovat avioliittoon kelpaamattomia, on toisia, joista ihmiset ovat tehneet sellaisia, ja on niitä, jotka itse, taivasten valtakunnan tähden, ovat ottaneet osakseen naimattomuuden. Joka voi valita tämän ratkaisun, valitkoon!

\footnotetext{
${ }^{10}$ Witherington 2004, 25, 69.

${ }^{11}$ Witheringtonin näkökulma asiaan on heteronormatiivinen. Tämä tulee esiin siinä, ettei hän pohdi lainkaan, olisiko Jeesuksen naimattomuudelle voinut olla muita syitä - kuten kiinnostuksen puute naisia kohtaan. Kuten jatkosta käy ilmi, sama näkökulma on muutenkin tavallinen, kun tutkijat pohtivat Jeesuksen seksuaalisuutta.
} 
Kirkkoraamatun käännös "ovat ottaneet osakseen naimattomuuden" on tarpeettoman kaunisteleva ja vesittää alkuperäisen kielikuvan täysin. ${ }^{12}$ Kreikankielisessä alkutekstissä käytetään tässä kohtaa kuohitsemista tarkoittavaa verbiä (eunoukhizō) ja puhutaan kuohilaista eli eunukeista (eunoukhos). Käännöksen pitäisi siis kuulua tältä osin: ”... ja on eunukkeja, jotka ovat kuohinneet itsensä taivasten valtakunnan vuoksi.”

Jeesuksen opetuksen tekee erityisen hätkähdyttäväksi se, että Vanhassa testamentissa kastroiduilta kielletään osallistuminen jumalanpalveluselämään (5. Moos. 23:1-2). ${ }^{13}$ Jeesus rinnastaa näin ne, jotka luopuvat perheen perustamisesta Jumalan valtakunnan tähden, niihin, jotka oli suljettu uskonnollisen yhteisön ulkopuolelle poikkeavana, vääränlaisena ja epätäydellisenä pidetyn seksuaalisuutensa vuoksi.

Jeesus tuskin halusi seuraajiensa oikeasti kuohitsevan itsensä; vasta aleksandrialainen kristitty opettaja Origenes (185-254) tulkitsi kohdan kirjaimellisesti ja "ryhtyi tekoon, joka oli epäkypsän ja nuorekkaan mielen, mutta samalla myös uskon ja pidättyväisyyden selvä merkki"14 eli kuohitsi itsensä.

Jeesus käytti taivasten valtakunnan eunukkeja vertauskuvana, jonka tarkoituksena oli korostaa, että Jumalan valtakunnan vuoksi on luovuttava tavallisista perhesiteistä. Vertauskuva nousi kenties ajatuksesta, että naimattomuuden valinnut joutui avioliiton merkitystä korostaneessa juutalaisessa yhteisössä samanlaisen halveksunnan kohteeksi ja ulkopuolisen rooliin kuin yhteisön ulkopuolelle suljetut eunukit. ${ }^{15}$ Eunukit olivat myös sikäli hyvä valinta, että Vanhassa testamentissa esiintyvän profetian mukaan heidätkin lopulta hyväksytään Jumalan kansan jäseniksi (Jes. 56:3-5). Näin eunukkien käyttö vertauskuvana sopii hyvin Jeesuksen julistuksen ja toiminnan yleislinjaan, jolle oli ominaista ulkopuolelle jätettyjen kutsuminen Jumalan valtakuntaan.

Vaikka Jeesus hyväksyi avioliiton, hän suhtautui siihen varauksellisesti. Hän vertasi oman aikansa ihmisiä Nooan päivien

\footnotetext{
${ }^{12}$ Jakson tulkinnasta ks. Aejmelaeus 1991.

${ }^{13}$ Luz 1997, 109-110.

${ }^{14}$ Eusebios, Kirkkohistoria 6.8.1-3.

${ }^{15}$ Tulkinnan tutkimushistoriasta ks. Aejmelaeus 1991, 23-24.
} 
ihmisiin, jotka "söivät, joivat, menivät naimisiin ja naittivat (tyttärensä)" (Luuk. 17:27 // Matt. 24:38). Periaatteessa kuvauksessa on kyse siitä, että Nooan ajan ihmiset elivät aivan tavallista elämää tietämättöminä tulevasta tuhosta. Avioliiton solmiminen kuitenkin kuuluu selvästi tähän maailmaan, ei tulevaan pelastuksen aikaan. Jeesuksen mukaan "ne jotka heräävät kuolleista eivät mene naimisiin eikä heitä naiteta, vaan he ovat kuin taivaan enkelit." (Mark. 12:25.) Tulevassa Jumalan valtakunnassa Jeesuksen mukaan syödään ja juodaan (Luuk. 22:30; vrt. Luuk. 13:29 // Matt. 8:11) kuten Nooan päivinäkin, mutta siellä ei enää harrasteta seksiä. ${ }^{16}$

Jeesuksen opetuksissa ei ole säilynyt lausumia, joissa seksin ihanuutta ylistettäisiin. Ainoa seksuaaliseen haluun liittyvä Jeesuksen opetus on muotoiltu kielteisesti. Hän esittää tiukennetun tulkinnan Vanhan testamentin avionrikkomiskiellosta: "Teille on opetettu tämä käsky: 'Älä tee aviorikosta.' Mutta minä sanon teille: jokainen, joka katsoo naista niin, että alkaa himoita häntä, on sydämessään jo tehnyt aviorikoksen hänen kanssaan” (Matt. 5:27-28.)

Kohta on yksi Jeesuksen vuorisaarnan niin sanotuista antiteeseistä, joissa hän kumoaa, täydentää ja terävöittää Vanhan testamentin käskyjä ("mutta minä sanon teille"). Antiteesien tarkoitus ei ole osoittaa ihmisen pohjimmainen kyvyttömyys noudattaa lakia, vaan ne on annettu todellisiksi eettisiksi ohjeiksi. Antiteesien tehtävänä on osoittaa, miten Jeesuksen seuraajat voivat noudattaa "Jumalan tahtoa paljon paremmin kuin lainopettajat ja fariseukset.” (Matt. 5:20.) Tämä koskee myös Jeesuksen opetusta seksuaalisesta himosta: hänen seuraajansa voivat halutessaan välttää himoiten katsomisen.

Kohdassa ei puhuta ohimenevästä impulssista, vaan päämäärätietoisesta toiminnasta himon synnyttämiseksi; kreikankielisen tekstin voisi kääntää "joka katsoo naista himoitakseen häntä.” Jeesus ei siis ymmärrä himoa tahdosta riippumattomaksi, ihmisen väkisin mukaansatempaavaksi asiaksi. Hänen opetuksensa edellyttää, että ihminen voi

\footnotetext{
${ }^{16}$ Ajatus, ettei enkeleillä ole avioelämää, oli peräisin juutalaisesta apokalyptiikasta (Et. Henok 15:7; vrt. Gnilka 1979, 159).
} 
kontrolloida himoaan: sen voi tahdonvaraisesti kohdentaa tai olla kohdentamatta tiettyyn henkilöön.

Kohdassa naisesta käytetty kreikankielinen sana (gynē) tarkoittaa pääsänntöisesti naimisissa olevaa naista. Kyse ei siis ole seksuaalisesta himosta yleensä, vaan toisen miehen vaimon himoitsemisesta. ${ }^{17}$ Jeesuksen sanat jättävät avoimeksi kysymyksen, miten pitäisi suhtautua sellaiseen seksuaaliseen himoon, joka $e i$ kohdistu toisen miehen vaimoon. ${ }^{18}$ Mikäli Jeesus seurasi Vanhan testamentin seksuaalista käyttäytymistä koskevia linjauksia, hän saattoi hyväksyä esimerkiksi sen, että mies voi vierailla prostituoitujen luona (esim. 1. Moos. 38:13-18) tai harjoittaa seksiä orjattarensa kanssa. ${ }^{19}$ Siitä oliko Jeesuksen kanta todella tämä vai joku muu (vai oliko hänellä yleensä mitään erityistä mielipidettä asiasta) ei kuitenkaan ole säilynyt todistusaineistoa.

\section{Oliko Jeesuksella salarakas?}

Uuden testamentin evankeliumit eivät kerro mitään Jeesuksen omasta seksuaalisesta elämästä tai parisuhteesta. On mahdotonta tietää, johtuuko tämä Jeesuksen vai evankelistojen kiinnostuksen puutteesta asiaa kohtaan. Ainoa Uudessa testamentissa mainittu Jeesuksen perhe on joka tapauksessa se, jossa hän varttui, eikä hänen suhteensa siihen ollut paras mahdollinen: hän torjui äitinsä ja veljensä, kun nämä yrittivät saada häntä lähtemään kanssaan kotiin (Mark. 3:31-35). Johanneksen evankeliumissa Jeesus ensin torjuu äitinsä pyynnön tehdä lisää viiniä Kaanan häissä - mutta tekee sitä kuitenkin (Joh. 2:1-12).

\footnotetext{
${ }^{17}$ Luz 1997, 264.

${ }_{18}$ Mikäli kertomus Jeesuksesta ja avionrikkojanaisesta (Joh. 7:53-8:11) edustaa varhaista traditiota, siitä voidaan päätellä, että Jeesus piti aviorikosta syntinä (kertomus päättyy sanoihin naiselle: "mene, äläkä enää tee syntiä"), mutta toisaalta ei tuominnut aviorikoksen tehnyttä. Kertomus ei kuitenkaan kuulunut alun perin Johanneksen evankeliumiin eikä esiinny sen varhaisimmissa käsikirjoituksissa. Se voi olla irrallinen, suhteellisen varhainen kertomus, joka jälkikäteen sijoitettiin tähän yhteyteen, mutta yhtä hyvin kyseinen kertomus voi olla myös syntynyt suhteellisen myöhään.

${ }^{19}$ Vanhan testamentin seksuaalista käyttäytymistä koskevasta koodistosta ks. Veijola 1988, 183-184.
} 
Jeesuksen veljet eivät tämän evankeliumin mukaan uskoneet häneen lainkaan (Joh. 7:5). Heidän tilalleen astuukin salaperäinen, ainoastaan Johanneksen evankeliumissa esiintyvä, ”opetuslapsi, jota Jeesus rakasti." ${ }^{20}$ Tästä oppilaasta Jeesus teki ristillä riippuessaan äitinsä uuden huoltajan (Joh. 19:25-27). Lempioppilas siis korvaa Jeesuksen veljet ottamalla vastuulleen tehtävän, joka olisi kuulunut heille. Johanneksen evankeliumi vaikenee tässä yhteydessä täysin Jaakobin, Jeesuksen veljen, roolista varhaisen kirkon johtohahmona. ${ }^{21}$

Muistakaan varhaiskristillisen ajan teksteistä ei löydy todisteita Jeesuksen avioliitosta tai lapsista. Toisin kuin Da Vinci -koodissa väitetään, koptinkielisissä varhaiskristillisissä teksteissä Magdalan Mariaa ei esitellä Jeesuksen puolisoksi, vaan hänen lähimmäksi oppilaakseen ja työtoverikseen. Tämä Mariasta kertovien tekstien keskeinen piirre jää pimentoon yhtä lailla Dan Brownin romaanissa kuin sen lähteenä toimineessa, spekulatiivisen historiankirjoituksen mestariteoksessa Holy Blood, Holy Grail. ${ }^{22}$

Molemmat teokset ovatkin ytimeltään yllättävän sovinistisia: Maria on niiden kannalta kiinnostava vain ja ainoastaan, mikäli voidaan todistaa, että hän oli Jeesuksen puoliso ja lapsen äiti. ${ }^{23}$ Tästä syystä mainituille teksteille asetetaan kysymyksiä, joihin ne eivät vastaa. Niissä nimittäin ei olla kiinnostuneita Jeesuksen ja Marian parisuhteen

\footnotetext{
${ }^{20}$ Eräiden tutkijoiden mukaan Johanneksen evankeliumissa kuvattu "opetuslapsi, jota Jeesus rakasti” oli todellisuudessa Magdalan Maria. Näkemys on kuitenkin hyvin hankalasti perusteltavissa (vrt. Dunderberg 2006, 118 n. 5). Johanneksen evankeliumissa kuvattu lempioppilas on yksiselitteisesti miespuolinen hahmo, josta puhuttaessa käytetään maskuliinimuotoisia artikkeleja ja pronomineja. Lisäksi Maria ja lempioppilas ovat erillisiä hahmoja, jotka voivat esiintyä samassakin kertomuksessa (Joh. 20:2).

${ }^{21}$ Jaakobista, Jeesuksen veljestä, tuli ensimmäisten kristittyjen johtaja, jota jo Paavali kuvasi varhaisen seurakunnan keskushahmoksi Pietarin ja Johanneksen rinnalla (Gal. 2:9). Tätä taustaa vasten Johanneksen evankeliumissa kuvattu lempioppilashahmo voidaan nähdä kriittiseksi kannanotoksi Jeesuksen perheelle osoitettua arvonantoa kohtaan: evankeliumin kirjoittaja kyseenalaistaa Jeesuksen veljien uskon ja antaa lempioppilaan korvata heidät sekä Jeesuksen äidin huoltajana että Jeesuksen opetuksen takuumiehenä (Dunderberg 2006, 134 135, 186-197).

${ }^{22}$ Baigent, Leigh ja Lincoln 1982.

${ }^{23}$ Vrt. Salmesvuori 2005, 18-19 (Dan Brownin Maria-kuvauksesta): "Eikö naisesta tehdä jälleen väline, jonka avulla miehen kuninkaallinen siemen jatkaa uljasta ja vaaroja täynnä olevaa elämää.”
} 
luonteesta eikä niissä ole mainintaa heidän jälkeläisistään. Brownin ja kumppanien yritykset löytää näistä teksteistä tähän suuntaan osoittavia viitteitä jäävät kerta toisensa jälkeen ohuiksi:

1) Filippuksen evankeliumissa ja Marian evankeliumissa Jeesuksen kerrotaan rakastaneen Mariaa enemmän kuin muita oppilaitaan (Fil. ev. 55-56; Mar. ev. 10). Maininta ei kuitenkaan ole ainoalaatuinen. Samankaltaisia lempioppilaita varhaiskristillisissä teksteissä ovat esimerkiksi "opetuslapsi jota Jeesus rakasti" Johanneksen evankeliumissa, Tuomas Tuomaan evankeliumissa ja Tuomas Kilvoittelijan kirjassa, Jaakob Jaakobin salaisessa kirjassa sekä Juudas hiljattain julkaistussa Juudaksen evankeliumissa. Kaikki nämä hahmot kuvataan Marian tavoin Jeesuksen erityisen läheisiksi seuraajiksi ja ilmoituksen välittäjiksi.

2) Filippuksen evankeliumissa (55-56) Jeesuksen kerrotaan suudelleen Mariaa. Tämä maininta on tulkittu viittaukseksi eroottiseen suhteeseen, mutta aivan samanlainen kuvaus esiintyy teksteissä, joissa Jeesuksen lähimmäksi oppilaaksi kuvataan Jaakob: Jeesuksen kerrotaan suudelleen häntäkin (2 Jaak. ilm. 56). Oliko Jeesuksella siis Marian lisäksi seksisuhde oman veljensäkin kanssa? Ei ainakaan näiden tekstien perusteella. Suudelma on molemmissa tapauksissa osoitus suosikkioppilaan erityisen läheisestä suhteesta Jeesukseen ja asemasta ilmoituksen välittäjänä.

3) Maria kuvataan Filippuksen evankeliumissa myös Jeesuksen "kumppaniksi" (Fil. ev. 32, 55-56). Kohdassa käytetty kreikkalainen termi koinônos tarkoittaa minkälaista kumppania tahansa - aviopuolisosta liiketoveriin. Tekstiyhteys ei anna tukea oletukselle, että Marian olisi ajateltu olleen Jeesuksen vaimo; aviovaimosta käytetään Filippuksen evankeliumissa toista sanaa, joka tarkoittaa "naista" (shime).

Muiden Maria-tekstien perusteella on todennäköisintä, että kohdassa mainittu kumppanuus liittyi nimenomaan Marian rooliin Jeesuksen ilmoituksen välittäjänä. Näiden tekstien kirjoittajien suhde seksiin on lisäksi usein hyvin kielteinen; he ajattelivat, että Jeesus tuli maailmaan tehdäkseen tyhjäksi "naiseuden teot" eli lasten synnyttämisen. He olisivat todennäköisesti olleet yhtä kauhuissaan kuin monet nykykristityt ajatuksesta, että Jeesus olisi harrastanut seksiä Marian kanssa. 
Jäljelle jää yleisellä tasolla tehty väite, ettei Jeesuksen ikäinen juutalainen mies voinut olla naimaton eikä varsinkaan toimia rabbina, mikäli hän ei ollut naimisissa. On totta, että Jeesuksen ajan juutalaisuus edellytti pääsääntöisesti avioliiton solmimista. Tämä ei kuitenkaan ollut ehdoton sääntö juutalaisuudessa, vaan siitä oli myös poikkeuksia. ${ }^{24}$ Vanhassa testamentissa Jumala kielsi profeetta Jeremiaa solmimasta avioliittoa (Jer. 16:2). Jeesuksen ajan juutalaisuudessa esiintyi pyhitysliikkeitä kuten essealaiset, joista osa valitsi naimattomuuden. ${ }^{25}$ Qumranin yhteisön seksuaaliseen epäpuhtauteen liittyvät säädökset ovat jyrkempiä kuin Vanhassa testamentissa: yöllisen siemensyöksyn ja yhdynnän aiheuttaman epäpuhtauden katsottiin jatkuvan kolme päivää eli kaksi päivää pidempään kuin Mooseksen laeissa, ${ }^{26}$ eikä seksiä saanut harrastaa lainkaan Jerusalemissa, pyhässä kaupungissa. ${ }^{27}$

Jeesus ei kuulunut essealaisiin, mutta uransa alkuvaiheessa hän oli Johannes Kastajan oppilas. ${ }^{28}$ Johannes ja hänen oppilaansa noudattivat askeettista elämäntapaa (Mark. 2:18; Matt. 11:18; Luuk. 7:33). Jeesus jossain vaiheessa irtautui Johanneksen ryhmästä, ja hänet tunnettiin "syömärinä ja juomarina" (Matt. 11:19; Luuk. 7:34). Silti on mahdollista, että hän muiden juutalaisten hurskausliikkeiden edustajien tavoin oli tehnyt päätöksen pysyä naimattomana. Hänen opetuksensa taivasten valtakunnan eunukeista voisi viitata tällaiseen päätökseen. ${ }^{29}$

Vai oliko Jeesus naimaton siksi, ettei hänen seksuaalinen kiinnostuksensa kohdistunut naisiin - vaan miehiin? Jeesus-tutkijoiden

\footnotetext{
${ }^{24}$ Tästä aiheesta tarkemmin ks. Aejmelaeus 1991, 20-21.

${ }^{25}$ Josefus, Ant. 18.1.5.

${ }^{26}$ Temppelikäärö 45.

${ }^{27}$ Damaskon kirja 12; Sanders 1992, 353. Kohta osoittaa, etteivät kaikki Qumranin yhteisön vaikutuspiiriin kuuluneet juutalaiset valinneet selibaattia.

${ }^{28}$ Johannes Kastajasta ja Jeesuksen suhteesta häneen ks. Uro 1997.

${ }^{29}$ Baigent, Leigh ja Lincoln "unohtavat" mainita tämän kohdan käsitellessään kysymystä Jeesuksen avioliitosta (1982, 330-333). Lisäksi he argumentoivat, että Kaanaan häät, joissa Jeesus teki 600 litraa viiniä (Joh. 2:1-12), olivat hänen omat häänsä. (Tätä ei tietenkään sanota Johanneksen evankeliumissa, mutta ei sen niin väliä.) Viinin määrästä he myöhemmin päättelevät, että häiden täytyi olla ylelliset, joten Jeesuksen täytyi kuulua ylhäisöön (346). Näin päästään ajatukseen Jeesuksen kuninkaallisesta suvusta, joka puolestaan on "puuttuva linkki" juutalaisuuden ja merovingien kuningassuvun välillä (387-389). Päättelyketju on hyvä esimerkki siitä, kuinka Baigent \& co. etenevät huterasta lähtökohtaoletuksesta hurjiin ja entistä huterampiin jatkopäätelmiin.
} 
heteronormatiivinen näkökulma tulee esiin siinä, etteivät he yleensä pohdi tätä mahdollisuutta lainkaan. ${ }^{30}$ Tämänkään teorian puolesta ei kuitenkaan voida esittää kovinkaan vakuuttavia todisteita.

Homoeroottista latausta on nähty Johanneksen evankeliumin kuvauksessa Jeesuksen lempioppilaasta, jonka kerrotaan viimeisellä aterialla maanneen Jeesuksen "rintaa vasten" tai "sylissä" (Joh. 13:25; vrt. 21:20). ${ }^{31}$ Ilmaisu voi herättää seksuaalisia mielleyhtymiä, ${ }^{32}$ mutta sitä käytetään myös kuvattaessa kunniavieraan asemaa aterialla, ja juuri tästä on kysymys kyseisessä Johanneksen evankeliumin kohdassa. ${ }^{33}$ Johanneksen evankeliumissa ilmaisu saa lisäväriä siitä, että samaa kuvausta käytetään myös Jeesuksen suhteesta Isään: hänen kerrotaan olevan Isän "sylissä" (Joh. 1:18). ${ }^{34}$ Samankaltaisten ilmausten tarkoituksena on rinnastaa Jeesus, joka ilmoittaa Isän ihmisille (Joh. 1:18), ja lempioppilas, joka välittää tämän ilmoituksen luotettavasti evankeliumin lukijoille. ${ }^{35}$

Kiistellyssä Markuksen salaisessa evankeliumissa kerrotaan nuorukaisesta, jonka Jeesus herätti kuolleista ja joka rakasti Jeesusta. Eräänä iltana tämä "nuori mies tuli hänen luokseen pukeutuneena pellavaiseen vaatteeseen, joka verhosi hänen alastoman ruumiinsa, ja jäi hänen luokseen siksi yöksi." ${ }^{36}$ Vaikka tekstissä ei suoraan puhutakaan homoseksuaalisesta aktista, kyseisen kohtauksen on ajateltu vihjaavan siihen. ${ }^{37}$ Uusin tutkimus on kuitenkin osoittanut, että kyseinen teksti

\footnotetext{
${ }^{30}$ Martin 2006.

31 van Tilborg 1993; Martin 2006. Kumpikaan tutkija ei väitä, että kyseinen maininta osoittaisi Jeesuksen todella olleen homo. van Tilborgin teoriasta ja sen ongelmista ks. Dunderberg 1995, 363-364.

${ }^{32}$ van Tilborg 1993, 89.

${ }^{33}$ Dunderberg 2006, 133 (jossa myös viitteitä aiempaan kirjallisuuteen).

34 Konkreettinen, syliä kuvaava metafora ei välity Kirkkoraamatun käännöksessä "Isän vierellä”.

${ }^{35}$ Dunderberg 2006, 141-142.

${ }^{36}$ Lauha 1987a sisältää suomennoksen Markuksen salaisesta evankeliumista ja kuvauksen tekstin aitouteen liittyvistä ongelmista.

${ }^{37}$ Vrt. Smith 1973a, 185; 1973b, 113-114. Jälkimmäisessä kohdassa Smith pohtii, saattoiko Markuksen salaisessa evankeliumissa kuvattua yöllistä initiaatiota Jumalan valtakunnan salaisuuksiin seurata fyysinen yhdyntä. Markuksen salaisessa evankeliumissa myös kerrotaan nimettömän nuorukaisen rakastaneen Jeesusta (3.4). Smith vihjaa mutkan kautta, että ilmaisu voi tarkoittaa homoseksuaalista suhdetta. Hän nimittäin selittää juutalaisten reaktion
} 
on moderni, 1900-luvun jälkipuoliskolla tehty väärennös. ${ }^{38}$ Näin sillä ei ole lähdearvoa pohdittaessa Jeesuksen seksuaalista suuntautumista.

Mielestäni historiallisesti todennäköisin vaihtoehto on edelleen, että Jeesus oli uskonnollisista syistä valinnut naimattomuuden. Tämä valinta saattoi liittyä hänen taustaansa Johannes Kastajan askeettista elämäntapaa korostaneessa ryhmässä, josta hän tosin myöhemmin erkaantui. Hän näyttää ajatelleen, että naimattomuus jollain tavoin edesauttoi hänen ja hänen seuraajiensa asemaa Jumalan valtakunnan julistajana. Naimattomuus saattoi liittyä myös tulevan pelastuksen ajan ennakoimiseen: sen valinnut toteutti jo tässä maailmassa tulevan maailman "enkelielämää", johon seksi ei kuulunut. Naimattomuus oli kuitenkin pikemminkin suositus kuin ehdoton vaatimus; Jeesuksen oppilaiden joukossa oli nimittäin myös perheellisiä miehiä kuten Pietari. ${ }^{39}$

\section{Harhaoppisten orgiat - totta vai tarua?}

Jeesuksen seksuaalisesta suuntautumisesta ei ole säilynyt tietoa ja hänen seksiin liittyvistä käsityksistäänkin tiedetään vain niukasti. Sen sijaan varhaiskristillisen ajan teksteissä on suhteellisen paljon kuvauksia eräiden kristillisten ryhmien villeistä kokoontumisista, joissa vapaa seksi kukoisti. Niistä yksityiskohtaisin on Epifanioksen kuvaus gnostilaisista

Jeesuksen itkuun Lasaruksen haudalle mentäessä ("Katso, kuinka tämä rakasti häntä", Joh. 11:36) näin: "Juutalaiset väänsivät Jeesuksen viattoman surun todisteeksi homoseksuaalisuussyytöksen puolesta.” (Smith 1973a, 154.) Looginen seuraus tästä selityksestä on, että maininta nuorukaisen rakkaudesta Jeesusta kohtaan Markuksen salaisessa evankeliumissa viittasi homoeroottiseen rakkauteen.

${ }^{38}$ Carlson (2005) on argumentoinut vakuuttavasti, että Markuksen salaisen evankeliumin todennäköisin kirjoittaja on Morton Smith, joka esiintyi tekstin julkaisijana ja toimittajana (Smith 1973a; 1973b). Oletus väärennöksestä selittää, miksi Markuksen salainen evankeliumi vaikuttaa Uuden testamentin evankeliumeista poimittujen ilmaisujen kollaasilta (tämän havaitsee esim. Lauha 1987b), ja miksi siinä kuvattu kertomus nuorukaisen kuolleista herättämisestä muistuttaa läheisesti tutkijoiden olettamaa varhaisempaa versiota Lasaruksen kuolleista herättämisestä (Joh. 11:1-46).

${ }^{39}$ Historian ironiaa on, että avioliiton solminutta Pietaria, joka kuljetti vaimoaan mukanaan matkustellessaan, alettiin myöhemmin pitää ensimmäisenä Rooman piispana, mutta viran myöhemmiltä haltijoilta on historian saatossa edellytetty naimattomuutta. 
kristityistä, jotka harrastivat rituaalista seksiä, nauttivat spermaa ja kuukautisverta ja antoivat vaimonsa veljienkin käyttöön.

Muitakin samansuuntaisia kuvauksia kristinuskon ensimmäisiltä vuosisadoilta on säilynyt. Silti väitteet harhaoppisten kristittyjen villeistä seksiorgioista ovat suuresti liioiteltuja. On jopa mahdollista, että ne ovat kokonaan perättömiä. Varhaiskristillisissä teksteissä esiintyy usein syytöksiä vastustajien seksuaalisesta moraalittomuudesta, mutta samalta ajalta on peräisin myös tekstejä, joissa sama syytös esitetään kaikkia kristittyjä vastaan. ${ }^{40}$ Heidän huhuttiin öisten kokouksiensa päätteeksi harjoittaneen rajoittamatonta seksiä, johon kaikki, lapsista kaiken ikäisiin aikuisiin, osallistuivat. ${ }^{41}$

Yksi tapa reagoida tällaisiin syytöksiin oli väittää, etteivät ne olleet totta kaikkien kristittyjen osalta, vaan harhaoppisina pidetyt kristityt vetivät käyttäytymisellään lokaan muidenkin kristittyjen maineen. ${ }^{42}$ Tämä selitys, jonka muutamat nykytutkijatkin ovat omaksuneet, sivuuttaa kuitenkin antiikin tekstien poleemisen retoriikan, jossa usein turvauduttiin vastustajien häikäilemättömään mustamaalaukseen. ${ }^{43}$ Aivan samoja syytöksiä esittivät esimerkiksi filosofit kilpailevien filosofikoulukuntien jäsenistä. Epikurolaiset leimattiin hillittömiksi nautinnon tavoittelijoiksi, vaikka he todellisuudessa korostivat kohtuullisuutta niin seksin kuin ruuankin suhteen. Toisaalta epikurolainen Filodemus syytti stoalaisia, joita yleensä pidetään roomalaisen yhteiskunnan moraalisena selkärankana, kaikista kuviteltavissa olevista

${ }^{40}$ Kristittyjä syytettiin moraalittomuudesta esimerkiksi varhaisessa kuvauksessa Viennan ja Lyonin marttyyreistä, jotka saivat surmansa vainoissa 177 (Eusebios, Kirkkohistoria 5.1.163): "... orjat syyttivät meitä valheellisesti Tyesteen-aterioista ja Oidipus-yhteyksistä ja sellaisesta, jota emme saa sanoa tai ajatella tai edes usko, että jotakin sellaista on milloinkaan tapahtunut ihmisten keskuudessa." Tyesteen ateriat liittyivät kannibalismiin, "Oidipusyhteydet" puolestaan insestiin.

${ }^{41}$ Väitteen esittää kristityn apologeetin Minucius Felixin tutkielmassa Octavius roomalainen M. Cornelius Fronto (9.6-7).

${ }^{42}$ Näin esim. Irenaeus, Harh. 1.25.3. Muutamat tutkijat ovat omaksuneet saman selityksen: lähteissä esiintyvät väitteet moraalittomuudesta ovat totta, kun on kyse gnostilaisista tai muista harhaoppisina pidetyistä ryhmistä, mutta eivät pidä paikkaansa kristityistä yleensä. Tämän selitysmallin edustajista ja siihen liittyvistä ongelmista ks. Williams 1996, 182-184.

43 Vrt. Knust 2005, 3, joka toteaa aivan perustellusti: "Tällaisissa historiallisissa rekonstruktioissa ei oteta huomioon seksuaaliseen holtittomuuteen liittyvien syytösten retorisia ja diskursiivisia tarkoitusperiä." 
seksuaalisista paheista, paraatiesimerkkeinä insesti ja homoseksuaalisuus. $^{44}$ Syytöksiä seksuaalisesta hillittömyydestä käytettiin myös poliittisista syistä. Hallitsijoita arvosteltiin esittelemällä heidän irstaita elämäntapojaan, ja samaan keinoon turvauduttiin, kun haluttiin luoda ja vahvistaa ennakkoluuloja muita kansoja kohtaan: "Juutalaisten väitettiin olevan himokkaita, ... juutalaiset luonnehtivat kreikkalaisia tai egyptiläisiä irstaiksi, perversseiksi ja avionrikkojiksi, kreikkalaiset kuvasivat persialaiset orjamaisiksi ja irstaileviksi; kuitenkin monien roomalaisten kirjailijoiden mukaan juuri kreikkalaiset ovat himokkaita nautinnon metsästäjiä.” ${ }^{35}$

Kun kristittyjen toisiaan vastaan esittämät syytökset sijoitetaan tähän laajempaan yhteyteen, on selvää, ettei niitä voi pitää sellaisenaan historiallisesti luotettavina. Syytökset vastustajien seksuaalisesta holtittomuudesta olivat yksi keino luoda ja vahvistaa kuva yhtäältä aidosta ja hyväksyttävästä kristillisestä identiteetistä ja toisaalta oikean kristinuskon vastaisesta toisesta, jota tulee kaikin keinoin karttaa. ${ }^{46}$ Uudet tekstilöydöt kuten Nag Hammadin kirjasto eivät anna minkäänlaista lisätukea tällaisille syytöksille. Kirjaston teksteissä paheksutaan ja kehotetaan karttamaan juuri samoja asioita kuin gnostilaisia kristittyjä vastaan kirjoitetuissa tutkielmissa. Sama näkökulma tulee esiin myös hiljattain julkaistussa Juudaksen evankeliumissa: siinä Jeesus mainitsee homoseksuaalisuuden yhtenä osoituksena maailman turmeltuneisuudesta.

Nag Hammadin kirjasto edustaa pääosin askeettisesti suuntautunutta ja seksiin torjuvasti suhtautuvaa kristillisyyttä. Seksuaalista aktia kuvataan kirjaston teksteissä inhoten:

Piinaava on tuli, joka polttaa ihmisten ruumiissa ja sisimmässä! Se palaa heissä yötä [päivää] ja kuluttaa heidän jäseniään. Se juovuttaa heidän mielensä ja saa heidän sielunsa suunniltaan. Se [...] miehissä ja naisissa [yötä päivää]. Se

\footnotetext{
${ }^{44}$ Filodemus, Stoalaisista.

${ }^{45}$ Knust 2005, 4.

${ }^{46}$ Knust 2005, 160-163.
} 
kiihottaa heidät liikkeeseen ... Miehet [liikkuvat ... naisten] päällä ja naiset [miesten päällä]. ${ }^{47}$

Muutamissa kirjaston teksteissä kuvattu alempi luojajumala Jaldabaoth, joka luo maailman, kuvataan seksuaalisen halun riivaamaksi olennoksi. Gnostilaisessa myytissä kuvataan, kuinka hän raiskaa Eevan ja tartuttaa näin seksuaalisen halun ihmiskuntaan:

Tähän päivään asti sukupuoliyhteys on jatkunut ensimmäisen hallitsijan (Jaldabaothin) tähden. Hän kylvi siemenen Aadamin puolisoon. Hän sai aikaan sen, että ruumiiden kopiot saavat alkunsa yhdynnästä. Hän antoi heille värristyneen hengen. ${ }^{48}$

Saman tekstin mukaan alemmat luojaolennot tekivät ihmiselle ruumiin, jotta hän unohtaisi jumalallisen alkuperänsä. ${ }^{49}$ Pelastuminen merkitsee käänteistä prosessia, jossa ihminen muistaa jälleen todellisen minänsä ja lakkaa elämästä ruumiinsa tarpeiden vieteltävänä.

Todennäköisesti gnostilaiset kristityt pyrkivät pääsääntöisesti noudattamaan erityisen korkeita moraalisia ihanteita. Valentinolaisia gnostilaisia vastaan kirjoittanut Irenaeuskin joutui myöntämään, että osa heistä eli moitteettomasti. Tämäkään ei tosin Irenaeukselle kelvannut; hänen mukaansa nämä valentinolaiset olivat ylpeitä ja käyskentelivät pöyhkeinä ympäriinsä kuin kukot konsanaan. ${ }^{50}$

Irenaeuksella on luonnollisesti enemmän kerrottavaa valentinolaisten moraalittomuudesta kuin moitteettomuudesta. Erityisen yksityiskohtaisesti hän kertoo Markos-nimisen valentinolaisen opettajan johtamasta ryhmästä, jonka jäsenet viettelivät naisia. Markos itse oli vietellyt jopa Irenaeuksen tunteman diakonin vaimon Vähässä-Aasiassa, ${ }^{51}$ ja sama meno jatkui markolaisten parissa Lyonin lähistöllä. Markolaisten joukosta Irenaeuksen johtamaan kristittyjen ryhmään palanneet naiset

\footnotetext{
${ }^{47}$ Tuomas Kilvoittelijan kirja 139.

${ }^{48}$ Johanneksen salainen kirja 24.

${ }^{49}$ Joh. sal. 21.

${ }^{50}$ Irenaeus, Harh. 3.15.2.

${ }^{51}$ Irenaeus, Harh. 1.13.4.
} 
tunnustivat julkisesti joutuneensa seksuaalisen hyväksikäytön kohteiksi. $^{52}$

Syytökset vastustajien moraalittomuudesta palvelivat Irenaeuksen päämäärä siinä missä teologinen kädenvääntökin. Hänen teoksensa ensisijainen tavoite oli estää uusia ihmisiä liittymästä valentinolaisiin ryhmiin. Väittämällä, että valentinolaiset kaiken muun pahan lisäksi vievät kunniallisten kristittyjen miesten vaimot, Irenaeus sai sellaisetkin lukijat (erityisesti aviomiehet!), jotka eivät pitäneet valentinolaisten poikkeavaa teologiaa suurena ongelmana, huolestumaan asiasta.

Valentinolaisilla, joihin Markoksen ryhmäkin lukeutui, oli erityinen morsiushuoneen sakramentti. Irenaeus syyttää valentinolaisia siitä, että he "aina ja joka paikassa panevat toimeen" kyseisen rituaalin. ${ }^{53}$ Maininta on ilkeämielinen vihjaus rituaalin seksuaalisesta luonteesta. Epäselvää on, mitä morsiushuoneen sakramentissa todella tapahtui. Kyse on mitä ilmeisimmin todellisesta rituaalista, sillä se mainitaan samassa yhteydessä kuin kaste, voitelu ja ehtoollinen. ${ }^{54}$ Valentinolaisten omissa teksteissä puhutaan kuitenkin ainoastaan morsiushuoneen sakramentin hengellisestä sisällöstä, ei sen käytännön toteutuksesta. Morsiushuoneen sakramentissa Kristuksen uskottiin korjaavan aikojen alussa tapahtuneen jakautumisen kahteen sukupuoleen:

Nainen ja mies eivät kuolisi, ellei nainen olisi irtautunut miehestä. Kuolema sai alkunsa ihmisen jakautumisesta. Kristus tuli korjatakseen alussa tapahtuneen jakautumisen, yhdistämään nämä kaksi, antamaan elämän niille, jotka jakautuneina olivat olleet kuolleita, ja yhdistämään heidät. Nainen yhtyy mieheensä morsiushuoneessa. Niitä jotka ovat yhtyneet morsiushuoneessa, ei voi erottaa toisistaan. Eeva irtautui Aadamista siksi, ettei hän yhtynyt tähän morsiushuoneessa. ${ }^{55}$

Tulkinta viittaa siihen, että sakramentti oli luonteeltaan pikemminkin askeettinen kuin orgiastinen. Sakramentti merkitsi paluuta paratiisin-

52 Irenaeus, Harh. 1.13.7.

${ }^{53}$ Irenaeus, Harh. 1.6.4.

${ }^{54}$ Fil. ev. 68. Kohta puhuu sitä tulkintaa vastaan, ettei valentinolaisilla ollut lainkaan erityistä morsiushuoneen rituaalia, vaan kyse oli hengellistä täyttymystä kuvaavasta vertauskuvasta.

${ }^{55}$ Fil. ev. $78-79$. 
omaiseen alkutilaan, jossa ei ollut sukupuolten välistä eroa eikä sen seurausta, kuolemaa: "Niin kauan kuin Eeva oli Aadamin sisällä, kuolemaa ei ollut. Kuolema sai alkunsa, kun hänet erotettiin Aadamista. Kun hän palaa takaisin ja Aadam ottaa hänet luokseen, kuolemaa ei enää ole." ${ }^{56}$

Muista 100-luvun gnostilaisista kristityistä Karpokrateen ja Basilideen seuraajien kerrotaan hyväksyneen seksuaalisen hillittömyyden ja uudelleen avioitumisen, sillä "Jumala ei sellaisista asioista piittaa." 7 Basilideen pojan Isidoroksen näkemykset eivät kuitenkaan tue tätä syytöstä. Teoksessaan Eettiset kysymykset (Ethika) hän pohti, milloin ja millä edellytyksillä avioliitosta voi pidättäytyä. Hänenkin mukaansa olisi järkevää olla menemättä naimisiin, mutta tämä ei ole ehdoton sääntö. Jos pidättyvyys nimittäin ei onnistu luonnostaan, vaan sen seuraamisesta tulee koko elämänsisältö, on parempi mennä naimisiin. ${ }^{58}$

Isidoros kuitenkin suositteli pidättyvyyttä niille, jotka ovat nuoria tai joilla on taipumus siveyteen ja jotka haluavat "järkisyistä" olla menemättä naimisiin. Isidoros korostaa, että seksuaalinen nautinto on "luonnollinen mutta ei välttämätön" tarve - toisin kuin esimerkiksi vaatetus, joka on sekä luonnollinen että välttämätön. Isidoroksen pohdinnoista ei löydy mitään, mikä tukisi Basilideen seuraajia vastaan esitettyjä poleemisia syytöksiä.

Karpokrateen 17-vuotiaana kuollut poika Epifanes ehti kirjoittaa tutkielman nimeltä Vanhurskaudesta, jossa hän piti ihanteena vaimojen yhteisomistusta. ${ }^{59}$ Sama ajatus esiintyi jo Platonin kuvauksessa ihanneyhteiskunnasta, joten Epifanios vetosi mahdollisesti siihen. ${ }^{60}$ Epifaneksen pohdinnat ovat kuitenkin teoreettisia. Hän halusi kuvata, millaista elämä olisi sellaisessa yhteiskunnassa, jossa ei olisi lainkaan itsekkyyttä eikä yksityisomistusta, vaan ihmiset olisivat epäitsekkäitä ja valmiita jakamaan kaiken keskenään. Epifaneksen näkemyksistä ei siis

\footnotetext{
${ }^{56}$ Fil. ev. 71.

${ }^{57}$ Irenaeus, Harh. 1.28.2.

${ }^{58}$ Clemens Aleksandrialainen, Strom. 3.1-3; tekstin tulkinnasta ks. Löhr 1995, 101-122.

${ }^{59}$ Clemens Aleksandrialainen, Strom. 3.6.1-3.9.3; tekstin tulkinnasta ks. Löhr 1993.

${ }^{60}$ Platon, Valtio 457c-471; tästä ja muista esikuvista ks. Löhr 1993, 19-21.
} 
voi päätellä, että Karpokrateen seuraajat olisivat todellakin pitäneet yhteisiä vaimoja, ${ }^{61}$ vaikka tällaisia huhuja innokkaasti levitettiinkin. ${ }^{62}$

Näistä huhuista on lyhyt matka Epifanioksen kuvaukseen gnostilaisten kristittyjen villeistä orgioista. Epifanioksen kuvausta on joskus pidetty luotettavana siksi, että hän näyttää tunteneen henkilökohtaisesti gnostilaisia kristittyjä. Hän nimittäin kertoo, kuinka tällaisiin ryhmiin kuuluneet naiset melkein saivat houkutelluksi hänetkin joukkoihinsa, kun hän oli vielä nuorukainen. ${ }^{63}$ Hän kuitenkin viime hetkellä onnistui perääntymään naisten houkutuksista. Siksi hänellä ei ole ensi käden kokemuksia mainituista rituaaleista, vaan hänen kuvauksensa niistä perustuvat näiden ryhmien käyttämiin teksteihin ja päätelmiin, joita hän niistä teki. ${ }^{64}$

On myös hyvin mahdollista, että Epifanios sepitti hurjia tarinoita vastustajistaan. Hän turvautui yleisiin syytöksiin, joita singottiin eri uskonnollisten ryhmien kesken. Erityisen rakastettu yksityiskohta uskonnollisessa polemiikissa oli Epifanioksen mainitsema siemennesteen ja kuukautisveren nauttiminen: mandalaiset syyttivät siitä kristittyjä ja kristityt manikealaisia; gnostilaiset kristityt pitivät käytäntöä erityisen karmaisevana osoituksena yleisestä tapainturmeluksesta (Pistis Sofia 4.147). Yhteistä kaikille näille kuvauksille on, että paheellista tapaa harrastaa joku toinen, vastustetun ryhmän jäsen. ${ }^{65}$

Varhaiskristillisissä teksteissä esitetyt syytökset seksuaalisesta moraalittomuudesta eivät kohdistuneet ainoastaan gnostilaisiin kristittyihin. Kerinthos-niminen kristitty odotti Jumalan valtakunnan toteutuvan maan päällä. Hän saattoi vedota näkemyksensä tueksi Vanhaan testamenttiin, jossa tuleva pelastuksen aika merkitsee maanpäällisen elämän jatkumista, pitkäikäisyyttä, vaivojen päättymistä ja runsasta satoa (Jes. 65:17-25). Jeesus itsekin edusti samanlaista odotusta opettaessaan, että Jumalan valtakunnassa kokoonnutaan

\footnotetext{
${ }^{61}$ Löhr 1993, 25.

${ }^{62}$ Clemens, Strom. 3.5.1.

${ }^{63}$ Epifanios, Lääkelaukku 26.17.4.

${ }^{64}$ Williams 1996, 181.

${ }^{65}$ Williams 1996, 179-184.
} 
yhteiselle aterialle (Matt. 8:11-12; Luuk. 13:28-29). Vastustajat kuitenkin väänsivät Kerinthoksen juutalaiskristillisestä taustasta nousevan, konkreettisen tulevaisuudenodotuksen osoitukseksi hänen alhaisesta moraalistaan. He leimasivat hänet vatsanpalvojaksi ja seksuaalisten himojen orjaksi:

Tämä oli hänen opettamansa opinkappale, että Kristuksen valtakunta olisi maallinen, ja hän haaveili, että se olisi sitä mitä hän itse, ruumista rakastavana täydellisesti lihallisena ihmisenä, tavoitteli, vatsan ja vatsan alapuolella olevien osien nautintoja eli ruokaa ja juomaa ja häitä ja sitä, millä hän luuli voivansa kauniimmalla nimellä hankkia itselleen tätä, juhlissa ja uhreissa ja uhrieläinten teurastamisessa. ${ }^{66}$

Seksuaaliseen moraalittomuuteen liittyvät syytökset toistuvat siis varhaiskristillisissä teksteissä pitkälti samanlaisina riippumatta siitä, mistä vääräoppisena pidetystä kristillisestä ryhmästä on kyse tai kuka syytöksiä kulloinkin esitti. Vaikka näiden tekstien varhaiset lukijat todennäköisesti tunsivat hyvin mustamaalaamisen retoriikan, sitä ei voi pitää harmittomana. Huhujen levittämisen tarkoituksena oli synnyttää vihaa ja inhoa toisinajattelevia ryhmiä kohtaan. Aluksi tarkoituksena oli luoda mahdollisimman selkeät rajat "meidän" ja "muiden" välille ja estää oman ryhmän kannattajia siirtymästä väärään leiriin. Vihan retoriikasta on kuitenkin lyhyt matka väkivaltaiseen toimintaan. Kristinuskon historiassa retoriikasta siirryttiin tekoihin, kun kristillinen kirkko vakiinnutti asemansa Rooman valtakunnassa 300-luvulta alkaen ja alkoi vainota harhaoppisina pidettyjä kristillisiä ryhmiä. ${ }^{67}$

${ }^{66}$ Eusebios, Kirkkohistoria 3.28.5. Eusebios esittää kohdan lainauksena Aleksandrian piispa Dionysioksen teoksesta Lupaukset. Kerinthoksen ajatusten juutalaiskristillisestä taustasta ja häntä vastaan esitetyistä syytöksistä ks. Myllykoski 2002, 530-532; 2005a, 236-243.

67 Valentinolaisten kristittyjen kokemasta vainosta kristillisessä Roomassa ks. esim. Dunderberg 2005a, 11-12. 



\section{Jeesuksen sanojen traditioista imperiumin tutkimukseen}





\section{Mitä Jeesus opetti naisista?}

(1993)

Jeesuksen suhde naisiin herättää intohimoja nykyäänkin. Muutama vuosi sitten elokuva Kristuksen viimeinen kiusaus synnytti kiivaan keskustelun eri puolilla maailmaa. Suomessa tämä keskustelu on noussut uudestaan lehtien otsikoihin, sillä sekä Porvoon että Järvenpään seurakuntaneuvostoissa on pohdittu, voiko elokuvaa näyttää Raamatun teemavuoden ohjelman osana.

Kiistanalaisena elokuvassa pidettiin varsinkin kohtausta, jossa Jeesus rakastelee Magdalan Marian kanssa. Vain harva näki kohtauksen laajemman yhteyden. Kyse oli Kristuksen viimeisestä kiusauksesta, joka oli astua alas ristiltä ja viettää tavallisen ihmisen elämää. Elokuvassa Kristus lopulta voittaa tämänkin kiusauksen. Tavallinen elämä jää elokuvassakin vain unikuvaksi. Tästä huolimatta juuri tämänkaltaiset mielikuvat Jeesukseen yhdistettyinä herättävät närkästystä.

Jeesusta on totuttu pitämään poikkeavana ja ihanteellisena hahmona. Evankeliumien mukaan Jeesus opettaa paremmin kuin oman aikansa lainoppineet (hän opettaa niin kuin se, jolla on valta). Kiistoissa Jeesus saa vastustajansa hämilleen, eikä ihme, sillä hän tietää heidän ajatuksensa jo etukäteen. Jeesus parantaa sairaita ja tekee muita ihmeitä.

Hahmon ihanteellisuudella on vaaransa. Kuvamme Jeesuksesta värittyy helposti sen mukaan, mikä vastaa meidän ihanteitamme. Nykyaikana voidaan esimerkiksi lähes huomaamatta korostaa yksipuolisesti Jeesuksen ymmärtäväisyyttä ja lempeyttä, koska tällaisia piirteitä pidetään sopivina tämän ajan ihanteelliselle ihmiselle.

Myös seuraava ihannekuva on helppo hahmotella: Jeesus poikkesi edukseen oman aikansa opettajista, kun oli kyse suhtautumisesta 
naisiin. Toisin kuin Paavali ja juutalaiset opettajat Jeesus puhui ja taisteli naisten tasa-arvon puolesta.

Tällainen näkemys ei ole täysin perusteeton. Silti se perustuu helposti viholliskuviin, joita myös raamatuntutkijat ovat pitkään viljelleet. Jeesuksen ajan juutalaisuus esitetään mahdollisimman synkin värein, jotta Jeesuksen erinomaisuus kirkastuisi.

Viholliskuvat perustuvat kuitenkin usein väärään tai yksipuoliseen tietoon. On esimerkiksi totta, että muuan juutalainen rabbi on sanonut, ettei naisille saa opettaa lakia. On kuitenkin muistettava, että tämä lausuma on vain yksittäinen toteamus, joka sitä paitsi lienee myöhemmältä ajalta kuin evankeliumit. Se ei siis välttämättä heijasta Jeesuksen ajan tyypillistä suhtautumista naisiin. Lausuma ei myöskään kuvaa koko juutalaista naiskäsitystä. Rabbiininen kirjallisuus tuntee myös esimerkiksi merkittävien lainopettajien vaimoja, jotka selvästikin tunsivat tooran ja tulkitsivat sitä.

Pohdittaessa Jeesuksen suhtautumista naisiin on yleensä lähdetty liikkeelle Jeesuksen toiminnasta ja yleisestä suhtautumistavasta naisia kohtaan. Selvästi vähemmän on mietitty, mikä asema naisella on Jeesuksen opetuksissa, eikä ihme, sillä aineistoa on suhteellisen niukasti. Silti juuri Jeesuksen opetuksiin liittyy kiinnostavia kysymyksiä. Pyrkikö Jeesus määrätietoisesti vaikuttamaan naisen asemaan omana aikanaan? Oliko hänellä valmista sosiaalipoliittista ohjelmaa tasa-arvosta vai pitääkö tällainen lukea vain "rivien välistä"?

\section{Naiset Jeesuksen vertauksissa}

Evankeliumeissa muutamat Jeesuksen vertaukset muodostavat parin, jonka ensimmäisessä osassa kuvataan miehen toimintaa, jälkimmäisessä naisen. Jeesuksen elämästä kertovaan aineistoon liittyy kuitenkin lähdeongelmia. Varhaisimmatkin evankeliumit ovat syntyneet vasta 40 vuotta Jeesuksen kuoleman jälkeen. Tällä välin kertomuksiin ovat vaikuttaneet niiden seurakuntien ihanteet, joissa kertomukset ovat säilyneet tai syntyneet. Eri evankeliumit antavat Jeesuksesta erilaisen kuvan poiketen toisistaan milloin pienehköissä yksityiskohdissa, milloin suuremmissa linjoissa. 
Tällaisia ongelmia heijastelee vertaus kadonneesta kolikosta, jota nainen etsii (Luuk. 15:8-10). Luukkaan evankeliumissa se seuraa vertausta kadonneesta lampaasta, jonka mies lopulta löytää (Luuk. 15:47). Vertauksia voidaan pitää parina, sillä molemmissa vertauksissa korostetaan löytämisen aiheuttamaa riemua lähes samoilla sanoilla. Vertaukset päättyvät samaan sovellutukseen: näin riemuitaan myös taivaassa parannuksen tehneestä syntisestä.

Vertauksen kadonneesta lampaasta Luukas on saanut Jeesuksen puheiden kokoelmasta, jota myös Matteus on käyttänyt (Matt. 18:1214). Vain Luukas puhuu tässä yhteydessä ystävien kutsumisesta ja "parannuksesta." Vertaus kadonneesta kolikosta ei kuitenkaan kuulunut Luukkaan käyttämään lähteeseen. Tämän vertauksen yhteydet edelliseen selittyvät parhaiten siten, että Luukas on luonut jälkimmäisen vertauksen edellisen pariksi.

Mainitussa Matteuksen ja Luukkaan käyttämässä lähteessä on kuitenkin ollut yksi kaksoisvertaus, jossa miehisen vertauskuvan rinnalle tulee kuva naisen maailmasta: mies istuttaa sinapinsiemenen, nainen laittaa taikinaan hapatteen (Matt. 13:31-33; Luuk. 13:18-21). Vertauksessa ei tosin ole edes kyse naisen asemasta, vaan Jumalan valtakunnan salatusta leviämisestä. Voidaan kuitenkin ajatella, että Jeesus saattoi käyttää kuvia naisen arkipäivästä siinä missä miehenkin - jos vertaus todella on peräisin Jeesukselta. Ei nimittäin ole varmaa, muodostavatko nämäkään vertaukset alkuperäisen parin. Markuksella vertaus sinapinsiemenestä esiintyy yksinään (Mark. 4:30-32) ja Tuomaan evankeliumissa parin osat esiintyvät erillään toisistaan (Tuom. ev. 20 ja 96).

Muutamissa vertauksissa käytetään hyväksi mielikuvaa naisen asemasta. Vertauksessa väärämielisestä tuomarista (Luuk. 18:2-5) itsepintainen leski saa taivutettua tuomarin hoitamaan asiansa. Tutkijat ovat eri mieltä siitä, onko tämä vertaus peräisin Jeesukselta vai onko Luukas luonut sen.

Joka tapauksessa naisen, tässä tapauksessa lesken, huonoa asemaa käytetään vertauksessa tarvittavan vastakohdan luomiseen. Tuomari on hyvässä asemassa eikä pelkää Jumalaa: näin hänellä ei ole syytä pelätä, että hänen laiminlyöntinsä tuomittaisiin. Leski taas kuului aikansa alimpiin sosiaaliluokkiin. Naisen elatus perustui tuon ajan yhteiskun- 
nassa ensi sijassa miehen tuloihin, joten leskeksi joutuminen tarkoitti lähes säännöllisesti varattomuutta.

Kertomuksen tuomari kuvaa lesken hänelle aiheuttamaa vaivaa jopa huvittavin sanakääntein. Uuden Kirkkoraamatun mukaan tuomari sanoo: "Minä autan häntä saamaan oikeuden, muuten hän ennen pitkää repii minulta silmät päästä.” Tämä kielikuva on valittu ehkä siksi, että sitä käytetään lähinnä riitelevistä naisista. Harvemmin ainakaan kuulee puhuttavan miehistä, jotka aikoisivat "repiä silmät toistensa päästä"!

Uusi käännös pelaa perinteisillä mielikuvilla naisellisesta käyttäytymisestä - ehkä tarpeettomastikin, sillä samalla osa tuomarin ironiasta katoaa. Kreikkalaisen alkutekstin voisi kääntää nimittäin sanatarkasti näin: "Autan häntä saamaan oikeutensa, ettei hän lopulta tulisi ja vetäisi minua turpiin."

Naisen, tässä tapauksessa lesken, asemaan vertauksessa ei oteta kantaa. Leski ei ole esimerkki sen enempää kuin tuomarikaan. Kaikki huomio keskittyy sovellutukseen: jos väärämielinen tuomarikin lopulta taipuu lesken alituisiin pyyntöihin, sitä suuremmalla syyllä Jumala tuomarina kuulee omiensa pyynnöt ja kostaa heidän puolestaan - ja viipymättä toisin kuin tuomari, joka toimii vasta pitkän ajan kuluttua.

Vertauksessa tyhmistä ja viisaista neitsyistä (Matt. 25:1-13) käsitellään selvästi myöhemmän ajan ongelmia, joita Jeesuksen takaisinpaluun viivästyminen aiheutti (vrt. j. 5: "Kun sulhanen viipyi..."). Jeesuksen naiskäsityksestä ei siis tämän vertauksen kohdalla voi puhua.

Evankeliumeissa kerrotut Jeesuksen vertaukset eivät paljasta kovinkaan paljoa siitä, mitä Jeesus ajatteli naisista. Tähän ovat syynä lähteisiin liittyvät ongelmat, mutta myös vertausten luonne: ne palvelevat sovellutusta, eikä niihin sisälly suoraa opetusta esimerkiksi naisen asemasta. Jotta kuulijat ymmärtäisivät vertauksia, esimerkit väistämättä perustuvat vanhoihin kaavoihin. Näin vertaukset ovat pakostakin aina jossain määrin "vanhoillisia." 


\section{Naiset Jeesuksen muissa opetuksissa}

Jeesus ei näytä missään antavan selkeitä ohjeita, jotka koskisivat vain tai ennen kaikkea naisia. Esimerkiksi aina kun Vuorisaarnassa - joka on tosin Matteuksen toimittama Jeesuksen puheiden kokoelma - viitataan "kuulijoiden" sukupuoleen, puhutaan miehistä. "Jokainen joka katsoo naista niin, että alkaa himoita häntä, on sydämessään jo tehnyt aviorikoksen hänen kanssaan” (Matt. 5:28).

Joitain vihjeitä voi kuitenkin saada siitä, miten Jeesuksen kerrotaan suhtautuneen avioeroon. Tätäkin kysymystä eri evankelistat kuvaavat hieman eri tavoin. Joka tapauksessa Jeesus näyttää vaatineen avioliiton säilyttämistä. Tämän opetuksen varhaisin versio on kirjattu kuitenkin jälleen pelkästään miehen näkökulmasta: "Jokainen, joka hylkää vaimonsa ja nai toisen, tekee aviorikoksen, ja samoin tekee aviorikoksen se, joka nai miehensä hylkäämän naisen" (Luuk. 16:18). Matteus lieventää tätä lausumaa lisäämällä: "muun syyn kuin haureuden tähden" ja toteaa hieman oudosti: "ajaa hänet (ts. vaimon) aviorikokseen" (Matt. 5:32).

Vain Markus puhuu myös tässä yhteydessä naisen toiminnasta: ”Ja jos vaimo hylkää miehensä ja menee naimisiin toisen kanssa, hänkin tekee aviorikoksen” (Mark. 10:12). Erot eivät johdu siitä, että Jeesus olisi opettanut eri yhteyksissä eri tavoin. Markuksen esittämä lausuma on ilmeisesti Jeesuksen sanoista tehty sovellutus uudenlaisessa kulttuuriympäristössä, jossa nainenkin saattoi ottaa avioeron. Tosin juutalaisessakin maailmassa tämä oli tietyin edellytyksin mahdollista. Tällaisia edellytyksiä olivat esimerkiksi se, ettei mies kyennyt elättämään vaimoaan tai että mies joutui jostain syystä olemaan pitkään erossa vaimostaan.

Vastakohta Jeesuksen ja paatuneiden juutalaisten välillä, jotka voivat noin vain jättää vaimolleen erokirjan, sopii varmasti evankelistojen korostuksiin. Väärien viholliskuvien välttämiseksi on kuitenkin korostettava, että myös monet juutalaiset rabbit korostivat avioliiton purkamattomuutta.

Toisaalta evankeliumeissa on säilynyt varsin jyrkkiä kielteisiä kannanottoja perheeseen. Markus kertoo, kuinka Jeesus torjui perheensä, samalla myös äitinsä (Mark. 3:31-35): "Se joka tekee Jumalan tahdon, on minun veljeni ja sisareni ja äitini." Kertomus voi heijastella 
Jeesuksen todellista suhdetta perheeseensä, sillä tällaista kertomusta olisi tuskin voitu luoda aivan tyhjästä. Sama pätee Jeesuksen jyrkkiin sanoihin: "Luuletteko, että ole tullut tuomaan maan päälle rauhaa? En suinkaan, vaan riitaa! Tästedes saman perheen jäsenet ovat eri puolta: viidestä on kolme kahta, kaksi kolmea vastaan. Isä joutuu vastakkain poikansa kanssa, poika isänsä, äiti tyttärensä ja tytär äitinsä, anoppi miniänsä ja miniä anoppinsa kanssa.” (Luuk. 12:51-53; vrt. Matt. 10:34-36) Tai: "Jos joku tulee minun luokseni mutta ei ole valmis luopumaan isästään ja äidistään, vaimostaan ja lapsistaan, veljistään ja sisaristaan, vieläpä omasta elämästään, hän ei voi olla minun opetuslapseni." (Luuk. 14:26-27; vrt. Matt. 10:37-38, jossa "rakastaa enemmän on myöhempi lievennys; Luukas puhuu oikeastaan "vihaamisesta"). Voi tietenkin kysyä, miten tällainen opetus sopii yhteen Jeesuksen opetukseen avioerosta.

Johanneksen evankeliumissa naiset ovat keskeisemmässä asemassa opetuksen kohteina. Samarialainen nainen (Joh 4) ja Martta (Joh 11) esitetään Jeesuksen keskustelukumppaneiksi (kertomus avionrikkojanaisesta, Joh 7:53-8:11, on lisätty evankeliumiin myöhemmin). Näiden yhteydessä voi kiinnittää huomiota ensinnäkin siihen, että naisille varataan Johanneksen evankeliumissa oikeus samaan kuin miehillekin: väärinkäsityksiin (vrt. Joh 3 ja 14). Jeesus puhuu tasapuolisesti niin miesten kuin naistenkin ohi. Toiseksi varsinkin Jeesus ja Martta keskustelevat selvästi teologisista aiheista, tässä tapauksessa ylösnousemuksesta (Joh 11:23-27). Tällainen esitystapa tulee lähelle gnostilaisia evankeliumeja, joissa Jeesuksen ja Magdalan Marian keskustelut ovat usein keskeisiä.

Johanneksen evankeliumin keskustelut eivät kuitenkaan paljasta kovinkaan paljoa Jeesuksesta naisten opettajana, sillä tällaisia laajoja opillisia keskusteluja pidetään yleisesti Johanneksen evankeliumin kirjoittajan (kirjoittajien) kirjallisina luomuksina. 


\section{Nainen esikuvana}

Evankeliumeissa on runsaasti kertomuksia, joissa naisen toiminnasta tehdään esikuva. Ehkä malliesimerkki tästä on kertomus lesken rovosta (Mark. 12:41-44). Jeesuksen kerrotaan myös puolustaneen naista, joka voiteli hänet ennen ristinkuolemaa (Mark. 14:3-9 par.). Mahdollisesti juuri tähän kertomukseen perustuu Luukkaan tarina Jeesuksesta ja syntisestä naisesta, joka päättyy sanoihin: "Hän sai paljot syntinsä anteeksi, sillä hän rakasti paljon" (Luuk. 7:47; uuden kirkkoraamatun käännös "sen vuoksi” on väärä). Foinikialainen nainen ei puolestaan tyydy siihen, ettei Jeesus suostu parantamaan hänen tytärtään. Hänen viisas vastauksensa saa jopa Jeesuksen muuttamaan mieltään! (Mark. 7:24-30) Martan sisko Maria taas on Jeesuksen sanoja kuunnellessaan valinnut hyvän osan (Luuk. 10:38-42).

Tällaisissa kertomuksissa Jeesuksen sanan avulla korostetaan naisen toiminnan esikuvallisuutta. Tutkijat ovat kuitenkin eri mieltä siitä, kuinka paljon näissä esimerkkikertomuksissa on historiallista ydintä. Ilmeistä on nimittäin se, että yksinkertaisemmat kertomukset (esimerkiksi pelkistetyt parantamiskertomukset) ovat usein vasta myöhemmin kehittyneet esimerkkikertomuksiksi.

\section{Yhteenveto}

Olen edellä keskittynyt Jeesuksen opetuksiin. Näkökulma on tietenkin varsin yksipuolinen, eikä se sellaisenaan paljasta, mitä Jeesus ajatteli naisista. Minusta näyttää jopa siltä, etteivät evankeliumeissa kuvatut Jeesuksen opetukset ole tasapainossa Jeesuksen toiminnan kuvauksen kanssa. Jeesuksen toiminnan perusteella hänestä voisi piirtää paljon rohkeamman kuvan kuin opetuksista käsin. Eri evankeliumeissa Jeesus kuvataan syntisten ja sorrettujen ystäväksi, joka ei kaihtanut huonomaineistenkaan naisten seuraa.

On helpompaa todeta tällainen epäsuhta kuin selittää, mistä se johtuu. Alettiinko Jeesuksen myönteistä suhdetta naisiin korostaa vasta siinä vaiheessa, kun tarinat Jeesuksesta levisivät uusiin piireihin, joissa naisilla oli parempi asema? Vai sensuroitiinko Jeesuksen naisille 
kohdistettuja opetuksia ennen evankeliumien syntymistä? Vai eivätkö Jeesuksen opetukset ja toiminta yksinkertaisesti vain muodostaneet tällä kohtaa johdonmukaista kokonaisuutta? Kaikki nämä vaihtoehdot ovat käsittääkseni historiallisesti mahdollisia.

Ainakaan Raamatun evankeliumien välittämän kuvan perusteella Jeesus ei opettaessaan poikennut kovinkaan paljon oman aikansa "patriarkaalisista" peruslähtökohdista: käytännöllisiin kysymyksiin (esimerkiksi avioeroon) syvennytään miehen näkökulmasta. Missään ei kerrota, että Jeesus olisi vaatinut selviä muutoksia naisen asemaan.

Toisaalta missään Jeesuksen ei kerrota suhtautuneen naisiin torjuvasti vain siksi, että he olivat naisia, tai että Jeesus olisi esittänyt naista summittaisesti halventavia arvioita tai edes varoituksia pahoista naisista (kuten Sananlaskuissa). Tämän perusteella ei kuitenkaan voi päätellä kovinkaan paljoa, sillä lähteet ovat vaikenevia lähteitä. 


\section{Martta ja Maria Uudessa testamentissa}

(1992)

Ainoa Uudessa testamentissa nimeltä tunnettu sisaruspari, Martta ja Maria, mainitaan sekä Luukkaan että Johanneksen evankeliumeissa. Näistä kahdesta kertomuksesta lienee tutumpi Luukkaan lyhyt kertomus (Luuk. 10:38-42), jossa Martta kutsuu Jeesuksen kotiinsa ja palvelee häntä. Luukkaan kertomuksessa Martta närkästyy sisareensa Mariaan, joka sen sijaan, että auttaisi siskoaan kotitaloustöissä, istuu Jeesuksen jalkojen juuressa kuunnellen opettajansa sanoja. Kun Martta huomauttaa asiasta Jeesukselle, Jeesus vastaa: "Martta, Martta, moninaisista sinä huolehdit ja murehdit, mutta tarpeellisia on vain (vähän tai) ${ }^{1}$ yksi ainoa. Maria on valinnut hyvän osan, jota häneltä ei oteta pois." Tämän jälkeen sisaruksia ei enää mainita Luukkaan evankeliumissa.

Johanneksen evankeliumissa Martta ja Maria esiintyvät kertomuksessa Lasaruksen kuolleista herättämisestä (Joh. 11:1-46) eli aivan toisessa yhteydessä kuin Luukkaalla. Johanneksen evankeliumissa kerrotaan myös, kuinka Jeesukselle valmistettiin Martan ja Marian kotona ateria, jonka yhteydessä Maria voiteli Jeesuksen jalat (Joh. 12:18).

\footnotetext{
${ }^{1}$ Sanat "vähän tai" esiintyvät vanhassa (1938) mutta eivät uudessa (1992) Kirkkoraamatussa. Sanojen pois jättämistä pohditaan tässä artikkelissa tuonnempana tarkemmin.
} 
Vaikka Uuden testamentin kertomukset antavat varsin vähän tietoa Martasta ja Mariasta, on heitä 200-luvulta jKr. alettu pitää kahden erilaisen kristillisen elämäntavan esikuvina. Kirkkoisä Origeneelta (n. 185-252) on peräisin tulkinta, jonka mukaan Martta on toimivan, aktiivisen elämän (vita activa) vertauskuva, kun taas Maria edustaa hiljaista, mietiskelevää elämäntapaa (vita contemplativa). ${ }^{2}$ Erityisesti Luukkaan kertomuksen Martasta ja Mariasta on nähty viittaavan siihen, että vaikka "aktiivinen" elämä onkin tärkeää, loppujen lopuksi on arvokkainta mietiskelevä kristillisyys, jossa maalliset murheet on jätetty toisten surtaviksi. Vaikka tämä vertauskuvallinen tulkinta onkin Origeneesta lähtien ollut yleinen kirkollisessa Raamatun selityksessä, se tuskin tekee oikeutta Uuden testamentin antamalle kuvalle Martasta ja Mariasta. Pyrin seuraavassa lähestymään aihetta siitä käsin, miten Luukas ja Johannes kuvaavat tätä sisarusparia ja mitä he kuvauksensa avulla haluavat sanoa. Koska näiden kahden evankeliumin kertomukset poikkeavat toisistaan huomattavasti, käsittelen ne aluksi erikseen.

\section{Murehtia vai kuunnella? (Luuk. 10:38-42)}

Luukkaan lyhyen Martta ja Maria -kertomuksen tulkintaan sisältyy tiettyjä vaikeuksia. On selvää, että kertomuksen ydin on Jeesuksen sanoissa Martalle (j. 41-42). Juuri näihin sanoihin kuitenkin liittyy eräs kertomuksen keskeisimmistä ongelmista: mitä Jeesus itse asiassa Luukkaan mukaan sanoo Martalle? Uuden testamentin vanhimmat käsikirjoitukset poikkeavat tällä kohtaa toisistaan. Eri lukutapoja on kaiken kaikkiaan seitsemän, joista seuraavassa esitellään suomennettuina neljä tärkeintä. ${ }^{3}$

\footnotetext{
${ }^{2}$ Origenes, Fragmentti Luukkaan evankeliumiin 39. GCS 9, 298. Origenes piti mahdollisena myös myöhemmin vähemmälle huomiolle jäänyttä tulkintaa, jonka mukaan Martan hahmo kuvaa tekoihin keskittyvää juutalaiskristittyä ja Maria pakanakristittyä, jolle tärkeintä tekojen tekemisen sijasta on Jeesuksen sanojen kuunteleminen.

3 Jaottelu neljään pääryhmään perustuu Silvolan 1987, 235-236 esittämään luetteloon. Käännökset noudattelevat Raamatunkäännöskomitean Luukkaan evankeliumin suomennosta.
} 
1. "Martta, Martta, Maria on valinnut hyvän osan, eikä sitä oteta häneltä pois."

2. "Martta, Martta, sinä huolehdit ja hätäilet niin monista asioista, mutta vain vähän on tarpeen. Maria on valinnut..."

3. "Martta, Martta, sinä huolehdit ja hätäilet niin monista asioista. Vain yksi on tarpeen. Maria on valinnut..."

4. "Martta, Martta, sinä hätäilet ja huolehdit niin monista asioista, mutta vain vähän tai yksi ainoa on tarpeen. Maria on valinnut..."

Näistä vaihtoehdoista kaksi ensimmäistä eivät voi olla alkuperäisiä, sillä ne eivät esiinny vanhimmissa Uuden testamentin käsikirjoituksissa. Tutkijat ovat sen sijaan eri mieltä siitä, kumpi kahdesta viimeksi mainitusta vaihtoehdosta on alkuperäisempi, mikä näkyy myös siinä, että vanha (1938) ja uusi (1992) Kirkkoraamattu poikkeavat tällä kohtaa toisistaan. ${ }^{4}$ Vaihtoehdoissa ei ole kysymys ainoastaan jonkun sanan pois jättämisestä tai lisäämisestä, vaan valitun vaihtoehdon mukaan Jeesuksen sanojen painopiste muuttuu. Jos lukutapa 4 olisi alkuperäinen, Jeesuksen sanat voitaisiin tulkita Martan turhan innokkaan kestiystävällisyyden lempeäksi moitteeksi. Tämän vaihtoehdon perusteella on ajateltu, että Jeesus viittaisi sanoillaan ruokalajien määrään: Vain muutama tai ehkäpä vain yksi laji riittää, eikä Marian sen takia tarvitse lähteä auttamaan sisartaan aterian valmisteluissa. ${ }^{5}$

Tässä artikkelissa käytän tulkinnan lähtökohtana lukutapaa 3, jota hyvällä syyllä voi pitää alkuperäisimpänä lukutapana. ${ }^{6}$ Tämän lukutavan perusteella Jeesuksen sanat sisältävät terävän moitteen Martalle, joka mahdollisuuksiensa mukaan haluaa huolehtia arvostamastaan vieraasta.

\footnotetext{
${ }^{4}$ Vuoden 1938 käännös perustuu vaihtoehtoon 4, vuoden 1992 käännös vaihtoehtoon 3. (Teksti on tältä osin muokattu vastaamaan nykyistä terminologiaa. Alkuperäisessä artikkelissa puhuttiin tässä kohtaa "Kirkkoraamatusta" ja "Raamatunkäännöskomitean ehdotuksesta.")

${ }^{5}$ Tämän lukutavan alkuperäisyyttä on viimeksi puolustanut Silvola 1987, 238.

${ }^{6}$ Tämä lukutapa on lyhin, ulkoisesti parhaiten tuettu ja vaikein. Perusteluista ks. tarkemmin Baker 1965, 136-137 ja erityisesti Brutscheck 1986, 11-12.
} 
Martan monenlaisen hyvää tarkoittavan puuhailun vastapainoksi tulevat sanat: "Vain yksi on tarpeen."

Jako monenlaisten asioiden ja yhden tärkeän välillä esiintyy muuallakin Luukkaan evankeliumissa. Jeesus kehottaa rikasta nuorukaista, joka sanoo noudattaneensa lakia viimeistä piirtoa myöten, myymään koko omaisuutensa alkaen sanoilla: "Yksi sinulta vielä puuttuu" (Luuk. 18:22). Myös vertaukseen rikkaasta miehestä, joka päätti rakentaa isomman aitan saadakseen kaiken omaisuutensa mahtumaan saman katon alle (Luuk. 12:12-21), sisältyy sama perusajatus. Rikas mies huolehtii monista tärkeistä asioista, mutta rivien välistä voi lukea, että hän on unohtanut "yhden tarpeellisen", sillä vertaus loppuu miehelle osoitettuihin sanoihin: "Sinä hullu! Tänä yönä sinun elämäsi vaaditaan sinulta takaisin. Ja kaikki, minkä olet itsellesi varannut kenelle se joutuu?" (j. 20) Kertomuksessa Martasta ja Mariasta ei ole kyse rikkauden vaaroista, mutta perusasetelma on sama. Palvelemisella ei ole pysyvää luonnetta sen paremmin kuin rikkaudellakaan, vaan ainoastaan Jeesuksen sanojen kuuntelemisella. ${ }^{7}$

Asettaako Luukkaan kertomus lähimmäisen palvelemisen vähäpätöiseen asemaan? Onko kertomuksessa kyse, kuten vanhan kirkon selittäjien tulkinnasta voisi päätellä, toimivan kristillisyyden halveksimisesta ja mietiskelevän kristillisyyden arvostamisesta? Tällaisesta vastakohta-asettelusta kertomuksessa tuskin on kyse. Itäsaksalainen tutkija Jutta Brutscheck, joka on tehnyt perusteellisen monografian Martasta ja Mariasta Luukkaan evankeliumista, toteaa, ettei kertomuksessa aseteta vastakkain palvelemista ja kuuntelemista, vaan murehtiminen ja kuunteleminen. Jeesuksen moite ei Luukkaan kertomuksessa kohdistu siihen, että Martta uhraa aikaansa palvelemiseen, vaan siihen, että Martta huolehtii ja hätäilee monista asioista. ${ }^{8}$ Kertomuksen keskeinen sisältö muistuttaa näin Luukkaan evankeliumissa myöhemmin esiintyviä kehotuksia Jeesuksen opetuslapsille:

\footnotetext{
${ }^{7}$ Se, että kertomuksen keskeinen opetus sopii saumattomasti Luukkaan kokonaisteologiaan, asettaa kyseenalaiseksi Bultmannin $(1970,33)$ esittämän kertomuksen muodon määrittelyn evankelistan traditiosta saamaksi biografiseksi apofthegmaksi.

${ }^{8}$ Brutscheck 1986, 47-48.
} 
Sen tähden minä sanon teille: Älkää murehtiko hengestänne, mitä söisitte, älkääkä ruumiistanne, mitä päällenne pukisitte. Sillä henki on enemmän kuin ruoka ja ruumis enemmän kuin vaatteet. ... Ja kuka teistä voi murehtimisellaan lisätä ikäänsä kyynäränkään vertaa? ... Älkää siis tekään etsikö, mitä söisitte ja mitä joisitte, älkääkä korkeita tavoitelko. Sillä näitä kaikkia pakanakansat tavoittelevat; mutta teidän Isänne kyllä tietää teidän niitä tarvitsevan." (Luuk. 12:22-23, 25, 29-30; vrt. Matt. 7:25-32.)

Koska Jeesuksen Martalle antama ohje murehtimisen välttämisestä näyttää liittyvän Luukkaan kenttäsaarnassa esiintyviin kehotuksiin, ${ }^{9}$ voi näistä kehotuksista etsiä lisävalaistusta myös siihen, mitä Martta ja Maria -kertomuksessa esiintyvä "hyvä osa" Luukkaan kokonaisesityksessä mahdollisesti tarkoittaa. Kenttäsaarnan ohjeissa tavallisista asioista murehtimisen vastapainoksi asetetaan jälleen yksi tärkeä: "Vaan etsikää ensin Jumalan valtakuntaa, niin myös nämä teille annetaan sen ohessa" (Luuk. 12:31; vrt. Matt. 7:33). Marian hyvää osaa voi pitää "Jumalan valtakunnan etsimisenä”, jonka tunnusmerkkinä on Jeesuksen sanojen kuunteleminen kaiken muun huolehtimisen ja murehtimisen sijaan.

Myös se yhteys, johon Luukas sijoittaa kertomuksen Martasta ja Mariasta, vaikuttaa kertomuksen ymmärtämiseen. Kertomusta edeltää vertaus laupiaasta samarialaisesta (Luuk. 10:30-37), esimerkki lähimmäisen auttamisen tärkeydestä. Eräät raamatunselittäjät ovat sitä mieltä, että kertomus Martasta ja Mariasta muodostaa vastaparin tämän Jeesuksen vertauksen kanssa. On jopa esitetty, että vertaus laupiaasta samarialaisesta havainnollistaa rakkauden kaksoiskäskyn jälkimmäistä osaa, kun taas kertomus Martasta ja Mariasta kuvaa samaisen kaksoiskäskyn ensimmäisen osan noudattamisen tärkeyttä palvelemiseen verrattuna. ${ }^{10}$ Tämä tulkinta asettaa kuitenkin vertauksen laupiaasta samarialaisesta ja Martta ja Maria -kertomuksen väärälä tavalla vastakkain. On epätodennäköistä, että asia, jota vertaus laupiaasta

\footnotetext{
9 Huomionarvoinen yksityiskohta tässä yhteydessä on, että huolehtimista tarkoittavaa verbiä $\mu \varepsilon \rho \iota \nu \tilde{a} \nu$ käytetään Luukaan evankeliumissa Martta ja Maria -kertomuksen ohella (10:41) ainoastaan Kenttäsaarnaan kuuluvissa kehotuksissa (12:11, 22, 25, 26). Matteuksessa samaa verbiä käytetään mainittujen Kenttäsaarnan kohtien rinnakkaiskohdassa kuudesti (Matt. 6:25, 27, 28, 31, 34 [2x]) sekä näiden kohtien ulkopuolella kerran (10:19).

${ }^{10}$ Näin esim. Hendriksen 1983, 597.
} 
samarialaisesta korostaa, mitätöitäisiin tai edes asetettaisiin epäsuotuisaan valoon heti seuraavassa kertomuksessa. Asianmukaisempi tulkinta näiden kahden kertomusten välisistä suhteista lienee, että vertaus laupiaasta samarialaisesta osoittaa, miten Jeesus tulkitsee rakkauden käskyn (Luuk. 10:27). Kertomus Martasta ja Mariasta puolestaan painottaa, ettei mikään ole tärkeämpää kuin kuunnella tätä Jeesuksen opetusta. ${ }^{11}$ Koska Luukkaan esitys jatkuu sarjalla Jeesuksen opetuksia opetuslapsilleen (Luuk. 11:1-13), on mahdollista myös, että Jeesuksen opetuksen kuuntelemisen painotus Martta ja Maria -kertomuksessa liittyy ennen kaikkea jatkossa seuraavaan opetukseen.

Se, miten Luukkaan evankeliumissa yleensä puhutaan Jeesuksen sanojen kuulemisesta, osoittaa, ettei Mariaa Luukkaan kertomuksen perusteella voi pitää perinteisessä mielessä "mietiskelevän" elämän esikuvana. Luukkaalla sanojen kuulemiseen liittyy johdonmukaisesti myös sanojen toteuttaminen (esim. Luuk. 8:15, 21). Erityisen selkeästi tämä korostus näkyy Luukkaan kertomuksessa Jeesuksen ja Sakkeuksen kohtaamisesta (Luuk. 19:1-9). Sakkeus tottelee Jeesuksen sanoja (j. 5), mistä automaattisesti näyttää seuraavan lähimmäisen palveleminen ja väärinkäytösten korjaaminen (j. 8). Samaa asiaa korostaa myös Jeesuksen toteamus pian Martta ja Maria -kertomuksen jälkeen: "Autuaita ovat kaikki, jotka kuulevat Jumalan sanan ja noudattavat sitä" (Luuk. 11:28). Jeesuksen sanojen kuuleminen ei merkitse Luukkaan evankeliumissa muusta maailmasta eristäytyvää hartauden harjoittamista, vaan pikemminkin käytännön toiminnassa toteutuvaa hartautta. ${ }^{12}$

On perusteltua kysyä, minkälaista kuvaa naisen roolista Luukkaan Martta ja Maria -kertomus edustaa. Valmistaessaan aterian arvostetulle vieraalle Martta näyttää täyttävän roolin, jota naiselta tuon ajan yhteiskunnassa perinteisesti oli odotettu. Vanhassa testamentissa esiintyvässä "kelpo vaimon ylistyksessä" (Sananl. 31:10-29) vaimon

\footnotetext{
${ }^{11}$ Brutscheck 1986, 54. Nikolainen $(1980,214)$ pitää molempien kertomusten yhteisenä johtoajatuksena "keskittymistä tärkeimpään.” Tämä tulkinta ei tosin aseta kertomuksia vastakkain, mutta ongelmaksi jää kertomusten erilainen painopiste. Jos molemmat kertomukset keskittyvät tärkeimpään, antavat ne tästä "tärkeimmästä" asiasta toisistaan selvästi poikkeavan kuvan.

${ }^{12}$ Fitzmyer 1981, 893.
} 
hyviksi ominaisuuksiksi tosin mainitaan "viisauden sanat" ja "lempeä opetus" (j. 26), mutta samassa jaksossa muuten keskitytään erilaisten kotitaloustöiden luettelemiseen. Naisen esimerkillistä vieraanvaraisuutta Jumalan miestä kohtaan korostaa erityisesti Vanhan testamentin kertomus, jossa Elisa herättää sunemilaisen naisen pojan (2. Kun. 4:837). Sen lisäksi, että nainen kutsuu Elisan taloonsa aterioimaan, pyytää hän miestään rakennuttamaan Elisalle yläkerran huoneen, jonka sisustus on ylellinen. ${ }^{13}$ Naisen osoittamaa vieraanvaraisuutta arvostetaan selvästi, sillä Elisa lupaa eräänlaisena Jumalan miehen vastalahjana lapsettomalle naiselle pojan (j. 13-17). ${ }^{14}$ Tämä kertomus lienee ollut pohjana juutalaisten rabbien opetukselle, jonka mukaan nainen ymmärtää vieraiden huolehtimisesta paremmin kuin mies. ${ }^{15}$ Osoittaessaan vieraanvaraisuutta Martta siis toteuttaa oman aikansa näkökulmasta katsottuna juuri sitä tehtävää, jota naiselta oli totuttu odottamaan.

Maria puolestaan näyttää rikkovan perinteisiä odotuksia Luukkaan kertomuksessa asettumalla Jeesuksen jalkojen juureen ja kuuntelemalla Jeesuksen sanoja. Tässä yhteydessä on otettava huomioon se, että Luukkaalla sanonta "istua/olla jonkun jalkojen juuressa" kuvaa ensisijaisesti oppilaan suhdetta opettajaansa. Sama ilmaisu esiintyy Luukkaan historiateoksen jälkimmäisessä osassa, kun Paavalin kerrotaan olleen tunnetun rabbi Gamalielin oppilas: ”... ja Gamalielin jalkojen

\footnotetext{
${ }^{13}$ Vain sängyn, joka jo sinänsä oli ylellisyyttä aikana, jolloin tavalliset ihmiset nukkuivat paljaalla maalla (Würthwein 1984, 291), mainitseminen olisi tarpeen kertomuksen jatkon kannalta (j. 21, 33). Tämän lisäksi sunemilainen nainen kuitenkin ehdottaa miehelleen, että huoneeseen laitettaisiin myös tuoli, pöytä ja lamppu.

14 Kertomus Elisasta ja sunemilaisesta naisesta muistuttaa huomiota herättävän paljon kertomusta Jahven vierailusta Aabrahamin ja Saaran luona (1. Moos. 18:1-16) sekä mainintaa Iisakin syntymästä (1. Moos. 21:2) nimenomaan kertomuksissa esiintyvän jumalallista vierasta kohtaan osoitetun vieraanvaraisuuden suhteen. (Muista näitä kertomuksia yhdistävistä piirteistä ks. Van Seters 1975, 205). Selkeänä erona kuitenkin näiden kertomusten välillä kuitenkin on, että 1. Moos. 18:6-8 Aabraham on vieraanvaraisuuden varsinainen osoittaja. Saara ainoastaan noudattaa Aabrahamin antamia ohjeita (j. 6), kun taas sunemilaisnainen antaa vieraanvaraisuuteen liittyviä ohjeita miehelleen (2. Kun. 4:9-10). Se, että sunemilaisnaisen vieraanvaraisuutta korostetaan jaksossa 2. Kun. 4:8-37 erityisen painokkaalla tavalla, näkyy siinä, että vastaavanlaista korostusta ei esiinny kertomuksen (ilmeisesti varhaisemmassa) rinnakkaismuodossa 1. Kun 17:2-24, jossa sarpatilainen leski huolehtii Eliasta, koska Elia häntä niin käskee (j. 10, 13).

${ }^{15}$ Billerbeck 1983, 185.
} 
juuressa opetettu tarkkaan noudattamaan isien lakia.” (Ap.t. 22:3). Kertomuksessa Martasta ja Mariasta ilmaisu saa aivan erityisen painavuuden, sillä Jeesuksen aikana naisten opettamista ei pidetty sopivana. Mooseksen lain opiskelu oli itse asiassa kielletty naisilta jyrkin sanoin. ${ }^{16}$

Luukkaan kertomuksessa Martasta ja Mariasta naisiin kohdistuvia rooliodotuksia ei ainoastaan aseteta kyseenalaisiksi, vaan ne käännetään päälaelleen. Vastoin odotuksia tunnollinen emäntä saa nuhteet, joiden ydin on kärkevä: touhutessaan ja murehtiessaan Martta on unohtanut tärkeimmän. Oppilaasta, joka ei edes saisi olla oppilaana, sen sijaan sanotaan: "Maria on valinnut hyvän osan, jota häneltä ei oteta pois." Oppilaana oleminen eli Jeesuksen sanojen kuunteleminen on Luukkaan mukaan myös naiselle hyvä osa. Vaikka Luukas näyttää muualla korostavankin, että naisen tehtävänä on palvelu (esim. Luuk. 8:1-3), se ei ohita Jumalan sanan kuuntelemisen tärkeyttä. ${ }^{17}$ Luukkaan kertomuksessa esiintyvä Jeesuksen asenne on omana aikanaan ollut poikkeuksellisen ennakkoluuloton. Jyrkkää vastakohtaa oman ajan odotuksiin korostaa hyvälle emännälle kohdistettu moite. Tässä suhteessa Luukkaan kertomus Martasta ja Mariasta muistuttaa hetkeä aikaisemmin esitettyä vertausta, jossa halveksittu samarialainen kohotetaan "juutalaisen hurskauden virallisten edustajien" 18 yläpuolelle. Perinteiset juutalaisen yhteiskunnan rooliodotukset romutetaan molemmissa kertomuksissa. ${ }^{19}$

\footnotetext{
${ }^{16}$ Oepke 1933, 781-782.

${ }^{17}$ Vrt. Jervell 1983, 87.

${ }^{18}$ Nikolainen 1980, 213.

${ }^{19}$ Jervell (1983) korostaa sitä, kuinka Luukas historiateoksessaan jopa peittelee naisten suurta vaikutusta alkuseurakunnassa. Tämä piirre näyttää todella esiintyvän Apostolien teoissa, mutta siitä huolimatta on syytä kysyä (etenkin Luukkaan Martta ja Maria -kertomuksen pohjalta, jonka Jervell artikkelissaan sivuuttaa lähes kokonaan), onko Jervellin kuvaus Luukkaan naiskuvan tosiasiallisesta sovinnaisuudesta liian kärjistetty.
} 


\section{Martta, Maria ja Lasarus (Joh. 11:1-46; 12:1-8)}

Johanneksen evankeliumissa Martta ja Maria esiintyvät kertomuksessa Lasaruksen kuolleista herättämisestä. Tämän kertomuksen, joka ei esiinny muissa kanonisissa evankeliumeissa, ${ }^{20}$ asema on Johanneksen evankeliumissa keskeinen, sillä Lasaruksen herättämisestä muodostuu lopullinen syy, jonka perusteella ylipapit ja fariseukset päättävät surmata Jeesuksen (Joh. 11:47-53). Ihmekertomukseksi kertomus on suhteellisen pitkä ja keskeisen sijan siinä itse ihmeen rinnalla saavat Jeesuksen käymät keskustelut opetuslasten (11:7-16) ja Martan (j. 2127) kanssa. On todennäköistä, että kertomuksen nykyinen muoto perustuu varhaisempaan ihmekertomukseen, jonka painopiste on selvemmin ollut Lasaruksen herättämisessä.

Kertomuksen varhaisempien muotojen hahmottelemiseen ovat johtaneet kertomuksessa esiintyvät epäyhtenäisyydet ja sisäiset jännitteet. Ensinnäkin Jeesuksen itseilmoituksen (Joh. 11:25-26) tarkoituksena on osoittaa, että kuolema on tullut merkityksettömäksi sille, joka uskoo. Näin se on ristiriidassa itse kuolleistaherättämiskertomuksen kanssa, jossa kuolema kuvataan "aggressiiviseksi viholliseksi", jonka Jeesus lopulta voittaa. Toiseksi tietyt osat katkaisevat kertomuksen sujuvan etenemisen (esim. j. 2, 4, 16, 24-26, 40). Kolmanneksi kertomuksen sisältö on sisällöllisesti epäyhtenäinen. Toisaalta Lasaruksen kerrotaan olevan Martan ja Marian veli (j. 2, 19, 21, 23, 32, 39), toisaalta vain eräs mies Betaniasta, jonka suhde Marttaan ja Mariaan selittyy yhteisestä kotipaikkakunnasta Betaniasta (j. 1). ${ }^{21}$ Ilmeistä on, että kertomuksen nykyistä, niin kutsutun kirkollisen redaktorin toimittamaa lopullista muotoa edeltää ainakin kaksi varhaisempaa kirjallista kerrostumaa, tunnustekolähteen (semeia-

\footnotetext{
${ }^{20}$ Lasaruksen kuolleistaherättämiskertomusta muistuttaa läheisesti Clemens Aleksandrialaisen nimissä säilyneessä kirjeessä (suomennettuna ks. Lauha 1987a, 206-207) esiintyvä katkelma ns. Markuksen salaisesta evankeliumista, joka kuitenkin lienee Johanneksen evankeliumia myöhempi kooste, sillä se edellyttää tunnetuksi kaikki neljä evankeliumia (Lauha 1987b, 402-404).

${ }^{21}$ Becker 1979-81 (1991), 344.
} 
lähde) ja "evankelistan" teksti. ${ }^{22}$ Varhaisin kirjallinen muoto eli tunnustekolähteen versio kertomuksesta on mahdollisesti ollut seuraavanlainen: ${ }^{23}$

Oli eräs sairas, Lasarus Betaniasta, Martan ja Marian kylästä. Sisarukset lähettivät (viestinviejän) Jeesuksen luokse kutsuen häntä. Tästä kuultuaan Jeesus [sanoi: "Tämä tauti ei ole kuolemaksi." Sitten hän] jäi kahdeksi päiväksi siihen paikkaan, jossa oli. Sen jälkeen hän sanoi opetuslapsilleen: "Ystävämme Lasarus on nukkunut (pois), mutta minä [menen, jotta] herätän hänet. Lähtekäämme hänen luokseen."

Tultuaan Jeesus sai tietää (tai: löysi) hänen olevan [jo] neljättä päivää haudassa. Martta tuli häntä vastaan, mutta Maria istui kotona. Martta sanoi Jeesukselle: "[Herra,] jos olisit ollut täällä, Lasarus ei olisi kuollut." [Ja tämän sanottuaan] hän meni pois ja kutsui Mariaa [salaa] ja sanoi: "Opettaja on täällä.” Tämä nousi nopeasti ja meni hänen luokseen. Ne, jotka [olivat hänen kanssaan ja] lohduttivat häntä, seurasivat häntä.

Maria tuli sinne, missä Jeesus oli, ja polvistui. Jeesus näki hänet ja ne, jotka olivat seuranneet häntä, ja liikuttui hengessään ja itki. Ja hän sanoi: "Minne olette laittaneet hänet?" He sanoivat [hänelle]: "Tule ja katso!"

Siellä oli kallioluola ja sen suulla oli kivi. Jeesus sanoi: "Nostakaa kivi pois!" He nostivat kiven. Mutta Jeesus kohotti silmänsä ylös ja huusi suurella äänellä: "Lasarus, tänne, ulos!" Kuollut, jonka jalat oli sidottu ja kädet käärinliinoilla, ja hänen kasvojensa ympärillä oli hikiliina, tuli ulos. Jeesus sanoi heille: "Pästäkää hänet ja antakaa hänen mennä."

Tässä artikkelissa keskityn siihen, minkälaisen kuvan kertomus nykyisessä muodossaan antaa Martasta ja Mariasta. Kun Johanneksen evankeliumin kuvausta Martasta ja Mariasta verrataan Luukkaan kertomukseen, ensimmäinen uusi piirre on, että Johanneksen mukaan sisarukset asuvat Betaniassa, vajaan kolmen kilometrin ("viidentoista vakomitan”, Joh. 11:18) päässä Jerusalemista. Luukas ei mainitse

\footnotetext{
${ }^{22}$ Tämän etenkin Rudolf Bultmannin Johannes-kommentaarissaan tunnetuksi tekemän kirjallisuuskriittisen lähtökohdan perusteista ja tunnetuimmista edustajista ks. Becker 1979_ 81 (1991), 32-36.

23 Esitetty rekonstruktio perustuu pro gradu -tutkielmassani esittämääni ratkaisuun (Dunderberg 1987, 145). Kursivoidut kohdat eivät esiinny kertomuksen nykyisessä versiossa, mutta ovat voineet esiintyä lähteessä. Hakasulkeissa esiintyvät sanat voivat olla joko lähteestä tai evankelistalta peräisin. Tavallisissa suluissa olevat sanat on lisätty suomenkieliseen käännökseen selkeyden takia.
} 
Martan ja Marian kotikylää nimeltä, vaan kertoo ainoastaan, että Jeesus meni "muutamaan kylään" (Luuk. 10:38). Luukkaan kertomuskokonaisuudessa ei tällä kohtaa kuitenkaan voi kyseessä olla Jerusalemin lähellä oleva Betania, sillä Luukkaan esityksessä Jeesus on juuri hetkeä aiemmin vasta aloittanut matkansa Galileasta Jerusalemiin (Luuk. 9:51, 53). Luukkaan kertomuksessa Martasta ja Mariasta ei ole myöskään mainittu Lasarusta, josta Johanneksen evankeliumin toimitusvaiheiden myötä on lopulta tullut Martan ja Marian veli.

Kertomus Lasaruksen kuolleista herättämisestä poikkeaa tavallisesta ihmekertomuksesta, sillä itse ihme näyttää jäävän taka-alalle. Kertomuksen päähenkilönä Jeesuksen ohella ei olekaan kuolleista herätetty Lasarus, vaan Martta ja Maria. Jo kertomuksen alussa sisarukset toimivat keskeisessä roolissa kutsuessaan Jeesuksen apuun Lasaruksen sairastuttua vakavasti (Joh. 11:3). Kertomuksen edetessä varsinkin Martan rooli muuttuu yhä keskeisemmäksi. Kun Jeesus tulee Betaniaan, Martta rientää häntä vastaan Marian jäädessä kotiin istumaan (j. 20). Lisäksi kertomuksen nykyisen muodon painopiste on kuolleista herättämisen ohella ja jopa sijasta Jeesuksen ja Martan ylösnousemususkoa käsittelevässä keskustelussa, joka huipentuu Jeesuksen sanoihin: "Minä olen ylösnousemus ja elämä; joka uskoo minuun, se elää, vaikka olisi kuollut. Eikä yksikään, joka elää ja uskoo minuun, ikinä kuole. Uskotko sen?” (Joh. 11:25-26). Kuten Gérard Rochais on aiheellisesti todennut Martan roolista kertomuksessa, "evankelista ilmaisee teologista ajatteluaan Martan hahmon avulla." ${ }^{24}$

\footnotetext{
${ }^{24}$ Rochais 1981, 118. Tämän havainnon perusteella Rochais (1981, 118-121, 123) pyrkii osoittamaan, että Martan hahmo kertomuksessa on kokonaisuudessaan evankelistan tekemä lisäys tekstiin - mikä ei suinkaan automaattisesti seuraa siitä, että evankelista käyttää Martan hahmoa apuna tuodessaan esiin omia teologisia korostuksiansa - ja että evankelistan käyttämässä lähteessä Maria olisi esiintynyt yksinään. Ratkaisunsa tueksi Rochais esittää suppean sanastollisen analyysin, jossa ei kuitenkaan ole riittävällä tavalla otettu huomioon Johanneksen monikerroksisuutta, lähinnä sitä, että Johanneksen tekstiä on muokattu myös evankelistan jälkeen. Lisäksi Rochais joutuu turvautumaan kirjallisuuskriittisesti kyseenalaiseen ratkaisuun, että lähes kaikki myöhemmän lisäyksen tuntomerkit täyttävä Joh. 11:2 olisi peräisin lähteestä. Lopuksi on syytä huomauttaa, että Marian roolia korostava Joh. 11:45 sellaisena kuin Rochais sen rekonstruoimassaan lähteessä $(1981,123)$ esittää, ts. ilman mainintaa juutalaisista, sisältää jo pelkästään sanastollisesti evankelistan tekemän lisäyksen
} 
Jeesuksen sanoja ylösnousemuksesta ja elämästä edeltää keskustelu, jonka Martta aloittaa toteamalla, ettei Lasarus olisi kuollut, jos Jeesus olisi ollut paikalla (j. 21). Jos tämä toteamus esiintyisi ilman jatkoa, sen voisi tulkita tarkoittavan, ettei Martta usko edes Jeesuksen voivan enää auttaa. Välittömästi tämän jälkeen Martta kuitenkin toteaa uskovansa, että Jeesus saa Jumalalta kaiken haluamansa (j. 22). Jossain määrin jännitteisesti edelliseen jakeeseen verrattuna Martan sanat siis sisältävät epäsuoran pyynnön Lasaruksen herättämisestä. ${ }^{25}$ Tilanne ei vieläkään ole toivoton, vaikka Lasarus on jo neljättä päivää haudassa (j. 17).

Martan ilmaiseman toiveikkuuden jälkeen keskustelu saa yllättävän suunnan, kun Jeesus vastaa ikään kuin tavallisena lohdutteluna kuoleman tapauksen yhteydessä, että Lasarus on "nouseva ylös" (Joh. 11:23) viittaamatta lainkaan aiemmin esillä olleeseen mahdollisuuteen (j. 11), että hän voisi herättää Lasaruksen kuolleista. Jeesus näyttää puhuvan epämääräisesti yleisesti tunnetusta ja yleisellä tasolla olevasta ylösnousemustoivosta. Näin Martta myös tulkitsee Jeesuksen sanat, joihin vastaukseksi hän toistaa oman aikansa ylösnousemusopin: "Minä tiedän hänen nousevan ylösnousemuksessa, viimeisenä päivänä." (j. 24) Martta näyttää edustavan perinteistä, tuon ajan juutalaisuudessa ja varhaiskristillisissä seurakunnissa vallinnutta oikeaoppista käsitystä kuolleiden herättämisestä viimeisenä päivänä. Martan esittämä kommentti on jossain mielessä täysin odotettavissa ja ilmaisee sellaisenaan paremminkin uskon vakaumusta kuin sen puutetta. Tässä yhteydessä Martan vastaus on kuitenkin ongelmallinen, sillä se on jälleen jännitteinen hänen edellisen repliikkinsä kanssa, jolla hän osoitti vieläkin uskovansa Jeesuksen mahdollisuuksiin, vaikka Lasarus oli jo kuollut (j. 22). Nyt Martta puhuu Jeesuksen sanojen johdattamana yleisestä ylösnousemuksesta - ikään kuin olisi unohtanut juuri hetkeä aikaisemmin ilmaise-

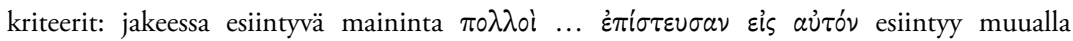
Johanneksen evankeliumissa seitsemän kertaa (4:39; 7:31a; 8:30; 10:42; 12:11, 42).

${ }^{25}$ Joh. 11:22 on redaktorin tekemä lisäys evankelistan tekstiin, mikä osaltaan selittää jakeen sisältämän jännitteen edeltävään jakeeseen 21 nähden. Tätä kirjallisuuskriittistä ratkaisua tukee se, että j. 22 viittaa selvästi Jeesuksen jäh̆hyäispuheen sekundaarin laajennuksen (Joh. 15-17) osaan Joh. 16:23-24 (Dunderberg 1987, 92-95). 
mansa luottamuksen Jeesuksen mahdollisuuksiin toivottomaltakin näyttävässä tilanteessa. ${ }^{26}$

Martan kysymyksiä herättävän vastauksen jälkeen keskustelun suunta kuitenkin kääntyy jälleen. Martan oikeaoppiseen toteamukseen Jeesus vastaa sanoillaan ylösnousemuksesta ja elämästä. Ylösnousemus ei ole vain tapahtuma epämääräisessä tulevaisuudessa, vaan se on jo läsnä Jeesuksen persoonassa. ${ }^{27}$ Näin Jeesus oikaisee Martan käsityksen ylösnousemuksesta. On ilmeistä, että evankelista keskustelun kirjoittajana haluaa asettaa vastakkain perinteisen, Lasarus-kertomuksessa Martan edustaman käsityksen tulevaisuudessa tapahtuvasta ylösnousemuksesta ja Jeesuksen sanoihin sisältyvän presenttisen opetuksen ylösnousemuksesta. $^{28}$

Jeesuksen sanojen tarkoituksena on siis oikaista Martan käsitystä ylösnousemuksesta. Vaikka Martan vastaus Jeesukselle olikin johdonmukainen jatko Jeesuksen sanoille, hänet esitetään kertomuksessa henkilönä, joka ymmärtää Jeesuksen sanat väärin. Johanneksen evankeliumissa tällaista väärinkäsitystä käytetään erityisesti Jeesuksen keskusteluissa juutalaisten kanssa (Joh. 2:19-22; 3:3-4; 6:41-42, 51-52; 7:3336; 8:21-22, 31-33, 51-53, 56-58) kirjallisena keinona, joka osoittaa keskustelukumppanien epäuskon. ${ }^{29}$ Vaikka Martan vastaus Jeesukselle ei, kuten edellä mainitut keskustelut, perustukaan Jeesuksen sanojen käsittämiseen "maallisesti", itse väärinymmärtämisen ja sen oikaisemisen ajatus on tässä keskustelussa sama. Tämän perusteella on mahdollista päätellä, ettei Martta edusta keskustelussa vain riittämättömän vastauksen antajaa, vaan myös epäuskoa. ${ }^{30}$

\footnotetext{
${ }^{26}$ Vrt. Haenchen 1980, 405.

${ }^{27}$ Vrt. Kotila 1988, 87: "Se, joka uskoo Poikaan, on jo nyt osallinen ylösnousemuksesta ja elämästä. Kuolema ja katoavaisuus ovat näin menettäneet merkityksensä, sillä ylösnoussut uskova ei koskaan kuole."

28 Siitä, kuinka tämä evankelistan edustama presenttinen eskatologia näkyy muualla Johanneksen evankeliumissa ja kuinka redaktori on tätä korostusta muokannut takaisin perinteisempään suuntaan, ks. esim. Kotila 1988, 84-91.

${ }^{29}$ Becker 1979-81 (1991), 135-136.

${ }^{30}$ Kotilan $(1988,91)$ mukaan on todennäköistä, ettei evankelista kiistänyt aikojen lopussa tulevaa tuomiota ja ylösnousemusta, vaikka näillä ei olekaan keskeistä asemaa evankelistan julistuksessa. Jaksossa Joh. 11:21, 23-26 evankelista kuitenkin asettaa Martan futuurisen
} 
Jeesuksen esittämään kysymykseen "Uskotko sen?" Martta vastaa lauseella, joka vaikuttaa täysimittaiselta kristilliseltä tunnustukselta: "Kyllä, Herra, minä olen uskonut (ja uskon edelleen) ${ }^{31}$, että sinä olet Kristus, Jumalan Poika, se, joka tulee maailmaan" (Joh. 11:27)..$^{32}$ Niin vakuuttavalta kuin Martan tunnustus vaikuttaakin, se ei ole täysin ongelmaton, sillä Martta näyttää vastaavan Jeesuksen esittämän kysymyksen ohi. Jeesus kysyy, uskooko Martta sen, mitä Jeesus on edellä sanonut. Martta ei kuitenkaan vastaa suoraan tähän kysymykseen, vaan toteaa tähänkin asti uskoneensa, että Jeesus on Jumalan poika. ${ }^{33}$ Jossain määrin samanlainen asetelma Jeesuksen kysymyksen ja annetun vastauksen suhteen esiintyy Johanneksen evankeliumissa myös Jeesuksen ja samarialaisen naisen välisessä keskustelussa, jossa Jeesus esittelee itsensä elävänä vetenä, mutta nainen pitää häntä profeettana $(4: 13-19) .^{34}$

Martta esiintyy Jeesuksen keskustelukumppanina myös Lasaruksen haudalla (Joh. 11:39-40). Keskustelun perusteella Martan Kristustunnustus joutuu kyseenalaiseen valoon. Jeesuksen käskettyä Lasaruksen haudalle tulleita ihmisiä ottamaan kiven Jeesuksen haudalta pois Martta huomauttaa, että Lasaruksen ruumis haisee jo (j. 39). Huomautuksen tarkoituksena on selvästi estää haudan avaaminen. Koska muissa Johanneksen ihmekertomuksissa Jeesuksen käskyä seuraa maininta sen toteuttamisesta joko välittömästi $(2: 7-8 ; 6: 20-21 ; 9: 7)$ tai lyhyen välihuomautuksen jälkeen $(4: 50 ; 5: 9 ; 6: 10)$ ja vasta tämän jälkeen varsinainen ihme, voi Jeesuksen käskyn noudattamista pitää ihmeen tapahtumisen yhtenä edellytyksenä Johanneksen evankeliumissa. Näin

eskatologian, ts. viittauksen viimeisenä päivänä tapahtuvaan ylösnousemukseen vastakohdaksi Jeesuksen presenttistä eskatologiaa edustaville sanoille ylösnousemuksesta ja elämästä.

31 Kreikan kielessä on tässä yhteydessä käytetty perfektiä $\pi \varepsilon \pi i \sigma \tau \varepsilon u \varkappa a$, joka viittaa menneisyydessä alkaneeseen ja nykyhetkessä jatkuvaan uskomiseen. Perfektimuodon käyttö verbistä $\pi\llcorner\sigma \tau \varepsilon u ́ \varepsilon \iota \nu$ voi viitata myös vakiintuneeseen, kristologista tunnustusta edeltävään formeliin (vrt. Joh. 6:67; 1. Joh. 4:16).

${ }^{32}$ Koska Kirkkoraamatun (1938) käännös jakeesta Joh. 11:27 on jossain määrin epätarkka, tässä yhteydessä on käytetty mahdollisimman suoraa käännöstä alkukielestä.

33 Jeesuksen kysymyksen ja Martan vastauksen välinen ongelma ei tule näkyviin Kirkkoraamatun (1938) käännöksessä, jossa sanonta vaì xúpıє ("kyllä, Herra”) on suomennettu "uskon, Herra."

${ }^{34}$ Brown 1966, 405. 
Martan väliintulon voi tulkita vain merkiksi epäuskosta: huolimatta kristologisesta tunnustuksestaan (j. 27) Martta ei usko ihmeen mahdollisuuteen. Tämän vahvistaa myös Jeesuksen vastaus Martalle: "Enkö minä sanonut sinulle, että jos uskoisit, niin sinä näkisit Jumalan kirkkauden?” (j. 40) Vaikka Martta on edellä tunnustanut Jeesuksen Jumalan pojaksi, hänen käyttäytymisensä osoittaa, ettei hän usko Jumalan pojan mahdollisuuksiin kuoleman edessä. ${ }^{35}$

Martta näyttää kaikessa ristiriitaisuudessaan kuvaavan Johanneksen evankeliumissa ihmistä, joka horjuu uskon ja epäuskon välillä. Martta sanoo uskovansa, mutta ei kuitenkaan lopulta usko. Tässä yhteydessä on aiheellista kysyä, onko tällä horjuvuuden korostuksella haluttu kuvata nimenomaan naisen ailahtelevaisuutta? Tätä mahdollisuutta ei voi sulkea pois, jos otetaan huomioon se aika, jona Johanneksen evankeliumi on kirjoitettu (n. 90 jKr.). Tämä tulkinta vaikuttaa kuitenkin monestakin syystä epätodennäköiseltä.

Ensinnäkin vaikka Martan usko kuvataan kertomuksessa horjuvaksi ja lopulta epäuskoon taipuvaksi, keskustelu Jeesuksen kanssa ilmentää käsitystä, jonka mukaan myös naisella on oikeus keskustella uskonnollisista kysymyksistä ja saada "uskonnollisten salaisuuksien" opetusta. $^{36}$ Tämä piirre, joka ei Johanneksen evankeliumin kirjoitta-

\footnotetext{
${ }^{35}$ Schneiders $(1987,55-56)$ joutuu melkoisiin vaikeuksiin yrittäessään selittää, että Martan reaktio Jeesuksen käskyyn ei johtuisi Martan uskon puutteesta vaan muista syistä: "In this scene the Evangelist summarizes the Fourth Gospel's teaching on the relationship between signs and faith, between seeing and believing. Martha, who without seeing has believed in the word of Jesus, is able to see the glory in the sign (11:40)." Schneidersin selitys ontuu ensinnäkin siksi, että kohdassa Joh. 11:27 Martta viittaa nimenomaan Jeesuksen persoonaan, ei sanoihin, ja toiseksi siksi, että Joh. 11:40 ei edes parhaalla tahdolla tulkittuna implikoi Martan kykenevän - pikemminkin päinvastoin - näkemään Jumalan kirkkautta tunnusteossa. Schneidersin tavoin myös Seim $(1987,72)$ korostaa hyvin yksipuolisesti Martan "uskovaa" roolia kertomuksessa: "Before the miracle itself takes place, she [Martta] has through the conversation reached a clarification and understanding that has the effect of making the miracle almost superfluous. Martha believes even before she has seen." Seimin mukaan ihme tuleekin Martalle täydellisenä yllätyksenä, minkä osoittaa Martan reaktio Jeesuksen käskyä vastaan. Seimin esittämän tulkinnan suurimpana heikkoutena - samoin kuin Schneidersin tulkinnan - on tällä kohtaa se, että siinä sivuutetaan täysin Jeesuksen kriittinen vastaus Martalle (Joh. 11:40).

36 Tätä piirrettä korostaa Lasarus-kertomuksen tulkinnassa erityisesti Witherington (1984, 109), joka tosin melko tavalla vesittää Martan epäuskoisen esiintymisen haudalla pitäen sitä merkkinä siitä, että evankelistan kuvauksen mukaan "Martallakin oli heikot hetkensä."
} 
misen aikoihin ei ollut mikään itsestäänselvyys, esiintyy Johanneksen evankeliumissa myös kertomuksessa Jeesuksesta ja samarialaisesta naisesta. Tässäkin keskustelussa otetaan esiin teologisia ongelmia, jopa sillä seurauksella, että nainen vie keskustelua eteenpäin (esim. 4:19-24).

Toiseksi uskossa horjumista ei ole evankeliumeissa jätetty Martan tai muiden naisten yksinoikeudeksi. Martta sellaisena kuin hänet kertomuksessa Lasaruksen kuolleista herättämisestä kuvataan tulee yllättävän lähelle sitä kuvaa, jonka evankeliumit välittävät meille Jeesuksen opetuslapsien johtajahahmosta, Simon Pietarista. Keskustellessaan Jeesuksen kanssa Martta käyttää selkeää uskon vakaumusta korostavia ilmaisuja "minä tiedän" (Joh. 11:22, 24) tai "minä uskon" (j. 27). Samanlaiseksi uskossaan varmaksi henkilöksi kuvataan myös Pietari: "Vaikka kaikki muut loukkaantuisivat sinuun, niin minä en loukkaannu.” (Matt. 26:33) Erityisesti Matteuksen esittämässä muodossa Pietari tunnustaa Jeesuksen Herrakseen jopa lähes samoin sanoin kuin Martta: "Sinä olet Kristus, elävän Jumalan Poika" (Matt. 16:16; vrt. Mark. 8:29; Luuk. 9:20; Joh. 6:68-69). ${ }^{37}$ Markuksen ja Matteuksen evankeliumeissa tätä tunnustusta seuraa kohtaus, jossa Pietari loukkaantuu, kun Jeesus puhuu tulevista kärsimyksistään. Martan tavoin Pietari yrittää estää tapahtumien kulun, mutta saa osakseen nuhteet: "Mene pois minun edestäni, saatana; sillä sinä et ajattele sitä, mikä on Jumalan, vaan sitä, mikä on ihmisten." (Mark. 8:33 // Matt. 16:23) Johanneksesta (ja Luukkaasta!) tämä tunnustusta seuraava jatko puuttuu, mutta myös Johanneksen evankeliumissa mainitaan Pietarin uskonvarmuus ennen Jeesuksen kärsimystä ("Henkeni minä annan sinun edestäsi"; Joh. 13:38) ja kerrotaan, kuinka Pietari lopulta kieltää Jeesuksen kolme kertaa (Joh. 18:15-18, 25-27). Se, millaiseksi Pietari evankeliumitraditiossa kuvataan, osoittaa, että Martan horjuvuus uskossa tuskin liittyy mitenkään siihen, että hän on nainen. Tällaiseen tulkintaan ei löydy tukea myöskään itse Lasarus-kertomuksesta. Martan hahmo muotoutuu Lasarus-kertomuksessa traagiseksi samoin kuin Pietarin hahmo toisaalla. Johanneksen kuvaama Martta on

${ }^{37}$ Pietarin ja Martan tunnustusten välistä paralleelisuutta korostaa erityisesti Brown 1979, 190. 
uskossaan varma, mutta lopulta heikko ihminen, joka ei jaksa uskoa ihmeen mahdollisuuteen. Johanneksen kertomuksessa (tai ainakaan sen nykyisessä muodossa) esiintyvää Marttaa tuskin voi pitää tunnetun Johannes-tutkijan Raymond E. Brownin tavoin johannekselaisen seurakunnan muistoissa elävänä "sankarittarena"38 - Martan täydelliseltä kuullostavasta Kristus-tunnustuksesta huolimatta.

Naisen rooliin liittyvä kysymys Lasarus-kertomuksessa on myös Martan "värinkäsitys" (Joh. 11:24). Halutaanko sen avulla korostaa, että nimenomaan nainen ymmärtää helposti värin uskonnollisia kysymyksiä? Esiintyyhän samanlainen väärinkäsitys Johanneksen evankeliumissa myös Jeesuksen ja samarialaisen naisen välisessä keskustelussa (Joh. 4:10-15). Lisäksi muun muassa Pastoraalikirjeet osoittavat, ettei tällainen kysymyksenasettelu olisi ollut välttämättä kovin kaukaa haettu Johanneksen evankeliumin kirjoittamisen aikoihin. Kuten edellä kuitenkin on jo todettu, asioiden ilmaiseminen "väärinkäsitysten" avulla kuuluu neljännelle evankeliumille tyypillisiin tyylikeinoihin. Sen, ettei tällä tyylikeinolla haluta ensisijaisesti korostaa naisen ymmärtämättömyyttä uskonnollisissa kysymyksissä, osoittaa kuitenkin jo se, että samanlainen väärinkäsitys esiintyy esimerkiksi Jeesuksen ja lainopettaja Nikodemuksen välisessä keskustelussa (3:3-4).

Kun Martasta siirrytään Marian roolin tarkasteluun, kiinnittää huomion ensinnäkin se seikka, että kertomuksessa Lasaruksen kuolleista herättämisestä esiintyvä Marian hahmo muistuttaa jossain määrin Luukkaan kuvausta Mariasta. Ensinnäkin, kun Martta lähti Jeesusta vastaan, Marian kerrotaan myös Johanneksen evankeliumissa "istuneen kotona" (Joh. 11:20). Toiseksi, kun Maria ei Luukkaan kertomuksessa puhu mitään, ei hänellä Lasarus-kertomuksessakaan ole kuin yksi repliikki (j. 32), joka sekin on toisinto Martan sanoista Jeesukselle (j. 21): "Herra, jos olisit ollut täällä, ei minun veljeni olisi kuollut." Mitään Martan ja Jeesuksen keskustelua vastaavaa vuoropuhelua ei käydä Marian ja Jeesuksen välillä. Lasarus-kertomuksessa Marian rooli kuitenkin korostuu kertomuksen lopussa mielenkiintoisella tavalla: kun

${ }^{38}$ Brown 1979, 191. 
aiemmin on puhuttu Martan ja Maria luokse tulleista juutalaisista (j. 19), mainitaan kertomuksen lopussa ainoastaan Marian luokse tulleet juutalaiset (j. 45-46). Kertomuksessa ei anneta mitään suoranaista selitystä sille, miksi Marttaa ei mainita kertomuksen lopussa. Kertomuksen kirjoittaja on tuskin voinut tarkoittaa, että kyseessä olisi jonkinlainen tuomio Martan epäuskosta Lasaruksen haudan äärellä, sillä Martalla on täysin positiivinen rooli voitelukertomuksen alussa: aterian aikana hän palvelee muita (Joh. 12:2) Martan nimen sivuuttamiseen kuolleistaherättämiskertomuksen lopussa voi olla syynä se, että juutalaiset tulevat haudalle nimenomaan Marian mukana (Joh. 11:31) ${ }^{39}$ ja näkevät Lasaruksen kuolleista herättämisen. Juutalaisilla puolestaan on jatkoa ajatellen tärkeä kerronnallinen osuus, sillä osa heistä vie viestin kuolleista herättämisestä fariseuksille (j. 46), jotka puolestaan (yhdessä ylipappien kanssa) tekevät päätöksen Jeesuksen surmaamisesta (j. 47-53). On aiheellisesti todettu, että "episodin [Joh. 11:31-37] kirjallisena tehtävänä on tuoda näyttämölle jossain määrin kerronnallisesti uskottavalla tavalla Marian surevat seuralaiset, juutalaiset, jotka kertovat Jeesuksesta viranomaisille." 40 Samalla kun Mariasta kertovat jaksot palvelevat lähinnä jatkossa seuraavien tapahtumien niveltämistä Lasarus-kertomukseen, itse Marian hahmo jää Lasarus-kertomuksessa sisällöllisesti ohueksi: "Marian tehtävänä tässä kertomuksessa on itkeä." 41

Keskeinen rooli Marialla on Johanneksen evankeliumin kertomuksessa Jeesuksen jalkojen voitelemisesta (Joh. 12:1-8). Muiden evankeliumien mukaan Jeesuksen voitelun suoritti tuntematon nainen (Matt. 26:6-13 // Mark. 14:3-9; vrt. Luuk. 7:36-38). Johanneksen evankeliumissa voitelun kerrotaan tapahtuneen erään aterian yhteydessä. Yhteistä Luukkaan kuvaukseen Mariasta on, että Marian kuvataan olevan Jeesuksen jalkojen juuressa. Luukkaan kertomusta Martasta ja Mariasta muistuttaa lisäksi jollain tapaa voitelukertomuksen

\footnotetext{
39 Tässä kohtaa kertomus sisältää jännitteen: juutalaiset seuraavat Marian perässä, vaikka Martta kutsui Marian "salaa" (j. 28).

${ }^{40}$ Schneiders 1987, 53-54.

${ }^{41}$ Schneiders 1987, 54.
} 
loppu, jossa Jeesus asettaa Marian käytöksen esimerkiksi ja torjuu Mariaa nuhtelevan henkilön moitteet. Johanneksen evankeliumissa ei kuitenkaan Luukkaan tavoin aseteta Marttaa ja Mariaa vastakkain. ${ }^{42}$ Moitteiden kohteena on nyt Martan sijasta Juudas Iskariot (j. 4-8).

Kun Johanneksen evankeliumin voitelukertomusta verrataan Luukkaan kuvaukseen Martasta ja Mariasta, on selvin ero itse peruskertomusten välisen eron ohella se, ettei Johanneksen evankeliumissa Mariaa kuvata Jeesuksen sanojen kuuntelijaksi, vaan aktiiviseksi henkilöksi, joka palvelee Jeesusta teoillaan siinä missä Marttakin. Martta valmistaa aterian (mihin ei Johanneksessa, toisin kuin Luukkaassa, kiinnitetä erityistä huomiota), Maria voitelee arvostetun vieraan jalat. Martan ja Marian välillä ei ole periaatteellista eroa. Kumpikin on saanut palvelijan roolin. Marian suorittamaa palvelusta tosin pidetään voitelukertomuksessa selvästi "arvokkaampana" kuin Martan, sillä Marian katsotaan toimittaneen voitelun Jeesuksen hautaamispäivän varalle (Joh. 12:7).

Matteuksen ja Markuksen esittämistä voitelukertomuksista Johanneksen voitelukertomus poikkeaa toisaalta siinä, että Jeesuksen voitelija nimetään Mariaksi, Martan siskoksi, ja toisaalta siinä, että Maria voitelee Jeesuksen jalat - ei päätä, kuten tuntematon nainen Matteuksen (26:7) ja Markuksen (14:2) mukaan - ja yllättäen kuivaa voiteen hiuksillaan pois. Tässä kohtaa kertomus muistuttaa Luukkaan voitelukertomusta (Luuk. 7:36-50), jossa tapahtumien järjestys on kuitenkin loogisempi: nainen kastelee Jeesuksen jalat kyynelillään, kuivaa ne hiuksillaan ja vasta sitten voitelee jalat hajuvoiteella (j. 38). Johanneksen esittämä omaperäinen tapahtumien järjestys selittynee parhaiten lyhennyksenä Luukkaan versiosta. ${ }^{43}$ Toisaalta on syytä kiinnittää huomiota siihen, että Johanneksessa esiintyvä tapahtumien järjestys muistuttaa kertomusta, jossa Jeesus pesee opetuslasten jalat ja kuivaa ne. Turid Karlsen Seim, joka viimeksi on kiinnittänyt tähän piirteeseen huomiota, toteaa, että "hän [Maria] on etukäteen täyttänyt

\footnotetext{
${ }^{42}$ Ks. Seim 1987, 73.

${ }^{43}$ Becker 1979-81 (1991), 373.
} 
hänen [Jeesuksen] vaatimuksensa opetuslapsille kohdassa 12[po. 13]:14s." ${ }^{\text {4 }}$

Ehkä juuri Johanneksen voitelukertomus antaa hyvän lähtökohdan sen pohtimiselle, kuinka erilaisen kuvan Martasta ja Mariasta Luukas ja Johannes loppujen lopuksi antavat. Luukkaalla Marian hyvä osa on Jumalan valtakunnan etsimistä, mikä näkyy Jeesuksen sanojen kuulemisena. Marialla on oikeus olla Jeesuksen oppilaana ja kuunnella tämän opetuksia. Tässä suhteessa sisarusten roolit ovat Johanneksen evankeliumissa juuri päinvastaiset. Johanneksessa nimenomaan Martta on oppilaan roolissa. Hän keskustelee Jeesuksen kanssa ylösnousemususkosta ja saa kuunnella Jeesuksen opetusta. Sen sijaan Marialle Jeesus ei puhu Johanneksen kertomuksissa mitään. Toisaalta voitelukertomuksessa Maria esiintyy aktiivisena palvelijana, ei niinkään Jeesuksen sanojen kuuntelijana. Yhteistä Luukkaalle ja Johannekselle on ainoastaan se, että Marian kerrotaan olleen Jeesuksen jalkojen juuressa. Marialle annetun roolin sisältö on kummassakin evankeliumissa aivan erilainen.

Sekä Luukkaan että Johanneksen kertomuksissa Jeesus myös nuhtelee Marttaa. Mutta tässäkin yhteydessä nuhteiden syyt poikkeavat toisistaan täysin. Luukkaan mukaan nuhteiden syynä on se, että Martta huolehtii ja murehtii monista käytännön elämään liittyvistä asioista unohtaen samalla "yhden tärkeän". Johanneksessa nuhteiden syyksi esitetään Martan epäusko, joka tavallaan ilmenee jo ylösnousemususkosta käydyssä keskustelussa, mutta selvimmin Lasaruksen haudalla. Mainintaa, että Martta palveli Jeesusta, ei Johanneksen evankeliumissa kommentoida tai arvioida teologisesti lainkaan.

Miksi Luukkaan ja Johanneksen kuvaukset sitten poikkeavat toisistaan niin selvästi? Tärkein syy tähän on se, että näiden

${ }^{44}$ Seim 1987, 73. 
evankeliumien kirjoittajilla on ollut omat teologiset korostuksensa, joita he ovat halunneet havainnollistaa Martan ja Marian hahmojen avulla. Erityisen selvästi tämä piirre näkyy, kuten edellä todettiin, Luukkaan kertomuksessa. Johanneksen evankeliumissa yksiselitteisen kuvan antamista vaikeuttaa se, että kertomuksen nykyisen muodon lisäksi pitäisi kohta kohdalta perehtyä myös siihen, miten kertomuksen varhaisempien kirjallisten vaiheiden esittämät kuvaukset Martasta ja Mariasta poikkeavat nykyisestä, kertomuksen "lopullisesta" muodosta. ${ }^{45}$ Samalla on syytä huomata, että Luukkaan ja Johanneksen evankeliumeissa olevat kertomukset antavat meille yllättävän vähän tietoja itse sisaruksista, kahdesta naisesta, joiden nimet olivat Martta ja Maria ja joiden elämäntarina liittyi jollain tavalla Jeesuksen elämäntarinaan. Näiden evankeliumeissa esiintyvien, keskenään osittain ristiriitaisten tietojen varassa voi tuskin paljoa sanoa siitä, minkälaisia ihmisiä Martta ja Maria lopulta olivat tai minkälaisia naisen rooleja he omana aikanaan tosi asiassa edustivat.

${ }^{45}$ Sisarusten roolin tulkintaan vaikuttavat esimerkiksi Joh. 11:2 (Maria), 22 (Martta), jotka on lisätty tekstiin todennäköisesti kertomuksen viimeisessä toimitusvaiheessa. 


\section{Marian evankeliumi - Johanneksen evankeliumin jatko-osa?}

(2012)

Johanneksen evankeliumin asema varhaisessa kirkossa on ollut viime vuosina vilkkaan keskustelun kohteena. ${ }^{1}$ Yksi osoitus tästä on hiljattain ilmestynyt, Tuomas Rasimuksen toimittama artikkelikokoelma The Legacy of John: Second-Century Reception of the Fourth Gospel. ${ }^{2}$ Aiheesta on 2000-luvulla ilmestynyt myös kaksi laajaa monografiaa. Niiden kirjoittajat, Titus Nagel ja Charles Hill, ovat yhtä mieltä siitä, että Johanneksen evankeliumin käytöstä on selviä merkkejä heti toisen vuosisadan alussa, erityisesti Ignatius Antiokialaisen kirjeissä ja Papiaksella. $^{3}$ Keskustelu Johanneksen varhaisimmasta reseptiosta kuitenkin jatkuu. Andrew Gregoryn ja Christopher Tuckettin toimittaman artikkelikokoelman The Reception of the New Testament in Apostolic Fathers kirjoittajat pitävät epävarmoina todisteita Johanneksen

\footnotetext{
${ }^{1}$ Artikkeli perustuu toisessa yhteydessä julkaistuun, laajempaan artikkeliini (Dunderberg 2013). Haluan tässä yhteydessä onnitella ja kiittää opettajaani ja sittemmin pitkäaikaista ja läheistä työtoveriani Antti Marjasta, joka yhdessä Risto Uron kanssa herätti kiinnostukseni koptinkielisiin evankeliumeihin ja gnostilaisuuteen ja on sen jälkeen vuosien varrella asiantuntevilla ja tarkoilla kommenteillaan vaikuttanut merkittävästi omiin tutkimuksiini. Antilla on ollut keskeinen rooli myös tämän artikkelin synnyssä: hän toimi kärsivällisesti keskustelukumppanina esittämäni tulkinnan alkuvaiheissa.

${ }^{2}$ Rasimus 2010.

${ }^{3}$ Nagel 2000; Hill 2004.
} 
evankeliumin käytöstä sekä Ignatiuksen kirjeissä että monissa muissa Apostolisten isien kokoelmaan kuuluvissa teksteissä. ${ }^{4}$

Marian evankeliumi on jäänyt vähäiselle huomiolle Johanneksen varhaista vaikutushistoriaa käsittelevissä kokonaisesityksissä. Nagel mainitsee tekstin ainoastaan yhdessä alaviitteessä; Hill ei käsittele sitä lainkaan, eikä siitä ole myöskään omaa lukua Rasimuksen kokoelmassa. ${ }^{5}$ Useimmat Marian evankeliumin tutkijat kuitenkin näkevät siinä merkkejä Johanneksen evankeliumin suorasta tai epäsuorasta vaikutuksesta. Yksi ilmeinen esimerkki on Jeesuksen Marian evankeliumissa käyttämä ilmaus "minun rauhani;" se on, kuten Antti Marjanenkin totesi väitöskirjassaan, "selvästi tyypillinen johanneslainen ilmaus (Joh. 14:27)."6

Marian evankeliumissa on muitakin kohtia, jotka näyttävät viittaavaan Johanneksen evankeliumin vaikutukseen. Tutkijat ovat erimielisiä lähinnä siitä, kuinka merkittäviä tällaiset yhteydet ovat Marian evankeliumin tulkinnan kannalta. Toiset pitävät yhteyksiä sattumanvaraisina, kun taas toisten mukaan Marian evankeliumin suhde Johanneksen evankeliumiin on hyvinkin keskeinen.

Keskeinen lähtökohta tässä artikkelissa on havainto, että Marian evankeliumi tavallaan jatkaa siitä, mihin Johanneksen evankeliumissa jäätiin: Marian evankeliumissa kuvattu tilanne on juuri se, johon Jeesus Johanneksen evankeliumin jäh̆hyäispuheessa ennustaa oppilaidensa joutuvan. Lisäksi tapa, jolla Marian rooli kuvataan Marian evankeliumissa, sopii hyvin yhteen Johanneksen evankeliumista nousevien ajatusten kanssa. Tällaiset yhteydet luovat riittävän perustan Marian evankeliumin intertekstuaaliselle tulkinnalle, jossa Johanneksen evankeliumi otetaan huomioon yhtenä merkittävänä taustatekijänä.

\footnotetext{
${ }^{4}$ Gregory \& Tuckett 2005. Tässä kokoelmassa pidetään epätodennäköisenä Johanneksen evankeliumin käyttöä seuraavissa teksteissä: Ignatiuksen kirjeet (P. Foster, 184); Polykarpoksen Kirje filippiläisille (M. F. Holmes, 199); Barnabaan kirje (J. Carleton Paiget, 237-238); Klemens Roomalaisen Kirje korinttilaisille (Gregory, 139-140); 2. Klemensin kirje (Gregory \& Tuckett, 253); Didakhe (Tuckett, 93-94).

${ }_{6}^{5}$ Nagel 2000, 48 n. 167.

${ }^{6}$ Marjanen 1996, 98 n. 19. Marjanen $(1996,61)$ huomauttaa, että samaa ilmausta käytetään myös Nag Hammadin tekstissä Jeesuksen Kristuksen Viisaus (91.20-23).
} 


\section{Varhaisilla kristityillä oli erilaisia tapoja käyttää tekstejä}

Kun selvitetään Marian evankeliumin kaltaisten ei-kanonisten tekstien suhdetta kanonisiin, helposti oletetaan, että kaanoniin kuuluvien tekstien käyttö ei-kanonisessa tekstissä heijastaa aina jonkinlaista suhdetta koko kaanoniin, eräänlaista kanonista tietoisuutta. Eikanonisesta tekstistä etsitään tällöin ensi sijassa reaktioita, joko hyväksyviä tai torjuvia, kanonisiin teksteihin ja usein myös koko kaanoniin. Tästä on lyhyt matka moralisointiin: tutkijatkin syyttävät eikanonisia varhaiskristillisiä tekstejä herkästi kanonisten tekstien "vääristelystä."” Oletuksena tällöin on, että kanonisilla teksteillä on helposti havaittava "oikea" merkitys, joka ei-kanonisissa teksteissä sivuutetaan laskelmoidusti. Kanonisten tekstien käytön motiivit kuvataan yleensä kyseenalaisiksi: ei-kanonisissa teksteissä arvovaltaisempiin kanonisiin teksteihin ei viitata siksi, että niiden sisältö olisi tärkeä ei-kanonisten tekstien kirjoittajille, vaan siksi, että tällaisilla viittauksilla annetaan uskottavuuden leima uusille, epäilyttäville teksteille kanoniset tekstit hyväksyvien lukijoiden parissa.

Julkilausumattomana oletuksena tällaisessa ajatusketjussa on, että varhaiset kristityt hyväksyivät kanonisten tekstien arvovallan kaikkialla samalla tavoin. Todellisuudessa heillä oli kuitenkin hyvin erilaisia näkökulmia pyhiin teksteihin. Amerikkalainen kirkkohistorioitsija David Brakke on hiljattain hahmotellut kolme erilaista pyhien kirjoitusten käyttökontekstia varhaiskristillisellä kaudella: ${ }^{8}$

1. opiskelu ja mietiskely;

2. ilmoitus ja jatkuva ilmoitus;

3. yhteinen jumalanpalvelus ja hengellinen rakentuminen.

\footnotetext{
${ }^{7}$ Muutamia esimerkkejä: Dunderberg 2013, 67 n. 3.

${ }^{8}$ Brakke 2011.
} 
Ensimmäistä ryhmää edustavat Brakken mukaan "akateemiset" kristityt, jotka opiskelivat pyhiä tekstejä, pohtivat miten niitä pitäisi tulkita, kirjoittivat niihin selitysteoksia, vertailivat käsikirjoituksia ja toimittivat tekstieditioita ja muita tulkinnan apuvälineitä. Kaanon ei ollut tiukasti rajattu: osa tähän ryhmään kuuluvista opettajista käytti Jeesuksen opetuksen lähteinä myös Uuden testamentin ulkopuolelle jääneitä tekstejä. Tämän ryhmän edustajat eivät ottaneet kaanonia annettuna tosiasiana vaan kävivät keskustelua siitä, mitä tekstejä siihen kuuluu. Markion on ilmeinen esimerkki, mutta Brakke sijoittaa tähän ryhmään monet tunnetut aleksandrialaiset teologit (Valentinos, Clemens ja Origenes) sekä - hieman yllättäen, mutta perustellusti - Kirkkohistoriateoksestaan tunnetun Eusebios Kesarealaisen. ${ }^{9}$

Toisen ryhmän Brakken jaottelussa muodostavat uusia ilmestyksiä kokeneet varhaiset kristityt. He eivät tehneet tarkkaa rajaa "kanonisten" ja uusien "ei-kanonisten" kirjoitusten välille. Sen sijaan "aiemmin hyväksytyt pyhät tekstit tarjosivat materiaalia uusien ilmestysten kirjoittamiselle, kun kuvauksia ilmestyksistä kierrätettiin tai kertomuksia yksinkertaisesti kirjoitettiin uudelleen.” Esimerkiksi Nag Hammadin kirjastossa ja muissa koptinkielisissä kokoelmissa säilyneet dialogievankeliumit kuuluvat tähän ryhmään.

Selkeästi rajattu kaanon muodostui tärkeäksi kolmannessa kontekstissa eli jumalanpalvelusyhteisössä. Sitä varten tuli tehdä selkeitä päätöksiä, mitä tekstejä voidaan lukea julkisesti kristittyjen yhteisissä jumalanpalveluksissa. Jumalanpalveluselämää varten tarvittiin selvästi rajattu kokoelma tekstejä, jotka olivat laajasti hyväksyttyjä ja joiden katsottiin varmasti edistävän oikeaa oppia. Keskeinen rooli tässä suhteessa oli piispoilla. Tosin heidänkin kantansa toisinaan vaihtelivat:

\footnotetext{
${ }^{9}$ Markion ehdotti hyvin suppeaa kaanonia, johon kuuluivat vain vahvasti editoitu Luukkaan evankeliumi ja osa Paavalin kirjeistä. Eusebios jakoi Uuden testamentin kirjat kolmeen osastoon: yleisesti hyväksyttyihin, kiisteltyihin ja epäperäisiin. Eusebioksen kaanon jäi jossain määrin avoimeksi: hän ei ottanut lopullista kantaa esimerkiksi siihen, kuuluuko Johanneksen ilmestys "hyväksyttyihin" vai "epäperäisiin," vaan mainitsee molemmat vaihtoehdot (Kirkkohistoria 3.25). Myöhemmin hän lainaa hyvin laajasti ja ilmeisesti hyväksyen Dionysiuksen, Aleksandrian piispan (piispana 247-264), havaintoja, joiden perusteella Johanneksen ilmestyksen kirjoittaja ei voi olla Johannes Sebedeuksen poika (Kirkkohistoria 7.25).
} 
Antiokian piispa Serapion (piispana 190-211) ensin salli ja myöhemmin - tutustuttuaan tekstiin itse! - kielsi Pietarin evankeliumin lukemisen paikallisseurakunnassa, jossa sitä oli pidetty suuressa arvossa. $^{10}$

Marian evankeliumi epäilemättä kuuluu Brakken kategoriaan 2, sillä se on dialogievankeliumi, jossa kuvataan ylösnousseen Jeesuksen keskusteluja seuraajiensa kanssa. Tällaisessa tekstissä ei ole tapana suoraan lainata varhaisempia evankeliumeja siinäkään tapauksessa, että kirjoittaja tunsi ne.

Marian evankeliumissa on muutamia ilmeisen selviä viittauksia Uuden testamentin evankeliumeihin. ${ }^{11}$ Viittaukset eivät kuitenkaan välttämättä osoita, että tekstin kirjoittaja halusi antaa omalle tekstilleen luotettavuuden leiman matkimalla kanonisina pidettyjä tekstejä. Uuteen testamenttiin päätyneitä evankeliumeita käytetään Marian evankeliumissa samalla tavalla itsenäisesti kuin Johanneksen evankeliumin kirjoittajan täytyy olettaa käyttäneen synoptisia evankeliumeja, mikäli hän tunsi ne. Marian evankeliumin kirjoittajan päämäärä oli esittää kuvaus uudesta ilmestyksestä, ei kannanottoa kaanonia koskevissa kiistoissa.

\section{Kiista Marian ilmestyksestä}

Marian evankeliumi koostuu kahdesta Vapahtajan seuraajiensa kanssa käymästä keskustelusta. Ensimmäinen dialogi, jossa Jeesus keskustelee oppilaidensa kanssa, päättyy kuvaukseen siitä, kuinka oppilaat joutuvat syvän murheen ja ahdistuksen valtaan hänen lähdettyään pois. Toisessa dialogissa Maria lohduttaa Jeesuksen oppilaita ja Pietarin nimenomaisesta pyynnöstä kertoo heille, kuinka Jeesus ilmestyi hänelle ja opetti

\footnotetext{
${ }^{10}$ Eusebios, Kirkkohistoria 6.12.3-6. Asiaan paneuduttuaan Serapion huolestui, että teksti edistää dokeettista harhaoppia. Hän ei kuitenkaan kiistänyt Pietarin evankeliumia täysin: ”... suurin osa on Vapahtajan oikeaa oppia” (käänn. Heikel).

${ }^{11}$ Lyhyt yhteenveto: Marjanen 1996, 98 n. 19. Yksityiskohtainen tarkastelu: Tuckett 2007, 55-74.
} 
häntä. Tämän jälkeen tapahtuu erikoinen käänne: Jeesuksen muut oppilaat alkavat kiistellä Marian näystä. Kohtaus paljastaa kirjoittajan ennakoivan, että jotkut lukijat voivat pitää evankeliumissa kuvattua salaista ilmestystä "outona opetuksena" (Mar. ev. 17). ${ }^{12}$

Evankeliumissa ei selitetä, miksi Jeesuksen oppilaat torjuvat Marian ilmestyksen. Andreas toteaa ykskantaan, ettei hän usko Marian puheita. Pietari jatkaa samalla linjalla: "Puhuiko Vapahtaja todella salaa, meidän tietämättämme, naisen kanssa? Pitäisikö meidän kaikkien muuttaa mielemme ja kuunnella Mariaa? Pitikö Vapahtaja häntä meitä parempana?" (Mar. ev. 17). Muotoseikkoihin vedotaan usein silloinkin, kun ollaan eri mieltä itse asiasta: Pietari ei yksilöi, mikä Marian opetuksessa on pielessä, vaan torjuu sen siksi, että muut eivät sitä kuulleet, ja siksi, että sen saaja on väärää sukupuolta. ${ }^{13}$ Paavalin tavoin (Gal. 2:11-14) Marian evankeliumin kirjoittaja kuvaa Pietarin takinkääntäjäksi. Juuri Pietari oli nimittäin hetkeä aiemmin tunnustanut Marian erityisaseman ja pysi tätä kertomaan heille Vapahtajan salaisen opetuksen: "Sisar, me tiedämme, että Vapahtaja rakasti sinua enemmän kuin muita naisia. Kerro meille Vapahtajan sanoja, jotka sinä tiedät, mutta joita me emme ole kuulleet" (Mar. ev. $10)$.

\section{Evankeliumi toisen vuosisadan puolivälistä}

Marian evankeliumin tulkintaa vaikeuttaa se, ettei tekstiä tunneta kokonaan. Teksti on säilynyt koptinkielisenä käännöksenä koodeksikäsikirjoituksessa, joka tunnetaan nimellä Berlinus Gnosticus $(B G) .{ }^{14}$ Siitä kuitenkin on jossain vaiheessa kadonnut sivuja juuri

\footnotetext{
${ }^{12}$ Ks. Marjanen 2005, 56-57.

${ }^{13}$ King (1995, 624; vrt. Marjanen 1996, 120) katsoo, että Marian evankeliumissa näkyy naisen asemaa koskevan varhaiskristillisen debatin toinen puoli; toista puolta edustaa naisen hengellistä johtajuutta (ja muutakin julkista asemaa) jyrkästi vastustava 1. Timoteuskirjeen kirjoittaja (1. Tim. 2:8-15).

${ }^{14}$ Usein virheellisesti väitetään, että Marian evankeliumi kuuluu Nag Hammadin kirjastoon. Tuorein esimerkki: Eskola 2011, 56, 58 n. 73. Viimeksi mainitussa kohdassa $B G$ kuvataan
} 
Marian evankeliumin kohdalla: evankeliumin alkusivut puuttuvat (mahdollisesti sivut 1-6), ${ }^{15}$ samoin neljän sivun jakso tekstin keskellä (11-14). Tekstistä on säilynyt kaksi lyhyttä kreikankielistä katkelmaa (P. Oxy. 3525; P. Ryl. 463), mutta ne osuvat kohtiin, jotka ovat myös koptinkielisessä käsikirjoituksessa, joten niistä ei ole apua mainittujen suurien aukkokohtien täydentämisessä.

Marian evankeliumin kreikankieliset katkelmat ovat 200-luvulta. Teksti itse on todennäköisesti peräisin 100-luvun puolivälistä. Tähän ajoitukseen viittaavat Uuden testamentin evankeliumien vaikutuksen lisäksi Marian evankeliumissa esiin nousevat filosofiset kysymyksenasettelut. Evankeliumi alkaa kesken kohdasta, jossa Jeesuksen oppilaat kysyvät, "tuhoutuuko aine vai ei?" (Mar. ev. 7.) Kohta osoittaa, että Jeesus ja oppilaat ovat edellä keskustelleet luomisen peruselementtinä pidetystä "aineesta" ( hylē).

Keskustelua luomisessa käytetyn "aineen" olemuksesta ja kohtalosta oli käyty pitkään filosofien parissa, mutta oppineet kristityt kiinnostuivat aiheesta juuri toisen vuosisadan puolivälissä. Yleinen filosofinen teoria oli, ettei Jumala luonut maailmaa tyhjästä vaan muotoili sen jonkinlaisesta "alkumateriasta," joka oli samalla tavalla ikuinen luomisen lähtökohta kuin Jumala. Varhaisimmat kristityt filosofit kuten Justinos ja Athenagoras ehtivät hyväksyä tämän tulkinnan, ennen kuin ajatus, että Jumala loi kaiken tyhjästä (creatio ex nibilo), vakiintui yleiseksi kristilliseksi käsitykseksi. ${ }^{16}$ Toisen vuosisadan puolivälissä "alkumateria" nousee keskeiseen asemaan myös valentinolaisten ja setiläisten kristittyjen luomismyyteissä. ${ }^{17}$

virheellisesti "Nag Hammadin käsikirjoitukseksi." Lisäksi Eskola väittää, että Marian evankeliumi "on lyhyt yhdistelmä kahdesta eri fragmentista . . . ." BG:ssa säilynyt teksti kuitenkin muodostaa yhden kokonaisuuden, josta vain puuttuu sivuja alusta ja keskeltä. "Kaksi fragmenttia," jotka tämän tekstin yhteydessä usein mainitaan, ovat tekstistä säilyneet kreikkalaiset katkelmat.

${ }^{15}$ Koska nämä ovat $B G: n$ ensimmäiset sivut, ei voida varmuudella tietää, kuuluiko koko puuttuva jakso Marian evankeliumiin vai oliko koodeksin alussa joku toinen teksti. Koodeksissa Marian evankeliumi alkaa kesken, joten sen tekstiä on ollut puuttuvilla sivuilla jonkin verran, mutta on mahdotonta sanoa, kuinka paljon.

${ }^{16}$ Heidän käsityksistään ks. May 1994, 122, 138-139.

${ }^{17}$ Ks. Dunderberg 2008, 67-72, 124-128. 
Toinen antiikin filosofiaan läheisesti liittyvä piirre Marian evankeliumissa on, että siinä kiinnitetään huomiota tunteisiin ja niistä vapautumiseen. ${ }^{18}$ Evankeliumin jälkimmäisessä osassa kuvataan korkeuksiin palaavaa sielua. Paluun yrittävät estää himo, tietämättömyys ja viha, jotka kuulustelevat sielua: "Himo sanoi: 'En nähnyt sinun laskeutuvan, mutta nyt näen sinut matkalla ylös. Miksi valehtelet, vaikka kuulut minulle?' Sielu vastasi: 'Minä näin sinut, mutta sinä et nähnyt etkä tunnistanut minua. Olin sinulle vain vaate etkä tuntenut minua" (Mar. ev. 15). ${ }^{19}$ Samanlaisen keskustelun sielu käy myös tietämättömyyden ja vihan kanssa. Kuulustelujen lopussa sielu toteaa päässeensä voitolle näistä voimista: "Himoni on laantunut ja tietämättömyys on kuollut. Maailmasta minut on vapautettu toisen maailman avulla, kuvasta ylhäällä olevan kuvan avulla. ... Tästä hetkestä alkaen pääsen lepoon ajan, hetken ja aikakauden vaihtumisesta ja saavutan hiljaisuuden" (Mar. ev. 16-17). Sielun voitto kohdassa kuvataan tavalla, joka muistuttaa stoalaista ajatusta, että ihmisen tavoitteena on saavuttaa apatheia, täydellinen vapautuminen haitallisista, järjenvastaiseen toimintaan johtavista tunteista. ${ }^{20}$

Filosofian vaikutukseen viittaa myös Marian evankeliumin lopussa oleva kehotus "pukea yllemme täydellinen ihminen" (Mar. ev. 18). "Täydellinen ihminen" (ho teleios) oli käsite, jonka avulla filosofit havainnollistivat käsitystään ihanneihmisestä. Täydellisen ihmisen keskeinen piirre on, että hän toimii kaikissa tilanteissa automaattisesti oikein. Hän ei tarvitse käskyjä eikä kehotusta, ei myöskään tarkkaa harkintaa. Hän toimii oikein luonnostaan ja vaivatta. ${ }^{21}$ Marian evankeliumi yhtyy tähän ihanteeseen. ”Täydelliseen ihmiseen” liitetään tässä tekstissä vapaus laista ja kaikista muista säännöistä paitsi Vapahtajan ohjeista:

\footnotetext{
${ }^{18}$ Olen käsitellyt aihetta Teologisessa Aikakauskirjassa (Dunderberg 1998a; laajempi versio: Dunderberg 2008, 95-118). Tunteista ja niiden terapiasta antiikin filosofiassa kattavammin ks. Knuuttila 2004; Nussbaum 1994.

${ }^{19}$ Lainaukseni Marian evankeliumista tässä artikkelissa ovat Antti Marjasen suomennoksesta (Marjanen 2001).

${ }^{20}$ On syytä korostaa, että stoalainen ihanne ei ollut apatia tunteettomuuden merkityksessä; tavoitteena oli päästä eroon järjenvastaisista, ihmisen elämää haittaavista tunteista ja korvata ne järkevillä "hyvillä tunteilla" (eupatheiai).

${ }^{21}$ Täydellisen ihmisen ideaalista ks. Engberg-Pedersen 2004.
} 
"Meidän pitää hävetä, pukea yllemme täydellinen ihminen ja sitten tehdä niin kuin meitä käskettiin: meidän tulee saarnata evankeliumia eikä meidän pidä vaatia noudettavaksi muuta sääntöä tai lakia kuin sitä, minkä Vapahtaja ilmoitti meille.” (Mar. ev. 18.)

Marian evankeliumin yhteydet antiikin filosofisiin teorioihin osoittavat, että sen kirjoittaja oli koulutusta saanut varhainen kristitty toisen vuosisadan puolivälin paikkeilla, jolloin filosofian vaikutus varhaisten kristittyjen ajatuksiin alkoi näkyä entistä selvemmin. ${ }^{22}$

\section{Viittauksia Johanneksen evankeliumiin}

Edellä on jo todettu, että Marian evankeliumissa näyttää olevan viitteitä Johanneksen evankeliumiin. Miten sen vaikutus näkyy Marian evankeliumissa? Ensinnäkin Johanneksen kuvaus Magdalan Mariasta Jeesuksen haudalla ja ylösnousemuksen ensimmäisenä todistajana (Joh. 20:1-2, 11-18) näyttää heijastuvan Marian evankeliumiinkin. Johanneksessa Maria todistaa ylösnousemuksesta Jeesuksen oppilaille: "Olen nähnyt Herran" (20:18); Marian evankeliumissa Maria aloittaa puheensa Jeesuksen oppilaille samalla tavalla: "Minä näin Herran näyssä...” (Mar. ev. 10). Kummassakin evankeliumissa kuvataan, kuinka Maria itki, tosin eri syistä: Johanneksen mukaan Maria itki, koska luuli jonkun vieneen Jeesuksen ruumiin haudasta; Marian evankeliumissa hänen itkunsa syynä ovat hänen opetustaan vastaan esitetyt epäilykset (Mar. ev. 18). Vaikka konteksti on erilainen, on hyvin mahdollista, että Marian itku on Johanneksen kuvaukseen

\footnotetext{
${ }^{22}$ Marian evankeliumin yhteydet antiikin filosofisiin teemoihin ovat huomattavasti selvempiä kuin Johanneksen evankeliumin. Vaikka Johanneksen evankeliumissa on joitain selvästi filosofisia piirteitä (kuten logos-teologia), siitä vielä puuttuu "ainetta” koskeva spekulointi eikä siinä puhuta emootioistakaan yhtä selkeästi stoalaiseen tapaan kuin Marian evankeliumissa. Gitte Buch-Hansen argumentoi väitöskirjassaan, että stoalainen filosofia vaikutti merkittävästi Johannekseen (Buch-Hansen 2010), mutta ei nähdäkseni pysty esittämään riittävän selkeitä yhtymäkohtia teoriansa tueksi; konkreettisimmat hänen esittämistään vertailukohdista tulevat Filonilta, eivät stoalaisten filosofien omista teksteistä.
} 
perustuva, "tuttu" yksityiskohta, joka Marian evankeliumissa on sijoitettu uuteen yhteyteen. ${ }^{23}$

Marialla on Marian evankeliumissa samanlainen rooli Jeesuksen "suosikkioppilaana" kuin Johanneksen evankeliumin nimettömällä "opetuslapsella jota Jeesus rakasti." Johanneksen lempioppilaan tavoin Maria kuvataan "hahmoksi, joka Jeesuksen erityisenä suosikkina vahvistaa [evankeliumin] paikkansapitävyyden." ${ }^{24}$ Kahden evankeliumin välinen yhteys ei kuitenkaan tältä osin ole erityisen läheinen, sillä Marian evankeliumissa Maria ei esiinny samoissa tilanteissa tai rooleissa kuin lempioppilas Johanneksen evankeliumissa. Marian evankeliumin kirjoittaja ei siis käyttänyt tilaisuutta vihjatakseen, että Johanneksessa kuvattu "opetuslapsi jota Jeesus rakasti" oli Maria. ${ }^{25}$

Kuten edellä totesin, useimmat Marian evankeliumin tutkijat katsovat, että evankeliumissa näkyy Johanneksen vaikutus, mutta ovat eri mieltä, kuinka merkittävää tämä vaikutus on. Esimerkiksi Nagelin mukaan Johanneksen käyttö Marian evankeliumissa on vähäistä. Nagel pitää tätä osoituksena siitä, ettei evankeliumin sanoma sopinut kovin hyvin "niille kristillis-gnostilaisille piireille, joiden keskellä Marian evankeliumi syntyi." 26

23 Myös "nousemisen" teema yhdistää Marian evankeliumin Johanneksen kuvaukseen Jeesuksesta ja Magdalan Mariasta. Teemaa käsitellään hyvin eri tavoin: Johanneksessa on kyse Jeesuksen noususta Isän luokse (Joh. 20:17), Marian evankeliumissa taas puhutaan sielun noususta yleisemmin. Johanneksen esityksessä tässä kohtaa esiintyvä, oudoksi jäävä yksityiskohta (Jeesus ei ole vielä noussut Isän luokse) kuitenkin herätti jo varhain pohdintoja sielun ja ruumiin suhteesta (näin erityisesti Origenes; ks. Lehtipuu 2015). Tätä taustaa vasten on mahdollista ajatella, että Johanneksen kuvaus Jeesuksen ja Marian kohtaamisesta saattoi johtaa Marian evankeliumissa esitettyyn kuvaukseen sielun noususta.

${ }_{24}$ Marjanen 2005, 56; ks. myös Marjanen 1996, 116. Keskeinen ero Johanneksen lempioppilaaseen on, että Marian evankeliumissa vedotaan Marian ilmestyksessä saamaan erityisilmoitukseen Jeesuksen opetuksesta.

${ }^{25}$ de Boer (2000) esittää, että Johanneksessa kuvatun lempioppilaan taustalla on Magdalan Marian hahmo. Ilmeinen ongelma hänen näkemyksessään on, että Johanneksessa lempioppilas on miespuolinen hahmo; tämän osoittavat maskuliininen artikkeli ja maskuliiniset relatiivipronominit kaikissa niissä yhteyksissä, joissa "opetuslapsi jota Jeesus rakasti" mainitaan (Marjanen 2005, 59 n. 6). Lisäksi Johanneksen kertomuksessa tyhjästä haudasta (Joh. 20:1-18) Maria ja lempioppilas ovat kaksi erillistä hahmoa (j. 2).

${ }^{26}$ Nagel 2000, 469. Tutkijat ovat eri mieltä, onko Marian evankeliumi "gnostilainen" teksti; yhteenveto tutkimustilanteesta: Tuckett 2007, 42-54. Tuckett kiinnittää katsauksessaan huomiota myös siihen, että Antti Marjanen aluksi piti Marian evankeliumia gnostilaisena tekstinä (Marjanen 1996), mutta on sittemmin muuttanut mielensä (Marjanen 2002, 32). 
Edellä mainittujen yksityiskohtien lisäksi Marian evankeliumissa on kuitenkin myös syvällisempiä temaattisia yhteyksiä Johanneksen evankeliumiin. ${ }^{27}$ Johanneksen evankeliumin jäähyväispuheessa Jeesus ennustaa, kuinka hänen oppilaansa saavat hänen poismenonsa jälkeen "itkeä ja valittaa" (Joh. 16:20). Aivan samalla tavalla kuvataan Jeesuksen oppilaiden tilanne Marian evankeliumissa, kun Jeesus poistuu heidän luotaan: "Oppilaat itkivät epätoivoisesti" (Mar. ev. 8). Yhteistä molemmille evankeliumeille on myös Jeesuksen oppilaiden tuntema pelko. Johanneksen evankeliumissa he kokoontuvat ylösnousemuksen jälkeen lukittujen ovien takana, "sillä he pelkäsivät juutalaisia" (Joh. 20:19). Samanlaista pelkoa Jeesuksen oppilaat osoittavat myös Marian evankeliumissa: "Kuinka voimme mennä saarnaamaan valtakunnan evankeliumia tosi ihmisestä muille ihmisille? Kun he eivät säästäneet Vapahtajaa, kuinka he säästäisivät meitäkään?” (Mar. ev. 8).

Marian evankeliumissa Maria kuvataan Jeesuksen oppilaiden lohduttajaksi. Hänen roolinsa on tältä osin samanlainen kuin Jeesuksen Johanneksen evankeliumissa (Joh. 14:27). Toisaalta Maria muistuttaa myös Johanneksen evankeliumissa luvattua Puolustajaa, Pyhää Henkeä: hän lohduttaa ja rohkaisee Jeesuksen oppilaita tämän uusilla (tai aiemmin salatuksi jääneillä) opetuksilla. Johanneksen evankeliumi pitää portin auki tällaiselle täydentävälle opetukselle: "Paljon enemmänkin minulla olisi teille puhuttavaa, mutta te ette vielä kykene ottamaan sitä vastaan" (Joh. 16:12).

Johanneksessa kuvatun Puolustajan tehtäviin kuuluu myös Jeesuksen opetuksista muistuttaminen: "Puolustaja, Pyhä Henki, jonka Isä minun nimessäni lähettää, opettaa teille kaiken ja palauttaa mieleenne kaiken, mitä olen teille puhunut" (Joh. 14:26). Muistamisen näkökulmalla on keskeinen asema Marian evankeliumissakin: Pietari pyytää nimenomaisesti Mariaa kertomaan ne sanat, jotka tämä muistaa (Mar. ev. 10). Kreikankielisessä katkelmassa Maria itsekin korostaa tässä kohdassa muistamisen merkitystä luvaten kertoa Jeesuksen oppilaille

${ }^{27}$ Näitä yhteyksiä nostavat esiin King 2003; Petersen 1999. 
"kaiken sen mitä minä muistan mutta mitä te ette tiedä" (P. Oxy. 3525.17).

Yhteydet Johanneksessa kuvattuun Puolustajaan eivät lopu vielä tähän. Marian ilmestyksen lopuksi todetaan: "Tämän sanottuaan Maria vaikeni, sillä Vapahtaja ei ollut puhunut hänelle enempää" (Mar. ev. 17). Tämä päätös sopii hyvin yhteen sen kanssa, miten Johanneksen evankeliumissa kuvataan totuuden hengen toimintaa: "Hän ei puhu omissa nimissään, vaan puhuu sen, minkä kuulee, ja ilmoittaa teille sen, mitä on tuleva" (Joh. 16:13).

\section{Johanneksen evankeliumi intertekstinä}

Marian evankeliumissa on niin paljon yhteyksiä Johanneksen evankeliumiin, että on mielekästä pohtia, millaisia intertekstuaalisia tulkintoja näiden kahden tekstin suhteesta nousee. Intertekstuaalinen näkökulma korostaa tekstin lukijan ja tulkitsijan näkökulmaa. Tarkoituksena ei ole niinkään paljastaa tekstin, tässä tapauksessa Marian evankeliumin, kirjoittajan intentio kuin pohtia, millä tavalla evankeliumin tulkintaan vaikuttaa, jos sen rinnalla luetaan Johanneksen evankeliumia.

Intertekstuaalisessa tulkinnassa kysymys voidaan asettaa myös toisin päin: avaako myöhemmin kirjoitettu Marian evankeliumi uusia näkökulmia aikaisemmin kirjoitettuun Johanneksen evankeliumiin? Karen King on esittänyt tämänsuuntaisen tulkinnan: hänen mukaansa Marian evankeliumin kuvaus Mariasta näkijänä, lohduttajana ja opettajana paljastaa, kuinka "hänen asemaansa on rajoitettu Johanneksen evankeliumissa." Marian evankeliumi osoittaa Kingin mukaan, kuinka Johanneksen evankeliumissa "Marian arvovalta ylösnousemuksen todistajana alistetaan miesoppilaiden arvovallalle, erityisesti rajaamalla hänelle annettu tehtävä vain siihen, että hän todistaa muille oppilaille." $28^{28}$

${ }^{28}$ King 2003, 131. 
King ei varsinaisesti oleta, että Johanneksen evankeliumi ja Marian evankeliumi edustavat kahta vastakkaista puoluetta varhaisten kristittyjen kiistoissa naisen asemasta; silti hänen tulkintansa tulee hyvin lähelle tällaista selitysmallia. On selvää, että Marian evankeliumi luo moniulotteisemman kuvan Magdalan Mariasta kuin Johanneksen evankeliumi. Kingin tulkinta kuitenkin johtaa mielestäni tarpeettomaan negatiiviseen käsitykseen Johanneksen evankeliumin naiskuvasta. Väite, että Johannes rajaa Marian asemaa ylösnousemuksen todistajana, vaatisi mielestäni selkeämmän näytön siitä, että Johanneksen käyttämässä traditiossa Marialla oli aktiivisempi rooli, jota Johannes omalla kertomuksellaan halusi heikentää. Marian evankeliumiin perustuva jälkiviisaus ei tee täyttä oikeutta Johanneksen evankeliumin kirjoittajaa kohtaan, jonka kuvauksessa korostuu Marian myönteinen rooli ylösnousemuksen todistajana. Lisäksi Johanneksella ei ole pyrkimystä rajoittaa naisen roolia todistajana, pikemminkin päinvastoin: evankeliumissa kuvatulla samarialaisella naisella (Joh. 4) on keskeinen rooli sekä keskustelussa Jeesuksen kanssa että todistajana, joka kutsuu muut samarialaiset Jeesuksen luokse.

Toisaalta ei ole myöskään täysin selvää, kuinka aktiivinen Marian asema lopulta on Marian evankeliumissa. Hän toimii aktiivisesti Jeesuksen oppilaiden lohduttajana, mutta epäselväksi jää, kuuluuko hän itse tähän joukkoon, jonka tehtäväksi Jeesus antaa evankeliumin julistaminen kaikkeen maailmaan. Evankeliumissa kuvattu ongelma on, etteivät Jeesuksen oppilaat halua noudattaa Jeesuksen käskyä julistaa evankeliumia (Mar. ev. 9). Evankeliumin lopussa ongelma ratkeaa: Jeesuksen oppilaat - tai ainakin osa heistä - ryhtyy julistamaan evankeliumia Vapahtajan käskyn mukaan (Mar. ev. 18). Maria ei ainakaan kuulu pelokkaisiin oppilaisiin, sillä hän kehottaa heitä olemaan pelkäämättä. Tekstistä ei käy suoraan ilmi, onko hän yksi niistä, joka lopulta lähtee julistamaan evankeliumia, vai rajoittuuko hänen roolinsa siihen, että hän saa Jeesuksen oppilaat liikkeelle. 


\section{Retorinen tilanne: vainot ja pelon voittaminen}

Yhteydet Johanneksen ja Marian evankeliumin välillä viittaavat nähdäkseni pikemmin jatkuvuuteen kuin ristiriitaan. Marian evankeliumi ikään kuin jatkaa siitä tilanteesta, johon Johanneksen evankeliumissa jäätiin, ja Maria itse kuvataan pitkälti samanlaiseksi hahmoksi kuin Johanneksen evankeliumissa luvattu Puolustaja. Marian evankeliumi pikemminkin rakentuu Johanneksen evankeliumissa esitettyjen ajatusten varaan ja kehittää niitä edelleen kuin asettaa ne kriittiseen valoon.

Totesin jo edellä, että Marian evankeliumissa on selkeitä viittauksia antiikin filosofiasta omaksuttuihin käsityksiin. Miten Johanneksen evankeliumiin palautuvat piirteet sopivat tällaiseen kontekstiin? Huomionarvoista on, ettei Marian evankeliumi tartu Johanneksen logosteologiaan, vaikka juuri se olisi tarjonnut selkeimmän lähtökohdan filosofisesti suuntautuneelle tulkintatavalle. Sen sijaan Marian evankeliumissa kertomuksen avainkohdaksi on nostettu Jeesuksen oppilaiden pelko, jota kuvataan samalla tavoin kuin Johanneksen evankeliumissa. Sama teema esiintyy muissakin dialogievankeliumeissa, mutta Marian evankeliumissa sillä on poikkeuksellisen keskeinen asema koko kertomuksen keskeisenä juonteena.

Jeesuksen oppilaiden pelko on keskeinen piirre Marian evankeliumissa siksi, että tämä teema tarjoaa kirjoittajalle tilaisuuden kuvata sielun nousua korkeuksiin. Jeesuksen oppilaat ovat aluksi pelon halvaannuttamia eivätkä pysty noudattamaan Jeesuksen käskyä: "Kuinka voimme mennä saarnaamaan valtakunnan evankeliumia tosi ihmisestä muille ihmisille? Kun he eivät säästäneet Vapahtajaa, kuinka he säästäisivät meitäkään?” (Mar. ev. 9.) Evankeliumin kertomus sielusta tarjoaa ratkaisun tähän ongelmaan: kertomus osoittaa Jeesuksen oppilaille, että sielu voi saavuttaa sellaisen järkähtämättömyyden tilan, ettei ruumiin kokemilla tuskilla enää ole siihen vaikutusta: "Surmattu on se, joka on pitänyt minua vallassaan. Kukistettu on se, joka on ympäröinyt minua” (Mar. ev. 16). Lisäksi evankeliumissa todetaan, että tällainen sielun voitto ruumiista on mahdollinen jo tässä elämässä: sielu on jo "vapautettu" ja pääsee lepoon "tästä hetkestä alkaen" (Mar. ev. 17). 
On mahdollista, että Marian evankeliumissa kuvatun opetuksen sielun noususta korkeuksiin tekivät ajankohtaiseksi kristittyjen kokemat vainot tai niiden uhka. Clemens Aleksandrialainen esitti hyvin samankaltaisia pohdintoja siitä, miten ihannekristitty, josta Clemens käytti termiä "gnostikko", on sisäisesti niin vahva, ettei hänen tarvitse pelätä vainojen ruumiille aiheuttamaa tuskaa. Tästä näkökulmasta katsottuna filosofisen opetuksen tarkoituksena on auttaa tekstin lukijoita kohtaamaan vainon mahdollisuus rohkeasti: oikeanlainen henkinen lujuus ja asenne auttavat heitä kestämään ruumiin kokeman tuskan. ${ }^{29}$

Ei ole kuitenkaan varmaa, että Marian evankeliumissa kuvattu retorinen tilanne on sama kuin oletettujen lukijoiden tilanne. Vainoja pelkäävien Jeesuksen oppilaiden kuvauksesta ei voi suoraan päätellä, että Marian evankeliumin lukijat elivät vainojen keskellä. On myös mahdollista, että evankeliumin kirjoittaja kuvaa Jeesuksen oppilaiden tilanteen antaakseen vaikuttavan esimerkin, kuinka pelko lamaannuttaa ihmisen. Marian saama Vapahtajan ilmoitus tarjoaa tähän pelkoon lääkkeen: siinä kuvataan, kuinka sielu voi saavuttaa tilan, jossa se on päässyt irti aineellisen maailman kahleista, joita ovat erityisesti ruumis ja siitä nousevat haitalliset tunteet.

Jos Marian evankeliumia luetaan tästä näkökulmasta käsin, Jeesuksen oppilaiden esittämät epäilykset Marian opetusta kohtaan paljastavat sielun sairauden vakavuuden: he eivät ota vastaan Marian heille tarjoamaa lääkettä, joka auttaisi heitä voittamaan pelkonsa.

Kertomus päättyy tässä suhteessa onnellisesti - ainakin joidenkin osalta: evankeliumin lopussa kerrotaan, kuinka Jeesuksen seuraajat lopulta noudattavat hänen käskyään ja lähtevät julistamaan evankeliumia (Mar. ev. 18). Evankeliumin lopetuksesta on kuitenkin kaksi erilaista versiota. Kreikankielisen katkelman mukaan ainoastaan Mariaa puolustanut Leevi lähti julistamaan. Koptinkielisessä versiossa samassa kohtaa käytetään monikollista muotoilua "he lähtivät ja alkoivat julistaa

\footnotetext{
${ }^{29}$ Ajatus toistuu useita kertoja Clemensin Stromateis-teoksen 4. luvussa, jossa aiheena on marttyyrius.
} 
ja saarnata."30 Tässä versiossa jää avoimeksi, ketkä lähtivät; vaihtoehdot ovat Leevi ja Maria tai kaikki Jeesuksen oppilaat. Kreikankielisen version mukaan vain yksi Jeesuksen oppilas voitti pelkonsa Marian opetuksen ansiosta, kun taas koptinkielinen versio voidaan hyvällä tahdolla tulkita niin, että kaikille kävi samoin.

\section{Lopuksi}

Edellä hahmottelemani kaksi tulkintaa vainojen ja filosofisen opetuksen suhteesta Marian evankeliumista eivät välttämättä sulje toisiaan pois. On ilmeistä, että evankeliumin tulkintaan vaikuttivat todellisten lukijoiden erilaiset tilanteet. Clemens Aleksandrialaisen pohdinnat, kuinka sielua voi etukäteen harjaannuttaa kohtaamaan marttyyriuden osoittavat, että tämänkaltaisella opetuksella oli tarvetta.

Vaikka Marian evankeliumi kuuluu selvästi David Brakken kuvaamaan "uuden ilmestyksen" kategoriaan, siinä on merkkejä myös "akateemisesta" näkökulmasta, johon antiikin filosofia osaltaan vaikutti. Rajat Brakken kuvaamien kategorioiden välillä ovat siis jossain määrin liukuvia. ${ }^{31}$ Johanneksen evankeliumista nousevien teemojen osalta Marian evankeliumi joka tapauksessa tukee Brakken esittämää mallia: Marian evankeliumissa ei esitetä suoria lainauksia eikä tehdä "eksegeesiä" Johanneksesta. Johanneksen evankeliumi voi olla Marialle annettujen piirteiden taustalla. Vain osa niistä palautuu Johanneksen kuvaukseen Magdalan Mariasta; olennaisempi piirre on Johanneksessa kuvattujen Jeesuksen ja Puolustajan ominaisuuksien siirtyminen Marian hahmoon.

\footnotetext{
30 Marjanen (2001, 442) valitsee Marian evankeliumin suomennoksessaan tässä kohtaa kreikankielisen version: "Tämän sanottuaan Leevi lähti ja alkoi julistaa evankeliumia." Koptinkielinen versio, jota Marjanen toisaalla (1996, 119) epäilee sekundääriksi, on käännetty suomennoksen alaviitteessä.

${ }^{31}$ Brakke $(2011,271)$ itsekin huomauttaa jaottelunsa heuristisesta luonteesta: "Tarkoitukseni on, että nämä kategoriat toimivat weberiläisten ideaalityyppien tavoin: vaikka lainaan erityisiä esimerkkejä jokaisesta ryhmästä kristinuskon historian neljän ensimmäisen vuosisadan ajalta, ei ole olemassa minkään ryhmän puhdasta edustajaa.”
} 
Ennen kaikkea Johanneksen vaikutus näkyy kertomuksen tasolla: Marian evankeliumissa kuvattu retorinen tilanne liittyy läheisesti Johanneksen evankeliumiin. Varsinkin tässä suhteessa Marian evankeliumi voi näyttää Johanneksen evankeliumin "jatko-osalta." Eri asia on, pyrkikö Marian evankeliumin kirjoittaja todella antamaan tällaisen vaikutelman Johanneksen jatko-osasta. Edellä kuvatut yhteydet Johanneksen ja Marian evankeliumin välillä eivät ole niin tarkkoja, että niiden perusteella Marian evankeliumin kirjoittajan voisi olettaa laskelmoidusti poimineen kerronnallisia lainoja Johannekselta. Monet yhtymäkohdat, kuten Jeesuksen oppilaiden pelon ja Marian itkun kuvaus, ovat tunteisiin vetoavia ja siksi helposti mieliin painuvia yksityiskohtia. ${ }^{32}$ Voidaan olettaa, että tällaiset Johanneksen evankeliumista lähtöisin olevat piirteet olivat toisen vuosisadan puolivälissä jo piirtyneet monien varhaisten kristittyjen "sosiaaliseen muistiin." Tämän vuoksi on hyvin mahdollista, että Marian evankeliumi toimii Johanneksen evankeliumin pohjalta syntyneen kertomustradition varassa pikemminkin kuin käyttää Johanneksen evankeliumia suoraan lähteenään. ${ }^{33}$

\footnotetext{
${ }^{32}$ Czachesz (2010) osoittaa, että monia varhaiskristilliseen kirjallisuuteen liittyviä oletuksia pitää arvioida uudelleen uusimman muistitutkimuksen valossa. Yksi muistin toimintaa aktivoivista tekijöistä on hänen mukaansa se, että teksti herättää tunteita (438-439).

${ }^{33}$ Esittämäni tulkinta Marian evankeliumista menee samaan suuntaan kuin Uron (1998b, 32) näkemys, että ainakin joissain Tuomaan evankeliumin lausumissa näkyy "toisen vaiheen suullisuus" (secondary orality), toisin sanoen sellainen suullinen traditio, jonka sisältöön varhaisemmat evankeliumit ovat osaltaan vaikuttaneet.
} 


\section{Jeesuksen oppilaat kirjureina}

(1999)

\section{Apostolit varhaisessa kirkossa}

"Apostolisuutta" pidetään tavallisesti yhtenä "oikeaoppisen" kirkon tunnusmerkkinä. "Apostolisella kirkolla" tarkoitetaan kirkkoa, joka perustuu Jeesuksen opetuslasten opetuksiin ja heidän todistukseensa Jeesuksen sanoista ja teoista. Kirkollisessa perinteessä apostolisen perinteen edustajaksi luetaan myös Paavali, joskin hänen asemansa "apostolina" jää vielä Uudessa testamentissa epäselväksi. Paavali lukee itsensä apostolien joukkoon, vaikkakin vain "vähäisimpänä" heistä (1. Kor. 15:9). Luukas sen sijaan kutsuu häntä apostoliksi vain kahdessa poikkeustapauksessa (Ap.t. 14:4, 14). Varsinaisia apostoleja Luukkaan esityksessä ovat Jeesuksen kaksitoista opetuslasta (esim. Luuk. 6:13).

Kristillisen kirkon katsotaan joka tapauksessa vaalivan apostolien perintöä. Apostolit ymmärretään nykyisin lähinnä sen kristinuskon tulkinnan takuumiehiksi, joka pääsi voitolle kirkon varhaisessa historiassa. Tilanne ei ollut yhtä selvä toisella vuosisadalla jKr., jolloin ei vielä tiedetty, ketkä kuuluvat voittajiin ja ketkä häviäjiin. Tässä vaiheessa apostoleihin ja heidän perimätietoonsa vetosivat yhtä hyvin "oikeaoppiset" kuin "harhaoppisetkin."

Ensiksi mainituista kirkkoisä Irenaeus vetosi Efeson seurakunnan apostoliseen traditioon, joka oli peräisin seurakunnan perustajilta, Paavalilta ja Johannekselta (Harh. 3.3.4). Apostolien opetuksiin vetosivat kuitenkin myös ne "harhaoppiset", joita vastaan Irenaeus hyökkäsi. Valentinoksen kerrotaan saaneen oppinsa Theudakselta, Paavalin 
oppilaalta, ja Basilideen Glaukiaalta, Pietarin tulkilta (Clemens Aleksandrialainen, Stromateis 7.106.4). Glaukias näyttää olleen kilpaileva vaihtoehto sille suhteellisen varhaiselle kirkolliselle perimätiedolle, jonka mukaan Pietarin tulkkina toimi Markus. "Harhaoppisista" apostolisuuden periaatetta edisti omalla tavallaan myös Markion, joka "ensimmäisenä uskonpuhdistajana" hyväksyi lähinnä vain Paavalin opetukset.

\section{Kirjoittajafiktio Uuden testamentin evankeliumeissa}

Toisella vuosisadalla apostolisuuteen vedottiin hyvin erilaisten kristillisten tulkintojen yhteydessä. Varhaiskristillisessä kirjallisuudessa tämä näkyy pseudepigrafian lisääntymisenä. Yhä useampia kirjoituksia alettiin kirjoittaa Jeesuksen opetuslasten nimiin. Näissä kirjoituksissa niin sanotusta kirjoittajafiktiosta on tullut kirjallisen esityksen keskeinen piirre.

"Kirjoittajafiktio" tarkoittaa tapaa, jolla tietyssä kirjallisessa teoksessa kuvataan sen omaa syntyä. Vaikka termiin sisältyykin sana "fiktio", se ei sellaisenaan vielä ole kannanotto kirjoittajaa koskevien tietojen historialliseen todenperäisyyteen. Kirjoittajafiktio voi tapauksesta riippuen olla historiallisesti tosi tai epätosi. Historiallista totuusarvoa kiinnostavampi kysymys onkin se, miten kirjoittajafiktiota eri kirjoituksissa käytetään hyväksi.

Uuden testamentin kahdessa varhaisimmassa evankeliumissa (Matteus ja Markus) ei vielä esiinny erillisiä viittauksia näiden teosten kirjoittajiin. Sen sijaan Luukkaan evankeliumin kirjoittaja kuvaa oman kirjoituksensa syntyä seikkaperäisesti (Luuk. 1:1-4). Evankeliumin avausjakson tarkoituksena on vakuuttaa lukija siitä, että nyt käsillä oleva kirjoitus on erityisen luotettava esitys Jeesuksen vaiheista.

Johanneksen evankeliumi on Uuden testamentin evankeliumeista ainoa, jonka kirjoittajaksi ilmoitetaan Jeesuksen oma oppilas. Kirjoittajan henkilöllisyys paljastetaan lukijalle aivan evankeliumin lopussa: "Juuri tämä opetuslapsi todistaa kaikesta tästä. Hän on tämän kirjoittanut, ja me tiedämme, että hänen todistuksensa on luotettava" (Joh. 21:24). 
Johanneksen evankeliumin lopussa mainittu "tämä opetuslapsi" on vain tässä evankeliumissa esiintyvä "opetuslapsi jota Jeesus rakasti". Hahmo on esiintynyt aiemmin myös itse evankeliumikertomuksessa. Evankeliumissa kuvatulla viimeisellä aterialla hän on kunniapaikalla "Jeesuksen sylissä" (Joh. 13:23; KR tosin kääntää - homoeroottisia vivahteita peläten? - "Jeesuksen vierellä"). Ei liene sattuma, että evankeliumissa samaa ilmaisua käytetään Jeesuksen ja Isän läheisestä suhteesta (Joh. 1:18).

Jeesuksen rakastama opetuslapsi esiintyy erityisesti kuvauksissa Jeesuksen kärsimyksestä ja ylösnousemuksesta. Hän on ainoana opetuslapsena Jeesuksen ristin juurella ja todistaa tämän kuoleman. Juuri ennen kuolemaansa Jeesus uskoo äitinsä tämän oppilaan holhoukseen (Joh. 19:25-26, 34-35). Samainen oppilas ehtii opetuslapsista ensimmäisenä tyhjän haudan luona (Joh. 20:2-10) ja tunnistaa ensimmäisenä ylösnousseen, kun tämä ilmestyy Tiberiaanjärven rannalla (Joh. 21:18). Nämä piirteet osoittavat, että Johanneksen evankeliumissa kirjoittajan kuvataan olleen erityisasemassa Jeesukseen oppilaiden joukossa.

Historiallisesti arvioituna Johanneksen evankeliumin kirjoittajafiktio on ongelmallinen. Jeesuksen rakastama oppilas esiintyy sellaisissa kertomuksissa, jotka on kuvattu myös kolmessa muussa Uuden testamentin evankeliumissa. Näissä muiden evankeliumien rinnakkaiskohdissa häntä ei kuitenkaan mainita kertaakaan. Tämän havainnon perusteella on ilmeistä, että lempioppilas on lisätty niihin kertomuksiin, joissa hän esiintyy, vasta suhteellisen myöhäisessä vaiheessa.

Osa tutkijoista olettaa, että "Jeesuksen rakkaimman oppilaan" hahmon taustalla on todellinen henkilö, jolla oli merkittävä asema evankeliumin taustalla olleessa yhteisössä. Tässä tapauksessa hän olisi voinut olla kyseisen yhteisön perustaja ja/tai Johanneksen evankeliumin alkuperäinen kirjoittaja, josta jälkikäteen olisi sijoitettu uutena hahmona evankeliumikertomukseen - hieman samaan tapaan taiteilijat ovat sijoittaneet oman aikansa merkkihenkilöitä raamatullisia aiheita kuvaaviin tauluihinsa. Toiset tutkijat taas olettavat, että hahmo on puhtaasti kuvitteellinen. Kummassakin tapauksessa on selvää, että tämän hahmon, jossa yhdistyvät kirjoittaja ja erityisasemassa oleva opetuslapsi, ensisijaisena tehtävänä on vakuuttaa lukija Johanneksen evankeliumin luotettavuudesta. 


\section{Kirjoittajafiktio ja "alkuperäinen" teksti}

Se, että kirjoituksien autenttisuutta korostettiin kertomalla niiden kirjoittajasta, ei ollut varhaiskristillisellä kaudella uusi ilmiö. Esimerkiksi juutalaisessa apokalyptisessa kirjallisuudessa kirjoittajafiktiota käytettiin samaan tarkoitukseen. Apokalyptisissa kirjoituksissa ei ainoastaan kerrottu kuka tekstin oli kirjoittanut, vaan niissä kuvattiin tekstin syntytilannetta usein hyvinkin seikkaperäisesti.

Henokin nimiin kirjoitetuissa apokalyptisissa teksteissä, kerrotaan muun muassa kuinka Henokille annettiin kynä ja muita kirjoitusvälineitä, jotta hän voisi kirjoittaa muistiin saman tien ne salaisuudet, jotka jumalallinen ilmoittajahahmo hänelle paljastaa (2 Henokin kirja 22-23). Kirjoituksen varsinaisen syntytilanteen lisäksi voidaan kuvata sitä, kuinka kirjoitus tulee säilymään vuosisatojen halki. Tällainen selitys oli tarpeen varsinkin sellaisten kirjoitusten yhteydessä, joiden kirjoittajaksi on nimetty joku muinaisajan merkkihenkilö. Henokin kirjan kuvataan olevan erityisessä jumalallisessa varjeluksessa: kirja pelastuu kuin ihmeen kaupalla vedenpaisumuksesta.

Kirjoituksen autenttisuutta voitiin korostaa myös muilla tavoin. Juutalaisessa Kahdentoista patriarkan testamentissa kukin Israelin kahdestatoista kantaisästä kuvaa lapsilleen elämäänsä ja kertoo heille viimeisen tahtonsa. Yksittäiset "testamentit" alkavat säännöllisesti maininnalla "tämä on jäljennös patriarkka n:n testamentista". Kysymys ei enää tarkalleen ottaen ole "kirjoittajafiktiosta", vaan kuvauksesta, jonka perusteella tiettyä käsillä olevaa tekstiä voidaan pitää luotettavana kopiona alkuperäisestä. Tässäkin tapauksessa lukija halutaan vakuuttaa siitä, että hän on mahdollisimman suorassa yhteydessä "alkuperäiseen" tekstiin ja sen sanomaan.

\section{Jeesuksen oppilaat kirjureina}

Johanneksen evankeliumi eroaa edellä mainituista teksteistä siinä, että sen kirjoittajafiktio ei ole kovinkaan konkreettinen. Evankeliumissa ei kerrota, missä tilanteessa tai millaisilla välineillä ”Jeesuksen rakkain opetuslapsi” evankeliuminsa kirjoitti. Myöhempi kirkollinen perimä- 
tieto tosin täydensi tämän puutteen: nimetön opetuslapsi nimettiin Johannekseksi, Sebedeuksen pojaksi, jonka kerrottiin kirjoittaneen evankeliuminsa omien oppilaidensa nimenomaisesta kehotuksesta.

Muista varhaiskristillisistä teksteistä löytyy tarkkoja kuvauksia opetuslapsista kirjoittajina ja kirjoittamistilanteesta. Nämä kuvaukset eivät yksityiskohtaisuudessaan jää jälkeen Henokin nimiin kirjoitetuista teksteistä.

Koptilainen Pistis Sofia - joka muutamien tutkijoiden mielestä edustaa gnostilaisuuden myöhäistä, jo rappeutunutta vaihetta - esittelee lukijalle koko joukon Jeesuksen rakastamia opetuslapsia, jotka kirjoittavat Jeesuksen sanoja muistiin. Erityistä huomiota tässä tekstissä kiinnitetään Filippokseen. Eräässä tilanteessa hänen vastauksensa Jeesukselle osoittautuu erinomaisen ymmärtäväiseksi. Tämän seurauksena Jeesus valtuuttaa Filippoksen kirjurikseen: ”Erinomaista, Filippos, sinä rakastettu. Tule, istu alas ja kirjoita muistiin kaikki sanat jotka minä sanon, ne teot joita teen ja kaiken mitä vielä näet.” Tämän jälkeen kuvataan, kuinka Filippos välittömästi noudatti Jeesuksen kehotusta ja alkoi kirjoittaa tämän sanoja muistiin (Pistis Sofia 75.1-6).

Nag Hammadin kirjastoon kuuluvan Tuomas Kilvoittelijan kirjan alussa opetuslapsi Mattaias kuvaa tilanteen, jossa hän kuuli Vapahtajan keskustelevan Tuomaan kanssa. Kirja perustuu tästä keskustelusta tehtyihin muistiinpanoihin: "Nämä salaiset sanat Vapahtaja puhui Juudas Tuomaalle ja minä, Mattaias, kirjoitin ne muistiin. Kuulin heidän keskustelevan, kun olin kävelyllä” (Tuom. kilv. 138.1-4; käännös: Dunderberg, Marjanen \& Uro). Tässä tapauksessa kirjoittajafiktio on välillinen: kirjoittaja ei ole ilmoituksen ensisijainen vastaanottaja, vaan sattumalta paikalle osunut sivullinen. Kirjuri Mattaias osoittautuukin tässä kirjoituksessa toissijaiseksi hahmoksi. Hänen sijastaan teksti saa nimensä Jeesuksen keskustelukumppanin, Tuomaan mukaan: "Tuomaan kirja, Kilvoittelija kirjoittaa täydellisille" (Tuom. kilv. 145.17-19).

Näissä kahdessa esimerkissä kirjoittajafiktio on huomattavasti konkreettisempi kuin Johanneksen evankeliumissa. Johanneksen evankeliumin kirjoittajafiktiota lähempänä onkin Tuomaan evankeliumin vastaava kuvaus. Tämän Jeesuksen sanojen kokoelman alussa mainitaan vain kirjoittaja, mutta kirjoittamistilannetta ei kuvata 
tarkemmin: "Nämä ovat salaiset sanat, jotka elävä Jeesus puhui ja jotka Didymos Juudas Tuomas kirjoitti muistiin" (Tuom. ev., johdanto; käännös: Huuhtanen, Marjanen \& Uro).

Tuomaan evankeliumissa kirjoittajafiktio ja tapa, jolla kirjoittajaa kuvataan muualla evankeliumissa, liittyvät läheisesti toisiinsa. Kuten lempioppilas Johanneksen evankeliumissa, Tuomas on Tuomaan evankeliumissa erityisasemassa Jeesuksen oppilaiden joukossa. Tämä erityisasema kuitenkin kuvataan toisella tavalla. Tuomaan kuvataan oivaltaneen sen, mitä muut oppilaat eivät tajunneet: Jeesusta ei voi verrata kehenkään tai mihinkään muuhun. Tuomaan osoittama ymmärrys tekee hänestä tasa-arvoisen Jeesuksen kanssa eikä hänen enää tarvitse kutsua tätä opettajaksi. Tämän ymmärryksen seurauksena Jeesus paljastaa Tuomaalle kahden kesken kolme salaista sanaa, joita muut opetuslapset eivät saa tietää (Tuom. ev. 13).

Tuomaan saavuttama tasavertaisuus Jeesuksen kanssa tekee hänestä esikuvallisen hahmon Tuomaan evankeliumissa. Tila, jonka hän on jo saavuttanut, kuvataan myöhemmin samassa kirjoituksessa yleiseksi, kaikkia Jeesuksen seuraajia koskevaksi tavoitteeksi: "Jeesus sanoi: 'Joka haluaa juoda minun suustani, siitä tulee minun kaltaiseni. Minusta tulee hän, ja salatut asiat paljastuvat hänelle” (Tuom. ev. 108).

Tuomaan evankeliumin kuvaus kirjoittajastaan poikkeaa siis jossain määrin Johanneksen evankeliumin kirjoittajafiktiosta. Ei ole selvää, että Johanneksen evankeliumissa Jeesuksen rakastama opetuslapsi olisi kuvattu erityisen älykkääksi ja ymmärtäväiseksi hahmoksi. Johanneksen evankeliumissa ei korosteta, että hänellä olisi ollut muilta oppilailta salattua tietoa Jeesuksen opetuksista. Häntä ei myöskään selkeästi kuvata roolimalliksi, vaikka häntä onkin usein sellaisena pidetty. Jeesuksen ja hänen oppilaansa läheistä suhdetta hyödynnetään yksipuolisemmin kuin Tuomaan evankeliumissa vakuuttamaan lukija kirjoituksen taustalla olevan "traditioketjun" luotettavuudesta. Tuomaan evankeliumissa tämä aspekti on vain yksi monien joukossa. 


\section{Pohdintaa}

Varsinkin viime aikoina raamatuntutkimuksesta käydyssä keskustelussa "historiallista kritiikkiä" on pidetty valistusajan lapsena. Väite pitää epäilemättä paikkansa, mutta vain osittain. Jo antiikin aikana osattiin tehdä kriittisiä havaintoja. Pseudepigrafia, peite- tai väärennetyn nimen turvissa kirjoittaminen, oli siksi yleistä, että tiedonantoihin kirjoittajista osattiin suhtautua varauksella. Joidenkin antiikin ajan kirjoittajien tiedetään jo elinaikanaan valittaneen, että liikkeellä oli heidän nimissään kirjoitettuja väärennöksiä.

Opetuslasten käyttö varhaiskristillisten kirjoitusten takuumiehinä ei automaattisesti merkinnyt, että varhaiset kristityt olisivat hyväksyneet ne muitta mutkitta. Varhaisessa kirkossa epäilyjä kohdistettiin jopa jo kanonisen aseman saavuttaneisiin evankeliumeihin. Vielä 300-luvulla eräiden kristittyjen tiedetään kyseenalaistaneen Johanneksen evankeliumin luotettavuuden. Syynä heidän kielteiseen arvioonsa oli epäilemättä se, että Johanneksen evankeliumi poikkesi huomattavasti muista evankeliumeista.

Varhaisen kristinuskon piirissä tämänkaltaista historiallista kritiikkiä esiintyi, mutta se näyttää vaimentuneen samoihin aikoihin kun kristinuskon asema Rooman valtakunnassa virallistui. Uudella ajalla virinnyt Raamatun historiallis-kriittinen tutkimus jatkoi pitkälti siitä mihin 300-luvulla oli jääty eli tekijäkysymyksen kriittisestä tarkastelusta.

Uskonnonfilosofisessa keskustelussa on uskonnollisen kielen vakuuttavuutta pohdittaessa yhtenä ratkaisuna esitetty, että uskonnollisella kielellä on omat sisäiset lainalaisuutensa ja pelisääntönsä, joihin sen vakuuttavuus perustuu. Tämän filosofisen näkökulman rinnalla on kuitenkin otettava huomioon toinen, historiallinen näkökulma eli se, että myös uskonnollinen kieli ja sen vakuuttavuus ovat aina monin tavoin sidoksissa omaan aikaansa. Tavat, joilla uskonnolliselle viestille etsitään vakuuttavuutta, ovat eri aikoina erilaisia aivan kuten sekin, mikä koetaan vakuuttavaksi ja luotettavaksi.

Opetuslasten käyttö varhaiskristillisten kirjoitusten sisällön takuumiehinä oli yksi omaan aikaansa sidotuista keinoista, jolla uskonnollisen sanoman vakuuttavuudelle haettiin lisäpontta. Keino ei vaikuta erityisen "uskonnolliselta" eikä se sitä ollutkaan antiikin maailmassa, jossa 
entisaikojen merkkihenkilöiden nimiin kirjoitettiin kirjallisuutta laidasta laitaan. Keinon aikasidonnaisuutta kuvaa hyvin se, että tuskin kovin monelle meidän aikanamme tulisi mieleen vakuuttaa lukijansa uskonnollisesta sanottavastaan uudella Jeesuksen opetuslasten nimiin kirjoitetulla tekstillä. 


\section{Viimeiset tapahtumat ja Jeesuksen sanojen perimätieto}

(1998)

\section{Johdanto}

Käsillä olevan kirjan [Aikojen taite: Kirkko kolmannen vuosituhannen vaihteessa, 1998] suunnitteluvaiheessa minulle tarjottiin mahdollisuus kirjoittaa Uuden testamentin eskatologiaa käsittelevä artikkeli, jossa "hahmottuisi pelastushistoriallinen käsitys lopusta". Kirjoitukseni ei kuitenkaan ole kokonaisesitys Uuden testamentin eskatologiasta, ja pelkään pahoin, ettei siitä myöskään hahmotu toivottua "pelastushistoriallista” linjaa. Olen yksinkertaisesti valinnut tiettyjä Uuden testamentin eskatologiaan liittyviä teemoja ja keskittynyt käsittelemään niitä. Nämä teemat ovat seuraavat:

1. varhaiskristillisyyden ja apokalyptisen ajattelun suhde;

2. tulevaisuuden odotukset Jeesuksen ajan juutalaisuudessa;

3. kysymys "historian Jeesuksen" tulevaisuuden odotuksesta, ja tähän liittyen neljä erityiskysymystä:

4. Jeesuksen ja varhaisten kristittyjen käsitys Jumalan valtakunnasta;

5. varhaisimmat kuvaukset Ihmisen pojan paluusta;

6. käsitykset tulevasta tuomiosta;

7. miten varhaiset kristityt ratkaisivat "viivästyneen lopun" ongelman? 
Yhden sysäyksen valitsemalleni näkökulmalle on antanut viime aikoina vilkastunut tieteellinen keskustelu "historiallisesta Jeesuksesta." Yhtenä vedenjakajana tässä keskustelussa ovat olleet erilaiset arviot Jeesuksen tulevaisuudenodotuksista. Tavoitteenani on ennen kaikkea kuvata, kuinka moniulotteisen kuvan Jeesuksen sanojen varhainen perimätieto tästä kysymyksestä antaa. Lopullista ratkaisua historiallisen Jeesuksen ongelmaan tuskin voidaan antaa, sillä useissa tapauksissa on lähes mahdotonta arvioida, mikä lähiodotuksen osa-alue on historiallisesti varhaisin. Jeesuksen sanojen traditiossa joka tapauksessa on erilaisia käsityksiä siitä, mitä tulevaisuudelta odotetaan, eikä niiden välisten erojen harmonisointi ole aina mahdollista.

Varhaisimman synoptisen perimätiedon ohella (Markus ja Matteuksen ja Luukkaan käyttämä Jeesuksen sanojen kokoelma, niin sanottu Q-lähde) olen kiinnittänyt tarvittaessa huomiota Paavalin kirjeisiin, joissa usein heijastuvat varhaisimmat kristilliset näkemykset. Lisäksi olen muutamissa kohdissa viitannut Tuomaan evankeliumiin. Tämä Uuden testamentin ulkopuolinen Jeesuksen opetusten kokoelma muistuttaa monessa suhteessa synoptista Jeesuksen sanojen traditioita, mutta poikkeaa siitä etenkin eskatologian osalta huomattavasti.

Monia Uuden testamentin eskatologian keskeisiä ja mielenkiintoisia teemoja sivutaan tässä kirjoituksessa vain lyhyesti. Esimerkiksi kysymys ruumiin kohtalosta ylösnousemuksessa olisi keskeinen, mutta samalla laaja aihe, joka olisi vaatinut kokonaan oman tutkielmansa. Sama ongelma liittyy Ilmestyskirjan tulkintaan, joka sinänsä, etenkin vuoden 2000 kynnyksellä, olisi epäilemättä ollut ajankohtainen aihe.

\section{Kristillisen teologian äiti?}

Varhaiset kristityt odottivat tulevaisuudelta pian koittavaa, suurta käännettä, jolloin Herra palaa omiensa luokse. Tämä lähiodotus tulee näkyviin arameankielisessä huudahduksessa "maranata" ("Herramme, tule!", 1. Kor. 16:22; Didakhe 10:6), joka kuului jo Paavalia varhaisempaan kristilliseen perimätietoon. Lähiodotusta ja siihen liittyviä ongelmia heijastavat yhtä lailla Uuden testamentin varhaisin (1. Tess., n. 50 jKr.) kuin myöhäisinkin kirjoitus (2. Piet., n. 150 jKr.). Edellisessä kyse 
on lähinnä erityistapauksesta (osa seurakunnassa olevista kristityistä on ehtinyt kuolla ennen Herran paluuta, 1. Tess. 4:13-18), kun taas jälkimmäisessä ongelma on selvästi periaatteellisempi:

Erityisesti tietäkää, että lopun aikoina tulee pilkkaajia, jotka ovat omien himojensa vietävinä. He sanovat pilkaten: "Onko hän muka tullut, niin kuin lupasi? Isämme ovat nukkuneet pois, ja kaikki on entisellään, niin kuin on ollut maailman luomisesta asti." (2. Piet. 3:3-4)

Lähiodotusta voidaan pitää yhtenä selkeimmistä osoituksista siitä, että varhainen kristinusko oli apokalyptinen liike. ${ }^{1}$ Tunnettu ja usein siteerattu on saksalaisen Ernst Käsemannin toteamus, että "apokalyptiikka on kaiken kristillisen teologian äiti” ${ }^{2}$ Käsemann tosin puhuu apokalyptiikasta hyvin rajatussa merkityksessä: kyse on nimenomaan varhaiskristillisestä "paruusian lähiodotuksesta". ${ }^{3}$

"Apokalyptista ajattelua" määriteltäessä lähdetään yleensä liikkeelle sekä juutalaisissa että kristillisissä piireissä esiintyneestä kirjallisuuden lajista, ilmestyskirjallisuudesta. Sille on ominainen ajatus salatusta viisaudesta: tietyn kirjan kirjoittajalle tai profeetalliselle hahmolle paljastetaan jumalallisia salaisuuksia yliluonnollisella tavalla, tavallisesti näyissä tai taivasmatkojen yhteydessä. Salaisuuksien paljastajana on useimmiten taivaallinen olento, ei kuitenkaan Jumala itse, vaan hänen tähän tehtävään valtuuttamansa välittäjähahmo.

Ilmestyskirjallisuus ei ole ajatusmaailmaltaan yhtenäinen kirjallisuuden laji. Osittain tämä johtuu ilmestyskirjallisuudessa käytetystä värikkäästä kuvakielestä, jonka lopullinen, 'oikea' tulkinta jää usein hämäräksi, mutta myös siitä, että kirjoittajilla on ollut todella toisistaan poikkeavia käsityksiä tulevaisuudesta. Silti ilmestyskirjallisuudessa esiintyy yhteisiä, usein toistuvia painotuksia, joiden perusteella voidaan puhua apokalyptisesta ajattelusta. Apokalyptisen ajattelun ytimenä voi pitää dualismia, joka ilmenee kolmella eri tavalla: ${ }^{4}$

\footnotetext{
${ }^{1}$ Ks. esim. Uro 1988.

${ }^{2}$ Käsemann 1965a, 100.

${ }^{3}$ Käsemann 1965b, 105-106 n. 1.

${ }^{4}$ Vrt. Meeks 1983, 689.
} 
1. kosminen dualismi: taivas on Jumalan hallinta-alue ja sellaisena turmeltumaton, maa puolestaan on ihmisten turmeltunut asuinpaikka.

2. ajan dualismi: apokalyptiselle ajattelulle on ominaista "tämän ajan" ja "tulevan ajan" välille tehty ero. "Tämä aika" ymmärretään kielteisesti: sille on ominaista kiihtyvällä vauhdilla kasvava pahuus.

3. sosiaalinen dualismi: apokalyptisessa ajattelussa "valon lapset", "vanhurskaat" ja "valitut" erotetaan selkeästi "pimeyden lapsista", "väärämielisistä" ja "maailmasta".

Apokalyptiseen ajatteluun sisältyy muitakin tunnusomaisia piirteitä. Ilmestyskirjallisuudessa keskeistä on tulevaisuuden odotus, johon sisältyy ajatus pian koittavasta suuresta muutoksesta, jonka usein ajatellaan olevan kosminen, koko universumia koskeva käänne. Tähän odotukseen perustuu apokalyptinen maailmankuva, jonka amerikkalainen apokalyptiikan asiantuntija, John J. Collins, kiteyttää seuraavasti:

Elämä maailmassa perustuu yliluonnollisten olentojen, sekä hyvien että pahojen, toimintaan. Historian kulku on määrätty etukäteen, joskin yksityisillä ihmisillä on jonkin verran valinnanvaraa oman paikkansa suhteen. Tulossa on jumalallinen tuomio, jossa hyvät palkitaan ja pahat tuomitaan, eikä tämä tuomio rajoitu ainoastaan viimeiseen sukupolveen, vaan myös yksittäisiin kuolleisiin. ${ }^{5}$

Apokalyptiselle ajattelulle ominainen lähiodotus näkyy myös varhaisempien kirjoitusten tulkinnassa: niiden ajatellaan kuvaavan juuri sitä tilannetta, jossa apokalyptisen yhteisön jäsenet parhaillaan elävät. "Apokalyptiselle tulkitsijalle nykyhetki ja hänen oma lahkonsa ovat koko ilmoituksen polttopisteessä."6

"Apokalyptiikan" ja "eskatologian" välille on tehtävä käsitteellinen ero. Eskatologian piiriin kuuluvat kaikki näkemykset ja uskomukset, jotka tavalla tai toisella liittyvät "viimeisiin asioihin" (ta eskhata), oli

${ }^{5}$ Collins $1997,7$.

${ }^{6}$ Meeks 1983, 697. 
sitten kyse yksittäisen ihmisen tai koko ihmiskunnan kuolemanjälkeisestä kohtalosta tai koko universumin tulevaisuudesta. ${ }^{7}$ Apokalyptiikka on rajatumpi käsite kuin eskatologia: sille ovat ominaisia nimenomaan edellä kuvatut käsitykset (dualismi ja lähiodotus, johon usein liittyy ajatus kosmisesta katastrofista).

Kristinusko on monessa suhteessa juutalaisen apokalyptisen perinteen jatkaja ja ylläpitäjä. Apokalyptiikan kolminkertaiselle dualismille on edelleen helppo löytää yhtymäkohtia kristinuskon sisältä, vaikka sen piirissä on pitkään pyritty löytämään myönteisempiäkin näkökulmia olemassa olevaan todellisuuteen. Edellä lainattu kuvaus apokalyptisesta maailmankuvasta ei myöskään sanottavasti poikkea kristinuskon omaksumista peruskäsityksistä.

\section{Tulevaisuuden odotus juutalaisuudessa}

\section{Kansan tulevaisuus}

Eskatologisia teemoja systematisoitaessa tehdään tavallisesti ero koko maailman tulevaisuutta ja yksilön tuonpuoleista kohtaloa koskevien näkemysten välillä (universaalieskatologia ja individuaalieskatologia). ${ }^{8}$ Vanhan testamentin ja myöhempien juutalaisten kirjoituksissa kumpikaan näistä näkökulmista ei ole kuitenkaan yhtä keskeinen kuin kansallinen eskatologia, kansan tulevaisuuteen kohdistetut odotukset.

Jo Vanhan testamentin profeettojen julistuksessa tulevaisuuden odotus liittyi nimenomaan kansan kohtaloon. Varhaiset profeetat julistivat tuhoa sekä Israelille että Juudalle (esimerkiksi Aamos ja Hoosea). Pakkosiirtolaisuuden ajan profeettojen julistuksessa keskeistä oli lupaus omaan maahan palaamisesta ja tulevasta onnen ajasta siellä. Tulevaisuuden odotus liittyi läheisesti vallitsevaan historiallis-poliittiseen tilanteeseen, jota tulkittiin uskonnollisesti: Jahve salli vieraiden

\footnotetext{
${ }^{7}$ Wißmann 1982, 254.

${ }^{8}$ Esim. Wißmann, 1982, 255.
} 
kansojen tuhoavan kansan, joka oli hänet hylännyt, ja Jahven tahdosta vieras hallitsija, Kyyros, antoi kansan palata omaan maahansa (näin erityisesti Jes. 45:1-7).

Myös roomalaisajan juutalaisuudessa kansallinen eskatologia korostui. Useimpien juutalaisten yhteinen toive oli, että Jumala yhdistäisi hajallaan olevan Israelin ja palauttaisi kansan kunnian. ${ }^{9}$ Näihin odotuksiin liittyi ajatus uskonnollisesta muutoksesta: Jerusalemin temppeli puhdistettaisiin väärinkäytöksistä tai rakennettaisiin kokonaan uudelleen, jumalanpalveluselämä uudistettaisiin ja ihmiset alkaisivat vihdoin elää oikein sekä uskonnollisesti että eettisesti.

Eräänlaista "kansallista universaalieskatologiaa" edustivat pakanakansoja koskevat näkemykset. Pakanakansojen tulevaisuus liitettiin tavalla tai toisella Jumalan oman kansan kohtaloon. Pakanakansojen tilanteen odotettiin muuttuvan ratkaisevasti tulevaisuudessa. Siitä millainen tämä muutos olisi, esiintyi erilaisia käsityksiä alkaen pakanoiden joukkokääntymyksestä juutalaisuuteen ja päätyen pakanakansojen massiiviseen tuhoamiseen. ${ }^{10}$

Filonin, Aleksandriassa asuneen juutalaisen filosofin, tulkinta kansallisesta eskatologiasta oli avarampi kuin monien muiden aikalaistensa. Filon halusi osoittaa, että juutalainen uskonto on pohjimmiltaan yhdenmukainen kreikkalaisen filosofian kanssa, mikä antoi hänen ajattelulleen universalistisen perusvireen. ${ }^{11}$ Filonin käsitys "juutalaisesta kansasta" olikin pikemminkin uskonnollis-eettinen kuin poliittinen: "Yhteistä syntyperää, verisukulaisuutta tärkeämpää on hyveelle, yhteiselle Jumalan palvomiselle ja yhteisille laeille perustuva sukulaisuus." 12 Universalistisuus näkyy myös Filonin tulevaisuuden odotuksista. Hänen utopiansa oli, että juutalainen laki ja monoteismi lopulta leviävät kaikkien ihmisten keskuuteen ja tuovat pysyvän onnen tilan koko

\footnotetext{
${ }^{9}$ Sanders 1992, 278.

${ }^{10}$ Sanders 1992, 291-294.

${ }^{11}$ Ks. Fischer 1978, 184-213.

${ }^{12}$ Fischer 1978, 212.
} 
ihmiskunnalle. Tässä onnen tilassa kansojen väliset poliittiset ja sosiaaliset ristiriidat katoaisivat. ${ }^{13}$

Daavidin sukuun kuuluvan Messiaan odotus ei ollut niin yleistä kuin kristinuskon näkökulmasta voisi olettaa. Roomalaiskauden juutalaisessa kirjallisuudessa Messias-odotukseen viitataan yllättävän harvoin, ja niidenkin parissa, jotka todella odottivat Messiasta, käsitykset tästä hahmosta poikkesivat toisistaan. Esimerkiksi Qumranin yhteisössä odotettiin kahta messiasta, joista toinen oli Aaronin sukuun kuuluva pappismessias ja toinen maallinen hallitsija, "Israelin Messias". ${ }^{14}$

\section{Kuolemanjälkeinen elämä}

Ihmisen kuolemanjälkeinen elämä ei ole Vanhassa testamentissa samalla tavalla keskeinen aihe kuin kansan tulevaisuus. Lähinnä Vanhan testamentin psalmien perusteella voidaan hahmottaa jonkinlainen yleiskuva siitä, mitä ihmiselle ajateltiin tapahtuvan kuoleman jälkeen. Todennäköisesti kaikkien ihmisten (vrt. Ps. 89:49) ajateltiin joutuvan tuonelaan (šoo). Tuonelan asukkaita kutsutaan nimellä refaim, "kuolleiden henget"; nimitys lienee alun perin tarkoittanut veltoksi tai hervottomaksi käynyttä. Tuonela on hiljaisuuden maa (Ps. 94:17), jossa ei enää ole mahdollista ylistää Jahvea, elävien Jumalaa (Ps. 6:6; 88:1113; Ps. 115:17; Jes. 38:18-19). ${ }^{15}$

Vanhassa testamentissa suhtaudutaan hyvin pidättyvästi tuonpuoleisuuden kuvaamiseen ja erityisesti "kuolleiden kulttiin". Vanhan testamentin pidättyvyys edustaa eräänlaista "virallista kantaa", jonka tarkoituksena oli estää Israelin uskonnon sekoittuminen naapurikansoihin. Periaatteessa vainajahenkiä voitiin manata esiin, mutta heillä ei ole eläville mitään sanottavaa, mitä nämä eivät tietäisi muutenkin (1. Sam. 28). Mooseksen laissa esitetään rajoituksia surunilmauksille kuolemantapauksien yhteydessä (3. Moos. 19:27-28; 5. Moos. 14:1). Kiellosta

\footnotetext{
${ }^{13}$ Fischer 1978, 212.

${ }^{14}$ Sanders 1992, 296-297.

${ }^{15}$ Lewis 1992.
} 
huolimatta tällaisia tapoja todennäköisesti toteutettiin käytännössä (esim. Jer. 16:5-7), ja tietyissä yhteyksissä Jahve itse saattoi kehottaa niihin (Jes. 22:12). Koska tällaiset tavat olivat naapurikansojen keskuudessa yleisiä, vaarana oli, että myös Israelissa niihin liittyi muiden jumalien palvontaa (vrt. Ps. 106:28). ${ }^{16}$

Ajatus kuolleiden herättämisestä tulevaisuudessa esiintyy Vanhassa testamentissa vain harvoin. Varhaisin viite ylösnousemukseen on mahdollisesti Jes. 26:19, joka voidaan kuitenkin tulkita myös kuvaukseksi kansakunnan palaamisesta entiseen asemaansa. Vaikka Jesajan kirjan myöhemmissä osissa puhutaan uudesta taivaasta ja maasta, tulevaisuuden odotus on pitkälti tämänpuoleista: elämän odotetaan jatkuvan maan päällä, ei enkelten maailmassa. ${ }^{17}$ Edes Jumalan luomassa "uudessa maassa" elämän ei ajatella jatkuvan ikuisesti. Ihmiset tosin elävät siellä kauemmin eivätkä kuole ennenaikaisesti (Jes. 65:20, 22).

Yksiselitteisesti ylösnousemuksesta puhutaan vasta Vanhan testamentin nuorimmassa kirjoituksessa, Danielin kirjassa. Siinäkään ylösnousemusta ei kuvata kaikkia ihmisiä koskevaksi tapahtumaksi, vaan sen kokevat "monet maan tomussa nukkuvista" (Dan. 12:1-2). Näiden herätettyjen kohtalo on kahtalainen: osa pelastuu, osa taas joutuu "häpeään ja ikuiseen kauhuun".

Danielin kirjan kuvaus liittyy ylösnousemususkon varhaisvaiheeseen. Alun perin ylösnousemususkossa oli kyse hurskaan, mutta elämässään vääryyttä kärsineen uskovan tulevasta kohtalosta: Jumalan odotettiin korottavan nöyryytetyn palvelijansa viimeistään kuoleman jälkeen. Vastaavasti ylösnousemuksen myötä koittavaa tuomiota ei alun perin ymmärretty yleiseksi, vaan sillä oli selkeä kohderyhmä. Tuomion uskottiin koskevan ennen kaikkea niitä, jotka olivat vainonneet uskovia, ja niitä, jotka olivat luopuneet uskostaan. ${ }^{18}$ Ylösnousemususkoon kuului jo alun perin sekä myönteinen tulevaisuuden odotus että koston ja uhkauksen näkökulma. Viesti oli erityisesti suunnattu niille, jotka olivat

\footnotetext{
${ }^{16}$ Carroll 1986, 339.

${ }^{17}$ Collins 1992, 284.

${ }^{18}$ Tästä kehityksestä ks. Nickelsburg 1972.
} 
vaarassa luopua uskostaan. Tämä näkyy siinä, että nimenomaan luopioiden ajateltiin joutuvan ankarimpien rangaistuksien kohteeksi.

Ylösnousemususko ei roomalaisajalla ollut samalla tavalla juutalaisia yhdistävä tekijä kuin toora tai kansallinen eskatologia. Palestiinassa lähinnä ylimystöä ja temppelipapistoa edustaneet saddukeukset eivät uskoneet kuolemanjälkeiseen elämään. Egyptin juutalaisten hautakirjoituksissa esiintyy usein lakoninen, kreikkalaisilta omaksuttu toteamus "kukaan ei ole kuolematon" (oudeis athanatos). Tähän lauseeseen saatettiin lisätä vielä toivotus "ole rohkea". Toivotuksen tarkoituksesta on erilaisia tulkintoja. Sitä on pidetty merkkinä ehdottomasta tämänpuoleisuudesta: vainajaa lohdutetaan kuolemalla. ${ }^{19}$ Toivotuksen tarkoituksena voi kuitenkin olla myös toivottaa vainajalle rohkeutta tuonpuoleisuudessa, jolloin se samalla ilmaisisi uskoa kuolemanjälkeiseen elämään. ${ }^{20}$

Ylösnousemususko eli Palestiinassa todennäköisesti lähinnä fariseusten ja essealaisten piirissä. Juutalainen historioitsijan Josefuksen mukaan nämä ryhmät tosin uskoivat ainoastaan sielun kuolemattomuuteen (Ant. 18:14-18). Kuvaus ei välttämättä ole luotettava, sillä Josefus halusi antaa kreikkalaisen sivistyksen saaneille lukijoilleen näistä juutalaisista ryhmistä mahdollisimman sivistyneen kuvan, johon konkreettisemmat käsitykset kuolemanjälkeisestä elämästä eivät sopineet.

Ylösnousemususkon asemasta Qumranin essealaisen yhteisön kirjoituksissa on viime aikoina esitetty erilaisia tulkintoja. Toisaalta niissä on nähty viitteitä uskosta tulevaan ylösnousemukseen, sillä yhteisön tulevaisuuden odotus muutenkin muistuttaa Danielin kirjan visioita: viimeisinä aikoina Jumalan enkeli, Mikael, käy voittoisaan sotaan jumalattomia vastaan. Tämän jälkeen jumalattomat tuomitaan ja hurskaat saavat elää ikuisesti. ${ }^{21}$ Toisaalta on todettu, että yhteisön keskeisimmissä kirjoituksissa ihmisen ajatellaan saavan ikuisen palkkionsa tai rangaistuksensa välittömästi kuolemansa jälkeen. Muuta-

\footnotetext{
${ }^{19}$ Fischer 1978, 223-224.

${ }^{20}$ van der Horst 1994, 137-138.

${ }^{21}$ Puech 1993, 771-802.
} 
missa Kuolleen meren kirjoituksissa viitataan tulevaan ylösnousemukseen, mutta ei ole varmaa, ovatko ne peräisin Qumranin yhteisöltä. ${ }^{22}$

\section{Lopun ajat ja "historian Jeesus"}

Käsemann, joka korosti apokalyptiikan asemaa "varhaisen kristillisen teologian äitinä", esitti yhden poikkeuksen säännöstä: Jeesus ei ollut varsinaisesti apokalyptinen julistaja.

Jeesuksen taustalla oli Kastajan apokalyptinen julistus, mutta apokalyptiikka ei pohjimmiltaan leimannut hänen omaa julistustaan, vaan hän julisti Jumalan olevan välittömästi lähellä. Se, joka tämän askeleen otti, ei mielestäni voinut odottaa tulevaa Ihmisen Poikaa, kahdentoista heimon ennalleen asettamista messiaanisessa valtakunnassa ja siihen liittyvää paruusian koittamista. ... pääsiäinen ja Hengen saaminen johtivat siihen, että alkukristillisyys alkoi tulkita Jeesuksen julistusta lähellä olevasta Jumalasta jälleen apokalyptisesti ja tietyssä mielessä irtautua tästä julistuksesta. ${ }^{23}$

Käsemann kuuluu niihin tutkijoihin, jotka 1950-luvulla käynnistivät historian Jeesuksen tutkimuksen uuden tutkimusvaiheen ("new quest"). Ensimmäisen vaiheen oli päättänyt Albert Schweitzer, jonka mukaan aikaisemmissa "historiallisen Jeesuksen" kuvauksissa oli lähes tyystin (Johannes Weissia lukuun ottamatta) unohdettu Jeesuksen julistuksen apokalyptinen perusvire. Tämän jälkeen kysymys historian Jeesuksesta jäi jossain määrin taka-alalle, kun sekä Barth että Bultmann omalla tavallaan minimoivat historiallisen Jeesuksen merkityksen kristilliselle teologialle. Jeesus-tutkimuksen uudessa vaiheessa haluttiin palauttaa kysymys historian Jeesuksesta Uuden testamentin tutkimuksen keskeisten teemojen joukkoon. ${ }^{24}$

Viime vuosina on alettu puhu historian Jeesuksen kolmannesta tutkimusvaiheesta ("third quest"). Suuren yleisön kiinnostuksen aihee-

\footnotetext{
${ }^{22}$ Collins 1996, 129.

${ }^{23}$ Käsemann 1965, 99-100.

${ }^{24}$ Wright 1992.
} 
seen on herättänyt amerikkalainen Jeesus-seminaari, joka on kokoontumisissaan äänestänyt Jeesuksen sanojen aitoudesta erivärisin lapuin. Seminaariin osallistuneet tutkijat ovat selvästi kallistuneet kannattamaan näkemystä, ettei historian Jeesus ollut apokalyptinen julistaja vaan pikemminkin viisauden opettaja. Seminaarin työskentely on herättänyt myös voimakasta arvostelua, joka on kohdistunut äänestysmenettelyn julkisuushakuisuuden ohella seminaarin tuloksiin. Seminaarin työskentelyä ei kuitenkaan voi sivuuttaa kokonaan. Äänestykset ovat perustuneet huolellisesti laadittuihin alustuksiin ja niistä käytyihin keskusteluihin. Seminaarin tuloksia popularisoiva evankeliumikirja sisältää myös lyhyen selvityksen kunkin ratkaisun tärkeimmistä perusteista. ${ }^{25}$

Osa Jeesus-seminaarin työhön osallistuvista on nähnyt eiapokalyptisessa Jeesuksessa kreikkalaisille kyynikkofilosofeille ominaisia piirteitä: näiden tapaan Jeesus oli vaeltava saarnaaja, joka kyseenalaisti oman aikansa yhteiskunnallisen järjestyksen ja arvot. ${ }^{26}$ Jeesuksen julistuksen yhteiskunnallista ulottuvuutta pitää esillä myös amerikkalainen Marcus Borg. Hän ei periaatteessa kiistä, etteikö Jeesus olisi puhunut tulevasta ylösnousemuksesta ja kadotuksesta. Jeesus ei kuitenkaan Borgin mukaan ollut apokalyptinen profeetta, sillä hän ei ajatellut lopun olevan välittömästi käsillä. Sen sijaan hän oli "vaihtoehtoisen viisauden" opettaja, joka kyseenalaisti "perinteisen viisauden". ${ }^{27}$ Borgin mukaan Jeesus pyrki muuttamaan konkreettista sosiaalista tilannetta, eikä tähän muutokseen välttämättä liittynyt ajatusta Jumalan näkyvästä väliintulosta.

Uudessa tutkimustilanteessa apokalyptista Jeesus-kuvaa on pitänyt esillä ennen kaikkea E. P. Sanders. Hänen Jeesus-tulkintansa kulmakiviä ovat juuri ne piirteet, jotka Käsemann hylkäsi epähistoriallisina: Jeesus julisti pian koittavaa muutosta ja valitsi 12 opetuslasta tulevan Israelin heimojen johtajiksi. Jeesus ei Sandersin mukaan pyrkinyt poliittiseen reformiin vaan odotti Jumalan puuttuvan tapahtumien kulkuun. Jeesus odotti tulevaisuudelta erityisesti sitä, että Jumala itse

\footnotetext{
${ }^{25}$ Funk \& Hoover 1993.

${ }^{26}$ Ks. Mack 1993, 114-121, 203.

${ }^{27}$ Borg 1992.
} 
rakentaa Jerusalemiin uuden temppelin (vrt. Mark. 14:58; Joh. 2:19). Pöytien kaataminen temppelissä oli profeetallinen merkki, joka symboloi tätä odotusta. ${ }^{28}$

Edellä esitetyt ratkaisut ovat jo lähtökohdiltaan hyvin erilaisia. Oletus "ei-apokalyptisesta" Jeesuksesta perustuu pitkälti arvioihin Jeesuksen sanojen kokoelman synnystä. Monet tutkijat olettavat, ettei tämä kokoelma alun perin ollut luonteeltaan apokalyptinen, vaan tuomionjulistus "tälle sukupolvelle" tuli sen osaksi vasta myöhäisemmässä toimitusvaiheessa. ${ }^{29}$

Sanders ei usko oletukseen Q-lähteestä, saati sitten teorioihin sen varhaisista kerrostumista. Hänen apokalyptisen Jeesus-kuvansa lähtökohtana onkin se, mitä Jeesus teki. Siitä, että Jeesus antoi Johannes Kastajan kastaa itsensä, voidaan päätellä, että hänen opetuksensa oli jossain määrin samankaltaista kuin Kastajan. Pöytien kaataminen temppelissä ei ainoastaan kuvaa Jeesuksen suhdetta temppeliin vaan antaa myös uskottavan historiallisen syyn Jeesuksen teloitukselle. ${ }^{30}$ Sanders ei jätä Jeesuksen sanoja kokonaan vaille huomiotta, mutta huomauttaa näiden tulkintaan liittyvästä epävarmuudesta: "Emme voi koskaan olla täysin varmoja aitoudesta, ja voimme tietää kunkin lauseen alkuperäisen yhteyden todennäköisesti vain harvoin, jos koskaan." ${ }^{11}$

\section{Jumalan valtakunta}

Markuksen evankeliumin alussa Jeesuksen julistus tiivistetään sanoihin: "Aika on täyttynyt, Jumalan valtakunta on tullut lähelle. Kääntykää ja uskokaa evankeliumi” (Mark. 1:14). Jo tähän tiivistelmään sisältyy yksi keskeinen Jumalan valtakuntaan liittyvä tulkintaongelma. Vaikka siinä puhutaan ajan täyttymisestä, Jumalan valtakunnan ei sanota toteu-

\footnotetext{
${ }^{28}$ Sanders 1985; 1993.

29 Tämän näkemyksen puolesta on argumentoinut erityisesti Kloppenborg (1987a), joka tosin ei ota kantaa kysymykseen "historian Jeesuksesta".

${ }^{30}$ Sanders 1985, 61-76.

${ }^{31}$ Sanders 1985, 156.
} 
tuneen, vaan tulleen lähelle. Perinteinen tulkintaongelma on, miten täyttymys ja tulevaisuuden odotus liittyvät toisiinsa.

Yksimielisyys vallitsee siitä, että Jumalan valtakunta oli Jeesuksen julistuksen keskeinen teema. Lisäksi eri näkemyksiä edustavat tutkijat ovat pitkälti samaa mieltä siitä, mitä Jumalan valtakunta periaatteessa tarkoittaa: kyse on Jumalan hallinta- ja tuomiovallasta ja/tai paikasta, jossa Jumalan hallintavalta voi toteutua. ${ }^{32}$ Tähän perusmerkitykseen voi liittyä sekä presenttisiä että futuurisia korostuksia ilman että ne välttämättä sulkisivat toisensa pois. Mikäli "presenttinen" käsitys valtakunnasta tarkoittaa, että Jumala on kuningas ja toimii hallitsijana jo nyt, useimmat Jeesuksen ajan juutalaiset olisivat epäilemättä hyväksyneet sen.

... lähes kuka tahansa juutalainen olisi voinut olla yhtä mieltä siitä, että Jumala hallitsee tässä ja nyt, sillä hän pitää kaikesta huolen ja säätelee sitä, mitä lopulta tapahtuu. Juutalaiset ajattelivat yleisesti, että Jumala oli taivaan herra ja että hän loppujen lopuksi hallitsee kaikkea täydellisesti. ${ }^{33}$

Tällainen käsitys valtakunnasta ei sulkenut pois tulevaisuuden odotusta. Monet juutalaiset odottivat, että tulevana aikana kaikki kansat tulevat osaksi Jumalan valtakuntaa alistuen tavalla tai toisella Jumalan hallintavallan alle (ks. ed.). Tällainen odotus ei kyseenalaistanut uskoa Jumalan toimintaan ja hallintavaltaa nykyhetkessä. Pikemminkin kyse oli Jumalan hallintavallan eskatologisesta ulottuvuudesta.

Uudelleen virinneessä keskustelussa historian Jeesuksesta on kiinnitetty aiempaa tarkempaa huomiota niihin erilaisiin painotuksiin, joita "Jumalan hallintavaltaan" voidaan liittää. Termin käyttöä selkiyttää apokalyptisten ja viisauskirjallisuudesta nousevien käsitysten välillä tehty ero.

Apokalyptinen [valtakunta] on tuleva valtakunta. Se perustuu siihen, että Jumala ottaa kaiken haltuunsa palauttaakseen oikeudenmukaisuuden ja rauhan epäoikeudenmukaisuuden ja sorron runtelemaan maailmaan. Uskovat

\footnotetext{
${ }^{32}$ Mack 1993, 123.

${ }^{33}$ Sanders 1993, 171.
} 
voivat korkeintaan valmistaa tai anoa, tutkia tai edesauttaa valtakunnan tulemista, mutta sen toteutuminen on yksin jumalallisen voiman varassa. ... Viisauskirjallisuudessa valtakunta liittyy pikemminkin tähän hetkeen kuin tulevaisuuteen. Keskeistä on pohtia, kuinka ihminen voi elää tässä ja nyt jumalallisen hallintavallan alla, joka on jo nyt tai on aina ollut saavutettavissa. Tähän valtakuntaan päästän viisauden tai hyvyyden, hyveen, oikeudenmukaisuuden tai vapauden perusteella. Siksi se on eettinen valtakunta. On kuitenkin korostettava, että se voi olla yhtä eskatologinen kuin apokalyptinen valtakunta. $^{34}$

Erimielisyydet "Jumalan valtakunnasta" nousevat esiin, kun on kyse tämän käsitteen tarkemmasta tulkinnasta. Useat tutkijat pitävät Jeesuksen julistusta Jumalan valtakunnasta merkkinä "presenttisestä" tai "toteutuneesta" eskatologiasta (present/realized eschatology). Tämän tulkinnan avainlauseena on pidetty Jeesuksen sanoja riivaajien karkottamisesta "Jumalan sormella":

Mutta jos minä ajan pahoja henkiä Belsebulin avulla, kenen avulla sitten teikäläiset niitä karkottavat? Heistä te saatte itsellenne tuomarit. Jos minä sitä vastoin ajan pahoja henkiä ihmisistä Jumalan sormella, silloinhan Jumalan valtakunta on jo tullut teidän luoksenne. (Luuk. 11:19-20; vrt. Matt. 12:28.)

Tästä kohdasta on päätelty, että Jeesus uskoi Jumalan valtakunnan toteutuneen jo omassa toiminnassaan. Tämänkaltaisen presenttisen eskatologian on puolestaan nähty erottavan Jeesuksen ja apokalyptisen perinteen edustajat toisistaan.

Eskhaton on siirtynyt tulevaisuudesta nykyhetkeen, odotuksista toteutuneeseen kokemukseen. Siksi on epävarmaa olettaa, että tämän käsityksen, "Jumalan valtakunnan" Jeesuksen tarkoittamassa merkityksessä, sisältö voitaisiin täydentää apokalyptisten kirjoittajien spekulaatioista käsin. He viittasivat johonkin tulevaisuudessa, joka voitiin ymmärtää vain mielikuvituksen avulla. Hän puhui jostakin, mikä ainakin yhdessä suhteessa oli kokemuksen kohde. ${ }^{35}$

${ }^{34}$ Crossan 1993, 292.

${ }^{35}$ Dodd 1961, 34; ks. Sanders 1985, 131. 
Vastaavasti monet saksalaiset tutkijat ovat korostaneet, ettei Jeesus varsinaisesti ollut apokalyptinen julistaja. ${ }^{36}$ Edellä lainattu lauselma, johon tämän näkemyksen tueksi usein vedotaan, ei kuitenkaan ole niin yksiselitteisen presenttinen kuin on oletettu. Kohdassa käytetty kreikan verbi (fthanein) ei välttämättä tarkoita, että valtakunta olisi todella tullut jo. Verbi voi viitata siihen, että tapahtuman ajatellaan toteutuvan väistämättä - mutta yhtä kaikki tulevaisuudessa. ${ }^{37}$ Vastaavalla tavalla voidaan ymmärtää myös "pakanakansoille" osoitettu uhkaus, jossa käytetään samaa verbiä (1. Tess. 2:16). Lisäksi ei ole täysin varmaa, että lauselma todella olisi peräisin historian Jeesukselta, vaikka useimmat tutkijat ovatkin tätä mieltä. ${ }^{38}$

Toisaalta Jeesuksen sanojen perimätiedossa "Jumalan valtakunta" ei ole pääsääntöisesti tulevaisuuteen viittaava käsite. Valtakuntaa kuvaavissa vertauksissa ei yleensä esiinny selkeitä apokalyptisia piirteitä kuten kuvauksia mullistavasta käänteestä tai tulevasta tuomiosta. Esimerkiksi vertauksiin sinapinsiemenestä (Mark. 4:30-32 // Matt. 13:3132 // Luuk. 13:18-19; Tuom. ev. 20) ja hapatuksesta (Matt. 13:33 // Luuk. 13:20-21; Tuom. ev. 96) ei liity ajatusta äkillisestä historiallisesta, poliittisesta tai kosmisesta käänteestä, vaan ne kuvaavat Jumalan valtakunnan vähittäistä ja aluksi huomaamatonta leviämistä ihmisten keskuuteen. Poikkeus Jumalan valtakuntaa kuvaavien vertausten joukossa on vertaus rikkaviljasta (Matt. 13:24-30; Tuom. ev. 57; ks. alla).

Selkeitä viitteitä lopun odotukseen ei esiinny myöskään niissä kohdissa, joissa kuvataan, millä ehdoilla Jumalan valtakuntaan pääsee tai keille Jumalan valtakunta kuuluu. Näissä kohdissa korostetaan valtakunnan "käänteisiä arvoja", jotka ovat voimassa jo nyt. Jumalan valtakunta on (estin) köyhien (Matt. 5:3 // Luuk. 6:20). "Käänteisiä arvoja" edustavat myös valtakunnan sisäänpääsyehdot. Valtakuntaan pääsevät ne, jotka tulevat lasten kaltaisiksi (Mark. 10:13-16; vrt. Tuom. ev. 22) tai syntyvät uudelleen (Joh. 3:3-8). Toisaalta rikkaiden on vaikea, ellei mahdotonta, päästä valtakuntaan (Mark. 10:23). Valtakun-

\footnotetext{
${ }^{36}$ Esim. Bornkamm 1983, 58-60; Becker 1996, 61.

${ }^{37}$ Sanders 1985, 134.

${ }^{38}$ Ks. Räisänen 1996.
} 
nasta saatetaan puhua tilana (tai yhteisönä), jossa ihmiset voivat olla jo: "Kaikkein vähäisin, joka on Jumalan valtakunnassa on suurempi" kuin Johannes Kastaja (Matt. 11:11 // Luuk. 7:28). Näissä kohdissa "Jumalan valtakunta" on pikemminkin tietyn yhteisön määritelmä itsestään ja omasta uskostaan. Näissä kohdissa tulevaisuuden odotuksen sijasta keskeistä on, miten Jumalan valtakuntaan päästään ja miten sen piirissä pysytään. ${ }^{39}$ Näin ymmärrettynä Jumalan valtakunta ei ole ainoastaan "lähellä", vaan se on mahdollisuus, joka voi toteutua jo nyt.

Eräissä kohdissa voidaan painottaa myös valtakunnan sisäistä luonnetta. Tätä piirrettä korostetaan varoittamalla, ettei valtakuntaa kannata etsiä mistään näkyvästä.

Ei Jumalan valtakunta tule niin, että sen tulemista voidaan tarkkailla. Eikä voida sanoa: "Se on täällä", tai "Se on tuolla." Katsokaa: Jumalan valtakunta on teidän keskellänne/sisäisesti teissä (Luuk. 17:21; vaihtoehtoinen käännös on mainittu KR:n alaviitteessä).

Ei-kanonisessa Jeesuksen sanojen traditiossa tämänkaltaista käsitystä valtakunnasta Tuomaan evankeliumi. Siinä korostetaan, ettei valtakunnan tulemista voi tarkkailla, sillä valtakunta on huomaamatta jo levinnyt maailmaan. Tuomaan evankeliumin mukaan valtakunta on kaikkialla, sekä opetuslasten sisällä että ulkopuolella.

Teidän johtajanne saattavat sanoa teille: "Valtakunta on taivaassa", mutta silloinhan taivaan linnut ehtivät sinne ennen teitä. He voivat myös sanoa: "Se on meressä", mutta silloin kalat ehtivät sinne ennen teitä. Tosiasiassa valtakunta on sekä teidän sisällänne että ulkopuolellanne. (Tuom. ev. 3.)

Hänen oppilaansa kysyivät häneltä: "Milloin valtakunta tulee?” Jeesus vastasi: " "Se ei tule niin, että sen tulemista voisi tarkkailla. Ei voida sanoa: 'Se on täällä,' tai: 'Se on tuolla.' Isän valtakunta on levinnyt yli maan, mutta ihmiset eivät näe sitä." (Tuom. ev. 113; suom. Huuhtanen, Uro \& Marjanen 1994.)

${ }^{39}$ Sanders 1985, 141-142. 
Varhaiskristillisessä Jeesuksen sanojen traditiossa Jumalan valtakuntaan liitetään myös tulevaisuuteen kohdistuvia odotuksia. Näissä yhteyksissä valtakunnasta ei puhuta jo olemassa olevana tilana, vaan tulevaisuudessa tapahtuvana muutoksena. Tulevaisuuteen viittaa esimerkiksi kuvaus Jumalan valtakunnassa toteutuvasta suuresta ateriasta, johon osallistuvat patriarkat ja maailman eri kolkista tulevat ihmiset (Matt. 8:11-12 // Luuk. 13:28-29). Jeesuksen opetuslapset odottivat todennäköisesti oman asemansa muuttuvan ratkaisevasti tulevassa valtakunnassa (vrt. Matt. 19:28). He näyttävät ajatelleen, että Jeesus voi jakaa heille erityispaikkoja tulevassa Jumalan valtakunnassa (Mark. 10:35-40).

Myös Paavalin kirjeissä "Jumalan valtakunta" liittyy tulevaisuuden odotuksiin. Paavalin käsitys tulevasta valtakunnasta ei ole samalla tavalla konkreettinen kuin Jeesuksen sanojen traditiossa esiintyvä kuvaus suuresta ateriasta. Valtakunta on selkeämmin "tuonpuoleinen”, sillä liha ja veri eivät saa sitä omakseen (1. Kor. 15:50). Valtakuntaan liittyy myös kosminen muutos: Kristus "kukistettuaan kaiken vallan, mahdin ja voiman" luovuttaa valtakunnan (KR: "kuninkuuden") Isälle (1. Kor. 15:24). Vaikka Paavalilla on näkemys tulevaisuudessa toteutuvasta valtakunnasta, myös hän voi puhua valtakunnasta jo olemassa olevana todellisuutena (1. Kor. 4:19). ${ }^{40}$

Mikä lopulta oli historian Jeesuksen käsitys Jumalan valtakunnasta? Ajatus täysin ei-apokalyptisestä Jeesuksesta edellyttäisi, että Jeesus olisi ollut täysin erillään sekä taustahahmostaan (Johannes Kastaja) että synnyttämästään liikkeestä (varhaiset kristityt), mikä ei ole todennäköinen vaihtoehto. Sandersin oletus apokalyptisesta Jeesuksesta selittää paremmin varhaisten kristittyjen parissa ilmenneen lähiodotuksen.

Valtakunnan osalta Sandersin tulkinta ei kuitenkaan ole täysin ongelmaton. Sanders korostaa Jumalan valtakuntaan liittyneitä konkreettisia piirteitä. Muun muassa Isä meidän -rukouksesta Sanders päättelee, että Jeesus odotti maanpäällistä valtakuntaa: ”Tulkoon sinun valtakuntasi, tapahtukoon sinun tahtosi niin maan päällä kuin taivaassa." ${ }^{\circledR 1}$ Nämä pyynnöt voidaan kuitenkin tulkita yhtä hyvin

\footnotetext{
${ }^{40}$ Sanders 1985 , 126-127.

${ }^{41}$ Sanders 1993, 171-174.
} 
vaihtoehtoisesta näkemyksestä käsin: kyse on Jumalan hallintavallan toteutumisesta maan päällä jo nyt. Nykyhetkeen viittaa erityisesti se, että rukouksen jatkossa esitetään pyyntö "jokapäiväisestä leivästä”.

Lisäksi näyttää siltä, että varhaiset kristityt käsittivät Jumalan valtakunnan ja "viimeiset tapahtumat" erillisiksi asioiksi. Useimmat valtakuntaa kuvaavat lauselmat viittaavat lähiodotukseen (ainoa selvä poikkeus on Mark. 9:1). ${ }^{42}$ Jeesuksen sanojen traditiossa Jumalan valtakuntaa ei myöskään mainita apokalyptisissa "viimeisten tapahtumien" kuvauksissa (Mark. 13; Luuk. 17:22-37). Jumalan valtakuntaan liittyy yhteisöllisiä ja tiettyyn elämäntapaan liittyviä piirteitä, ${ }^{43}$ joiden osalta se ei enää kuulu kristittyjen tulevaisuuden odotuksiin, vaan heidän nykyhetkeensä. Tämä ei tarkoita, että varhaiset kristityt eivät olisi odottaneet Jumalan valtakunnan toteutumista tulevaisuudessa, mutta jossain mielessä sen ymmärrettiin olevan totta jo nykyhetkessä. On hyvin mahdollista, että tämä näkemys perustuu historiallisen Jeesuksen julistukseen Jumalan valtakunnasta.

\section{Herran päivä}

\section{Paavali}

Ajatus Herran paluusta oli kuulunut kristilliseen julistukseen Tessalonikin seurakunnassa jo ennen kuin Paavali kirjoitti seurakunnalle. 1. Tess:n vastaanottajille oli jo aiemmin opetettu, että "Herran päivä tulee kuin varas yöllä" (1. Tess. 5:2). Kirjeessään Paavali keskittyykin Herran odotukseen liittynyttä erityisongelmaa: miten käy kuolleiden kristittyjen, kun Herra palaa? Kirjeen vastaanottajat eivät selvästikään olleet yhdistäneet Kristuksen ylösnousemusta ja kuolleiden kristittyjen ylösnousemusta toisiinsa. He eivät siis osanneet pitää Jeesuksen ylösnousemusta "ennakkotapauksena" vaan todennäköisesti

\footnotetext{
42 Borg 1986.

${ }^{43}$ Vrt. Uro 1995, 39-43.
} 
pitivät sitä erityistapauksena. Analogian Kristuksen ja kaikkien kristittyjen ylösnousemuksen välillä esittää seurakuntalaisille vasta Paavali.

Kuvatessaan Herran paluuta Paavali tukeutuu traditioon, joka oli vakiintunut muotoonsa jo aiemmin: ${ }^{44}$

Itse Herra laskeutuu taivaasta ylienkelien käskyhuudon kuuluessa ja Jumalan pasuunan soidessa, ja ensin nousevat ylös ne, jotka ovat kuolleet Kristukseen uskovina. Meidät, jotka olemme vielä elossa ja täällä jäljellä, temmataan sitten yhdessä heidän kanssaan pilvissä yläilmoihin Herraa vastaan. Näin saamme olla aina Herran kanssa. (1. Tess. 4:16-17)

Kuvaus on niin lyhyt, ettei sen perusteella voi päätellä kovinkaan tarkasti, mitä Paavali odotti "Herran päivänä" tapahtuvan. Paavali käyttää vastaavaa traditiota myös kohdassa 1 . Kor. 15:52, mutta ei tässäkään kohdassa kuvaa odotuksiaan tarkemmin. "Pasuuna" liittää Paavalin vanhatestamentillisiin kuvauksiin käänteestä, jossa Jahve puuttuu suoraan tapahtumien kulkuun (Jes. 27:13; Sak. 9:14). Vanhassa testamentissa "pasuunaa" ei liitetä suoranaisesti ylösnousemukseen, rabbiinisessa kirjallisuudessa kylläkin. ${ }^{45}$

Paavalin mukaan Herra tulee pilvien keskellä, minne uskovat kuolleet ja elossa olevat yhtä lailla - "temmataan" häntä vastaan. Tekstistä ei käy ilmi, ajatellaanko uskovien jäävän pilvien keskelle Herran kanssa vai tulevan hänen kanssaan maan päälle. Koska Paavali sanoo uskovien menevän Herraansa vastaan (eis apantèsin, j. 17), on todennäköistä, että hän ajattelee Kristuksen palaavan omiensa saattelemana maan päälle. ${ }^{46}$

\footnotetext{
${ }^{44}$ Ks. esim. Meeks 1983, 693.

${ }^{45}$ Holtz 1986, 201 n. 286.

${ }^{46}$ Holtz 1986, 203.
} 


\section{Ihmisen Poika: eksegeettinen ongelma}

Paavali ei käytä Herran paluuta kuvatessaan eikä muuallakaan termiä "Ihmisen Poika". Sen sijaan synoptisessa Jeesuksen sanojen traditiossa termi esiintyy usein ja monissa yhteyksissä se liittyy viimeisten tapahtumien kuvaukseen. Tavalla tai toisella Ihmisen Poika yhdistetään tulevaan tuomioon, jonka yhteydessä epäuskoiset tuomitaan. Ihmisen Poikaan liittyy useita eksegeettisiä ongelmia. ${ }^{47}$ Yksi näistä on, miksi Paavali ei mainitse tätä termiä. Korvasiko hän termin tutummilla sanoilla kuten "Kristus" tai "Herra", vai eikö termi kuulunut lainkaan siihen varhaiskristilliseen traditioon, jota hän edusti?

Paavali viittaa siihen, että Herran odotetaan palaavan pilvien keskellä. Tämä yhdistää Paavalinkin odotuksen Danielin kirjan kuvaukseen, jossa kerrotaan kuinka "ihmisen pojan" kaltainen saapuu pilvien keskellä (Dan. 7:13). Ei ole mahdotonta, että Paavali olisi korvannut arvonimen Ihmisen Poika sanoilla "Herra" tai "Kristus" (1. Kor. 15:24-28). Toisaalta on mahdollista, että Jeesuksesta alettiin käyttää tätä arvonimeä vasta kun hänet ensin oli muuten liitetty "ihmisen pojan kaltaiseen" hahmoon. ${ }^{48}$

Myös itse termiin "Ihmisen Poika" liittyy runsaasti eksegeettisiä ongelmia. Vanhassa testamentissa "ihmisen poikaa" käytetään synonyymina "ihmiselle" (esim. Ps. 8:5). Näin termiä käytetään myös Danielin kirjassa. "Ihmisen poika" ei ole siinä arvonimi, vaan termin avulla kuvataan apokalyptisen hahmon olleen ihmisen kaltainen (Dan. 7:13-14; KR kääntää: "näöltään kuin ihminen”). Samoin nimeä käytetään muissakin apokalyptisissa kirjoituksissa (1 Henok 46.1-4; 4 Esra 13:1-4; Ilm. 1:13; 14:14). Jeesuksen sanojen traditiossakin "ihmisen pojista" voidaan puhua tarkoittaen ihmisiä yleensä. Kohdassa Mark. 3:28 puhutaan kaikkien syntien anteeksiantamisesta "ihmisten pojille" (KR: "ihmisille"). Myös lauselma ihmisen pojasta, joka ei löydä asuinsijaa, on alun perin voinut tarkoittaa "ihmisiä" yleensä (esim. Matt. 8:19-20 // Luuk. 9:57-58).

\footnotetext{
${ }^{47}$ Ks. näistä Myllykoski 1987.

${ }^{48}$ Crossan 1991, 245.
} 
Evankeliumien kirjoittajat käyttävät termiä Ihmisen Poika jo yksiselitteisesti Jeesukselle varattuna arvonimenä. ${ }^{49}$ Tämän kehityksen taustalla on Danielin kirjassa mainittu "ihmisen pojan" kaltainen hahmo. Tutkijat eivät kuitenkaan ole yksimielisiä siitä, puhuiko historiallinen Jeesus (a) Ihmisen Pojasta apokalyptisena hahmona, ja (b) jos puhui, viittasiko hän tällä termillä itseensä vai johonkin toiseen hahmoon.

Esimerkiksi Jeesus-seminaari pitää kaikkia kärsivästä tai tulevasta Ihmisen pojasta puhuvia jaksoja alkuseurakunnan luomuksina. Sen sijaan kohdat, joissa termiä käytetään "ihmisistä" yleensä, voivat seminaarin mukaan olla peräisin Jeesuksen omasta julistuksesta. Toiset tutkijat olettavat, että historiallinen Jeesus odotti tulevaa Ihmisen poikaa, mutta ei varsinaisesti identifioinut itseään häneen. ${ }^{50}$ Tätä näkemystä tukee lauselma, joissa Jeesus puhuu hänet hylänneiden ihmisten kohtalosta. Lauselmasta on jo Jeesuksen sanojen varhaisimmassa traditiossa kaksi erilaista versiota. Toinen näistä on Markuksen evankeliumissa esiintyvä muoto (A), toinen Matteuksen ja Luukkaan käyttämässä Qlähteessä (B).

A

Joka tämän uskottoman ja syntisen sukupolven keskellä häpeää minua ja minun sanojani, sitä on Ihmisen Poika häpeävä, kun hän tulee Isänsä kirkkaudessa pyhien enkelien kanssa. (Mark. 8:38, rinnakkaiskohdat: Matt. 16:27; Luuk. 9:26)

B

Joka tunnustautuu minun omakseni ihmisten edessä, sen minäkin tunnustan omakseni Isäni edessä taivaassa. Mutta joka ihmisten edessä kieltää minut, sen minäkin kiellän Isäni edessä taivaissa. (Matt. 10:3233)

Minä sanon teille: Joka tunnustautuu minun omakseni ihmisten edessä, sen on Ihmisen Poika tunnustava omakseen Jumalan enkelien edessä. Mutta joka ihmisten edessä kieltää minut, se tullaan kieltämään Jumalan enkelien edessä. (Luuk. 12:8-9)

${ }^{49}$ Myllykoski 1987.

${ }^{50}$ Ks. Yarbro Collins 1996, 151-158. 
Sekä A että B sisältävät ajatuksen, että suhde Jeesukseen sanomaan ratkaisee ihmisen kohtalon tulevaisuudessa. Täysin varmaa ei ole, mainittiinko B-versiossa alun perin "Ihmisen Poika", sillä termi esiintyy vain Luukkaan versiossa. Matteuksen rinnakkaiskohdassa sen tilalla on pelkkä "minä". Todennäköistä on, että Luukkaan "Ihmisen Poika" on alkuperäisempi kuin Matteuksen "minä". ${ }^{1}$ On mahdollista, että Matteus on muuttanut kohdan juuri siksi, ettei siinä alun perin samastettu selkeästi Ihmisen Poikaa ja Jeesusta.

Molempiin versioihin liittyy ajatus Ihmisen Pojasta tulevana tuomarina, jolla on erityisasema Jumalan "hovissa", enkeleiden keskellä. Mikäli näissä lauselmissa Jeesus ja Ihmisen Poika todella ymmärretään erillisiksi hahmoiksi, ne tuskin voivat olla varhaisen kristillisen seurakunnan luomuksia, sillä varhaiset kristityt todennäköisesti hyvin varhaisessa vaiheessa samastivat Jeesuksen ja Ihmisen Pojan toisiinsa. Tämä viittaa siihen, että historian Jeesus todella puhui apokalyptisesta Ihmisen Pojasta.

Ainoastaan versiossa A viitataan Ihmisen Pojan tulemiseen. Versiossa B jää avoimeksi, missä tilanteessa Ihmisen Pojan odotetaan tuomitsevan ne, jotka ovat "kieltäneet" Jeesuksen. Q-lähteessä, jossa versio $B$ on alun perin säilynyt, on myös kuvaus Ihmisen Pojan paluusta (ks. alla), mutta kummassakaan kohdassa ei kuvata tulevaa tuomiota. Samassa lähteessä esiintyvässä tulevan tuomion kuvauksessa (ks. alla) ei taas mainita Ihmisen Poikaa. Ihmisen Pojan asemaa viimeisellä tuomiolla kuvataan tarkemmin ainoastaan Matteuksen evankeliumissa (Matt. 25:31-46).

Ihmisen Pojan paluusta synoptisessa Jeesuksen sanojen traditiossa puhutaan eri yhteyksissä (Matt. 24-25; Mark. 13; Luuk. 17:22-37; 21:5-38). Varhaisimmat kuvaukset ovat peräisin Markuksen evankeliumista ja Q-lähteestä. Matteuksen ja Luukkaan vastaavat jaksot perustuvat pitkälti näistä lähteistä saatuun aineistoon. Jo varhaisimpien Ihmisen Pojan paluuta kuvaavien versioiden välillä on tiettyjä eroja, joihin jatkossa kiinnitetään tarkempaa huomiota.

${ }^{51}$ Luz 1990, 123. 


\section{Markus 13: "historiallinen" apokalypsi}

Markus 13 on opetuskeskustelu, jonka aiheena on viimeisten tapahtumien ajankohta. Keskustelun johdantona on kohtaus, jossa Jeesus ennustaa temppelin tuhoutuvan perin pohjin (Mark. 13:1-2). Toisessa tilanteessa valikoitu joukko Jeesuksen oppilaita kysyy viimeisten tapahtumien tarkemmasta ajankohdasta (Mark. 13:3-4). KR:n käännös opetuslasten kysymyksestä ("Milloin kaikki se tapahtuu?") hämärtää sisällöllisen yhteyden, joka näiden jaksojen välillä on: Kreikkalaisessa alkutekstissä opetuslapset kysyvät itse asiassa, milloin Jeesuksen ennustus temppelin tuhoutumisesta toteutuu: "Milloin kaikki tämä (touto) tapahtuu?" Tulevaisuuden odotus siis liittyy tässä opetuskeskustelussa läheisesti Jerusalemin temppelin kohtaloon.

Opetuslasten kysymykseen annetaan puheessa kahtalainen vastaus. Puheen ensimmäisessä osassa (Mark. 13:5-27) kuvataan viimeisiä tapahtumia vaiheittain, paikoitellen hyvinkin konkreettisesti (erityisesti Mark. 13:14-16). Puheen loppuosassa (Mark. 13:28-37) ei enää kuvata aikataulua, vaan keskitytään kuulijoille annettuihin kehotuksiin. Loppuosassa viimeisten tapahtumien ajankohtaan liitetään selkeä varaus: eivät enkelit eikä edes Poika tiedä hetkeä (Mark. 13:32); kuulijoiden on siis oltava valveilla kaiken aikaa, sillä he eivät "tiedä milloin se aika tulee" (Mark. 13:33-37).

Ei ole täysin selvää, miten erilaisten painotusten välinen jännite tulisi parhaiten tulkita. Se, että lopun tarkka ajankohta jätetään opetuskeskustelun loppuosassa avoimeksi, ei välttämättä ole osoitus evankeliumin kirjoittajan "antiapokalyptisesta" suhtautumisesta viimeisiin tapahtumiin, kuten joskus on oletettu. Läheisen lopun odotus näkyy nimittäin myös ja erityisesti puheen loppuosassa: ”... tämä sukupolvi ei katoa ennen kuin kaikki tämä tapahtuu” (Mark. 13:30).

Varovaisuus tarkan ajankohdan suhteen ei sinänsä ole poikkeuksellinen ilmiö lähiodotusta heijastavissa teksteissä. Vaikka Paavali varhaisimmassa kirjeessään uskoi olevansa vielä elossa, kun paruusia koittaa, hän samalla muistuttaa kirjeen lukijoita, ettei Herran 
päivän tarkkaa ajankohtaa voi tietää (1. Tess. 5:1-2). Vastaavasti myös juutalaisessa apokalyptisessa kirjallisuudessa lopun tarkka ajankohta voidaan jättää avoimeksi. ${ }^{52}$

Vaikka jaksossa Mark. 13 ei esiinnykään useille apokalyptisille kirjoituksille tyypillistä jakoa tietyn mittaisiin aikakausiin (esimerkiksi Danielin kirjassa mainitut tarkat päivämäärät, Dan. 12:11-12), siinäkin tuleva historia esitetään vaiheittain. Jakson ensimmäisessä pääosassa esitetään kolmivaiheinen "aikataulu". Kaksi ensimmäistä vaihetta on ilmaistu tekstin sisällä olevilla, puheen vastaanottajille suunnatuilla huomautuksilla: "kun kuulette taistelun ääniä ja sanomia sodista..." (Mark. 13:7); "kun te näette turmion iljetyksen seisovan paikassa, jossa se ei saisi olla..." (Mark. 13:14). Ensimmäistä vaihetta kuvataan "synnytystuskien aluksi" (Mark. 13:8), toista puolestaan ahdingoksi, "jollaista ei ole ollut luomakunnan alusta..." (Mark. 13:19). Kolmas ja viimeinen vaihe alkaa puolestaan suoralla viittauksella toiseen vaiheeseen: "Mutta noina päivinä, tuon ahdingon jälkeen..." (Mark. 13:24). Toisistaan erottuvia vaiheita on siis kolme:

1. "Synnytystuskien alku", Mark. 13:5-12.

2. Suuri "ahdinko", Mark. 13:14-23.

3. Ihmisen Pojan paluu, Mark. 13:24-27.

Vaiheet poikkeavat toisistaan monessa suhteessa. Vaiheessa (1) kuulijoita neuvotaan ainoastaan olemaan pelkäämättä, kun taas vaiheessa (2) niiden, jotka asuvat Juudeassa, on paettava vuorille (Mark. 13:14). Vaihetta (1) kuvataan yleisellä tasolla: sen tuntomerkkejä ovat sodat, maanjäristykset ja nälänhätä. Vaihe (2) sen sijaan edellyttää konkreettisen tilanteen, jonka varalta annetaan tarkempia ohjeita. Kirjoittaja olettaa, että lukijat osaavat tulkita oikein jakeessa Mark. 13:14 mainitun "turmion iljetyksen" ja toimivat annettujen ohjeiden mukaan. Vaihe (3) eroaa edellisistä vaiheista, joissa kuvattiin historiallisia tapahtumia, sillä siinä tapahtuu kosmisia, koko luoma-

${ }^{52}$ Brandenburg 1984, 111, viitaten kohtiin 4 Esra 4:51-52; 6:10. 
kuntaa koskevia muutoksia: aurinko ja kuu pimenevät, tähdet tippuvat taivaalta ja "taivaiden voimat järkkyvät" (Mark. 13:24-25).

Eri vaiheita yhdistää huoli "valittujen" kohtalosta. Sekä vaiheessa (1) että (2) kuulijoita varoitetaan vääristä julistajista, jotka voivat "eksyttää" tai "johtaa harhaan" (Mark. 13:5-6, 21-22). Näissä kohdissa viitataan ilmeisesti nimenomaan seurakunnan sisäisiin ongelmiin, sillä eksyttäjien ajatellaan esiintyvän "minun nimelläni" (Mark. 13:5). Ulkopuolelta tulevaan vaaraan viitataan erityisesti vaiheen yhteydessä: kristityt joutuvat vastaamaan uskostaan sekä juutalaisten että roomalaisten viranomaisten edessä (Mark. 13:9-11) eivätkä he säästy vainolta edes perheidensä keskellä.

Markuksen apokalyptiselle jaksolle ovat ominaisia lukuisat kehotukset. Näitä on runsaasti jo eskatologista "aikataulua" kuvaavassa jaksossa (Mark. 13:5-27: "varokaa", "pitäkää varanne", "rukoilkaa" jne.), mutta erityisesti opetuspuheen loppuosassa (Mark. 13:28-37). Markuksen eskatologisen jakson pareneettista yleissävyä on usein pidetty osoituksena siitä, että evankeliumin kirjoittajan varsinaisena päämääränä ei ollut antaa apokalyptista opetusta, vaan kehottavaa opastusta. ${ }^{53}$ Tällainen päätelmä perustuu kuitenkin "apokalyptisen" ja "pareneettisen" aineksen vääränlaiseen vastakkainasetteluun. Apokalyptinen kirjallisuus on yleensä aina pareneettista: yksi sen tärkeimmistä päämääristä on saada ihmiset säilyttämään uskonsa viimeisinä aikoina. Tämä päämäärä näkyy hyvin myös Markuksen apokalyptisessa jaksossa, jonka keskeinen huolenaihe on, ettei kukaan johtaisi "teitä" tai "valittuja" harhaan ennen viimeisiä tapahtumia (Mark. 13:5, 22). Tekstin pareneettiset ainekset sopivat siis hyvin yhteen "apokalyptisen ajattelutavan" kanssa. ${ }^{54}$

Mihin ajankohtaisiin tapahtumiin evankeliumin alkuperäiset lukijat liittivät opetusjaksossa kuvatut vaiheet? On hyvin todennäköistä, että Markuksen evankeliumin ensimmäiset lukijat tulkitsivat ennustuksen "tästä sukupolvesta", joka ei katoa ennen kuin loppu koittaa (Mark. 13:30), tarkoittavan juuri heidän aikaansa. Yhtä lailla

${ }^{53}$ Gräßer 1960, 156.

${ }^{54}$ Brandenburg 1984, 19. 
ajankohtaisiksi he epäilemättä kokivat puheet kristittyjä vastaan käydyistä oikeudenkäynneistä (Mark. 13:9-11). Yksityiskohtaiset ohjeet Juudeassa asuville (Mark. 13:14-16) näyttävät niin ikään edellyttävän, että alkuperäiset lukijat ajattelivat lopunajallisen käänteen tapahtuvan omana aikanaan.

Yhden historiallisen kiinnekohdan antaa se, että koko opetusjakso alkaa ennustuksella Jerusalemin temppelin tuhosta (Mark. 13:2). Tällainen ennustus tuli erityisen ajankohtaiseksi juutalaissodan (66-70 jKr.) loppuvaiheissa, kun roomalaiset Tituksen johdolla valtasivat Jerusalemin ja temppeli tuhoutui tulipalossa. Mainittua ennustusta tuskin voi pitää apokalyptiselle kirjallisuudelle sinänsä ominaiselle tavalle kuvata jo tapahtuneita vaiheita ennustuksen muodossa (vaticinium ex eventu). Tässä tapauksessa olisi ollut todennäköistä, että ennustuksessa olisi viitattu myös temppelin tuhonneeseen tulipaloon. Joka tapauksessa on ilmeistä, että Markuksen evankeliumin ensimmäiset lukijat ymmärsivät ennustuksen toteutuneen laajemmassa merkityksessä Jerusalemin valloituksen myötä. Tämä tapahtuma tulkittiin mitä todennäköisimmin viimeisten tapahtumien lähtölaukaukseksi.

Viittauksena Jerusalemin kohtaloon on pidetty myös historiakatsauksen toisen vaiheen alussa mainittua "turmion iljetystä" (Mark. 13:14). Tätä termiä ei tekstissä kuvata tarkemmin, mutta evankeliumin alkuperäisten lukijoiden oletetaan osaavan tulkita, mistä tapahtumasta on kyse, sillä siihen liittyy konkreettinen ohje paeta Juudeasta mahdollisimman pian. Mikä lukijoiden historiallinen viitekehys oli, jää kuitenkin arvailujen varaan. Selvää on, että termi "turmion iljetys" sinänsä on peräisin Danielin kirjasta (Dan. 11:31; 12:11; vrt. myös 1 . Makk. 1:54; 6:7), jossa termiä käytetään kuvattaessa, kuinka vieraat joukot saastuttivat Jerusalemin temppelin tuomalla tai rakentamalla sinne jotain, todennäköisesti vieraan uskonnon jumalakuvan (Dan. 11:31). Ennustus on kuvaus tilanteesta, jossa syyrialainen hallitsija, Antiokhos IV Epifanes (175-164 eKr.) muutti Jerusalemin temppelin Zeuksen pyhäköksi (167 eKr.).

Koska Danielin kirjassa ei suoraan mainita Antiokhosta, ei ole varmaa, että Markuksen evankeliumin kirjoittaja tai lukijat olisivat osanneet yhdistää "turmion iljetyksen" tähän jo aiemmin tapahtuneeseen tilanteeseen. Temppelin saastuttamiseen Danielin kirja kuitenkin 
viittaa yksiselitteisesti. Siksi on ilmeistä, että myös Markuksen evankeliumissa "turmion iljetyksen" tavalla tai toisella ajateltiin liittyvän temppelin kohtaloon. Termillä viitattiin mahdollisesti temppeliin vietyihin vieraan vallan symboleihin. Tämänkaltaisia tilanteita oli esiintynyt Palestiinan lähihistoriassa. Pilatus oli suututtanut juutalaiset heti maaherrakautensa (26-36 jKr.) alussa tuomalla legioonien tunnusmerkit Jerusalemiin, ilmeisesti temppelin läheisyyteen, ja joutui poistamaan merkit juutalaisten painostuksen vuoksi. Vuonna 40 keisari Caligula oli vaatinut kuvapatsaansa pystyttämistä Jerusalemin temppeliin, mutta aie kaatui jälleen juutalaisten jyrkkään vastarintaan. ${ }^{55}$

"Turmion iljetys" on usein liitetty tämänkaltaisiin tapauksiin. Niiden perusteella on jopa oletettu, että Markuksen eskatologisen opetuskeskustelun taustalla olisi varhaisempi juutalainen "lentolehtinen", joka oli suunnattu nimenomaan Caligulan aietta vastaan vuoden 40 vaiheilla. Vaikka tämän teorian puolesta voidaan tuskin esittää kovin vahvoja perusteita, on mahdollista, että evankeliumin alkuperäiset lukijat ajattelivat "turmion iljetyksen" viittaavan juuri tämänkaltaisiin tapahtumiin. Tekstissä oleva kieliopillinen erikoisuus saattaa viitata siihen, että "turmion iljetyksellä" todella tarkoitettaisiin keisarillista patsasta. Vaikka kreikan sana, jonka KR kääntää "iljetys", on suvultaan neutri (to bdelygma), siihen liittyvä partisiippi on maskuliini (hestēkota). Yksi - tosin ei ainoa - selitys tälle erikoisuudelle on se, että antiikin maailmassa patsaan ajateltiin tavallaan tekevän myös siinä kuvatun henkilön läsnä olevaksi; mikäli oli kyse keisarin kuvasta, siihen voitiin viitata maskuliinimuodolla. ${ }^{56}$

Vaikka tiettyjä viitteitä Markuksen evankeliumissa olevan eskatologisen opetuskeskustelun historiallisista liittymäkohdista on olemassa, jakso ei ole suora kuvaus evankeliumin lukijoiden historiallisesta tilanteesta, vaan se on vahvasti intertekstuaalisuuden värittämä kokonaisuus, jossa lopun tapahtumia kuvataan pitkälti Vanhasta testamentista ja apokalyptisesta kirjallisuudesta omaksutulla perinteisellä kielellä. Danielin kirjasta lainattu "turmion iljetys" on vain yksi

${ }^{55}$ Ks. Huuhtanen 1989, 55-56, 63-65.

${ }^{56}$ Brandenburg 1984, 51 n. 105. 
esimerkki tästä ilmiöstä. Jo Vanhan testamentin profeettakirjoissa esitetään uhkauksia sekä Jerusalemia (Miika 3:12) että temppeliä (esim. Jer. 7:14; 26:6) kohtaan; motiivi esiintyy lisäksi myös apokalyptisissa kirjoituksissa (1. Henok 90:28). Sodat, maanjäristykset ja nälänhätä yhdistetään Herran päivään jo Vanhassa testamentissa (esim. Jes. 13:13; 19:2), samoin maininnat kaikkien sodasta kaikkia vastaan (Jes. 19:2; vrt. Jes. 3:5; 9:4; Hes. 38:21), tulevasta ahdingosta (Dan. 12:1) ja kosmisista mullistuksista (Joel 2:10). Pako vuorille esiintyy toistuvasti Jesajan kirjan kuvauksessa Herran päivästä (Jes. 2:6-21) ja tuhon alla ihmiset toivovat vuorten peittävän heidät (Hoos. 10:8; vrt. Luuk. 23:30; Ilm. 6:16). Viimeksi mainitussa tapauksessa taustalla voi olla myös kuvaus makkabilaiskapinallisten paosta vuorille (1. Makk. 2:2830). Vanhasta testamentista on myös peräisin kuvaus perheen sisäisistä ristiriidoista (Miika 7:5-6). Tämän aiheen ajankohtaisuudesta varhaisten kristittyjen keskuudessa kertoo se, että samansisältöinen lause on säilynyt myös Q-lähteessä, tosin eri yhteydessä (Matt. 10:34-36 // Luuk. 12:51-52).

Perinteisen aineksen käyttö ja uudelleentulkinta ovat tyypillisiä piirteitä apokalyptisissa kirjoituksissa. Perinteisen kuvakielen käyttö mahdollistaa sen, että apokalyptisen opetuksen sisältö jää lopulta aina jossain määrin hämäräksi ja tulkinnan varaiseksi. Niinkin historialliselta vaikuttavalla motiivilla kuin opetuslasten kokemalla vainolla (Mark. 13:9-11) voi olla erilaisia funktioita, eikä siitä voi suoraan päätellä, millaisessa tilanteessa tekstin alkuperäisten lukijoiden oletetaan olevan.

Jopa viittaukset Jeesuksen opetuslasten selvään vainoon voivat esiintyä teksteissä, jotka ovat syntyneet erilaisissa sosiaalisissa oloissa. Opetuksen kohteena voi olla vainosta kärsivä yhteisö, ja tarkoituksena on rohkaista sitä näkemään elämänsä heijastuksena Jeesuksen ja hänen oppilaidensa elämästä ja katsoa sen ohi ylösnousemuksen toivoon. Vaihtoehtoisesti sama opetus voi olla suunnattu yhteisölle, joka elää turvallista elämää vapaana vainosta; tarkoituksena on tällöin herättää yhteisö huomaamaan, ettei se elä Jeesuksen ja hänen oppilaidensa antaman esimerkin mukaan. Tekstissä voi heijastua myös 
Jeesuksen ja hänen ensimmäisten oppilaidensa historiallinen tilanne, jonka kuvauksen tarkoituksena on herättää jäljittelyn sijasta myötätuntoisuutta. ${ }^{57}$

Markuksen evankeliumin apokalyptisen jakson rakenne ei tue sitä usein esiintyvää tulkintaa, että vertaus viikunapuusta (Mark. 13:28-29) kuvaisi Israelin asemaa viimeisten tapahtumien aikataulussa ja erityisesti modernin Israelin valtion perustamista toisen maailmansodan jälkeen. Eskatologisen aikataulun kuvaus on päättynyt juuri edellisissä jakeissa Ihmisen Pojan paluuseen ja valittujen kokoamiseen. Viikunapuuvertaus aloittaa opetuspuheen pareneettisen loppuosan. Viikunapuuhun tuskin sisältyy tässä yhteydessä mitään salaperäistä merkitystä; mikäli sen avulla olisi haluttu kuvata Israelin kohtaloa viimeisten tapahtumien yhteydessä, tällaisen opetuksen paikka olisi ollut opetuspuheen ensimmäisessä pääjaksossa, ei pareneettisessa loppuosassa.

Ottakaa oppia vertauskuvasta, jonka viikunapuu tarjoaa: kun sen oksa virkoaa ja alkaa tulla lehteen, te tiedätte, että kesä on lähellä. Samalla tavalla te nähdessänne tämän tapahtuvan tiedätte, että se aika on lähellä, aivan ovella. (Mark. 13:28-29)

Kyse on todella vertauksesta, jonka sovellus ilmaistaan tekstissä selvästi: edellä kuvatut tapahtumat ovat yhtä varma merkki Ihmisen Pojan paluusta viittaa kuin viikunapuun versominen kesän tulosta. Lause "nähdessänne tämän tapahtuvan" viittaa opetuspuheen ensimmäiseen osaan - eikä vertauksessa käytettyyn kuvaan viikunapuun versomisesta.

\section{Ihmisen Pojan yllättävä paluu: Q-apokalypsi}

Q-lähteessä olleesta apokalyptisesta jaksosta on säilynyt jälkiä sekä Matteuksen että Luukkaan evankeliumissa. Jakson sisältö voidaan pääpiirteissään paljastaa vertailemalla niitä kohtia, jotka ovat yhteisiä Matteuksella ja Luukkaalla eivätkä perustu Markuksen evankeliumiin.

${ }^{57}$ Sanders \& Davies 1989, 221-222. 
Matteus on sijoittanut Q-lähteen aineiston (Matt. 24:26-28, 37-41) samaan kokonaisuuteen kuin Markuksesta saamansa materiaalin (Matt. 24-25), mutta Luukkaalla tästä lähteestä oleva kuvaus on kokonaan toisessa yhteydessä (Luuk. 17:23-37).

Aivan tarkasti Q-lähteen apokalyptisen jakson sanamuotoa ei voida tietää, sillä Matteus ja Luukas poikkeavat toisistaan tietyissä yksityiskohdissa. Näissä tapauksissa ei voida sanoa varmasti, kumpi evankelista talletti lähteen alkuperäisen sanamuodon - vai tallettiko kumpikaan. Tällainen ero liittyy muun muassa varoitukseen messiasehdokkaista. Matteuksen versiossa he ovat "autiomaassa" ja "sisällä talossa" (Matt. 24:26), Luukkaalla puolestaan "täällä" ja "siellä" (Luuk. 17:23). Myös aineiston järjestys on osin erilainen. Jo Q-lähteessä esiintynyt vertauskuva raadosta ja sen ympärille kerääntyvistä korppikotkista esiintyy Matteuksella keskellä puhetta (Matt. 24:28), Luukkaalla taas puheen lopussa (Luuk. 17:37).

Vaikka Q-lähteen kuvaus Ihmisen pojan paluusta kuvaavan jakson jää sanamuodoltaan epävarmaksi, puheen keskeiset elementit käyvät hyvin ilmi vertailemalla Matteuksen ja Luukkaan yhteistä aineistoa. Nämä elementit ovat seuraavat:

1. Puhe alkaa varoituksella vääristä messiaista tai profeetoista.

2. Ihmisen Pojan paluuta verrataan salaman välähdykseen; kyse on siis kaikille ilmeisestä tapahtumasta, joten Ihmisen Poikaa ei tarvitse lähteä etsimään mistään erityisistä paikoista.

3. Ihmisen Pojan päivän arvaamattomuutta verrataan yllättävään tuhoon, joka koitui Nooan ajan ihmisten kohtaloksi.

4. Puhe päättyy kuvauksella Ihmisen pojan ilmestymisen seurauksista ihmisten keskuudessa: toinen otetaan, toinen jätetään. 
Seuraavan, Matteuksen ja Luukkaan perusteella rakennetun hahmotelman tarkoituksena on lähinnä havainnollistaa, miltä Qlähteen kuvaus Ihmisen pojan paluusta mahdollisesti näytti: ${ }^{58}$

Kun teille sanotaan: "Hän on tuolla autiomaassa", älkää lähtekö sinne, tai jos sanotaan: "Hän on sisällä talossa", älkää uskoko sitä. Sillä niin kuin salama leimahtaa idässä ja valaisee taivaan länteen asti, niin on oleva Ihmisen Pojan tulo.

Niin kuin oli Nooan päivinä, niin on Ihmisen pojan päivinä oleva. Ihmiset söivät ja joivat, menivät naimisiin ja naittivat tyttäriään aina siihen päivään asti, jona Nooa meni arkkiin, ja tulva tuli ja tuhosi heidät kaikki. Samoin käy sinä päivänä, jona Ihmisen Poika ilmestyy. Kaksi miestä on pellolla: toinen otetaan, toinen jätetään. Kaksi naista on jauhamassa: toinen otetaan, toinen jätetään.

Selkein ero Q-lähteen ja Markuksen apokalyptisten jaksojen liittyy Ihmisen Pojan paluuta edeltäviin vaiheisiin. Markuksen evankeliumissa lueteltiin joukko tällaisia tapahtumia, mutta Q-lähteestä Markuksen historiallinen näkökulma puuttuu tyystin. Siinä ei kuvata ajan merkkejä, ei esitetä historian etenemistä vaiheesta toiseen eikä lopun tapahtumia yhdistetä Jerusalemin temppelin kohtaloon. Päinvastoin: Ihmisen Poika tulee täysin yllättäen, ihmisten arkipäiväisen elämän keskelle.

Q-lähteessä Ihmisen Pojan paluuta verrataan Nooan aikaisen vedenpaisumuksen tuottamaan yllätykseen. Juutalaisessa kirjallisuudessa vedenpaisumusta edeltänyttä sukupolvea käytettiin usein esimerkkinä erityisen rappeutuneesta aikakaudesta. ${ }^{59}$ Q-lähteessä Nooan ajan ihmisiin ei kuitenkaan liitetä tätä merkitystä. Heidän moraalisia heikkouksiaan ei korosteta, vaan heidän kuvataan eläneen aivan tavallista elämä: he söivät ja joivat, menivät naimisiin ja antoivat tyttäriään vaimoiksi. Yhdistävä tekijä Nooan ajan ja Ihmisen Pojan paluun välillä on tuhon yllätyksellisyys ja suuruus, ei välttämättä moraalinen rappio.

\footnotetext{
${ }^{58}$ Vrt. Mack 1993, 101.

${ }^{59}$ Becker 1996, 71.
} 
Q-lähteen kuvaus viimeisistä tapahtumista päättyy toteamukseen siitä, kuinka toinen otetaan ja toinen jätetään. Tässäkin kohdassa Matteus ja Luukas poikkeavat hieman toisistaan: Matteus puhuu kahdesta miehestä pellolla, Luukas kahdesta ihmisestä, jotka lepäävät samalla vuoteella. Ajatus on kuitenkin sama: Ihmisen Poika jakaa tultuaan samassa elämänpiirissä elävät ihmiset yllättäen kahteen leiriin.

Passiivimuodot "otetaan" ja "jätetään" viittaavat siihen, että jaon suorittaja on Jumala itse (passivum divinum). KR:n käännös "otetaan" johtaa helposti ajatukseen, että kyse olisi uskovien "pois ottamisesta" tai "tempaamisesta" yläilmoihin. Jakson tulkinta ei ole näin yksiselitteinen. Lähteen kuvauksessa ei ole edes aivan selvää, luvataanko kohdassa parempi kohtalo sille, joka otetaan, vai sille joka jätetään. Viimeksi mainitussa tapauksessa tuhosta pelastumista kuvattaisiin puhumalla siitä, joka jää jäljelle, kun taas "poisottaminen” viittaisi kuolemaan. Lopullista ratkaisua näiden vaihtoehtojen välillä voidaan tuskin esittää. Tuomaan evankeliumissa vastaava lauselma on joka tapauksessa ymmärretty jälkimmäisellä tavalla: ensiksi mainitun kohtalona on kuolema, kun taas toinen pelastuu: "Kaksi lepää vuoteella. Toinen heistä kuolee, toinen jää eloon" (Tuom. ev. 61).

Tuomaan evankeliumin ohella jälkimmäistä vaihtoehtoa voisi tukea se, että synoptisessa lauselmassa "jättämisestä" käytetty verbi (afienai) joissain yhteyksissä tarkoittaa tuhosta pelastumista (esim. Mark. 13:2) ja "ottamisesta" käytetty verbi (paralambanein) voi viitata tuhon yhteydessä tapahtuvaan "pois pyyhkimiseen."60

Toisaalta juuri samojen verbien perusteella lauseen sisältö voidaan tulkita myös siten, että "poisotetun" kohtalo ymmärretään paremmaksi kuin "jätetyn". Verbiä paralambanein käytetään usein myönteisissä merkityksissä kuten "ottaa vastaan", "ottaa luokseen", "hyväksyä" (esim. Joh. 1:11). Sitä voidaan käyttää myös hyvin konkreettisissa yhteyksissä kuten puhuttaessa esimerkiksi vaimon ottamisesta ja lapsen adoptoinnista. Verbillä afienai on puolestaan usein kielteinen merkitys "hylätä", (esim. 1. Kor. 7:11-13). Tässä merkityksessä verbiä käytetään myös

${ }^{60}$ Kloppenborg 1987b, 303. 
toisaalla Jeesuksen sanojen kokoelmassa, Jerusalemin hävittämisestä puhuvassa kohdassa (Matt. 23:38 // Luuk. 13:35). Oma arvioni on, että jälkimmäinen tulkinta on lopulta todennäköisempi. Edes tässä tapauksessa kyse ei kuitenkaan ole kristittyjen pois tempaamisesta, vaan siitä, että Jumala hyväksyy osan ihmisistä (ja tässä mielessä ottaa heidät luokseen) ja hylkää muut.

Markuksen apokalypsin tavoin Q-lähteen kuvaukseen Ihmisen pojan paluusta ei sisälly selvitystä siitä, mitä Ihmisen Pojan palattua tarkalleen tapahtuu. Jaksosta ei käy ilmi, millaisessa prosessissa Jumalan hyväksymisen ja hylkäämisen ajateltiin toteutuvan, ei myöskään, missä ja millaisena elämän uskottiin jatkuvan Ihmisen Pojan palattua: maan päällä vai taivaassa, ruumiissa vai jossain muussa olomuodossa - esimerkiksi "enkelien kaltaisena” (vrt. Mark. 12:18-27). Q-lähteessä säilynyt kuvaus ateriasta patriarkkojen kanssa (ks. ed.) saattaa tosin viitata suhteellisen konkreettiseen tulevaisuuden odotukseen siinä ryhmässä, josta tämä lähde on alun perin lähtöisin.

\section{Ylösnousemus, tuomio ja helvetti}

\section{Paavali ja Markus}

Varhaisimmista Ihmisen Pojan paluuta kuvaavista teksteistä puuttuu universaali näkökulma. Niissä ei kuvata yleistä ylösnousemusta eikä viimeistä tuomiota, ei myöskään "valittujen" tai valitsematta jääneiden tuonpuoleista kohtaloa. Paavalin Ensimmäisessä tessalonikalaiskirjeessä esittämä kuvaus viimeisistä tapahtumista päättyi Herran ja uskovien jälleennäkemiseen (1. Tess. 4:16-17). Samoin Markuksen tulevaisuudenkuvaus päättyy siihen, että Ihmisen poika palaa ja kokoaa valittunsa luokseen. Huomio kiinnittyy yksinomaan "valittujen” kohtaloon. Qlähteessä Ihmisen Pojan paluuta seuraava tilanne on kuvattu niin lyhyesti, ettei ole edes täysin selvää, kummat pelastuvat, "otetut" vai "jätetyt". Missään näistä teksteistä ei edes viitata Danielin kirjan mainintaan ylösnousemuksesta (Dan. 12:2-3), vaikka Danielin kirjan kuvaus "ihmisen pojan" kaltaisesta apokalyptisesta hahmosta on epäilemättä kaikkien niiden taustalla. 
Kyse ei ole siitä, etteivätkö varhaiset kristityt olisi olleet kiinnostuneita myös siitä, mitä Ihmisen Pojan paluun jälkeen tapahtuu. Paavali pohtii, millaisen muutoksen Kristuksen paluu aiheuttaa kristittyjen ruumiillisessa olomuodossa (1. Kor. 15:22-28). Ajatus, että kaikki ihmiset joutuvat tuomiolle Jumalan eteen, oli hänelle selviö (esim. Room. 2:16; 3:6; 14:10; 2. Kor. 5:10). Hän voi myös vaatia yksittäisen seurakuntalaisen hylkäämistä Saatanan haltuun (1. Kor. 5:5). ${ }^{61}$

Myös Markuksen evankeliumissa pohditaan, missä muodossa kuolleet nousevat ylös (Mark. 12:18-27). Tässä jaksossa ylösnousemusta ei ymmärretä maallisen elämän jatkeeksi, vaan ylösnousseiden ajatellaan elävän enkelien kaltaisena. "Enkelielämää" ei kuitenkaan kuvata tarkemmin. Kohdasta käy ainoastaan ilmi, ettei siihen sisälly mahdollisuutta solmia avioliittoja.

Ihmisen tuonpuoleista kohtaloa ei evankeliumeissa ja Paavalin kirjeissä kuvata kovinkaan tarkasti. Markuksen evankeliumissa puhutaan helvetistä, sammumattomasta tulesta, jonne ihminen voi joutua. Tämä paikka on Jumalan valtakunnan vastakohta, mutta muuten sitä ei kuvata tarkemmin (Mark. 9:42-48). 'Helvetistä' käytetty seemiläinen sana 'gehenna' viittaa varhaiseen kristilliseen traditioon. Alun perin sana tarkoitti Jerusalemin eteläpuolella sijainnutta "Hinnomin (poikien) laaksoa" (Joos. 15:8; 18:16), jota pidettiin erityisen turmiollisena paikkana siellä toimitettujen lapsiuhrien vuoksi (2. Kun. 16:3; 21:6; 23:10; vrt. Jer. 7:32; 19:6). Apokalyptisessa kirjallisuudessa laakso yhdistettiin Jesajan kirjassa mainittuun, Jerusalemissa sijaitsevaan "hehkuvaan pätsiin” (Jes. 31:9) ja vähitellen sanaa alettiin käyttää kuvaamaan 'tulihelvettiä' yleensä. ${ }^{62}$

\footnotetext{
61 Viimeksi mainitusta kohdasta ei käy suoraan ilmi, että kohdassa mainittu "ruumis" tarkoittaisi Saatanan haltuun hylätyn ihmisen ruumiista, vaikka KR:n käännös näin edellyttääkin. Paavali on pikemminkin huolissaan seurakunnan, "Kristuksen ruumiin" puhtaudesta. Seurakunnan jäsenen erottaminen vaurioittaa tätä ruumista, mutta "viallisen osan" poistaminen on välttämätön edellytys seurakunnan "hengen" pelastumiselle; ks. Martin 1995, 169.

${ }^{62}$ Ks. Böcher 1992.
} 


\section{Tuomionjulistus "tälle sukupolvelle"}

Q-lähteessä tuomionjulistus on keskeinen teema. Kun tässä Jeesuksen sanojen kokoelmassa puhutaan tulevasta ylösnousemuksesta, kyse on aina tuomion julistuksesta "tälle sukupolvelle". Menneisyyden merkittävät hahmot, Etelän kuningatar ja Niniven asukkaat heräävät "yhdessä tämän sukupolven ihmisten kanssa" ja tuomitsevat heidät (Matt. 12:41-42 // Luuk. 19:31-32). Kohta viittaa lähiodotuksen lientymiseen, sillä "tämän sukupolven" ajatellaan tulevan samalla tavalla tuomiolle kuin jo aiemmin eläneiden sukupolvien. Q-lähteessä kuvataan myös, kuinka idästä ja lännestä tulee ihmisiä, jotka "käyvät aterialle Jumalan valtakunnassa” yhdessä patriarkkojen kanssa, kun taas toisilta evätään pääsy sinne (Matt. 8:11-12 // Luuk. 13:28-29).

Tuomion kohteena on Q-lähteessä Israel, jota pidetään syyllisenä Jumalan lähettiläiden surmaamiseen. "Tämä sukupolvi” joutuu kantamaan vastuun profeettojen surmista (Matt. 23:29-36 // Luuk. 11:4751). Tuomionjulistus liittyy läheisesti Jeesuksen seuraajien kohtaloon. Kaupunki, joka torjuu Jeesuksen lähettiläitä, on tuomiopäivänä huonommassa asemassa kuin pahuudestaan kuulu Sodoma (Matt. 10:15 // Luuk. 10:12). Pakanakaupungit Tyros ja Sidon pääsevät tuomiopäivänä vähemmällä kuin Israelin kaupungit Betsaida ja Korasin, joissa Jeesukseen ei uskottu; Kapernaum "syöstään alas tuonelaan" (Matt. 10:21-24 // Luuk. 10:13-16). Jyrkkä Israelin vastainen tuomionjulistus heijastanee sen yhteisön tilannetta, jonka keskellä Q-lähde muotoutui: yhteisön julistusta ei otettu vastaan vaan torjuttiin. ${ }^{63}$

\section{Vuohet ja lampaat}

Eniten huomiota tulevan tuomion yksityiskohtiin kiinnittää Uuden testamentin evankeliumeista Matteus. Tässä evankeliumissa viimeisiä tapahtumia koskeva opetus on koottu laajaksi kokonaisuudeksi (Matt.

${ }^{63}$ Uro 1996, 92. 
24-25), jossa on yhdistetty aineksia Markuksen evankeliumista (Mark. 13), Q-lähteestä (ks. ed.) ja Matteuksen omasta erityismateriaalista. Vasta tässä Matteuksen laajennetussa opetusjaksossa on kuvaus Ihmisen Pojan toimittamasta tuomiosta (Matt. 25:31-46).

Matteus on muuallakin laajentanut Markukselta saamaansa aineistoa kuvauksilla viimeisestä tuomiosta. Kadotuksesta käytetty ilmaus "itku ja hammasten kiristys" esiintyy miltei yksinomaan Matteuksen evankeliumissa. (Ainoa poikkeus on jakeen Matt. 8:12 rinnakkaiskohta Luuk. 13:28; muille kohdille ei ole rinnakkaiskohtia.) Markuksen evankeliumin vertauksista koottuun puheeseen (Mark. 4) Matteus on lisännyt muun muassa kaksi tulevan tuhon kuvaukseen päättyvää vertausta (vertaus rikkaviljasta, Matt. 13:24-30, ja sen selitys, 13:36-43; vertaus nuotasta, Matt. 13:47-50). Kummankin vertauksen tulkinta on samanlainen: ne kuvaavat, kuinka enkelit aikojen lopulla kokoavat pahantekijät ja heittävät heidät tuliseen pätsiin (Matt. 13:42, 49). Tulevaisuuden odotus on näissä vertauksissa tämänpuoleista: vanhurskaita ei oteta pois pahan maailman keskeltä, vaan pahat poistetaan vanhurskaiden joukosta. ${ }^{64}$

Matteuksen kuvaus Ihmisen Pojan toimittamasta viimeisestä tuomiosta poikkeaa jossain määrin edellä kuvatuista vertauksista. Vaikka sen alussa puhutaan enkeleistä, näillä ei jatkossa seuraavassa tuomion kuvauksessa ole itsenäistä roolia. Enkelit eivät heitä tuomittuja kadotukseen, vaan he menevät sinne itse (Matt. 25:46). Tuomarina toimii Ihmisen Poika, joka lajittelee paimenen tavoin ihmiset vuohiin ja lampaisiin, ja kuninkaana tuomitsee heidät.

Tuomion perustana ovat teot ja laiminlyönnit. Toivotut teot ovat hyvin konkreettisia: kyse on nälkäisten ruokkimisesta, alastomien vaatettamisesta, kodittomien majoittamisesta ja vierailuista vankien luona (Matt. 25:35-36, 42-43). Osittain kyse on teoista, joita on pidetty arvossa jo Vanhassa testamentissa ja juutalaisissa kirjoituksissa. Esimerkiksi Hesekielin kirjassa vanhurskaan yksi tuntomerkki on se, että hän "antaa leivästään nälkäiselle ja vaatettaa alastoman." ${ }^{35}$

${ }^{64}$ Ks. Luz 1990, 360.

${ }^{65}$ Hes. 18:7, 16; muista rinnakkaiskohdista ks. Luomanen 1996, 154. 
Vankien luona käyminen on Vanhan testamentin traditiosta poikkeava piirre, joka ilmeisesti viittaa varhaisten kristillisten saarnaajien kokemaan kohtaloon (vrt. 2. Kor. 4:5; 11:23). Näin on mahdollista, että "vähimmillä veljillä" tarkoitettiin alun perin juuri vaeltavia saarnaajia. Tällöin kaikkien kansojen kohtalon ajatellaan perustuvan siihen, miten ne ovat suhtautuneet kristillisen sanoman julistajiin. Tällaisella opetuksella oli todennäköisesti myös pareneettinen päämäärä seurakunnan sisällä: se kannusti seurakuntalaisia pitämään vaeltavista saarnaajista hyvää huolta. ${ }^{66}$

Viimeistä tuomiota kuvaavan jakson tulkinta on monessa suhteessa ongelmallinen. Jakso ei edusta luterilaisen teologian parhaita perinteitä, sillä sen mukaan ihmiset tuomitaan sen perusteella, mitä ovat tehneet tai jättäneet tekemättä. Kuin varmemmaksi vakuudeksi Matteus esittää saman näkemyksen muuallakin evankeliumissaan. Toisessa yhteydessä hän on lisännyt Markus-aineistoon huomautuksen, joka ennakoi myöhemmin esitettävää viimeisen tuomion kuvausta: "Ihmisen Poika on tuleva Isänsä kirkkaudessa enkeliensä kanssa, ja silloin hän maksaa jokaiselle tekojensa mukaan” (Matt. 16:27).

Tekojen keskeinen osuus viimeisellä tuomiolla voidaan ymmärtää Matteuksen apokalyptisesta ajattelusta käsin. Matteuksen kuvaus viimeisestä tuomiosta todennäköisesti heijastaa apokalyptisissa kirjoituksissa usein esiintyvää käsitystä siitä, kuinka tuleva tuomio liittyy suoraan apokalyptisen yhteisön jäsenten kokemaan kohtaloon: kaikki kansat saavat tuomionsa nimenomaan sen perusteella, miten ne ovat näihin jäseniin aikanaan suhtautuneet. ${ }^{67}$

\section{Jo tänään paratiisissa: Luukas}

Luukkaan evankeliumissa tuonpuoleisuudesta esitetään toisistaan selvästi poikkeavia käsityksiä. Toisaalta evankeliumin kirjoittaja on ottanut mukaan Q-lähteen kuvaukset viimeisestä tuomiosta (ks. ed.),

\footnotetext{
${ }^{66}$ Luomanen 1996, 154-157.

${ }^{67}$ Tämän tulkinnan edustajista ks. Luomanen 1996, 155-156.
} 
mikä viittaisi siihen, että hänen käsityksensä ihmisten tuonpuoleisesta kohtalosta olisi samankaltainen kuin Q-lähteessä. Toisaalta näyttää siltä, että kirjoittaja on ajatellut tuonpuoleisen palkkion ja rangaistuksen kohtaavan ihmistä välittömästi kuoleman jälkeen. Ainoastaan Luukkaan evankeliumissa esiintyvä vertaus rikkaasta miehestä ja Lasaruksesta edellyttää, että ihmiset päätyvät "Abrahamin luokse" tai tuonelaan heti kuoltuaan (Luuk. 16:19-31). Niin ikään ainoastaan Luukkaan evankeliumissa kuvataan, kuinka Jeesus lupaa parannuksen tehneelle ryövärille: "Jo tänään olet minun kanssani paratiisissa" (Luuk. 23:43). Sitä, miten tuleva ylösnousemus ja välitön pääsy paratiisiin tulisi sovittaa yhteen, ei Luukkaan evankeliumissa pohdita.

\section{Tuomionjulistus ja historian Jeesus}

Edellä on jo viitattu siihen, että tutkijat ovat eri mieltä tuomion asemasta historiallisen Jeesuksen julistuksessa. Ei-apokalyptisen Jeesuskuvan kannalla olevat tutkijat pitävät tuomionjulistusta myöhäisenä elementtinä Jeesuksen sanojen perimätiedossa. ${ }^{68}$ Toisaalta tuomionjulistusta on pidetty välttämättömänä edellytyksenä historiallisen Jeesuksen julistuksen ymmärtämiselle. Jeesuksen tuomionjulistuksen keskeinen sisältö tämän näkemyksen mukaan on, ettei Israel enää ole erityisasemassa:

Jeesus arvioi omana aikanaan elävän Israelin sukupolven samoin kuin Kastaja: se on epäonnistunut suhteessaan Jumalaan niin perusteellisesti, että Jumalan Israelille antamat lupaukset valinnasta ja liitosta on kulutettu loppuun. ${ }^{69}$

Ongelmallista tässä näkemyksessä on Jeesuksen jyrkkä erottaminen juutalaisesta taustastaan. Hänen tuomionjulistuksen kohteena pidetään seuraavalla tavalla määriteltyä juutalaista "liittonomismia": "Jumalan valinta ja tooran velvoittavuus ymmärretään siten, että ihmisten toimin-

\footnotetext{
${ }^{68}$ Esim. Mack 1993, 131-147.

${ }^{69}$ Becker 1996, 91.
} 
ta ja teot määräärät, mihin ihminen lopulta päätyy.” Näin määritellyn "liittonomismin" vaihtoehtona Jeesus julisti ehdotonta luottamusta Jumalan kaikille ihmisille osoittamaan hyvyyteen. Jumalan viha uhkaa nimenomaan niitä, jotka edelleen pitävät kiinni liittonomismista. ${ }^{70}$

Tällainen tulkinta liittonomismista on ongelmallinen. Sanders, joka tämän termin on tuonut tieteelliseen keskusteluun, antaa sille aivan erilaisen sisällön. Hänen mukaansa liittonomismin perusta oli ajatus Jumalan tekemästä liitto Israelin kanssa; lain noudattaminen ('nomismi') ymmärrettiin vastaukseksi tähän Jumalan tekoon, ei pelastuksen ehdoksi; lisäksi liittonomismiin kuului ajatus katumisen mahdollisuudesta. $^{71}$ Sanders kritisoi suoraan juuri edellä kuvattua, sinänsä yleistä käsitystä juutalaisuudesta tekoihin perustuvana uskontona.

Kun kristityt tutkijat keskustelevat juutalaisuudesta, he yleensä pitävät palkkioita ja rangaistusta "oppina pelastuksesta": Jumala palkitsee hyvää tekevät ikuisella elämällä, mutta tuomitsee pahantekijät. Monet tutkijat päättelevät tästä mekaanisesti: Jumala laskee tekoja ja pelastaa ne, joilla on enemmän hyviä kuin pahoja tekoja. ... Tämä on karkea väärintulkinta todistusaineistosta. Useimmissa tämän ajan juutalaisissa kirjoituksissa käydyissä keskusteluissa palkkio ja rangaistus toteutuvat jo tässä elämässä ... Kun juutalaiset ajattelivat tämän maailman jälkeen koittavaa pelastusta, he eivät olettaneet, että 51 prosenttia yksilön teoista ratkaisee asian. Jumalan armo nousee aina esiin kaikkein tärkeimpänä asiana. Katumus oli lopulta ulottuvuuksiltaan kokonaisvaltainen. ... kokonaan paha ihminenkin saattoi katua lopuksi ja pelastua. ${ }^{72}$

Voidaan myös kysyä, missä määrin Jeesuksen tarjoama "vaihtoehto" "liittonomismille" todella erosi juutalaisesta teologiasta. Ajatus Jumalan huolenpidosta ja hyvyydestä tuskin oli ristiriidassa juutalaisuuden peruskorostuksien kanssa. Tuomionjulistukseen liittyvä ongelma onkin etupäässä Jeesuksen sanojen perimätiedon sisäinen: jos Jeesuksen julistuksen keskeisenä tavoitteena oli saada ihmiset uskomaan Jumalan ehdot-

${ }^{70}$ Becker 1996, 92-93, 98.

${ }^{71}$ Sanders 1992, 262-272.

72 Sanders 1992, 272-273. 
tomaan hyvyyteen, joka ulottui jopa pahantekijöihin, miten jyrkkä tuomionjulistus palveli tätä keskeistä tavoitetta? ${ }^{73}$

Ongelma tuskin ratkeaa olettamalla, että tuomionjulistus tuli osaksi Jeesuksen sanojen perimätietoa vasta varhaisen Jeesus-liikkeen piirissä, seurauksena sen kohtaamasta vastarinnasta juutalaisten parissa; tällaisessa tilanteessa tosin Jeesuksen sanojen traditioon kuuluva tuomionjulistus saattoi tulla erityisen ajankohtaiseksi. Tuomionjulistus ei rajoitu vain yhteen Jeesuksen sanojen haaraan, vaan tulee laajasti esiin Jeesuksen sanojen varhaisimmassa traditiossa. Tulevan tuomion julistus liittää Jeesuksen sanoman Vanhan testamentin profeetalliseen julistukseen, mutta myös Vanhan testamentin jälkeen kirjoitettuihin juutalaisiin teksteihin ${ }^{74}$ ja todennäköisesti myös Johannes Kastajan julistukseen.

Mikä sitten oli Jeesuksen tuomionjulistuksen tavoite? Ilmeistä on, että kyse todella oli kutsusta parannuksen tekoon. ${ }^{75}$ Tähän viittaa se, että eräissä kohdissa Jeesuksen tuomionjulistuksella on selvästi eettinen päämäärä. Esimerkiksi Matteuksen vertaus kuninkaasta ja palvelijasta (Matt. 18:23-34) kuvaa tuomiota, joka seuraa palvelijan anteeksiantamattomuudesta. ${ }^{76}$ Tuomionjulistuksella oli myös yhteiskunnallinen sanoma, johon sisältyi ajatus osien vaihtumisesta ("status reversal"): yllättävän tuomion kohteeksi joutuvat erityisesti rikkaat (Luuk. 12:1620). ${ }^{77}$

\footnotetext{
${ }^{73}$ Vrt. Räisänen 1994, 15.

${ }^{74}$ Ks. Zager 1996, 314.

${ }^{75}$ Sanders tosin arvelee Jeesuksen julistuksessa herättäneen pahennusta herätti juuri sen, että Jeesus ei vaatinut syntisten tekevän parannusta: Sanders 1985, 209-210; tähän näkemykseen liittyvistä ongelmista ks. kuitenkin Räisänen 1994, 14-16.

${ }^{76}$ Vrt. Zager 1996, 315.

${ }^{77}$ Ks. Becker 1996, 65-66.
} 


\section{Vastauksia viivästyneen lopun ongelmaan}

Tuntuisi luonnolliselta olettaa, että lähiodotus ja siinä koettu pettymys tekisivät lopunajallisista liikkeistä hyvin lyhytikäisiä ilmiöitä. ${ }^{78}$ Historia on kuitenkin osoittanut, etteivät lopunajalliset liikkeet aina hajoa lähiodotuksessa koettuun pettymykseen. Lähiodotus voi väliaikaisen hiipumisen jälkeen aktualisoitua uudelleen, ja pettymyksen aiheuttama tiedollinen ristiriita voidaan ratkaista ilman, että yhteisö hajoaa. Varhaisen kirkon ajalla esiintynyt montanolaisuus on hyvä esimerkki tästä: liike ei kaatunut siihen, ettei sen odottamaa maailmanloppua ei 100-luvun puolivälissä tullutkaan, vaan se säilytti elinvoimansa vielä 200-luvulla. Tosin liikkeen korostukset jossain määrin muuttuivat; lähiodotuksen korvasivat muut omaan perinteeseen perustuvat korostukset. $^{79}$

Yhtä ilmeinen tosiasia kuin varhaiskristillinen läheisen lopun odotus sinänsä on se, että tässä odotuksessa jouduttiin pettymään. Pietarin toisessa kirjeessä mainittua kokemusta siitä, että "isät ovat nukkuneet pois”, voi pitää yhtenä varhaisen kristinuskon merkittävimmistä taitekohdista: Odotettua loppua ei tullut, vaikka kristittyjen ensimmäinen ja pian toinenkin sukupolvi oli kadonnut. ${ }^{80}$

Pettymys ei kuitenkaan hajottanut varhaista kristinuskoa, vaan se säilytti elinvoimaisuutensa uudessakin tilanteessa. Uuden testamentin sisältä löytyy sekä viitteitä viivästyneen lopun aiheuttamiin ongelmiin että siihen, minkälaisia ratkaisuja niihin esitettiin. Apokalyptisiin odotuksiin liitetty varaus, ettei kukaan tiedä tarkkaa hetkeä, todennäköisesti helpotti lähiodotuksen uudelleentulkintaa.

Yksi mahdollisuus kohdata viivästyneen lopun ongelma oli korostaa varhaisemman apokalyptisen opetuksen pitävän edelleen paikkansa. Pietarin toisessa kirjeessä lukijoita muistutetaan jo vakiintuneesta kristillisestä traditiosta, että Herran päivä tulee kuin varas (2. Piet. 3:10; vrt. Matt. 24:42-44 // Luuk. 12:39-40; 1. Tess. 5:1-2; Ilm. 16:15), ja

\footnotetext{
${ }^{78}$ Vrt. Uro 1988, 30.

${ }^{79}$ Ks. Marjanen 1988.

${ }^{80}$ Vrt. Becker 1993, 87-89.
} 
siitä, että on tulossa tuomion päivä, jolloin jumalattomat tuomitaan (2. Piet. 3:7). Toisaalta kirjeen kirjoittaja joutuu ottamaan kantaa väitteisiin Herran paluun viivästymisestä. Hän esittää tähän ongelmaan itse asiassa useitakin ratkaisuja. Retorisesti tehokkain ratkaisu on epäilemättä vastustajien demonisointi: juuri ne jotka väittävät, ettei odotettua loppua tulekaan, ovat merkki siitä, että lopun aika on käsillä juuri nyt (2. Piet. 3:3).

Kirjeen kirjoittaja käyttää hyväkseen myös Vanhaa testamenttia, josta käy ilmi, ettei Jumalan käsitys ajasta ole sama kuin ihmisten: "Herralle yksi päivä on kuin tuhat vuotta ja tuhat vuotta kuin yksi päivä" (Ps. 90:4). Tällainen ajatus ei sovi kovinkaan hyvin yhteen apokalyptiikalle ominaiseen läheisen lopun odotukseen eikä edes siihen, että kirjoittaja itse uskoo lopun ajan jo koittaneen. Kirjoittaja voi kuitenkin olettaa lukijoidensa hyväksyvän tällaisen apokalyptisen tradition uudelleentulkinnan, koska se perustuu kristittyjen toiseen tärkeänä pitämään traditioon, Vanhaan testamenttiin.

Lopuksi kirjoittaja vetoaa vielä yleisempään teologiseen ajatukseen Jumalan armahtavaisuudesta: hän "ei halua kenenkään tuhoutuvan" (2. Piet. 3:9) ja siksi tuomion päivä ei vielä ole koittanut. Jumalan hyväntahtoisuuteen ei kuitenkaan saa tuudittautua, kuten kirjoittajan viittaukset tulevaan tuomioon osoittavat. Selvää on joka tapauksessa, että Toisen Pietarin kirjeen kirjoittaja haluaa kannustaa lukijoitaan "perinteiseen" lopunodotukseen, vaikka tilanne näyttääkin muuttuneen. Hänelle kyse on epäilemättä kristillisen sanoman uskottavuudesta yleensä; siksi hän vakuuttaa, ettei "Herra vitkastele täyttäessään lupaustaan, vaikka hän joidenkin mielestä on myöhässä".

Toisen Pietarin kirjeen kirjoittaja esittää lopun odotukseen joukon erilaisia näkökulmia, joiden välinen suhde jää jossain määrin jännitteiseksi. Kyse on pitkälti assimilaatiosta: kirjoittaja liittää toisiinsa erilaisia ajatuksia, jotka hänen lukijansa todennäköisesti hyväksyvät, mutta ei pyrikään varsinaisesti tasoittamaan niiden välisiä jännitteitä. ${ }^{81}$

${ }^{81}$ Assimilaatiosta ks. Syreeni 1995, 220. 
Ilmeistä on, että myös Ilmestyskirja on kirjoitettu tilanteessa, jossa lopun odotus oli alkanut heikentyä. Toisin kuin on usein oletettu, Ilmestyskirja ei välttämättä ole syntynyt vainojen keskellä. Kirjan näkijä ei ole niinkään huolissaan kristittyjen kohtaamista vainoista kuin heidän vähittäisestä sopeutumisestaan roomalaiseen yhteiskuntaan. Tällainen huoli tulee esiin erityisesti Vähän-Aasian seitsemälle seurakunnalle osoitetuissa kirjeissä, jotka ovat kirjan alussa. Näissä kirjeissä kahteenkin otteeseen mainittu uhrilihan syönti (Ilm. 2:14, 20) oli Ilmestyskirjan alkuperäisille lukijoille ajankohtainen ongelma. Uhrilihaa syötiin esimerkiksi perhejuhlissa ja kauppakiltojen kokoontumisissa; viimeksi mainittuihin kokouksiin osallistuminen oli edellytys kauppiaan toimen harjoittamiselle. Ilmestyskirjassa ympäröivään maailmaan ja erityisesti kaupankäyntiin erityisesti suhtaudutaan kielteisesti. Tämä kielteisyys näkyy siinä, että kirjassa mainittu "pedon merkki" liittyy oikeuteen käydä kauppaa (Ilm. 13:17). Ilmestyskirjan kirjoittajan tavoitteena on pitää kristityt erillään kaikesta, mikä viittaa Rooman hirmuvaltaan. ${ }^{82}$

Pietarin toisen kirjeen tavoin Ilmestyskirjassa halutaan osoittaa, että lähiodotuksesta ei ole syytä luopua. Kirjan kirjoittaja turvautuu Vanhan testamentin ja apokalyptisen kirjallisuuden tarjoamiin kuvauksiin viimeisistä tapahtumista. Kirjan kuvaukset vainoista eivät välttämättä kuvaa lukijoiden omaa tilannetta, vaan tarkoituksena on muistuttaa heitä niistä kristityistä, jotka olivat menettäneet henkensä vainoissa. Lukijoille kuvataan elävästi, kuinka vainoissa kuolleet vaativat taivaassa Jumalalta kostoa "maan asukkaille" (Ilm. 6:9-10), ja Ilmestyskirja kokonaisuutena kuvaa, kuinka tämä kosto toteutuu pian. Tavoitteena on estää lukijoiden sopeutuminen Rooman valtakuntaan. He eivät saa unohtaa, että juuri tämä Rooma on muutamia vuosia aiemmin vainonnut heidän uskonveljiään ja voi aloittaa uudet vainot millä hetkellä hyvänsä.

"Isien poisnukkumisen" aiheuttama ongelma näkyy myös Johanneksen evankeliumissa. Siinä ongelmaa ei kuitenkaan ratkaista toistamalla lähiodotuksen keskeisiä opinkappaleita. Evankeliumin

${ }^{82}$ Räisänen 1992. 
lopussa kerrotaan, kuinka Jeesuksen rakkaimmasta opetuslapsesta levisi sana, ettei hän kuole ennen kuin Jeesus tulee takaisin. Tätä lähiodotusta heijastavaa käsitystä pidetään väärinkäsityksenä. Jeesuksen oppilaat eivät huomanneet, että Jeesus asetti sanansa varovaisemmin: "Mitä se sinulle kuuluu, vaikka tahtoisin hänen jäävän tänne aina siihen asti kun tulen?" (Joh. 21:22, 23). Liian konkreettinen lähiodotus perustuu evankeliumin kirjoittajan mukaan siis virhetulkintaan Jeesuksen sanoista. Jakson tarkoituksena voi olla myös osoittaa, ettei evankeliumissa esitettyjä lupauksia jo nyt saavutettavasta kuolemattomuudesta (etenkin Joh. 11:25-26) tule tulkita liian konkreettisesti: nykyhetkessä koettava, "presenttinen" kuolemattomuus ei säästä ihmistä fyysiseltä kuolemalta. ${ }^{83}$

Johanneksen evankeliumissa lähiodotuksen hiipuminen näkyy aineiston valinnassa ja tulkinnassa muutenkin. Tulevaisuuden odotus on periaatteessa säilynyt: Jeesus palaa noutamaan omansa taivaallisiin asuntoihin (Joh. 14:1-3) ja evankeliumissa viitataan lyhyesti kaikkien kuolleiden herättämiseen tulevaisuudessa (Joh. 5:28-29; jaksoa pidetään tosin usein myöhempänä lisäyksenä evankeliumiin). Näihin tulevaisuuden kuviin ei kuitenkaan liitetä ajatusta pian koittavasta lopusta. Maininnat opetuslasten kokemista vainoista (Joh. 16:1-4) ja odottavan naisen synnytystuskista (Joh. 16:21-22) liittyvät tulevaisuuden odotukseen, mutta niiden yhteydessä ei viitata läheisen lopun odotukseen.

Johanneksen evankeliumissa painopiste on siirtynyt tulevaisuuden odotuksesta "nykyhetkeen". Se minkä tavallisesti odotetaan tapahtuvan vasta tulevaisuudessa, on toteutunut jo nyt Jeesuksen julistuksessa. Se joka uskoo "on saanut ikuisen elämän" ja "on jo siirtynyt kuolemasta elämään” (Joh. 5:24) eikä häntä tuomita lainkaan; toisaalta "se, joka ei usko, on jo tuomittu" (Joh. 3:18).

Siinä yhteisössä, jonka piirissä Johanneksen evankeliumi syntyi, esiintyi myös apokalyptisia traditioita. Nämä traditiot tulivat ajankohtaisiksi yhteisöä koetelleessa kriisitilanteessa. Ensimmäisessä Johanneksen kirjeessä esiintyvät sulassa sovussa evankeliumista tutut presenttiset

${ }^{83}$ Dunderberg 1997, 142-143. 
korostukset (1. Joh. 5:11-12), vakaumus, että "viimeinen aika on käsillä” (1. Joh. 2:18) ja Kristuksen paluun odotus (1. Joh. 2:28). Kirjeen perusteella lukijoiden voi olettaa tuntevan ajatuksen Antikristuksen ilmestymisestä. Kirjoittaja esittää tästä ajatuksesta uuden, ajankohtaisen sovelluksen: ei ole ilmaantunut ainoastaan yhtä Antikristusta, vaan monia antikristuksia. Jatko paljastaa, ettei kirjoittaja puhu myyttisistä lopun ajan hahmoista, vaan "antikristuksia" ovat oman yhteisön entiset jäsenet. Eskatologisesta traditiosta muokkautui sopiva lyömäase yhteisön sisäisissä välienselvittelyissä.

Lapset, viimeinen aika on käsillä. Te olette kuulleet, että on tulossa Antikristus, ja niin onkin nyt monia antikristuksia ilmaantunut. Tästä me tiedämme, että viimeinen aika on käsillä. He ovat lähtöisin meidän joukostamme, mutta he eivät olleet meidän joukkoamme. Jos he olisivat kuuluneet meihin, he olisivat pysyneet keskuudessamme. Mutta täytyihän käydä ilmi, etteivät kaikki kuulu meihin. (1. Joh. 2:18-19)

Ensimmäinen Johanneksen kirje osoittaa, että "presenttinen eskatologia" ei varhaiskristillisyydessä ollut puhtaaksiviljelty teologinen oppi, joka varsinaisesti olisi korvannut tulevan tuomion päivän odotuksen. Pikemminkin se perustui apokalyptiseen eskatologiaan ja yhdistettiin ongelmitta siihen, mikäli tarve vaati.

Johanneksen evankeliumin "presenttiset" korostukset muistuttavat Paavalin oppilaiden esittämiä käsityksiä. Efesolaiskirjeessä ylösnousemus ymmärretään jo tapahtuneeksi tosiasiaksi (Ef. 2:6; 5:14). Tästä aiheesta tosin ilmeisesti oli Paavalin koulukunnassa ristiriitaisia näkemyksiä. $\mathrm{Ne}$ Toisessa Timoteus-kirjeessä torjutut opettajat, jotka väittivät ylösnousemuksen tapahtuneen jo (2. Tim. 2:18), saattoivat edustaa hyvin samanlaista käsitystä kuin Efesolaiskirjeen kirjoittaja. Kolossalaiskirjeessä puolestaan puhutaan jo kasteen yhteydessä tapahtuvasta kuolleista nousemisesta (Kol. 2:12-13); Paavali itse oli varonut puhumasta kasteen yhteydessä toteutuneesta ylösnousemuksesta, vaikka hän rinnastikin toisiinsa kasteen ja Kristuksen kuoleman (Room. 6:14). 
Sekä Johanneksen evankeliumin että Paavalin oppilaiden kirjeiden voi katsoa edustavan yhtä ratkaisumallia viivästyneen lopun odotukseen: "Mitä odotettavaa uskovalla on tulevaisuudelta? Ei mitään, mitä hänellä ei jo olisi." ${ }^{\text {44 }}$ Tällaiset näkemykset eivät sulje pois tulevaisuuden odotusta sinänsä (esim. Joh. 5:28-29; 14:1-3), mutta niihin ei enää liity selkeää lähiodotusta.

Presenttinen eskatologia ei ollut täysin ainoalaatuinen piirre omana aikanaan, vaikka sitä usein onkin pidetty nimenomaan kristillisenä piirteenä. Vastaavanlaisia korostuksia esiintyi myös Qumranin yhteisössä, jonka jäsenet erityisesti yhteisissä kokoontumisissa kokivat jo nyt elävänsä tulevan ajan "enkelielämää". ${ }^{85}$ Tällainen kultillisesti painottunut presenttinen eskatologia ei myöskään Qumranissa korvannut kokonaan yhteisön apokalyptisia odotuksia, vaan eli näiden kanssa rinnakkain. Historiallisesti katsottuna presenttinen eskatologia ei siis ole vaihtoehto apokalyptiikalle.

\section{Lopuksi}

Eskatologisissa näkemyksissä esiintyviä eroja voi pitää haasteena erityisesti kirkolliselle raamatuntulkinnalle. Tutkimuksen näkökulmasta erilaisuus on helppo hyväksyä olemassa olevana ja sinänsä mielenkiintoisena ilmiönä. Mutta mikä olisi sopiva kirkollinen näkökulma samaan ilmiöön? Pitäisikö varhaiskristillisten, toisistaan poikkeavien eskatologisten käsitysten perusteella luoda viimeisistä tapahtumista ohjeellinen kuvaus, jossa erilaiset näkemykset sulautuisivat mahdollisimman yhtenäiseksi kokonaisuudeksi?

Tällaisen lähestymistavan ongelma on nähdäkseni sama kuin alkukirkon ajoilta asti tunnettujen evankeliumiharmonioiden: se ei tee oikeutta Jeesuksen sanojen perimätiedon eri haarojen omille erityiskorostuksille. Yrittäessään olla uskollinen yhtä aikaa eri eskatologisille

\footnotetext{
${ }^{84}$ Conzelmann \& Lindemann 1987, 402.

${ }^{85}$ Collins 1997, 128-129.
} 
traditioille tällainen tulkinta ei lopulta olisi varsinaisesti uskollinen millekään niistä. Lisäksi yhteys kristinuskon historialliseen taustaan katkeaa, jos unohdetaan ne yhteisöt, joissa Jeesuksen sanoja alun perin käytettiin ja talletettiin, ja se tilanne, joka teki eskatologisista teksteistä omana aikanaan ajankohtaisia. On syytä muistaa, ettei varhaiskristillisiä tekstejä olisi tallennettu ja kopioitu lainkaan, ellei niitä olisi koettu ajankohtaiseksi siinä yhteisössä, jonka piirissä teksti syntyi.

Historiallisen tutkimuksen näkökulma voisi nähdäkseni olla rakentava vaihtoehto myös eskatologisten tekstien kirkollisessa tulkinnassa. Tällainen näkökulma tarkoittaisi seuraavien kysymysten esittämistä: Mitä nämä tekstit merkitsivät omana syntyaikanaan? Miten evankeliumien varhaiset lukijat ymmärsivät ne tai miten heidän toivottiin ymmärtävän ne? Millaisessa tilanteessa näiden tekstien sanoma koettiin ajankohtaiseksi? Tällainen lähestymistapa tekisi varhaiskristillisistä eskatologisista teksteistä uudella tavalla ajankohtaisia ja eläviä. Se voisi tarjota toisenlaisen näkökulman niille seurakuntalaisille, joille nykyajan apokalyptiikasta tullut ongelma, joko liian kiehtovana, kaiken muun alleen peittävänä, tai liian kauhistavana asiana. Apokalyptiikalle on usein ominaista historiallisen ajattelun kapeutuminen: tärkeää on vain tämä hetki ja lähitulevaisuus. Edellä mainitut kysymykset voisivat avartaa tätä kapeutunutta käsitystä ja lopulta auttaa ymmärtämään paremmin apokalyptisia tekstejä. Teologeille edellä mainittujen kysymysten esittäminen tarkoittaa lisäksi uutta haastetta tutustua näitä aiheita käsittelevään tutkimukseen. Tutkimus ei tosin anna näihin kysymyksiin lopullisia vastauksia, mutta sen piirissä niitä on pohdittu mahdollisimman huolellisesti ja eri näkökulmista. 


\section{Synnin sosiologiaa Ensimmäisessä Johanneksen kirjeessä}

(2013)

\section{Johdanto}

Ensimmäisessä Johanneksen kirjeessä esitetään synnistä ja synnittömyydestä ristiriitaisilta vaikuttavia väitteitä. Kirjeen kirjoittaja kiistää väitteen, että kukaan voisi olla synnitön (1. Joh. 1:8). Silti hän vain hetkeä myöhemmin toteaa, ettei Jumalasta syntynyt tee eikä edes voi tehdä syntiä (1. Joh. 3:9).

Väitteiden välinen ristiriita on ilmeinen, ja sitä on selitetty eri tavoin. Nykyisin useimmat ratkaisut perustuvat ajatukselle, että ongelma liittyy tavalla tai toisella kirjeen kirjoittamistilanteeseen. Kirje on kirjoitettu tilanteessa, jossa vastaanottajien yhteisö on hajaantumassa kahtia. Kirjoittajalla on vastustajia, jotka hänen mielestään johtavat vastaanottajien joukkoon kuuluvia harhaan. Kirjeen keskeisenä tarkoituksena onkin estää vastaanottajien siirtyminen "väärään" leiriin. Kirjoittajan syntiä ja synnittömyyttä koskevat väitteet palvelevat tätä päätavoitetta. Kirjoittaja tekee niiden avulla jyrkän rajan yhteisön ja ulkopuolisten välillä, mutta samalla hän luo ihannekuvan sisäpiiristä jäsenistään huolehtivana, tasa-arvoisena ja terapeuttisena yhteisönä. Tämä piirre muistuttaa jossain määrin antiikin filosofiyhteisöistä esiintyviä kuvauksia, joihin palaan artikkelin loppuosassa.

Ensimmäistä Johanneksen kirjettä on usein tulkittu "sosiologisesti”, sillä ryhmien väliset suhteet ovat olleet keskeisessä asemassa erilaisissa selitysmalleissa. Tutkijat ovat pyrkineet kirjeen perusteella 
luomaan mahdollisimman tarkan kuvan siitä, mitä kirjoittajan vastustajat opettivat. Viittauksia vastustajien näkemyksiin - tai jopa suoria lainauksia heiltä - on nähty sellaisissakin kirjeen kohdissa, joissa heitä ei suoraan mainita. Tämä näkökulma johtaa helposti tulkintaan, että kirjoittaja toimii reaktiivisesti: hän nostaa esiin vastustajien opetuksia ja kumoaa niitä. Kuten jatkossa käy ilmi, myös kirjoittajan opetuksia synnistä ja synnittömyydestä on selitetty usein tästä näkökulmasta.

Tässä tulkintamallissa oletetaan, että kirje heijastaa kohtuullisen hyvin todellista tilannetta vastaanottajien parissa ja että kaikki kirjeessä esiintyvät näkemykset tulee tulkita tästä tilanteesta käsin. Tällaista näkökulmaa Uuden testamentin teksteihin on kutsuttu "peililuennaksi" (mirror-reading). Toinen tällaisesta tulkinnasta käytetty metafora on, että teksti tarjoaa "ikkunan" tekstin taustalla olevaan sosiaaliseen todellisuuteen.

Hyppy tekstin kuvaamasta todellisuudesta taustalla olevaan tilanteeseen ei kuitenkaan ole ongelmaton. Kirjeen kirjoittaja luonnollisesti kuvaa tilanteen omista päämääristään käsin. Tätä hahmotelmaa kutsutaan joko yleisemmin tekstin "retoriseksi tilanteeksi" (rhetorical situation) tai kirjeen ollessa kyseessä "kirjetilanteeksi" (epistolary situation).

Kummallakin käsitteellä halutaan korostaa, että kirjeessä kuvattu tilanne $e i$ vastaa yksi yhteen lukijoiden kokemusta. Kuvaus tilanteesta on kirjoittajan luomus (konstruktio), joka palvelee hänen päämääriään. Kirje ei tästä syystä välttämättä heijasta suoraan edes kirjoittajan käsitystä tilanteesta. Koska kirjeen tarkoituksena on vaikuttaa vastaanottajien käyttäytymiseen, kirjoittaja luo tilanteesta kuvan, joka tehokkaimmin palvelee tätä päämäärää. Kirje ei ole vain reaktio tilanteeseen, vaan sen tarkoituksena on saada lukijat näkemään tilanne uudella tavalla. Ensimmäisessä Johanneksen kirjeessä on kirjoittajan kuvaus siitä, miten kirjeen vastaanottajien pitäisi tulkita tilanne, ei siitä, millainen yhteisön tilanne todellisuudessa on. Tässä tapauksessa siitä, miten asioiden pitäisi olla (= kirjoittajan kuvaama tilanne) ei voi päätellä, miten ne ovat (vrt. Humen giljotiinina tunnettu periaate: "Siitä miten asiat ovat ei voi päätellä miten niiden pitäisi olla.”)

Ajatus, että teksti ei heijasta todellisuutta vaan luo oman todellisuutensa, on ominainen "lingvistisille käänteelle" (linguistic turn), joka on viime vuosikymmeninä ulottanut vaikutuksensa myös historiallisten 
tekstien tulkintaan. Äärimmilleen pelkistettynä tämän tulkintamallin keskeinen slogan on, että "tekstin takana ei ole mitään." Ensimmäistä Johanneksen kirjettäkin on tulkittu tämän periaatteen mukaan. Tällöin korostetaan esimerkiksi, että "vastustajat" ovat retorinen tyylikeino, joilla ei ole lainkaan vastineita "todellisessa" maailmassa; kirjoittaja puhuu vastustajista nostaakseen esiin tärkeitä teemoja, käydäkseen keskustelua niistä ja korostaakseen käsittelemänsä asian tärkeyttä. ${ }^{1}$

Tällainen lingvistisen käänteen inspiroima tulkinta rajaa tekstin taustalla olevan historiallisen tilanteen kokonaan pois. Näin päästään kätevästi eroon kirjeen syntytilanteen hahmottamiseen liittyvistä epävarmuustekijöistä. Tulkinta ei kuitenkaan tee oikeutta Ensimmäisen Johanneksen kirjeen kaltaiselle tekstille. Kirje on tarkoitettu kommunikaatioksi kirjoittajan ja vastaanottajien välillä. Voidaan hyvällä syyllä olettaa, että vastaanottajien parissa oli tapahtunut jotain, minkä vuoksi kirje kirjoitettiin, ja että kirjoittaja pyrkii vaikuttamaan vastaanottajien toimintaan tässä tilanteessa. Tällaisen vaikuttamisen edellytyksenä on, että lukijat pystyvät kirjeen luettuaan ymmärtämään, mistä kirjoittaja puhuu. Kirjoittajan kuvaaman retorisen tilanteen täytyi siis olla lukijoiden tunnistettavissa, vaikka hänen kuvauksestaan ei voikaan suoraan päätellä, mitä yhteisössä oli tarkalleen tapahtunut tai mitä hänen vastustajansa opettivat.

Tällaiset tekstin "poliittiset” ulottuvuudet jäävät helposti sivuun, jos korostetaan yksipuolisesti, ettei tekstin takana ole mitään. Tekstit eivät elä vain tekstien maailmassa, vaan ne liittyvät myös sosiaaliseen maailmaan, etenkin sellaiset tekstit, joilla pyritään suoraan vaikuttamaan ihmisten mielipiteiden lisäksi käyttäytymiseen, esimerkiksi oikean ryhmän valintaan ja väärän torjumiseen. Ensimmäisen Johanneksen kirjeen tarkoituksena oli epäilemättä saada lukijat tunnistamaan ne, jotka "lähtivät pois meidän joukostamme" (1. Joh. 2:19) ja "jotka tahtovat johtaa teitä harhaan" (2:26), ja karttamaan heitä. Kirjoittaja turvautuu kovaan, apokalyptisesta traditiosta nousevaan retoriikkaan kuvatessaan väärään leiriin kuuluvia: he ovat "antikristuksia" ja heidän

\footnotetext{
${ }^{1}$ Schmid 2002.
} 
ilmaantumisensa on merkki "viimeisistä ajoista" (1. Joh. 2:18). Kirjoittaja viittaa myös Kristuksen toiseen tulemiseen. Hänen toivomuksessaan, ettei hän eivätkä kirjeen vastaanottajat "joudu häveten väistymään (Kristuksen) luota, kun hän saapuu” (1. Joh. 2:28), voidaan nähdä epäsuora uhkaus niille, jotka ovat vaarassa ajautua kirjoittajan vastustamien kristittyjen joukkoon.

Ensimmäisessä Johanneksen kirjeessä hahmotellussa retorisessa tilanteessa "meidän" ja "muiden" välillä on jo selvä raja. Jako ei kuitenkaan näytä olleen yhtä selvä vastaanottajien parissa. Kirjoittaja on yhä huolissaan "niistä, jotka tahtovat johtaa teitä harhaan" (1. Joh. 2:26). Kohdan perusteella myös kirjoittajan vastustamat opettajat olivat edelleen tekemisissä kirjeen vastaanottajien kanssa ja pyrkivät saamaan heidät puolelleen. Kirjoittajan näkökulmasta tämä on eksytystä, mutta hän ei voi olla varma, ovatko kirjeen vastaanottajat samaa mieltä. (Jos kirjoittaja olisi voinut olla varma, että vastaanottajat näkivät tilanteen hänen kuvaamallaan tavalla, koko kirjettä ei olisi tarvittu.) Kirjeen tarkoituksena on vaikuttaa vastaanottajien tulkintaan tilanteesta ja synnyttää "yhteys meihin" (1. Joh. 1:3) - väärinä pidettyjen opettajien sijasta.

\section{Synti ja synnittömyys Ensimmäisessä Johanneksen kirjeessä}

Koska kirjeen kirjoittaja puhuu joissain yhteyksissä suoraan vastustajista, aiemmin oli tavallista olettaa, että kirjoittajan syntiä ja synnittömyyttä koskevat väitteet liittyvät jollain tavalla vastustajien opetuksiin. Uudemmassa tutkimuksessa on kuitenkin toistuvasti todettu, millaisia sudenkuoppia liittyy oletukseen, että kaikki kirjeessä esitetyt väitteet olisivat reaktioita vastustajien opetuksiin (ks. alla). Syntiä ja synnittömyyttä koskevien väitteiden osalta tämä tulkinnan lähtökohta on erityisen ongelmallinen: kirjeen kirjoittaja ei tästä aiheesta puhuessaan viittaa kertaakaan suoraan vastustajiinsa. Kuva siitä, mitä vastustajat opettivat, jää muutenkin hyvin epäselväksi, joten ei ole perusteltua rakentaa kirjeen tulkintaa arvailuille heidän näkemyksistään. 
Kun kirjeen syntiä ja synnittömyyttä käsitteleviä kohtia katsotaan tarkemmin, käy ilmi, että kirjoittaja puhuu aiheesta useammalla kuin kahdella tavalla. Luvussa 3 kirjoittaja väittää painokkaasti, että "syntiä ei tee kukaan, joka pysyy Kristuksessa," että "yksikään Jumalasta syntynyt ei tee syntiä," ja että tällainen oikeanlainen kristitty ei edes "voi tehdä syntiä, koska on syntynyt Jumalasta." (1. Joh. 3:4-10.) Näitä väitteitä siivittää jyrkkä jako kahteen ryhmään, Jumalan ja paholaisen lapsiin: se joka tekee syntiä "on Paholaisesta".

Kirjoittaja esittää väitteen Jumalan lasten synnittömyydestä yhteisenä näkemyksenä: " Me tiedämme, ettei yksikään Jumalasta syntynyt tee syntiä" (1. Joh. 5:18). Samaa ilmaisua käytetään Johanneksen evankeliumissa silloin, kun on kyse joko vahvasta uskon ilmauksesta tai yleisesti hyväksytystä opista (Joh. 3:2; 9:29, 31; 16:30; vrt. myös Joh. 11:24 "minä tiedän, että..."). Käyttämällä ilmaisua "me tiedämme" kirjoittaja haluaa luoda siis kuvan, että hänen esittämänsä ajatus uskovien synnittömyydestä on yleisesti hyväksytty, itsestään selvä totuus.

Uskovien synnittömyys ei kuitenkaan ole itsestään selvä asia edes Ensimmäisessä Johanneksen kirjeessä. Kirjeensä alussa kirjoittaja torjuu ajatuksen synnittömyydestä yhtä päättäväisesti kuin hän puoltaa sitä myöhemmin. Hänen mukaansa olisi virhe väittää, "ettemme ole syntisiä.” Tässäkin yhteydessä kirjoittaja turvautuu vahvaan retoriikkaan: väite synnittömyydestä tekisi Jumalasta valehtelijan ja osoittaisi, ettei "hänen sanansa ole meissä" (1. Joh. 1:8, 10).

Kirjoittaja puhuu asiasta tässä yhteydessä hieman eri tavalla kuin silloin, kun hän puhuu synnittömyydestä myönteisesti. Kohdassa, jossa hän pitää synnittömyyttä mahdollisena, hän puhuu synnin tekemisestä: "jokainen joka tekee syntiä (päs ho poiōn tèn hamartian)", "se joka tekee syntiä on paholaisesta"; "syntiä ei tee kukaan, joka hänessä pysyy." Kun kirjoittaja kirjeen alussa korostaa kaikkien ("meidän") syntisyyttä, hän torjuu väitteen, ettei "meillä ole syntiä" (hamartian ouk ekhomen). Yksi selitys ilmaisujen väliseen eroon voisi olla yksinkertaisesti olemisen ("being") ja tekemisen ("doing") ero: ihmiset ovat luonnostaan syntisiä, mutta voivat olla tekemättä syntiä. On mahdollista, että kirjoittajalla oli mielessään tällainen jako, sillä se perustuu heprealaiseen Raamattuun (ks. alla). 
Toinen ero synnittömyyden kiistävien ja sitä puoltavien lausumien välillä liittyy aikamuotoihin. Kirjoittaja käyttää preesens-muotoa todetessaan, että Jumalasta syntyneet eivät tee syntiä. Kirjeen alussa hän sen sijaan käyttää perfektimuotoa kuvatessaan torjumaansa näkemystä: "jos väitämme, ettemme ole tehneet syntiä (ouk hēmartēkamen)". Ilmaisuja ei kuitenkaan voi tulkita niin, että perfektillä viitattaisiin kristityn syntiseen menneisyyteen (jota hän ei voi kieltää), kun taas preesensmuodolla kuvattaisiin kristityn uutta, synnitöntä elämää kääntymyksen jälkeen. Kreikan kielessä perfektillä ei kuvata menneisyyteen sijoittuvaa tapahtumaa, vaan nykytilaa, joka on saanut alkunsa menneisyydessä. Perfektimuotoa käyttämällä kirjoittaja sanoo, että ihmisen syntisyys on menneisyydessä alkunsa saanut tila, joka on edelleen voimassa.

Joka tapauksessa kirjoittaja olettaa, että uskovat tekevät syntiä edelleen, senkin jälkeen kun heistä on tullut kristittyjä. Vaikka hän jakeessa 2:1 kehottaa vastaanottajia olemaan tekemättä syntiä, hän pitää mahdollisena, että he edelleen tekevät syntiä: ”Jos joku kuitenkin tekee syntiä, meillä on Isän luona puolustaja, joka on vanhurskas, Jeesus Kristus.” Sama ajatus tulee esiin kirjeen lopussa, kun kirjoittaja käy keskustelua kuolemansynneistä ja muista synneistä. Vain kuolemansynti on ongelma yhteisölle, muut synnit eivät. Kirjoittaja jopa suosittelee poikkeuksellisen lempeää linjaa niihin, jotka syyllistyvät jälkimmäisiin: hän kehottaa vastaanottajia ainoastaan rukoilemaan syntiä tekevän yhteisön jäsenen puolesta (1. Joh. 5:16-17). Kuten jatkossa käy ilmi, tavallisempi ohje antiikin oppineiden keskuudessa oli syntiin langenneen nuhteleminen.

Myös kehotukset synnin välttämiseen osoittavat, ettei kirjeen kirjoittaja ollut täysin vakuuttunut siitä, että Jumalasta syntynyt ei tee syntiä. Syntiin lankeaminen on edelleen mahdollista, eikä synti välttämättä johda erottamiseen yhteisöstä, vaikka tämä näyttääkin olevan ristiriidassa sen väitteen kanssa, että Jumalan lapset eivät tee eivätkä edes voi tehdä syntiä.

Yhteisöstä erottaminen voi kuitenkin tulla eteen, jos - mitä? Tämän kysymyksen kirjoittaja jättää yllättävän hämäräksi. Kirjoittaja ei sano auki, mitä on synti, "joka johtaa kuolemaan" ja jonka tekijän puolesta ei saa rukoilla (1. Joh. 5:17). Ajatteleeko hän tässä yhteydessä syntejä, joista heprealaisessa Raamatussa määrätään kuolemanrangaistus, 
esimerkiksi luopumus (apostasia), jumalanpilkka, sapatin rikkominen, tottelemattomuus, aviorikos tai miesten väliset sukupuolisuhteet? ${ }^{2}$

Jos kirjoittajan mielessä oli joku näistä kuolemansynneistä, vahvin ehdokas on apostasia, joka näkyy piittaamattomuutena yhteisön normeista. Muihin edellä mainittuihin kuolemansynteihin ei viitata Ensimmäisessä Johanneksen kirjeessä, mutta yhteisön hajaantuminen on keskeinen ongelma kirjeessä. Kirjoittaja syyttää vastustajiaan myös murhamiehiksi (1. Joh. 3:15), mutta syytös on niin selvästi poleeminen, ettei sitä voi ottaa kirjaimellisesti. Tällainen syyttely on äärimmäisen kärjekäs tapa kuvata luopioita, joiden toiminnan kirjoittaja tulkitsee osoittavan vihaa hänen linjalleen uskollisina pysyneitä kohtaan.

On selvää, että kirjoittaja tekee rajaa joihinkin kristittyihin, joiden kanssa hän on jyrkästi eri mieltä. Myös kirjoittajan näkemyksiä synnistä ja synnittömyydestä on yritetty selittää reaktioina vastustajien opetuksiin. ${ }^{3}$ Yhden teorian mukaan kirjoittaja piti vastustajia vääränlaisina perfektionisteina, jotka korostivat vain synnittömyyden vaatimusta, kun taas kirjoittaja edustaa "oikeanlaista" perfektionismia, jossa synnittömyyden ihanne ja synnin väistämättömyys ovat tasapainoisesti esillä. Toisaalta on ehdotettu, että vastustajat olivat moraalisista säännöistä piittaamattomia libertinistejä, joiden vuoksi kirjoittaja joutuu korostamaan syntiteeman vakavuutta ja synnittömyyden ihannetta.

Ei kuitenkaan ole selvää, oliko opetus synnistä ja synnittömyydestä todella yksi erimielisyyden aiheista kirjoittajan ja hänen vastustamiensa kristittyjen välillä. Edellä kuvatuissa selitysmalleissa on oletettu, että kirjoittaja lainaa vastustajiensa iskulauseita esittämissään ehtolauseissa "jos me väitämme, ettemme ole syntisiä," ja "jos väitämme, ettemme ole syntiä tehneet" (1. Joh. 1:8-10). Kirjoittaja ei kuitenkaan tässä yhteydessä viittaa vastustajiin, toisin kuin puhuessaan "antikristuksista", jotka ovat kirjoittajan mukaan jättäneet yhteisön (1. Joh. 2:18-19). Sen sijaan kirjoittajan käyttämissä ilmauksissa korostuu sisäpiirin näkö-

\footnotetext{
${ }^{2}$ Vrt. Westbrook 1992, 555; ks. myös Juntunen 1997, 153-158, 189-190.

${ }^{3}$ Vastustajahypoteeseista ja niiden ongelmista ks. esim. Griffith 1998; Juntunen 1997, 4853; Streett 2011, 5-111.
} 
kulma. ${ }^{4}$ Kirjoittaja muotoilee väitteet niin, että niitä esiintyy - tai voisi esiintyä - hänen hyväksymiensä kristittyjen ("me") joukossa. Ristiriidat vastaanottajien yhteisössä eivät siis selitä kirjoittajan ristiriitaisilta vaikuttavia väitteitä synnistä ja synnittömyydestä.

\section{Synnin sosiologiaa heprealaisessa Raamatussa}

"Synti" on keskeinen käsite juutalaisessa ja kristillisessä uskonnollisessa perinteessä. Aiheeseen liittyy monia teologisen reflektion kannalta suuria periaatekysymyksiä kuten mitä synnin varsinaisesti ajatellaan olevan, onko se periytyvä, kaikille ihmisille ominainen piirre vai onko kyse ihmisen omasta valinnasta. Toisaalta syntiin liittyy hyvin käytännöllisiä kysymyksiä kuten se, millaisilla rituaalisilla tai muilla keinoilla ihminen voi puhdistua tekemistään synneistä.

Tässä yhteydessä ei ole mahdollista eikä tarpeen hahmotella yleiskuvaa tällaisten teemojen osalta. Ensimmäisen Johanneksen kirjeen kirjoittajan ristiriitaiselta vaikuttavaa tapaa puhua synnistä ja synnittömyydestä auttaa ymmärtämään ennen kaikkea heprealaisen Raamatun kahtalainen tapa puhua "synnistä": ${ }^{5}$

(1) "Synti" kuvaa kaikkien ihmisten tilannetta Jumalaan verrattuna ja Jumalan edessä (coram deo). Näin käytettynä synti on käsite, joka ilmaisee ihmisten ja Jumalan välisen, ylittämättömän kuilun. Synti määrittelee ihmisen olemuksen: kyse ei ole vain siitä, mitä ihmiset tekevät tai jättävät tekemättä, vaan siitä, mitä ihmiset ovat. Psalmin sanoin: "Älä vaadi palvelijaasi tuomiolle,/ sillä sinun edessäsi ei yksikään ole syytön." (Ps. 143:2; vrt. esim. 1. Kun. 8:46; Sananl. 20:9; Saarn. 7:20.)

Näin ymmärrettynä synti ei liity vain tekoihin, joista henkilö on itse vastuussa, vaan hänen koko ihmisyyteensä, mukaan lukien tavan,

\footnotetext{
${ }^{4}$ Vrt. Griffith 1998; Hahn 2009, 169-170; Juntunen 1997, 93.

5 Tästä kahtalaisuudesta ks. erityisesti Cover 1992; vrt. myös Juntunen 1997, 66-71; Räisänen 2011, 115-121.
} 
jolla hän sai alkunsa: "Katso, synnissä minut synnytettiin, tuskien saattelemana,/ synnin kiimassa äitini tuli raskaaksi” (Ps. 51:7). ${ }^{6}$

(2) "Synti” liittyy rajanvetoon "meidän" ja "muiden" välillä. Tässä diskurssissa "syntisiä" ovat ne, jotka eivät noudata sisäpiirin normeja, ja heidän vastakohtanaan ovat "hurskaat." Muut kansat ovat syntisiä yksinkertaisesti siksi, että heillä ei ole Tooraa. Syntisiä ovat myös sellaiset Jumalan kansan jäsenet, jotka eivät piittaa Tooran määräyksistä. Tässä diskurssissa syntisiä ovat siis tapasyntiset, eivät ne Jumalan kansan "satunnaiset syntiset", jotka toisinaan tekevät virheitä mutta katuvat niitä ja ovat sitoutuneita Toorassa määrättyyn elämäntapaan.

Kun synti kuvaa eroa meidän ja muiden välillä, silloin on myös mahdollista puhua "meistä" synnittöminä:

Minun suuni ei puhu pahaa.

En ole tehnyt niin kuin muut tekevät.

Olen totellut sinua

ja välttänyt väkivallan teitä.

Sinun poluillasi minä olen pysynyt, jalkani eivät ole horjahtaneet sinun tieltäsi pois. (Ps. 17:4-5)

Samanlaisia vakuutteluja, että joku henkilö on vaeltanut moitteettomasti koko elämänsä ajan, esiintyy myöhemminkin juutalaisissa teksteissä. ${ }^{7}$

Kun ensimmäisessä diskurssissa kaikki ovat syntymästään asti syntisiä, toisessa diskurssissa alusta pitäen syntisiä ovat vain muut: "Väärämieliset ovat harhateillä syntymästään saakka,/ äitinsä kohdusta asti ovat valehtelijat eksyksissä" (Ps. 58:4; vrt. Jes. 48:8). Jumalattomat ovat kaikin tavoin pahoja:

${ }^{6}$ Kirkkoraamatun käännös "synnin alaisuuteen sikisin äitini kohtuun" vie terän psalmin kirjoittajan käyttämän kielikuvan kärjekkyydeltä. Kohdassa äidin "synnin” yhteydessä käytetty verbi esiintyy muualla heprealaisessa Raamatussa ainoastaan kuvattaessa eläinten kiimaa ja parittelua: 1 . Moos. 30:38-41; 31:10.

${ }^{7}$ Esim. Riemuvuosien kirja 35:3-6; Sebulonin testamentti 1:4-5; Joosefin testamentti 1:3; ks. Talbert 2005, 20; vrt. myös Juntunen 1997, 71-76. 
He sortavat sinun kansaasi, polkevat alleen sinun omiasi.

He murhaavat leskiä ja orpolapsia, surmaavat maassaan asuvia muukalaisia ja sanovat: "Ei Herra tätä näe, Ei Jaakobin Jumala tätä huomaa.” (Ps. 94:5-7)

Hellenistijuutalaisessa traditiossa Kain kuvattiin jumalattoman ihmisen perikuvaksi: "Mutta jumalaton hylkäsi vihassaan viisauden, ja mieletön veljesmurha vei hänet perikatoon" (Viis. 10:3). Tämä traditio toimi Ensimmäisen Johanneksen kirjeen kirjoittajan esikuvana, kun hän rinnasti vastustajansa veljesmurhaajiin.

Heprealaisessa Raamatussa ja sen perustalle rakentuvassa juutalaisessa traditiossa pätee väite, että kaikki ovat syntisiä silloin kun on kyse Jumalan ja ihmisten välisestä suhteesta. Kun taas on kyse ihmisten keskinäisistä suhteista, silloin pätee väite, että toiset ovat syntisiä, toiset hurskaita. Näin on mahdollista, että "Vanha testamentti sisältää 'vanhurskaan' ihmisen täydellisen ja synnittömän elämän kuvauksia vastakohtana 'syntisten' elämälle. Tällainen 'vanhurskas' saattaa kuitenkin esittää syvällisiä synnintunnustuksia ja rukoilla armoa."8

Juutalainen tausta selkeyttää Ensimmäisen Johanneksen kirjeen hämmentäviä ajatuksia synnistä ja synnittömyydestä. Ne palvelevat kirjoittajan päämäärää kahdella tavalla. Yhtäältä kirjoittaja tukeutuu heprealaisesta Raamatusta periytyvään ajatukseen synnistä rajanvedon välineenä. Tästä näkökulmasta katsottuna ne, jotka ovat jättäneet sisäryhmän, ovat automaattisesti "syntisiä": heidän käyttäytymisensä - toisin sanoen se, etteivät he enää kuulu "meihin" - osoittaa, etteivät he enää ole uskollisia sisäpiirille ja kirjoittajan sille asettamille normeille. $\mathrm{Ne}$, jotka ovat pysyneet uskollisina sisäpiirin jäseninä, eivät ole - eivätkä voi olla - "syntisiä", sillä he eivät ole jättäneet yhteisöä.

Kun lähtökohtana on, että käsitteillä "synti" ja "syntinen” rakennetaan ryhmäidentiteettiä, silloin on helpompi ymmärtää kirjoittajan väitettä, että sisäpiirin jäsenet eivät ole tehneet - eivätkä edes voi tehdä - syntiä. Samaan päämäärän kirjoittaja pyrkii kuvatessaan sisäpiiri-

${ }^{8}$ Juntunen 1997, 119. 
läisten olevan syntyisin Jumalasta. Tämäkin piirre määritellään ryhmään kuulumisesta käsin. Ne jotka ovat irtautuneet sisäpiiristä ovat tällä teollaan osoittaneet, että "he eivät olleet meidän joukkoamme." Kirjoittajan peruste on yksinkertainen: "Jos he olisivat kuuluneet meihin, he olisivat pysyneet keskuudessamme" (1. Joh. 2:19). Myöhemmin kirjoittaja lisää poleemista terävyyttä: hän kuvaa vastustajansa veljesmurhaajiksi (ks. ed.), Kristuksen kieltäjiksi (2:22-23; 4:1-3), Paholaisen lapsiksi (3:7-10) ja vääriksi profeetoiksi (4:4). Kirjoittajan näkemys "meistä" ja "muista" paljastuu lopulta hyvin suoraviivaiseksi: "Me olemme Jumalasta. Joka tuntee Jumalan, kuuntelee meitä, mutta joka ei ole Jumalasta, se ei meitä kuuntele. Tästä me tunnemme totuuden hengen ja eksytyksen hengen" (1. Joh. 4:6).

Kirjoittaja kuvaa yhteisön ja ulkopuolisten tilannetta deterministisesti: ne jotka ovat irtautuneet sisäpiiristä, eivät ole koskaan kuuluneetkaan siihen. Heidän tekonsa paljasti, että he eivät olleet syntyisin Jumalasta, vaan Paholaisesta. Kirjoittaja ei välttämättä "oikeasti” ajattele näin deterministisesti. Antiikin teksteissä ihmisen alkuperä usein kuvattiin muuttumattomaksi, olemusta määrääväksi tekijäksi. Silti alkuperä oli "joustava" ominaisuus, josta voitiin käydä keskustelua ja jota voitiin tarpeen tullen määritellä uudelleen tai jopa "vaihtaa".

Samanlaista alkuperän retoriikkaan liittyvää joustavuutta esiintyy myös Ensimmäisessä Johanneksen kirjeessä. Kirjoittajan käymä keskustelu "synnistä, joka on kuolemaksi" osoittaa, että sellainenkin henkilö, joka nyt on sisäpiirissä ja "syntyisin Jumalasta," on vaarassa langeta väärälle puolelle. Jos näin käy, tällaisen ryhmän jäsenen alkuperä "vaihtuu”, kun hänen todellinen alkuperänsä ("Paholaisen lapsi") paljastuu.

Ensimmäisessä Johanneksen kirjeessä esiintyy myös ajatus kaikkien ihmisten syntisyydestä Jumalan edessä. Heprealaisesta Raamatusta poiketen kirjeen kirjoittaja ei kuitenkaan käytä tätä diskurssia universaalisti - kaikkia ihmisiä koskevana. Väite, että kaikki ovat syntisiä, esiintyy kirjeessä vain sellaisissa yhteyksissä, joissa on kyse sisäpiiriin kuuluvista. Kirjeen kirjoittaja hyväksyy sisäpiirin osalta ajatuksen, että kaikki ovat

\footnotetext{
${ }^{9}$ Buell 2005.
} 
syntisiä, ja kannustaa tähän sisäpiiriin kuuluvia ("meitä") tunnustamaan rohkeasti syntinsä, ja korostaa Jumalan ehdotonta anteeksiantoa.

Molemmat näkökulmat palvelevat kirjoittajan keskeistä tavoitetta, yhteisön vahvistamista. Jyrkkä jako syntisiin ja synnittömiin tekee yhteisön rajan selväksi suhteessa ulkopuolisiin. Kirjoittaja vahvistaa rajaa kuitenkin myös sisältä päin: hän luo kirjeessään kuvan ihanteellisesta yhteisöstä, jonka sisällä vallitsee yhteys, keskinäinen rakkaus ja luottamus. Yhteisön sisällä pätee, että "me voimme rohkeasti lähestyä Jumalaa” ja rukouksiin vastataan (1. Joh. 3:21-22; 5:14). Yhteisön jäsenen ei tarvitse olla huolissaan edes silloin, jos hänen sydämensä "syyttää" häntä, sillä "Jumala on meidän sydäntämme suurempi ja tietää kaiken" (1. Joh. 3:20). Väite, että "me olemme syntisiä", on tärkeä myös siksi, että se luo tarpeen synneistä puhdistamiselle, jonka kirjoittajan mukaan saa aikaan Jeesuksen veri (1. Joh. 1:7). Vaikka kirjeessä pilkahtaa universaalimpikin ajatus, että Jeesus on myös koko maailman syntien sovittaja (1. Joh. 2:2), syntien anteeksiantaminen on mahdollista vain sisäpiiriin kuuluville. Tällainen korostus toimii samalla epäsuorasti uhkauksena niille, jotka ovat vaarassa livetä väärälle puolelle: jos he jättävät sisäpiirin, syntien anteeksiantaminen ei enää koske heitä.

\section{Terapeuttisen yhteisön ihanne}

Ensimmäisen Johanneksen kirjeessä hahmoteltu "terapeuttisen" yhteisön ihannekuva on jossain määrin samankaltainen kuin eräissä antiikin ajan filosofikoulukunnissa. Selkeimmin tällainen kuva filosofiyhteisöstä tulee esiin epikurolaisen Filodemuksen teksteissä. Filodemus eli ensimmäisellä vuosisadalla eKr., ja hänen tekstejään on säilynyt Vesuviuksen purkauksen (79 jKr.) jäljiltä esiin kaivetussa yksityiskodissa, joka sijaitsi Herculaneumissa, Pompeijin läheisyydessä.

Yksi Filodemuksen keskeisistä teemoista on, kuinka kritiikkiä tulee antaa ja ottaa vastaan. Filosofikoulukuntiin kuuluvien odotettiin kestävän opettajiltaan suorasanaista kritiikkiä ja nuhtelua silloin, kun siihen oli aihetta. Kritiikin kohteena olivat yhteisön jäsenten elämäntapaan liittyneet "virheet" tai "erehdykset". Tässä yhteydessä käytettiin usein 
samaa kreikankielen sanaa hamartia, joka Raamatussa yleensä käännetään "synniksi."

Kritiikillä oli terapeuttinen päämäärä. Filodemus kuvaa opettajan lääkäriksi, joka suoralla puheellaan (parrhèsia) pyrkii parantamaan väärään elämäntapaa hairahtuneen oppilaan. Filodemus myös korostaa, että opettajan tulee jatkaa hoitoa, kunnes "sairaus" on kokonaan parannettu (Filodemus, Suorasta puheesta, frg. 64).

Filodemuksen teksteistä käy kuitenkin ilmi, että tarjottua lääkettä oli usein vaikea niellä: kritiikin kohteeksi joutunut ei helposti hyväksynyt häneen kohdistettuja moitteita. Filodemuksen mukaan tästä ongelmasta kärsivät käytännössä kaikki ihmisryhmät: nuoret miehet, vanhat miehet, naiset, hyvässä yhteiskunnallisessa asemassa olevat - ja akateemiset opettajat! (frgg. 31, 39; col. XXa-XXIVb). Filodemuksen mukaan kannattaa ottaa huomioon, kuinka paljon nuhdellut sietävät moitteita. Niitä jotka eivät niitä oikein sulata, ei kannata moittia terävästi, vaan pitää etsiä lempeämpiä tapoja esittää asia, jotta päämäärään päästäisiin.

Huomionarvoista on, että yksi Filodemuksen kuvaamista, huonosti kritiikkiä kestävistä ryhmistä ovat ne, jotka neuvovat toisia mutta uskovat itse jo päässeensä vapaiksi hairahduksista (tai "synneistä", Filodemus käyttää termiä hamartēma, col. XIXb). Filodemuksen kuvaus tulee yllättävän lähelle Ensimmäisessä Johanneksen kirjeessä esiintyvää polemiikkia sitä ajatusta kohtaan, että yhteisön jäsenet voisivat olla synnittömiä. Filodemuksella tällaiset henkilöt ajattelevat "ajattelevat olevansa älykkäämpiä kuin muut ... ja uskovat, että heillä on [oikeus] suoraan puheeseen, kun he moittivat toisia ja kehottavat velttoilijoita" (col. XIXa). Ne, jotka ajattelevat päässeensä hairahduksista eroon, olivat siis joko toisten opettajia tai ainakin pitkälle edistyneitä oppilaita.

Ei ole todennäköistä, että Ensimmäisen Johanneksen kirjeen kirjoittaja tunsi Filodemuksen tekstejä. Filodemuksen kuvaus osoittaa kuitenkin konkreettisesti, että oppineiden yhteisöissä harrastettiin suoraa kritiikkiä ja että tällainen kritiikki saattoi aiheuttaa yhteisössä ongelmia. Filodemus on huolissaan siitä, ettei kritiikin terapeuttinen päämäärä toteudu, jos nuhtelu tulee sellaisessa muodossa, että vastaanottaja ei sitä siedä. Tällainen terapia ei johda virheiden - tai 
"syntien" - tunnustamiseen, vaan vastaanottajan pahastumiseen, mikä voi aiheuttaa ongelmia koko yhteisölle.

Filodemus ja Ensimmäisen Johanneksen kirjeen kirjoittaja reagoivat samanlaiseen ongelmaan jossain määrin samalla tavalla. Kumpikin hylkää ajatuksen, että yhteisössä joku voisi olla jo virheetön. Filodemus korostaa, etteivät opettajat voi ainoastaan kritisoida muita, vaan heidän tulee hyväksyä toisten opettajien nuhtelu ja ottaa siitä opikseen. Ensimmäisen Johanneksen kirjeen kirjoittaja kehottaa kaikkia yhteisön jäseniä ("me") tunnustamaan virheensä ja etsimään anteeksiantoa.

Toisin kuin monet muut antiikin filosofit, Filodemus suosittelee suoran kritiikin sijasta lempeämpää lähestymistapaa, jossa otetaan huomioon nuhdeltavan henkilön sietokyky. Ensimmäisen Johanneksen kirjeen kirjoittaja menee huomattavasti pidemmälle. Vaikka hän kehottaa yhteisön jäseniä syntien tunnustamiseen, hän ei anna lainkaan ohjeita, miten virheitä tehneitä tulisi ojentaa tai nuhdella. Kirjeen kirjoittaja ei suosittele konkreettista interventiota tilanteessa, jossa yhteisön jäsenen tulkitaan tekevän syntiä. Ohje, että syntiä tekevän veljen puolesta tulee rukoilla, on poikkeuksellisen "lempeä" - jopa Filodemukseen verrattuna. Ensimmäisen Johanneksen kirjeen linja on myös lempeämpi kuin Matteuksen evankeliumin, jossa annetaan tarkat ohjeet syntiä tekevän veljen nuhtelemisesta (Matt. 18:15-18). ${ }^{10}$

\section{Johtopäätökset}

Miksi Ensimmäisen Johanneksen kirjeen kirjoittaja ei yhdy omana aikanaan yleiseen moraalisen opastuksen käytäntöön, jonka myös jotkut varhaiset kristityt - ainakin Matteuksen yhteisö - näyttävät omaksuneen? Tämä saattaa olla yksi merkki siitä, kuinka herkässä tilanteessa kirjoittaja joutui tasapainoilemaan. Toisaalta hän tekee jyrkän rajan niihin, jotka hänen näkökulmastaan ovat jättäneet yhteisön; toisaalta

\footnotetext{
${ }^{10}$ Kohdassa käytetty kreikan verbi elegkhō on vuoden 1992 raamatunkäännöksessä käännetty "ota asia puheeksi”. Verbi tarkoittaa kuitenkin selvästi "nuhtelemista", ja tässä merkityksessä sitä käytetään myös antiikin filosofissa teksteissä.
} 
hän tekee kaikkensa synnyttääkseen niissä, jotka eivät ole lähteneet, aiempaa suurempaa yhteenkuuluvuuden tunnetta. Hän välttää kaikkia sellaisia toimenpiteitä, jotka saattaisivat lisätä jännitteitä sisäpiirin sisällä. Filodemuksen teksteistä käy ilmi se, minkä olemme usein oppineet omasta kokemuksesta: nuhtelun kohteeksi joutuminen ärsyttää, ja tällainen ärsytys saattaa johtaa vetäytymiseen yhteisöstä. Ensimmäisen Johanneksen kirjeen kirjoittajalla ei ole varaa suositella sellaisia käytäntöjä, jotka voisivat lisätä poislähteneiden määrää; siitä syystä hän suosittelee rukousta syntisen veljen puolesta, ei tämän nuhtelemista.

Olen edellä korostanut, että Ensimmäisessä Johanneksen kirjeessä esiintyvistä kuvauksista ei voi suoraan päätellä, millainen vastaanottajayhteisön tilanne todellisuudessa oli. Kirjeestä ei synny selvää kuvaa siitä, mistä yhteisössä kiisteltiin. Usein on oletettu, että kiista liittyi Jeesusta koskeviin käsityksiin. Kohdasta 1. Joh. 4:1-3 on päätelty, että kirjoittajan vastustajat kielsivät Kristuksen lihaksitulemisen. Tämä tulkinta on valittu myös vuoden 1992 raamatunkäännöksessä: "Jokainen henki, joka tunnustaa Jeesuksen Kristuksen ihmiseksi, lihaan tulleeksi, on Jumalasta” (1. Joh. 4:2).

Käännöksessä käytetylle sanalle "ihmiseksi" ei ole lainkaan vastinetta kreikankielisessä tekstissä. Sanan lisäys perustunee oletukseen, että kiistan kohteena oli Jeesuksen tosi ihmisyys. Kreikankielisen alkutekstin perusteella tunnustamisen varsinainen kohde on kuitenkin "Jeesus Kristus", jota kuvataan lisämääreellä "joka on tullut lihaan". ${ }^{11}$ Oikean tunnustuksen sisältö ei siis ole, että Jeesus on tullut ihmiseksi, vaan kirjoittaja väittää, että väärät opettajat eivät tunnusta Jeesusta lainkaan.

Tätä näkemystä tukevat muut kirjeen kohdat. Samassa tekstiyhteydessä kirjoittaja jo toteaa: "Yksikään henki, joka kieltää Jeesuksen, ei ole Jumalasta." Jo aiemmin kirjoittaja on kuvannut vastustajansa Kristuksen kieltäjiksi - ilman viittausta tämän ihmiseksitulemiseen: "Kuka on valehtelija, ellei se, joka kieltää Jeesuksen olevan Kristus. Sellainen ihminen on antikristus, niin Isän kuin Pojan kieltäjä. Joka

${ }^{11}$ Lieu 2008, 166-170; Streett 2011, 247-248. 
kieltää Pojan, hänellä ei ole Isääkään...” (2:22-23). Kun kirjoittaja myöhemmin palaa tunnustamisteemaan, hän ei mainitse ihmiseksi tulemista: "Joka tunnustaa Jeesuksen Jumalan Pojaksi, hänessä Jumala pysyy, ja hän pysyy Jumalassa" (1. Joh. 4:15).

Kirjoittaja kuvaa vastaanottajien yhteisön tilanteen polaarisesti: on vain Kristuksen tunnustajia ja kieltäjiä. Hän osoittaa kirjeensä vain tunnustajille, kun taas Kristuksen kieltäjät ovat hänen mukaansa jo jättäneet yhteisön: "Jos he olisivat kuuluneet meihin, he olisivat pysyneet keskuudessamme. Mutta täytyihän käydä ilmi, etteivät kaikki kuulu meihin" (1. Joh. 2:19).

On syytä toistaa jo alussa esitetty varaus, että tämä on tekstissä hahmoteltu "retorinen tilanne" tai "kirjetilanne". Kirjoittajan kuvauksesta ei voi suoraan päätellä, millainen tilanne oli kirjeen oletettujen lukijoiden yhteisössä. Yhteisön jakautuminen kahtia ei ollut vastaanottajille yhtä ilmeinen asia kuin kirjoittajalle. Tämä käy ilmi siitä, että kirjoittaja on yhä huolissaan "niistä jotka haluavat johtaa teitä harhaan" (1. Joh. 2:26; vrt. 3:7: "Lapseni, älkää antako kenenkään johtaa itseänne harhaan"). Maininnan perusteella näyttää siltä, ettei vastaanottajien ryhmä ollutkaan jakautunut kahtia, vaikka kirjoittaja kuvaa tilanteen näin, vaan heidän keskuudessaan vallitsi kristillisten opettajien välinen kilpailutilanne. 


\section{Nöyrä auttaja vai välikäsi? Varhaiskristillisen diakonia-käsitteen uudelleenarviointia}

(2005)

\section{Johdanto}

Protestanttisessa Saksassa ja Pohjois-Euroopassa diakoniaan ja siihen liittyviin virkoihin on tavallisesti yhdistetty ajatus nöyrästä ja pyyteettömästä lähimmäisen palvelemisesta. ${ }^{1}$ Varsinkin diakonissan virkaan liittyi pitkään ajatus koko elämän omistamisesta kristilliselle palvelutehtävälle. Diakonissat muodostivat eräänlaisen protestanttisen sääntökunnan, joka sääteli siihen kuuluvien elämäntapaa samaan tapaan kuin katoliset nunna- ja munkkijärjestöt. Diakonissat asuivat kristillisissä, sairaanhoitoon keskittyneissä laitoksissa eivätkä menneet naimisiin.

Vaikka käsitys diakonian virasta on vuosien kuluessa laajentunut ja monipuolistunut protestanttisen kristinuskon piirissä, tähän virkaan liitetään yhä helposti erityinen nöyryyden korostus. Diakonian viranhaltijoiden ajatellaan ja odotetaan tekevän hiljaista palvelutyötä kulissien takana samalla, kun seurakunnan muille työaloille, erityisesti julistustyölle on pyritty saamaan mahdollisimman paljon julkisuutta ja näkyvyyttä. Vaikka leipäjonot ovatkin nostaneet kirkollisen diakonia-

${ }^{1}$ Artikkeli perustuu laajempaan saksankieliseen artikkeliin (Dunderberg 2003). Samassa kirjassa, jossa artikkelini on julkaistu, on myös useita muita arvioita Collinsin kirjasta (Benedict 2003; Dietzel 2003; Starnitzke 2003). 
työn julkista näkyvyyttä, kuvaavaa on, etteivät jonottajat yleensä seiso kirkkojen pääovilla vaan vähemmän huomiota herättävissä paikoissa.

Tätä taustaa vasten on merkittävää, että jo 15 vuotta sitten ilmestyneessä tutkimuksessaan diakonia-termistä John N. Collins on kyseenalaistanut edellä kuvatun diakonia-käsityksen molemmat puolet. Collins selvittää tutkimuksessaan, miten alun perin kreikankielistä diakonia-termiä ja siihen liittyviä muita sanoja (verbi diakoneo, substantiivi diakonos "diakoni") käytettiin antiikin kirjallisuudessa, Uusi testamentti ja varhaiskristillinen kirjallisuus mukaan lukien. Collinsin mukaan diakoniaan ei näissä lähteissä ensinnäkään yhdistetä erityistä palvelemisen ajatusta, vaan termillä kuvataan erilaisia välikäsiä ("middleman") tai lähettejä ("envoy"), joita tarvitaan niin yhteiskunnassa kuin ihmisen ja jumalten tai Jumalan välisissä suhteissakin. Toiseksi Collins korostaa, etteivät diakonia ja nöyryys tai alamaisuus kulje antiikin lähteissä käsi kädessä.

Tutkimuksensa perusteella Collins toteaakin, että edellä hahmotellun kaltainen protestanttinen käsitys diakoniasta on pohjimmiltaan virheellinen: "'Diakonin' ja 'diakonissan' nimityksien käyttöönotto 1800-luvulla perustui väärän käsitykseen, että apostolinen diakonaatti oli olennaisesti armon töitä (works of mercy) varten.” ${ }^{2}$

Collins on katolinen tutkija, joka tutkimuksensa perusteella ehdotti katolisen diakonin viran perinpohjaista uudelleen arviointia. Collinsin ehdottama ratkaisu on kiinnostavalla tavalla käänteinen verrattuna viimeaikaiseen suomalaiseen virkakeskusteluun. Katolisessa kirkossa diakonin virka on pappeuden ensimmäinen aste, mutta Collins ehdottaa tämän kytköksen purkamista. Hän ehdottaa, että diakonin virasta voitaisiin katolisessa kirkossa tehdä virka, jota myös maallikot voisivat hoitaa, tarvittaessa jopa vain tietyn määräajan. Suomessa keskustelu on menossa juuri päinvastaiseen suuntaan: diakonian virka haluttaisiin kytkeä aikaisempaa läheisemmin pappeuteen osana kirkon kolmisäikeistä virkaa.

${ }^{2}$ Collins 1990, 255. 
Collinsin antiikin kirjallisuudesta esiin nostama materiaali ei mielestäni johda suoranaisesti kumpaankaan suuntaan; päätelmät diakonian viran ja pappisviran suhteesta on tehtävä muilla perusteilla. Collins esittää kuitenkin mielenkiintoisen ja huomionarvoisen tulkinnan siitä, mistä diakoniassa alun perin oli kyse. Oma arvioni on, että hänen tulkintansa toinen päääite pitää paikkansa. Collins pystyy osoittamaan, ettei diakoniaan välttämättä eikä itsestään selvästi liity voimakasta nöyryyden ajatusta. "Diakonia" ei myöskään tarkoittanut alun perin "pöytäpalvelua", kuten sanan "alkuperäistä" merkitystä on usein selitetty.

Sen sijaan en ole vakuuttunut Collinsin toisesta näkemyksestä, jonka mukaan "diakonialla" antiikin lähteissä ei varsinaisesti ollut mitään tekemistä palvelemisen kanssa. Tekstit, joiden Collins tulkitsee puhuvan "välikäsistä", liittyvät yleensä toimintaan, johon näyttää luontevasti liittyvän myös palvelemisen aspekti. Yksi syy tähän on, että "välikäden" ja "palvelijan" tehtävät ovat usein niin samankaltaisia, että niitä on vaikea varmuudella erottaa toisistaan. Tehtävät samaistuvat myös siksi, että antiikin maailmassa palvelijat usein toimivat "välikäsinä", esimerkiksi lähetteinä ja kirjeiden kuljettajina.

\section{Diakonia, pöytäpalvelu ja juutalaisvastaisuus}

Erityisen terävästi Collins kritisoi näkemystä, jonka mukaan "diakonia" tarkoitti alun perin palvelemista pöydän ääressä. Tässä tapauksessa "diakonin" ajatellaan olleen aluksi käytännössä "tarjoilija", ja ajatuksen "diakoniasta" laaja-alaisempana palvelutyönä uskotaan kehittyneen sanan suppean perusmerkityksen pohjalta.

Tulkinnan taustalla on mahdollisesti Apostolien tekojen kuvaus seitsemän diakonin valinnasta. Heidät valitaan siksi, ettei apostolien ole sopivaa "palvella pöydissä jättäen sivuun Jumalan sanan" (Ap.t. 6:2, oma "sanatarkka" käännökseni; vrt. KR "ruoan jakamisen tähden"; NRSV "wait at the table"). Valittujen diakonien ensisijainen tehtävä oli pöytäpalvelus, mikä kohdan perusteella ei tarkoittanut tarjoilijan työtä, vaan seurakunnan köyhistä leskistä huolehtimista (Ap.t. 6:1-4). Valittujen diakonien ei tosin kerrota toimineen tässä roolissa, vaan 
heidät kuvataan Jumalan sanan julistajiksi siinä missä apostolitkin (Stefanos, Ap.t. 6:8-7:60; Filippos, 8:4-13, 26-40).

Collinsin kritisoimaa ajatusta, että diakonia tarkoitti alun perin pöytäpalvelua ja tarjoilemista, edustaa erityisesti Hermann Wolfgang Beyer, joka kirjoitti aihetta käsittelevän hakusanan saksalaiseen Uuden testamentin teologiseen sanakirjaan (Theologisches Wörterbuch zum Neuen Testament). Tämä 10-osainen hakuteos on alansa perusteos, jota sekä tutkijat että muut teologit ovat paljon käyttäneet. Sanakirjaa alettiin koota Saksassa Kolmannen valtakunnan aikana. Tätä taustaa vasten teoksen välittämä kuva juutalaisuudesta on hätkähdyttävän synkkä. Juutalaisuus esiintyy kerta toisensa jälkeen rappioilmiönä, jonka rinnalla kristinuskon valo loistaa kirkkaammin. Sanakirjan leimallinen juutalaisvastaisuus näkyy myös Beyerin diakonia-sanuetta käsittelevässä artikkelissa. Yllättävää (ja myös huolestuttavaa) on, ettei Collins puutu Beyerin näkemysten mustimpaan puoleen lainkaan, vaan keskittyy torjumaan tämän ajatuksen diakoniasta pöytäpalveluna.

Beyerin mukaan Uudessa testamentissa näkyvä kristillinen käsitys palvelemisesta ylittää kaikki aiemmat vertailukohdat, erityisesti juutalaisen perinteen. Beyer väittää, että kreikkalaiset pitivät palvelemista arvottomana. (Tämäkään väite ei pidä paikkaansa yleisenä totuutena, kuten jatkossa käy ilmi.) Juutalaisilla sen sijaan oli alun perin syvempi ymmärrys palvelun merkityksestä, mutta se hämärtyi vähitellen. Aidosta palvelusta tuli teko, jolla yritettiin ansaita Jumalan armo. Niinpä Jeesus Beyerin mukaan "puhdisti palvelun käsitteen niistä väärennöksistä, joita se oli kokenut juutalaisuudessa." 3

Beyerin diskurssi osuu yksiin 1930-luvun saksalaisen natsiideologian kanssa: juutalaisuus luo väärennöksiä, kristinusko puhdistaa niistä. Erityisen paljaaksi Beyerin juutalaisvastaisen tendenssin tekee se, että hän esittää artikkelissaan esimerkkejä juutalaisista oppineista, jotka arvostavat pyyteetöntä palvelemista. Tämä aineisto kumoaa Beyerin manaamat ennakkoluulot juutalaisista täysin. Toiset rabbit esimerkiksi ylistivät tunnettua rabbi Gamaliel II:a, jonka kerrotaan yllättäen

\footnotetext{
${ }^{3}$ Beyer 1935, 81-83.
} 
palvelleen muita aterian yhteydessä, Abrahamin ja Jumalan veroiseksi palvelutyönsä ansiosta.

Lisäksi Uuden testamentin tutkimuksessa on viime vuosikymmeninä kumottu toinen Beyerin tulkinnassa esiintyvä, tosin yhä tavallinen ennakkoluulo juutalaisuudesta tekouskontona. Erityisesti amerikkalainen E. P. Sanders on korostanut, ettei juutalaisuudessa armoa yritetä ansaita teoilla. Pelastuksen lähtökohtana on Jumalan armollinen teko (Israelin valinta), johon ihmisen odotetaan vastaavan noudattamalla Jumalan tahtoa (laki). Lisäksi juutalaisuudessa anteeksiantamuksen näkökulma on vahvasti esillä aivan kuten kristinuskossakin. ${ }^{4}$

\section{Collinsin tulkinta diakoniasta}

Collins kiistää Beyerin oletuksen, että diakonia tarkoitti antiikin lähteissä alun perin pöytäpalvelua. Tältä osin Collinsin kritiikki osuu nähdäkseni oikeaan. Antiikin lähteiden valossa ei ole lainkaan selvää, millaista palvelemista "diakonia" alun perin tarkoitti. Collinsin uudelleen tulkinta ei kuitenkaan rajoitu tähän. Hänen mukaansa diakonia ei tarkoittanut antiikin teksteissä palvelemista ensinkään, vaan sana viittaa välikätenä toimimiseen. Antiikin kreikan kielessä diakonos ("diakoni") on hänen mukaansa yksinkertaisesti henkilö, joka toimittaa tehtävän jonkun toisen puolesta. Sanalla kuvataan usein erilaisia toimeksiantoja saaneita henkilöitä kuten sanansaattajia, "luottamushenkilöistä” ja tietyn ryhmän puhemiehiä. Sanaa käytetään myös kauppiaista, jotka välittävät maataloustuotteita maatiloilta kaupunkeihin, papeista, jotka toimivat välittäjinä ihmisten ja jumalten välillä, ja erityisesti sellaisista jumalolennoista, jotka kuvataan Zeuksen läheteiksi (erityisesti Hermes).

Collins käy tutkimuksessaan läpi suuren määrän antiikin kirjallisuutta, jossa diakoniaan liittyvää kreikankielistä terminologiaa esiintyy. Kun olen itse tutustunut Collinsin kirjan perusteella samaan materiaaliin, suurimmaksi ongelmaksi on paljastunut se, että "välikäden" ja

\footnotetext{
${ }^{4}$ Esim. Sanders 1992, 262-278.
} 
palvelijan välinen ero näissä teksteissä on usein hiuksenhieno. Useissa Collinsin esiin nostamissa teksteissä myös perinteinen tulkinta, että diakonia tarkoittaa palvelua, on aivan mahdollinen, ja joissain tapauksissa Collinsin ehdottama tulkinta näyttää jopa ongelmalliselta.

\section{Platon: Diakonit ovat yhteiskunnan palvelijoita}

Collins kiinnittää paljon huomiota siihen, miten Platon (427-347 eKr.), antiikin tunnetuin kreikkalainen filosofi, käyttää sanaa diakonos. Teoksessaan Valtio Platon kuvaa ihanneyhteiskuntaa, jonka yksi keskeinen tuntomerkki on kansalaisten pitkälle kehittynyt erikoistuminen. Platon esimerkiksi korosti, ettei jokaisen ole järkevää rakentaa omaa taloa itse, vaan tehtävä kannattaa antaa ammattimiehelle. Vastaavalla tavalla Platonin mukaan on järkevää, että maatilojen omistajat keskittyvät maataloustuotteiden tuottamiseen. Heidän ei kannata tuhlata aikaansa myymällä tuotteitaan torilla, vaan antaa tuotteensa tähän tehtävään erikoistuneiden henkilöiden eli kauppiaiden hoidettaviksi. Juuri tällaisista henkilöistä, jotka tekevät jotain toisen puolesta, Platon käyttää sanaa diakonos. ${ }^{5}$

Collinsin mukaan kyse on siitä, että Platonin mukaan diakonos on "välittäjä" tai "välikäsi". Kuitenkin Platonin ihanneyhteiskunnassa kauppiaiden toiminta voidaan ymmärtää myös palvelukseksi maanviljelijöille: kauppiaat vapauttavat heidät keskittymään heidän tärkeimpään osaamisalueeseensa eli maanviljelyyn. Lisäksi sanan diakonos käyttö ei Platonilla rajoitu kauppiaisiin tai muihin henkilöihin, joiden tehtävänä on "välikätenä" toimiminen. Platon käyttää sanaa diakonos myös palkollisista, jotka auttavat maanviljelijöitä tilan töissä (Valtio 371e). Nämä palkolliset eivät ole tilallisen orjia, mutta he selvästi tekevät - korvausta vastaan - työpanoksellaan palveluksen tilan isännälle.

${ }^{5}$ Valtio 370; Collins 1990, 78-79. 
Platon käyttää sanaa diakonos myös "kunnanisistä" eli kaupunkivaltion (polis) neuvoston jäsenistä. ${ }^{6}$ Tässä yhteydessä sanan käyttö on vähemmän mairittelevaa. Platonin mukaan demokraattisen pääöksenteon ongelma on, että kaupungin johtohenkilöt yrittävät liian innokkaasti täyttää kansalaisten toiveet (!) eivätkä siksi katso kaupungin parasta pitkällä tähtäimellä. Tällaisia johtajia Platon vertaa palvelijaan (diakonos), joka tavoittelee omaa etuaan mielistelemällä isäntiään. Tässä yhteydessä "palvelija" ei nähdäkseni missän tapauksessa voi olla Collinsin ehdottama "välikäsi". Koko jakso perustuu palvelijan ja isännän välisen aseman kuvaamiseen.

Nykyisenkin diakonia-käsityksen kannalta kiinnostavaa on, että Platon käyttää sanasta muodostettua adjektiivia (diakonike, "diakoninen", "diakoniaan liittyvä"), kuvaamaan kaikkia sellaisia toimia, joiden päämääränä on tyydyttää sellaisia fyysisiä tarpeita kuin nälkä, jano ja kylmyys (Gorgias 517d). Periaatteessa aivan samanlainen käsitys siitä, mitä "diakonia" on, esiintyy myös Apostolien tekojen kuvauksessa diakonien tehtävistä (ruokahuolto) sekä Matteuksen evankeliumin kuvauksessa viimeisestä tuomiosta. Tällaisiin "diakoniaan liittyviin" töihin ovat Platonin mukaan erikoistuneet tietyt ammattiryhmät kuten leipurit, kokit ja kutojat, jotka saavat mainituista töistä rahallisen korvauksen. Jälleen on ilmeistä, että kyse on yhteiskunnassa tarjottavista palveluista, ei niinkään "välikätenä" toimimisesta. Platonilla "diakoniaan" liittyy kuitenkin maksullisen palvelun ajatus. Diakonos ei hänen dialogeissaan ole orja, vaan henkilö, joka saa tekemistään palveluksista maksun.

Edellä mainitut kohdat Platonilta osoittavat toteen sen Collinsin väitteen, ettei diakonian "alkuperäinen" merkitys ole pöytäpalvelu. Sanaa käytetään myös muissa yhteyksissä jo hyvin varhaisissa lähteissä. Toisaalta on syytä huomata, että yksi sanan tavallisimmista merkityksistä on kuitenkin juuri pöytäpalvelu. Tämä toteaa myös Collins. Hänen mukaansa diakoniasta puhuttaessa "viittaus pöydässä tapahtuvaan palveluun on yleisin yksittäinen käyttötapa" antiikin lähteissä.

\footnotetext{
${ }^{6}$ Gorgias 517b; Collins 1990, 87-88.

${ }^{7}$ Collins 1990, 72.
} 
Diakonia yhdistettiin usein myös muihin kotitaloustöihin, ja diakonos on usein kotitaloustöihin erikoistunut palvelija. Siksi voi vaikuttaa hiusten halkomiselta väittely siitä, onko tämä merkitys "alkuperäinen" vai ei; joka tapauksessa se oli hyvin yleinen antiikin maailmassa.

\section{Jumalalliset sanansaattajat}

Collins osoittaa kirjassaan, että sanaa diakonos käytetään antiikin kreikkalaisessa kirjallisuudessa usein erilaisista sanansaattajista. Tämä ei kuitenkaan välttämättä merkitse, että sanan ensisijainen merkitys olisi ollut "välikäsi". Sanan käyttö tässä yhteydessä liittyy yksinkertaisesti siihen, että antiikin yhteiskunnassa, jossa ei ollut organisoitua postilaitosta, isännät usein käyttivät palvelijoitaan viestinviejinä. ${ }^{8}$

Sanaa diakonos käytettiin myös jumalhahmoista. Näissä yhteyksissä on selvää, ettei diakonos välttämättä ole alamainen suhteessa siihen, joka hänelle esittää pyynnön tehdä jotain. Collinsin mukaan "diakoniaan" liittyvien sanojen käyttö jumalhahmoilta pyydettyjen asioiden yhteydessä osoittaa, että sana tarkoitti "välineenä" (medium) toimimista."

Tässäkään tapauksessa Collinsin ehdottama tulkinta ei ole ainoa mahdollinen. Alempiarvoinen (ihminen) voi pyytää palvelusta ylempiarvoiselta (jumala). Tällainen käytäntö oli hyvin yleinen antiikin sosiaalisissa suhteissa myös ihmisten kesken. Kokonainen sosiaalisten suhteiden verkko rakentui sille, että yhteiskunnan varakkailla jäsenillä (patronus) oli suojatteja (klientti), jotka tekivät palveluksia patronuksille ja vastavuoroisesti saivat näiltä tarvitessaan palveluksia (esimerkiksi tukea oikeustapauksissa). Suhde jumaliin miellettiin epäilemättä samanlaiseksi: jumalia lähestyttiin patronuksina, joilta toivottiin tietynlaisia, usein hyvinkin konkreettisia palveluksia. Vastineeksi luvattiin osoittaa kunnioitusta eri tavoin, esimerkiksi jumalan kunniaksi uhraamalla.

\footnotetext{
${ }^{8}$ Näin myös Collins 1990, 125.

${ }^{9}$ Collins 1990, 100-104.
} 
Myös ihmisiä voitiin kuvata "Zeuksen diakoniksi (diakonos)." Näin kutsuttiin muun muassa kyynikkofilosofi Diogenesta, jota antiikin maailmassa pidettiin esimerkkinä täydellisestä omistautumisesta filosofin elämäntavalle. Collins itsekin myöntää, että tässä yhteydessä "palvelija" on paremmin sopiva merkitys kuin "sanansaattaja."10

\section{Diakonos ja diakonia Uudessa testamentissa}

Edellä on käynyt ilmi, että "diakonia" yhdistettiin antiikin kirjallisuudessa päsääntöisesti palvelemiseen. Tämä on nähdäkseni termin päämerkitys, kun taas Collinsin korostama "välittäänä", "välikätenä" tai "välikappaleena" toimiminen on yksi siihen sisältyvä lisävivahde tietyissä tapauksissa. Sanaan liittyy myös usein alamaisuuden sävy. Tämä käy ilmi myös Uudesta testamentista. Sanaa diakonos käytetään paikoitellen orjaa kuvaavien sanojen (doulos, syndoulos) synonyymeinä (Mark. 10:43-45; Kol. 1:7). Paavali voi puhua yhtä hyvin "synnin palvelijasta" (diakonos, Gal. 2:17) kuin "synnin orjastakin" (doulos, Room. 6:17, 20; vrt. Joh. 8:34). Uudessa testamentissa on myös useita kohtia, joissa "diakonia" tai vastaavat muut termit (verbi diakoneo, substantiivi diakonos) yhdistetään joko tarjoiluun pöydässä (Matt. 22:13; Luuk. 22:27) tai kotitaloustöihin yleisemmin (Mark. 1:31; Luuk. 10:40; Joh. 12:2).

Keskustelua on herättänyt se, missä merkityksessä Paavali käyttää itsestään nimitystä diakonos (1. Kor. 3:5) tai toiminnastaan apostolina termiä diakonia (2. Kor. 6:3-4; vrt. Ap.t. 1:17). Ensiksi mainitussa kohdassa Paavalin tarkoituksena on selvästi vähätellä sekä itsensä että Apolloksen roolia (he ovat pelkkiä palvelijoita), jotta korinttilaiset antaisivat kunnian Jumalalle eivätkä ihmisille. Toisesta korinttilaiskirjeestä käy ilmi, että Paavalin vastustajat kutsuivat itseään "Kristuksen palvelijoiksi". Halutessaan osoittaa olevansa heidän veroisensa Paavali vetoaa kärsimiinsä vaikeuksiin: lyönteihin, kuolemanvaaraan, raipparan-

${ }^{10}$ Collins 1974, 88-92; toisin Georgi 1964, 27-32. 
gaistuksiin, kivitykseen, merihätään, nälkään, janoon jne. Kaikessa tässä on kyse siitä, että Paavali on kantanut huolta seurakunnasta (2. Kor. 11:22-28). Hän kuvaa siis itsensä seurakunnan palvelijaksi, aivan kuten Platonin "kunnanisät" olivat poliksen palvelijoita.

Yllättävää on, että Collins hyökkää jyrkästi diakonian karitatiivista aspektia kohtaan eli ajatusta pyyteettömästä palvelemisesta. Edellä kävi ilmi, että antiikin diakonia ei välttämättä ollut "karitatiivista", vaan palvelun saaja joutui maksamaan palvelun tarjoajalle. Kuitenkin Paavalin tapaan käyttää sanaa liittyy myös karitatiivinen puoli. Tämä käy ilmi esimerkiksi siitä, että Paavali puhuu liittää "diakonian” rahankeräykseen, jonka hän toimitti Jerusalemin kristittyjen auttamiseksi (2. Kor. $8: 4)$. Kyse on painokkaasti köyhien auttamisesta, kuten muualta Paavalin kirjeistä näkyy (Room. 15:26; Gal. 2:10). Juuri tästä syystä Paavali puhuu keräyksen yhteydessä diakoniasta - ei siksi, että Paavali välittää tämän keräyksen Jerusalemiin. ${ }^{11}$

Viittasin jo edellä Matteuksen evankeliumin kuvaukseen viimeisestä tuomiosta (Matt. 25). Jakso on sikäli erikoinen, että se löytyy ainoastaan tästä evankeliumista. Se on siis todennäköisesti peräisin kirjoittajan oman seurakunnan erityistraditiosta. Tässä hätkähdyttävässä kertomuksessa kuningas tuomitsee vasemmalla seisovat siksi, etteivät he tarjonneet hänelle ruokaa, juomista eivätkä vaatteita eivätkä käyneet hänen luonaan vankilassa. Tuomitut vastaavat: "Herra, milloin me näimme sinut nälissäsi tai janoissasi, kodittomana tai alasti, tai sairaana tai vankilassa, emmekä auttaneet sinua?” (Matt. 25:44)

Kohdassa käytetty kreikan verbi, joka uudessa Kirkkoraamatussa on käännetty "auttaa", on diakoneō, "palvella". Tässä tapauksessa sitä käytetään viittaamaan kaikkiin niihin tekoihin, joita syytettyjen olisi pitänyt tehdä, eli siis ruokkia nälkäiset, juottaa janoiset, pukea alastomat ja vierailla vankien luona. Viimeksi mainittua teemaa lukuun ottamatta kyse on siis täsmälleen samoista asioista, jotka jo Platonin käsityksen mukaan kuuluivat "diakoniseen" toimintaan. Matteuksen kuvauksessa ei kuitenkaan ole kyse palveluyhteiskunnan teoreettisesta pohdinnasta

${ }^{11}$ Näin Collins 1990, 217-221. 
kuten Platonilla, vaan konkreettisesta toiminnasta. Matteuksen kuvauksessa diakoniseen toimintaan ei myöskään liitetä ajatusta palvelujen ostamisesta kuten Platonilla, vaan yksinkertaisesti hädässä olevien auttamisesta.

Diakonian palveluaspekti korostuu myös varhaiskristillisessä kirjallisuudessa, joka jäi Uuden testamentin ulkopuolelle. Apostolisten isien kuuluva Hermaan paimen, joka kirjoitettiin todennäköisesti Roomassa 100-luvun ensimmäisellä puoliskolla, moititaan tehtävänsä huonosti hoitaneita diakoneja: he ovat "ryöstäneet leskien ja orpojen elannon ja itse rikastuneet diakoninvirasta."12 Kohta osoittaa, että diakonien tehtävänä pidettiin ennen kaikkea leskistä ja orvoista huolehtimista (vrt. Ap.t. 6). Mielenkiintoista on, että tämä tehtävä ei Hermaan paimenen mukaan kuulu ainoastaan diakoneille, vaan myös piispoille. Diakoninen toiminta on nimittäin hyvän piispan keskeinen tuntomerkki: "Nämä piispat ovat aina palvelusvirkaansa toteuttaen uupumatta hoitaneet vähävaraisia ja leskiä ja aina vaeltaneet moitteettomasti." ${ }^{13}$

\section{Johtopäätöksiä}

John N. Collinsin tulkinta varhaiskristillisestä diakonia-käsityksestä ei nähdäkseni johda niin perustavaan uudelleen arviointiin kuin Collins itse ajattelee. Jo antiikin ajan teksteissä, sekä ei-kristillisissä että kristillisissä, diakoniseen toimintaan liittyviin termeihin yhdistyy poikkeuksetta läheisesti palvelun ajatus. Palvelu voidaan tosin ymmärtää hyvin eri tavoin. Diakonia voi yksinkertaisesti tarkoittaa palveluyhteiskuntaa, jossa tiettyjä palveluja ostetaan niiden tuottamiseen erikoistuneilta ihmisiltä. Kyse ei siis välttämättä ole karitatiivisesta toiminnasta, mutta siitäkin on esimerkkejä antiikin kirjallisuudessa.

Antiikin lähteissä diakonos ei välttämättä ole hiljainen, nöyrä ja pyyteetön palvelija eikä myöskään välttämättä kenenkään alamainen.

\footnotetext{
${ }^{12}$ Vert. 9.26.2; suom. Heikki Koskenniemi.

${ }^{13}$ Vert. 9.27.2; suom. Koskenniemi; vrt. Collins 1990, 228-229.
} 
Itse asiassa sekä Paavali että kreikkalaisten rakastama Diogenes Sinopelainen (n. 400-n. 320 eKr.) ovat esimerkkejä hyvin toisenlaisista "palvelijoista." "Zeuksen palvelijaksi" kutsuttu Diogenes ei piitannut yhteiskunnassa vallitsevista säännöistä; hänet tunnettiin suorapuheisuudestaan ja huonoista tavoistaan. Juuri hänen riippumattomuutensa yhteisön normeista teki hänestä toisten silmissä yhden kreikkalais-roomalaisen maailman ihannefilosofeista. ${ }^{14}$ Samoin Paavali "Kristuksen palvelijana" korostaa usein, ettei hän ole kenenkään muun alamainen. Antiikin lähteissä kuvattu palveleminen ei siis välttämättä vastaa sitä asennetta, joka protestanttisessa perinteessä on usein yhdistetty diakoniseen toimintaan.

Antiikin lähteistä ei kuitenkaan voi suoraan päätellä, mikä on "diakonisena" pidetyn toiminnan ala meidän aikanamme tai miten diakonian virka pitäisi määritellä Suomen kirkossa juuri nyt. Antiikin maailmassa diakoninen toiminta oli osa yhteiskuntaa, joka perustui keskinäisten palvelujen verkostolle, patronusten ja heidän suojattiensa tarkoin määritellyille suhteille. Edellä kuvaamissani varhaiskristillisissä teksteissä esiintyy joka tapauksessa hyvin vahvana ajatus, että "diakonia" ei ole vain minkä tahansa tehtävän toimittamista toisen puolesta (kuten Collins ehdottaa), vaan painopiste on karitatiivisessa toiminnassa hädänalaisten auttamiseksi.

Tällainen toiminta, erityisesti sairaiden hoitaminen epidemioiden aikana, oli itse asiassa todennäköisesti yksi varhaisen kristinuskon tärkeimmistä menestystekijöistä. ${ }^{15}$ Vaikka karitatiivinen toiminta onkin antiikin lähteiden valossa vain yksi tapa ymmärtää diakoninen toiminta, juuri näin ymmärrettynä diakonia on osoittanut pysyvän arvonsa kristinuskon historiassa - ja toivottavasti tämä arvo säilyy myös tulevaisuudessa.

\footnotetext{
${ }^{14}$ Diogenes Sinopelaisesta ks. Diogenes Laertios 6.2.

${ }^{15}$ Stark 1997, 73-94.
} 


\section{Halusiko Johannes korvata muut evankeliumit?}

(1994)

\section{Mistä on kysymys?}

Johanneksen evankeliumi on erilainen. Verrattuna Matteuksen, Markuksen ja Luukkaan kutakuinkin yhtäpitävään kuvaukseen Johanneksen Jeesus on kuin mies toiselta planeetalta. Hän ei puhu arkisista asioista kuten taikinan hapatuksesta, talon rakentamisesta tai kylväjästä, joka lähti kylvämään, vaan esittää pitkiä puheita itsestään ja Isästään. Hän ei aja ihmisistä pois räyhähenkiä eikä osallistu veronkantajien syöminkeihin. Hän ei ole edes erityisen kiinnostunut kutsumaan vähäosaisia ja syrjittyjä seuraansa. Vihollisten rakastamisen ja toisen posken kääntämisen sijasta hän opettaa oppilailleen keskinäistä rakkautta. Hänen ei tarvitse rukoilla, että Jumala estäisi hänen kärsimyksensä. Edes ristillä hän ei tunne (tai ainakaan alennu valittamaan) hylätyksi tulemisen tunnetta.

Toisaalta tämän evankeliumin tietyt kertomukset ovat tuttuja muistakin evankeliumeista. Jeesuksen toiminnan alku liittyy jollain tavalla Johannes Kastajaan, joskaan tämän ei kerrota kastaneen Jeesusta (Joh. 1:19-51). Jeesus ruokkii viidellä leivällä ja kahdella kalalla 5000 ihmistä. Pian tämän jälkeen hän kävelee aaltojen yli oppilaidensa luo (Joh. 6:1-21). Ennen kuolemaansa hänet voidellaan ja hän ratsastaa aasilla Jerusalemiin (Joh. 12:1-19). Juutalaisille johtajille hänet kavaltaa oma oppilas, Juudas (Joh. 13; 18). Jeesuksen tarina päättyy tässäkin evankeliumissa kuolemaan ristillä ja ylösnousseen ilmestyksiin (Joh. 1921). 
Johanneksen evankeliumi on pääasiassa erilainen, mutta kuitenkin jossain määrin samanlainen kuin muut evankeliumit. On perusteltua kysyä, mistä erot ja yhtäläisyydet johtuvat. Vaikka neljää evankeliumia voidaan pitää eräänlaisena rikkautena, niiden erilaisuus aiheuttaa päänvaivaa ei vain tutkijalle vaan kenelle tahansa raamatunlukijalle.

\section{Kirkon perimätieto}

Kirkon piirissä Johanneksen evankeliumin erilaisuus jouduttiin ottamaan vakavasti suhteellisen varhain. Jo kirkkoisien toteamuksista käy ilmi, että Johanneksen uskottiin kirjoittaneen evankeliuminsa vasta muiden evankelistojen jälkeen. Erilaisuuden syynä pidettiin sitä, ettei Johannes enää halunnut toistad aiemmin sanottua. Hän halusi pikemminkin keskittyä aiemmin kuvattujen tapahtumien syvempään, hengelliseen ulottuvuuteen: "Kun Johannes näki, että Jeesuksen (ruumiillinen) puoli oli esitetty (edellisissä evankeliumeissa), kirjoitti hän viimeisenä oppilaidensa kehotuksesta Jumalan hengen johdattamana henkisen evankeliumin." ${ }^{\prime 1}$ Lisäksi ajateltiin, että Johannes halusi kertoa niistä tapahtumista, jotka muut evankelistat olivat jostain syystä jättäneet kertomatta. ${ }^{2}$ Näin Johanneksen ajateltiin nimenomaan täydentävän muita evankeliumeja.

Kirkon historiassa tämä ratkaisu on vaikuttanut ja vaikuttaa edelleen merkittävällä tavalla Johanneksen evankeliumin tulkintaan. Näinhän Johanneksen ja muiden evankeliumien välistä erilaisuutta ei tarvitsisi pitää ristiriitaisuutena, vaan keskinäisenä täydentävyytenä. Käyttökelpoisuus ei kuitenkaan vahvista tätä ratkaisua oikeaksi. Suurimman käyttövoimansa se saa edelleen kirkollisen perimätiedon arvovallasta, ei Johanneksen evankeliumista itsestäñ.

\footnotetext{
${ }^{1}$ Näin Clemens Aleksandrialainen Eusebioksen Kirkkohistorian (6.14.7) mukaan.

2 Tähän perustuu Johanneksen evankeliumin luonnehdinta paralipomenoiksi (kreikan $\tau \dot{\alpha}$ $\pi \alpha \rho \alpha \lambda \varepsilon ı \pi^{\prime} \mu \varepsilon v \alpha$, "jäljelle jääneet"). Tämän ajatuksen varhaisia edustajia olivat mm. Epifanios ja Theodor Mopsuestilainen (Windisch 1926, 4.7-8).
} 


\section{Tieteellinen tutkimus}

Tieteellisen raamatuntutkimuksen aikakaudella kysymystä Johanneksen evankeliumin suhteesta edeltäjiinsä on pohdittu yhä uudelleen. Evankeliumitutkimuksen keskeisimpiä käännekohtia oli oivallus, ettei Johanneksen evankeliumia voi käyttää samanarvoisena lähteenä Jeesuksen elämästä kuin muita evankeliumeja. Neljännen evankeliumin Jeesus-kuvaan on vaikuttanut vielä muita evankeliumeja selkeämmin kirjoittajan (tai kirjoittajien) oma teologinen ajattelu.

Tällä vuosisadalla Johanneksen suhteesta toisiin evankeliumeihin on esitetty kaksi päinvastaista, keskenään kilpailevaa ratkaisua (sekä luonnollisesti koko joukko "välittäviä ratkaisuja" näiden kahden ääripään välillä). ${ }^{3}$ 1900-luvun tutkimuksessa on aaltoliikkeen tavoin siirrytty ratkaisusta toiseen. Vuosisadan alussa ajateltiin yleisesti, että neljännen evankeliumin kirjoittaja tunsi aiemmat evankeliumit ja käytti niitä hyväkseen. Pian toisen maailmansodan jälkeen monet merkittävät tutkijat kääntyivät täysin päinvastaiseen suuntaan. Heidän mukaansa kirjoittaja ei käyttänyt eikä edes tuntenut muita evankeliumeja. ${ }^{4}$ Viimeisen kymmenen vuoden aikana Johanneksen evankeliumissa on kuitenkin jälleen alettu jälleen nähdä merkkejä muiden evankeliumien vaikutuksesta. $^{5}$

Tutkimuksen uoman kääntyessä monet vanhat, muutamaksi vuosikymmeneksi unohdetut kysymykset muuttuvat jälleen ajankohtaisiksi. Ennen kaikkea on kysyttävä, mitä neljännen evankeliumin kirjoittaja ajatteli edeltäjistään. Ajatteliko hän teoksensa olevan aiempien evankeliumien jatke? Pyrkikö hän omalla kirjallaan vahvistamaan varhaisempien evankeliumien luotettavuuden - vai kyseenalaistamaan sen?

\footnotetext{
3 1900-luvulla esitetyistä perusratkaisuista ks. tarkemmin Smith 1992; Dunderberg 1994, $12-23$.

${ }^{4}$ Tämän ratkaisun kannattajista ks. Dunderberg 1993.

5 Väitöskirjassani olen pyrkinyt osoittamaan, etteivät tällaiset ajatukset ole täysin tuulesta temmattuja (Dunderberg 1994; vrt. Dunderberg 1993).
} 


\section{Hans Windisch}

Uudessa tutkimustilanteessa tämänkaltaisia kysymyksiä on toistaiseksi pohdittu hyvin vähän. Vuosisatamme ensimmäisellä neljänneksellä niistä ehdittiin kuitenkin jo kiistellä vilkkaasti. Erityisen selkeä on tässä suhteessa Hans Windischin tutkimus (1926), jonka alaotsikko kiteytti koko kysymyksen muotoon: "Halusiko Johannes täydentää vai korvata vanhemmat evankeliumit?"

Windischin vastaus tähän kysymykseen on selkeä. Toisin kuin kirkollinen perimätieto opetti, Johannes halusi syrjäyttää aiemmat evankeliumit seurakunnallisesta käytöstä. Johanneksen tavoitteena oli evankeliumi, jonka jälkeen muita ei enää tarvittaisi. Tämän evankeliumin sijoittaminen Uuteen testamenttiin neljänneksi evankeliumiksi, muiden jatkoksi, oli näin täydellistä kohtalonivaa ja neljännen evankelistan omien pyrkimysten vastainen toimenpide. ${ }^{6}$

Windischin näkemykset herättivät aikanaan keskustelua, mutta vain lyhyen aikaa hukkuakseen sitten "uuden aallon" nostattamiin kuohuihin. Windischin usein kärkevät mielipiteet menettivät parhaimman teränsä, kun alettiin pohtia, oliko Johanneksen evankeliumia sittenkin aliarvostettu Jeesuksen elämän yhtenä historiallisena lähteenä. Koska näiden pohdintojen peruslähtökohta oli, ettei Johannes tunne synoptikkoja, Windisch ja hänen näkemyksensä voitiin rauhassa unohtaa.

Edes viime aikoina Windischin ajatuksiin ei ole otettu kantaa, vaikka niistä muuttuneen tutkimustilanteen myötä on tullut jälleen päivänpolttavia. ${ }^{7}$ Windisch osoittaa nimittäin vääjäämättä, että jos

\footnotetext{
${ }^{6}$ Windisch 1926, 134.

${ }^{7}$ Esim. D. Moody Smith esittelee uudessa tutkimushistoriassaan Windischin ratkaisun ja siihen liittyneen keskustelun hyvinkin huolellisesti, mutta ei lopulta sano omaa kantaansa siihen (Smith 1992, 19-37). Martin Hengel toteaa, joskin ylimalkaisesti, että Windischin esitys on "edelleen paras kuvaus Johanneksen asenteesta muihin evankeliumeihin." Hengelin mukaan evankeliumin toimittajat eivät kuitenkaan halunneet syrjäyttää muita evankeliumeja (Hengel 1993, 209 n. 16 = Hengel 1990, 194 n. 8). Hengelin oma, Johanneksen apostolisia alkujuuria korostava kokonaisnäkemys poikkeaa kuitenkin Windischistä, joka kiistää Johanneksen evankeliumin apostolisuuden juuri siksi, koska se poikkeaa historiallisesti luotetta-
} 
Johanneksen evankeliumi on riippuvainen varhaisemmista evankeliumeista, sen tarkoituksena ei voi olla näiden täydentäminen. Hänen tärkeimpiä perustelujaan ovat seuraavat: ${ }^{8}$

1. Jos kirjoittajan tavoitteena olisi täydentää aiempia evankeliumeja vain siltä osin mitä aiemmin oli jäänyt kertomatta, miksi hän kuitenkin esittää myös samoja kertomuksia kuin muut evankeliumit?

2. Johanneksen evankeliumissa mainitaan kirjan tavoite, joka ei kuitenkaan ole aikaisempien evankeliumien täydentäminen. Tavoite on sen sijaan, että "tämä kirja", toisin sanoen Johanneksen evankeliumi sellaisenaan herättäisi uskon siihen, että Jeesus on Jumalan poika (Joh. 20:30-31). Tässä suhteessa neljäs evankeliumi on itsenäinen eikä kaipaa muita täydentäviä esityksiä tuekseen.

3. Myös Johanneksen evankeliumin rakenne on itsenäinen. Jo evankeliumin runkona toimiva matkakertomus poikkeaa muista evankeliumeista: vain Johanneksen mukaan Jeesus käy Jerusalemissa kolme kertaa julkisen toimintansa aikana. Lisäksi Johannes esittää tapahtumat usein eri järjestyksessä kuin muut evankeliumit. Esimerkiksi temppelin puhdistamisesta kerrotaan evankeliumin alussa, ei Jeesuksen julkisen toiminnan loppuvaiheiden yhteydessä.

4. Evankeliumin kirjoittaja ei anna minkäänlaisia selityksiä kohtiin, joissa hän poikkeaa edeltäjistään. Hän ei siis pyri rauhoittelemaan oman esityksensä takia epävarmaksi tullutta lukijaa. Tällaista epävarmuuttahan voisi aiheuttaa esimerkiksi se, että Johannes kuvaa Jeesuksen viimeisen aterian mainitsematta lainkaan ehtoollisen asettamista.

5. Neljännen evankeliumin vaikeneminen tietyistä muiden evankeliumien kertomuksista ei tarkoita niiden hyväksymistä tai vahvistamista. Vaitiolo ei siis tässä tapauksessa ole myöntymisen merkki. Windischin mukaan Johannes on esittänyt omassa evankeliumissaan kaiken mainitsemisen arvoisen Jeesuksen elämästä. Jos hän ei toista jotain

vammista synoptisista evankeliumeista (Windisch 1926, 136-137). Tämän keskeisen ongelman Hengel sivuuttaa omassa työssään kokonaan.

${ }^{8}$ Osa Windischin argumenteista esiintyy jo syrjäyttämisteorian aikaisemmilla edustajilla, Eduard Schwartzilla ja Franz Overbeckillä, joihin Windisch myös usein vetoaa. 
muissa evankeliumeissa mainittua, hän pitää sitä joko ala-arvoisena tai vähintäänkin vähäpätöisenä.

6. Johanneksen evankeliumeissa ei mainita muiden evankeliumien olemassaoloa eikä niitä ei kehoteta käyttämään Johanneksen esitystä täydentävinä teoksina, ei myöskään Johanneksen evankeliumia niiden täydennyksenä.

Windischin havaintojen perusteella Johanneksen evankeliumi on riippumaton muista evankeliumeista myös siinä tapauksessa, että näitä olisi käytetty evankeliumia kirjoitettaessa. Neljäs evankeliumi on itsenäinen, omaehtoinen evankeliumi, ei varhaisempien evankeliumien jatke tai niiden varhainen selitysteos.

\section{Evankeliumi ja sen lukijat}

Windischiä voi arvostella siitä, että hän kärjistää Johanneksen ja synoptisten evankeliumien suhteen äärimmilleen. Vaikka neljäs evankeliumi osoittautuukin itsenäiseksi teokseksi, siitä itsestään ei käy ilmi, että sen tarkoituksena olisi estää lukijoitaan tutustumasta muihin kirjoituksiin. ${ }^{9}$ Tämä ei vähennä kuitenkaan Windischin tekemien havaintojen arvoa. Useimmat niistä eivät itse asiassa välttämättä vaadi selityksekseen suurisuuntaista syrjäyttämishanketta. Niiden perusteella on pikemminkin luontevaa olettaa, että neljäs evankeliumi on alun perin tarkoitettu lukijoille, jotka eivät yksinkertaisesti vielä tunteneet muita evankeliumeja. ${ }^{10}$

Jos tämä oletus pitää paikkansa, Johanneksen evankeliumin erilaisuus ei ollut ensimmäisille lukijoille ongelma. Erilaisuuden ongelma

\footnotetext{
${ }^{9}$ Näin kuitenkin Windisch 1926, 133. Koska Johanneksen evankeliumissa ei missään kohtaa suoraan kritisoida synoptisia evankeliumeja Windisch joutuu turvautumaan varsin yleisiin argumentteihin radikaalin syrjäyttämishypoteesinsa tueksi. Niinpä "edeltäjien ignorointi merkitsee niiden hylkäämistä" (1926, 129); "tietoisuus omasta itseriittoisuudesta merkitsee samalla suvaitsemattomuutta” (1926, 134; pitää ehkä paikkansa yleisenä elämänviisautena!). Suoran kritiikin puute puolestaan johtuu Windischin mukaan neljännen evankelistan "hyvästä mausta - varoitus muista kirjoituksista ei sopinut hänen kirjansa tyyliin" (1926, 177)!

${ }^{10}$ Dunderberg 1994, 192.
} 
syntyy varsinaisesti vasta silloin, kun Johanneksen evankeliumin asema vakiintuu ja sitä aletaan lukea muiden evankeliumien rinnalla. Silloin nimittäin paljastuu, että jos neljännen evankeliumin kirjoittaja tunsi muut evankeliumit, hän ei pitänyt niiden kuvaa Jeesuksesta millään tavalla lopullisena tai koskemattomana.

Jos kirjoittaja tunsi muut evankeliumit, hänen oman kirjoituksena erilaisuus korostuu entisestään. Eroista vaikeneminen tai niiden silottelu eivät näin ratkaise toisenlaisen evankeliumin aiheuttamia ongelmia. Neljän evankeliumin ohjeellinen kokoelma tekee moneuden ongelmasta pysyvän. Erilaisuus on kohdattava ja sitä täytyy vähintään sietää. Kuten oikeassakin elämässä, paras vaihtoehto olisi hyväksyä se. 


\section{Johannes, synoptikot ja Ockhamin partaveitsi}

(1993)

Kirjassa Paholaisen asianajaja: Opaskirja skeptikoille Ockhamin partaveitsi määritellään periaatteeksi, joka "kieltää selitysten rakentajaa tuomasta teorioihinsa enempää selittäviä periaatteita kuin on ehdottomasti tarpeellista” (10). Ockhamin partaveitsen soveltamisesta erilaisten ilmiöiden selittämiseen kirjassa todetaan:

Tämä periaate kehottaa hylkäämään kaikki sellaiset teoriat tai niiden osat, jotka ovat ilmiöiden selittämisen kannalta hyödyttömiä tai tarpeettomia. Jotkut teoriat ja niiden osat on luotu selittämään ilmiöitä, joiden olemassaoloa ei ole kyetty todistamaan - nämä osat ovat partaveitsen mukaan tarpeettomia. Toiset teorioiden osat taas on luotu selittämään olemassaolevia ilmiöitä, mutta ne eivät onnistu tekemään ilmiöistä vakuuttavia - tällaiset osat ovat selityksissä hyödyttömiä. Occamin partaveitsi vaatii leikkaamaan malleista pois kaiken turhan ja ylimääräisen. (12)

Ockhamin periaate, ettei moneutta ei saa olettaa ilman pakkoa (pluralitas non est ponenda sine necessible) ${ }^{1}$, on alkanut entistä useammin vilahdella myös siinä keskustelussa, jota viime aikoina on käyty Johanneksen evankeliumin suhteesta synoptikkoihin.

Johanneksen evankeliumin erityisasemaan kiinnitettiin huomiota jo varhain kirkon historiassa. Evankeliumien väliset erot heikensivät

\footnotetext{
${ }^{1}$ Ockhamin periaatteesta ks. Holopainen 1991, 9 n. 18.
} 
monien mielestä kristinuskon luotettavuutta. Kristinuskon vastustajat osasivat tehdä kiusallisen tarkkoja vertailuja, ${ }^{2}$ mutta myös ja ennen kaikkea kristillisissä piireissä eroista tehtiin jyrkkiä päätelmiä. Kirkkoisä Epifanios kertoo ryhmästä, jolle hän antoi nimen alogit. Nämä totesivat oman synoptisen vertailunsa perusteella yksikantaan: "Johanneksen nimissä kulkeva evankeliumi on valhetta" (Panarion 51.18.1). ${ }^{3}$ Origeneen mukaan monet menettivät uskonsa evankeliumien välisten erojen takia ja irtautuivat seurakunnasta (Comm. Joh. 10.3.10). ${ }^{4}$

\section{Gardner-Smith}

Tällä vuosisadalla Johanneksen evankeliumin ja synoptikkojen suhteisiin on tietenkin otettu kantaa useissa eri yhteyksissä. Hieman yllättävää on kuitenkin, että juuri Percival Gardner-Smithin teoksesta St. John and the Synoptics tuli alan klassikko, joka määräsi tutkimuksen suunnan vuosikymmeniksi eteenpäin. Tämä vajaa satasivuinen tutkielma ilmestyi vuonna 1938. Gardner-Smithin oman, hieman yleistävän arvion mukaan sen hetkinen tutkimus oli päätynyt konsensukseen, jonka mukaan neljäs evankelista tunsi synoptikot ja käytti niitä lähteinään. ${ }^{5}$ Tämän käsityksen Gardner-Smith torjui työssään päättäväisesti. Hänen mukaansa Johannes ei ollut käyttänyt, lukenut eikä edes tuntenut synoptisia evankeliumeja. Johanneksen yhtäläisyydet synoptikkoihin Gardner-Smithin mukaan on aina mahdollista selittää yhteisen suullisen tai kirjallisen lähteen avulla, toisin sanoen yhteisellä traditiolla.

Gardner-Smithin työ synnytti ajan mittaan uuden konsensuksen. ${ }^{6}$ Useat tunnetut Johannes-tutkijat ovat asettuneet Gardner-Smithin kannalle, muun muassa Charles Harold Dodd, Raymond E. Brown,

\footnotetext{
${ }^{2}$ Merkel 1971, 8-31.

${ }^{3}$ Alogeista ks. Merkel 1971, 35; Hall 1978, 290-295.

${ }^{4}$ Merkel 1971, 32.

${ }^{5}$ Gardner-Smith ei viittaa esim. Julius Schniewindin tutkimukseen vuodelta 1914. Siinäkin korostetaan Johanneksen ja Luukkaan taustalla olevaa yhteistä traditiota (Schniewind 1914, 95-96).

${ }^{6}$ Gardner-Smithin työn vaikutushistoriasta ks. tarkemmin Verheyden 1992, 436-451.
} 
Ernst Haenchen, Dwight Moody Smith, Rudolf Schnackenburg, Robert Tomson Fortna ja Jürgen Becker. ${ }^{7}$ Jos Gardner-Smithin tutkimukseen kuitenkin perehtyy tarkemmin, kirjan saamaa suosiota ei voi olla ihmettelemättä. ${ }^{8}$

Gardner-Smithin näkemykset perustuvat nimittäin enemmän common sense -ajatteluun kuin tarkkaan eksegeettiseen analyysiin. Yhtäläisyydet Johanneksen ja synoptikkojen välillä selittyvät kirjassa sivu sivun jälkeen yksinkertaisesti piirteinä, jotka on helppo muistaa. ${ }^{9}$ Yhteiset kertomukset ovat Gardner-Smithin mukaan tarinoita, jotka jokaisen ensimmäisen vuosisadan kristityn oli täytynyt kuulla. ${ }^{10}$ Näitä väitteitään Gardner-Smith ei vaivaudu perustelemaan tarkemmin, kuten ei seuraaviakaan: erojen taustalla ovat Johanneksen huonosti informoidut opettajat; ${ }^{11}$ suullisessa traditiossa eri kertomukset assimiloituvat toisiin$\mathrm{sa},{ }^{12}$ mutta taitava kirjoittaja ei sulata toisiinsa eri kertomuksia. ${ }^{13}$ Kertomuksessa Jeesuksen oikeudenkäynnistä Gardner-Smith olettaa jopa, että evankelista olisi jollain tapaa ottanut mainittuun oikeudenkäyntiin osaa! Tekstianalyysien yhteydessä otan tarkemmin kantaa siihen GardnerSmithin näkemykseen, jonka mukaan sekaannus (confusion) olisi ominaista nimenomaan suulliselle traditiolle.

Gardner-Smithin metodi perustuu yhtäläisyyksien ja erojen luetteloimiseen. Niiden merkitystä ei arvioida lähemmin. Gardner-Smithin tapa selittää yhtäläisyydet yhteisten, usein varsin epämääräisten suullisten traditioiden avulla johtaa sisäisesti haavoittumattomaan päättelyyn: yhtäläisyydet eivät voi viitata minkään evankelistan omaan redaktioon, sillä ne a priori selittyvät yhteisen tradition avulla. Keskeiseksi

\footnotetext{
${ }^{7}$ Dodd 1963, 8-9; Brown 1966, xlvii; Haenchen 1965, 78-113. Postuumisti julkaistussa kommentaarissaan Haenchen kuitenkin poikkeaa tästä näkemyksestä muutamien kertomusten kohdalla (ks. esim. Haenchen 1980, 568). Smith 1987, 105, 169-170; Schnackenburg 1981, 30-32; Fortna 1970; 1988; Becker 1986; 1979-81 (1991), 41-45.

${ }^{8}$ Verheyden $(1992,452)$ on havainnut, että Gardner-Smithiin vedotaan lähinnä ohjelmanjulistajana. Yksittäisissä tekstianalyyseissä Gardner-Smithin argumentteihin viitataan varsin harvoin!

${ }^{9}$ Ks. esim. Gardner-Smith 1938, 49, 53, 54.

${ }^{10}$ Gardner-Smith 1938, 9, 23, 33, 56, 61, 64.

${ }^{11}$ Gardner-Smith 1938, 24.

${ }^{12}$ Gardner-Smith 1938, 28, 48.

${ }^{13}$ Gardner-Smith 1938, 27, 48.
} 
kysymykseksi nousee, voiko näin saavutettuja tuloksia yhdistää muiden lähdemallien, ennen kaikkea kaksilähdeteorian kanssa.

\section{Dauer ja "Leuvenin koulu"}

Gardner-Smithin synnyttämä konsensus ei missään vaiheessa ollut täysin aukoton. Sitä kritisoivat jo 1950-luvun lopussa muun muassa C. K. Barrett, sekä 1960-luvulla muun muassa Joseph Blinzler ja Werner Kümmel. Nämä tutkijat pitävät mahdollisina, että Johannes tunsi ainakin Markuksen, mahdollisesti myös Luukkaan (tai Matteuksen). ${ }^{14}$ Käydyn keskustelun eräksi merkkipaaluksi muodostui kuitenkin Anton Dauerin tutkimus Johanneksen evankeliumin kärsimyskertomuksesta (1972).

Dauer kiinnitti työssään huomionsa erityisesti kohtiin, joissa Johanneksen esitys pitää yhtä Matteuksen ja Luukkaan kanssa Markusta vastaan. Tällaiset kohdat kirjoittaja arvioi synoptisen redaktiokritiikin näkökulmasta ja totesi kerta toisensa jälkeen, että ne selittyvät kaksilähdeteoriasta käsin. Johanneksen esitys siis viittaa Matteuksen tai Luukkaan redaktioon. Looginen johtopäätös tästä on, että Johanneksen teksti jossain muodossa edellyttää Matteuksen ja Luukkaan esityksen.

Dauerin metodinen edistysaskel oli varsin yksinkertainen. Hän ei johtanut Johanneksen yhteyksistä Luukkaaseen tai Matteukseen oletuksia erilaisista esisynoptisista lähteistä. Dauer ei kuitenkaan uskonut neljännen evankelistan käyttäneen synoptikkoja suoraan lähteinään, vaan oletti, että Matteuksen ja Luukkaan kirjoittamisen jälkeen näiden teosten perusteella syntyi uutta suullista traditiota. ${ }^{15}$ Tällainen toisen vaiheen suullinen traditio olisi taas vaikuttanut Johanneksen kirjoittajan käyttämään lähteeseen. ${ }^{16}$

\footnotetext{
${ }^{14}$ Barrett 1978 (1. painos 1955), 15-17; Blinzler 1965; Kümmel 1983, 167-170.

15 Samansuuntaisia ajatuksia Johanneksen kärsimyskertomuksesta oli aiemmin esittänyt jo norjalainen Peder Borgen (Borgen 1958/1959).

${ }^{16}$ Dauer 1972, 60, 99, 164, 226; sama ratkaisu toistuu Dauerin uudemmassa tutkimuksessa (Dauer 1984).
} 
Dauerin metodinen lähtökohta Johanneksen ja synoptikkojen välisen suhteen tutkimiseen on selkeä ja perusteltu. Mutta onko Dauerin asiaan esittämä ratkaisu liian monimutkainen? Sellaisena sitä pitivät ainakin kaksi Leuvenin yliopiston professoria, Maurits Sabbe ja Frans Neirynck. Sabbe tarttui Dauerin esittämän analyysin yksityiskohtiin ja pyrki osoittamaan, että esiin otetut erot ja yhtäläisyydet voisivat selittyä myös siten, että Johannes on saanut tietonsa suoraan synoptisista evankeliumeista. ${ }^{17}$ Neirynckin mukaan taas kysymys siitä, onko Johanneksen evankeliumi riippuvainen synoptikoista vai ei, ratkeaa yksinomaan synoptisen redaktiokritiikin perusteella. Tästä lähtökohdasta käsin Neirynck on lukuisissa artikkeleissaan pyrkinyt osoittamaan, että Johanneksen evankeliumin kirjoittaja on tuntenut synoptikot ja käyttänyt niitä lähteinään. ${ }^{18}$

Sabben ja Neirynckin pelkistetty malli Johanneksen ja synoptikkojen suhteista on herättänyt kritiikkiä. Esimerkiksi Jürgen Becker on pitänyt mahdottomana ajatusta, jonka mukaan neljäs evankelista olisi valinnut kolmesta muusta evankeliumista sieltä täältä sopivia kohtia. ${ }^{19}$ Neirynckin esittämät näkemykset ovat kuitenkin saaneet myönteistä vastakaikua eri puolilla ${ }^{20}$ - erityisesti Saksassa. Tätä näkemystä tukevat muun muassa Françis Vouga, ${ }^{21}$ Ulrich Busse, ${ }^{22}$ Dietrich-Alex Koch ${ }^{23}$ ja erityisen näyttävästi Hartwig Thyen. Thyen on jopa julistanut kaikki varhaisemmat kirjallisuuskriittiset hahmotelmansa harha-askeleiksi. Hänen mukaansa synoptikot ovat käytännössä neljännen evankelistan ainoat lähteet. ${ }^{24}$

Gardner-Smithin synnyttämä konsensusratkaisu on siis murtunut selvästi 1990-luvun alkaessa. Uudessa tutkimustilanteessa myös Ockhamin partaveitsi on otettu jälleen käyttöön. Säästäväisyyden periaatteen

\footnotetext{
${ }^{17}$ Sabbe 1977; vrt. myös Sabbe 1992.

${ }^{18}$ Neirynck 1982, 335-455; 1991, 571-616, 651-687, 699-711.

${ }^{19}$ Becker 1986, 22; vrt. Myllykoski 1991b, 118.

${ }^{20}$ Ks. Neirynck 1992, 3-9.

${ }^{21}$ Vouga 1992.

${ }^{22}$ Busse 1992, 303-306.

${ }^{23}$ Koch $(1992,1982)$, joka tosin on päätelmissään varsin varovainen: jakson Joh. 1,19-34 taustalla voi olla Markuksen evankeliumi, mutta tätä ei voi todistaa ehdottoman varmasti.

${ }^{24}$ Thyen 1988, 208-211; 1992a, 2021-2022; 1992b, 81-85.
} 
on katsottu puhuvan sen näkemyksen puolesta, että neljäs evankeliumi on suoraan riippuvainen synoptikoista. ${ }^{25}$ Ockhamin partaveitsellä on leikattu hypoteesit erilaisista lähteistä, joiden avulla Johanneksen ja synoptikkojen välisiä yhteyksiä aiemmin on yritetty selittää.

Partaveitsen käyttö suuntautuu yhtäältä Dauerin mallin tapaisia ratkaisuja vastaan. Samalla se kuitenkin heijastaa myös laajempaa eksegeettisen paradigman muutosta. Johanneksen evankeliumin tutkijat turvautuvat erilaisiin lähdeoletuksiin entistä varovaisemmin. Jos Johannes on käyttänyt synoptikkoja, tarvitaanko enää oletusta esimerkiksi Johanneksen evankeliumin taustalla olleesta tunnustekolähteestä?

Toisaalta Ockhamin partaveitsi suuntautuu yhä useammin myös Johanneksen evankeliumin kirjallisuuskritiikkiä vastaan. On luonnollisesti mahdollista, että juuri synoptikkojen käyttö lähteinä on synnyttänyt koko joukon ongelmia, jotka aiemmin ratkaistiin olettamalla eri kirjallisia tasoja. Useat niistä, jotka ovat omaksuneet Neirynckin ratkaisun, päätyvät kuitenkin melkoiseen eksegeettiseen purismiin: Johanneksen evankeliumilla on vain yksi kirjoittaja, joka on käyttänyt lähteinään vain synoptikkoja. Eri asia on sitten, selittyvätkö kaikki Johanneksen evankeliumin kirjalliset katkot todellakin vain synoptikkojen avulla. ${ }^{26}$

\section{Suullinen ja kirjallinen - mahdolliset selitysmallit}

Käydyssä keskustelussa Johanneksen ja synoptikkojen suhteista on puolin ja toisin varsin vähän pohdittu suullisen ja kirjallisen välistä periaatteellista suhdetta. Kysymys on joka tapauksessa keskeinen: Dauer olettaa, että Matteus ja Luukas ovat synnyttäneet uutta suullista traditiota, joka on sittemmin vaikuttanut Johanneksen lähteisiin. Neirynck taas puhuu suoran kirjallisen yhteyden puolesta. Hän ja hänen seuraajansa ovat leikanneet Ockhamin partaveitsellä erilaisten

${ }^{25}$ Ks. esim. Barrett 1992, 67; Kieffer 1992, 118; Vouga 1992, 269.

${ }^{26}$ Vrt. Becker 1986, 23-24. 
välivaiheiden mahdollisuuden. Välivaiheita pidetään joko tarpeettomina tai epätodennäköisinä selityksinä.

Werner Kelber on kuitenkin virittänyt keskustelun suullisen tradition merkittävästä osuudesta siinä prosessissa, jonka lopputuloksena evankeliumit syntyivät. ${ }^{27}$ Kelberin mukaan varsinkin erilaiset aforistiset Jeesuksen lausumat saattoivat hyvinkin levitä suullisen tradition välityksellä eri puolille kristikuntaa. Näin edes sanatarkat yhtäläisyydet kahden varhaiskristillisen tekstin välillä eivät välttämättä osoita näiden kirjallista riippuvuutta toisistaan. ${ }^{28}$

Toisaalta jo varhaisimmassa kristillisyydessä on havaittavissa taipumus intertekstuaalisuuteen. Intertekstuaalisuudella tarkoitetaan varhaiskristillisten tekstien tutkimuksen yhteydessä lähinnä sitä, että kahden tekstin välillä vallitsee kirjallinen riippuvuus. ${ }^{29}$ Jo Matteus ja Luukas osoittavat, että kirjallisia lähteitä pyrittiin tilaisuuden tullen käyttämään.

Molemmat selitystavat, suullinen ja kirjallinen yhteys ovat siis historiallisesti mahdollisia. Kumpaakaan ei voi torjua etukäteen. Varhaisin kristillinen traditio levisi alkuvaiheissaan lähinnä suullisesti. Näin esimerkiksi tiettyjen yhteisten lausumien esiintyminen Johanneksen evankeliumeissa ja synoptikoilla ei auta selvittämään näiden teosten kirjallista suhdetta. Yhteydet voivat johtua yhteisestä traditiosta.

Mahdollisen intertekstuaalisuuden jäljille pääsee parhaiten vertailemalla Johanneksen ja synoptikkojen yhteistä kertomusainesta. Käsittääkseni juuri tämä kertomusaines osoittaa, ettei Johanneksen evankeliumin suhdetta synoptikkoihin voi tyhjentävästi selittää vain yhteisten suullisten traditioiden avulla. Jatkossa esiin otettavien kertomusten kohdalla yritän pohtia myös kysymystä, miten suullisen ja kirjallisen yhteyden voisi mahdollisesti erottaa toisistaan. Millä

\footnotetext{
${ }^{27}$ Kelber 1984.

${ }^{28}$ Kelber ei kuitenkaan itse oleta, että Johanneksen evankeliumi olisi syntynyt täysin irrallaan Markuksesta: "Kun evankeliumin kirjoitettu muoto oli jo olemassa, Matteus ja Luukas, samoin myös Johannes, saattoivat palauttaa henkiin elävän Herran äänen” (Kelber 1984, 209).

${ }^{29}$ Näin Cartlidge (1990, 404), joka samalla vetää rajan intertekstuaalisuuteen modernina kirjallisuustieteellisenä tulkintatapana.
} 
perusteilla on mahdollista valita erilaisten traditiohistoriallisten selitysten ja suoran kirjallisen yhteyden välillä?

\section{Ruokkimisihme (Joh. 6:1-15)}

Johanneksen kertomus ruokkimisihmeestä sisältää runsaasti yhtäläisyyksiä synoptisiin kertomuksiin. Johanneksen evankeliumin kertomuksen perusrakenne on sama kuin vastaavien synoptisten kertomusten (Mark. 6:30-44; Matt. 14:13-21 // Luuk. 9:10-17): (a) suuri kansanjoukko seuraa Jeesusta. (b) Jeesus asettaa opetuslapset kokeeseen. (c) Jeesus ruokkii muutamalla leivällä ja kalalla koko häntä seuranneen kansanjoukon. (d) Ruokkimisihmeen jälkeen kerätään tähteet.

Kerronnan struktuurin lisäksi koko numeerinen traditio on sama. Aluksi viitataan 200 denaarin leipiin, joita kuitenkaan ei hankita. Leipiä on lopulta viisi, kaloja kaksi. Noin viidentuhannen miehen jäljiltä kerätään 12 korillista tähteitä. Tällaiset yhteydet eivät voi olla satunnaisia. Johanneksen kertomus on olennaisilta osiltaan sama kuin synoptisten evankeliumien ensimmäinen ruokkimiskertomus.

Oman ongelmansa muodostaa perikooppien esittämisjärjestys jaksossa Joh. 6 (kaavio 1). Se ei vastaa mitään synoptista evankeliumia sellaisenaan. Silti siinä on selviä viitteitä synoptikkoihin. Ruokkimisihmeen jälkeen seuraa kertomus Jeesuksen veden päällä kävelystä (Joh. 6:16-21). Järjestys vastaa Markuksen ja Matteuksen esitystä, jotka myös sijoittavat veden pä̈llä kävelyn ensimmäisen ruokkimisihmeen jälkeen (Mark. 6:45-52 // Matt. 14:22-33).

Seuraava yhteys synoptikkoihin löytyy Jeesuksen "leipäpuheen" alkuosasta, jossa juutalaiset kysyvät Jeesukselta: "Minkä tunnusteon teet, että me sen nähtyämme uskomme sinuun?" (Joh. 6:30) Tunnusteon vaatimus seuraa myös Markuksen esityksessä ruokkimisihmeen jälkeen; ei kuitenkaan ensimmäisen, vaan toisen ruokkimisihmeen jälkeen (Mark. 8:11-13; vrt. Matt. 16:1-4). 
I Ruokkimisihme

1. Johdanto

Joh.

Mark. Matt.

Luuk.

$6: 1-4$

$14: 13$ ! (diff

$9: 11$ ! (diff

Mark. 6:32);

Mark. 6:32)

15:29-31!! (diff

Mark. 7: 31-

37)

2. Kertomus 5000:n

$6: 5-15$

$6: 36-44$

14:15-21

$9: 12-17$

ruokkimisesta viidellä

leivällä ja kahdella

kalalla

II Veden päällä kävely

6:16-21

$6: 45-52$ !

14:22-33!

III Jeesukselta

$6: 30$

$8: 11-13$ !

16:1-4!

vaaditaan tunnusteko

ruokkimisihmeen

jälkeen

IV Pietarin tunnustus

$6: 66-71$

$8: 27-30$

$16: 13-20$

9:18-21!! (diff

(ruokkimisihmeen

Mark.)

yhteydessä tai

lähikontekstissa)

KAAVIO 1: JOH 6 - KERTOMUSTEN JÄRJESTYS

Johanneksen evankeliumissa kertomuskokonaisuuden päätää Pietarin tunnustus, jolle löytyy rinnakkaiskohta Markuksesta ja Matteuksesta, jälleen toisen ruokkimisihmeen jälkeen (Mark. 8:27-30 // Matt. 6:1320). Luukas puolestaan sijoittaa Pietarin tunnustuksen ensimmäisen (ja Luukkaalla ainoan) ruokkimisihmeen perään (Luuk. 9:18-21) - siis periaatteessa samaan kohtaan kuin Johanneksen evankeliumi.

Voiko Johanneksen esittämisjärjestys perustua esimarkuslaiseen kokoelmaan? Markusta edeltänyt valmis kokoelma, jossa yhdistyisivät ensimmäinen ruokkimisihme, Jeesuksen veden päällä kävely, tunnusteon vaatimus ja lopulta Pietarin tunnustus on Markuksen evankeliumin redaktiokritiikin näkökulmasta on epätodennäköinen ratkaisu. Jo 
liitos ruokkimisihmeen ja sitä seuraavan kertomuksen, Jeesuksen veden päällä kävelyn välillä (Mark. 6:45-46) viittaa Markuksen redaktioon sekä kielellisin että kompositioon liittyvin perustein. ${ }^{30}$ Markusta edeltävä kokoelma perustellaankin yleensä lähinnä sillä, että sama kertomusjärjestys esiintyy myös Johanneksella! ${ }^{31}$ Tällainen päättely johtaa tietenkin kehään, jonka avulla Johanneksen suhdetta synoptikkoihin ei voi selvittää.

Myös itse ruokkimiskertomukseen liittyvät havainnot viittaavat siihen, että Johanneksen lähteinä on käytetty synoptisten evankeliumien lopullisia versioita. Todennäköistä on, että Markus on tuntenut kaksi erillistä ruokkimiskertomusta. Ensimmäisessä on puhuttu viidestä leivästä, kahdesta kalasta, 12 korista ja viidestätuhannesta miehestä. Toisen kertomuksen numeerinen traditio on vaatimattomampi: seitsemällä leivällä ja muutamalla kalalla Jeesus ruokkii 4000 ihmistä; tähteitä kerätään vain seitsemän korillista (Mark. 8:1-10).

Kahden kertomuksen olemassaolo ei kuitenkaan suoralta kädeltä tarkoita sitä, että kaikki Markuksen ensimmäisessä ruokkimisihmeessä mainitut luvut olisivat peräisin Markuksen käyttämästä traditiosta. Opetuslasten mainitsema 200 denaaria (Mark. 6:37) on tässä suhteessa ongelmallinen. Sitä on pidetty Markusta varhaisempana tiedonantona Johanneksen rinnakkaiskertomuksen perusteella! ${ }^{32}$ Luvun mainitseminen liittyy kuitenkin yhteyksiin, jotka on totuttu näkemään nimenomaan Markukselle ominaisina. Jeesus pyytää opetuslapsia antamaan kansanjoukolle syötävää, mitä opetuslapset pitävät kummallisena ajatuksena: pitäisikö heidän lähteä ostamaan leipää 200 denaarilla? Markuksen mukaanhan Jeesus oli juuri kutsunut oppilaansa yksinäiseen paikkaan lepäämään (j. 31).

\footnotetext{
${ }^{30}$ Mark. 6:45-46 viittaa sisällöllisesti jaksoon 6:31-34, jota pidetään yleisesti Markuksen luomana johdantona ruokkimiskertomukseen. Lisäksi juuri Markus redaktiossaan korostaa vuoren ja yksinäisyyden yhteyttä; näin esim. 1:35 (ks. Gnilka 1978, 88); 9:2 (ks. Taylor 1952, 388); 14:32b, 33a (ks. Myllykoski 1991a, 149).

${ }^{31}$ Näin esim. Gnilka 1978, 266. Tätä näkemystä on pidetty jopa niin vahvana, että sen voi ongelmitta liittää siihen ajatukseen, että jakeet $45-46$ ovat peräisin Markukselta (Lührmann $1987,121)$ !

${ }^{32}$ Gnilka 1978, 255.
} 
Absurdiksi opetuslasten kysymyksen tekee se, että Markuksen kokonaisesityksen mukaan opetuslapset olivat juuri palanneet menestyksekkäältä parantamis- ja saarnakiertueelta (Mark. 6:30). Silti he ymmärtävät Jeesuksen pyynnön "antakaa te heidän syödä" nyt siten, että heidän pitäisi lähteä ostamaan leipää. Kyseessä on opetuslasten karkea väärinkäsitys - toisin sanoen juuri se teema, joka korostuu Markuksen luomassa ruokkimiskertomusten jälkinäytöksessä (Mark. 8:14-21), jonka mukaan opetuslapset murehtivat jälleen leivän puutetta (j. 14, 16). Tähän Jeesus vastaa - nyt ruokkimisihmeisiin viitaten - kahdesti: "Ettekö vieläkään ymmärrä." (j. 17, 21) 200 denaaria siis liittyy varsin todennäköisesti Markuksen omaan korostukseen. Johanneksen kertomus ei siis tällä kohtaa viittaa varhaiseen traditioon, vaan mitä ilmeisimmin Markuksen redaktioon.

Johanneksen evankeliumin ruokkimiskertomuksen yhteydet Luukkaan esitykseen rajoittuvat yhteiseen tiedonantoon, jonka mukaan kansanjoukot seurasivat Jeesusta (Luuk. 9:11 // Joh. 6:2). Sama piirre esiintyy myös Matteuksella (14:13), joten sen varassa ei voi päätellä, että Johanneksen kertomus edellyttäisi Luukkaan version. Tiedonanto voi selittyä joko kunkin evankelistan itsenäisenä toimitustyönä tai siten, että Johanneksen kertomuksen taustalla on Matteuksen versio.

Joh. 6:n kompositioon liittyviä kysymyksiä tässä yhteydessä ei voi ottaa riittävässä laajuudessa esille. On syytä kuitenkin huomata, että vain Luukas ja Johannes puhuvat yhdestä ruokkimisihmeestä. Toisen ruokkimiskertomuksen poisjättöön voi olla erilaisia syitä (esimerkiksi pienempi numeerinen traditio, dupletin välttö jne.).

Itsestään selvää ei kuitenkaan ole, että sekä Johannes että Luukas sijoittavat Pietarin tunnustuksen välittömästi ruokkimiskertomuksen yhteyteen. Markus ei liitä Pietarin tunnustusta suoraan toiseen ihmekertomukseen, joten asettelu on peräisin yksinomaan Luukkaan redaktion tulos. Yhteys Luukkaan ja Johanneksen välillä on siis komposition tasolla. Tällä on merkitystä pohdittaessa kysymystä, onko Luukkaan vaikutus välillistä vai suoraa. Komposition samankaltaisuus viittaa nimittäin kirjalliseen prosessiin! Johanneksen kertomusjärjestys näyttää perustuvan niin Markuksen kuin Luukkaankin laajoihin kertomuskokoelmiin, joiden kulkeutuminen suullisessa traditiossa olisi varsin epätodennäköistä. 
Erityisen silmiinpistävä on Johanneksen kertomuksen yhteys Matteuksen redaktioon. Tässä yhteydessä on käsittääkseni mahdollista jälleen päätellä jotain Johanneksen ja synoptikkojen yhteyksien luonteesta, toisin sanoen pohtia kysymystä, millä perusteilla suora kirjallinen yhteys voidaan erottaa mahdollisesta epäsuorasta käytöstä.

Johanneksen ruokkimiskertomuksen johdannossa mainitaan, että Jeesus kiipesi opetuslapsineen vuorelle ja istuutui sinne (Joh. 6:3). Esitys vastaa lähes sanatarkasti sitä tiedonantoa, joka Matteuksella edeltää toista ruokkimisihmettä (Matt. 15:29), eli kertomusta, joka ei Johanneksessa esiinny lainkaan. Mainittu kohta on selvästi peräisin Matteukselta. ${ }^{33}$ Oletus Matteuksen ja Johanneksen yhteisestä lähteestä, joka poikkeaisi Markuksesta, on näin tarpeeton. Johanneksen tiedonanto perustuu tällä kohdalla Matteuksen redaktioon. ${ }^{34}$

Vanha kirjallisuuskriittinen ratkaisu on, että maininta vuorelle menosta on lisätty Johanneksen kertomukseen vasta myöhemmin. Ratkaisu perustuu siihen tosiasiaan, että vuorimotiivi aiheuttaa sekaannuksen Johanneksen kertomuksessa. Ruokkimiskertomuksen lopussa (j. 15) kerrotaan Jeesuksen paluusta vuorelle ilman, että välillä olisi kerrottu Jeesuksen poistuneen vuorelta. ${ }^{35}$ Ongelma ei kuitenkaan ratkea jakeen 2 poistolla. Jakeen 15 muotoilu edellyttää, että Jeesuksen on aiemmin mainittu olleen vuorella; muuten ei voitaisi puhua Jeesuksen paluusta vuorelle. Synoptikkoihin viittaava sekaannus ei siis tällä kohtaa selity kirjallisuuskriittisesti eri kerrostumien avulla.

Olisi uskaliasta olettaa, että tämän tyyppinen sekaannuksen taustalla olisi täysin Matteuksen redaktiosta riippumaton traditio. Mutta Dauerinkaan malli ei selitä ilmiötä: olisiko Matteuksesta vaikutteita saanut suullinen traditio säilyttänyt tällaisen sekaannuksen sellaisenaan? Sekaannuksia voi tietenkin tapahtua sekä suullisessa että kirjallisessa perimätiedossa, mutta niiden voi olettaa pysyvän sellaisinaan lähinnä kirjallisessa perimätiedossa. Suullinen traditio voi korjata itse itseään

\footnotetext{
${ }^{33}$ Jakso Matt. 15:29-31 korvaa redaktionaalisesti jakson Mark. 7:31-37. Myös vuorimotiivi on Matteukselle ominainen (vrt. Matt. 5:5).

${ }^{34}$ Konings 1988, 159-161.

${ }^{35}$ Wellhausen 1908, 28.
} 
saman tien. Kuulija voisi huomauttaa havaitsemastaan ongelmasta suoraan kertojalle tai korjata "virheen" automaattisesti mielessään. Vai olivatko suullisen tradition kuulijat niin "tekstiuskollisia", etteivät uskaltaneet selventää diffuusia traditiota edes pienellä, teologisesti täysin harmittomalla huomautuksella, että Jeesus laskeutui välillä vuorelta alas?

Tämänkaltaisen sekaannuksen säilyminen Johanneksen tekstissä ei käsittääkseni voi selittyä suullisella traditiolla. Se tuskin olisi voinut myöskään säilyä muuttumattomana kovin monessa välivaiheessa Johanneksen ja synoptikkojen välillä. Selkeä kompositioon liittyvä sekaannus, joka perustuu kahden eri lähteen erilaisiin tiedonantoihin, viittaa kirjallisten lähteiden kirjalliseen työstämiseen, toisin sanoen intertekstuaalisuuteen. Tätä ei tue ainoastaan se, että sekaannuksen aikaansaaneet ovat lähdeteksteissä ainakin osin redaktionaalisia. On huomattava myös, että sekaannuksen aiheuttanut kohta tunkeutuu Johanneksen kertomukseen Matteuksen evankeliumin kokonaan toisesta, mutta samalla kuitenkin jossain määrin samanlaisesta kertomuskokonaisuudesta.

\section{Jeesuksen voitelu (Joh. 12:3-8)}

Toisena esimerkkinä otan esiin kertomuksen Jeesuksen voitelusta, josta kaikki neljä evankeliumia kertovat oman versionsa. Kertomusten perusstruktuuri on samanlainen: (a) johdannossa todetaan Jeesuksen olleen aterialla. (b) Nainen voitelee joko Jeesuksen pään tai kädet, mistä seuraa (c) läsnäolijoiden protesti. (d) Jeesus torjuu tämän protestin ja puolustaa naista. $^{36}$

Johanneksen kertomus Jeesuksen voitelusta muistuttaa ennen kaikkea Markuksen ja Matteuksen versiota (ks. kaavio 2).

${ }^{36}$ Vrt. Kiilunen 1992, 107. 


\begin{tabular}{|c|c|c|c|c|}
\hline & Joh. & Mark. & Matt. & Luuk. \\
\hline I Voiteen kuvaus & $12: 3 a$ & $14: 3 b ! !$ & $26: 7 !$ & $(7: 37)$ \\
\hline $\begin{array}{l}\text { II Nainen voitelee } \\
\text { Jeesuksen jalat ja } \\
\text { kuivaa ne } \\
\text { hiuksillaan }\end{array}$ & $12: 3 \mathrm{ab}$ & - & - & $7: 38,44 f, 46 b ! !$ \\
\hline III Protesti & & & & \\
\hline $\begin{array}{l}\text { 1. Protestin esittää } \\
\text { opetuslapsi }\end{array}$ & $12: 4 \mathrm{a}$ & - & $\begin{array}{l}\text { 26:8a!! (diff } \\
\text { Mark. 14:4a) }\end{array}$ & - \\
\hline $\begin{array}{l}\text { 2. Köyhien } \\
\text { auttaminen } \\
\text { protestin motiivina }\end{array}$ & $12: 5$ & $14: 5 ! !$ & $26: 9 !$ & - \\
\hline $\begin{array}{l}\text { IV Huomautus } \\
\text { Juudaksesta }\end{array}$ & $\begin{array}{l}12: 6 \\
\text { (JohRed!) }\end{array}$ & - & - & - \\
\hline $\begin{array}{l}\text { V Jeesus puolustaa } \\
\text { naista }\end{array}$ & & & & \\
\hline 1. Kehotus & $12: 7 b$ & $14: 7 \mathrm{~b} !$ & - & - \\
\hline $\begin{array}{l}\text { 2. Voitelun } \\
\text { tarkoitus }\end{array}$ & $12: 7 \mathrm{c}$ & $14: 8 !$ & $26: 12 !$ & - \\
\hline 3. Logion köyhistä & $12: 8$ & $14: 7 !$ & $\begin{array}{l}\text { 26:11!! (diff } \\
\text { Mark. 14:7) }\end{array}$ & - \\
\hline
\end{tabular}

Johannes kuvaa arvokkaan voiteen samanlaisella kolmen genetiivin sarjalla kuin Markus; Matteus on tällä kohtaa lyhentänyt esitystä. Protestin motiivi on erityisesti Markuksessa ja Johanneksessa samanlainen. Yhteisenä piirteenä on voiteen arvon mittaaminen tietyllä rahasummalla, 300 denaarilla. Matteus jättää viimeksi mainitun piirteen pois. Jeesus puolustaa naista aloittaen sekä Markuksessa että Johanneksessa

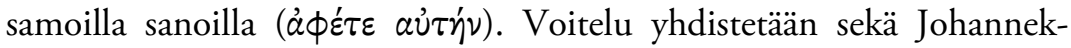
sessa, Markuksessa että Matteuksessa Jeesuksen hautaamiseen. Kaikissa kolmessa kertomuksessa esiintyy myös lausuma köyhistä. Vaikka Johanneksen esitysjärjestys on osin toinen kuin Markuksen ja Matteuksen, on selvää, että kyse on samasta kertomuksesta.

Johanneksen esitys sisältää kaksi selkeää viittausta Matteuksen redaktioon. Vasta Matteus identifioi Markuksen mainitsemat "eräät" 
napisijat opetuslapsiksi. Johanneksen mukaan protestin esittää ”Juudas, yksi Jeesuksen opetuslapsista”. Logionin köyhistä Johannes ja Matteus esittävät sanatarkasti samassa, Markukseen verrattuna lyhennetyssä muodossa: "Köyhät teillä on aina keskuudessanne, mutta minua teillä ei ole aina."

Synoptisten voitelukertomusten redaktiokritiikki muodostaa oman erityisongelmansa. Luukkaan kertomus (Luuk. 7:36-50) poikkeaa Markuksen kertomuksesta sekä sijainniltaan että sisällöltään. Näiden kahden kertomuksen välinen suhde on tutkimuksen kiistakysymys, johon tässä yhteydessä ei ole mahdollista paneutua. Myös Markuksen voitelukertomuksen traditiosta ja redaktiosta on esitetty varsin monensuuntaisia näkemyksiä.

Edellä mainituista syistä Johanneksen yhteydet Markuksen ja Luukkaan redaktioon täytyy jättää tässä yhteydessä avoimiksi. On kuitenkin selvää, että Johanneksella on joku yhteys Luukkaan kertomukseen. Johanneksen versiossa Markuksen ja Luukkaan kertomukset yhdistyvät toisiinsa omituisella tavalla. Johannes noudattaa pääpiirteissään Markuksesta ja Matteuksesta tuttua kaavaa. Itse voitelun Johannes kuvaa kuitenkin samoin kuin Luukas: kertomukseen sisältyy jalkojen voitelu - pään voitelun sijasta - ja kuivaaminen hiuksilla.

Miten tämän kaltaiset yhteydet synoptikkoihin selittyvät? Useat tutkijat pitävät kiinni oletuksesta, että yhteydet ovat traditiohistoriallisia. $^{37}$ Tämän näkemyksen mukaan Markusta ja Luukasta edeltävät erillistraditiot ovat sekoittuneet toisiinsa Johanneksen käyttämässä traditiossa. Oireellista on, että useat tämän suunnan edustajat selittävät Johanneksen yhteyden Matteukseen arveluttavalla tavalla: logion köyhistä (Joh. 12:8) on heidän mukaansa Johanneksessa myöhäisempi reunahuomautus. ${ }^{38}$ Tätä näkemystä voi perustella vain sen kokonaisnäkemyksen avulla, jonka mukaan Johannes ei käyttänyt synoptikkoja lähteenään. Teksti- tai kirjallisuuskriittisesti arvioituna ratkaisu on täysin tuulesta temmattu.

37 Perusteellisen listan tämän ratkaisun edustajista antaa Dauer 1984, 140-148; ks. myös Silvola 1989, 91-93, 101, 168, 262.

${ }^{38}$ Esim. Brown 1970, 449; Dodd 1963, 166; Fortna 1970, 151. 
Johanneksen kertomus ei myöskään viittaa mihin tahansa kahden kertomuksen epämääräiseen yhteensulautumiseen. Yhtäläisyyksien luonne näyttää viittaavan enemmänkin siihen, että joku todellakin on yhdistänyt toisiinsa kaksi kertomusta. Vaikutteet Luukkaan kertomuksesta tulevat esiin vain yhdessä kohdassa. Voitelu kuvataan vain Luukkaan kertomuksesta tutulla sanastolla - koko muu kertomus taas liittyy vain Markuksen ja Matteuksen kertomukseen. Tällainen yhteys kahteen synoptiseen kertomukseen viittaa siihen, että tiettyä peruskertomusta täydennetään - tai paremminkin korjataan - yhdessä kohdassa tietoisesti toisen kertomuksen yhdellä osalla. ${ }^{39}$

Ruokkimisihmeen tavoin voitelukertomukseen näyttää liittyvän jonkinasteinen sekaannus juuri siinä kohdassa, jossa lähdepohja mahdollisesti on vaihtunut. Johanneksen kertomuksessa voiteluun liittyvien tapahtumien järjestys on jossain märin epäselvä. ${ }^{40}$ Luukkaan esitys etenee johdonmukaisesti: syntinen nainen pesee Jeesuksen jalat, kuivaa ne hiuksillaan ja voitelee ne. Tähän verrattuna Johanneksen versiossa tulee esiin jonkinasteinen sekaannus: Maria voitelee ensin Jeesuksen jalat ja sitten yllättäen kuivaa ne saman tien hiuksillaan. Sekaannus voidaan tulkita merkiksi suullisesta traditiosta. ${ }^{41}$ Mutta kuinka monessa suullisen tradition vaiheessa tämän laatuinen sekaannus olisi voinut säilyä muuttumattomana?

Traditiohistoriallinen selitys perustuu lisäksi ajatukseen, jonka mukaan voitelukertomus kuuluu Johanneksen varhaisimpiin, toisin sanoen evankelistaa edeltäviin kirjallisiin kerrostumiin. Tällainen näkemys ei kuitenkaan ole itsestään selvä. Varsin vähän on kiinnitetty huomiota siihen, että Johanneksen voitelukertomus itse asiassa katkaisee sitä ympäröivien jakeiden yhteyden. Voitelukertomusta ennen mainitaan Jeesuksen saapuminen Betaniaan ja Lasaruksen läsnäolo yhteisellä aterialla. Näihin tiedonantoihin viitataan heti voitelukertomuksen jäl-

\footnotetext{
${ }^{39}$ Myös Myllykoski 1991a, 188; 1991b, 140-141 olettaa kirjallisten lähteiden käytön, mutta hänen mukaansa Johanneksen kertomuksen kirjoittaja on yhdistänyt aineksia Luukkaan erityistraditiosta passiolähteeseen, joka olennaisilta osiltaan vastaa Markusta edeltävää "laajennettua passiokertomusta”.

${ }^{40}$ Ks. esim. Becker 1979-81 (1991), 438; Myllykoski 1991a, 188.

${ }^{41}$ Näin esim. Brown 1970, 451.
} 
keen: ”Niin suuri kansanjoukko juutalaisista sai tietää, että hän [Jeesus] oli siellä, ja he tulivat, eivät ainoastaan Jeesuksen takia, vaan myös nähdäkseen Lasaruksen, jonka hän herätti kuolleista” (Joh. 12:9).

Näin voitelukertomus ei nivoudu saumattomasti Johanneksen kokonaisesitykseen, eikä siihen viitata Johanneksessa enää myöhemmin. Muualla Johanneksessa Jeesuksen voiteluun viitataan vain kerran. Kohdassa Joh. 11:2 todetaan: "Maria oli se, joka voiteli Herran jalat tuoksuöljyllä ja kuivasi ne hiuksillaan, ja sairas Lasarus oli hänen veljensä." Kohta on voitelukertomuksen kannalta mielenkiintoinen, sillä se on selkeästi myöhempi lisäys. ${ }^{42}$ Jae katkaisee varsin kömpelösti Lasaruksen kuolleistaherättämiskertomuksen johdannon. Voitelukertomuksen asema Johanneksen varhaisimmissa kerrostumissa osoittautuu siis myös tästä näkökulmasta käsin katsottuna varsin epävarmaksi. Todennäköisempää on, että voitelukertomus on jakeen Joh. 11:2 tavoin lisätty neljänteen evankeliumiin vasta myöhäisessä redaktiovaiheessa varhaisempaan kirjalliseen kokonaisuuteen, jossa oli jo kerrottu Lasaruksen kuolleista herättämisestä ja sen vaikutuksista. ${ }^{43}$

Johanneksen varhaisempaa kirjallista versiota on siis ilmeisesti täydennetty synoptisen kertomuksen avulla. Tästä ratkaisusta avautuisi luonnollisesti mielenkiintoisia näköaloja siihen, miksi Johanneksen evankeliumissa ylipäätään esiintyy synoptista kertomusmateriaalia. Tällainen menettely voi heijastaa tilannetta, jossa synoptisesta perimätiedosta on tullut erilaisuutensa takia ongelma Johanneksen seurakunnille. $^{44}$

\section{Johannes, synoptikot ja kirjallisuuskritiikki}

Jo pelkkä mahdollisuus, että synoptikot kuuluvat Johanneksen evankeliumin lähteisiin, pitää ottaa eksegeettisessä työskentelyssä huomioon. Ensimmäinen metodinen huomioni liittyykin ennen kaikkea tapaan,

\footnotetext{
${ }^{42}$ Kirjallisuudesta ks. Dunderberg 1992, 569 n. 33.

${ }^{43}$ Dunderberg 1992, 569.

${ }^{44}$ Dunderberg 1992, 570.
} 
jolla Johannesta käytetään synoptikkojen tradition ja redaktion erottelussa. Hypoteesit Markuksen taustalla olleista traditioista perustellaan luvattoman usein Johanneksen vastaavilla rinnakkaiskohdilla. Näin oletetaan samalla, että Johannes ja Markus ovat toisistaan riippumattomia. Tällainen asetelma on jo sinänsä metodisesti arveluttava, mutta erityisen ongelmalliseksi sen tekee nykyinen tutkimustilanne. Konsensusta Johanneksen ja Markuksen riippumattomuudesta ei enää ole. Tästä seuraa - tai ainakin pitäisi seurata - ettei Markuksen tutkija voi ongelmattomasti käyttää Johannesta oman traditioratkaisunsa tukena. Jos Johanneksen ja Markuksen yhteiseen lähteeseen halutaan vedota, tällaisen lähteen olemassaolo pitää todistaa kussakin kohdassa uskottavasti sekä Markuksesta että Johanneksesta käsin, ilman että näiden analyysit sekoitettaisiin keskenään. Sama lähtökohta pätee luonnollisesti soveltuvin osin Q:n, Matteuksen ja Luukkaan tutkimukseen.

Synoptikkoja on myös käytetty Johanneksen kirjallisuuskritiikin tukena. Vaikka edellä oletinkin, että synoptikkoja on käytetty Johanneksen myöhemmissä kerrostumissa, on syytä suhtautua varauksellisesti synoptikkojen käyttöön Johanneksen kirjallisuuskritiikin tukena, sillä se johtaa väistämättä kehäpäätelmään. Lisäksi se perustuu usein näkemykseen, että yhden kertomuksen perusteella tehdyt päätelmät voisi yleistää koskemaan koko evankeliumia.

Tässä suhteessa jo vallitsevan kirjavan käytännön pitäisi itse asiassa olla varoittava esimerkki. Vanhat kirjallisuuskriitikot, ennen kaikkea Eduard Schwartz ${ }^{45}$, Julius Wellhausen ${ }^{46}$ ja Friedrich Spitta ${ }^{47}$ käyttivät yhteyksiä synoptikkoihin todisteena Johanneksen myöhäisestä kirjallisesta kerrostumasta. Samoin Marie-Émile Boismard lähtee liikkeelle oletuksesta, että yksi Johanneksen myöhemmistä kerrostumista perustuisi synoptisen materiaalin käyttöön. Niinpä yhteydet synoptikkoihin osoittavat, milloin tämä nimenomainen kerrostuma (Jean II-B) on kyseessä. ${ }^{48}$ Monet kirjallisuuskriitikot, esimerkiksi Robert Tomson

\footnotetext{
${ }^{45}$ Schwartz 1907-1908.

${ }^{46}$ Wellhausen 1908.

${ }^{47}$ Spitta 1910.

${ }^{48}$ Boismard \& Lamouille 1977.
} 
Fortna, lähtevät taas liikkeelle Gardner-Smithin ratkaisusta. Tämän jälkeen päättely kulkee seuraavassa kehässä: Koska yhteydet synoptikkoihin eivät selity suoralla riippuvuudella, Johanneksen käyttämä lähde voidaan rekonstruoida synoptikkojen vastaavien esitysten tai jopa kielellisten yhteyksien avulla. Näin evankelista tai muu kertomuksen kirjoittaja on voinut lisätä kertomukseen vain ainesta, joka ei viittaa synoptikkojen käyttöön!

\section{Ockhamin partaveitsi eksegeettisenä metodina?}

Esittämäni näkemykset Johanneksen ja synoptikkojen suhteista viittaavat samaan suuntaan kuin ne, jotka on saavutettu käyttämällä yksinkertaisesti Ockhamin partaveistä. Olen kuitenkin tietoisesti varonut vetoamasta tähän periaatteeseen, sillä Ockhamin partaveitsen käytöllä eksegeettisenä metodina on käsittääkseni tiettyjä rajoituksia.

1. Käydyssä keskustelussa Johanneksen ja synoptikkojen suhteista Ockhamin partaveitsen käyttöä voisi luonnehtia seuraavasti: on parempi olettaa riippuvuus olemassa oleviin lähteisiin, toisin sanoen synoptisiin evankeliumeihin kuin lähteisiin, joiden olemassaoloa ei ulkoisin perustein ole voitu todistaa. ${ }^{49}$

Tällainen sovellutus on kuitenkin jossain määrin ongelmallinen: se tuottaa jo metodina sinänsä vain yhdenlaisia tuloksia. Jos kahden tekstin välillä ylipäätään on yhtäläisyyksiä, tämän sovellutuksen perusteella niiden täytyy olla kirjallisesti toisistaan riippuvaisia. Jos tämä metodi otetaan lähtökohdaksi, voidaan kaikki muu keskustelu Johanneksen ja synoptikkojen suhteista unohtaa.

2. Jos mainittua sovellutusta käytetään asiaan kuuluvalla johdonmukaisuudella, voimme heittää hyvästit myös Jeesuksen puheiden kokoelmalle (Q). ${ }^{50}$ Tästä lähteestä ei toistaiseksi ole löytynyt yhtään käsikirjoitusta, vaan se on rekonstruoitu kaksilähdeteorian pohjalta.

\footnotetext{
${ }^{49}$ Vrt. Sabbe 1992, 385.

${ }^{50}$ Näin itse asiassa toimii Goulder uudessa Luukkaan kommentaarissaan, jossa hän hylkää koko Q-hypoteesin tarpeettomana. Samalla hän kritisoi jyrkästi Neirynckiä, joka tukee Q-
} 
3. On syytä lisäksi kysyä, voiko Ockhamin partaveitsen avulla, toisin sanoen tieto-opillisella argumentilla todellakin leikata pois sen historiallisen mahdollisuuden, että Matteuksen tai Luukkaan perusteella olisi syntynyt uutta suullista traditiota, joka olisi voinut kulkeutua Johanneksen kirjoittajan käsiin tai korviin..$^{51}$ Toisin sanoen soveltuuko Ockhamin partaveitsi historialliseen tutkimukseen - etenkin sellaiseen, jonka lähdepohja joka tapauksessa on riittämätön, ja jos soveltuu, niin millä ehdoilla?

Päätelmäni on kaksiosainen. (a) Ockhamin partaveitsen korostaminen vie huomion sivuun siitä Daueria ja Neirynckiä yhdistävästä metodisesta perusoivalluksesta, että synoptikkojen sisäinen redaktiokritiikki liittyy erottamattomasti Johanneksen ja synoptikkojen suhteiden arviointiin. (b) Dauerin ja Neirynckin mallien välistä paremmuutta ei lopullisesti voi ratkaista pelkän Ockhamin partaveitsen perusteella, ei myöskään kysymystä, tunsivatko Johanneksen kirjoittajat synoptikot vai eivät.

Ockhamin periaatetta ei tietenkään pidä hylätä kokonaan. Eksegeettisessä keskustelussa Ockhamin partaveitsellä voi leikata ennen kaikkea päällekkäisiä hypoteeseja - jollainen esimerkiksi Dauerin malli ei kuitenkaan mielestäni ole. Tällaisista päällekkäisistä hypoteeseista, jotka joutaisivat hyvin leikatuiksi, voisi mainita esimerkkinä Günter Reimin $^{52}$ esittämän teorian: Johannes ei käyttänyt synoptikkoja, vaan neljättä synoptista evankeliumia, jota ei kuitenkaan ole enää säilynyt.

Näin voinkin lopuksi palata kirjaan Paholaisen asianajaja, jonka määritelmää Ockhamin partaveitsestä lainasin alussa. Kirjassa todetaan - ehkä osin turhankin toiveikkaasti, mutta monin kohdin osuvasti:

Tieteellisissä teorioissa käsitellään usein arkijärjen ulottumattomissa olevia asioita, mutta hyvä tiede ei koskaan loukkaa Occamin periaatetta, ei ainakaan pitkään. Tieteen edistyminen vaatii tosin rohkeiden hypoteesien tekoa, ja rohkeilla hypoteeseilla on taipumus olla virheellisiä [!], mutta tutkimuksen

lähdettä, vaikka torjuukin kategorisesti Johanneksen ja synoptikkojen yhteiset lähteet (Goulder 1992, 24-25).

${ }^{51}$ Vrt. Denaux 1992, xviii.

${ }^{52}$ Reim 1974, 209-216. 
avoimuus kritiikille leikkaa ajan myötä turhan painolastin pois elinkelpoisen tieteen reunoilta. (12) 


\section{Uusi testamentti antiikin maailmassa}

\section{Johdanto}

Erillinen Uuden testamentin eksegetiikan professuuri perustettiin Helsingin yliopistoon, kun se vielä tunnettiin Keisarillisena Aleksanterin-yliopistona. Tsaari Nikolai II:n antamassa asetuksessa viran alaksi märiteltiin "Uuden testamentin kirjoitusten tulkinta alkukielen pohjalta sekä tekstikritiikki." En ole varma, käytettiinkö termiä "tekstikritiikki" jo tuolloin samassa erityismerkityksessä kuin nykyisin eli kuvaamaan Raamatun käsikirjoitusten vertailevaa tutkimusta. Joka tapauksessa lähinnä tälle alueelle sijoittuivat viran ensimmäisten haltijoiden tutkimukset.

Tultaessa 1910-luvulle Uuden testamentin tutkimuksen ala oli jo selvästi laajentunut Helsingissäkin. Eräs tuon ajan teologian jatkoopiskelija kuvaa muistelmissaan omia tutkimusaikeitaan näin:

Luin Deissmannin kirjan "Licht vom Osten", joka valaisee konkreettisin esimerkein vanhojen papyruslöytöjen merkitystä U.T:n tutkimukselle. Se oli kylläkin hyödyllinen läksy. Tällaisen johdannon jälkeen aloin etsiä uudemmista kreikkalaisista tekstilöydöistä, joista oli jo painettu useita kokoelmia, joitain merkkejä hellenistisen ajan kansanomaisesta etiikasta. Se olisi voinut olla meriitti sekä ... apulaisen virkaan että Uuden testamentin professorin virkaan. Suosin eetillisiä käsitteitä sen tähden, että minun teki toistaiseksi mieli kiertää dogmaattisia riitakysymyksiä ja varsinaista raamatunkritiikkiä.

Opiskelijan suunnitelma jäi kuitenkin puolitiehen. Hän jatkaa: ”Koottuani vähän aikaa hajanaisia perusaineksia väsähdin ja jätin papyrukset toisille tutkijoille." Opiskelijan akateeminen ura ei kuitenkaan jäänyt tähän. Aarni Voipio siirtyi tutkimaan horrossaarnaajia, ja hänestä tuli 
teologisen tiedekunnan pitkäaikainen opettaja; käytännöllisen teologian professoriksi hänet nimitettiin vuonna 1935.

Jos Voipio olisi pitäytynyt alkuperäisessä tutkimusaiheessaan, hänen tutkimuksensa saattaisi olla erityisen ajankohtainen juuri nyt. Nyt, 2000-luvun alussa, Uuden testamentin suhde antiikin filosofiaan ja erityisesti Voipion mainitsemiin "eetillisiin kysymyksiin" on noussut jälleen vahvasti esiin.

Muun humanistisen tutkimuksen tavoin Uuden testamentin tutkimuksessakin voisi puhua yleisemminkin "historian paluusta." Tai ehkä "historian paluu" tapahtui niin nopeasti, etteivät monet Uuden testamentin tutkijat edes ehtineet huomata historian poissaoloa; siinä määrin läheisesti Uuden testamentin tutkimus on perinteisesti liittynyt antiikintutkimukseen.

Uuden testamentin tutkimus on kuitenkin sikäli erityisasemassa antiikintutkimuksen osana, että Raamattu on edelleen kristittyjen pyhä kirja, johon suhtaudutaan toisin kuin muihin antiikin teksteihin. Tästä syystä historiallisen raamatuntutkimuksen tuloksiin reagoidaan herkemmin kielteisesti kuin antiikintutkimuksen tuloksiin yleensä. Toisaalta Raamatun erityisasema näkyy siinä, että Uuden testamentin tutkimuksessa on muuta antiikintutkimusta aktiivisemmin nostettu esiin sellaisia aiheita, joilla on liittymäkohtia nykyajan maailmaan.

Esittelen tässä luennossa kaksi tällaista aihepiiriä. Ensimmäinen liittyy etniseen identiteettiin. Aiheesta on tullut keskeinen monikulttuurisuuden kasvaessa länsimaissa, mutta teema oli keskeinen myös Uuden testamentin maailmassa. Toinen teema on Rooman valtakunnan poliittinen retoriikka ja varhaisten kristittyjen suhde siihen. Imperiumin tutkimuksesta ("empire studies") on tullut viime vuosina yksi Uuden testamentin tutkimuksen erityisaloista. Sen syntyyn on vaikuttanut vapautuksen teologia, minkä vuoksi aihetta käsitteleviin tutkimuksiin liittyy yleensä myös poliittinen reflektio. Kriittinen analyysi Rooman valtakunnasta on yhdistetty kriittisiin pohdintoihin erityisesti Yhdysvaltojen taloudellisesta ja poliittisesta vallasta meidän aikamme maailmassa. 


\section{Paavalin monet identiteetit}

Suuri osa roomalaisajan kirjallisista lähteistä on peräisin Rooman valtakunnan eliittiin kuuluneilta henkilöiltä. Uusi testamentti on tässä suhteessa poikkeus. Sen kirjoittajat eivät kuuluneet aivan alimpiin luokkiin roomalaisessa yhteiskunnassa, mutta he eivät myöskään kuuluneet valtakunnalliseen tai edes paikalliseen eliittiin.

Erityisen kiinnostava hahmo tässä suhteessa on Paavali. Hän kertoo tehneensä työtä "omin käsin" (1. Kor. 4:12) ja jopa "yötä päivää" (1. Tess. 2:9). Siitä huolimatta että Paavali ansaitsi elantonsa käsityöläisenä, hän kuitenkin pystyi sommittelemaan laajoja opetuskirjeitä, joissa näkyy argumentoinnin rakentamisen taito ja kreikkalaisen retoriikan hallinta. Paavalin kirjeistä on päätelty, että hänellä oli suhteellisen laaja retorinen koulutus sekä jonkinasteinen antiikin filosofisten suuntausten tuntemus. Paavali on näin esimerkki siitä, kuinka kreikkalainen koulutus oli antiikin maailmassa myös niiden ulottuvilla, jotka eivät kuuluneet eliittiin.

Kreikkalainen ja juutalainen kulttuuri kohtasivat Paavalin persoonassa. Vaikka Paavali oli saanut kreikkalaisen koulutuksen, hän korostaa juutalaista taustaansa. Hän kertoo olevansa "heprealaista" syntyperää ja kuuluneensa fariseusten ryhmään ennen kääntymistään kristinuskoon (Fil. 3:3).

Paavali tekee selvän eron "kreikkalaisen" ja "juutalaisen" identiteetin välillä, mutta asettuu itse näiden väliin. Yhtäältä hän jakaa ihmiset selkeästi "juutalaisiin" ja "kreikkalaisiin" tai "niihin joilla ei ole lakia." Toisaalta, mikäli uskomme Paavalin kuvausta itsestään, hänellä itsellään oli sekä juutalainen että ei-juutalainen identiteetti, joista hän saattoi kytkeä päälle kumman tahansa:

Voittaakseni Kristuksen omaksi juutalaisia olen ollut näille kuin juutalainen; voittaakseni lain alaisina eläviä olen näille ollut kuin lain alainen, vaikka en olekaan lain alainen. Voittaakseni ilman lakia eläviä olen näille ollut kuin eläisin ilman lakia, vaikka en olekaan Jumalan lakia vailla - onhan minulla Kristuksen laki. (1. Kor. 9:20)

Paavali sekä kaatoi että pystytti etnisiä raja-aitoja. Hänen mukaansa kristittyjen keskuudessa on "yhdentekevää, oletko juutalainen vai kreik- 
kalainen, orja vai vapaa, mies vai nainen.” (Gal. 3:26) Toisaalta Paavali harrasti mustamaalausta etnisin perustein. Juutalaisten Paavali vihjaa olevan aviorikkojia, varkaita ja temppelin ryöstäjiä (Room. 2:21-24). Ei-juutalaisten hän kertoo olevan halpamaisia, ahneita, pahoja, kateellisia, ymmärtämättömiä, epäluotettavia, rakkaudettomia ja säälimättömiä. He ovat täysin himojensa vallassa, mistä osoituksena ovat varsinkin homoseksuaaliset suhteet (Room. 1:23, 29-31).

Samanlaisia syytöksiä toisten kansojen täydellisestä moraalittomuudessa levittivät roomalaiset kreikkalaisista, kreikkalaiset roomalaisista, juutalaiset roomalaisista ja kreikkalaisista ja kreikkalaiset ja roomalaiset juutalaisista. Myös antiikin filosofit mustamaalasivat kilpailevien ryhmien edustajia Paavalin tavoin. Erityisesti epikurolaisia syytettiin pitkälti väärin perustein - ruumiin nautintojen tavoittelusta. Vähemmälle huomiolle on jäänyt, että epikurolainen filosofi Filodemos syytti yhteiskunnan pilareina pidettyjä stoalaisia isänmurhista ja homoseksuaalisista suhteista.

Paavali on poikkeuksellisen moniulotteinen tapausesimerkki siitä, kuinka ihmiset roomalaisajalla loivat itselleen erilaisia identiteettejä. Edes etninen identiteetti ei ollut muuttumaton tekijä, vaan se voitiin määritellä uusiksi tilanteen mukaan. Usein identiteetin määrittely tapahtui negaation kautta, toisin sanoen kertomalla, keitä me emme ole.

\section{Kristityt Rooman valtakunnassa}

Keisariajan Rooma on usein mielletty hirmuvallaksi, joka hallitsi rautaisella otteella valloittamiaan provinsseja. Tällainen kuva on kuitenkin vain osittain oikea. Esimerkiksi Vähässä-Aasiassa, joka oli varhaisen kristinuskon kanta-aluetta, Rooman ja paikallisen väestön suhteet olivat erittäin lämpimät. Kaupankäynti Rooman kanssa toi vaurautta Vähään-Aasiaan, ja Rooma rahoitti alueen maanjäristyksissä vaurioituneiden kaupunkien suuria jälleenrakennustöitä.

Imperiumin retoriikkaa käsittelevissä tutkimuksissa kristinusko kuvataan vaihtoehtoliikkeeksi, joka kyseenalaisti Rooman keisarivallan. Tämä näkemys ei sinänsä ole uusi. Adolf Deissmann esitti ajatuksen keisarikultin ja Kristuksen kultin poleemisesta suhteesta jo vuonna 
1908 ilmestyneessä tutkimuksessaan Licht vom Osten, jonka Aarni Voipiokin mainitsi innoittajanaan.

Konkreettisin esimerkki kahden kultin kilpailutilanteesta on Jeesuksesta käytetty nimitys "Jumalan Poika." Samaa nimitystä käytettiin myös Rooman keisareista. Rooman senaatti osoitti kunnioitustaan edesmenneille keisareille julistamalla heidät jumaliksi. Samalla uudesta keisarista tuli jo elinaikanaan "Jumalan poika" (divi filius).

Keisarillisella teologialla ja kristittyjen näkemyksillä Jeesuksesta oli muitakin yhteisiä piirteitä. Yhden tradition mukaan Augustuksen äiti oli ihminen, mutta isä jumala, Apollo. Runoilija Horatius ylisti Augustusta kansansa syntien sovittajaksi ja "läsnä olevaksi jumalaksi" (praesens deus). Provinssien piirtokirjoituksissa Augustuksesta käytetään nimitystä "jumala jumalasta”, ja hänet kuvataan "Vapahtajaksi, joka loistaa suuren taivaallisen Pelastajan kirkkautta." Vähässä-Aasiassa oli alueita, joissa kaikkien asukkaiden kaupungeissa ja maaseudulla tuli viranomaisten edessä vannoa ikuista uskollisuutta jumalille, Augustus mukaan lukien. Kun Paavali siis kutsuu Jeesusta "Jumalan Pojaksi" ja "maailman Vapahtajaksi," hän näyttää olevan vastakulttuurin edustaja, tai hän on ainakin vaarassa leimautua sellaiseksi.

Paavali epäilemättä kyseenalaistikin roomalaisten hallitsijoiden asettamisen jumalan asemaan, kun hän kirjoitti: "Onhan tosin sekä taivaassa että maan päällä niin sanottuja jumalia, moniakin jumalia ja herroja, mutta meillä on vain yksi Jumala, Isä.” (1. Kor. 8:5). Paavali ei kuitenkaan kyseenalaistanut keisarin ylläpitämää yhteiskuntaa. Päinvastoin: hän vaatii kristityiltä kuuliaisuutta roomalaista esivaltaa kohtaan, sillä sen valta on peräisin itse Jumalalta (Room. 13:1-7). Paavali ei myöskään johdonmukaisesti torju "imperiumin retoriikkaa", vaan käyttää sitä itsekin. Esimerkiksi hänen kuvauksensa siitä, kuinka aikojen lopussa Kristus kukistaa "kaiken vallan, mahdin ja voiman" ja alistaa "vihollisensa" jalkojensa alle (1. Kor. 15:24-25), muistuttaa ihannoivia kuvauksia Rooman keisareista, jotka alistivat kapinoivat kansat valtaansa.

Ilmestyskirja edustaa huomattavasti kielteisempää kantaa roomalaiseen yhteiskuntaan kuin Paavali. Vähän-Aasian seitsemälle seurakunnalle kirjoitettu Ilmestyskirja paljastaa, että samalla kun 
Vähän-Aasian kaupunkien eliitti ja todennäköisesti myös asukkaiden enemmistö piti yllä hyviä suhteita Roomaan, pinnan alla kyti protesti.

Ilmestyskirjassa Rooman valtakuntaa pilkataan helakan punaisiin pukeutuvaksi portoksi, joka istuu seitsemän vuoren päällä ja "hallitsee maan kaikkia hallitsijoita." (Ilm. 17:18) Ilmestyskirjan kirjoittaja ei katso hyvällä Vähän-Aasian poliittista ja taloudellista yhteistyötä Rooman kanssa: "... kaikki maailman kuninkaat ovat irstailleet hänen kanssaan, ja kaikki maailman kauppamiehet ovat rikastuneet hänen vauraudestaan ja ylellisestä elämästään.” (Ilm. 18:3) Rooman valtakunnalle kirjoittaja povaa pikaista loppua. Erityisen seikkaperäisesti hän kuvaa, kuinka kauppiaat valittavat tuhoutunutta kaupunkia:

Maailman kauppamiehet itkevät ja surevat häntä, sillä enää ei kukaan osta heidän tavaroitaan: ei kultaa, hopeaa, jalokiviä eikä helmiä, ei pellavakangasta, ei purppurakangasta, ei silkkiä eikä helakanpunaisia kankaita, ei tuoksuvaa tuijapuuta, ei norsunluusta eikä jalopuusta tehtyjä esineitä, ei pronssi-, rautaeikä marmoritöitä, ei kanelia eikä muita mausteita, ei suitsukkeita, ei hajuvoiteita eikä suitsutuspihkaa, ei viiniä eikä öljyä, ei hienoja jauhoja eikä viljaa, ei nautakarjaa, ei lampaita, ei hevosia eikä vaunuja, ei orjia, ihmisiä ruumiineen ja sieluineen. (Ilm. 18:11-13)

Ilmestyskirjan näkökulma poikkeaa jyrkästi Vähän-Aasian yleisestä, Rooma-myönteisestä ilmapiiristä. Ilmestyskirja osoittaa samalla, etteivät alueen kaikki asukkaat olleet tyytyväisiä vallitsevaan poliittiseen ja taloudelliseen tilanteeseen kasvaneesta vauraudesta huolimatta.

llmestyskirjankaan retoriikka ei kuitenkaan ole puhtaasti antiimperialistista. Kirjan kirjoittaja ei ole huolissaan maailman rikkauksien kerääntymisestä yhteen paikkaan, vaan pikemminkin siitä, että rikkaudet ovat kerääntyneet väärään paikkaan. Ilmestyskirjan lopussa kuvataan, kuinka taivaasta maan päälle laskeutuu Uusi Jerusalem, jonne tuodaan "kaikki kansojen kalleudet ja ihanuudet." Sinne myös "maailman kuninkaat" tuovat "mahtinsa kaiken loiston", ja kristityt saavat hallita "kuninkaina aina ja ikuisesti." (Ilm. 21:24-22:5) Rooma-kritiikistä huolimatta Ilmestyskirja päättyy näin yhdenlaiseen toisintoon ikuisen Rooman ja sen ikuisen hallitusvallan teemasta.

Ehkä sitä kuuluisaa historian ironiaa voi nähdä siinä, että Uuden testamentin alalle, jolle tsaari Nikolai II aikanaan perusti oppituolin, on 
syntynyt vahvasti imperiumikriittinen tutkimussuunta. Tämän tutkimussuunnan vaarana on, että siinä luodaan yksipuolinen kuva varhaisista kristityistä pelkästään "imperiumin retoriikan" vastustajina. Siitä miten asioiden pitäisi olla on päätelty miten ne ovat olleet. Edellä kuvaamani esimerkit osoittavat, että varhaiset kristityt eivät ainoastaan vastustaneet imperiumia, vaan heillä oli myös unelma omasta, toisenlaisesta imperiumista, jossa siinäkin viholliset joko hävitetään maan päältä tai alistetaan uuden vallan alle.

Tästä huolimatta imperiumin tutkimus on mielestäni tärkeä Uuden testamentin tutkimuksen osa-alue yhtälltä historiallisen näkökulman kannalta, mutta toisaalta myös siksi, että se voi synnyttää teologikunnassa, niin opiskelijoissa kuin opettajissakin, tervettä kriittisyyttä oman aikamme imperiumeja kohtaan. 


\section{Varhainen kristinusko ja "gnostilaisuus"}





\section{Gnostilaisuus ja kristinusko}

(2005)

\section{Nag Hammadin kirjasto ja Da Vinci -koodi}

Kolme egyptiläistä maanviljelijäveljestä pienestä al-Qasrin kylästä teki vuonna 1945 sattumalta yhden viime vuosisadan merkittävimmistä tekstilöydöistä. He olivat kaivamassa lannoitemaata läheisen vuoren juurella, kun yhden veljeksen hakku osui ruukkuun. Sen sisältä paljastui 12 tai 13 papyrusarkeille kirjoitettua, niteiksi koottua kirjaa, jotka oli päällystetty kauniisti koristelluilla nahkakansilla. Tämän kokoelman tekstit, joita on yhteensä 52, olivat suurelta osin aiemmin tuntemattomia kristillis-gnostilaisia tekstejä. Kokoelma on peräisin 350-luvulta jKr., mutta useimmat siihen kuuluvista teksteistä on kirjoitettu 100200-luvuilla. Veljesten löytämä muinaisten tekstien kokoelma tunnetaan nykyisin Nag Hammadin kirjastona, sillä Nag Hammadi on ainoa hieman suurempi paikkakunta löytöpaikan lähistöllä. Tutkijapiireissä kulkevan sitkeän huhun mukaan kirjasto sai nimensä Nag Hammadin mukaan, koska siellä oli löytöpaikan lähin baari, joten kokoelman ensimmäiset tutkijat asettuivat sinne.

Varhaisen kristinuskon tutkimuksen kannalta Nag Hammadin kirjastolla on suuri merkitys. Gnostilaista kristinuskoa alettiin jo varhain pitää harhaoppina. Kun kristinusko nousi erityisasemaan Rooman valtakunnassa 300-luvulla jKr., gnostilaisten kristittyjen suhteellisen laajaa kirjallista tuotantoa alettiin hävittää, ja heidän näkemyksensä tunnettiin tämän jälkeen ainoastaan heitä vastustaneiden kristittyjen opettajien ja piispojen poleemisista kuvauksista. Nag Hammadin kirjasto on erityisen merkittävä siksi, että suuri osa siinä olevista 
kirjoituksista on gnostilaisten kristittyjen itsensä kirjoittamia tekstejä, toisin sanoen ensi käden lähteitä.

Viime vuonna ja tämän vuoden alussa Nag Hammadin kirjasto on noussut esille Dan Brownin menestysromaanin Da Vinci-koodi ansiosta. Kirjan mukaan Nag Hammadin tekstit paljastavat sellaisen totuuden kristinuskosta, jota kirkossa on yritetty vaientaa vuosisatojen ajan. Da Vinci -koodissa Nag Hammadin kirjastoa ja Kuolleen meren tekstejä, jotka löydettiin vain kaksi vuotta Nag Hammadin kirjaston jälkeen, pidetään todisteina varhaisimmasta, mutta sittemmin salatusta kristinuskosta. Kuolleen meren teksteillä ei tosin oikeasti ole mitään tekemistä gnostilaisen tai minkään muunlaisenkaan kristinuskon kanssa; nämä tekstit ovat peräisin muusta yhteiskunnasta erilleen vetäytyneeltä juutalaiselta yhteisöltä.

Nag Hammadin kirjaston tekstit sen sijaan rikastuttavat käsitystämme varhaisesta kristinuskosta ja sen monimuotoisuudesta. Ne eivät tosin anna yksiselitteistä tukea $D a$ Vinci -koodissa esitetyille väitteille. ${ }^{1}$ Dan Brown on kuitenkin onnistunut siinä, missä gnostilaisuuden tutkijat ovat pitkälti epäonnistuneet: hänen kirjassaan esitetty teoria, että gnostilaisista teksteistä löytyy kirkon tähän asti tarkoin varjelema totuus Jeesuksesta, on saanut ihmiset kiinnostumaan aivan uudella tavalla näistä teksteistä.

\section{Mitä on gnostilaisuus?}

Suurin osa Nag Hammadin kirjaston teksteistä edustaa gnostilaista tulkintaa kristinuskosta. On tosin syytä huomauttaa, etteivät kirjaston kaikki tekstit ole gnostilaisia. Kirjastossa on säilynyt muun muassa koptinkielinen katkelma Platonin teoksesta Valtio sekä katkelma hermeettisestä tutkielmasta Asklepios. Myöskään kirjaston tunnetuin teksti, Tuomaan evankeliumi, ei ole varsinaisesti gnostilainen, vaikka monet tutkijat näin olettavatkin. Tämä teksti on varhainen,

\footnotetext{
${ }^{1}$ Dunderberg 2005b.
} 
todennäköisimmin ensimmäisen ja toisen vuosisadan taitteessa syntynyt kokoelma Jeesuksen opetuksia.

Mitä sitten on gnostilaisuus, jota useimpien Nag Hammadin tekstien katsotaan edustavan? Uusimmissa aihetta käsittelevissä tutkimuksissa ja yleisesityksissä on kiinnitetty huomiota termin 'gnostilaisuus' käyttöön liittyviin ongelmiin. Termi ei esiinny antiikin lähteissä toisin kuin esimerkiksi juutalaisuus, ioudaismos, tai kristinusko, khristianismos. Termin gnostilaisuus, tai paremminkin 'gnostisismi' ('gnosticisme') loi 1600-luvulla elänyt englantilainen Henry More, joka käytti termiä kuvaamaan yhtä Ilmestyskirjan alkusivuilla vastustettua oppia. ${ }^{2}$ Kyse on eräänlaisesta taudinmäärityksestä varhaista kristinuskoa vaivanneelle 'harhaopille'. Kuvaavaa on, että More kehitti termin 'gnostisismi' samoihin aikoihin kuin alettiin puhua 'homoseksualismista' yhtenä sairauden kategoriana.

Moresta lähtien sanan 'gnostilaisuus' (tai 'gnostisismi') käyttö on yleensä ollut kaikkea muuta kuin arvovapaata. Harvardin yliopiston professori Karen King on kiinnittänyt huomiota erityisesti siihen, mihin tutkijat oikeastaan ovat tarvinneet termiä gnostilaisuus. Sen avulla on ennen kaikkea haluttu luoda kuva 'toisesta', johon sitten on verrattu 'aitoa' tai 'alkuperäistä' kristinuskoa:

Gnostilaisuus on paljolti luotu harhaoppiseksi toiseksi, joka on suhteessa monenlaisiin ja alati muuttuviin käsityksiin oikeaoppisesta kristinuskosta. ... Gnostilaisuudesta tekee järjellisen kategorian pitkälti juuri apologeettinen pyrkimys puolustaa normatiivista kristinuskoa. ... Gnostilaisuus on tulkittu marginaaliseksi, lahkolaiseksi, esoteeriseksi, myyttiseksi, synkretistiseksi, loismaiseksi ja itäiseksi uskonnoksi. Sen vastakohta ovat oikeaoppisen kristinuskon kaltaiset uskonnot, jotka edustavat pääuomaa ja ovat alkuperäisiä, etnisiä, historiallisia, järjellisiä ja universaaleja. ${ }^{3}$

Termin 'gnostilaisuus' sisältöä hämärtää entisestään se, että sanaa on käytetty mitä erilaisimpien ilmiöiden yhteydessä. Romanialainen uskontotieteilijä ja gnostilaisuuden tutkija Ioan Culianu kuvaa tätä

\footnotetext{
${ }^{2}$ Layton 1995.

${ }^{3}$ King 2003b, 2-3.
} 
ongelmaa hauskasti; on huomautettava, ettei yksikään hänen luettelemistaan esimerkeistä ei ole keksitty, vaan ne kaikki perustuvat humanistisessa tutkimuksessa esitettyihin väitteisiin:

Aikoinaan uskoin, että gnostilaisuus oli tarkasti määritelty, myöhäisantiikin uskonnonhistoriaan kuuluva ilmiö. ... Kuitenkin jouduin pian huomaamaan, että olin ollut todella lapsellinen. Gnostilaista ei ollut ainoastaan gnosis, vaan myös katoliset kirjoittajat olivat gnostilaisia, samoin uusplatonikot; uskonpuhdistus oli gnostilaista, kommunismi oli gnostilaista, natsismi oli gnostilaisuutta, samoin liberalismi, eksistentialismi ja psykoanalyysi olivat gnostilaisia, moderni biologia oli gnostilaista, Blake, Yeats, Kafka, Rilke, Proust, Joyce, Musil, Hesse ja Thomas Mann olivat gnostilaisia. Gnosiksen erittäin arvovaltaisilta tutkijoilta opin vielä, että tiede on gnostilaista ja taikausko on gnostilaista; valta, vallan vastustaminen ja vallan puute ovat gnostilaisia; vasen on gnostilaista ja oikea on gnostilaista; Hegel on gnostilainen ja Marx on gnostilainen; Freud on gnostilainen ja Jung on gnostilainen; kaikki asiat ja niiden vastakohdat ovat yhtä lailla gnostilaisia. ${ }^{4}$

Culianun kuvauksen valossa ei ole ihme, että eräät gnostilaisuuden tutkijat ovat ehdottaneet luopumista termistä 'gnostilaisuus' kokonaan. Amerikkalainen Michael Williamsin mukaan 'gnostilaisuudesta' puhuminen antaa harhaanjohtavan kuvan yhtenäisestä ajattelutavasta ja itsenäisestä uskonnosta, jota ei ole koskaan ollut olemassa ainakaan siinä muodossa kuin sitä kuvataan nykyaikaisessa tutkimuksessa. 'Gnostilaisuudesta' ja 'gnostilaisista' puhuttaessa toistetaan lähes automaattisesti ennakkoluuloja ja yleistyksiä, jotka perustuvat pelkästään tämän suuntauksen vastustajien syytöksiin. Siksi termille gnostilaisuus olisi Williamsin mukaan pyrittävä etsimään neutraalimpia ja tutkimuksellisesti informatiivisempia vastineita. ${ }^{5}$

Williamsin oma ehdotus 'raamatulliset demiurgitraditiot' ei kuitenkaan ole herättänyt suurta ihastusta edes tutkijoiden parissa, eikä termi gnostilaisuus ole kadonnut yleisestä käytöstä. Termiin suhtaudutaan nyt kuitenkin huomattavasti varovaisemmin kuin vielä vuosikymmen sitten, ja sen määrittelyyn yhtä hyvin kuin siihen, mitä varten

${ }^{4}$ Culianu 1984, 290.

${ }^{5}$ Williams 1996. 
tällaisia määritelmiä yleensä luodaan ja mihin niitä tarvitaan, on paneuduttu aiempaa huomattavasti tarkemmin.

\section{Pelastava tieto}

Termi 'gnostilaisuus' on johdettu kreikan kielen sanasta gnosis, joka tarkoittaa tietoa. Vaikka Moren luoma termi 'gnostisismi' on myöhäinen, substantiivista gnosis johdettu adjektiivi gnostikos esiintyy jo varhaisissa lähteissä. Lyonin piispa Irenaeus kirjoitti 180 -luvulla jKr. viisiosaisen teoksen valentinolaista kristinuskoa vastaan, joka oli varhaiskristillisistä gnostilaisista ryhmistä merkittävin. Tässä teoksessa, joka tunnetaan parhaiten nimellä Harhaoppeja vastaan (Adversus Haereses), Irenaeus mainitsee varhaiskristillisen ryhmän, jonka jäsenet kutsuivat itseään 'gnostikoiksi'. Irenaeus käyttää heistä myös nimitystä 'gnostilainen koulukunta' (he gnostike hairesis), ja on mahdollista, että nimitystä käyttivät myös kyseiseen ryhmään kuuluneet jäsenet. ${ }^{6}$

Nimityksen taustalla voidaan nähdä Platonin filosofinen perintö. Platon erotti toisistaan 'käytännöllisen tiedon' eli erilaiset taidot ja teoreettisen tiedon, joka voitiin saavuttaa puhtaiden tieteiden kuten matematiikan avulla. Tästä teoreettisesta tiedosta Platon käytti sanoja gnosis ja gnostikos. Irenaeuksen kuvaama ryhmä on kuitenkin nähtävästi ensimmäinen, joka alkoi käyttää itsestään nimitystä 'gnostikos', 'gnostilainen'.

Gnostilaisten kristittyjen käsitys gnosiksen sisällöstä oli kuitenkin erilainen kuin Platonilla. Heille gnosis oli ennen kaikkea tietoa, joka auttaa ihmistä ymmärtämään oman paikkansa maailmassa ja tarjoaa tien sisäiseen oivallukseen ja sitä kautta pelastukseen. Klassinen kuvaus tällaisen tiedon sisällöstä on peräisin valentinolaiselta Theodotosnimiseltä kristityltä, joka toimi opettajana toisen vuosisadan jälkipuoliskolla:

\footnotetext{
${ }^{6}$ Layton 1995.
} 
Meitä ei tee vapaaksi pelkkä kaste, vaan tieto siitä, keitä me olimme ja mitä meistä on tullut, missä olemme olleet tai mihin olemme joutuneet, minne olemme matkalla ja mistä meidät on vapautettu, mitä on syntymä ja mitä jälleensyntyminen.

(Clemens Aleksandrialainen, Katkelmia Theodotokselta 76.2)

Tunnistettavin ja samalla kiistanalaisin kohta gnostilaisessa ajattelussa oli oletus, ettei maailmaa ole luonut korkein Jumala, Kaikkeuden Isä, vaan alempi, tietämätön luojajumala, demiurgi. Tämä käsitys merkitsi luonnollisesti syvää juopaa perinteiseen juutalaiskristilliseen ajatteluun, jossa korkein Jumala ja maailman luoja olivat yksi ja sama hahmo. Tämä käsitys on epäilemättä myös tärkein syy siihen, että gnostilaista kristinuskoa alettiin pitää harhaoppina.

Gnostikkojen ajatus tietämättömästä luojajumalasta ei kohdannut vastustusta ainoastaan toisten kristittyjen parissa, vaan siihen kiinnittivät huomionsa myös ei-kristityt filosofit, jotka tukeutuivat Platonin käsityksiin. Platon esitti tosin näkemyksen demiurgista eli 'käsityöläisestä', joka loi aistein havaittavan maailman käyttäen mallinaan muuttumattomana pysyvää ideoiden maailmaa, mutta hän ei olisi missään tapauksessa yhtynyt gnostilaiseen ajatukseen tietämättömästä demiurgista. Hänen mukaansa maailmankaikkeus on paras mahdollinen juuri siksi, että demiurgi on luonut sen:

Jos käsityöläinen pitää aina silmällä sitä, mikä pysyy samana, käyttäen sitä esikuvana ja muovaten esineen sen hahmon ja kyvyn mukaiseksi, tulee hänen teoksestaan pakostakin kaunis. ... Jos maailmankaikkeus on kaunis ja sen luoja hyvä, on selvää, että hän sitä luodessaan on kiinnittänyt katseensa ikuiseen. ... Sillä kaikesta mitä on syntynyt, maailmankaikkeus on kauneinta ja sen luoja on kaikkien syiden joukossa paras. (Timaios 28a-29a; suom. A. M. Anttila)

Toinen keskeinen ajatus gnostilaisessa kristinuskon tulkinnassa on, että ihminen on sukua korkeimmalle Jumalalle. Vaikka ihmisen ruumis onkin peräisin luojajumalalta, hänen sisällään on korkeimmalta Jumalalta saatu, eläväksi tekevä henki. Vasta tämän hengen saatuaan ihminen muuttuu saviveistoksesta eläväksi olennoksi. Ihminen on kuitenkin vaarassa unohtaa sisällään asuvan hengen; unohduksen saa 
aikaan demiurgin luoma ruumis. Tästä syystä tarvitaan erityinen, taivaasta alas laskeutuva ilmoittaja, joka muistuttaa ihmistä tämän jumalallisesta alkuperästä. Kristillisistä gnostilaisuutta edustavissa teksteissä juuri tämä on Kristuksen päätehtävä: hän herättää ihmisen unohduksen unesta ja saa tämän muistamaan taivaallisen alkuperänsä. Meille tutumpi ajatus Kristuksesta syntien sovittajana loistaa poissaolollaan Nag Hammadin teksteissä.

\section{Gnostilaisuus ja kristinusko}

Gnostilaiseen kristinuskoon liittyi epäilemättä ajatus keskimääräistä korkeamman tason kristillisyydestä. Nag Hammadin teksteissä ei esiinny kertaakaan termi 'gnostilainen', vaan niissä käytetään muita termejä kuten 'valitut', 'valon lapset', 'järkkymätön sukukunta' ja 'Setin jälkeläiset'. Edellä mainitut valentinolaiset kristityt pitivät itseään 'hengellisinä' kristittyinä erotuksena tavallisista kirkkokristityistä, jotka olivat 'sielullisia'; jaottelun taustalla oli Paavalin jako hengellisiin ja sielullisiin kristittyihin.

Ajatus korkeamman tason kristillisyydestä oli toinen keskeinen syy gnostilaisen kristinuskon kohtaamaan vastustukseen. Konfliktin syy ei siis ollut ainoastaan teologinen, vaan myös sosiaalinen. Irenaeus valitti, että hänen vastustamansa valentinolaiset kristityt ylemmyydentunnossaan jopa kävelivät eri tavoin kuin muut kristityt: he "käyskentelivät pönäkästi ja pilkallinen ilme kasvoillaan, heillä oli pöyhkeän kukon kaikki elkeet," Irenaeus toteaa. ${ }^{7}$ Tämänkaltaisilla kommenteilla Irenaeus pyrki saattamaan vastustajansa naurunalaisiksi ja herättämään epäilyksiä heidän edustamaansa hengellisyyttä kohtaan. Varmemmaksi vakuudeksi Irenaeus lisää, että valentinolaiset myös viettelivät naisia, söivät epäjumalille uhrattua lihaa, osallistuivat pakanallisiin juhliin ja jopa gladiaattoriotteluihin. Tosin Irenaeuskin joutui myöntämään, että

${ }^{7}$ Harh. 3.15.2; vrt. Dunderberg 2004, 157-158. 
muutamat hänen vastustajistaan elivät esimerkillisesti, mutta he olivat juuri tämän vuoksi aivan sietämättömän ylimielisiä.

Kaiken tämän perusteella voisi kuvitella, että Irenaeuksen vastustamat valentinolaiset gnostikot olisivat erottuneet selkeästi omaksi ryhmäkseen. Näin ei kuitenkaan ollut asian laita. Irenaeuksen teoksesta Harhaoppeja vastaan käy ilmi, että valentinolaiset osallistuivat muiden kristittyjen kanssa yhteisiin jumalanpalveluksiin, yhtyivät samaan uskontunnustukseen ja lukivat samoja tekstejä kuten Paavalin kirjeitä ja Johanneksen evankeliumia. Vielä tämän teoksen kirjoittamisen jälkeen valentinolaisia oli korkeilla paikoilla Rooman seurakunnan kirkollisessa hierarkiassa. Ero valentinolaisen ja 'tavallisen' kristinuskon välillä oli siis kaikkea muuta kuin selvä.

Irenaeus pyrki teoksellaan luomaan selvän rajan valentinolaisuuden ja 'oikean' kristinuskon välillä. Siksi voidaan ajatella, että vasta hän eräällä tavalla loi valentinolaisuuden sellaisena kuin se nykyisin tunnetaan; sitä ei ollut olemassa selkeänä oppijärjestelmänä ennen kuin Irenaeus rakensi käytettävissä olleiden lähteidensä pohjalta systemaattisen kuvan vastustajiensa käsityksistä. Nag Hammadin kirjaston tekstit osoittavat, että valentinolaiset kristityt olivat kiinnostuneita monista sellaisista teemoista, joita Irenaeus ei teoksessaan mainitse lainkaan. $\mathrm{He}$ olivat muun muassa yhtä lailla huolissaan kirkkoa kohdanneista vainoista kuin muutkin kristityt ja antoivat ohjeita siitä, miten kristittyjen tulisi elää.

\section{Kertovatko Nag Hammadin tekstit salatun totuuden kristinuskosta?}

Artikkelini alussa viittasin Dan Brownin kirjaan Da Vinci -koodi ja siinä esitettyyn teoriaan, että Nag Hammadin kirjasto paljastaa salatun totuuden kristinuskosta. Olisiko mahdollisesti näin? Riippuu siitä, mitä tämän salatun totuuden ajatellaan olevan. Nag Hammadin teksteistä ei löydy selviä todisteita Jeesuksen ja Marian avioliitosta tai jälkeläisistä. Nag Hammadin tekstit eivät myöskään korosta Jeesuksen inhimillisyyttä, kuten $D a$ Vinci -koodissa väitetään. Kristus esitetään niissä pikemminkin vielä selkeämmin jumalallisena hahmona kuin Uudessa 
testamentissa: hän on Jumalan luota alas laskeutunut ilmoittaja, joka ylösnousemuksensa jälkeen kertoo sanomansa valituille opetuslapsilleen.

Kätkettyä viisautta Nag Hammadin tekstit kuitenkin tarjoavat monessakin mielessä. Monet kirjaston teksteistä esitellään Jeesuksen salattuna opetuksena; tunnetuin esimerkki on Tuomaan evankeliumin alku: "Elävä Jeesus puhui nämä salaiset sanat, ja Didymos Juudas Tuomas kirjoitti ne muistiin. Hän (Jeesus?) sanoi: 'Joka löytää näiden sanojen selityksen, se ei ole näkevä kuolemaa.’” Kätkettyä viisautta Nag Hammadin tekstit ovat myös siinä mielessä, että kirjasto kätkettiin samoihin aikoihin, kun keisarin arvovallan taakseen saanut oikeaoppinen kristinusko alkoi taistella harhaoppeja vastaan myös Egyptissä. Aleksandrian piispa Athanasios hyökkäsi 300-luvun puolivälissä kirjoittamassaan kiertokirjeessään tarmokkaasti Uuden testamentin ulkopuolisia varhaiskristillisiä tekstejä vastaan. On hyvin mahdollista, että Nag Hammadin kirjasto kätkettiin sen jälkeen kun tämä kirje tuli tiedoksi tekstien löytöpaikan lähellä muinoin sijainneeseen luostariin, jossa kirjaston tekstit oli kopioitu. ${ }^{8}$

Sensuuri ei ollut ainoa harhaoppisiin kohdistunut painostustoimenpide. Vain muutamaa vuosikymmentä myöhemmältä ajalta on säilynyt tieto, että kiivaat oikeaoppiset munkit olivat polttaneet sekä juutalaisten synagogan että harhaoppisiksi leimattujen valentinolaisten kirkon ilman että esivalta olisi puuttunut asiaan. ${ }^{9}$ Kaiken tämän tukahduttamisen ja painostuksen jälkeen on kiinnostava historian oikku, että harhaoppisiksi tuomittujen kristittyjen kirjasto löytyi sattumalta 1600 vuotta myöhemmin. Kirjasto ei yksinään kerro koko totuutta varhaisesta kristinuskosta, mutta tarjoaa uutta ja mielenkiintoista aineistoa tämän totuuden etsijöille.

\footnotetext{
${ }^{8}$ Pagels 2003, 174-177.

${ }^{9}$ Ambrosius, Kirjeet 40-41; vrt. Dunderberg 2005a, 12.
} 


\section{Gnostilaisuus uskontojen ja uskonnonfilosofian risteyksessä}

(2001)

Uskonnolliset virtaukset ovat aina jossain määrin synkretistisiä. $\mathrm{Ne}$ omaksuvat joitain aineksia niitä ympäröivästä teologisesta, henkisestä ja sosiaalisesta kulttuurista. Gnostilaisuuden yhtenä tuntomerkkinä on pidetty sitä, että se on imenyt itseensä poikkeuksellisen paljon ulkopuolisia vaikutteita. Tähän arvioon on usein liitetty vähemmän mairittelevia vertauskuvia. Gnostilaisuutta on usein kuvattu loiseksi tai virukseksi, joka tunkeutuu ja pesiytyy helposti eri emouskontoihin.

Gnostilaisia on myös luonnehdittu "hellenistisen ajan intellektuaalisen maailman harakoiksi”, jotka keräilivät vaikutteita sieltä täältä. ${ }^{1}$ Tämä John Dillonin, arvostetun hellenistisen filosofian asiantuntijan hiljattain esittämä luonnehdinta gnostilaisista perustuu siihen sinänsä oikeaan havaintoon, että gnostilaisessa ajattelussa näkyy sekä juutalaisuudesta, kristinuskosta että hellenistisen ajan platonismista omaksuttuja ajatuksia. Kuitenkin on kyseenalaista leimata juuri gnostilaiset tällä perusteella "harakoiksi". Samoihin aineksiin perustui esimerkiksi 200luvun merkittävimpien aleksandrialaisten kristittyjen opettajien, Clemensin ja Origeneen, ajattelu, vaikka he päätyivätkin (ainakin osittain) gnostilaisista käsityksistä poikkeaviin näkemyksiin.

Gnostilainen tulkinta kristinuskosta oli joka tapauksessa merkittävä haastaja, kun varhaiskristillisellä kaudella kiisteltiin kristillisen sanoman

${ }^{1}$ Dillon 1999, 74. 
oikeasta tulkinnasta. Sen asema heikkeni selvästi vasta kun kristinusko sai suosituimmuusaseman Rooman valtakunnassa 300-luvulla jKr. Gnostilaisuus oli leimattu kristilliseksi harhaopiksi jo aiemmin, mutta nyt sen vastustajat saivat taakseen roomalaisen valtiovallan.

Koska gnostilaisia pidettiin harhaoppisina, heidän kirjoituksiaan on säilynyt ainoastaan poikkeustapauksissa. Kirkkoisien teoksissa on katkelmia heidän opetuksistaan, mutta vasta uudet tekstilöydöt, erityisesti Egyptistä 1945 löytynyt Nag Hammadin koptilais-gnostilainen kirjasto, ovat tuoneet tutkijoiden käyttöön runsaasti ensi käden lähteitä gnostilaisesta ajattelusta varhaiskristillisellä ajalla.

\section{Termi "gnostilaisuus"}

"Gnostilaisuus" sinänsä on ongelmallinen tieteellinen kategoria, jolle on poikkeuksellisen vaikeaa esittää yksiselitteistä määritelmää. ${ }^{2}$ Gnostilainen ajattelu määritellään usein niin väljästi, että sen piiriin sopisi hyvin erilaisia ajatustapoja. Erään teorian mukaan lähes kaikki uuden ajan filosofiset ja poliittiset virtaukset kuten hegeliläisyys, kommunismi, kansallissosialismi sekä kehitys- ja tiedeusko ovat tavalla toisella gnostilaisia aatevirtauksia. Useiden kirjailijoiden tuotannossa, kuten William Blaken ja Thomas Mannin, tuotannossa on nähty gnostilaisia piirteitä. ${ }^{3}$ Tavallisesti kuitenkin jää hämäräksi, mitä sana "gnostilainen" näissä yhteyksissä tarkalleen ottaen merkitsee. ${ }^{4}$

Kreikan "tietoa" tarkoittavasta sanasta gnosis johdettu termi "gnostilaisuus" ei esiinny antiikin ajan teksteissä, vaan se luotiin vasta

\footnotetext{
${ }^{2}$ Termin "gnostilaisuus" käyttöön liittyvistä ongelmista ks. Williams 1996.

${ }^{3}$ Ks. Culianu 1984, 290.

${ }^{4}$ Esimerkiksi juutalaisen mystiikan tutkimuksessa gnostilaisen ajattelun tuntomerkkeinä on pidetty "sellaisen tiedon omistamista, jota ei voi saavuttaa tavallisin älyllisin keinoin, vaan ainoastaan ilmoituksen ja mystisen valaistumisen avulla; taivaallisten maailmojen järjestystä koskevan salaisen opin omistamista; sekä sellaisten liturgisten ja liturgis-maagisten keinojen tuntemista, jotka avaavat kulkutien näihin maailmoihin.” Näin juutalaisen mystiikan tunnetuin tutkija G. Scholem; lainaus Rudolphin (1996, 157 n. 33) mukaan.
} 
1600-luvulla.5 Sen sijaan jo Platon käytti sanaa "gnosis" ja siitä johdettua adjektiivia "gnostilainen" (gnōstikos) puhuessaan sellaisesta tiedosta, joka liittyi "puhtaisiin tieteisiin" kuten matematiikkaan. Kyse oli "teoreettisesta tiedosta", jonka Platon erotti "käytännöllisestä tiedosta" eli erilaisista käytännön taidoista. ${ }^{6}$

Platon ei kuitenkaan käyttänyt adjektiivia "gnostilainen" substantivoituna henkilöistä, "gnostikoista", joilla olisi hallussaan "korkeampi" tieto. Kuitenkin toisella vuosisadalla $\mathrm{jKr}$. eräät ryhmät alkoivat kuitenkin kutsua itseään "gnostikoiksi." Kirkkoisä Irenaeus kuvaa näitä ryhmiä ja heidän opetuksiaan teoksessaan Harhaoppeja vastaan (180-luvulla jKr.). ${ }^{7}$ Irenaeuksen mukaan "gnostikot" opettivat, että jumalallinen maailma syntyi kaikkeuden Isän ja hänen ajatuksensa, Barbeloksi kutsutun hahmon, yhteistoiminnan tuloksena. Jumalallisessa maailmassa tapahtui heidän mukaansa muutos, kun yksi jumalallisista olennoista, Viisaus, loi ilman Isän suostumusta tietämättömän hallitsijan. Tämä hallitsija karkotetaan jumalallisesta maailmasta, ja hänestä tulee näkyvän maailman luoja, joka kuvittelee olevansa ainoa Jumala. ${ }^{8}$

Vaikka varhaiskristillisellä ajalla olikin itseään "gnostilaisiksi" kutsuneita ryhmiä, epäselvää on, kuinka laajasti tällaista nimeä todella käytettiin. Kirkkoisät alkoivat nimittää "gnostilaisiksi" myös sellaisia ryhmiä, jotka eivät itse käyttäneet tätä termiä, mutta joiden opetus muistutti edellä kuvattua "gnostilaisten" opetusta. Esimerkiksi Nag Hammadin kirjaston teksteissä sana "gnostilainen" ei esiinny lainkaan, vaan niissä omasta ryhmästä käytetään muita ilmauksia kuten "valitut", "valon lapset", "järkkymätön sukukunta", "hengelliset" - tai yksinkertaisesti "kristityt."

\footnotetext{
5 Termin gnostilaisuus, tai paremminkin 'gnostisismi' ('gnosticisme') loi tuolloin englantilainen Henry More, joka käytti termiä kuvaamaan yhtä Ilmestyskirjan alkusivuilla vastustettua oppia (Layton 1995).

${ }^{6}$ Platon erotti toisistaan tällaisen teoreettisen tiedon ja "käytännöllisen" tiedon eli erilaiset käytännön taidot (Valtiomies 258-259).

${ }^{7}$ Irenaeus käyttää heistä myös nimitystä 'gnostilainen koulukunta' (he gnostike hairesis), ja on mahdollista, että nimitystä käyttivät myös kyseiseen ryhmään kuuluneet jäsenet (Layton 1995).

${ }^{8}$ Irenaeus, Harh. 1.29 .
} 
Kun modernissa tutkimuksessa näiden ryhmien kannattajia kutsutaan gnostilaisiksi, termiä käytetään siis laajemmassa merkityksessä kuin antiikin aikana. Useat nykyisin "gnostilaisiksi" kutsutut henkilöt ymmärsivät itsensä lähinnä hengellisesti etuoikeutetuiksi kristityiksi. Osa heistä osallistui varhaisten kristillisten seurakuntien tavallisiin jumalanpalveluksiin, ja yhden gnostilaisen kristityn tiedetään toimineen Rooman piispa Viktorin läheisenä apulaisena vielä toisen ja kolmannen vuosisadan taitteessa. Gnostilaisuutta vastaan hyökänneille kirkkoisille erityisen suuri ongelma olikin se, ettei "gnostilaista" kristittyä ollut helppo erottaa "tavallisesta" seurakuntakristitystä.

Vaikka gnostilaisuus on terminä myöhäinen, se ei ole täysin harhaanjohtava. Gnostilaisissa teksteissä tiedolla todella on usein poikkeuksellisen keskeinen asema. "Tieto" ei näissä kirjoituksissa ole teoreettista tietoa kuten Platonilla, vaan sen kohteena on ihmisen jumalallinen alkuperä, johon ihmisen on märä palata. Lyhyenä yhteenvetona siitä, mistä gnostilaisessa ajattelussa on kyse, on usein käytetty seuraavaa katkelmaa Theodotoksen, gnostilaisen kristityn, opetuksista:

Meitä ei tee vapaaksi pelkkä kaste, vaan tieto siitä, keitä me olimme ja mitä meistä on tullut, missä olemme olleet tai mihin olemme joutuneet, minne olemme matkalla ja mistä meidät on vapautettu, mitä on syntymä ja mitä jälleensyntyminen.

(Clemens Aleksandrialainen, Katkelmia Theodotokselta, 78.2.)

Tieto ei kuitenkaan välttämättä korvaa uskoa gnostilaisessa ajattelussa, kuten usein oletetaan. Toisinaan usko todella ymmärretään tietoa selvästi alemmaksi hengellisyyden asteeksi, mutta usein "uskosta" puhutaan usein myös yhtä lailla arvostavasti kuin tiedosta. Edellä lainatussa katkelmassakaan kastetta ja tietoa ei aseteta vastakkain, vaan ne $y h d e s s a ̈$ takaavat ihmisen pelastumisen. 


\section{Onko gnostilaisuus uskonto?}

Vaikka tiettyjen varhaiskristilliseltä ajalta tunnettujen suuntausten yhteydessä voidaan perustellusti puhua "gnostilaisuudesta", tutkijat eivät ole yksimielisiä näiden suuntausten luonteesta. Tutkijat ovat eri mieltä siitä, mitkä ovat gnostilaisen ajattelun tunnusomaiset piirteet, ja erityisesti siitä, onko gnostilaisuus itsenäinen uskonto vai kristinuskon sisältä syntyisin oleva lahko.

Nag Hammadin kirjasto on pikemminkin vaikeuttanut kuin helpottanut gnostilaisen ajattelun yksiselitteistä määrittelemistä. Nag Hammadin tekstit eivät anna kuvaa yhtenäisestä gnostilaisesta ajattelutavasta, vaan ne edustavat toisistaan poikkeavia gnostilaisia käsityksiä. ${ }^{9}$ Aikaisempia yleistyksiä gnostilaisesta ajattelusta on jouduttu arvioimaan kirjaston löydyttyä uudelleen. Esimerkiksi kirkkoisien syytöksille gnostilaisten kristittyjen seksuaalisesta vapaamielisyydestä ei löydy tukea kirjaston teksteistä, vaan niissä korostetaan askeettista elämäntapaa.

Gnostilaisen ajattelun selkeimmin erottuva piirre jo varhaiskristillisellä kaudella oli ajatus kahdesta jumalasta, joita pidetään toisilleen vastakkaisina hahmoina. Todellinen, korkein Jumala, on maailmankaikkeuden yläpuolella tai "ympäröi" sitä, mutta hän ei ole maailman luoja. Maailman on luonut alempi luojajumala, demiurgi, tai ryhmä luojaenkeleitä. Luojajumalan keskeisin piirre on tietämättömyys: hän ei tunne todellista Jumalaa eikä tämän jumalallista maailmaa, vaan väittää olevansa ainoa Jumala. Kuten jatkosta käy ilmi, korkeimman Jumalan ja luojajumalan vastakkaisuuden aste tosin vaihtelee huomattavasti gnostilaisissa lähteissä.

Toinen gnostilaiselle ajattelulle tunnusomainen piirre on ihmiskäsitys, joka liittyy suoraan oppiin kahdesta jumalasta. Ihminen sijoittuu todellisen jumalan ja luojajumalan välimaastoon. Hänen ruumiinsa on peräisin luojajumalalta, mutta hänen sisällään on jumalallinen henki,

\footnotetext{
${ }^{9}$ Nag Hammadin kirjastossa on lisäksi sekä selvästi ei-gnostilaisia tekstejä (esim. katkelma Platonin dialogista Valtio) että sellaisia kirjoituksia, joiden "gnostilaisuudesta" tutkijat eivät ole yksimielisiä (esim. Tuomaan evankeliumi). Se että joku kirjoitus kuuluu Nag Hammadin kirjastoon, ei siis sinänsä vielä osoita, että kyseinen kirjoitus olisi gnostilainen.
} 
joka yhdistää hänet korkeimpaan Jumalaan. Tästä syystä myös ihmisen suhde luojajumalaan on vastakkainen. Tavallisesti luojajumalan kuvataan kadehtivan ihmistä tässä asuvan jumalallisen hengen takia, ja luojajumala yrittää saada ihmistä unohtamaan tämän hengen. Gnostilaisissa kirjoituksissa esiintyy usein ajatus ihmisestä, jonka luojajumala on vaivuttanut unohduksen uneen. Tällainen ihminen täytyy herättää, jotta hän muistaisi olevansa sukua todelliselle Jumalalle. Herättäjänä toimii yleensä ilmoittaja, joka on laskeutunut ihmisten maailmaan korkeimman Jumalan luota. Kristillisissä gnostilaisissa kirjoituksissa tätä ilmoittajaa kutsutaan yleensä Vapahtajaksi, mutta hänen tehtävänsä on hyvin erilainen kuin "valtauoman" kristillisyydessä.

Italian Messinassa vuonna 1966 pidetyssä konferenssissa tutkijat hahmottelivat edellä kuvattua huomattavasti yksityiskohtaisemman, mutta myös runsaasti arvostelua herättäneen määritelmän gnostilaisuudesta. ${ }^{10}$ Siinä erotettiin toisistaan "gnosis" ja "gnostilaisuus." "Gnosis" märiteltiin laajemmaksi uskonnolliseksi virtaukseksi, jonka tunnusmerkkinä on eliitille kuuluva tieto jumalallisista salaisuuksista. "Gnostilaisuus" sen sijaan rajattiin kuvaamaan sellaisia 100-luvulla jKr. esiintyneitä ryhmiä, joiden opetuksiin kuului ajatus jumalallisesta kipinästä ihmisen sisällä ja tämän todellisen minän pelastamisesta syntymän ja kuoleman hallitsemasta maailmasta.

Jako laajemman ilmiön, "gnosiksen", ja suppeammin rajatun "gnostilaisuuden" välillä perustui etenkin saksalaiseen tutkimusperinteeseen. Siinä "gnostilaisuudella" tarkoitetaan tavallisesti "gnosiksen" kristillistä muotoa, jonka rinnalla ajatellaan olevan muita "gnosiksen" ilmenemismuotoja kuten hermeettinen, juutalainen ja islamilainen gnosis. Jaottelun taustalla on oletus, että gnosis ja kristinusko ovat pohjimmiltaan toisistaan riippumattomia uskonnollisia ajattelutapoja. Gnosis ymmärretään ikään kuin virukseksi, joka "tunkeutuu kristinuskoon ja muodostaa sen kanssa erilaisia sekamuodostelmia" (Wilhelm Bousset), mutta joka voidaan tunnistaa ja erottaa "aidosti" kristillisistä näkemyksistä suhteellisen helposti.

${ }^{10}$ Bianchi 1967, xx-xxxii. 
Johdonmukainen seuraus tästä näkemyksestä on oletus, että on mahdollista hahmottaa gnosikselle ominainen, kristinuskosta poikkeava "ajattelumalli." Saksalaisen Kurt Rudolphin mukaan tällaisen ajattelumallin keskeiset piirteet ovat: ${ }^{11}$

- dualismi, joka näkyy erityisesti ajatuksessa alemmasta ja samalla epätäydellisestä luojajumalasta eli demiurgista. Koska demiurgi on epätäydellinen, myös hänen luomansa maailma ymmärretään pahaksi.

- monistinen käsitys siitä, että kaikki on alun perin lähtenyt liikkeelle jumalallisesta todellisuudesta ja että paluu tähän todellisuuteen on mahdollinen.

- pelastusoppi, jonka mukaan ihminen voi vapautua näkyvästä maailmasta saamansa uskonnollisen tiedon avulla. Keskeistä ei ole pelastuminen synnistä, kuten kristinuskossa, vaan sielun vapautuminen ruumiista ja aineen kahleista.

- eskatologia, jossa korostuu yksilön kokema sielun nousu jumalalliseen todellisuuteen, mutta johon sisältyy myös kosmisia ulottuvuuksia kuten pahojen henkivaltojen tuomitseminen aikojen lopussa.

- yhteisöelämä, jolle toisin kuin hierarkkiseen suuntaan kehittyvälle kirkolle oli luonteenomaista väljä organisaatio ja naisten aktiivinen osallistuminen.

- moraali, jolle luonteenomaisia ovat askeettiset korostukset, sekä kristinuskon valtauomaa kritisoivat käsitykset.

Näiden ominaispiirteiden perusteella Rudolph pitää gnosista alun perin ei-kristillisenä ja "suhteellisen itsenäisenä myöhäisantiikin uskontona." 12 Monet tutkijat ovat kuitenkin toista mieltä. Heidän mukaansa gnostilaisuuden synty on mahdollista selittää ainoastaan kristinuskosta

\footnotetext{
${ }^{11}$ Rudolph 1996, 19-26.

${ }^{12}$ Rudolph 1996, 61.
} 
käsin. ${ }^{13}$ Lisäksi Rudolphin luettelo "gnosiksen" tuntomerkeistä ei ole ongelmaton. Esimerkiksi oletus naisten aktiivisesta roolista gnostilaisissa yhteisöissä ei ole yksiselitteinen, sillä gnostilaisista kirjoituksista löytyy myös avoimen naisvihamielisiä korostuksia. ${ }^{14}$

Gnostilaisuuden tarkkaan määrittelyyn liittyvät ongelmat ovat johtaneet siihen, että amerikkalainen Michael Williams on vaatinut luopumista termin "gnostilaisuus" käytöstä kokonaan. Tilalle Williams ehdottaa käsitettä "raamatullinen demiurgismi." ${ }^{15}$ Williamsin ehdotuksen hyvä puoli on se, että se tuo esiin kaksi keskeistä taustatekijää, jotka ovat luonteenomaisia "gnostilaisina" pidetyille kirjoituksille: toisaalta niissä esitetään tulkintoja Vanhan testamentin luomiskertomuksista (="raamatullinen"), toisaalta niissä esiintyy kreikkalaisesta filosofiasta omaksuttu ajatus erillisestä luojajumalasta eli demiurgista (="demiurgismi"). Käsitteen "raamatullinen demiurgismi" ongelma on kuitenkin se, ettei se paljasta sitä negatiivista latausta, joka gnostilaisina pidetyissä kirjoituksissa lähes aina liittyy sekä luomiskertomusten tulkintaan että demiurgin hahmoon. Siksi "raamatullinen demiurgismi" tuskin syrjäyttää käytössä jo vakiintuneen gnostilaisuus-sanan.

Williams on kuitenkin osoittanut ilmeisiä ongelmia, jotka liittyvät oletukseen gnostilaisuudesta (tai gnosiksesta) itsenäisenä uskontona. Osa gnostikoista piti joka tapauksessa itseään kristittyinä, joten heidän määrittelynsä vieraan uskonnon edustajiksi ei tee oikeutta heidän itseymmärrykselleen. Gnostilaisista kirjoituksista pystytään kokoamaan uskonnolliseen toimintaan viittaavia piirteitä kuten mainintoja kasteesta, kuolleille annetusta viimeisestä voitelusta ja niin sanotusta morsiushuoneen sakramentista, jonka käytännön sisällöstä tosin ei ole säilynyt tietoja. Tällaiset rituaalit eivät kuitenkaan välttämättä olleet yhteisiä kaikille gnostilaisina pidetyille ryhmille, vaan ne olivat käytössä ainoastaan yksittäisissä ryhmissä. Gnostilaisista kirjoituksista ei voi hahmottaa kulttia, johon kaikki gnostilaiset olisivat osallistuneet. Tämä tekee oletuksen gnostilaisuudesta itsenäisenä uskontona ongelmalliseksi.

\footnotetext{
${ }^{13}$ Esim. Pétrement 1990; Logan 1996.

${ }^{14}$ Gnostilaisten kirjoitusten ambivalentista suhteesta naisiin ks. Marjanen 1996, 223-225.

${ }^{15}$ Williams 1996.
} 
Vasta myöhemmin gnostilaisen ajattelun pohjalta kehittyi kaksi selkeästi itsenäistä uskontoa, manikealaisuus ja mandalaisuus.

\section{Gnostilaisia suuntauksia}

Koska oletus gnostilaisuudesta itsenäisenä uskontona on epävarma, käytän termiä "gnostilaisuus" sellaisten ajattelutapojen kuvauksena, joiden keskeisiä tunnusmerkkejä ovat näkemys (1) korkeimman Jumalan ja alemman luojajumalan vastakkaisesta suhteesta sekä tähän näkemykseen yhdistyneenä (2) ajatus ihmisen sukulaisuudesta korkeimman Jumalan kanssa. ${ }^{16}$

Varhaiskristilliseltä ajalta tunnetaan monia koulukuntia, joiden käsitykset vastaavat edellä esitettyä määritelmää gnostilaisen ajattelun keskeisistä piirteistä. Useimmista gnostilaisista koulukunnista on kuitenkin säilynyt vain hyvin vähän tietoja, jotka ovat usein keskenään ristiriitaisia. Parhaiten tunnetaan kaksi gnostilaisen ajattelun suuntausta, valentinolainen kristillisyys ja setiläinen gnostilaisuus.

Kirkkoisien kirjoituksissa on poikkeuksellisen paljon kuvauksia valentinolaisesta koulukunnasta, sillä se oli merkittävä haastaja kiisteltäessä varhaisen kristinuskon oikeasta tulkinnasta. Kuvaa tämän ryhmän opetuksista täydentävät Nag Hammadin kirjaston valentinolaiset kirjoitukset, joita yleisen arvion mukaan ovat seuraavat: Apostoli Paavalin rukous, Totuuden evankeliumi, Tutkielma ylösnousemuksesta, Kolmiosainen tutkielma, Filippuksen evankeliumi, Ensimmäinen Jaakobin ilmestys, Tulkinta tiedosta sekä Valentinolainen tutkielma. Setiläisen gnostilaisuuden merkitys on paljastunut varsinaisesti vasta Nag Hammadin kirjaston myötä. Huomattava osa kirjaston teksteistä edustaa tätä suuntausta: Johanneksen salainen kirja, Hallitsijoiden olemus, Egyptiläisevankeliumi, Aadamin ilmestys, Setin kolme kivitaulua, Zostrianos, Melkisedek, Norean ajatus, Marsanes, Allogenes ja

\footnotetext{
${ }^{16}$ Ajatus ihmisen taivaallisesta alkuperästä tai sukulaisuudesta Jumalan kanssa ei sellaisenaan riitä gnostilaisen ajattelun tuntomerkiksi, sillä sama ajatus esiintyy hyvin erilaisissa traditioissa - esimerkiksi platonistisessa filosofiassa.
} 
Kolmimuotoinen Protennoia. Yksi Nag Hammadi -tutkimuksen keskeisimmistä ja pysyvimmistä tuloksista onkin juuri setiläisen gnostilaisuuden keskeisten piirteiden kartoitus.

Valentinolainen ja setiläinen suuntaus muistuttavat toisiaan siinä määrin, että niiden välinen suhde on herättänyt vilkasta keskustelua. Ongelmaan on esitetty kaksi vastakkaista ratkaisua. Toiset tutkijat pitävät setiläistä gnostilaisuutta gnostilaisen ajattelun varhaisimpana muotona, klassisena gnostilaisuutena, ja valentinolaisuutta sen kristillistettynä muunnoksena. Toiset taas ajattelevat setiläisen suuntauksen edustavan valentinolaisuutta selkeästi myöhäisempää kehitysvaihetta gnostilaisuuden historiassa.

Ongelman ratkaisua vaikeuttaa käytettävissä olevien lähteiden luonne. Erityisesti setiläisen gnostilaisuuden historiallinen tausta jää hämärän peittoon. Tätä suuntausta edustavissa kirjoituksissa ei kuvata taustayhteisön (tai -yhteisöjen) historiaa, vaan niissä keskitytään uskonnollisiin ja uskonnonfilosofisiin aiheisiin, erityisesti myytteihin maailman synnystä. Valentinolaisuuden historiasta on säilynyt hajatietoja kirkkoisien teoksissa, mutta selkeää kokonaiskuvaa niistäkään ei hahmotu.

\section{Setiläinen gnostilaisuus}

Oletus setiläisestä gnostilaisuudesta perustuu tietyissä Nag Hammadin teksteissä toistuviin yhteisiin piirteisiin. "Setiläisiksi" näitä tekstejä on alettu kutsua siksi, että useimmissa niistä Aadamin kolmannella pojalla, Setillä, on erityistehtävä jumalallisen tiedon välittäjänä. Muita setiläisten kirjoitusten keskeisiä korostuksia ovat seuraavat: ${ }^{17}$

\footnotetext{
${ }^{17}$ Schenke 1981, 166-167; King 1995, 36.
} 
- Jumaluus kuvataan Isän, Äidin (eli Barbelon) ja Ainoasyntyisen (Autogenēs) muodostamaksi kolminaisuudeksi.

- Jumalallisessa maailmassa on neljä valontuojaa (Harmozel, Oroiael, Davithe ja Eleleth; nimistä esiintyy myös muita muotoja)

- Aadam ja Set on kuvattu yleensä sekä taivaallisina (esikuva) että maallisina (kopio) hahmoina.

- ihmiskuntaa (erityisesti niitä, jotka pelastuvat) kutsutaan "Setin jälkeläisiksi."

- Jumalallisen maailman alapuolella on demiurgin valtakunta.

- Demiurgista käytetään nimeä Jaldabaoth, ja hänet kuvataan saatanalliseksi hahmoksi.

Setiläiset kirjoitukset eivät sisällä selviä viittauksia siihen, millaisessa yhteisössä ne ovat syntyneet. Kirkkoisä Epifanios tosin mainitsee "setiläisten" lahkon, mutta tämän ryhmän yhteys Nag Hammadin kirjoituksista hahmoteltuun setiläiseen gnostilaisuuteen jää hämäräksi.

Setiläinen gnostilaisuus ei välttämättä ollut selkeästi erottuva "koulukunta" kuten valentinolaisuus, vaan se näyttää saaneen hyvin erilaisia muotoja. Setiläisten kirjoitusten joukossa on tekstejä, joissa on selvästi kristillisiä elementtejä, mutta myös sellaisia, joissa kristillinen aines on vähäistä tai puuttuu kokonaan. Esimerkiksi setiläisesssä kirjoituksessa Allogenes ei viitata sen enempää juutalaisiin kuin kristillisiinkään hahmoihin tai ajatuksiin. ${ }^{18}$

Setiläisten kirjoitusten välisistä eroista on päätelty, että setiläisen gnostilaisuuden suhde kristinuskoon kehittyi useammassa vaiheessa. Setiläisyyden on oletettu olleen ei-kristillinen kastajalahko, joka 100luvun taitteessa jKr. alkoi omaksua kristillisiä aineksia, mutta erkani jälleen "oikeaoppiseksi" kehittyvästä kristinuskosta 100-luvun loppupuolella ja lähestyi ei-kristillistä filosofiaa, kunnes vieraantui siitäkin

${ }^{18}$ Vrt. King 1995, 42. 
200-luvun lopulla. ${ }^{19}$ Vaikka tämän teorian yksityiskohtainen todistaminen on mahdotonta käytettävissä olevien lähteiden avulla, se tarjoaa mahdollisen ja jopa uskottavan selitysmallin setiläisten kirjoitusten välisille eroille.

Setiläisen ajattelun merkittävin lähde on Johanneksen salainen kirja. Tämä teos oli poikkeuksellisen arvostettu jo omana aikanaan. Nag Hammadin kirjastossa siitä on säilynyt peräti kolme eri kopiota, minkä lisäksi siitä on yksi kopio jo aiemmin löydetyssä koptilais-gnostilaisessa käsikirjoituksessa (Berlinus Gnosticus eli BG). Lisäksi kirkkoisä Irenaeuksen edellä mainittu kuvaus "gnostilaisten" käsityksistä perustuu joko suoraan Johanneksen salaiseen kirjaan tai sitä läheisesti muistuttavaan lähteeseen.

Johanneksen salaisessa kirjassa kuvataan ylösnousseen Vapahtajan ja apostoli Johanneksen välistä opetuskeskustelua. Keskeisiä aiheita ovat näkyvän maailman synty ja se, ketkä ihmiskunnasta pelastuvat. Korkeinta Jumalaa kuvataan Johanneksen salaisen kirjassa niin kutsutun negatiivisen teologian keinoin. Aivan kuten "oikeaoppiset" kristityt ja useimmat kreikkalaiset filosofit, tämän tekstin kirjoittaja korostaa, ettei todellista Jumalaa voi ymmärtää ihmisjärjellä eikä kuvata sanoin:

Hän on tutkimaton, sillä ennen häntä ei ole ollut ketään, joka olisi päässyt selville hänestä. Hän on mittaamaton, sillä ennen häntä ei ole ollut ketään mittaamassa häntä. ... Hän on sanoin kuvaamaton, koska kukaan ei ole pystynyt tavoittamaan häntä puhuakseen hänestä. ${ }^{20}$

Todellisen Jumalan ominaisuuksia ovat lisäksi katoamattomuus, lepo ja hyvyys: "Hänen valtakuntansa on katoamaton. Hän lepää hiljaisuudessa, kaikessa rauhassa. Hän on ensimmäinen kaikista ja siksi hän on kaikkien ikuisten olentojen pää ja hyvyydessään tekee niistä vahvoja.”

\footnotetext{
${ }^{19}$ Ks. King $(1995,37)$, joka kuvaa John Turnerin esittämää teoriaa setiläisen gnostilaisuuden kehitysvaiheista.

${ }^{20}$ Tässä artikkelissa käytetyt käännökset Johanneksen salaisesta kirjasta ovat työryhmän Ismo Dunderberg, Antti Marjanen ja Erja Salmenkivi valmistamasta suomennoksesta. Suluissa annetut kohdat viittaavat käännetyn version (NHK II,1) sivuihin alkuperäisessä käsikirjoituksessa.
} 
Kaikkeuden Isän lisäksi jumalallisessa todellisuudessa on muita ikuisia olentoja eli aioneja. Kreikan sana aiōn tarkoittaa "aikaa" tai "ajanjaksoa", mutta myös ikuisuutta. Gnostilaisissa teksteissä sanalla kuvataan tavallisesti jumalallisessa todellisuudessa asuvia ikuisia olentoja, mutta sanaa käytetään myös lokaalisesti puhuttaessa kaikkeuden Isän "ikuisesta valtakunnasta." Ikuiset olennot on luonut Isä ja Isän ajatus, Barbelo, joka kuvataan ikään kuin itsenäiseksi hahmoksi.

Todellisen Jumalan maailmassa vallitsee sopusointu, kunnes yksi heistä, Viisaus, ryhtyy luomaan ilman kaikkeuden Isän suostumusta. Tuloksena on epätäydellinen hahmo, joka karkotetaan jumalallisen maailman ulkopuolelle. Tämä olento on Jaldabaoth, luojajumala. Hän luo aluksi erilaisia henkivaltoja ja demoneja ja sitten näiden avustamana näkyvän maailman. Jaldabaoth yhdistetään Vanhan testamentin Jumalaan. Hän julistaa olevansa ainoa Jumala kuten Jahve Vanhassa testamentissa: "Minä olen Jumala, eikä muuta Jumalaa ole" (Joh. sal. 11; vrt. Jes. 45:21; 46:9). Jaldabaoth kutsuu itseään "kiivaaksi Jumalaksi", jonka "rinnalla ei ole muita jumalia" (Joh. sal. 13; vrt. 2. Moos. 20:5; 34:14; Jes. 45:5-6). Näitä Jaldabaothin vaatimuksia pidetään kuitenkin osoituksena hänen röyhkeydestään ja tietämättömyydestään. Hän väittää olevansa ainoa Jumala vain siksi, ettei tunne korkeinta Jumalaa.

Jaldabaoth ja hänen apurinsa luovat ihmisen, mutta eivät saa tätä liikkeelle. Lopulta Jaldabaoth puhaltaa ihmiseen jumalallisen voiman, joka hänessä äitinsä takia oli - ja samalla menettää sen itse. Näin ihminen täyttyy jumalallisella valolla ja hänestä tulee viisaampi kuin Jaldabaothista ja tämän alamaisista. Jaldabaoth apureineen alkaa kadehtia ihmistä ja yrittää turmella tämän. Vasta tässä vaiheessa ihmiselle luodaan näkyvä ruumis. Sen tarkoituksena on saada ihminen unohtamaan hänessä asuva jumalallinen voima.

Ihmisessä oleva valon heijastus paljasti hänen olemuksensa. Hänen ajatuksensa suuntautuivat niiden yläpuolelle, jotka olivat luoneet hänet. Kun he kohottivat katseensa, he näkivät, että hänen ajattelunsa oli erinomaista. He laativat suunnitelman kaikkien hallitsijoiden ja enkelien kanssa. He ottivat tulta, maata ja vettä ja sekoittivat ne keskenään tulisen tuulen kanssa. He pakottivat ne yhteen ja aiheuttivat suuren sekaannuksen. He veivät ihmisen kuoleman varjoon luodakseen hänet uudelleen maasta, vedestä, tulesta, materiasta eli pimeyden tietämättömyydestä peräisin olevasta hengestä, halusta ja omasta 
väristyneestä hengestään. Tällä tavoin uudelleen luotu ruumis on luola, jonka ryövärit pukivat ihmisen ylle unohduksen kahleeksi. (Joh. sal. 20-21)

Jaldabaothin kielteiset piirteet eivät rajoitu siihen, että hän yrittää turmella ensimmäisen ihmisen. Hän raiskaa Eevan, joka synnytti hänelle Kainin ja Aabelin eli Javen ja Eloimin (jälkimmäiset nimet ovat samat kuin Jumalasta Vanhassa testamentissa käytetyt nimet Jahve ja Elohim) ja tartutti samalla seksuaalisen himonsa koko ihmiskuntaan.

Vasta Set on Aadamin lapsi, ja Setin jälkeläiset ovat niitä, joiden on mahdollista pelastua ruumiin kahleista. Setin jälkeläisetkin tarvitsevat kuitenkin pelastuakseen ulkopuolista apua. Siksi todellisen Jumalan luota laskeutuu alas Kaitselmus, joka herättää ihmisen unohduksen unesta ja kehottaa häntä palaamaan sinne mistä hän on peräisin (Joh. sal. 31). Johanneksen salaisen kirjan käsitys siitä, ketkä pelastuvat, on avara. Pelastuvien joukon ulkopuolelle suljetaan kategorisesti yksi ryhmä: luopiot. Heitä odottaa ikuinen rangaistus:

Minä kysyin: "Herra, entä ne, jotka saivat tiedon, mutta kääntyivät pois? Minne heidän sielunsa joutuvat?" Silloin hän vastasi: "Heidät viedään sinne, minne köyhyyden enkelit joutuvat. Siellä ei enää voi muuttaa mieltään. Heitä pidetään siellä siihen päivään asti, jolloin aletaan kiduttaa niitä, jotka ovat pilkanneet Henkeä. He saavat ikuisen rangaistuksen." (Joh. sal. 27)

\section{Valentinolainen kristillisyys}

Valentinolainen koulukunta on luonteeltaan selkeämmin kristillinen kuin setiläinen gnostilaisuus. Koulukunnan piirissä kirjoitettiin muun muassa allegorisia selitysteoksia Uuden testamentin kirjoituksiin, ja argumentoinnin keskeisinä tukipilareina käytettiin Jeesuksen sanoja ja tulkintoja Paavalin opetuksista. Koulukunnan perustajana pidetään Valentinos-nimistä kristittyä opettajaa, joka oli kotoisin Egyptistä ja vaikutti Rooman kristillisissä seurakunnissa 100-luvun puolivälistä 
alkaen. ${ }^{21}$ Valentinoksen omista kirjoituksista on säilynyt vain lyhyitä katkelmia, eikä niiden perusteella voi päätellä varmasti, missä määrin koulukunnan myöhemmät käsitykset vastasivat hänen käsityksiään. Muista valentinolaisista parhaiten tunnetaan Ptolemaios, Herakleon ja Theodotos, joiden opetuksista kirkkoisät esittävät sekä yhteenvetoja että suoria lainauksia. Nag Hammadin valentinolaisten kirjoitusten kirjoittajia ei tunneta nimeltä. Näitä kirjoituksia on tosin ajoittain yritetty yhdistää edellä mainittuihin opettajiin, mutta tällaiset oletukset ovat hyvin epävarmoja.

Valentinolaisten käsitysten kuvaamiseen liittyy kaksi suurta ongelmaa. Ensinnäkin kirkkoisät esittävät valentinolaisten opista toisistaan poikkeavia versioita, jotka perustuvat eri lähteisiin. Toiseksi kirkkoisien kuvaukset eivät ole kaikin osin sopusoinnussa valentinolaisilta opettajilta säilyneiden alkuperäiskatkelmien kanssa. Valentinolaisten käsityksiä kuvattaessa käytetään lähtökohtana yleensä Irenaeuksen laajaa yhteenvetoa (Harh. 1.1-8). On kuitenkin muistettava, että tämä on kuvaus valentinolaisen teologian suhteellisen myöhäisestä vaiheesta, jonka Irenaeus parhaiten tunsi.

Kirkkoisien toisistaan poikkeavissa versioissa valentinolaisesta järjestelemästä on kuitenkin selkeitä yhteisiä peruskorostuksia. Johanneksen salaisessa kirjassa esiintynyt myytti Viisauden lankeemuksesta, joka johtaa näkyvän maailman syntyyn, on keskeinen myös valentinolaisille. Yhteistä kirkkoisien kuvauksille valentinolaisesta Viisaus-myytistä on se, että (1) Viisaus toimii ilman korkeimman Jumalan suostumusta ja siksi epäonnistuu, ja että (2) Viisauden epäonnistumisen seurauksena syntyy demiurgi. Valentinolaisessa myytissä Viisaus jakautuu ikään kuin kahdeksi hahmoksi, joista toinen jatkaa elämäänsä jumalallisessa maailmassa ja toinen joutuu sen

21 Viimeaikaisessa tutkimuksessa Valentinoksen suhde valentinolaisen koulukunnan käsityksiin on problematisoitu. Valentinoksen omista teoksista on säilynyt vain lyhyitä katkelmia, eikä niiden perusteella voida päätellä varmasti, missä määrin hänen omat ajatuksensa muistuttivat gnostilaisia käsityksiä. (Ks. Markschies 1992; vrt. Dunderberg 1999.) 
ulkopuolelle. Ulkopuolelle jäänyt Viisaus on varsinaisesti maailman luoja; tietämätön demiurgi toimii hänen "suunaan ja käsinään."

Valentinolainen luojajumala ei ole yhtä kielteinen hahmo kuin setiläisten kirjoitusten Jaldabaoth. Valentinolaiset eivät käytä hänestä nimeä Jaldabaoth, vaan kutsuvat häntä platonistista traditiota seuraten "demiurgiksi" eli käsityöläiseksi. Myös käsitys luojajumalan asemasta luomakunnassa poikkeaa setiläisestä traditiosta. Valentinolaisissa lähteissä Viisauden ja demiurgin kuvataan toimivan yhteistyössä, vaikkakin demiurgin tietämättä. Valentinolainen demiurgi ei ole samalla tavalla ihmisiä uhkaava vaara kuin Jaldabaoth. Kun Vapahtaja ilmestyy maailmaan, hän käännyttää seuraajakseen myös demiurgin. Demiurgi rakastaa ja pitää erityistä huolta "hengellisistä" kristityistä, jollaisiksi valentinolaiset itsensä ymmärsivät. He eivät siis välttämättä tunteneet oloansa uhatuksi demiurgin luomassa maailmassa. ${ }^{22}$

Toinen valentinolaisen ajattelun tunnuspiirre on ihmisen jakaminen kolmeen eri tasoon. Kirkkoisät kiinnittivät paljon huomiota tähän piirteeseen, sillä siihen liittyi teoria kahden tason kristityistä. Valentinolaiset ajattelivat Aadamin koostuneen kolmesta näkymättömästä olemuksesta, aineesta, sielusta ja hengestä. Näiden lisäksi hänen ylleen oli puettu "nahkavaate" (vrt. 1. Moos. 3:21) eli ruumis. Kolmella olemuksella on erilainen kohtalo: aineellinen olemus tuhoutuu ja hengellinen pelastuu joka tapauksessa. Sielullinen olemus on näiden kahden olemuksen välissä: se joko tuhoutuu tai pelastuu sen perusteella, mihin se suuntautuu, aineelliseen vai hengelliseen.

Kirkkoisien mukaan valentinolaiset pitivät itseään hengellisinä kristittyinä, jotka pelastuvat heille annetun luonnon perusteella riippumatta siitä, mitä he tekevät, kun taas muut kristityt ovat "sielullisia", joiden täytyy pelastuakseen uskoa ja tehdä hyviä tekoja. ${ }^{23}$ Kirkkoisien mukaan valentinolaiset pitivät tällaista jakoa ennalta

\footnotetext{
Tässä referoitu versio valentinolaisesta demiurgikäsityksestä perustuu Irenaeuksen kuvaukseen valentinolaisen Ptolemaioksen seuraajien opista (Harh. 1.1-8).

${ }^{23}$ Kirkkoisät korostavat, että valentinolaisten mukaan hengelliset ihmiset saattoivat tehdä mitä tahansa vaarantamatta tulevaa pelastumistaan, mutta tämä kuva ei saa vahvistusta valentinolaisista alkuperäislähteistä.
} 
määrättynä. Näin yksioikoinen valentinolainen ihmiskäsitys tuskin kuitenkaan oli. Todennäköistä on, että he pitivät siirtymistä yhdestä ihmisluokasta toiseen mahdollisena, sekä "sielullisen" ihmisen ylentymistä hengelliseksi että oman jo saavutetun hengellisen aseman menettämistä.

\section{Gnostilaisten demiurgikäsitysten esikuvia}

Gnostilaisen ajattelun suhteesta muihin Lähi-idän uskonnollisiin ja filosofisiin virtauksiin on vaikea esittää täsmällistä kokonaiskuvaa. Gnostilaisissa kirjoituksissa yhdistellään hyvin monipuolista mytologista aineistoa. Niistä on löydetty yhteyksiä egyptiläisiin tai assyrialaisiin näkemyksiin, antiikin ajan astrologisiin ja numerologisiin teorioihin sekä maagisista lähteistä tunnettuihin piirteisiin.

Gnostilaisten käsitysten lähimmät vertailukohdat löytyvät kuitenkin edelleen juutalais-kristillisistä näkemyksistä ja kreikkalaisesta filosofiasta. Suhde näihin taustatekijöihin vaihtelee eri gnostilaisia suuntauksia edustavissa lähteissä. Esimerkkinä tästä käytän gnostilaisia käsityksiä tietämättömästä luojajumalasta.

Gnostilaisen luomiskäsityksen taustalla on selvästi Platonin filosofia. Platon oli Timaios-dialogissaan esittänyt ajatuksen demiurgista, joka maailmaa luodessaan käytti esikuvanaan jumalallista todellisuutta. ${ }^{24}$ Hellenistisen ja roomalaisen ajan filosofiassa tämä käsitys oli laajalti tunnettu ja hyväksytty. Platonistisen tradition pääuomasta poikkesi kuitenkin gnostilaisten kielteinen kuva demiurgista epätäydellisenä hahmona, joka tietämättään jäljitteli jumalallista maailmaa. Tämä oli yksi syy siihen, että gnostilaisia käsityksiä kritisoivat kirkkoisien lisäksi 200-luvulla myös Plotinos, ei-kristillinen uusplatonikko.

\footnotetext{
24 ”Jos käsityöläinen pitää aina silmällä sitä, mikä pysyy samana, käyttäen sitä esikuvana ja muovaten esineen sen hahmon ja kyvyn mukaiseksi, tulee hänen teoksestaan pakostakin kaunis. ... Jos maailmankaikkeus on kaunis ja sen luoja hyvä, on selvää, että hän sitä luodessaan on kiinnittänyt katseensa ikuiseen. ... Sillä kaikesta mitä on syntynyt, maailmankaikkeus on kauneinta ja sen luoja on kaikkien syiden joukossa paras." (Platon, Timaios, 28a-29a; suom. A. M. Anttila)
} 
Toisaalta jo platonismin varhaisemmassa vaiheessa, niin sanotussa keskiplatonismissa, oli esitetty sellaisia näkemyksiä, jotka saattoivat valmistaa tietä gnostilaisille käsityksille alemmasta luojajumalasta. Esimerkiksi uuspythagoralainen Numenius Apamealainen erotti toisistaan korkeimman Jumalan ja demiurgin. Edellä kuvatun Johanneksen salaisen kirjan tavoin Numenius ajatteli, että korkein Jumala "on levossa" ja pysyy ihmisille tuntemattomana, kun taas demiurgi on aktiivinen hahmo, maailman luoja, joka voidaan tuntea. Numenius liitti demiurgiin tietyn kielteisen varauksen, vaikka ei varsinaisesti pitänytkään tätä setiläisten tapaan pahana hahmona. Numeniuksen mukaan luomisen taustalla ei ollut ainoastaan se, että demiurgi halusi jäljitellä korkeimman Jumalan taivasta, vaan myös demiurgin ainetta kohtaan tuntema halu. ${ }^{25}$ Platonin filosofia johti siis myös keskiplatonismissa jossain määrin samansuuntaisiin tulkintoihin kuin gnostilaisuudessa.

Gnostilaisten käsitysten läheinen yhteys juutalaisiin näkemyksiin käy ilmi jo nimistä, joita Johanneksen salaisessa kirjassa ja muissa setiläisissä kirjoituksissa käytetään demiurgista. Jaldabaoth on seemiläisperäinen nimi, jonka merkitys tosin on epäselvä. Sana saattaa tarkoittaa "kaaoksen lasta" tai "Sebaotin isä", mutta muitakin teorioita on esitetty. Lisäksi demiurgia kutsutaan nimillä Saklas, joka tarkoittaa "typerystä", ja Samael, "sokea jumala." Näiden yksityiskohtien lisäksi yksittäisistä setiläisistä kirjoituksista on löydetty muitakin piirteitä, jotka ovat peräisin juutalaisesta Vanhan testamentin tulkintaperinteestä. Tällaisia yhteyksiä on vaikea selittää muuten kuin olettamalla, että gnostilaisen ajattelun juuret ovat ainakin osittain juutalaisuudessa.

Gnostilaisuuden suhde juutalaisuuteen on kuitenkin monimutkainen ongelma. Toisaalta gnostilaisissa kirjoituksissa hyödynnetään juutalaisia tulkintatraditioita, mutta toisaalta niissä suhtaudutaan Vanhaan testamenttiin hyvin kriittisesti. Esimerkiksi Johanneksen salaisessa kirjassa todetaan Mooseksen olleen väärässä, vaikka kirjoituksen kuvaus maailman synnystä pitkälti perustuukin Genesiksen luomiskertomukseen:

${ }^{25}$ Numeniuksen näkemyksistä ks. Dillon 1996, 366-372. 
Minä kysyin Vapahtajalta: "Mitä tarkoittaa 'uni' (vrt. 1. Moos. 2:21)?” Hän vastasi: "Olet kuullut, että Mooses kirjoitti ensimmäisessä kirjassaan: 'Jumala vaivutti Aadamin luonnolliseen uneen.' Näin ei ole, vaan Aadamin käsityskyky tainnutettiin. ... Ensimmäinen hallitsija otti osan Aadamissa olleesta voimasta. Sitten hän tekin toisen, naisen muotoisen luomuksen, joka oli hänelle ilmestyneen Älyn kaltainen, ja pani naishahmoon sen osan, jonka hän oli ihmisen voimasta ottanut. Aadamista ei siis otettu 'hänen kylkiluutaan' kuten Mooses väitti. (Joh. sal. 22-23)

Vielä kielteisemmin Vanhaan testamenttiin suhtaudutaan Suuren Setin toisessa tutkielmassa. Siinä Vanhan testamentin merkkihahmoja kuten Aadamia, Aabrahamia, Iisakia, Moosesta ja 12 profeettaa kutsutaan kutakin vuorollaan "naurun aiheeksi."

Gnostilaisten kirjoitusten kahtalaisesta suhteesta juutalaiseen perintöön on päätelty, että gnostilaisuus syntyi alun perin tietyn tyyppisestä juutalaisuudesta. Kurt Rudolphin mukaan gnostilaisuuden taustalla on juutalainen "maallikkoälymystö", jonka ajatuksiin vaikuttivat niin juutalaisessa viisauskirjallisuudessa esiin noussut skeptisismi (Saarnaajan kirja!) kuin apokalyptiselle juutalaiselle kirjallisuudelle ominainen dualismi. ${ }^{26}$ Tämä teoria ei ole kuitenkaan täysin vakuuttava, sillä selittämättä jää, miksi ja missä vaiheessa suhde Vanhan testamentin Jumalaan kääntyy niin kielteiseksi kuin se useissa gnostilaisissa kirjoituksissa on.

Gnostilainen näkemys demiurgista voi kuitenkin heijastaa sitä teologista kehitystä, joka seurasi juutalaisen ja kreikkalaisen ajattelun kohtaamisesta hellenistisellä kaudella. Juutalaisuudessakin Jumala alettiin vähitellen ymmärtää entistä selvemmin tuonpuoleiseksi hahmoksi, joka ei puutu maailman tapahtumiin suoraan, vaan erilaisten välittäjähahmojen välityksellä.

Yksi tällaisista välittäjistä Jumalan ja maailman välillä oli Jumalan Viisaus, jota vähitellen alettiin kuvata ikään kuin itsenäisenä olentona. Gnostilaisten kirjoitusten tavoin juutalaisessa viisauskirjallisuudessa Viisaus kuvataan luomisen välikappaleeksi (esim. Sananl. 8:22-31). Ajatusta Viisauden lankeemuksesta juutalaisessa viisauskirjallisuudessa

${ }^{26}$ Rudolph 1996, 144-169. 
ei tosin esiinny. Toisaalta myös gnostilaisessa ajattelussa Viisaudella on myönteinen rooli suhteessa ihmiskuntaan. Viisaus takaa sen, että jotain jumalallisesta maailmasta heijastuu myös ihmisten maailmaan, ja juuri Viisauden väliintulon ansiosta ihminen saa hengen, joka mahdollistaa hänen paluunsa jumalalliseen todellisuuteen.

Erityisesti hellenistisessä juutalaisuudessa Jumalan rinnalla oletettiin olleen muitakin jumalallisia olentoja, jotka ottivat itselleen osan Jumalalle perinteisesti kuuluneista tehtävistä. Näiden hahmojen hoidettavaksi tulivat erityisesti sellaiset tehtävät, joiden ei katsottu olevan sopusoinnussa Jumalan hyvyyden kanssa. Juutalainen keskiplatonisti Filon selitti Jumalan antaneen enkeleidensä tehtäväksi luoda sellaiset asiat, joihin liittyi joitain pahoja piirteitä. Filon ei pitänyt edes syntisten rankaisemista Jumalalle sopivana tehtävänä, vaan oletti, että tämän "likaisen työn" hoitivat muut Jumalan luomat voimat. Tällaisesta jaottelusta hyvän Jumalan ja syntisiä rankaisevien alempien jumalallisten olentojen välillä ei ole pitkä matka gnostilaiseen käsitykseen korkeimmasta Jumalasta ja tälle vastakkaisista demonisista luojajumalista, vaikka Filon itse ei tätä käsitystä olisikaan hyväksynyt. ${ }^{27}$

Jako korkeimman Jumalan ja alemman demiurgin välillä on mahdollista selittää myös kristinuskon ja juutalaisten käsitysten yhteentörmäyksestä käsin. Valentinolaisen Ptolemaioksen mukaan Vanhan testamentin Jumala ei ollut hyvä eikä paha, vaan oikeudenmukainen. Tämän Jumalan oikeudenmukaisuus ei ole hyvyyttä, sillä hänen antamassaan laissa esiintyy koston periaate "silmä silmästä, hammas hampaasta.” Koska Jeesus kumosi tämän periaatteen, hänen ilmoittamansa Jumala ei Ptolemaioksen mukaan voinut olla sama kuin Vanhan testamentin Jumala. Ptolemaioksen todistelu muistuttaa pitkälti Markionin tapaa erottaa toisistaan Jeesuksen julistama taivaallinen Isä, joka oli hyvä, ja Vanhan testamentin ja juutalaisten jumala. ${ }^{28}$ Ptolemaioksen

\footnotetext{
${ }^{27}$ Hellenistijuutalaisen ja gnostilaisen jumalakuvan yhteyksiä esittelee Fossum 1985, 197204.

${ }^{28}$ Käsitys alemmasta luojajumalasta on yhteinen Markionille ja gnostilaisille. Markionia ei kuitenkaan usein pidetä varsinaisesti "gnostikkona", sillä hänen näkemyksistään puuttuu toinen gnostilaisen ajattelun tunnusmerkeistä, ajatus ihmisen ja korkeimman Jumalan sukulaisuudesta.
} 
tavoin ja häntä kärjekkäämmin Markion kiinnitti huomionsa Vanhan testamentin jumalan inhimillisiin, "pikkumaisuutta" ja muihin epätäydellisyyttä ilmentäviin piirteisiin ja asetti ne vastakkain Jeesuksen sanojen kanssa.

Markionin ja Ptolemaioksen demiurgikäsityksen lähtökohtana oli siis havainto Vanhan testamentin ja kristillisen tradition välisestä jännitteestä. He eivät tosin ratkaisseet tätä jännitettä samalla tavalla. Markion vaati kristittyjä luopumaan Vanhasta testamentista kokonaan, kun taas Ptolemaios näki siinä "pysyviä arvoja" ja esitti allegorisia tulkintoja esimerkiksi Vanhan testamentin uhrilaista.

\section{Lopuksi}

Edellä kuvattujen esimerkkien tarkoituksena on ollut osittaa, ettei gnostilaisten käsitysten taustalta löydy välttämättä yhtä ainutta alkutraditiota, jota olisi sittemmin tulkittu eri tavoin. Esimerkiksi gnostilaiseen käsitykseen tietämättömästä luojajumalasta saatettiin päätyä eri teitä ja sitä perusteltiin hyvin erilaisista lähtökohdista käsin. Esimerkiksi Ptolemaioksen ja Johanneksen salaisen kirjan välillä on tässä suhteessa selvä ero. Vaikka Johanneksen salaisen kirjan kehyskertomus sisältää kristillisiä aineksia, sen kuvauksessa Jaldabaothista ei ole lainkaan viittauksia kristillisiin traditioihin. Sen sijaan Ptolemaioksella koko argumentoinnin lähtökohtana on Jeesuksen julistus Jumalasta ja sen suhde Vanhaan testamenttiin. Johanneksen salaisen kirjan traditiotausta on selvästi lähempänä juutalaisuutta kuin Ptolemaioksen, kun taas Ptolemaioksen näkemysten lähtökohtana on kristinuskon ja Vanhan testamentin väliseen suhteeseen liittyvä ongelma.

Johanneksen salaisen kirjan ja Ptolemaioksen välille ei välttämättä voikaan rakentaa yksinkertaista syy-seuraussuhdetta, joko siten, että Ptolemaios (tai hänen oppi-isänsä Valentinos) olisi tuntenut ja "kristillistänyt" setiläisen käsityksen demiurgista, tai niin, että setiläinen 
gnostilaisuus perustuisi valentinolaiseen kristillisyyteen. ${ }^{29}$ Mahdollista on, että samansuuntaisiin näkemyksiin päädyttiin eri lähtökohdista käsin ilman suoraa vaikutussuhdetta suuntaan tai toiseen.

Myös gnostilaisen ajattelun suhteesta juutalaisuuteen, kristinuskoon ja kreikkalaiseen filosofiaan on hankala esittää yksiselitteistä arviota. Suhde näihin taustatekijöihin vaihtelee sen mukaan, mistä gnostilaisesta suuntauksesta on kyse. Lisäksi näitä vaikuttajia ei ole aina mahdollista erottaa selkeästi toisistaan. Esimerkiksi platonistisen filosofian vaikutus gnostilaisuuteen on voinut olla yhtä hyvin suoraa kuin välillistäkin. Jälkimmäisessä tapauksessa välittäjänä on voinut toimia hellenistinen juutalaisuus tai kristinusko, jonka piirissä filosofian harrastus lisääntyi vähitellen 100-luvulta alkaen.

Vielä suuremmiksi tällaiset ongelmat käyvät, kun gnostilaisille käsityksille etsitään yhtymäkohtia laajemmin Lähi-idän uskonnollisesta kentästä. Vertailukohtia ja kiinnostavia yhtäläisyyksiä epäilemättä löytyy paljonkin, mutta niiden todistusarvoa on kussakin tapauksessa punnittava tarkkaan. Milloin ja millä edellytyksillä ne kertovat gnostilaisuuden suorista yhteyksistä varhaisempiin Lähi-idän uskontoihin tai kulttuureihin, ja milloin niiden taustalla on ainoastaan hieman epämääräiseksi jäävä "yleisitämainen perinne"?

${ }^{29}$ Kummallakin vaihtoehdolla on viimeaikaisessa tutkimuksessa kannattajansa; ks. Layton 1995; Logan 1996. 


\section{Gnostilaisuus kristinuskon "toisena": Kirjallisuuskatsaus}

(2005)

\section{Gnostilaisuus suomalaisessa julkisessa sanassa}

Viime kevään kuluessa gnostilaisuus pulpahti julkiseen keskusteluun kahdessakin eri yhteydessä. Dan Brownin menestysromaanissa Da Vinci -koodi (WSOY 2004) Nag Hammadin gnostilaisen kirjaston tekstien väitettiin paljastavan, että Magdalan Maria oli Jeesuksen salarakas ja hänen lapsiensa äiti. Kirjaston teksteistä ei tosin löydy tukea tälle käsitykselle kuten ei myöskään Brownin kirjassa esitetylle ajatukselle "pyhän naiseuden" ja siihen liittyvien seksuaaliriittien asemasta alkuperäisessä kristinuskossa. ${ }^{1}$ Brownin kirja on fiktiota, joten siihen liittyvien

${ }^{1}$ Olen hiljattain käsitellyt Da Vinci -koodissa esitettyjä väitteitä varhaisesta kristinuskosta ja Magdalan Mariasta toisaalla; vrt. Dunderberg 2005b, 469-476; 2005c, 3-10. Samassa Vartijan numerossa on myös kaksi muuta Dan Brownin kirjaa käsittelevää artikkelia: Salmesvuori 2005 ja Halme 2005. Ehkä tässäkin yhteydessä on kuitenkin syytä todeta, että vaikka Magdalan Maria esiintyy useissa Nag Hammadin teksteissä Jeesuksen keskustelukumppanina, läheisenä oppilaana ja työtoverina (Tuomaan evankeliumi; Jeesuksen Kristuksen Viisaus; Filippuksen evankeliumi; 1 Jaakobin ilmestys; Keskustelu Vapahtajan kanssa; tässä yhteydessä usein mainittu Marian evankeliumi ei kuulu Nag Hammadin kirjastoon, vaan toiseen, samantyylisiä kirjoituksia sisältävään kokoelmaan, ns. Berliinin koodeksiin), tämä ei tee näistä teksteistä erityisen naismyönteisiä, 'pyhästä naiseudesta' tai salaisista seksuaalisista riiteistä puhumattakaan. Kuvaavaa on, että vaikka Marialla on erityisasema Keskustelussa Vapahtajan kanssa, samassa tekstissä opetuslapsia kehotetaan rukoilemaan "siellä, missä ei ole naisia" ja luopumaan "siitä, mitä nainen tekee"; jälkimmäisen kehotuksen tulkitaan tarkoittavan, etteivät naiset enää synnytä lapsia (Kesk. Vap. 90-92). Magdalan Mariasta Nag Hammadin kirjastossa ja muissa vastaavissa teksteissä ks. Marjanen 1996; positiivisen Maria- 
asiavirheiden ja puolitotuuksien osoittelu voi tuntua turhankin ryppyotsaiselta, mutta ehkä tähän on kuitenkin tarvetta, sillä kirjan käsitykset voivat hyvin jäädä elämään monien lukijoiden mielissä. ${ }^{2}$

Astetta vakavampi puheenvuoro, jossa gnostilaisuus niin ikään nousi esille, oli Porvoon piispa Erik Vikströmin Kyrkpressen-lehdelle (3.3.2005) antama haastattelu. Siinä Vikström esitti huolensa kirkon rappiosta, joka hänen mukaansa juontaa juurensa eksegetiikan opetukseen Helsingin yliopistossa ja Kirkon koulutuskeskuksessa. Vikströmin mukaan "tietyt opettajat" (joita hän ei nimeä tarkemmin) ovat olleet "jonkin verran" amerikkalaisen Jeesus-seminaarin linjoilla, ja heidän turmiollinen vaikutuksensa näkyy papistossamme "erityisesti suomenkielisellä puolella." Vikström toteaa, että Suomen kirkkoa uhkaa "uusi gnostilaisuus", joka "virtaa sisään tuhansista kanavista ja rei'istä ja kulkee käsi kädessä täydellisen välinpitämättömyyden kanssa.”

Vaikka Vikströmin puheenvuoron taustalla on epäilemättä aito huoli kirkon tilasta, faktat eivät siinä ole paljoakaan paremmin kohdallaan kuin Da Vinci-koodissa. Vikströmin haastattelusta saa harhaanjohtavan kuvan sekä Helsingissä tehtävästä Uuden testamentin tutkimuksesta että gnostilaisuudesta. Ensiksi mainittuun liittyen todettakoon vain lyhyesti, etteivät Helsingin yliopiston eksegetiikan laitoksen tutkijat ole erityisesti sitoutuneet Jeesus-seminaarin toimintaan tai tuloksiin; sen sijaan on näyttöä heidän kriittisestä suhteestaan seminaarin Jeesus-kuvaa kohtaan. ${ }^{3}$ Jeesus-seminaarin suomalaisjäsenet, joita on

kuvan ja negatiivisen naiskäsityksen välisestä jännitteestä Keskustelussa Vapahtajan kanssa ks. Marjanen 1996, 88-93.

${ }^{2}$ Matti Myllykoski (2005b) toteaa, että "kymmenet tuhannet suomalaiset päätyvät Brownin jännittävän romaanin luettuaan epämäräisesti uskomaan, että Vatikaani on salannut totuuden Jeesuksen siviilisäädystä ja jälkeläisistä, Graalin maljasta ynnä muusta mieltä kiihottavasta."

${ }^{3}$ Ks. esim. Risto Uron lyhyt selostus Jeesus-seminaarista kirjassa Uro \& Lehtipuu 1997, 155. Jeesus-seminaarin tarjoamasta ei-eskatologisesta Jeesus-kuvasta ks. myös Räisänen 1997; Dunderberg 1998b, 20-21. Kriittinen suhde ei tosin tarkoita, että Jeesus-seminaarin työskentelyn arvo kiellettäisiin kategorisesti "harhakuvitelmina" kuten Vikström tekee. Seminaarin kieltämättä yksioikoinen Jeesus-kuva ja äänestysmenettely ovat helppoja polemiikin kohteita, mutta äänestysten taustaksi on tehty myös tieteellistä pohjatyötä, jota ei voi sivuuttaa olan kohautuksella. Havainnollisen kuvan Jeesus-seminaarin työskentelystä, sen perusteista ja tuloksista saa kirjasta Funk \& Hoover 1993. Varsinkin seminaarin jyrkkien 
kolme, ovat kaikki luterilaisen kirkon palveluksessa joko Suomessa tai Yhdysvalloissa. ${ }^{4}$

Mitä puolestaan tulee gnostilaisuuteen, sen yhdistäminen "täydelliseen välinpitämättömyyteen" on pahasti vanhentunut käsitys, jonka viimeistään Nag Hammadin kirjaston tekstit ovat vakavasti kyseenalaistaneet. Gnostilaisuutta käsittelevässä tutkimuksessa on osoitettu moneen otteeseen, että ajatus gnostilaisten moraalisesta välinpitämättömyydestä perustuu yksinomaan heidän vastustajiensa esittämiin poleemisiin syytöksiin; samanlaisia syytöksiä singottiin antiikin aikana etenkin filosofikoulukunnissa kaikkia kilpailijoita kohtaan. Asiasta on kirjoitettu Teologisen Aikakauskirjankin sivuilla, ${ }^{5}$ mutta ilmeisen laihoin tuloksin. Vanhat ennakkoluulot gnostilaisuudesta kumpuavat helposti esiin varsinkin, jos ja kun niille löytyy sopivaa käyttöä.

\section{Mihin termiä "gnostilaisuus" tarvitaan?}

Niin eri suuntiin kuin Dan Brownin ja Erik Vikströmin arviot gnostilaisuudesta kulkevatkin, ne osoittavat hyvin Karen Kingin uuden kirjan What is Gnosticism? ajankohtaisuuden. ${ }^{6}$ Kirjan keskeinen teesi on,

vastustajien soisi tutustuvan edes tähän kirjaan eikä perustavan mielipidettään ainoastaan seminaarin amerikkalaisessa mediassa herättämään julkiseen kohuun.

${ }^{4}$ Yksi on väitellyt Helsingissä Uuden testamentin eksegetiikan ja yksi uskonnonfilosofian alalta, ja yksi on työnsä ohessa Uuden testamentin eksegetiikan jatko-opiskelija. Jeesusseminaarin osallistujien ("Fellows") nimet löytyvät seminaarin kotisivuilta (http://www.westarinstitute.org/membership/westar-fellows/fellows-directory/).

${ }^{5}$ Dunderberg 1999, 244.

${ }^{6}$ King 2003. Mainittakoon, että Karen King on osallistunut myös em. Jeesus-seminaarin toimintaan. Hänen oma kontribuutionsa liittyi Jeesuksen sanojen autenttisuuteen Tuomaan evankeliumissa. Jokaisen Jeesus-seminaaria summittaisesti kritisoivan soisi tutustuvan Kingin aihetta käsittelevään artikkeliin: King 1987. Artikkeli on hyvä esimerkki huolellisesta tutkimustyöstä, jolla Jeesus-seminaarin työskentelyä pohjustettiin ennen eniten julkista huomiota saaneita äänestyksiä. Kingin perusteellinen analyysi vaikutti epäilemättä osaltaan siihen, että Jeesus-seminaari suhtautui äänestyksissään lopulta yllättävän kriittisesti Tuomaan evankeliumiin, vaikka sen korostukset olisivatkin sopineet hyvin seminaarin ei-eskatologiseen Jeesus-kuvaan. Seminaari piti "autenttisina" tai "mahdollisesti autenttisina" pääasiassa vain sellaisia Tuomaan evankeliumin lausumia, joille löytyy rinnakkaiskohta synoptisista evankeliumeista; ainoa poikkeus oli Tuom. ev. 98, jota pidettiin "mahdollisesti autenttisena", vaikka lausumaa ei löydykään Uudesta testamentista. Jeesus-seminaarin teologinen linja ei 
että "gnostilaisuuteen" on alusta alkaen liittynyt ajatus "toisesta", jota vasten omaa kristillistä identiteettiä on peilattu ja verrattu. Termi "gnostilaisuus" ei esiinny antiikin lähteissä, vaan sen loi vasta 1600luvulla englantilainen Henry More, joka käytti sitä kuvauksena Ilmestyskirjassa vastustetusta harhaopista.

King keskittyy kirjassaan siihen, miten termiä "gnostilaisuus" on Moren jälkeen käytetty aihepiirin kannalta keskeisimmässä tutkimuskirjallisuudessa. Näin syntyy selkeästi profiloitu kuva siitä, mihin oikeastaan on tarvittu kategoriaa, joka ei esiinny antiikin lähteissä lainkaan. King osoittaa, kuinka alan tunnetuimmat tutkijat (muun muassa Adolf von Harnack, Wilhelm Bousset, Rudolf Bultmann, Hans Jonas ja Kurt Rudolph) ovat kerta toisensa jälkeen luoneet kuvan gnostilaisuudesta kristinuskon "toisena." Gnostilaisuus on kuvattu "marginaaliseksi, esoteeriseksi, myyttiseksi, synkretistiseksi, loismaiseksi ja itäiseksi uskonnoksi”, jonka vastapainoksi on tarjottu mielikuva "autenttisista, etnisistä, historiallisista, järkevistä valtavirran uskonnoista, sellaisista kuten oikeaoppinen kristinusko."

Gnostilaisuutta ei siis ole kuvattu neutraalisti yhdeksi varhaiskristillisen ajan virtaukseksi, vaan se on lähes säännönmukaisesti ymmärretty joksikin toiseksi, oikean kristinuskon vastapuoleksi. Gnostilaisuutta kategoriana on tarvittu ennen kaikkea siksi, että se on tarjonnut negaation, jota vasten on määritelty, mitä on aito, oikea ja alkuperäinen kristinusko. King toteakkin, että "juuri apologeettiset pyrkimykset puolustaa normatiivista kristinuskoa tekevät gnostilaisuudesta järjellisen kategorian."

Kingin tutkimushistoriallinen katsaus on kiinnostava myös sen vuoksi, että hän kontekstualisoi hyvin esittelemänsä tutkijat. Hän sijoittaa heidän näkemyksensä ja tutkimusotteensa laajempaan, tietylle ajalle ominaiseen tieteelliseen diskurssiin. King osoittaa esimerkiksi, kuinka läheisesti Adolf von Harnackin kuvaus gnostilaisuudesta heijastelee protestanttista viholliskuvaa katolisesta kirkosta: sekä gnostilaisuudesta että katolisesta kristillisyydestä puuttui von Harnackin mukaan

siis ollut ainoa päätöksiin vaikuttanut seikka, vaan myös eksegeettisellä taustatyöskentelyllä oli merkittävä osuus sen tekemissä ratkaisuissa. 
evankeliumin alkuperäinen entusiasmi (66); vastaava havainto on toisaalla tehty varhaiskristillisen juutalaisuuden kuvausten ja protestanttien stereotyyppisen katoliskuvan välillä (esimerkiksi syytös "armon ansaitsemisesta teoilla" on kohdistettu yhtä lailla juutalaisiin kuin katolisiinkin).

Toinen kiinnostava esimerkki Kingin kirjassa on Walter Bauer: vaikka hän käänsi kuuluisassa tutkimuksessaan Rechtgläubigkeit und Ketzerei im älteren Christentum (1934) ylösalaisin perinteiset käsitykset oikea- ja harhaoppisuuden suosiosta ja levinneisyydestä varhaisen kirkon piirissä, hänen valitsemansa kysymyksenasettelu jo sinänsä myös ylläpiti ja jopa vahvisti ortodoksian ja heresian välistä jyrkkää vastakkainasettelua. Varhaiskristillisyyden tutkimuksen työkaluna tällainen dikotomia ei ole millään tavalla hedelmällinen lähtökohta.

Kingin kirjasta käy ilmi myös, ettei edes Nag Hammadin kirjaston löytyminen ole radikaalisti muuttanut gnostilaisuudesta esitettyjä typologioita, vaikka kirjaston teksteistä tuskin yksikään sopii niihin sellaisenaan. Gnostilaisuutta vastustaneiden varhaiskristillisten opettajien valitsemat näkökulmat ovat yllättävän vahvasti ohjanneet myös Nag Hammadin tekstien tutkimusta. Niistä on etsitty vahvistusta tai variaatioita teemoihin, jotka olivat keskeisiä gnostilaisuuden vastustajien poleemisissa teksteissä. Samalla sivuun on jäänyt monia muita teemoja, jotka näissä uusissa teksteissä voivat olla huomattavasti keskeisempiä sekä määrällisesti että antiikin yleisen kontekstin huomioon ottaen; yhtenä tällaisena teemana King mainitsee Nag Hammadin teksteissä esiintyvät pohdinnat emootioista.

Kingin kirja liittyy Nag Hammadin kirjaston jälkimainingeissa syntyneeseen keskusteluun siitä, miten gnostilaisuus tulisi uuden lähdemateriaalin valossa määritellä - tai voiko sitä yleensä enää määritellä millään mielekkäällä tavalla. Kirjan puutteena voi pitää sitä, ettei King vastaa kysymykseen, pitäisikö termin gnostilaisuus käytöstä luopua kokonaan sen sisältämien ongelmien vuoksi. Tämä ajatus saattaisi olla johdonmukainen seuraus siitä, mitä King kirjassaan sanoo ja mitä hän ei sano. Yhtältä hän toteaa kaikki tähänastiset kuvaukset gnostilaisuudesta ongelmallisiksi, eikä hän toisaalta tarjoa omaa uutta ehdotusta gnostilaisuuden määritelmäksi. 
Määritelmät ovat toisaalta välttämättömiä, sillä niitä tarvitaan todellisuuden hahmottamiseksi, mutta määritelmiä ja kategorioita luotaessa aina myös manipuloidaan ja suoraviivaistetaan moniäänistä lähdeaineistoa nostamalla toisia asioita esiin ja jättämällä toisia sivuun. Kyse on tällöin lopulta pitkälti tutkijan valinnoista, ei niinkään siitä, että lähdeaineisto vääjäämättä johtaisi johonkin yhteen ja selkeään tulokseen. Tästä näkökulmasta on tavallaan ymmärrettävää, ettei King esitä lainkaan omaa määritelmää gnostilaisuudesta. Silti jäin kaipaamaan Nag Hammadin tekstien yhdeltä tämän hetken merkittävimmältä asiantuntijalta selkeästi muotoiltua omaa kantaa kirjan otsikossa esitettyyn kysymykseen. Olisiko kenties mahdollista määritellä ja käyttää termiä gnostilaisuus vähemmän tendenssimäisesti kuin aikaisemmat tutkijat ovat tehneet? Kirjan keskeinen ajatus jää nyt hieman itsestään selväksi, tosin sinänsä tärkeäksi: tutkijoiden tulisi tiedostaa paremmin, missä merkityksessä ja mitä tarkoitusta silmällä pitäen he "gnostilaisuudesta" puhuvat.

\section{Lähestymistapa gnostilaisuutta kuvaaviin lähteisiin on muuttunut}

Yksi vastaus Kingin esiin nostamiin ongelmiin voisi olla se, että kiinnitetään aiempaa tarkempaa huomiota aihepiiriin liittyviin ensi käden lähteisiin. Nag Hammadin tekstien tutkimus on tässä suhteessa luonnollisesti erityisen keskeisessä asemassa, mutta myös gnostilaista kristinuskoa vastustaneiden kristillisten opettajien teksteissä on poleemisten kuvausten lisäksi myös jonkin verran suoria lainauksia, joskus jopa kokonaisia tekstejä, gnostilaisilta opettajilta. Näitä katkelmia on perinteisesti luettu sen valossa, mitä vastustajat ovat gnostilaisten koulukuntien opetuksista kertoneet. Sitä, että mainituista teksteistä usein puuttuu gnostilaiseen kristinuskon tulkintaan yhdistettyjä peruskorostuksia, on pidetty merkkinä siitä, että kyseiset gnostilaiset opettajat piilottelivat lukijoiltaan todellisia ajatuksiaan. Näin kirkkoisien poleemisia kuvauksia on käytännössä pidetty luotettavampana tiedonlähteenä gnostilaisten kristittyjen ajatuksista kuin heidän omia tekstejään. 
Tutkimusilmasto on kuitenkin tässä suhteessa muuttunut. Erityisesti saksalaisessa Wissenschaftliche Untersuchungen zum Neuen Testament -sarjassa on viimeisen kymmenen vuoden aikana ilmestynyt useita tutkimuksia, joissa merkittävimpiin nimeltä tunnettuihin gnostilaisiin opettajiin liittyvä aineisto on koottu ja analysoitu huolellisesti sen omilla ehdoilla. Aiemmassa kirjallisuuskatsauksessani esittelin tässä sarjassa julkaistut tutkimukset Valentinoksesta ja Basilideesta. ${ }^{7}$ Sarja on täydentynyt nyt kahdella uudella tutkimuksella, joiden kohteena ovat Herakleon ja "taikuriksi" kutsuttu Markus. Kaikki neljä tutkimusta on toteutettu hyvin samanlaisella sapluunalla. Aluksi esitetään kreikankielinen alkuteksti ja sen rinnalla saksalainen käännös tutkittavalta opettajalta säilyneistä katkelmista ja/tai hänen seuraajiensa historiaan liittyvistä kuvauksista, minkä jälkeen seuraa hyvin yksityiskohtainen kommentaari. Tutkimuksille on niin ikään yhteistä hyvin kriittinen suhde kirkkoisien poleemisiin kuvauksiin. Niiden sijasta taustaa kristillis-gnostilaisten opettajien ajatuksille etsitään yleisemmin toisen vuosisadan aatehistoriallisesta viitekehyksestä, etenkin aleksandrialaisesta, platonistisesti värittyneestä tavasta tulkita Raamattua.

\section{Herakleon}

Ansgar Wucherpfennigin tutkimuksen aiheena on Valentinoksen koulukuntaan kuulunut Herakleon, joka tunnetaan parhaiten varhaisimman tunnetun Johanneksen evankeliumin selitysteoksen kirjoittajana. ${ }^{8}$ Teos ei ole säilynyt kokonaisuudessaan, mutta siitä on muutamia katkelmia Origeneen Johannes-kommentaarissa. Origenes sai Herakleonin kommentaarin mahdollisesti Ambrosius-nimiseltä suojelijaltaan, joka oli entinen valentinolainen ja antoi hänelle tehtäväksi Johanneksen selitysteoksen kirjoittamisen. Ilmeisesti juuri tästä syystä Origenes esittää lainauksia Herakleonilta ja käy niistä keskustelua. Origenes tunsi

\footnotetext{
${ }^{7}$ Dunderberg 1999, 246-249.

${ }^{8}$ Wucherpfennig 2002.
} 
myös Irenaeuksen kuvauksen valentinolaisten opetuksesta ja tulkitsi Herakleonin opetuksia sen valossa.

Wucherpfennig ei käy kaikkia Herakleonin katkelmia yhtä tarkasti läpi, vaan keskittyy osaan niistä. Perusteeksi ei tosin mielestäni riitä käsiteltävän "tekstin laajuus" (47), sillä Herakleonilta säilynyttä materiaalia ei lopulta ole kovinkaan paljon. Mukaan otettujen tekstien osalta Wucherpfennig kuitenkin tekee erinomaisen huolellista työtä. Ennen kaikkea hän pystyy hahmottamaan hyvin katkelmallisten tekstien perusteella, miten Herakleon sovelsi omana aikanaan hyväksyttyjä pelisääntöjä selitettävän tekstin eri tasojen tulkinnassa. Tärkeä havainto on, ettei Herakleon esittänyt Johanneksen evankeliumista vain allegorisia tulkintoja, kuten yleensä on ajateltu, vaan teki myös tekstien historialliseen selittämiseen liittyviä havaintoja ja kommentteja. Lisäksi Wucherpfennig osoittaa tutkimuksessaan, että Herakleon tunsi ilmeisen hyvin oman aikansa luonnon- ja lääketieteellisiä näkemyksiä.

Yksi Herakleonin tulkintaan liittyvistä keskeisistä kysymyksistä liittyy hänen käsityksiinsä erilaisista ihmisluokista. Herakleon jakoi muiden valentinolaisten tavoin ihmiset kolmeen luokkaan, maallisiin, sielullisiin ja hengellisiin. Irenaeuksen mukaan valentinolaiset pitivät tätä jakoa ennalta määrättynä. He itse kuuluivat hengelliseen luokkaan, joka pelastuisi pelkästään jumalallisen luontonsa perusteella, kun taas muut kristityt olivat "sielullisia". Kiistaa käydään kuitenkin siitä, ajatteliko Herakleon samoin. Pitikö hänkin näitä luokkia ennalta määrättyinä vai uskoiko hän, että ihmiset voivat siirtyä luokasta toiseen? Wucherpfennig antaa merkittävää lisätukea jälkimmäisen vaihtoehdon taakse asettuneille tutkijoille (esimerkiksi Barbara Aland ja Elaine Pagels). Hän muistuttaa moneen otteeseen, että Origenes tunsi Irenaeuksen kuvauksen valentinolaisista ja tulkitsi Herakleonin näkemyksiä siitä käsin. Näin deterministinen tulkinta kolmesta ennalta määrätystä luonnosta ei perustu niinkään siihen, mitä Herakleon itse sanoi, kuin Origeneen ennakkokäsitykseen valentinolaisesta opista. Esimerkiksi ajatus, että Herakleon piti samarialaista naista (Joh. 4) "hengellisenä" eli pelkästään jumalallisen luontonsa perusteella pelastuvana ihmisenä, tulee esille ainoastaan Origeneen tulkinnassa Herakleonin käsityksistä; ajatus ei esiinny suorissa lainauksissa tämän opetuksista (338-339). 
Wucherpfennig esittää myös jonkinlaisen yleiskuvan Herakleonin elämänvaiheista, vaikka tiedot niistä ovatkin hyvin viitteenomaisia. Olemassa olevan aineiston valossa voidaan olettaa, että Herakleon toimi aluksi Roomassa, mutta siirtyi myöhemmin Aleksandriaan, missä hän ehkä myös kirjoitti Johannes-kommentaarinsa. Herakleon olisi näin siis Valentinoksen tavoin vaikuttanut sekä Egyptissä että Roomassa.

Mutta mikä oli Herakleonin suhde Valentinokseen? Tämä keskeinen kysymys jää tutkimuksessa lopulta epäselväksi. Tekijä vihjaa tosin, että Herakleonia pidettiin "erheellisesti" Valentinoksen oppilaana ja että hänen kommentaariinsa olisi lisätty myöhemmin valentinolaisia piirteitä (371). Oletus jää kuitenkin perustelematta, sillä varsinaisissa tekstianalyyseissä tällaisiin lisäyksiin viittaavia havaintoja ei esiinny.

Vaikka Wucherpfennigin tutkimus on kautta linjan asiantunteva ja hyvin kattava, muutamia aukkokohtia on jäänyt. Keskustellessaan ihmisten mahdollisuuksista siirtyä yhdestä ihmisluokasta toiseen Herakleon mainitsee yhtenä vertauskuvana "naisen muuttumisen mieheksi". Vertauskuvaa selittäessään (235-237) Wucherpfennig kiinnittää yllättävän vähän huomiota toisen valentinolaisen, Theodotoksen, vastaavaan käsitykseen ja sivuuttaa kokonaan Tuomaan evankeliumin samansisältöisen päätöslauselman (Tuom. ev. 114), jota koskevassa kirjallisuudessa on ehditty käydä läpi lukuisia eri mahdollisuuksia tulkita kyseistä ajatusta. Tutkimuksen sinänsä laajasta kirjallisuusluettelosta puuttuu muutamia aiheen kannalta keskeisiä teoksia (kuten Michael Williamsin Rethinking Gnosticism ja Michel Desjardinin Sin in Valentinianism). Jeffrey Trumbowerin Herakleon-tutkimus Born from Above mainitaan ainoastaan kerran, eikä sen kanssa ei käydä tarkempaa keskustelua.

Wucherpfennigin tutkimus Herakleonista vahvistaa joka tapauksessa osaltaan sen, että kutakin kristillis-gnostilaista opettajaa pitäisi tulkita aluksi tämän omilla ehdoilla sen sijaan, että koko todistusaineisto yritettäisiin harmonisoivilla tulkinnoilla sovittaa yhteen muottiin. 


\section{Markos "taikuri" - gnostilainen Casanova?}

Yksi gnostilaisuuden historian kiehtovimmista hahmoista on epäilemättä valentinolainen Markos, jota Irenaeus kuvaa tarkemmin kuin ketään muuta gnostilaista opettajaa (Harh. 1.13-16, mahdollisesti myös 1721). Irenaeus kertoo muun muassa Markoksen suorittamasta ehtoollisen kaltaisesta rituaalista, jossa vesi värjättiin jollain aineella punaiseksi; tästä rituaalista on peräisin Markokselle annettu lisänimi "taikuri" (magus). Tämän lisäksi Markoksen seuraajat toimittivat kuoleville apolytrosiksen ("lunastus") nimellä kulkeneen rituaalin. Siinä kuoleva voideltiin ja hänelle kerrottiin salaiset sanat, jotka takasivat sen, että kuoleva pelastui tuonpuoleisuuden portinvartijoiden käsistä ja pääsi palaamaan jumalalliseen täyteyden maailmaan (Irenaeus, Harh. 1.21.5). ${ }^{9}$

Irenaeuksen mukaan Markos etsi kannattajia erityisesti rikkaista naisista, käytti heitä seksuaalisesti hyväkseen ja sekoitteli heille lemmenjuomia. Varmemmaksi vakuudeksi Irenaeus kertoo henkilökohtaisesti tuntevansa Vähässä-Aasiassa erään diakonin, joka menetti vaimonsa Markokselle, sekä kertoo naisista, jotka palatessaan Markoksen joukosta kirkon hoiviin tunnustivat julkisesti seksuaaliset harharetkensä Markoksen ryhmässä. Jo Irenaeusta ennen Markoksesta oli jo ehditty sepittää pilkkaruno, jonka Irenaeus luonnollisesti lainaa kokonaisuudessaan.

Niclas Förster analysoi Markosta ja hänen seuraajiaan koskevan lähdemateriaalin samalla tavalla huolellisesti mutta jossain määrin eklektisesti kuin Wucherpfennig Herakleon-aineston. ${ }^{10}$ Tutkimuksensa ensimmäisessä osassa Förster esittelee kaikki lähteet, joissa Markos on mainittu, Irenaeuksesta aina Agapiuksen arabiankieliseen kirkkohistoriaan (Kitab al-'Unwan) saakka. Tutkimuksen päälähde on kuitenkin Irenaeuksen Harhaoppeja vastaan 1.13-16, jonka Förster kirjassaan analysoi käytännössä lause lauseelta (54-388). Viimeinen luku tarjoaa informatiivisen yhteenvedon siitä, mitä voidaan päätellä Markoksen

\footnotetext{
${ }^{9}$ Käännös mainitusta jaksosta samoin kuin sen rinnakkaiskohdasta Ensimmäisessä Jaakobin ilmestyksessä (33-34): Dunderberg 1997a, 147.

${ }^{10}$ Förster 1999.
} 
elämästä, perusajatuksista ja suhteesta niin Valentinoksen koulukuntaan kuin oman aikansa filosofisiin käsityksiin ja uskonnollisuuteenkin. Aineiston rajauksessa jää kuitenkin askarruttamaan se, että Förster jättää tarkastelunsa ulkopuolelle Irenaeuksen teoksen luvut 1.17-21, jotka hyvin voivat liittyä Markoksen seuraajien toimintaan. Niissä muun muassa kuvataan erilaisia versioita edellä mainitusta apolytrosisrituaalista, jonka Förster Hippolytoksen vastaavan kuvauksen perusteella yhdistää markolaisiin.

Förster torjuu selväsanaisesti Irenaeuksen syytökset Markuksen taikuruudesta ja seksuaalisista hurjasteluista: molemmissa on kyse "oman aikansa polemiikin standardiargumentista" (412), ei historiallisesti luotettavista tiedonannoista. Kiinnostava yksityiskohta on, että Hippolytos kertoo markolaisten kriittisistä reaktioista siihen, miten heidän apolytrosis-rituaaliaan oli kuvattu; kritiikin kohteena oli ilmeisesti juuri edellä mainittu Irenaeuksen teos. Ilmeisesti tämän kritiikin seurauksena Irenaeuksen tekstiä lähteenään käyttänyt Hippolytos jätti omasta tekstistään pois tämän kärkevimmät syytökset markolaisia vastaan.

Irenaeuksen ja Hippolytoksen kuvausten vertailusta nousee esiin myös toinen mielenkiintoinen tulos. Niistä voidaan päätellä, että markolaisuus loi vähitellen oman kirkon, jolla oli oma hierarkkinen rakenne. Hippolytoksen mukaan apolytrosis-rituaalin nimittäin toimitti markolainen piispa; Irenaeukselta tätä yksityiskohtaa ei vielä löydy. Itse asiassa rajat tavallisen kristillisen kirkon ja markolaisten ryhmien välillä eivät olleet kovinkaan selvät vielä Irenaeuksen aikana, sillä Irenaeus kertoo, kuinka muutamat kunniakkaat kristityt naiset olivat huomaamattaan joutuneet keskelle markolaisten kokousta!

Yksi Markoksen vaikeimmin lähestyttävistä puolista on hänen vaikeaselkoinen numerologiansa, jonka hän yhdisti valentinolaiseen järjestelmään. Tämä osa Markoksen näkemyksiä on epäilemättä peräisin uuspythagoralaisuudesta, kuten Förster hyvin osoittaa. Platonin vaikutus näkyy Markoksen negatiivisessa teologiassa ja stoalaisuuden vaikutus hänen opissaan maailmanpalosta. Försterin mukaan Markoksen näkemyksien monenkirjavassa näkyy "koulutuseklektisismi" (Bildungseklektizismus). Förster toteaa, että Markoksella "oli tavalliseen järjestelmään kuuluva 'ensyklopedinen' peruskoulutus, mutta hän ei 
ollut käynyt läpi filosofikoulussa annettua koulutusta. Hän oli todennäköisesti itseoppinut." (416) Viimeksi mainittu johtopäätös ei tosin ole välttämätön, sillä Försterin mainitsema "koulutuseklektisismi" ei sulje pois sitä mahdollisuutta, että Markos olisi saanut koulutusta esimerkiksi useammassa kuin yhdessä filosofikoulukunnassa - kuten Justinos ennen kääntymistään kristityksi.

Markos epäilemättä mielsi itsensä kristityksi opettajaksi. Hänen valentinolaista taustaansa vasten on kuitenkin erikoista, ettei häneltä ole jäänyt lainkaan lainauksia Johanneksen evankeliumista tai Paavalin kirjeistä, joihin muut valentinolaiset viittasivat usein. Sen sijaan Markos lainasi muutamia Psalmeja, ja hänen teologiassaan näkyy juutalaisen viisausajattelun vaikutus (397).

\section{Ajan tasalla oleva yleisesitys}

Kovin monen teologin aika tuskin riittää edellä kuvattujen pedanttien tutkimusten lukemiseen. Jos aihepiiri kuitenkin kiinnostaa, hyvän ja ajan tasalla olevan yleiskuvan gnostilaisuudesta saa Riemer Roukeman yleistajuisesta ja suhteellisen suppeasta johdannosta aiheeseen. ${ }^{11}$ Tämän alun perin hollanniksi vuonna 1998 ilmestyneen kirjan hyvästä englanninnoksesta vastaa John Bowden, joka tunnetaan monista muistakin Uuden testamentin ja varhaiskristillisyyden alaan liittyvien teosten käännöksistä.

Roukeman kirja on selkeä ja helppolukuinen, eikä sen lukeminen vaadi etukäteistietoja aiheesta. Kirjan rakenteessa on otettu huomioon pedagoginen näkökulma: ensimmäisessä pääjaksossa annetaan yleiskuva gnostilaisista käsityksistä, toisessa kuvataan gnostilaisen ajattelun taustatekijöitä, ja vasta kolmannessa esitellään tarkempi määritelmä gnostilaisuudesta sekä tutustutaan hieman laajemmin gnostilaisia opettajia ja tekstejä.

\footnotetext{
${ }^{11}$ Roukema 1999.
} 
Gnostilaisista käsityksistä annettavan yleiskuvauksen lähtökohtana on Irenaeuksen kuvaus varhaisista gnostikoista (Simon, Menander, Satornilos jne.). Siihen Roukema lisää sopivissa kohdissa kuvauksia yksittäisistä Nag Hammadin teksteistä (Kertomus sielusta, Johanneksen salainen kirja). Esitys perustuu suppeisiin referaatteihin lähdeteksteistä, mutta esiin on otettu kriittisiäkin näkökulmia, kuten se, ettei Irenaeuksen kuvaus Simon taikurin näkemyksistä palaudu historialliseen Simoniin (17). Paikoitellen analyyttisiä kommentteja on kuitenkin turhan vähän. Roukema ei esimerkiksi selitä, miksi hän esittelee Johanneksen salaisen kirjan juuri Satorniloksen yhteydessä. Hän ei myöskään jostain syystä mainitse tutkimuksessa vakiintunutta käsitettä "setiläinen gnostilaisuus", vaikka luetteleekin Johanneksen salaisen kirjan lisäksi kaikki muutkin tätä suuntausta edustavat kirjoitukset.

Gnostilaisuuden taustatekijöistä Roukema ottaa esiin juutalaisuuden, Platonin ja hänen koulukuntansa myöhemmät edustajat, sekä lopuksi mysteeriuskonnot ja varhaisen kristinuskon. Kirjan tämäkin osa on konkreettinen ja helposti seurattava, sillä siinä keskitytään muutamiin avainhahmoihin ja heidän käsityksiinsä. Erikseen Roukema mainitsee, miten esitellyt henkilöt tai suuntaukset ymmärsivät tiedon (gnosis, eräissä tapauksissa myös episteme) merkityksen. Kristinuskon osuus (97-101) on hyvin suppea, ja teologilukijasta sen sisältö voi tuntua suureksi osaksi triviaalilta.

Hollantilaisten tutkijoiden tapaan Roukema korostaa gnostilaisuuden läheistä yhteyttä antiikin filosofiseen perintöön. Hän katsoo termien "gnosis" ja "gnostilainen" viittaavan platonistisiin tulkintoihin olemassa olevasta uskonnosta yleensä. Näille tulkinnoille yhteisiä piirteitä ovat: (1) Maailman luonut Jumala on alempi kuin korkein Jumala; (2) ihmisen ruumis on luojajumalalta tai tämän työtovereilta; (3) ihmisessä on ylhäältä tullut jumalallinen olemus, jonka perusteella hän voi oppia tuntemaan korkeimman Jumalan. Kristillisestä gnosiksesta tai gnostilaisuudesta on kyse silloin, kun näihin käsityksiin yhdistyy runsaasti kristillisiä aineksia (123). Tämän jälkeen Roukema esittelee yksitellen keskeisiä gnostilaisuuden historiaan liittyviä tai liitettyjä opettajia (Kerinthoksesta Maniin) ja tekstejä. Tekstien valikoima on hieman erikoinen: viidestä esitellystä tekstistä kaksi edustaa Tuomas- 
kristillisyyttä (Tuomaan evankeliumi ja niin sanottu Helmihymni Tuomaan teoista).

Kirkollisia "gnostikkoja" (Clemens, Origenes ja Evagrios) esitellään lyhyesti kirjan viimeisessä pääosassa, missä Roukema ottaa myös itse etäisyyttä gnostilaiseen ajatteluun: "En haluaisi vaihtaa uskoa Jumalaan, joka toimii halki vuosisatojen, henkilökohtaiseen mystiikkaan, jossa on kyse vain minun ja kanssani samanmielisten sielujen pelastumisesta." (161)

Roukeman kirjan yleislinja on aatehistoriallinen. Sen vahva puoli on, että gnostilainen ajattelu sijoittuu poikkeuksellisen hyvin osaksi antiikin maailman filosofisia virtauksia. Kääntöpuolena on, ettei kirjassa kiinnitetä riittävästi huomiota gnostilaisten sosiaaliseen todellisuuteen liittyviin kysymyksiin, kuten mitä heidän yhteisöistään tiedetään tai miten heidän lopulta kävi.

Uusin aihetta käsittelevä tutkimus on otettu kirjassa hyvin huomioon. Tämä näkyy ennen kaikkea siinä, ettei Roukema esittele gnostilaisuutta absoluuttisen dualistisena uskontona, johon väistämättä liittyisi näkyvän maailman halveksunta. Kirkkoisien esittämiin syytöksiin gnostilaisten moraalittomasta elämäntavasta Roukema suhtautuu niin ikään varauksellisesti. Paikoitellen analyysi olisi kuitenkin voinut olla terävämpää ja johdonmukaisempaa. Roukema muistuttaa esimerkiksi tekstien Kertomus sielusta ja Tuomaan evankeliumi yhteydessä, ettei niitä yleensä pidetä yksiselitteisesti gnostilaisina. Silti tekstit esitellään kirjassa ikään kuin ne kuuluisivat gnostilaisiin kirjoituksiin.

Näistä ongelmista huolimatta Roukeman kirjaa voi suositella hyvänä johdatuksena niille, joiden mielenkiinto gnostilaisuuteen on herännyt, oli sitten syynä Da Vinci -koodi tai kirkon rappio ja siihen liitetty "uuden gnostilaisuuden" uhkakuva. Erityisesti viimeksi mainitun kaltaisten ajatusten leijuessa nyt ilmassa Roukeman kirjaa kannattaisi harkita jopa käännettäväksi suomeksi - tai miksi ei myös ruotsiksi. Ehkä sitten ainakin osa gnostilaisuutta koskevista faktoista osuisi paremmin kohdalleen, ja keskustelua voitaisiin jatkaa vähän asianmukaisemmista lähtökohdista. 


\section{Puhuiko Mooses totta?}

Helsingin Sanomien sunnuntaisivulla neuvontapalstaa pitävä Torsti joutui vastaamaan kysymykseen, millä kielillä Raamattu on aikanaan kirjoitettu. Näin Torsti: "Alun perin Raamatun kirjoittamisesta ja kokoamisesta ovat vastanneet juutalaiset. ... Ensimmäiset kristityt, jotka olivat juutalaisia, käyttivät Vanhaa testamenttia kreikkalaisena käännöksenä, ja sen oheen liitettiin kreikaksi laaditut Uuden testamentin kirjoitukset."

Torstin vastaus osoitti jälleen kerran hyvää asianhallintaa; hän on tikkaremminsä kanssa palstansa ansainnut. Kristinusko on juutalaiselta maaperältä noussut messiaaninen liike, ja monet sen keskeisistä käsityksistä selittyvät vain tästä taustasta käsin. Uudessa testamentissa ja muissa varhaisten kristittyjen kirjoittamissa teksteissä vedotaankin usein Vanhaan testamenttiin ja korostetaan oman Kristus-uskon liittymistä siihen.

\section{Kristityt ja Vanha testamentti}

Juutalaisuuden ja kristinuskon välinen jatkumo ei kuitenkaan ollut särötön. Juutalaisille Heprealaisen Raamatun keskus oli laki, viisi Mooseksen kirjaa. Heprealaisen Raamatun muut osat, esimerkiksi profeettakirjat, olivat tärkeitä ennen kaikkea Mooseksen lain tulkitsijoina: näissä kirjoissa profeetat muistuttavat valittua kansaa Mooseksen lain noudattamisen tärkeydestä.

Varhaiset kristityt taas pitivät profeettakirjoja Mooseksen lakia tärkeämpinä. Profeettakirjoista etsittiin ennustuksia Kristuksen kokemasta kohtalosta että uudesta messiaanisesta aikakaudesta, jota kristityt kokivat elävänsä. Yksi tämän ajatuksen kiteytymä löytyy Apostolien 
teoista: "Sillä tavoin Jumala pani täytäntöön sen, minkä hän oli ilmoittanut kaikkien profeettojen suulla: hänen Voideltunsa tuli kärsiä ja kuolla" (Ap.t. 3:18).

Osa kristityistä teki jo varhain myös sellaisia käytännön ratkaisuja, jotka tekivät säröjä jatkumoon. Mooseksen laissa määrätystä ympärileikkauksesta luopuminen oli epäilemättä tärkeä murroskohta. Tämän ratkaisun merkittävin puolustaja, apostoli Paavali, esitti juutalaiseksi ennenkuulumattoman kriittisiä näkemyksiä Mooseksen lain alkuperästä ja tarkoituksesta. Paavali sanoo: "Ne jotka luottavat lain noudattamiseen ovat kirouksen alaisia" (Gal. 3:10). Laki on Paavalin mukaan myöhäinen lisä: se annettiin vasta satoja vuosia Aabrahamille annetun lupauksen jälkeen. Lain tarkoitus on kielteinen: "Se säädettiin perästäpäin osoittamaan rikkomukset” (Gal. 3:19).

Matteuksen Vuorisaarnassa Jeesus asettaa vastakkain Vanhan testamentin laissa annetut määräykset ja korkeammat eettiset ihanteet: "Teille on opetettu: 'Silmä silmästä, hammas hampaasta.' Mutta minä sanon teille: Älkää tehkö pahalle vastarintaa” (Matt. 6:38). Johanneksen evankeliumin Jeesus puhuu "teidän laistanne" keskustellessaan juutalaisten kanssa - ikään kuin hän itse ei olisi juutalainen: "Mooses sääti teille ympärileikkauksen - se ei tosin ole peräisin Moosekselta vaan kantaisiltä, ja te toimitatte sen myös sapattina.”

Toisen vuosisadan alkupuoliskolla kirjoitetussa Barnabaan kirjeessä konkreettinen ympärileikkaus selitetään virhetulkinnaksi, jonka aiheutti juutalaiset harhaan johtanut "paha enkeli." Oikea ympärileikkaus on kuuloaistin ja sydämen ympärileikkaus (9:4-5). Tämän tekstin mukaan Vanhan testamentin kiellettyjen ruoka-aineiden listoja ei tule ottaa kirjaimellisesti. Oikein tulkittuna niissä on kyse ohjeista, miten kristittyjen tulee elää (10:1-12).

\section{Korkein Jumala ja alempi luojajumala}

Ensimmäisen vuosisadan kristityt olivat kuitenkin yhtä mieltä, että kristittyjen Jumala on sama Jumala, joka oli luonut maailman ja ilmoitti tahtonsa Vanhassa testamentissa. Keskeinen uusi murros toisella vuosisadalla oli sellaisten kristittyjen esiinmarssi, jotka tekivät aiempaa 
huomattavasti jyrkemmän pesäeron juutalaisuuteen. Heidän mukaansa Vanhassa testamentissa kuvattu Jumala ei ollut korkein jumala, vaan alempiarvoinen ja monin tavoin epätäydellinen luojajumala.

Tämä ajatus nousi esiin leveällä rintamalla. Se yhdisti monia tunnettuja, myöhemmin harhaoppisiksi leimattuja opettajia ja ryhmiä. Heihin kuuluivat rikas laivanvarustaja Markion, Egyptistä kotoisin olleet kristityt filosofit Basilides ja Valentinos, Justinos "gnostilainen" (jota ei pidä sekoittaa kaimaansa Justinos Marttyyriin) sekä niin sanotut setiläiset kristityt.

Nimitys "setiläinen" perustuu siihen, että nämä kristityt korostavat Setin, Aadamin ja Eevan kolmannen pojan, asemaa: hän välittää ihmiskunnalle salatun jumalallisen ilmoituksen. Termi "setiläinen" on tutkijoiden luomus, mutta tämän ryhmän edustajat käyttivät teksteissään itsestään nimitystä "Setin jälkeläiset."

Egyptistä vuonna 1945 löydetyn Nag Hammadin kirjasto paljasti setiläisen tulkinnan merkityksen. Tämä 300-luvulta peräisin oleva kokoelma sisältää huomattavan määrän aiemmin tuntematonta varhaiskristillistä kirjallisuutta koptinkielellä. Noin kolmasosa kirjaston teksteistä voidaan luokitella "setiläisiksi."

\section{Erilaisia käsityksiä luojajumalasta}

$\mathrm{Ne}$ kristityt, jotka ajattelivat juutalaisten Jumalan olevan alempi luojajumala, päätyivät tähän näkemykseen useita eri teitä. Markion katsoi, ettei Jeesuksen opetus yksinkertaisesti sovi yhteen Vanhassa testamentissa kuvatun Jumalan kanssa. Jeesuksen julistama täydellinen Jumala ei voi olla sama kuin Vanhassa testamentissa kuvattu Jumala, joka paratiisissa joutuu kysymään missä Adam on, joka suuttuu, vihoittelee ja leppyy, ja joka sallii koston itselleen ja muille ("silmä silmästä, hammas hampaasta”).

Markion tulkitsi Vanhaa testamenttia kirjaimellisesti ja päätteli, ettei se voi olla kristittyjen pyhä kirja. Toisenlaisen linjan valitsivat Valentinos, hänen oppilaansa ja edellä mainitut setiläiset. He loivat uusia, Vanhan testamentin luomiskertomuksiin perustuvia, kertomuksia maailman ja ihmiskunnan synnystä. Näissä uusiomyyteissä näkyy 
Raamatun alkukertomusten lisäksi kreikkalaisen filosofian vaikutus. Keskeinen inspiraation lähde oli Platonin Timaios-dialogi, mutta myös stoalaisen filosofian käytöstä on selviä merkkejä.

Uusia luomismyyttejä kehitelleitä kristittyjä yhdisti ajatus, että ihmiskunta - tai ainakin sen osa - on sukua korkeimmalle Jumalalle. Hekään eivät olleet kuitenkaan yhtenäinen joukko. Heillä oli hyvin erilaisia käsityksiä niin luojajumalasta kuin Vanhasta testamentistakin. Valentinoksen seuraajat kuvasivat luojajumalan tietämättömäksi mutta hyväntahtoiseksi. Heidän mukaansa Vanhasta testamentista löytyy todellisenkin Jumalan ilmoitusta, tosin sekoittuneena luojajumalan käskyihin ja ihmisten tekemiin lisäyksiin.

Setiläisten tekstien näkemys luojajumalasta on paljon kielteisempi. Hänet kuvataan ihmiskunnan viholliseksi numero yksi: hän on Saatanan kaltainen hahmo, jonka keskeisiä piirteitä ovat tyhmyyden lisäksi kateus ja seksuaalinen himo. Nag Hammadin kirjastossa on tekstejä, joissa pahan luojajumalan lisäksi torjutaan myös kaikki muu, mikä liittyy Vanhaan testamenttiin. On syytä korostaa, että tällainen "protestieksegeesi" ei ole "gnostilaisen" raamatuntulkinnan koko kuva, kuten joskus väitetään, vaan ääri-ilmiö, joka näkyy vain osassa käytettävissä olevista lähteistä.

\section{Vanha testamentti intertekstinä}

Kirjallisuudentutkimuksessa käytetty intertekstuaalisuuden näkökulma antaa välineitä ymmärtää valentinolaisia ja setiläisiä tulkintoja Vanhasta testamentista. Intertekstuaalinen tulkinta kiinnittää huomiota tekstissä esiintyvien kirjallisten lainausten ja viittausten synnyttämään merkitysten verkostoon. Tekstistä voi nousta esiin hyvin erilaisia suhteita aikaisempiin teksteihin. Tällaisia suhteita ovat esimerkiksi jäljittely, lainaaminen, hyväksyntä, vastustus, uudelleen muotoilu ja vaikeneminen. Valentinolaisten ja setiläisten kristittyjen teksteissä esiintyy näiden perusmuotojen lisäksi Vanhan testamentin kertomusten allegorisia tulkintoja, lyhennelmiä, laajennuksia, parodioita ja suoraa ivailuakin. Intertekstuaalisten suhteiden verkosto on tihein ja moniulotteisin Nag 
Hammadin kirjaston setiläisissä teksteissä, joten keskityn seuraavissa esimerkeissä niihin.

Ajatus erityisestä setiläisestä gnostilaisuudesta kuuluu Nag Hammadin kirjaston tutkimuksen keskeisimpiin tuloksiin. Itäsaksalainen Uuden testamentin professori ja koptologi Hans-Martin Schenke havaitsi osassa kirjaston teksteistä huomattavan määrän yhteisiä piirteitä, jotka puuttuivat kirjaston muista teksteistä. Näiden erityispiirteiden pohjalta Schenke hahmotteli ajatuksen gnostilaisen kristinuskon setiläisestä uomasta. Schenke havaitsi myös, että samoja erityispiirteitä oli myös kirkkoisä Irenaeuksen kuvauksessa valentinolaisia varhaisempien, itseään "gnostilaisiksi” kutsuneiden kristittyjen näkemyksistä. Irenaeuksen esityksen perusteella tämä ryhmä näyttää melko vähäpätöiseltä. Nag Hammadin kirjaston setiläiset tekstit paljastavat, että ryhmän vaikutus ulottui 300-luvun puoliväliin asti, jolloin kirjaston tekstit kopioitiin (ja sittemmin piilotettiin ruukkuihin).

Setiläisen kristillisyyden tärkein lähde on teksti nimeltä Johanneksen salainen kirja. Tekstin suosiosta kertoo se, että siitä on Nag Hammadin kirjastossa kolme toisistaan hieman poikkeavaa versiota. Niissä kirjaston koodeksiniteissä, joissa teksti on, se on aina ensimmäisenä. Lisäksi tekstistä on säilynyt neljäs versio toisessa samantyyppisessä, koptinkielellä säilyneiden tekstien kokoelmassa, joka tunnetaan nimellä Berlinus Gnosticus.

\section{Ihmisen jumalallinen olemus ja seksuaalinen himo}

Mooseksen ensimmäisen kirjan, Genesiksen, luova - ja samalla kriittinen - uudelleentulkinta on keskeisessä asemassa setiläisissä teksteissä. Platonistien tavoin setiläiset selittivät näkyvän maailman heijastumaksi todellisen ja ikuisen Jumalan maailmasta. Vaikka näkyvä maailma on epätäydellinen, se ei ole täysin erillään todellisen Jumalan maailmasta.

Setiläisissä luomismyyteissä todellisen Jumalan maailmassakin on Genesiksen luomiskertomukseen pohjautuvia hahmoja kuten Adamas, Set sekä "Setin jälkeläiset." Adamas on malli, jota alempi luojajumala käyttää luodessaan enkeliensä avustamana ensimmäisen ihmisen, Aada- 
min. Ihminen on luojajumalan epätäydellisyyden vuoksi vajavainen ja unohduksen tilassa.

Esikuva kuitenkin velvoittaa: mallisuhteen perua ihmisessä on sisäänrakennettuna yhteys "jumalalliseen ihmiseen" ja tätä kautta todelliseen Jumalaan. Jos tämä ihmisen sisässä piilevänä asuva jumalallinen olemus saadaan ravisteltua hereille, se vapauttaa ihmisen ruumiin kahleista kohti todellista, sisäistä minäänsä ja mahdollistaa sielun nousun todellisen Jumalan luokse.

Setiläisten tapa käyttää Genesiksestä nousevia teemoja liittyy tähän perusnäkemykseen. Heidän luomismyyttiensä tarkoituksena on ensinnäkin osoittaa, että kaikissa ihmisissä on edellä kuvattu jumalallinen olemus. Toinen keskeinen tarkoitus on kuvata, millaiset asiat estävät ihmistä tunnistamasta todellista minäänsä. Toisin sanoen: millä keinoilla paha ja kateellinen luojajumala Jaldabaoth estää sielun paluun todellisen Jumalan luokse?

Kuten tosi-TV:n tekijätkin tietävät: kun mikään muu ei auta, on turvauduttava seksiin. Ja väkivaltaan. Johanneksen salaisessa kirjassa kuvataan, kuinka Jaldabaoth ihastuu Eevaan ja raiskaa tämän. Raiskauksessa Jaldabaothin seksuaalinen himo tarttuu Eevaan ja siirtyy Eevan välityksellä ihmiskuntaan: "Tähän päivään asti sukupuoliyhteys on jatkunut ensimmäisen hallitsijan tähden. Hän kylvi halun siemenen Aadamin puolisoon. Hän sai aikaan sen, että ruumiiden kopiot saavat alkunsa yhdynnästä. Hän antoi heille vääristyneen hengen” (Joh. Sal. II 24). Teksti edellyttää, että raiskauksessa raiskatunkin seksuaalinen halu herää. Ajatus on pöyristyttävä, mutta ei aivan poikkeuksellinen antiikin maailmassa.

\section{Luojajumalan kritiikkiä}

Setiläiset samastivat toisiinsa Jaldabaothin ja Vanhan testamentin Jumalan. Jesajan kirjassa Jumala julistaa olevansa ainoa jumala: "Minä olen Herra. Ei ole ketään toista, ei ole muuta jumalaa kuin minä" (45:5). "Minä olen Jumala, eikä muuta Jumalaa ole. Minä olen Jumala, ei kukaan ole minun vertaiseni" (46:9). Setiläisissä teksteissä näitä kohtia lainataan - ja niitä pidetään merkkinä luojajumala Jaldabaothin 
rehentelystä ja täydellisen tietämättömyyden tuomasta väärästä varmuudesta.

Johanneksen salaisessa kirjassa Jesajan kirjan kohtaa kommentoidaan lakonisesti: "Hän väitti: 'Minä olen Jumala, eikä muuta Jumalaa ole.' Hän ei tuntenut voimaansa, paikkaa josta oli lähtöisin” (II 11). Teema toistuu muissakin setiläisissä teksteissä, esimerkiksi tekstissä, jonka nimi on Hallitsijoiden olemus. Siinä sanotaan: "Heidän johtajansa on sokea. Voimansa, tietämättömyytensä [sekä] pöyhkeytensä [tähden] hän [voimansa] tunnossa sanoi, 'Minä olen Jumala, eikä ole toista [minun lisäkseni.] Sanoessaan tämän hän teki syntiä [kaikkeutta] vastaan. ... Silloin ääni tuli turmeltumattomuudesta: 'Sinä olet väärässä, Samael! Nimi tarkoittaa 'sokeaa jumalaa'" (86-87).

Johanneksen salaisessa kirjassa kommentoidaan pilkallisesti myös toista Vanhan testamentin Jumalan keskeistä ominaisuutta, kiivautta: "Kun hän näki luomakunnan ympärillään ja vierellään lukemattomat enkelit, jotka olivat hänestä lähtöisin, hän sanoi heille: 'Minä olen kiivas Jumala, eikä ole muuta Jumalaa minun rinnallani.' Näin ilmoittaessaan hän osoitti luonaan olleille enkeleille, että on olemassa toinen Jumala. Jos toista nimittäin ei olisi, ketä vastaan hän oikein kiivailisi?" (Joh. sal. II 13). Vertaa 2. Moos. 20:4-5: "Minä, Herra, sinun Jumalasi, olen kiivas Jumala. Aina kolmanteen ja neljänteen polveen minä panen lapset vastaamaan isiensä pahoista teoista, vaadin tilille ne, jotka vihaavat minua."

\section{Vanha testamentti on väärässä - ja sittenkin oikeassa?}

Johanneksen salaisessa kirjassa Vanhan testamentin Jumala on muuttunut saatanalliseksi hahmoksi, josta ei ole mitään hyvää sanottavaa. Silti tekstissä ei hylätä Vanhaa testamenttia kokonaan. Hylkääminen ja hyväksyntä kietoutuvat erikoisella tavalla toisiinsa. Vaikka tekstissä kuvattu luomismyytti on monessa suhteessa uusi, ihmisen luomisen osalta kertomuksen runko seuraa pitkälti Genesiksen luomiskertomusta.

Genesiksen tulkinta on kuitenkin joka kohdassa luovaa: Johanneksen salaisessa kirjassa esitellään uusia käänteitä ja hahmoja. Siinä esi- 
merkiksi luetellaan yli 70 demonia, jotka ovat vastuussa Aadamin eri ruumiinosista. Uusi teema on esimerkiksi luojaenkelien tuntema kateus Aadamia kohtaan: "Kun he kohottivat katseensa, he näkivät että Aadamin ajattelu oli erinomaista. ... He veivät ihmisen kuoleman varjoon luodakseen hänet uudelleen. ... Tällä tavoin uudelleen luotu ruumis on luola, jonka ryövärit pukivat ihmisen ylle unohduksen kahleeksi.”

Paratiisi ei ole Johanneksen salaisessa kirjassa ihanteellinen alkutila, vaan paikka, jossa luojaenkelit tarjoavat Aadamille petollista nautintoa. Paratiisin keskellä olevan elämänpuun "juuri on katkera, sen oksat tappavat, sen varjo huokuu vihaa, sen lehdissä piilee petos, ja sen kukinto tihkuu pahuuden öljyä. Sen hedelmä on kuolema, halu on sen siemen, ja pimeydessä se puhkeaa kukkaan" (Joh. sal. 21-22).

Tällaiset kohdat ovat esimerkkejä protestieksegeesistä, jossa Vanhassa testamentissa kuvatuille tapahtumille annetaan uusi, alkuperäisen tekstin kannalta täysin vastakkainen sisältö. Mutta miksi yleensä kannatti luoda tällainen Vanhaan testamenttiin pohjautuva "vastamyytti," jos kirjoittaja oli täysin eri mieltä Vanhan testamentin kanssa? Yksi ratkaisu on, että Vanha testamentti oli kristityille tässä vaiheessa jo niin tärkeä teksti, ettei sitä voinut yksinkertaisesti sivuuttaa. Tämä ei kuitenkaan ole tyhjentävä selitys.

Yksi Johanneksen salaisen kirjan erikoisista piirteistä liittyy sen tapaan lainata Vanhaa testamenttia. Muutamissa Johanneksen salaisen kirjan kohdissa kuitenkin esitetään suoria lainauksia Vanhasta testamentista, ja heti todetaan sen jälkeen, ettei kohtaa pidä ymmärtää Mooseksen tavoin. Lukijan pitää nähdä tekstin kirjaimen takana oleva syvällisempi merkitys. Paras esimerkki tästä on kohtaus, jossa Vapahtaja kertoo Johannekselle, kuinka Jaldabaoth vaivutti Aadamin uneen. Tämän jälkeen seuraa kiinnostava keskustelu:

Minä kysyin Vapahtajalta: "Mitä tarkoittaa 'uni'?

Hän vastasi: "Olet kuullut, että Mooses kirjoitti ensimmäisessä kirjassaan: 'Jumala vaivutti Aadamin uneen.' Näin ei ole, vaan Aadamin käsityskyky tainnutettiin. Hän näet sanoi profeetan välityksellä: 'Minä paadutan heidän sydämensä, jotta he eivät ymmärtäisi eivätkä näkisi.’” (Jes. 6:10)

Tämän kohdan suhde Vanhaan testamenttiin on erityisen monisyinen. Kirjoittaja esittää ensin suoran lainauksen Genesiksestä ja torjuu sen 
saman tien Mooseksen tulkintana. Sitten kirjoittaja kuitenkin esittää allegorisen tulkinnan, joka perustuu samaiseen Vanhan testamentin kohtaan, ja lopuksi vielä puolustaa omaa tulkintaansa lainauksella Jesajan kirjasta. Vain hetkeä myöhemmin kirjoittaja siteeraa Genesiksestä Aadamin huudahduksen, kun hän tapasi Eevan ensimmäistä kertaa: "Tämä on luu minun luistani ja liha minun lihastani. Siksi mies jättää isänsä ja äitinsä ja liittyy vaimoonsa, niin että nämä kaksi tulevat yhdeksi lihaksi” (1. Moos. 2:23-24). Tämänkin kohdan kirjoittaja tulkitsee allegorisesti: Aadamin tunnistama puoliso on todellisen Jumalan hänelle lahjoittama "kirkas Äly."

\section{Mooses oli väärässä, mutta teksti ei}

Oliko Vanha testamentti tällaisen tekstin kirjoittajalle ohjeellinen vai ei? Kysymys on vaikea: lainausten perusteella kirjoittaja näyttää hyväksyvän Mooseksen kirjojen arvovallan, mutta samalla hän sanoo torjuvansa itse Mooseksen oman käsityksen.

Johanneksen salaisen kirjan suhdetta Genesikseen selventävät muut kohdat, joissa kirjoittaja mainitsee Mooseksen. Vain pari riviä myöhemmin tekstissä todetaan: "Aadamista ei siis otettu 'hänen kylkiluutaan' kuten Mooses väitti” (Joh. sal. 23). Aiemmassa kohdassa oli jo selitetty aivan Genesiksen alussa olevaa mainintaa, että Jumalan Henki liikkui vetten yllä (1. Moos. 1:2). Kun Johannes kysyy tästä kohdasta, Vapahtaja "hymyili ja sanoi: 'Älä luule, että hän "liikkui vetten yllä," kuten Mooses on sanonut." Vapahtaja selittää, että kohta kuvaa Jaldabaothin äidin, jumalallisen Viisauden tuntemaa katumusta, kun hän näki kaiken sen pahan, mitä hänen poikansa sai aikaan (Joh. sal. 13).

On mahdollista, että "Mooses" on näissä kohdissa symboli juutalaisuudelle, josta Johanneksen salaisen kirjan kirjoittaja haluaa irrottautua mahdollisimman selvästi. Ennen kaikkea "Mooses" näyttää kuitenkin edustavan kirjoittajan lainaamien kohtien kirjaimellista tulkintaa. Johanneksen salainen kirja edellyttää, että Mooseksen tekstillä on alkuperäisen kirjoittajan intentiosta riippumaton, syvempi merkitys, joka voidaan paljastaa allegorisen tulkinnan avulla: teksti sanoo yhtä ja tarkoittaa 
toista. Mooseksen kirjojen kirjaimellisen merkityksen alla tai takana on todellinen merkitys, josta edes Mooses itse ei ollut tietoinen.

Se että Johanneksen salaisessa kirjassa yleensä on allegorisia tulkintoja, osoittaa että sen kirjoittaja pitää Genesiksen tekstiä jollain tavalla pyhänä ja luovuttamattomana. Allegorisia tulkintoja ei antiikin maailmassa nimittäin esitetty mistä tahansa teksteistä, vaan ainoastaan niistä, jotka kuuluivat omaan pyhään traditioon. Kreikkalaisessa maailmassa näin selitettiin erityisesti Homeroksen teoksia. Ensimmäisellä vuosisadalla jKr. juutalainen Filon kirjoitti Aleksandriassa Mooseksen kirjoihin kokonaisen sarjan allegorisia selitysteoksia; niissä kertomus toisensa jälkeen paljastuu opetukseksi hyveistä ja paheista. Johanneksen salainen kirja on kieltämättä sikäli erikoinen luku allegorisen tulkinnan historiassa, että sen kirjoittaja hylkää Mooseksen, mutta ei tämän kirjoittamana pidettyä tekstiä.

\section{Muita näkökulmia Vanhaan testamenttiin}

Johanneksen salaisen kirjan tulkinta Vanhasta testamentista on selvästi kriittisempi kuin aiemmin mainitsemieni valentinolaisten kristittyjen käsitys. Valentinolainen Ptolemaios laati lyhyen mutta hyvin huolellisesti laaditun tutkielman Vanhan testamentin laista. Siinä Ptolemaios todistelee, ettei Vanhan testamentin laki ole täydellinen, ei myöskään sen säätänyt jumala.

Ptolemaioksen paraatiesimerkki on Vanhassa testamentissa hyväksytty periaate "silmä silmästä, hammas hampaasta." Ptolemaioksen mukaan tällaisen periaatteen noudattaminen vain lisää pahuutta, ei vähennä sitä, vaikka tämä olikin lainsäätäjän, alemman luojajumalan tarkoitus: "Osat vain vaihtuvat, mutta itse teko pysyy samana" (Flor. 3.5.4). Ptolemaios oli kuitenkin samaa mieltä esimerkiksi Barnabaan kanssa, että monet Vanhan testamentin säädökset voi ymmärtää hengellisesti: hänen mukaansa eläinten uhraamisen sijasta "on uhrattava hengellisiä uhreja, ylistystä, kiitosta, yhteyttä lähimmäisiin ja hyviä tekoja heitä kohtaan." Ympärileikkaus tarkoittaa "hengellisen sydämemme ympärileikkausta." Sapattia ja paastosäädöksiä noudatetaan "hengellisesti” pidättäytymällä pahoista teoista; myös fyysinen paasto voi joissakin 
tilanteissa "olla hyödyksi sielulle, kunhan sitä ei noudateta vain siksi, että matkittaisiin jotakuta toista tai pelkän tavan vuoksi tai tiettynä päivänä” (Flor. 3.5.8-14).

Toisaalta Johanneksen salaisen kirjan suhde Vanhaan testamenttiin ei ole kielteisin vaihtoehtokaan. Nag Hammadin kirjastossa on myös sellaisia tekstejä, joissa kaikki Vanhaan testamenttiin liittyvä torjutaan vielä jyrkemmin. Tekstissä nimeltä Suuren Setin toinen opetus koko joukko Vanhan testamentin merkkihahmoja - Aadam, Abraham, Iisak, Jaakob, Mooses David, Salomon, 12 profeettaa; listassa mainitaan myös Johannes Kastaja - todetaan yksi toisensa jälkeen pelkiksi "naurun aiheiksi." Tässä tekstissä - toisin kuin Johanneksen salaisessa kirjassa - ei pidetä mahdollisena, että Vanhassa testamentissa olisi minkäänlaisia kaikuja Jeesuksesta ja hänen sanomastaan. Mooseksesta sanotaan: "Aadamista Moosekseen ja Johannes Kastajaan asti yksikään ei tuntenut minua tai minun veljiäni." Tekstin kirjoittajan polemiikki kohdistuu juutalaisiin, jotka seuraavat "enkelien" oppia ja noudattavat ruokasäädöksiä. Kirjoittajan mukaan he löytävät vapauden vain, jos he luopuvat erehdyksestään ja oppivat tuntemaan Ihmisen pojan.

Samoilla linjoilla on Tutkielma totuudesta. Siinä esitetään lyhyt yhteenveto Vanhan testamentin alkukertomusten hankalimmista kohdista, kuten miksi Jumala kieltää Aadamia syömästä hyvän ja pahan tiedon puusta tai kuinka Jumala ei tiedä missä Aadam paratiisissa piileskelee. Yhteenveto huipentuu periaatteelliseen toteamukseen: "Suuri on niiden sokeus, jotka tällaisia lukevat, eivätkä he ymmärrä sitä" (Tutk. tot. 48). Vanhan testamentin torjunnan taustalla on tässäkin tekstissä pyrkimys tehdä selväksi raja "meidän” ja "muiden” välillä. Teksti kuitenkin poikkeaa edellisestä sikäli, että polemiikin kohteena ovat nyt toiset kristityt, eivät juutalaiset. Tekstissä torjutaan nimeltä mainiten muun muassa edellä mainitsemani Valentinos, joka tämän tekstin kirjoittajan mukaan ilmeisesti edustaa liian lepsua linjaa toisin ajatteleviin kristittyihin. 


\section{Pohdintaa}

Ne kristityt, jotka pitivät Vanhan testamentin jumalaa alempiarvoisena luojajumalana, jäivät lopulta tappiolle ja sen vuoksi unohduksiin. Tämä herättää kysymyksen kulttuuristen ja uskonnollisten murrosten rajoista. Menivätkö nämä kristityt liian pitkälle?

Kanadalainen uskontososiologi Rodney Stark on korostanut, että menestyvän uuden uskonnon salaisuus on jatkuvuuden ja uutuuden sopiva tasapaino. Toisaalta tarvitaan riittävästi liittymäkohtia sellaisiin ajatuksiin ja uskomuksiin, jotka ihmiset tuntevat jo entuudestaan. Toisaalta on tarjottava riittävästi uutta, että uusi uskonnollinen ryhmä erottuu riittävästi aikaisemmista. Tästä näkökulmasta katsottuna kuvaamieni kristittyjen irtiotto juutalaisuudesta näyttää liian jyrkältä; maltillisempi linja oli menestyksen tae. Mutta missä kulkee sopivan ja liian suuren murroksen raja? Paavalikin edusti melkoisen suurta murrosta, miksi se menestyi?

Toinen mahdollinen selitys on, että valentinolaisten ja setiläisten luomismyytit olivat liian vaativia tullakseen yleisesti suosituksi. Ei liene sattuma, että Johanneksen salaisen kirjan tarkka listaus yli 70 demonista jäi vähemmälle huomiolle kuin suuren suosion saavuttaneet tarinat egyptiläisen erämaaisä Antoniuksen taisteluista demonien kanssa. Tarinat jäävät paremmin muistiin kuin luettelot. Toisaalta on syytä muistaa, että kaikessa teknisyydessäänkin Johanneksen salainen kirja oli myös suosittu: tekstistä säilyneet koptinkieliset versiot osoittavat, että sillä täytyi olla kohtuullisen paljon lukijoita ja kuulijoita vielä satoja vuosia kirjoittamisen jälkeen.

Kolmanneksi ei voida unohtaa reaalipoliittista näkökulmaa. Tässä esitelmässä kuvaamani kristityt jäivät väärälle puolelle, kun kristinusko 300-luvulla vähitellen saavutti virallisen aseman Rooman valtakunnassa. Toisin kuin oppikirjoissa usein väitetään, kristittyjen vainojen aika ei tuolloin päättynyt. Yhdenlaiset kristityt alkoivat nyt valtiovallan tukemana vainota toisenlaisia kristittyjä. Harhaoppisina pidettyjen kristittyjen kokoustiloja poltettiin, heidän kirjoittamiaan tekstejä hävitettiin ja piilotettiin, ja heidän oikeuksiaan rajattiin. Kyse ei siis ollut vain liian pitkälle menneestä ja aatehistorian laboratoriossa mahdottomaksi 
osoittautuneesta eksperimentistä, vaan kyse oli myös suorasta vallankäytöstä, jolla toisinajattelijat vaiennettiin. 


\section{Vainot ja vainojen välttely varhaiskristillisenä aikana}

\section{Johdanto}

Kertomukset varhaiskristillisen kauden marttyyreistä Rooman valtakunnassa ovat erottamaton osa kristittyjen kollektiivista muistia ja sen varaan rakentuvaa itseymmärrystä. ${ }^{1}$ Marttyyrien periksiantamattomuutta pidetään yleensä osoituksena heidän uskonsa aitoudesta, joka teki vaikutuksen myös ulkopuolisiin ja sai näin ihmisiä kääntymään kristinuskoon. Marttyyrien siis ajatellaan kasvattaneen kristinuskon suosiota ensimmäisillä vuosisadoilla.

Tämä näkemys ei kuitenkaan ole itsestään selvä. Vainot eivät itse asiassa olleet kovinkaan todennäköinen syy ihmisten kääntymiselle kristinuskoon. Vaikka marttyyrien käytös herättikin ihailua, se tuskin selittää varhaisen kristinuskon kasvavaa suosiota Rooman valtakunnassa. Pikemminkin voisi ajatella, että ne, jotka kääntyivät kristityiksi, tekivät niin vainoista huolimatta. Lisäksi marttyyriuteen liitettiin jo varhain kriittisiä varauksia. Tällaisia varauksia eivät esittäneet ainoastaan eikristityt vaan myös toiset kristityt.

Marttyyrien määrästä varhaiskristillisellä kaudella ei ole tarkkaa tietoa, mutta sen arvioidaan nykyisin liikkuvan pikemminkin sadoissa

1 Laajempi ja tarkemmin dokumentoitu englanninkielinen versio samasta aiheesta: Dunderberg 2015, 57-78. Useimmat tässä luvussa käytetyt lähteet löytyvät helpoimmin kokoelmasta Herbert Musurillon toimittamasta kokoelmasta The Acts of the Christian Martyrs (Musurillo 1972). Näissä tapauksissa viittaan Musurillon kokoelman sivunumeroihin. Asiasta tarkemmin kiinnostunut löytää alkuperäiset lähteet helposti Musurillon avulla. 
kuin tuhansissa. Aina 250-luvulle asti kristittyjen vainot olivat paikallisia ja lyhytaikaisia. Koko valtakuntaan ulottuvia, systemaattisia vainoja oli vasta tämän jälkeen, ja silloinkin vain ajoittain.

Tästä huolimatta kristittyjen vainoilla on keskeinen asema kristittyjen kollektiivisen muistin lisäksi sekä Uuden testamentin että varhaiskristillisen kauden tutkimuksessa. Useiden Uuden testamentin kirjoitusten on katsottu heijastavan tilannetta, jossa kristittyjä vainoavat joko juutalaiset tai roomalaiset. Toisaalta tämä tulkintamalli on myös kyseenalaistettu. Esimerkiksi Raimo Hakola on torjunut vakuuttavasti yleisen näkemyksen, jonka mukaan Johanneksen evankeliumin jyrkkien juutalaisvastaisten lausumien syynä on se, että juutalaiset vainosivat kristittyjä. $^{2}$ Leonard Thompson, Heikki Räisänen ja monet muut tutkijat ovat puolestaan osoittaneet, ettei Johanneksen ilmestys ole syntynyt vainojen keskellä, kuten aiemmin ajateltiin. Kirjan verenhuuruisten näkyjen taustalla on pikemminkin kristittyjen helpottunut tilanne, joka johti aiempaa suurempaan sopeutumiseen Rooman valtakuntaan. ${ }^{3}$

Siinä missä Uuden testamentin tutkijat ovat osoittaneet lisääntyvää kriittisyyttä sen oletuksen suhteen, että juutalaiset vainosivat kristittyjä, varhaisen kirkkohistorian tutkijat (esimerkiksi Stephen Benko ja Martha Sordi) ovat edelleen yllättävän kritiikittömiä varhaiskristillisten marttyyrikertomusten suhteen, joista muutamissa syy kristittyjen vainoista vieritetään juutalaisten niskoille. Esimerkiksi Sordi todistelee, että roomalaiset alkoivat vainota kristittyjä nimenomaan juutalaisten aloitteesta. Näin raskaalle syytökselle juutalaisia kohtaan ei varhaiskristillisen ajan lähteistä löydy luotettavaa todistusaineistoa. ${ }^{4}$

Kuvaan aluksi, miksi ja millä tavalla kristittyjä vainottiin Rooman valtakunnassa. Tämän jälkeen kiinnitän tarkempaa huomiota varhaisten kristittyjen kriittisiin näkemyksiin marttyyreistä. Marttyyriuden

\footnotetext{
${ }^{2}$ Hakola 2005, 16-22, 41-86.

${ }^{3}$ Thompson 1990; Räisänen 1992; 2001, 141-189.

${ }^{4}$ Sordi 1983, 199 (vrt. Benko 1984, 20). Sordi perustelee näkemyksensä pelkästään viitteillä Luukkaan Apostolien tekoihin (199-203), jota ei tämän teeman osalta voi hyvällä tahdollakaan pitää asioita tasapuolisesti tarkastelevana lähteenä.
} 
todistusarvo ei ollut läheskään niin itsestään selvä kuin millaiseksi se vähitellen muotoutui kristillisen marttyyritradition synnyttämissä mielikuvissa.

\section{Vainojen syyt}

Kristittyjen näkökulmasta vainot olivat Jeesuksen sanojen täyttymys: "Tulee sekin aika, jolloin jokainen, joka surmaa jonkun teistä, luulee tekevänsä pyhän palveluksen Jumalalle" (Joh. 16:2). "Vaino" on luonnollisesti sisäpuolisten terminologiaa. Roomalaisten vallanpitäjien näkökulmasta kysymys ei ollut "vainosta," vaan niskoittelevien kansalaisten ojentamisesta lain sallimin keinoin.

Kristityt joutuivat siis Rooman valtakunnassa institutionaalisen, poliittisesti hyväksytyn väkivallan kohteiksi. Mutta miksi juuri he? Sikäli kuin kristityt kuuluivat aluksi juutalaiseen yhteisöön, heillä oli periaatteessa sama erivapaus keisarikultista kuin muillakin juutalaisilla. Kristityt kuitenkin tekivät muita juutalaisia ryhmiä aktiivisemmin käännytystyötä, ja tällainen toiminta todennäköisesti kasvatti jännitettä suhteessa yhteiskuntaan. Juutalaisuus oli sallittu uskonto, mutta kääntymistä juutalaisuuteen ei katsottu hyvällä Rooman valtakunnassa. On mahdollista, että kristittyjen aktiivinen käännytystyö loi jännitteitä myös juutalaisen yhteisön sisällä, sillä käännyttäjät vaaransivat toiminnallaan koko yhteisön aseman roomalaisten vallanpitäjien silmissä. ${ }^{5}$

Kristityt eivät olleet Rooman valtakunnassa ainoa ryhmä, joka joutui kurinpidon kohteeksi. Samalla tavalla kohdeltiin myös muita ryhmiä, esimerkiksi astrologeja ja juutalaisia - vaikka viimeksi mainituille oli myönnetty erivapaus valtiollisiin kulttimenoihin osallistumisesta. Näihin ryhmiin kuuluvia karkotettiin helposti Rooman kaupungista, mikäli oli syytä epäillä niiden häiritsevän yhteiskunnallista järjestystä. Keisarin poliittiset vastustajat, usein tasavaltalaisuuden

\footnotetext{
${ }^{5}$ Historiallisesti monipuolisen katsauksen kristittyjen vainojen syistä Rooman valtakunnassa antaa Remus 2002, johon tässä annettu yleiskuvaus perustuu.
} 
puolesta puhuneet senaattorit, joutuivat usein tekemään painostuksen alla itsemurhan. Vainotuiksi joutuivat myös filosofit, koska he suhtautuivat pilkallisesti yhteiskunnassa harjoitettuihin riitteihin ja seremonioihin. (Kysymys sananvapauden rajoista ei siis ole vain ongelma modernissa maailmassa sivilisaatioiden törmätessä toisiinsa, vaan näitä rajoja testattiin jo antiikin aikana.) Kristittyjen tavoin myös filosofit tekivät käännytystyötä, ja heitä syytettiin kristittyjen tavoin vetäytymisestä julkisesta elämästä.

Kristittyihin kohdistui syviä epäluuloja. Roomalaista eliittiä edustavien kirjoittajien teksteissä kristinusko kuvataan "uudeksi ja vahingolliseksi" tai "turmiolliseksi" taikauskoksi (superstitio). Kristittyjä syytettiin myös "vihasta ihmiskuntaa kohtaan" (odio humani generis). ${ }^{6}$ Taustalla lienee ilmeisesti kristittyjen julistus pian koittavasta maailmanlopusta ja ihmiskunnan tuomiosta. Kristittyjä syytettiin ateismista, mikä käytännössä tarkoitti torjuvaa asennetta jumalakuvia kohtaan. Roomalaista käsitystä hurskaudesta (pietas/eusébeia) loukkasi se, etteivät kristityt suostuneet uhraamaan jumalille. Lisäksi kristittyjen väitettiin syyllistyneen erilaisiin häpeällisiin tekoihin (flagitia), ${ }^{7}$ kuten kannibalismiin (mahdollisesti ehtoolliskäytäntöön liittyen), orgioihin (siksi että kristityt kokoontuivat öisin) sekä insestiin. ${ }^{8}$

Tutkimuskirjallisuudessa edellä mainitut syytökset ja ennakkoluulot kristittyjä kohtaan esitetään usein vainojen syyksi sen kummemmin erittelemättä. Kuitenkaan kaikki nämä syytökset eivät ilmeisesti olleet yhtä raskauttavia. Esimerkiksi syytökset moraalittomuudesta olivat antiikin maailmassa niin yleisiä, että jos niistä olisi jokaisessa tapauksessa nostettu oikeusjuttu, tuomioistuimet olisivat tukkiutuneet ja käyneet toimintakelvottomiksi. ${ }^{9}$ Aivan samoja syytöksiä orgioista, kannibalismista ja insestistä sinkosivat kristityt toisia kristittyjä vastaan ja filosofit

\footnotetext{
${ }^{6}$ Tacitus, Annaalit 15.44; superstitio myös mm. Plinius nuor. 10.96; Suetonius, Nero 16.

${ }^{7}$ Tacitus, Annaalit 15.44; Plinius nuor. 10.96.

${ }^{8}$ Tällaisista syytöksistä raportoivat mm. Justinos, 1. Apol. 26; 2. Apol. 12; Athenagoras, Leg. 3.

${ }^{9}$ Syytös moraalittomuudesta esiintyy kuitenkin kertomuksessa Lyonin marttyyreistä: palvelijat väittivät heidän syyllistyneen "Tyesteen aterioihin ja Oidipuksen kaltaisiin suhteisiin" (Musurillo 1972, 66).
} 
toisten filosofikoulukuntien kannattajia kohtaan. ${ }^{10}$ Sillä mitä koulukuntaa syytöksiä esittänyt henkilö sattui edustamaan, ei ollut suurtakaan merkitystä. Myöskään syytös taikauskosta ei ollut kovin painava, sillä roomalaiset leimasivat taikauskoksi kaikki uudet, idästä tulleet uskonnolliset virtaukset. Juridista merkitystä tällä syytöksellä oli vain, jos itämaiset kultit alkoivat häiritä yhteiskunnallista järjestystä Roomassa.

Juridisesti merkittävimpiä olivat syytökset ateismista ja hurskauden puutteesta. Kumpikin piirre liittyi roomalaiseen yhteiskuntauskontoon. Uhraaminen jumalille oli ensi sijassa osoitus henkilön lojaalisuudesta Rooman valtakunnalle. Siitä mihin henkilö itse sisimmässään uskoi, ei oltu kiinnostuneita.

Tämä tilanne näkyy hyvin Plinius nuoremman kirjeessä keisari Trajanukselle. Plinius kirjoitti kirjeen vuosien 111 ja 113 välisenä aikana, jolloin hän toimi Mustanmeren rantamilla sijainneen Pontoksen ja Bithynian maakunnan keisarillisena käskynhaltijana. Plinius pyytää kirjeessään keisarilta tarkempia ohjeita siitä, miten kristittyjen kanssa tulisi menetellä. ${ }^{11}$ Plinius kuvaa yksityiskohtaisesti, kuinka hän on tähän asti on toiminut tämän asian suhteen. Hän on edellyttänyt, että kristityiksi epäillyt ja tästä syystä ilmiannetut henkilöt "minun esimerkkini mukaan kutsuivat avuksi jumaliamme ja uhrasivat suitsukkeita ja viiniä sinun kuvallesi, jonka olin käskenyt tuoda paikalle tätä tarkoitusta varten. Lisäksi he kirosivat Kristuksen.”

Pliniuksen mukaan tämä menetelmä erotti tosikristityt muista: "Sanotaan, että mitään näistä asioista ei voida pakottamaan tekemään niitä, jotka ovat tosikristittyjä.” Jos syytetty tunnusti olevansa kristitty eikä peruuttanut tunnustustaan käskynhaltijan maanittelusta huolimatta, tämä jo sinänsä oli riittävä syy rangaista syytettyä.

Mielenkiintoinen on Pliniuksen lisäys: ”... en epäröinyt rangaista heitä, koska heitä pitää rangaista ainakin jääräpäisyydestä ja joustamat-

\footnotetext{
${ }^{10}$ Vrt. Gowan 1994; Wright 2006.

11 Plinius nuor. 10.96; suomennos kirjasta Plinius nuoremman kirjeitä Trajanuksen ajan Roomasta (kääntäneet ja toimittaneet Tuulikki Elo ja Heikki Laakkonen; Helsinki: SKS, 2005), 151-152.
} 
tomuudesta.” Maininta viittaa siihen, mikä muutenkin käy ilmi kirjeestä: Plinius tuntee epävarmuutta siitä, onko kristittyjä järkevää rangaista vain siksi, että he tunnustavat olevansa kristittyjä. Hän kysyykin kirjeessään, "rangaistaanko kristittyä, jos hänellä ei ole rikoksia vai vain silloin kun hänellä on rikoksia." Kuulusteluissa uskonsa kieltäneet kristityt nimittäin korostivat syyttömyyttään muihin rikoksiin, joista heitä syytettiin, eikä Pliniuksella ole syytä epäillä heitä. Hänen mukaansa kristityt "eivät varasta, eivät tee aviorikosta, eivätkä kieltäydy luovuttamasta takaisin huostaansa uskottua omaisuutta." Ainoa rikos, johon kristityt myönsivät syyllistyneensä, oli osallistuminen yöllisiin kokouksiin, jossa oli esitetty laulu Kristukselle "niin kuin jumalalle.” Näitäkään kokouksia he eivät olleet viettäneet sen jälkeen, kun Plinius kielsi ne.

Pliniuksen tapa kuulustella kristittyjä oli laajemmaltikin käytössä Rooman valtakunnassa. Sama vaatimus esiintyy esimerkiksi toisen vuosisadan loppupuolelle sijoittuvassa marttyyrikertomuksessa, jossa käskynhaltija Perennius vaatii kristittyä Apolloniusta tekemään parannuksen (!) ja suorittamaan uhrit jumalille ja keisari Commoduksen (keisarina 180-192) kuvalle. ${ }^{12}$ Yhtenäisiä ohjeita kristittyjen kuulusteluista maaherroilla tuskin kuitenkaan oli, sillä käytännöt selvästi vaihtelivat. Justinusta kumppaneineen vaadittiin ainoastaan uhraamaan jumalille. ${ }^{13}$ Muutamissa muissa marttyyrikertomuksissa kristittyjä taas vaaditaan vannomaan nimenomaan keisarin geniuksen eli sielun tai miehisen elinvoiman nimeen (esim. Skillan marttyyrit; Pol. martt. 9:2; Apoll. martt. 3). ${ }^{14}$

Pliniuksen tuomioperuste tuomiolle oli yleisesti tunnettu Rooman valtakunnan eri osissa. Tuomion syyksi riitti se, että syytetty myönsi olevansa kristitty. Tämä yksityiskohta Pliniuksen kirjeessä pitää yhtä lukuisten varhaisten marttyyrikertomusten kanssa, joissa syytetyt totea-

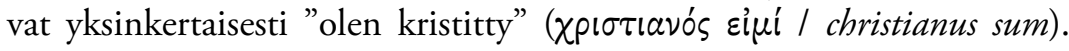
Tunnustus esiintyy pienin variaatioin yhtä lailla kertomuksessa Justinoksen ja hänen seuralaistensa kuulusteluista kuin kuvauksissa

\footnotetext{
${ }^{12}$ Musurillo 1972, 92.

${ }^{13}$ Musurillo 1972, 46.

${ }^{14}$ Musurillo 1972, 86.
} 
Viennan ja Lyonin marttyyreistä, jotka joutuivat vainon kohteeksi vuonna 177 jKr., sekä Skillan marttyyreistä: "Olen ollut kristitty, olen kristitty, ja kristittynä pysyn." (Hierax); ${ }^{15}$ "Olen kristitty!" (Blandina, yksi Lyonin marttyyreista); ${ }^{16}$ "Olen kristitty!" (Sanctus); ${ }^{17}$ "Olen kristitty!" (christiana sum, Vestia, yksi Skillan marttyyreistä); "Olen kristitty!" (Christianus sum; Speratus, yksi Skillan marttyyreistä). ${ }^{18}$ Kaikissa kertomuksissa tunnustus sellaisenaan johtaa suoraan kuulustelun päättymiseen ja on riittävä peruste teloitustuomiolle. Rooman valtakunnan provinsseissa oli siis jo toisen vuosisadan alussa selvää, että jos joku tunnusti olevansa kristitty, tämä merkitsi automaattisesti kieltäytymistä vaadituista kunnianosoituksista keisarille ja jumalille. Kertomukset osoittavat myös, että nämä kristityt eivät kuuluneet juutalaiseen synagogaan, sillä jos he olisivat kuuluneet, heiltä ei olisi vaadittu osallistumista keisarikulttiin.

Ennen 250-lukua viranomaiset eivät yleensä etsineet kristittyjä aktiivisesti tuomioistuinten eteen. (Tässä suhteessa varhaisten kristittyjen vainot poikkesivat juutalaisten vainosta natsi-Saksassa.) Normaalitapauksissa asia tuli käsittelyyn vain, jos joku teki ilmiannon viranomaisille. Ilmiantajien (delatores) motiivit olivat monenkirjavia. Ilmianto saattoi olla keino päästä eroon ikävästä naapurista tai samaa perintöä jakamassa olleesta sukulaisesta. Syynä saattoi olla myös avioriita: kun eräs kristityksi kääntynyt roomalainen ylhäisönainen erosi miehestään, mies kosti ilmiantamalla naisen kristityn opettajan, Ptolemaioksen. ${ }^{19}$ Ilmiannon motiivina saattoi olla myös halu edistyä virkatai sotilasuralla. Kun Marinus-nimisestä kristitystä aiottiin tehdä sadanpäämies, hierarkiassa seuraavana ollut teki hänestä ilmiannon saadakseen viran itselleen. ${ }^{20}$

\footnotetext{
${ }^{15}$ Musurillo 1972, 56.

${ }^{16}$ Musurillo 1972, 66.

${ }_{17}^{17}$ Musurillo 1972, 68.

${ }^{18}$ Musurillo 1972, 88.

19 Justinos, 2. Apol. 2.1-14. Tutkijat ovat erimielisiä, oliko tämä Ptolemaios sama henkilö kuin valentinolainen Ptolemaios (vrt. Dunderberg 2008, 91-92).

${ }^{20}$ Eusebios, Kirkkohistoria 7.15.1-4.
} 
Vaikka laajamittaisia kristittyjen vainoja oli Rooman valtakunnassa erittäin harvoin, ilmiannon mahdollisuus oli arkipäivää. Sen vuoksi kristittyjen asema roomalaisessa yhteiskunnassa oli ainakin periaatteessa kaiken aikaa vaakalaudalla. Kun pastoraalikirjeissä kehotetaan kristittyjä kuuliaisuuteen esivaltaa kohtaan ja ystävällisyyteen ja lempeyteen kaikkia ihmisiä kohtaan (Tit. 3:1-2), kyse ei ole niinkään kristinuskon pikkuporvarillistumisesta (kuten näiden kirjeiden tulkinnassa usein oletetaan) kuin reaalipolitiikasta. Oli järkevää pyrkiä elämään niin, ettei herättänyt ärtymystä ulkopuolisissa.

Trajanuksen vastaus Pliniuksen kirjeeseen osoittaa, että ilmiannoista tuli jo varhain riesa roomalaiselle oikeuslaitokselle. Trajanus nimittäin määrää kirjeessään, ettei nimettömiä ilmiantoja tule ottaa käsiteltäviksi ollenkaan. ${ }^{21}$ Maaherrat joutuivat ratkaisemaan valtavan määrän kiistakysymyksiä, kun he kiersivät provinsseissaan jakamassa oikeutta. On arvioitu, että heillä oli käytettävissään keskimäärin minuutti tapausta kohden. ${ }^{22}$ Käsittelyn piti siksi olla tehokasta, ja tarpeettomia syytöksiä yritettiin karsia.

Lisäksi roomalaiset oikeudenjakajat eivät varhaisissa lähteissä vaikuta niin verenhimoisilta kuin millaiseksi kristittyjen kollektiivinen muisti on heidät muokannut. He eivät yleensä tuominneet kristittyjä suoralta kädeltä, vaan antoivat heille tilaisuuden muuttaa mielensä. ${ }^{23}$ Plinius antoi uskonsa tunnustaneille kaksi mahdollisuutta katumukseen (!) ennen kuin tuomitsi heidät. Marinus sai kolmen tunnin harkintaajan ennen kuin hänet tuomittiin. ${ }^{24}$ Roomalainen Perennius yritti saada kristittyä Apolloniusta muuttamaan mielensä ("Tee parannus!"), ${ }^{25}$ ja Saturninus maanitteli Skyllan kristittyjä marttyyrejä: "Älkää te vain yhtykö tämän hulluuteen! ${ }^{26}$ Kyse ei ollut johonkin pysyvään piirteeseen kuten rotuun tai kansallisuuteen liittyvästä vainosta (kuten Saksassa kolmannen valtakunnan aikana tai Balkanin niemimaalla 1990-luvulla),

\footnotetext{
${ }^{21}$ Plinius nuor. 10.97; Laakkonen \& Elo 2005, 153.

${ }^{22}$ Lane Fox 1986, 423.

${ }^{23}$ Lane Fox 1986, 421.

${ }^{24}$ Eusebios, Kirkkohistoria 7.15.3.

${ }^{25}$ Musurillo 1972, 90.

${ }^{26}$ Musurillo 1972, 88.
} 
vaan kristityt joutuivat kärsimään siksi, etteivät olleet valmiita tekemään kompromisseja.

\section{Marttyyri ja venkoilija}

Amerikkalainen varhaisen juutalaisuuden ja kristinuskon tutkija Daniel Boyarin on tutkimuksessaan Dying for God hahmotellut kaksi erilaista tapaa reagoida vainoihin, kovan ja pehmeän - "fallisen" ja "ei-fallisen," kuten Boyarin niitä itse kuvaa. ${ }^{27}$ Kovaa linjaa edustavat Boyarin mukaan varhaiskristilliset marttyyrikertomukset, joiden sankari on uskonsa järkähtämättömästi tunnustava ja kuolemaa pelkäämätön kristitty marttyyri. Sen sijaan erityisesti juutalaisessa rabbiinisessa kirjallisuudessa sankariksi tällaisissa tilanteissa osoittautuu "venkoilija" (trickster), joka sopivan kaksiselitteisellä vastauksella pääsee pälkähästä kuulusteluissa ilman, että kieltäisi uskoaan.

Boyarin käyttää esimerkkinä kertomusta rabbi Eliezeristä, joka keisari Trajanuksen kaudella joutui viranomaisten eteen siksi, että häntä epäiltiin kristityksi. Kun hallitsija kysyi Eliezerin vastausta esitettyihin syytteisiin, Eliezer vastasi: "Luotan tuomariin." Hallitsija luuli Eliezerin osoittavan luottamusta häneen ja vapautti Eliezerin - vaikka Eliezer tietenkin tarkoitti "tuomarilla" "taivaallista Isäänsä" (Tosefta Hullin $2: 24) .^{28}$

Jako pehmeän ja kovan linjan välillä ei kulje selvästi kristinuskon ja juutalaisuuden välissä, vaan linjat risteävät. "Kovaa” linjaa edustavat esimerkiksi juutalaiset kertomukset makkabealaisajan marttyyreistä. Kristillisissä teksteissä on puolestaan yllättävän paljon merkkejä samanlaisesta "venkoilusta" viranomaisten edessä kuin Eliezerin tapauksessa. Itse asiassa tällaisia piirteitä on jo evankeliumien kertomuksissa Jeesuksen kuulusteluista. Kun juutalaisten ylipappi Johanneksen evankeliumissa haluaa tietää, mitä Jeesus opetti, tämä ei vastaa suoraan vaan

\footnotetext{
${ }^{27}$ Boyarin 1999.

${ }^{28}$ Boyarin 1999, 26-27.
} 
viittaa kuulijoihinsa: "Miksi sinä minulta kysyt? Kysy kuulijoiltani, mitä olen heille puhunut. He kyllä tietävät, mitä olen sanonut" (Joh. 18:21). Kun Pilatus samaisessa Johanneksen evankeliumissa kysyy hetkeä myöhemmin Jeesukselta, "Oletko sinä juutalaisten kuningas," Jeesus ei myönnä eikä kiellä, vaan vastaa kysymyksellä: ”Itsekö sinä niin ajattelet, vai ovatko muut sanoneet minusta niin?” (Joh. 19:33-34)

\section{Marttyyrius ja käytännön järki}

Vaikka kristilliset marttyyrikertomukset edustavat pääosin Boyarinin hahmottelemaa kovaa linjaa, monet kristityt valitsivat pehmeämmän linjan. Useimmat kuulusteluihin joutuneet kristityt tekivät kompromissin ja toimittivat vaaditut uhrit pelastaakseen henkensä. Käytännössä kompromisseja tekivät monet muutkin ja mitä erilaisimmilla perusteilla. Apostolien tekojen mukaan Herran enkeli vapautti ensimmäiset apostolit vankilasta (Ap.t. 5:17-21) ja myöhemmin Pietarin (Ap.t. 12:6-18). Paavali sen sijaan edusti kovempaa linjaa Apostolien teoissa. Vaikka hänelle tarjoutui maanjäristyksen seurauksena tilaisuus vapautua vankilasta, hän jäi tovereineen sinne odottamaan kuulusteluja. Toisaalta Paavalin kuvataan myös helposti lähtevän kaupungeista, joissa hänen asemansa käy tukalaksi (esim. Ap.t. 17:10-15: Paavali lähtee Beroiasta ja jättää juuri kristityiksi kääntyneet hankalaan tilanteeseen). Myöhempiä esimerkkejä löytyy, aivan kristinuskon huipultakin. Origeneen isä Leonidas ja oppilaita menehtyi vainoissa, mutta Origenes itse pelastui vainoilta siksi, että hänen äitinsä piilotti hänen vaatteensa eikä hän voinut lähteä kotoa. Hän kuitenkin kirjoitti vangitulle isälleen kirjeen, jossa kannusti tätä marttyyriuteen. ${ }^{29}$ Piispa Cyprianus piiloutui vainoilta - ja kirjoitti piilopaikastaan marttyyrejä vuolaasti ylistäviä kirjeitä. ${ }^{30}$

Pieni, mutta kiinnostava historiallinen yksityiskohta liittyy keisari Deciuksen vainoihin 200-luvun puolivälissä. Decius määräsi, että

\footnotetext{
${ }^{29}$ Eusebios, Kirkkohistoria 6.3-5.

${ }^{30}$ Lane Fox 1986, 495.
} 
kaikkien Rooman valtakunnan asukkaiden oli uhrattava jumalille viranomaisten edessä, jotka kirjoittivat uhraamisesta kirjallisen todistuksen, libelluksen. Ilmeisesti Deciuksen määräys kohdistui ensi sijassa niihin, joita epäiltiin kristityiksi. Jos valtakunnan kaikki asukkaat olisivat todella joutuneet viranomaisten eteen, määräyksestä olisi kehittynyt "byrokraattinen painajainen." ${ }^{11}$ Joka tapauksessa muutamia edellä mainittuja libellus-asiakirjoja on säilynyt. Kiinnostavaa on se, että osa niistä on selvästi väärennöksiä. ${ }^{32}$ Tästä voidaan päätellä, että osa kristityistä piti pienempänä rikoksena väärennetyn libellus-asiakirjan teettämistä kuin uhraamista jumalille.

Pragmaattista suhdetta vainoihin edustivat ilmeisesti myös elkesaiitit, joiden kerrotaan opettaneen, että ”... uskon kieltäminen on vähäarvoinen asia ja ... ymmärtäväinen mies ahdinkotilassa kieltää suullaan vaan ei sydämellään." 33 Kuvaus ei välttämättä ole pelkkää pahantahtoista panettelua, sillä samanlaisia näkemyksiä esiintyi myös edellä mainittujen juutalaisten oppineiden keskuudessa.

\section{Kriittisistä näkemyksiä vainojen todistusarvosta}

Vaikka marttyyreilla oli suuri symbolinen merkitys, heidän todistuksensa painoarvosta esiintyi jo varhain kriittisiä arvioita. Marttyyriutta eivät kyseenalaistaneet ainoastaan ulkopuoliset kuten keisari Marcus Aurelius, joka ihmetteli kristittyjen jääräpäisyyttä viranomaisten edessä ja asetti heidän käyttäytymisensä vastakohdaksi vapaaehtoisen itsemurhan ilman sankaruuden tavoittelua. ${ }^{34}$ Myös kristityt itse suhtautuivat marttyyriuden todistusarvoon varauksellisesti - silloin, kun vainon tai kurinpitotoimien kohteeksi joutuivat toisten ryhmien edustajat, joko juutalaiset tai toisinajattelevat kristityt.

${ }^{31}$ Lane Fox 1986, 455.

${ }^{32}$ Libelluksista ks. Lane Fox 1986, 455-457.

${ }^{33}$ Eusebios, Kirkkohistoria 6.38.

${ }^{34}$ Marcus Aurelius, Itselle 11.3. 
Apostolien tekojen kirjoittajalta ei heru sympatiaa Sosteneelle, juutalaisen synagogan esimiehelle, jonka kansanjoukko pieksi käskynhaltija Gallion seuratessa sivusta (Ap.t. 18:17). Myöskään harhaoppisina pidettyjen kristittyjen kokemaa vainoa ei pidetty minkään arvoisena. Eusebios lainaa Kirkkohistoria-teoksessaan toiselta vuosisadalta peräisin olevaa kristillistä tekstiä, jonka mukaan markionilaisten ja montanolaisten kokema vaino ei todista mitään (5.16.20-21):

Kun heidät (= montanolaiset) on siis kumottu kaikissa mainituissa kohdissa, he ovat joutuneet neuvottomuuteen, he koettavat turvautua marttyyreihin ja sanovat, että heillä on monta marttyyriä, ja että tämä on varma todistus heillä olevasta niin sanotusta profeetallisesta voimasta. Mutta tämä, siltä näyttää, on kaikkea muuta kuin totta. Sillä muutamilla muillakin lahkoilla on hyvin monta marttyyria, mutta emme kai siksi yhdy heihin tai tunnusta, että he omistavat totuuden. Ensi sijassa Markionin lahkoon kuuluvat niin sanotut markionilaiset sanovat, että heillä on hyvin monta Kristuksen marttyyria, mutta Kristusta itseään he todellisuudessa eivät tunnusta.

Niin syvä oli epäluulo eri kristillisten ryhmien välillä, etteivät edes yhteiset koettelemukset tuoneet heitä yhteen. Eusebioksen lainaamassa lähteessä kerrotaan, kuinka ne, jotka vankilassa valmistautuivat kuolemaan "oikean uskon" puolesta, eivät suostuneet seurustelemaan samassa tilanteessa olleiden montanolaisten marttyyrien kanssa.

Vähitellen kehittyvään marttyyriteologiaan liitettiin niin ikään kriittisiä huomautuksia. Toisella vuosisadalla Aleksandriassa elänyt kristillis-gnostilainen opettaja Basilides pöyristytti toisia kristittyjä väittämällä, että marttyyritkin kärsivät omien, tosin salaisten, syntiensä tähden. ${ }^{35}$ Viattoman kärsimys kyseenalaistaisi luottamuksen Jumalan kaitselmukseen. Siksi Basilides korosti, ettei kukaan ole vanhurskas Jumalan edessä. Basilides argumentoi, että marttyyrien kokema kärsimys koituu heidän omaksi parhaakseen. Heidän kärsimyksensä todellista syytä - salaisia syntejä tai halua niihin - ei paljasteta muille, vaan heitä syytetään siitä, että he ovat kristittyjä:

${ }^{35}$ Basilides, Frg. 7 = Clemens, Strom. 4.81.1-83.1; Löhr 1996, 122. 
Minä väitän siis kaikista niistä, jotka ovat joutuneet mainittuihin ahdistuksiin, että heitä on johdettu hyvää kohti, sillä he ovat salaa syyllistyneet muihin erheisiin. Heidän ohjaajansa hyvyyden vuoksi heitä vastaan esitetään syytteitä aivan muista asioista, etteivät he joutuisi kärsimään tunnustettujen pahojen tekojen vuoksi kuten rikolliset eikä heitä myöskään pilkattaisi avionrikkojiksi tai murhaajiksi, vaan siksi, että he ovat kristittyjä. Tämä lohduttaa heitä siinä määrin, että he eivät edes usko kärsivänsä.

On tosin harvinaista, että joutuu kärsimään ilman että olisi lainkaan tehnyt syntiä. Kuitenkaan kärsivä ei kärsi jonkun voiman tekemän juonen vuoksi, vaan hän kärsii kuten lapsi, joka näyttää siltä, ettei hän ole tehnyt syntiä...

Lapsi ei ole tehnyt syntiä aiemmin tai ei ainakaan ole toiminut syntisesti. Silti hänessä on olemassa synnin tekeminen. Kun hän joutuu kärsimään, se on hänelle hyväksi, sillä hän säästyy kaikesta vastenmielisestä. Juuri samoin sellainenkin ihminen, joka ei näytä tehneen syntisiä tekoja mutta silti joutuu kärsimään, kärsii samoin kuin lapsi. Hänen sisällään on taipumus syntiin. Hän ei ole kuitenkaan tehnyt syntiä, sillä hänelle ei ole tullut siihen aihetta. Näin ei siis voida pitää hänen ansionaan, ettei hän ole tehnyt syntiä. Onhan se joka haluaa tehdä aviorikoksen avionrikkoja, vaikka ei onnistuisikaan tekemään aviorikosta, ja se joka haluaa tehdä murhan on murhaaja, vaikka ei onnistuisikaan murhaamaan. Samoin jos näen edellä mainitun synnittömän kärsivän, vaikka hän ei olisikaan tehnyt mitään pahaa, väitän, että hän haluaa tehdä syntiä. Sanon mieluummin näin kuin väittäisin, että kaitselmus on paha...

Jos sivuutat kaikki nämä perusteet, saatat ehkä syyttää minua eräiden henkilöiden vuoksi sanoen: tämä ja tuo teki siis syntiä, koska hän joutuu kärsimään. Jos vain sallit, vastaan tähän, ettei hän tehnyt syntiä, mutta hän on samanlainen kuin lapsi, joka joutuu kärsimään. Mutta jos haluat laittaa oikein tiukoille, vastaan, että ihminen, kenet sitten nimeätkin, on vain ihminen, kun taas Jumala on vanhurskas. Sanoihan joku: "saastaisesta ei voi tulla puhdasta" (Job 14:4).

Basilideen kriittinen suhde marttyyriuteen epäilemättä loukkasi muita varhaisia kristittyjä. Tästä loukkaantumisesta saattoi kummuta väite, ettei Basilides piitannut, vaikka joku kieltäisikin uskonsa vainoissa. Ainakaan edellä mainitussa katkelmassa Basilides ei kuitenkaan kannusta kristittyjä kieltämään uskoaan vainoissa. Kyse on oikeasta suhteesta vainoihin: kristittyjen tulee pitää niitä Jumalan antamana koulutuksena, joka koituu heidän omaksi parhaakseen.

Toinen aleksandrialainen teologi, Clemens, piti Basilideen opetusta tyypillisenä esimerkkinä siitä, että harhaoppiset kristityt karttelivat 
vainoja. Kuitenkin lähes samaan hengenvetoon Clemens itse kritisoi niitä, jotka hänen mukaansa ovat "kiirehtineet kuolemaan" ja "antautuneet turhaan kuolemaan. ${ }^{36}$ Clemensin kritiikki kohdistuu niihin kristittyihin, joita ei vainottu ilmiannon perusteella, vaan jotka menivät itse viranomaisten luokse ja ilmoittautuivat kristityiksi. Tällaiset marttyyrin kruunua havitelleet kristityt olivat Clemensin mukaan vainoajien kanssarikollisia, ja jos he käyttäytyivät erityisen provosoivasti, syy oli kokonaan heidän. ${ }^{37}$ Kristillisistä teksteistä löytyy myös kitkeriä kommentteja siitä, kuinka kristityt osoittivat liian ylenpalttista huolenpitoa vangituille uskontovereilleen.

Vainojen todistusarvoon siis sisältyy hyvin pitkälti samanlaisia ongelmia kuin varhaiskristillisen ajan ihmekertomuksiinkin: sisäpiiriläisille ne ovat todiste uskon voimasta, mutta ulkopuoliset eivät niiden perusteella vakuutu.

\section{Gnostilaiset ja vainot}

Kirkkoisät syyttivät harhaoppisina pitämiään kristittyjä vainojen pakoilusta ja väittivät, ettei kukaan tunnetuista harhaopettajista ollut joutunut kärsimään uskonsa vuoksi. Tämä syytös ei välttämättä pidä paikkaansa Basilideen marttyyrikriittisistä näkemyksistä huolimatta. On esimerkiksi mahdollista, että edellä mainitsemani Ptolemaios-niminen kristitty opettaja, jonka kristityn naisen ex-puoliso ilmiantoi, oli sama henkilö kuin muista lähteistä tunnettu valentinolainen Ptolemaios.

Vainottu kirkko oli myös osa harhaoppisiksi tuomittujen kristittyjen kollektiivista muistia. Erityisen selkeästi tämä teema nousee esiin valentinolaisessa Kolmiosaisessa tutkielmassa. ${ }^{38}$ Sen mukaan on olemassa "vasemmalle" kuuluvien ryhmä, joka "ei ainoastaan hylännyt Herraa ja juonitellut häntä vastaan, vaan jonka viha, kiihko ja pahasuopuus kohdistuvat myös kirkkoon. Tästä syystä tuomitaan ne, jotka ovat

\footnotetext{
${ }^{36}$ Clemens, Strom. 4.4; vrt. Boyarin 1999, 61-64.

${ }^{37}$ Clemens, Strom. 10.

${ }^{38}$ Kristittyjen vainoista tässä tekstissä ks. Dunderberg 2008, 161-173.
} 
lähteneet liikkeelle ja ryhtyneet toimiin kirkkoa vastaan." ${ }^{39}$ Kristittyjä kuvataan samassa tekstissä näin: ”...heidän ruumiinsa ovat maan päällä, he joutuvat palvelemaan ..., he ovat heidän seurassaan heidän kärsimyksissään, vainoissa ja kun heitä alistetaan, kaikessa siinä mitä pyhät ovat joutuneet kokemaan kaikkialla." ${ }^{40}$ Kolmiosaisessa tutkielmassa vainon kohteeksi joutuminen on siis selvästi yksi kristillisen kirkon tuntomerkeistä.

Vainot liittyvät Kolmiosaisen tutkielmassa kysymykseen vallasta ja vallankäytöstä, mikä onkin tämän tekstin keskeinen teema. Tekstissä selitetään myytin avulla vallan alkuperä: vallanhimo sai alkunsa Logoksen lankeemuksesta, minkä seurauksena vallanhimo on koko maailmankaikkeuden perusta: se on järjestetty niin, että jokainen, suurimmasta pienimpään, henkivalloista ihmisiin, toimii toisen herrana. Kirkon kokema vaino kuvataan yhdeksi koko universumin läpäisevän vallanhimon seurauksista. Toisaalta Kolmiosaisessa tutkielmassa pidetään mahdollisena, että vainoajat siirtyvät kirkon puolelle ja tulevat osallisiksi sen kohtaamista kärsimyksistä.

Nag Hammadin kirjastossa on toinenkin teksti, jossa mainitaan vaino. Suuren Setin toisen opetuksen mukaan vaino kohdistuu sellaisiin kristittyihin, jotka ovat peräisin ylhäältä. Heitä eivät vainoa ainoastaan ulkopuoliset ("ne jotka ovat tietämättömiä"), vaan myös toiset kristityt:

Kun me lähdimme kotoamme, laskeuduimme tähän maailmaan ja synnyimme siihen ruumiissa, meitä eivät vihanneet ja vainonneet ainoastaan ne, jotka ovat tietämättömiä, vaan myös ne, jotka luulevat olevansa hyvin perillä Kristuksen nimestä mutta ovat tyhjiä tietämättömyydessään. Aivan kuten älyttömät eläimet he eivät tiedä, keitä he ovat. He vainoavat niitä, jotka minä olen tehnyt vapaiksi, sillä näitä he vihaavat. Jos he vain sulkisivat suunsa, he itkisivät huokaillen ilman hyötyä, sillä he eivät tunteneet minua täysin. ${ }^{41}$

Tekstissä vedetään jyrkkä raja "meidän" ja toisten kristittyjen välille. Jälkimmäiset julistavat "kuolleen miehen oppia," ja heidän kirkkonsa

\footnotetext{
${ }^{39}$ Kolm. tutk. 121-122.

${ }^{40}$ Kolm. tutk. 135.

${ }^{41} 2$ Set 59-60.
} 
on vain kopio todellisesta kirkosta. Setin opetuksen kirjoittaja ei kuvaa, millaisen vainon kohteeksi hänen kuvaamansa kristityt ovat konkreettisesti joutuneet tai keitä heitä vainoavat toiset kristityt ovat. Vastustajien kirkon tunnuspiirteitä ovat pelko, orjuus, maalliset huolet, vääränlainen jumalanpalvelus ja tiedon, gnosiksen, puute. Maininta vastustajien "kuolleen miehen opista" viittaa siihen, että nämä painottivat Jeesuksen sovituskuoleman merkitystä. ${ }^{42}$ Tekstissä vastustetut opettajat pitivät lisäksi tärkeinä omaa arvovaltaansa (eksousia) ja lakia (61:15) sekä noudattivat enkeleiltä peräisin olevia ruokasäädöksiä (64:1-3). Kuvaus sopii parhaiten sellaisiin kirkollisen viran asemaa korostaneisiin kristillisiin ryhmiin, jotka yhä noudattivat juutalaisia kosher-säädöksiä ainakin ruokailuun liittyvien tapojen osalta. Tällaisia kristillisiä ryhmiä oli epäilemättä olemassa varhaiskristillisenä aikana. Esimerkiksi Lyonin kristityt noudattivat vielä 100-luvun jälkipuoliskolla juutalaisia ruokailusäädöksiä, ${ }^{43}$ ja heidän johtajanaan toimi piispa, jolla selvästi oli hyvin arvovaltainen asema. Samanlaisia ryhmiä lienee ollut myös VähässäAasiassa, mistä suuri osa Lyonin kristityistä oli alun perin lähtöisin. ${ }^{44}$

Vastustajat ovat kirjoittajan mukaan myös "vähäisiä." ${ }^{45}$ Kohdasta on päätelty, että tekstin edustamaa ryhmää vainoavat kristityt olisivat mahdollisesti olleet vähemmistössä. ${ }^{46}$ Tulkinta on sikäli ongelmallinen, että tässä tapauksessa kirjoittajan huoli, että toiset kristityt vainoavat hänen hengenheimolaisiaan, olisi pikemminkin teoreettinen kuin todellinen. Lisäksi "vähäinen" tarkoittaa mainitussa kohdassa todennäköisemmin "vähempiarvoista" kuin "määrältään vähäistä." Vastustajat ovat nimittäin kirjoittajan mukaan myös "oppimattomia." Lisäksi heistä sanotaan samassa yhteydessä, etteivät he ole hyväksyneet "totuuden jalosukuisuutta." Kirjoittajan vastustajistaan käyttämät luonnehdinnat viittaavat siis pikemminkin vähäiseen arvoon kuin heidän lukumääräänsä. Jos tekstin kuvaama kristittyjen keskinäinen vaino

\footnotetext{
${ }^{42}$ Riley 1996, 135-136.

${ }^{43}$ Frend 1965, 18.

${ }^{44}$ Frend 1965, 3.

${ }^{45} 2$ Set 60.

${ }^{46}$ Riley 1996, 142.
} 
perustuu todellisiin kokemuksiin eikä ole vain kirjoittajan luomus, tekstin taustalle voidaan olettaa tilanne, jossa pieni itseään eliittikristittyinä pitävä joukko on joutunut suuremman kristittyjen ryhmän vainon kohteeksi.

Konkreettisempi kuva gnostilaisten kristittyjen kokemasta vainosta kristillisessä Rooman valtakunnassa välittyy Milanon piispa Ambrosiuksen ja keisari Theodosius I:n välisestä kirjeenvaihdosta 300-luvun lopulla. Kirjeenvaihdon taustalla oli se, että kristityt olivat polttaneet juutalaisten synagogan, ja nyt keisari aikoi ottaa kirkolta rahat sen jälleenrakentamiseen. Ambrosius kuitenkin valitti keisarin päätöksestä. Hän mainitsee kirjeessään myös valentinolaisten kristittyjen kirkon, jonka kiivastuneet munkit olivat jo aiemmin polttaneet. Ambrosius käyttää tapausta esimerkkinä, jonka tarkoituksena on osoittaa, että keisarin päätös johtaisi mahdottomiin seurauksiin. Mikäli kristittyjen täytyisi rahoittaa synagogan rakentaminen, kuten keisari vaati, heidänhän pitäisi saman logiikan mukaan korvata valentinolaistenkin poltettu kirkko. Tämä taas ei tule kysymykseenkään, sillä kirkon varoilla ei voida tukea "pakanoiden kokoontumista." Ambrosiuksen valitus johti toivottuun tulokseen: keisari pyörsi päätöksensä synagogan jälleenrakentamisen rahoittamisesta kristittyjen varoilla. ${ }^{47}$

${ }^{47}$ Ambrosius, Kirjeet 41-42. 


\section{Hengellinen johtajuus ja sen kritiikki: varhaiskristillisiä näkökulmia}

(2010)

\section{Vaihtoehtopiispoja ja piispaboikottia}

Kysymys piispojen hengellisestä vallasta on noussut kuluneen vuoden aikana otsikoihin useasti. Matti Väisäsen valinta ruotsalaisen Lähetysprovinssin piispaksi - ja samalla Suomessa Luther-säätiön toimintaan osallistuvien hengelliseksi kaitsijaksi - ja sitä seurannut erottaminen luterilaisen kirkon pappisvirasta on herättänyt keskustelua hengellisestä johtajuudesta. Kansanlähetysläisen Uuden tien päätoimittaja Leif Nummela puolestaan ehdotti kesällä niiden viiden suomalaisen piispan "hengellisistä palveluista" luopumista, jotka hyväksyvät homoseksuaalisen parisuhteen.

Väisäsen tapauksessa kyse ei ole vain siitä, voiko sama henkilö toimia samaan aikaan pappina yhdessä uskonnollisessa yhteisössä ja toisessa piispana, vaan ennen kaikkea siitä, kuka yleensä voi antaa mandaatin hengellisiin johtotehtäviin. Julkisuuteen ei ole tihkunut tietoa, miten Väisänen valittiin tehtäväänsä. Luther-säätiön sivustoilla valintaprosessista todetaan vain, että hänet valittiin piispaksi "Missionsprovinsenin kokouksessa" (17.1.2010). Voisiko siis esimerkiksi Tuomas-yhteisö tai mikä tahansa muu hengellistä toimintaa harjoittava ryhmä niin ikään valita "kokouksessaan" itselleen oman piispan, jos nykyiset viranhaltijat eivät satu miellyttämään? Vai tarvitaanko hengelliseen johtovirkaan luterilaisen kirkon monipolvinen, ainakin jossain määrin edustuksellisen demokratian periaatteita noudattava prosessi? 
Vaihtoehtopiispa herättää pohtimaan, kenelle hengellinen valta kuuluu, kuka sen antaa, millä perusteilla - ja millaista hengellinen valta luonteeltaan on. Jos hengellisen vallan ajatellaan tulevan suoraan Jumalalta, eikö silloin kuka tahansa voisi ilmoittaa olevansa piispa, jos kokee olemansa Jumalan tähän tehtävään kutsuma tai valtuuttama aivan kuten profeetat ja näkijät ovat usein kristinuskon piirissä itse ottaneet nämä roolit itselleen?

Nummelan puheenvuorossa piispojen "hengellisten palvelusten" käyttämättä jättämisestä ei ole muuta yllättävää kuin poikkeuksellisen konkreettinen kärki. Uuspietistisissä ryhmissä on aina ajateltu, etteivät kaikki papit ole oikeanlaisessa sydämen uskossa, eikä tällaisten pappien "hengellisiä palveluita" ole ennenkään haluttu käyttää. Uuspietismissä, ainakin sellaisena kuin itse sen tunnen 1970-luvulta, on sisänkirjoitettuna kriittinen suhde kirkon viranhaltijoihin. Jotkut heistä ovat oikeassa uskossa ja heidän hengellinen erityisasemansa hyväksytään, mutta se että joku on kirkon virassa, ei sinänsä takaa mitään. Tällaisella henkilöllä ei ole mitenkään automaattisesti, "viran puolesta," auktoriteettia hengellisissä asioissa.

Nummelan ehdotus poikkeaa aikaisemmasta vain siinä, että se vie perinteisen uuspietistisen periaatteen käytännön tasolle. Tähän asti hiippakunnan piispa on kutsuttu uuspietistien kesäjuhlille esittämään tervetulotoivotus - mutta ei yleensä yhtään sen enempää! Varsinainen hengellinen opastus on annettu järjestävän yhteisön luottohenkilöiden hoidettavaksi.

\section{Kiistoja vallasta on ollut aina}

Kiistat siitä, kenelle hengellinen valta ja johtajuus kuuluvat, eivät ole uusi ilmiö kristinuskon historiassa. Tällaisia kiistoja kristittyjen parissa on käyty viimeistään Paavalin ajoista lähtien eli käytännössä alusta asti. Paavali itse korosti kaikkien kristittyjen tasa-arvoa: "Yhdentekevää, oletko juutalainen vai kreikkalainen, orja vai vapaa, mies vai nainen, sillä Kristuksessa Jeesuksessa te kaikki olette yksi” (Gal. 3:28; vrt. 1. Kor. 12:13; Room. 10:12). Hän myös piikitteli Korintin seurakuntaa, jossa 
yksi oli Pietarin, toinen Apolloksen, kolmas Paavalin ja joku jopa itse Kristuksen puolella! (1. Kor. 1:12)

Toisaalta Paavali kävi tiukkaan taisteluun omasta asemastaan tilanteissa, joissa hänen hengellinen johtajuutensa kyseenalaistettiin. Kaikesta päätellen näitä tilanteita oli usein. Antiokiassa kiisteltiin siitä, voivatko pakanat ja juutalaiset osallistua kristittyjen yhteisille aterioille. Kiistan tuoksinassa Paavali kyseenalaisti Jerusalemin alkuseurakunnan kahden johtajan, Pietarin ja Jaakobin, hengellisen johtajuuden ja valitsi heidän näkemyksistään poikkeavan linjan. Paavali näyttää jääneen tappiolle Antiokiassa (Gal. 2:11-14), mutta jatkoi taistelua oman tulkintansa puolesta Galatalaiskirjeessä.

Korintissa Paavalin oma hengellinen johtajuus oli puolestaan vaakalaudalla, vaikka hän oli seurakunnan perustaja. Hän joutui puolustuskannalle kilpailevia opettajia vastaan, jotka kiistivät hänen olevan oikea apostoli, kyseenalaistivat hänen arvovaltansa - aivan kuten hän itse oli toiminut Antiokiassa Pietarin ja Jaakobin suhteen - ja vielä moittivat hänen heikkoa esiintymistaitoaankin. Paavali joutui pistämään peliin koko teologisen osaamisensa pelastaakseen oman asemansa. Tästä kontekstista kumpuaa Paavalin "heikkouden teologia," jonka avulla hän teki välttämättömyydestä - huonosta esiintymistaidostaan hyveen (2. Kor. 10-12). Kaikesta päätellen hän onnistuikin kääntämään valtapelin edukseen, mikäli 2. Kor. 1-9 on Korinttiin lähetetyn "kyynelkirjeen" (2. Kor. 10-13?) jälkeen seurannut sovintokirje.

Toinen varhainen esimerkki johtajuuteen liittyvistä kiistoista löytyy Johanneksen kirjeistä. Kirjeiden lähettäjä, nimettömäksi jäävä "vanhin," kieltää lukijoitaan osoittamasta vieraanvaraisuutta väärille opettajille: "Jokaisella, joka tässä opetuksessa pysyy, on sekä Isä että Poika. Jos joku tulee teidän luoksenne eikä opeta tällä tavoin, älkää ottako häntä kotiinne älkääkä edes tervehtikö häntä" (2. Joh. 9-10).

"Vanhin" joutui maistamaan omaa läkettään. Hän valittaa toisessa yhteydessä, kuinka Diotrefes-niminen henkilö ei ota vastaan hänen lähettämiään "veljiä," ei anna muidenkaan ottaa heitä vastaan ja jopa erottaa seurakunnasta ne, jotka näin haluaisivat tehdä (3. Joh. 9-10). Diotrefes siis noudatti aivan samaa periaatetta kuin "vanhin," mutta "vanhimman" ryhmää vastaan. Kun vallankäyttäjästä tulee vallankäytön kohde, ääni kellossa muuttuu. "Vanhin" ei hyväksy Diotrefeksen johta- 
juutta vaan kuvaa hänet vallanhimoiseksi. Kirjeen kirjoittaja käyttää vastustajastaan termiä filoproteuon, "se joka haluaa olla ensimmäinen, se joka rakastaa olla muiden johtaja" (3. Joh 9; KR: "mahtailee johtajana”).

\section{Valentinolaisista pietisteihin}

Valtaan liittyy monenlaisia ulottuvuuksia. Yhtältä tarvitaan henkilöitä, jotka pyrkivät valtaan, ja toisaalta tarvitaan yhteisö, joka antaa näille henkilöille mandaatin eli suostuu heidän johdettavikseen. Vallankäyttö synnyttää myös vastustusta. Varsinainen koetinkivi, joka lopullisesti tekee vallasta vallan, onkin se, kuinka hyvin vallantavoittelija onnistuu tukahduttamaan, vaimentamaan tai jollain muulla tavoin kääntämään edukseen vallankäyttönsä aiheuttaman vastustuksen.

Kristinuskon varhaisessa historiassa ja erityisesti sitä koskevassa historiankirjoituksessa on korostunut piispan arvovallan hyväksyvä uoma, sillä sieltä ovat olleet peräisin useimmat käytettävissä olevat varhaiset lähteet. Toisenlaista näkemystä edustavat tekstit ovat lähes poikkeuksetta peräisin varhaiskristillisellä kaudella kätketyistä kirjakokoelmista, mikä on merkki toisinajattelijoiden tehokkaasta vaientamisesta 300-luvulta lähtien.

Niin kutsuttujen apostolisten isien joukkoon luetut Ignatios Antiokialainen ja Clemens Roomalainen vaativat ensimmäisen ja toisen vuosisadan taitteessa ehdotonta kuuliaisuutta piispalle ja muille seurakunnan viranhaltijoille, ja tällainen vaatimus vain vahvistui vuosisatojen saatossa. Joitakin ongelmia tosin tiedettiin esiintyneen, kuten Aleksandriassa pitkään jatkuneet ristiriidat piispan ja kristittyjen huippututkijoiden (Clemens Aleksandrialainen ja Origenes) välillä.

Uudet tekstilöydöt kuten Nag Hammadin kirjasto ja vain neljä vuotta sitten julkisuuteen tullut Tchacos-koodeksi, jonka tunnetuin teksti on Juudaksen evankeliumi, paljastavat, että kriittistä keskustelua hengellisten vallanpitäjien arvovallasta käytiin laajalti varhaisten kristittyjen parissa.

Amerikkalainen tutkija Elaine Pagels on nähnyt yhtäläisyyksiä unohduksiin jääneiden varhaiskristittyjen valtakriittisten näkemysten ja 
Martin Lutherin ajatusten välillä. Pagelsin vertailu perustuu toisella vuosisadalla Roomassa vaikuttaneen Valentinoksen oppilaiden näkemykseen, että kristityt jakautuvat kahteen ryhmään, "hengellisiin" ja "sielullisiin." Jälkimmäiseen ryhmään kuuluvat palvelevat väärää jumalaa ja toimivat oikein rangaistuksen pelosta, kun taas "hengelliset" ovat ymmärtäneet kristinuskon totuuden syvällisemmin ja tästä syystä toimivat oikein ilman ohjeitakin.

Pagelsin mukaan tällainen ajatus sellaisenaan kyseenalaistaa kirkollisen auktoriteetin, sillä kirkollinen viranhaltija voi kuulua alempaan, "sielullisten" kristittyjen kastiin kuin "hengellisen" tason saavuttanut seurakuntalainen. On ilmeistä, ettei "sielullisena" pidetyn papin tai piispan ajateltu voivan toimia "hengellisen" kristityn oppaana. Se joka jo tietää miten asiat ovat, ei edes tarvitse tällaista opastusta, vaan osaa itse arvioida, miten kulloisessakin tilanteessa tulee toimia.

Edellä mainitsemani uuspietistit eivät ehkä pidä rinnastuksesta, mutta Pagelsin kuvaama asetelma toi mieleeni ennen kaikkea omasta nuoruudestani tutun, pietismille ominaisen jaon tosiuskoviin ja eiuskoviin, ja tähän jakoon liittyen vähintään epäilevän mutta useimmiten avoimen kriittisen suhteen seurakuntien hengellisen työn tekijöitä kohtaan. Nuoriso-ohjaajaharjoittelijoistakin tiedettiin heti, kumpaan joukkoon he kuuluivat, kun kuultiin, olivatko he tulossa Suomen Raamattuopistolta vai Luther-opistolta.

Mikäli valentinolaisten ajatukseen kahden tason kristityistä sisältyi kirkollisen vallan kritiikkiä, se oli kuitenkin pikemminkin epäsuoraa kuin suoraa. Valentinolaiset koettiin ongelmaksi nimenomaan siksi, että he eivät perustaneet omaa, "hengellisten" kristittyjen kirkkoa vaan katsoivat kuuluvansa samaan kirkkoon kuin muutkin kristityt. Yhden valentinolaisen tiedetään olleen Rooman piispa Viktorin läheinen avustaja 100-luvun loppupuolella, ja Valentinoksesta itsestään alkoi myöhemmin kiertää huhu, että hän oli lähellä tulla valituksi Rooman piispaksi. 


\section{Johtajat eivät tiedä mitään}

Nag Hammadin ja Tchacos-koodeksin teksteistä löytyy myös suoraviivaista hengellisten johtajien kritiikkiä. Rintamalinjat eivät kulkeneet piispoille kuuliaisen kristinuskon "valtauoman" ja piispoja vastustavien "gnostilaisten" välillä, vaan kritiikkiä kuuluu eri suunnilta.

Nag Hammadin kirjaston tunnetuin teksti, Tuomaan evankeliumi, ei ole sisällöltään erityisen "gnostilainen," mutta hengellisiä johtajia siinä kritisoidaan avoimesti: "Teidän johtajanne saattavat sanoa teille: 'Valtakunta on taivaassa', mutta silloinhan taivaan linnut ehtivät sinne ennen teitä. He voivat myös sanoa: 'Se on meressä', mutta silloin kalat ehtivät sinne ennen teitä. Tosiasiassa valtakunta on sekä teidän sisällänne että teidän ulkopuolellanne." (Tuom. ev. 3, käänn. Antti Marjanen \& Risto Uro)

Johtajien seuraamisen sijasta Tuomaan evankeliumi kannustaa kristittyjä etsimään itse siihen kirjattujen Jeesuksen sanojen tarkoituksen (Tuom. ev. 1), ja se joka tämän tarkoituksen löytää ei enää tarvitse toista opettajaa (Tuom. ev. 13, 108). Tällaisten lausumien valossa ei ole ihme, että Tuomaan evankeliumi mainittiin nimeltä 300-luvun jälkipuoliskolla nimeltä Aleksandrian piispa Athanasiuksen kiellettyjen kirjojen listassa.

Pietarin ilmestyksessä, joka niin ikään on sällynyt Nag Hammadin kirjastossa, kritiikin osoite on sanottu vielä selvemmin auki: "On myös muita ihmisiä, jotka eivät kuulu meihin. He kutsuvat itseään piispaksi ja diakoneiksi, ikään kuin he olisivat saaneet valtuutensa Jumalalta. He alistuvat niiden tuomittaviksi, jotka istuvat ensimmäisillä istuimilla. He ovat vedettömiä kanavia" (Piet. ilm. 79; käänn. Antti Marjanen). Tällaiset henkilöt "johtavat harhaan monia eläviä," sillä heidän valtansa hengellisissä kysymyksissä hyväksytään sokeasti: "Kun harhaanjohtajat mainitsevat sinun nimesi, heitä uskotaan" (Piet. ilm. 80).

Vaikka Pietarin ilmestyksen kirkkokriittinen äänenpaino on selvä, sen perimmäinen syy jää epäselväksi. Ilmeisesti kyse oli opillisista erimielisyyksistä. Pietarin ilmestyksen maailman luonut jumala ei ole tosi jumala eikä "elävä" Jeesus ei kuollut ristillä, vaan ristille naulittiin demonien hallitsema ihmisruumis (Piet. ilm. 82-83). Tällaisen näkemykset olivat epäilemättä jyrkässä ristiriidassa tekstissä kritisoitujen "piispojen ja diakonien" opetusten kanssa. 
Muutama vuosi sitten julkisuuteen tulleessa Jundaksen evankeliumissa kritiikin kohteeksi joutuvat apostolit itse. Jeesuksen opetuslapset Juudasta lukuun ottamatta! - paljastetaan tekstissä väärän jumalan palvelijoiksi, jotka edelleen noudattavat juutalaisia tapoja. Opetuslapset kuvataan uhrimenoja johtaviksi papeiksi, joiden luokse heidän eksyttämänsä kansanjoukko tulee kuin karja. Tähän joukkoon liittyvät myöhemmin lastensurmaajat, ne "jotka makaavat miesten kanssa" ja muut "epäpuhtautta, laittomuutta ja ihmisten eksyttämistä" harjoittavat (Jund. ev. 40-41).

Homoargumentti osoituksena kirkon suuresta luopumuksesta ei siis ole uusi. Juudaksen evankeliumi tosin on toistaiseksi ainoa varhaiskristillinen teksti, jossa Jeesus itse tuomitsee homot. Ehkä on syytä muistuttaa, että antiikin maailmassa vastustajia homoteltiin muutenkin; esimerkiksi epikurolainen (!) Filodemos sinkosi samanlaisia homosyytöksiä stoalaisia vastaan kuin Juudaksen evankeliumin kirjoittaja esittää "apostolisia" kristittyjä vastaan.

Jundaksen evankeliumissa nousee esiin yksi erityiskysymys, joka näyttää liittyvän apostolien hengellisen johtajuuden kritiikkiin. Tekstissä kiinnitetään erityistä huomiota ihmisuhreihin: alttarille tulevat "uhrasivat omia lapsiaan ja jotkut vaimojaan," ja samat ihmiset "kutsuivat avuksi sinun [nimeäsi]" (Juud. ev. 38.) Kuvauksen on tulkittu heijastavan kauhua, jota tekstin kirjoittaja tunsi nähdessään, kuinka kirkon johtajat kannustivat joukkojaan marttyyriuteen Kristuksen nimessä.

Tekstissä oleva kehotus "lopettakaa [uhraaminen]" (Juud. ev. 41) liittyy tämän tulkinnan mukaan sellaiseen kristilliseen marttyyriteologiaan, jota esimerkiksi piispa Ignatios Antiokiassa edusti: Juudaksen evankeliumissa torjutaan Kristuksen nimeen vetoaminen sellaisissa yhteyksissä, joissa kristityt kannustavat toinen toistaan kuolemaan uskonsa puolesta. Tulkinnasta ollaan erimielisiä, mutta minusta on vaikea kuvitella, etteivät Jundaksen evankeliumin varhaiset lukijat olisi nähneet siinä viittauksia kristittyihin marttyyreihin. 


\section{Vallanhimo, maailmankaikkeus ja me}

Hyvin erilaisesta näkökulmasta valtaan liittyviä kysymyksiä lähestytään valentinolaisessa, lähes 80-sivuisessa tekstissä Kolmiosainen tutkielma. Sen keskeinen teema on vallanhimo, jonka alkuperää kuvataan tekstin alkuosassa (74-80) ja vaikutuksia loppuosassa (120-22). Vallanhimo sai tekstissä kuvatun luomismyytin mukaan alkunsa, kun jumalallisen Sanan hairahduksesta syntyi kaksi toistensa kanssa vallasta kilpailevaa ryhmää. Ryhmien välisen taistelun ja sekoittumisen myötä vallanhimosta tuli koko maailmankaikkeuden rakenteen tärkeä osa. Jumalallinen Sana ratkaisi hairahduksensa jälkeen ongelman järjestämällä kosmoksen niin, että siinä kaikilla, henkivalloista maallisiin kuninkaisiin asti, on sekä ylempi hallitsija että alempia hallittavia.

Tutkielman jälkimmäisessä osassa kuvataan, kuinka kristillinen kirkko on joutunut ja joutuu vainotuksi maailmankaikkeudessa vallitsevan vallanhimon seurauksena. Kolmiosainen tutkielma ei siis tue sitä usein esitettyä ajatusta, että gnostilaisia kristittyjä ei olisi vainottu. Kirkko on tämänkin tekstin mukaan vainottu kirkko. Kirkon tilannetta ei kuitenkaan kuvata aivan toivottomaksi, sillä tekstissä pidetään mahdollisena, että jotkut vallanpitäjistä kääntyvät kristityiksi ja heistä tulee vainotun kirkon jäseniä. Tekstissä ei myöskään tuomita kokonaan valtarakenteiden olemassaoloa. Vaikka niiden taustalla on erehdyksestä alkunsa saanut vallanhimo, ylhältä alas ulottuva valtahierarkia esitetään tavaksi, jolla tämän vallanhimo pidetään aisoissa.

Joskus on esitetty kysymys, olisiko kristinusko päätynyt tasaarvoisempaan hallintamalliin, jos kristittyjen välinen taistelu vallasta olisi 300-luvun alussa päättynyt toisin. Tuskinpa, ainakaan jos on uskominen valentinolaista Nag Hammadin tekstiä, jonka nimeksi on annettu Tulkinta tiedosta. Siinä kuvataan seurakuntaa, joka on jakautunut kahteen vastakkaiseen leiriin, niihin joilla on hengellinen lahja, ja niihin joilla tätä lahjaa ei ole.

Vaikka tekstin kirjoittaja kannustaa kaikkia lukijoitaan sovintoon, hänen sympatiansa ovat selvästi ensiksi mainitun ryhmän puolella. Hänen mielestään koko ongelman ydin on "lahjattomien" kateus, ja hän vaatii tähän ryhmään kuuluvia tyytymään osaansa, ottamaan oppia 
korkeammalle tasolle edenneistä - ja pysymään vaiti seurakunnan kokouksissa!

Tulkinnassa tiedosta valta-asemaa ei määritellä kirkollisen hierarkian perusteella, tekstin kirjoittaja ei ole myöskään tasa-arvon kannattaja, vaan hän korostaa hengellisesti lahjakkaiden erityisasemaa seurakunnan kokoontumisissa. Tässä tekstissä ei kuitenkaan tehdä jyrkkää eroa tosiuskovien ja ei-uskovien välillä, vaan argumentoidaan, että kaikki seurakuntalaiset hyötyvät hengellisesti pitkälle edistyneiden opetuksesta kunhan vain vähemmän edistyneet malttavat pysyä hiljaa. Tekstissä esitetty malli edustaa antiikin maailmassa tyypillistä "patriarkaalista hyväntahtoisuutta," jossa ylhältä päin osattiin sanoa, mikä on parasta koko yhteiskunnalle ja suurimmaksi hyödyksi varsinkin alemmille kansanryhmille.

\section{Lopuksi}

Minulta kysytään silloin tällöin, mitä meidän pitäisi oppia uusista "gnostilaisista" lähteistä. Mitään yksiselitteistä vastausta minulla ei ole. Minusta on kiinnostavaa, että kristinuskon "virallisen totuuden" rinnalla on kulkenut pienempiä, "epävirallisia" totuuksia. Ne eivät aina vain yksinkertaisesti kadonneet, vaan niitä myös tukahdutettiin aktiivisesti. Tällaisten tekstien tutkimuksessa on kyse äänen palauttamisesta niille, joilta tämä ääni aikanaan vietiin.

"Virallisen totuuden" tarinassa kristinuskon keskeinen menestystekijä antiikin maailmassa oli kirkon vahva, selkeään hierarkiaan perustunut rakenne. "Epäviralliset" tai "unohdetut" lähteet osoittavat, etteivät kaikki kristityt pitäneet tällaista hierarkiaa itsestään selvänä, vaan valta synnytti vastustusta. Tällainen vastustus oli koko kristinuskon muotoutumisen kannalta tärkeää siksi, että se toimi "testinä", joka lopulta vahvisti niiden aseman, jotka olivat ottaneet käsiinsä vallan. Kirkollista valtaa ei luotu vain kirkolliskokousten päätöksillä ja piispojen kiertokirjeillä, vaan vallasta tuli valtaa myös siellä, missä vihastuneet munkkijoukot polttivat juutalaisten synagogia ja harhaoppisina pidettyjen valentinolaisten kirkkoja. 
Ja toisaalta: "virallisen totuuden" ulkopuolelle jääneissä kirjoituksissakaan ei ainoastaan kritisoitu hengellisiä johtajia, vaan niissä myös etsittiin hengellistä valtaa ja siihen pyrittiin siihen. Tulkinta tiedosta on esimerkki siitä, kuinka itseään hengellisenä eliittinä pitänyt ryhmä halusi järjestää yhteisen seurakunnan rakenteen ja käytännöt siten, että ne tukivat juuri tähän ryhmään kuuluvien asemaa. Toisin kuin Luthersäätiö, tämän varhaiskristillisen tekstin kirjoittaja ei pyrkinyt luomaan samanmielisille omaa jumalanpalvelusyhteisöä, jossa ehtoollista jaetaan vain oikein uskoville. Kirjoittaja kuitenkin vaati painokkaasti hengelliseen eliittiin kuuluville merkittäviä etuoikeuksia ja muilta alistumista.

Jotain tuttua tässäkin asetelmassa on. Naispappeutta ja uutta parisuhdelakia (joka antaisi demokraattisesti samanlaiset oikeudet kaikille kansalaisille) vastustavat ryhmät ovat alkaneet vaatia muilta suvaitsevaisuutta ja kotipaikkaoikeutta kirkossa. Samalla he kuvaavat itseään "perinteisiksi" ja "raamattu-uskollisiksi," mikä käytännössä tarkoittaa, etteivät ne, jotka kirkossa ajattelevat toisin kuin he, ole heidän mielestään "raamattu-uskollisia." Tällaiseen jaotteluun epäilemättä liittyy myös selvä näkemys siitä, kenen ehdoilla kirkossa oikeasti pitäisi toimia, kenellä oikeasti pitäisi olla oikeus käyttää kirkon ääntä ja keiden tulisi vaieta (esimerkiksi vääränsorttisten piispojen!). Piispaboikotissa ei ole kysymys vain "hengellisten palvelujen käyttämättä jättämisestä" vaan myös valtakamppailusta: hengellisen vallan uskotaan joutuneen vääränlaisten ihmisten käsiin, ja nyt se valta halutaan keskittää kokonaan omalle joukolle. 


\section{Valentinoksen koulukunta}

(2002)

Valentinoksen koulukunta on yksi parhaiten tunnetuista varhaisen kirkon toisinajattelevista ryhmistä. Koulukuntaan kuuluneiden kristittyjen opettajien kirjallisesta tuotannosta on tosin säilynyt kirkkoisien teoksissa ainoastaan yksi kokonainen kirjoitus, Ptolemaioksen Kirje Floralle, sekä satunnaisia katkelmia. Vasta Nag Hammadin koptinkielinen kirjasto, joka löytyi vuonna 1945, toi päivänvaloon useita valentinolaisten kristittyjen omia tekstejä. Valentinolaisuus tunnettiin kuitenkin hyvin jo ennen kirjaston löytymistä, sillä Lyonin piispa Irenaeus oli valinnut ryhmän kritiikkinsä pääkohteeksi 180-luvulla kirjoittamassaan teoksessa Harhaoppeja vastaan (Adversus Haereses). Sekä hän että muut kirkkoisät mainitsevat myös nimeltä useita valentinolaisia opettajia.

Irenaeuksen teoksen perusteella yksi suurimmista huolenaiheista oli se, etteivät valentinolaiset erottautuneet kyllin selvästi omaksi ryhmäkseen, vaan pysyivät kristillisen kirkon piirissä. Irenaeuskin myöntää, että "he sanovat samoja asioita ja he pitävät kiinni samasta opista" kuin muut kristityt eivätkä pidä itseään harhaoppisina (Harh. 3.15.2). He myös tunnustivat "yhden Jumalan ja Isän" sekä "Herramme Jeesuksen Kristuksen" (Harh. 4.33.3). Ero valentinolaisten ja muiden kristittyjen välillä ei siis ollut kovinkaan selvä - ei ainakaan niin selvä kuin Irenaeus olisi toivonut. Hänen tavoitteenaan olikin teoksellaan paljastaa, mitä valentinolaiset todella, mutta muilta salassa ajattelivat ja opettivat.

Muut kirkkoisät käyttivät valentinolaisia käsityksiä kuvatessaan Irenaeuksen teosta lähteenään ja esikuvanaan. Se on ollut pitkään perusta myös tutkijoiden esittämille kuvauksille valentinolaisuuden 
historiasta. Koska Irenaeuksen selvitys on pitkälti ohjannut valentinolaisista eri aikoina hahmoteltuja näkemyksiä, on tässäkin yhteydessä syytä lähteä liikkeelle siitä. Tämän jälkeen esittelen muutamia keskeisiä valentinolaisia opettajia ja heidän käsityksiään. Lopuksi pohdin, millaisen koulukunnan he yhdessä muodostivat.

\section{Irenaeuksen kuvaus valentinolaisten opista}

Viisiosaisen teoksensa ensimmäisessä osassa Irenaeus esittää laajan yhteenvedon valentinolaisten näkemyksistä (Harh. 1.1-8) ja pyrkii kumoamaan ne yksitellen kirjansa muissa osissa. Irenaeuksen valentinolaisuuden vastainen teos on samalla ensimmäinen laajahko systemaattinen yritys määritellä kristillisen opin rajat eli niin sanottu "uskon sääntö" (regula fidei). Irenaeuksella oli käytettävissään ensi käden lähteitä valentinolaisten käsityksistä. Tämä käy ilmi hänen teoksensa ensimmäisen osan esipuheesta, jossa hän mainitsee sekä keskustelleensa valentinolaisten kanssa että lukeneensa heidän kirjoituksiaan (Harh. 1, esipuhe). Jo tämän perusteella Irenaeuksen kuvaus valentinolaisten käsityksistä on useiden lähteiden pohjalta koottu tiivistelmä (epitomē), jonka tarkoituksena oli antaa kuva valentinolaisten opin peruspiirteistä. ${ }^{1}$

Irenaeus viittaa omassa esityksessään ainakin kahteen toisistaan jossain määrin poikkeavaan valentinolaiseen oppijärjestelmään. Lisäksi hän liittää jo tähän tiivistelmään omia pilkallisia huomautuksiaan, joiden tarkoituksena on osoittaa vastustajat typeryksiksi ja heidän käsityksensä naurunalaisiksi. Ilmeisesti Irenaeus onnistui tässä paremmin kuin hyvin. Esimerkiksi vieläkin usein käytetyn käännöskokoelman Anti-Nicene Fathers johdannossa Irenaeuksen teokseen valentinolaisten käsityksistä todetaan tylysti: 1 Tämänkaltaisiin tiivistelmiin, joissa käytettyjä lähteitä ei lainata sanasta sanaan vaan
tavoitteena oli kuvata tietyn opin peruslinjat, viittaa Snyder 2000, 13 . 
On valitettavaa, että niin suuri osa Irenaeuksen teoksesta käsittelee kaikenlaisia gnostilaisia spekulaatioita. Järjelliset olennot ovat tuskin koskaan saaneet päähänsä mitään niitä hullumpaa. ... Gnostilaisten spekulaatioiden perimmäisenä kohteena oli epäilemättä ratkaista uskonnonfilosofian kaksi suurta ongelmaa, ts. kuinka selittää pahan olemassaolo ja kuinka sovittaa äärellinen äärettömään. Painiskellessaan tällaisten kysymysten kanssa nämä muinaiset teoreetikot eivät kuitenkaan menestyneet yhtään paremmin kuin heidän nykyaikaiset seuraajansa. He antoivat mielikuvitukselleen täyden vallan ja rakensivat mitä epäjohdonmukaisimpia ja naurettavimpia systeemejä. He näet hylkäsivät Kirjoitusten opastuksen ja heidät eksytettiin mitä turmiollisimpiin ja mielettömimpiin virheisiin.

Yhteenvedon laatiminen eri lähteistä edellyttää väistämättä käytettävissä olevan aineiston valikoivaa käyttöä. Irenaeus keskittyy omassa tiivistelmässään niihin kysymyksiin, joista hän on valentinolaisten vastustajien kanssa eri mieltä. Tärkein erimielisyyden aihe on valentinolaisten käsitys, ettei maailmaa ole luonut korkein Jumala, vaan alempi luojajumala, jota he Platonia seuraten kutsuivat "demiurgiksi" eli käsityöläiseksi. Toinen keskeinen väite Irenaeuksen yhteenvedossa on, että valentinolaiset pitivät itseään muita parempina kristittyinä. Irenaeus ottaa esille lähes yksinomaan näihin kahteen kysymykseen liittyviä aiheita. Siksi hänen yhteenvetonsa antaa valentinolaisten käsityksistä hyvin toisella tapaa painottuneen kuvan kuin esimerkiksi Nag Hammadin kirjaston Totuuden evankeliumin meditatiiviset pohdinnat kristinuskon keskeisestä sanomasta. ${ }^{2}$ Toisaalta kirjastossa säilynyt Kolmiosainen tutkielma osoittaa, että valentinolaiset itsekin laativat laajoja systemaattisia esityksiä, joissa asioita käsiteltiin samankaltaisessa järjestyksessä kuin Irenaeuksen yhteenvedossa, mutta luonnollisesti paljon laajemmin.

Tiivistelmänsä ensimmäisessä osassa Irenaeus kuvaa valentinolaisten käsityksiä todellisen Jumalan maailmasta, jota he kutsuivat "täyteydeksi” (plērōma), sekä sitä, kuinka demiurgi sai alkunsa tässä maailmassa tapahtuneen epäjärjestyksen seurauksena. Kaiken lähtökohtana on näkymätön ja käsittämätön Isä, Syvyys. Hän vietti aikansa rauhassa ja levossa (hèsykhiai kai èremiai) ainoana seuranaan oma Ajatuksensa, jota

${ }^{2}$ Totuuden evankeliumista ks. Dunderberg \& Marjanen (toim.) 2005, 119-143. 
kutsuttiin myös Hiljaisuudeksi. Kaikkeus syntyy Isän päätöksestä, joka siemenen tavoin tekee Ajatuksen raskaaksi. Näin saavat alkunsa ikuiset olennot eli aionit, joista jumalallinen täyteyden maailma koostuu. Ikuiset olennot ovat nimiensä perusteella hyvin erilaisten abstraktien ominaisuuksien henkilöitymiä, kuten Sana, Elämä, Usko, Rakkaus, Ymmärrys ja Seurakunnallinen, ja muodostavat keskenään pareja.

Ikuiset olennot haluaisivat oppia tuntemaan kaikkeuden Isän, mutta se ei ole heille mahdollista. Kuitenkin nuorin heistä, Viisaus (sofia), ryhtyy mahdottomaan yritykseen ja pyrkii lähemmäksi Isää. ${ }^{3}$ Yritys johtaa Viisauden epätoivoon ja haitallisten tunteiden (pathos) valtaan. Näin jumalalliseen maailmaan on syntynyt jotain epätäydellistä, joka pitää siirtää sen ulkopuolelle. Tätä tehtävää varten luodaan Raja, joka puhdistaa Viisauden ja palauttaa heikkouden tilaan joutuneen täyteyden.

Rajan toiselle puolelle siirretään Viisauden kokemat emootiot, joista vaiheittain syntyy täyteyden ulkopuolinen maailma. Taivaallinen Kristus antaa Viisaudesta irrotetulle ei-toivotulle pyrkimykselle muodon. Näin syntyy alempi, täyteyden ulkopuolella oleva Viisaus eli Akhamot. Näkyvä maailma saa alkunsa Akhamotin mielenliikkeistä. Aineellinen olemus on peräisin hänen emootioistaan, sielullinen puolestaan hänen osoittamastaan katumuksesta. Hänessä on myös säilynyt alkuperäinen hengellinen olemus, mutta sitä Akhamot ei pysty siirtämään eteenpäin. Juuri Akhamot luo demiurgin ja tekee tämän välityksellä näkyvän maailman. Akhamotin luomuksena demiurgi on ainoastaan sielullinen olento, vaikka hän itse kuvitteleekin olevansa ainoa Jumala.

Irenaeus kertoo hyvin niukasti näkyvän maailman luomiseen liittyvistä yksityiskohdista. Sen sijaan hän kuvaa tarkasti valentinolaisten ihmiskäsitystä. Myös se perustuu edellä mainittuun jakoon kolmen eri olemuksen välillä. Demiurgi luo aineellisesta olemuksesta ihmisen, puhaltaa siihen oman, sielullisen henkensä. Samalla demiurgi tietämättään välittää ihmiseen Akhamotilta peräisin olevan hengellisen

\footnotetext{
${ }^{3}$ Valentinolaisesta Viisaus-myytistä ks. tarkemmin Dunderberg 1998.
} 
olemuksen. Lopuksi demiurgi pukee luomansa ihmisen nahkavaatteisiin (1. Moos. 3:21) eli ruumiiseen - joka ei siis ole sama asia kuin ihmisen luomisessa käytetty aineellinen olemus.

Ihminen koostuu siis kolmesta olemuksesta, joilla on erilainen alkuperä. Myös niiden tuleva kohtalo on erilainen. Aineellinen olemus tuhoutuu joka tapauksessa ja samoin hengellinen pelastuu joka tapauksessa. Sielulliselle olemukselle on sen sijaan ominaista valinnanvapaus: se joko tuhoutuu tai pelastuu sen mukaan, mihin se suuntautuu. Vastaavasti valentinolaiset Irenaeuksen mukaan jakavat ihmiskunnan kolmeen ryhmään. He pitävät itseään hengellisinä kristittyinä, jotka pelastuvat, vaikka tekisivät mitä. Muut kristityt ovat heidän mukaansa sielullisia ihmisiä, joiden täytyy pelastuakseen uskoa ja tehdä hyviä tekoja. Ei-kristityt puolestaan ovat aineellisia, joten heidän kohtalonaan on tuhoutuminen.

Irenaeus kiinnittää valentinolaisten Paavalin antropologisia näkemyksiä heijastelevaan kolmijakoon (vrt. esim. 1. Kor. 15) kahdesta syystä. Ensinnäkin hän haluaa osoittaa, että valentinolaiset pitivät itseään muita parempina kristittyinä ja kyseenalaistivat näin kristittyjen keskinäisen yhteyden. Toiseksi pelastusvarmuus teki hänen mukaansa valentinolaisista taipuvaisia kaikenlaiseen pahuuteen. $\mathrm{He}$ söivät epäjumalille uhrattua lihaa, osallistuivat pakanoiden juhliin ja viettelivät oikeaoppisten veljien vaimoja (Harh. 1.6.3). Näille syytöksille ei kuitenkaan löydy tukea Nag Hammadin kirjaston valentinolaisista teksteistä. ${ }^{4}$ Irenaeus itsekin myöntää, että valentinolaisten joukossa oli sellaisiakin, jotka pyrkivät nuhteettomaan elämään. Tämäkään ei kuitenkaan Irenaeukselle kelvannut, vaan hän piti näitä valentinolaisia "pöyhkeinä" (Harh. 3.15.2).

Kirkkoisien teoksissa säilyneitä lainauksia valentinolaisilta kristityiltä on tulkittu pitkälti Irenaeuksen kuvaamaan oppijärjestelmän valossa. Viime vuosina on kuitenkin ilmestynyt useita tutkimuksia, joissa lähtökohdaksi on todella otettu kustakin opettajasta säilyneet ensi käden lähteet ja niitä on pyritty tutkimaan niiden omilla ehdoilla.

\footnotetext{
${ }^{4}$ Desjardins 1990.
} 
Tulokset ovat olleet yllättäviä. Valentinokselta säilyneissä katkelmissa ei ole lainkaan selkeitä viitteitä Irenaeuksen kuvaamaan valentinolaiseen oppiin. ${ }^{5}$ Myös valentinolaisen Herakleonin suhde siihen on paljastunut hyvin etäiseksi. ${ }^{6}$ Yksittäisten valentinolaisten näkemyksiä kuvattaessa on siis perusteltua lähteä liikkeelle ensi käden lähteistä eikä yrittää sovittaa niitä väkisin yhteen Irenaeuksen kuvauksen kanssa. Toisaalta voidaan olettaa, että jonkinlainen jatkuvuus valentinolaisten kristittyjen käsityksissä oli Valentinoksesta aina Irenaeuksen kuvaamaan myöhäisvaiheeseen.

\section{Valentinos}

Egyptistä kotoisin ollut Valentinos tuli Roomaan 130-luvun lopulla jKr. ja viipyi siellä ainakin $15-20$ vuotta. ${ }^{7}$ Epävarmaksi jää, jättikö Valentinos tämän jälkeen Rooman kristityt. Kaksikin kirkkoisää väittää näin, mutta heidän versionsa tapahtuman syistä poikkeavat toisistaan täysin. Tertullianus kertoo, että Valentinos oli vähällä tulla valituksi Rooman piispaksi, mutta katkeroitui ja ryhtyi harhaoppiseksi, kun virka menikin toiselle, uskonsa vainoissa tunnustaneelle ehdokkaalle. ${ }^{8}$ Epifanios puolestaan väittää, että Valentinos matkusti Kyprokselle, menetti siellä järkensä, ja siksi hänestä tuli harhaoppinen. ${ }^{9}$ Kertomukset ovat siinä määrin poleemisia, että kumpaakaan niistä ei voine pitää historiallisesti luotettavana lähteenä. ${ }^{10}$ On kuitenkin mahdollista, että Valentinos jossain vaiheessa palasi Egyptiin. Tämä selittäisi parhaiten sen, että suurin osa hänen teoksistaan säilyneistä katkelmista on peräisin Clemens Aleksandrialaisen Stromateis-teoksesta.

\footnotetext{
${ }^{5}$ Markschies 1992.

${ }^{6}$ Wucherpfennig 2002.

${ }^{7}$ Ajoitus perustuu Irenaeuksen mainintaan, jonka mukaan Valentinos oli Roomassa kolmen piispan, Hyginoksen (136-140), Piuksen (140-155) ja Anietuksen (155-166) aikana (Harh. 3.4.5).

${ }^{8}$ Val. 4.1-2.

${ }^{9}$ Pan. 31.7.2.

10 Valentinoksen elämänvaiheista ja niitä kuvaaviin lähteisiin liittyvistä ongelmista ks. Markschies 1992, 294-336.
} 
Suoria lainauksia Valentinoksen kirjoituksista on säilynyt kaikkiaan kymmenkunta, ${ }^{11}$ joten ne antavat hyvin rajoitetun näkökulman hänen käsityksiinsä. Joka tapauksessa niistä käy ilmi ensinnäkin, että Valentinokselta oli säilynyt vielä Clemensin aikana kirjeitä (katkelmat 1-3), kirjallisia saarnoja (katkelmat 4,6) sekä yksi runo (katkelma 8). Toiseksi katkelmat osoittavat, että Valentinos oli kristillinen opettaja. Hän oli vakuuttunut, että Jeesus on ilmoittanut Isän (katkelma 2). Lisäksi hän esitti lainauksia Matteuksen evankeliumista ja pohti Jeesuksen jumalallista olemusta. Viimeksi mainitusta aiheesta Valentinos esitti nykyajan lukijan näkökulmasta hyvin erikoiselta vaikuttavan teorian (katkelma 3 ):

Hän kesti kaiken ja hallitsi itsensä. Jeesus toteutti jumaluuttaan käytännössä: hän söi ja joi poikkeavalla tavalla, sillä hän ei ulostanut ruokia. Niin vahva oli hänen pidättyvyytensä, ettei hänessä turmeltunut edes ravinto. Hänellä ei näet ollut mitään turmeltuvaa.

Kristuksen ruuansulatuksen pohtiminen voi tuntua nykyisten teologien näkökulmasta katsottuna tuntua etäiseltä ja Valentinoksen ratkaisu pilkanteolta. Siitä tuskin kuitenkaan on kysymys. Yhtenä keskeisenä todisteena inkarnaatiosta pidettiin sitä, että Kristus söi ja joi. ${ }^{12}$ Toisaalta dokeettisen käsityksen mukaan Kristus jumalallisena olentona ei tarvinnut lainkaan syömistä eikä juomista. Valentinoksen ratkaisu, että Kristus söi ja joi mutta ei ulostanut on eräänlainen kompromissi näiden kahden näkemyksen välillä. Valentinos ei missään tapauksessa edustanut varhaisen kirkon dokeettista äärilaitaa. Esimerkiksi Clemens yhdisti omassa tulkinnassaan varsin erikoisella tavalla dokeettisen kristologian peruskäsityksen ja sen vastustamisen. Hänen mukaansa Kristus tosin söi ja joi, mutta ei ruumiillisten tarpeidensa takia, vaan ainoastaan siksi, ettei hänestä leviäisi dokeettista harhaoppia! ${ }^{13}$ Kristuksella oli siis hänenkin mukaansa epätavallinen ruumis. Valentinos ei kuitenkaan

\footnotetext{
${ }^{11}$ Katkelmat on suomennettu kokoelmassa Dunderberg \& Marjanen (toim.) 2005, 109117. Siinä on annettu myös tarkat viittaukset kirkkoisien teoksiin, joista katkelmat löytyvät.

${ }^{12}$ Esim. Ignatios, Trall. 9; Irenaeus, Harh. 3.22.2.

${ }^{13}$ Strom. 6.71.2
} 
väitä Clemensin tavoin, ettei Kristus tästä syystä tarvinnut tavallista ravintoa, joten hänen käsityksensä on joka tapauksessa vähemmän dokeettinen kuin Clemensin. ${ }^{14}$

Valentinoksen katkelmat osoittavat myös, että hän tunsi ja käytti hyväkseen kreikkalaisia filosofisia käsityksiä tulkinnassaan kristillisestä sanomasta. Platonikkojen tavoin hän ajatteli, että maailma oli luotu "elävän ikuisen valtakunnan" antaman mallin perusteella. Vaikka maailma ei ole täydellinen, Valentinoksen mukaan siinä heijastuu "Jumalan näkymätön olemus", joka tekee siitä "luotettavan" (katkelma 5). Tämän perusteella Valentinoksen käsitys maailmasta ei ole dualistinen. Ei-dualistinen näkemys tulee näkyviin myös Valentinoksen runossa Sadonkorjuu (katkelma 8). Se perustuu stoalaisten filosofien ajatukseen koko maailmankaikkeuden läpäisevästä Hengestä, joka "kosmisena siteenä yhdistää sen elementit toisiinsa:

Näen kaiken olevan Hengen varassa, ymmärrän, että Henki kannattelee kaikkea:

lihaa, joka on sielun varassa;

sielua, joka on yhdistetty ilmaan;

ilmaa, joka on eetterin varassa;

hedelmiä, jotka tuodaan esiin syvyydestä;

lasta, joka tuodaan esiin kohdusta.

Valentinos ei siis edusta dualistista maailmankuvaa, jota on usein pidetty yhtenä gnostilaisen ajattelun tärkeimmistä tunnusmerkeistä. Kuitenkin hänen käsityksensä ihmisen luomisesta viittaa siihen, että hän tunsi gnostilaisiksi luokiteltavia traditioita. Valentinos kuvaa, kuinka Aadamin luoneet enkelit säikähtivät havaitessaan, että tässä oli "ylhäältä peräisin oleva olemus" ja "aiemmin olemassa ollut ihminen." Koska jumalallinen olemus nostaa Aadamin luojiensa yläpuolelle, enkelit yrittävät turmella hänet (katkelma 1). Hyvin samankaltainen kuvaus

\footnotetext{
${ }^{14}$ Dokeettista näkemystä kritisoidaan huomattavasti yksiselitteisemmin eräässä Nag Hammadin kirjaston gnostilaisessa kirjoituksessa: "He tulevat hänen nimessään ja väittävät hänestä, [että] hän ei ole syntynyt, vaikka hän on syntynyt, [että] hän ei syö, vaikka hän syö, [että] hän ei juo, vaikka hän juo” (Melk. 5.1-5). Doketismi ei siis välttämättä ole gnostilaisen ajattelun erottamaton osa.
} 
Aadamin luomisesta esiintyy niin sanottua setiläistä gnostilaisuutta edustavassa Johanneksen salaisessa kirjassa. ${ }^{15}$ Valentinos ei välttämättä tuntenut tätä teosta, mutta käytti Genesis-tulkinnassaan hyväkseen samanlaista gnostilaista traditiota kuin siinä on. ${ }^{16}$ Tässä suhteessa Valentinosta voi yhä pitää "gnostikkona", vaikka hänen opetuksensa eivät muuten viittaakaan gnostilaisina pidettyihin tai edes Irenaeuksen kuvaamiin valentinolaisiin näkemyksiin.

\section{Ptolemaios, Herakleon ja Theodotos}

Kirkkoisä Hippolytoksen mukaan Valentinoksen seuraajat jakautuivat kahteen ryhmään kristologisten käsitystensä perusteella. "Italialaiseksi" kutsutun suuntauksen edustajat ajattelivat, että Jeesuksella oli - muista ihmisistä poiketen - sielullinen ruumis, johon Henki laskeutui kasteen yhteydessä. "Itäisen" näkemyksen kannattajat sen sijaan olettivat, että Vapahtajan ruumiskin oli alusta asti hengellinen. Vapahtaja syntyi heidän mukaansa Neitsyt Mariasta ikään kuin putken kautta vailla kosketusta tämän ruumiiseen. Italialaisen tulkinnan tunnetuimmat edustajat olivat Hippolytoksen mukaan Ptolemaios ja Herakleon. ${ }^{17}$ Clemensin teoksen Katkelmia Theodotokselta (Excerpta ex Theodoto) täydellisessä otsikossa puolestaan mainitaan myös itäinen valentinolainen opetus. ${ }^{18}$ Näiden kolmen valentinolaisen opettajan teoksista on säilynyt jonkin verran enemmän katkelmia kuin Valentinokselta itseltään. Epifanios lainaa kokonaisuudessaan Ptolemaioksen opetus-

${ }^{15}$ Joh. sal. II, 20: "Hänestä tuli viisaampi kuin ne, jotka olivat hänet luoneet, ja jopa viisaampi kuin ensimmäinen hallitsija. Kun hallitsijat havaitsivat, että ihminen oli täynnä valoa, ymmärtäväisempi kuin he ja vailla pahuutta, he ottivat hänet ja heittivät materian alimpiin osiin.” (Käännös: Dunderberg, Marjanen \& Salmenkivi kirjassa Dunderberg \& Marjanen [toim.] 2005, 60.) Kuvaus toistuu samassa tekstissä hieman eri muodossa myöhemmin (Joh. sal. II, 21).

${ }^{16}$ Valentinos tulkitsee Genesistä myös saarnassaan, jossa hän kutsuu kuulijoitaan ”alusta asti kuolemattomiksi” (katkelma 4). Tämän katkelman tulkinnasta ja taustasta ks. Dunderberg $1997 \mathrm{a}$.

${ }_{17}^{17}$ Ref. 6.35.5-7.

18 Teoksen koko nimi kuuluu "Katkelmia Theodotokselta sekä niin sanotusta itäisestä opetuksesta Valentinoksen ajoilta." 
kirjeen Floralle, ${ }^{19}$ Origenes keskustelee Johannes-kommentaarissaan (Comm. Joh.) Herakleonin esittämistä tulkinnoista, ja Clemens esittää edellä mainitussa teoksessaan lainauksia Theodotoksen käsityksistä. ${ }^{20}$

Ptolemaioksesta ei henkilönä tiedetä kovinkaan paljoa. Mielenkiintoinen yksityiskohta on, että Justinos Marttyyri mainitsee Toisessa Apologiassaan (kirjoitettu n. 152) samannimisen kristityn opettajan, joka kuoli vainoissa prefekti Urbicuksen aikana (144-160). ${ }^{21}$ On mahdollista, että kyse oli yhdestä ja samasta henkilöstä, mutta täysin varma tämä oletus ei ole. Justinos ei esitä mitään kriittisiä varauksia mainitsemansa Ptolemaioksen suhteen. Mikäli tässä yhteydessä tarkoitetaan valentinolaista Ptolemaiosta, Justinoksen on täytynyt muuttaa myöhemmin kantaansa, sillä toisessa teoksessaan hän tuomitsi valentinolaiset harhaoppisina. ${ }^{22}$

Ptolemaioksen Kirje Floralle on ainoa hänen omista teoksistaan säilynyt teksti. ${ }^{23}$ Vaikka kirje on osoitettu yksityishenkilölle, se on todennäköisesti tarkoitettu laajemmalle lukijakunnalle. Kirjeen huolellinen sommittelu osoittaa, että Ptolemaios tunsi antiikin retoriikan mukaisen ilmaisutavan. Sisällöltään kirje on alkeisopetusta; tämä käy ilmi kirjeen lopusta, jossa Ptolemaios lupaa kirjeensä vastaanottajalle lisäopastusta (33.7.9). Kirjeessään Ptolemaios pyrkii perustelemaan luojajumalan eli demiurgin olemassaolon. Markionin tavoin Ptolemaios pyrkii osoittamaan, ettei demiurgi ole hyvä eikä paha vaan jäykän

${ }^{19}$ Pan. 33.3.1-7.10 Käännös: Dunderberg \& Marjanen 2005, 145-159.

${ }^{20}$ Clemensin teoksen tulkintaa hankaloittaa se, että siinä on Theodotoksen opetusten lisäksi yhteenvetoja muiden valentinolaisten näkemyksistä sekä Clemensin omia pohdintoja eikä näitä ole aina helppo erottaa toisistaan. Lähdeongelmasta ks. Casey 1934, 5-16, joka myös esittää siihen selkeähkön ja hyvin perustellun ratkaisun.

${ }^{21} 2$ Apol. 2.

${ }^{22}$ Dial. 35.

${ }^{23}$ Irenaeuksen kuvaamaa valentinolaista opetusta on usein kutsuttu Ptolemaioksen oppijärjestelmäksi, mutta Irenaeus itse kertoo saaneensa tietonsa Ptolemaioksen oppilailta, ei tältä itseltään (Harh. 1, esipuhe). Latinalaisissa käsikirjoituksissa Irenaeuksen yhteenveto valentinolaisten opista päättyy lauseeseen et Ptolemaeus quidem ita ("Näin todellakin Ptolemaios", Harh. 1.8.5). Ei ole kuitenkaan selvää, viittaako lause koko edellä kuvattuun yhteenvetoon (jossa joka tapauksessa on yhdistelty erilaisia valentinolaisia opetuksia) vai ainoastaan valentinolaisia tulkintoja Uudesta testamentista, joita Irenaeus on juuri edellä kuvannut. Lisäksi lause voi olla myöhäisempi lisäys, sillä se puuttuu tällä kohtaa käytettävissä olevasta Irenaeuksen teoksen kreikankielisestä katkelmasta. 
oikeudenmukainen. Osoittaakseen näkemyksensä oikeaksi Ptolemaios käy huolellista keskustelua Vanhan testamentin laista ja sen eri tasoista. Ensin hän erottaa toisistaan Vanhan testamentin Jumalan oman lain ja Mooseksen sekä kansain vanhimpien tekemät inhimilliset lisäykset. Tämän jälkeen hän argumentoi, ettei edes Jumalan oma laki Vanhassa testamentissa ole täydellinen. Tämän osoittaa siihen sisältyvä koston periaate "silmä silmästä ja hammas hampaasta". Sen tarkoituksena on pahuuden estäminen, mutta kun sitä toteutetaan, pahuus ainoastaan lisääntyy. Kun murhaaja tuomitaan kuolemaan, lain seurauksena on yhden murhan sijasta kaksi. Näin lain antanut Jumala joutui välttämättömyyden huijaamaksi, Ptolemaios toteaa.

Ptolemaios korostaa kirjeensä eri kohdissa kristillistä näkökulmaa käsiteltävään aiheeseen. Hän pyrkii todistamaan väitteensä oikeaksi Jeesuksen sanoilla ja apostolin (eli Paavalin) opetuksilla. Jeesus hyväksyi hänen mukaansa dekalogin, mutta vaati sen täydellisempää noudattamista. Tästä käy ilmi, ettei edes tämä Vanhan testamentin Jumalan lain osa ei ole sellaisenaan täydellinen. Silti se Vapahtajan sanojen tähden sitoo myös kristittyjä. Vanhan testamentin rituaalilait Ptolemaios tulkitsee Paavaliin vedoten allegorisesti. Koston periaatteeseen perustuvat lait Jeesus kuitenkin Ptolemaioksen mukaan mitätöi (vrt. Matt. 5:38-39). Ptolemaioksen johtopäätös tästä kaikesta on, ettei Vanhan testamentin lain antanut Jumala voi olla korkein ja täydellinen Jumala, vaan kyse on "oikeudenmukaisesta" luojajumalasta, joka "ei ole hyvä, mutta ei myöskään paha eikä väärämielinen.”

Ptolemaioksen kirje osoittaa, että hän tunsi hyvin omana aikanaan käytyä keskustelua Vanhan testamentin laista. Esimerkiksi inhimillisten lisäysten erottaminen ei ole hänen oman argumentointinsa kannalta kovin tärkeää. Oppineessa tutkielmassa tämä selitys oli kuitenkin syytä ottaa huomioon, sillä se tunnettiin sekä juutalaisissa että varhaiskristillisissä piireissä. ${ }^{24}$ Lisäksi Ptolemaioksen kirjeessä näkyy epäilemättä Markionin Rooman seurakunnissa herättämä debatti. Monet tutkijat ovat sitä mieltä, että Ptolemaios kirjoitti tutkielmansa Markionia

${ }^{24}$ Ks. esim. Räisänen 1983, 135, 225-226. 
vastaan. Ptolemaioksen omat johtopäätökset tulevat kuitenkin niin lähelle Markionin käsityksiä, että hän vaikuttaa pikemminkin itse maltilliselta markionilaiselta. Hän ei selvästikään hyväksy Markionin kaanonia eikä vaadi Vanhan testamentin hylkäämistä kristittyjen pyhänä kirjana. Silti hän päätyy hyvin samankaltaiseen käsitykseen Vanhan testamentin Jumalasta kuin Markion. Ptolemaios näyttää ottaneen Markionin ohjelman vakavasti, vaikka ei seurannutkaan sitä kaikilta osin.

Markionin näkemyksiin reagoi todennäköisesti myös Herakleon, ${ }^{25}$ jolta on peräisin varhaisin tunnettu Johanneksen evankeliumin kommentaari. Siitä on säilynyt hyvin pieni valikoima Origeneen vastaavassa teoksessa. ${ }^{26}$ Säilyneiden katkelmien perusteella on voitu kuitenkin todeta, että Herakleon ei esittänyt Johanneksen evankeliumista ainoastaan allegorisia tulkintoja, vaan otti huomioon antiikin ohjeiden mukaisen tekstintulkinnan muitakin tasoja kuten tekstikritiikin, sanojen selityksen, retorisen tulkinnan sekä tyylin analyysin. ${ }^{27}$ Allegorisissa tulkinnoissaan Herakleon olettaa Ptolemaioksen tavoin demiurgin olemassaolon, mutta selviä viitteitä valentinolaiseen Viisaus-myyttiin hänenkään katkelmissaan ei ole säilynyt. Demiurgi on Kristuksen alapuolella, sillä Kristus (Irenaeuksella Viisaus!) on todellinen luoja ja demiurgi ainoastaan hänen luomistyönsä välikappale. ${ }^{28}$ Demiurgi luottaa kuitenkin Vapahtajaan ja turvautuu tämän apuun, kun hänen luomansa ihminen on kuolemanvaarassa. ${ }^{29}$

Herakleon edellyttää useissa kohdin Irenaeuksen kuvaaman jaon hengelliseen, sielulliseen ja aineelliseen olemukseen. Tämä näkyy esimerkiksi hänen käsityksessään, että pakanat palvovat aineellista maailmaa ja juutalaiset demiurgia (ja enkeleitä), mutta "hengellisten"

\footnotetext{
${ }^{25}$ Ks. Wucherpfennig 2002, 156-158, 178 jne.

${ }^{26}$ Herakleonin selityksiä on säilynyt ainoastaan seuraaviin jaksoihin: Joh. 1:1-29; 2:12-20; 4:12-54; 8:21-22, 37, 44, 50. Clemensin teoksissa ovat lisäksi säilyneet Herakleonin tulkinnat jakeista Matt. 3:11// Luuk. 3:16 (Ecl. proph. 25.1) sekä Luuk. 12:8ss (Strom. 4.71-72).

${ }^{27}$ Wucherpfennig 2002, 44-45.

${ }^{28}$ Origenes, Joh. comm. 6.39; 13.19.

${ }^{29}$ Origenes, Joh. comm. 13.60 (selitys jaksoon Joh. 4:46-54).
} 
tulee palvoa vain totuuden Isää. ${ }^{30}$ Keskustelua on herättänyt se, pitääkö Herakleon näitä kategorioita ennalta määrättyinä ja pysyvinä (kuten Irenaeus väittää valentinolaisten ajatelleen) vai onko hänen mukaansa mahdollista edetä yhdestä ryhmästä toiseen. Jälkimmäinen vaihtoehto on todennäköisempi, sillä Herakleon korostaa usein muutoksen mahdollisuutta. "Niin kuin nainen muuttuu mieheksi", Herakleonin mukaan myös ääni, joka on sukua sanalle, muuttuu sanaksi. ${ }^{31}$ Kohdan voi tulkita tarkoittavan, että alempi sielullinen olemus voi muuttua hengelliseksi. Kertomuksen samarialaisesta naisesta (Joh. 4) Herakleon tulkitsee kuvaukseksi siitä, kuinka hengellinen olemus herää eloon. Hengellisten kristittyjen tehtävänä on hänen mukaansa myös tuoda muita Vapahtajan luokse. ${ }^{32}$

Theodotokselta on peräisin ehkä tunnetuin tiivistelmä gnostilaisittain ymmärretyn kristinuskon sisällöstä: ${ }^{33}$

Meitä ei tee vapaaksi pelkkä kaste, vaan tieto siitä, keitä me olimme ja mitä meistä on tullut, missä olemme olleet tai mihin olemme joutuneet, minne olemme matkalla ja mistä meidät on vapautettu, mitä on syntymä ja mitä jälleensyntyminen.

Theodotokselta säilyneissä katkelmissa on jo selvempiä yhteyksiä Irenaeuksen kuvaamaan oppijärjestelmään kuin edellä esitellyillä valentinolaisilla opettajilla. Hänen katkelmissaan on selviä viitteitä pleromaan, jossa jumalalliset olennot esiintyvät pareina. Niissä mainitaan lisäksi erikseen pleroman ja näkyvän maailman erottava Raja ja edellytetään samankaltainen Viisaus-myytti kuin se, jota Irenaeus kuvasi. $^{34}$

Kristityistä Theodotos käyttää nimitystä to diaferon sperma, joka voi tarkoittaa sekä "erinomaista" että "erilleen joutunutta" siementä.

\footnotetext{
${ }^{30}$ Joh. comm. 13.16.

${ }^{31}$ Joh. comm. 6.20-21; vrt. Tuom. ev. 114.

${ }^{32}$ Joh. comm. 13.31.

${ }^{33}$ Clemens, Exc. Theod. 78.2.

${ }^{34}$ Exc. Theod. 21; 32; 34; 35.1 .
} 
On mahdollista, että Theodotos käyttää termiä kummassakin merkityksessä. Kyse on yhtäältä jumalallisesta todellisuudesta peräisin olevasta ja siksi "erinomaisesta" siemenestä, mutta toisaalta tästä todellisuudesta eroon joutuneesta olemuksesta. Kun Jeesus kutsuu itseään Johanneksen evankeliumissa "portiksi" (Joh. 10:7, 9), Theodotos tulkitsee hänen tarkoittavan: "'Te, jotka kuulutte erinomaiseen/erillään olevaan siemeneen (to diaferon sperma), tulette Rajalle, jolla minä olen.' Kun hän sitten menee täyteyteen, myös siemen menee hänen kanssaan yhteen koottuna ja sisälle vietynä." ${ }^{35}$ Vapahtajan apuna toimivat enkelit, joiden tehtävänä on ohjata siemen oikeaan. Nämä enkelit ja Viisaus eivät pääse täyteyteen ennen kuin "erillään oleva siemen" on koottu yhteen. ${ }^{36}$

\section{Nag Hammadin valentinolaiset kirjoitukset}

Nag Hammadissa on yhteensä kymmenkunta valentinolaista tekstiä. Koska tässä yhteydessä ei ole mahdollista tarkastella niitä kaikkia, esittelen niistä vain osan. Laajin Nag Hammadin valentinolaisista teksteistä on Kolmiosainen tutkielma (NHK I, 4), joka on valentinolaisen opin systemaattinen esitys. ${ }^{37}$ Jo käsikirjoituksessa teksti on jaettu väliviivoilla kolmeen osaan; tähän kolmijakoon perustuu tutkijoiden tekstille antama nimi. Ensimmäinen osa (54-104) kuvaa Isä, jumalallisten olentojen maailmaa sekä koko maailmankaikkeuden järjestystä (oikonomia), johon kuuluu myös demiurgi apureineen. Toinen osa on lyhyt kuvaus ihmiskunnan luomisesta (104-108), ja kolmannessa esitellään joukko muita valentinolaisen teologian keskeisiä teemoja kuten Vapahtajaa koskevia näkemyksiä, ihmiskunnan jakautuminen kolmeen eri kastiin sekä pelastumisoppi (108-138).

\footnotetext{
${ }^{35}$ Exc. Theod. 26.1-2.

${ }^{36}$ Exc. Theod. 35.

37 Erikoinen piirre Kolmiosaisessa tutkielmassa on se, että moni sen jaksoista alkaa koptin sanalla tje, jota usein käytetään lainauksen edessä samaan tapaan kuin kreikan sanaa hoti. Tämän piirteen perusteella on ehdotettu, että Kolmiosainen tutkielma voisi laajuudestaan huolimatta olla lyhennelmä tai yhteenveto aikaisemmista lähteistä.
} 
Erikoista Kolmiosaisessa tutkielmassa on, että sen mukaan jumalallisen maailman saattoi epäjärjestykseen maskuliininen Sana (logos) eikä feminiininen Viisaus kuten Irenaeuksen kuvaamassa järjestelmässä. Viisauden tavoin Logos kuvataan maailman varsinaiseksi luojaksi, joka käyttää demiurgia "kätenään ja suunaan" (101). Demiurgin alamaisten keskeinen tuntomerkki on kuitenkin "vallanhalu", joka onkin yksi tekstin useimmin toistuvista teemoista. Huomionarvoista on lisäksi, ettei ihmiskunnan kolmijakoa ei pidetä tässä tekstissä ennalta märättynä, vaan "ihmisen sielun arkkityypissä on kaikki kolme mahdollisuutta, ${ }^{38}$ jotka tulevat esiin vasta, kun ihminen kohtaa Vapahtajan. "Sielullisille" ja "hengellisille" kristityille ei myöskään ole varattu erilaista pelastusta, vaan molemmat pääsevät yhtä lailla täyteyteen (123)..$^{39}$

Totuuden evankeliumi (NHK I, 2) on monessakin suhteessa kiinnostava teksti. ${ }^{40}$ Jo Irenaeus mainitsee, että valentinolaisilla oli käytössään tällä nimellä kulkeva kirjoitus. ${ }^{41} \mathrm{Nag}$ Hammadin kirjaston Totuuden evankeliumissa ei ole otsikkoa kuten eräissä muissa kirjoituksissa, vaan nimi perustuu kirjoituksen alkusanoihin (incipit). Koska tällainen viittauskäytäntö oli yleinen jo antiikin aikana, on mahdollista, että kyse on samasta teoksesta, jonka Irenaeus mainitsee. Maailman syntyyn kirjoituksessa viitataan vain ohimennen, eikä esimerkiksi Viisautta tai demiurgia mainita lainkaan. Hieman samaan tapaan kuin Irenaeuksen kuvaamassa myytissä maailman synnyn varsinaisena syynä pidetään sitä, ettei kaikkeus voinut tuntea Isää; tästä saa alkunsa erehdys, joka loi maailman, "kauniin korvikkeen totuudelle" (Tot. ev. 8). Pääpaino tekstissä on kuitenkin Jeesuksen tuomalla ilmoituksella. Hän "toi valon niille, jotka unohduksen takia olivat joutuneet pimeyteen" (18) ja "pelasti monet erehdyksen vallasta" (22). Kristus tulee maailmaan pelastamaan "ne, joiden nimet hän tiesi etukäteen"

\footnotetext{
${ }^{38}$ Attridge \& Pagels 1985, 187.

${ }^{39}$ Attridge \& Pagels 1985, 188-189.

${ }^{40}$ Laajempi johdanto Totuuden evankeliumiin sekä käännös: Dunderberg \& Marjanen 2005, $119-143$.

${ }^{41}$ Harh. 3.11.9. Tästä ei kuitenkaan voi päätellä, että Totuuden evankeliumi olisi Valentinoksen itsensä kirjoittama, kuten joskus on oletettu.
} 
(21). Heillä on tieto, joka saa heidät noudattamaan Vapahtajan kutsua (21-22). Jeesuksen ilmoituksen sisältöä kuvataan erilaisilla vertauskuvilla, mutta myös viittauksilla Uuteen testamenttiin: "Henki antoi ihmisten ymmärtää tiedon Isästä ja ilmoituksen tämän Pojasta. Kun he nimittäin olivat nähneet Pojan ja kuulleet häntä, hän antoi heidän maistaa itseään, tuntea tuoksunsa ja koskea rakastettua Poikaa” (30; vrt. 1. Joh. 1:1).

Totuuden evankeliumissa mainitaan myös Jeesuksen ristiinnaulitseminen: ”...hänet naulittiin ristinpuuhun. Ristillä hän ilmoitti Isän säädöksen. Kuinka valtava tämä oppi onkaan. Hän antoi itsensä kuolemaan, vaikka hänellä oli yllään ikuinen elämä.” Mikään ei viittaa siihen, että kirjoittaja olisi ajatellut Jeesuksen kärsimyksen olleen vain näennäistä tai että ristillä kärsi joku muu kuin Vapahtaja itse.

Totuuden evankeliumista käy lisäksi ilmi, etteivät valentinolaiset pitäneet hyvien tekojen tekemistä tarpeettomana kuten kirkkoisät väittivät vaan kannustivat niihin:

Julistakaa siis täydestä sydämestänne, sillä juuri te olette täydellinen päivä ja teissä on valo, joka ei himmene. Kertokaa totuudesta ja tiedosta niille, jotka sitä etsivät ja ovat tehneet syntiä erehdyksen vallassa. Vahvistakaa kompastuneiden jalat ja ojentakaa kätenne auttamaan sairaita. Ruokkikaa nälkäiset ja antakaa lepo uupuneille. Nostakaa ylös ne, jotka haluavat nousta. Herättäkää ne, jotka nukkuvat.

Tutkielma ylösnousemuksesta on samantapainen opetuskirje kuin Ptolemaioksen kirje Floralle. Se on osoitettu Rheginos-nimiselle henkilölle ja aiheena ovat ylösnousemusta koskevat käsitykset. Tekstissä keskustellaan myös ylösnousemusruumiista, mutta tavalla, joka on jättänyt tilaa hyvin erilaisille tulkinnoille. Tekstissä esiintyy kysymys "Miksi et saisi ruumista, kun pääset tulevaan maailmaan?" (47). Se voidaan tulkita retoriseksi kysymykseksi, jolla kirjoittaja haluaa sanoa, että tietenkin uskovat saavat ruumiin ylösnousemuksen yhteydessä. Teksti voidaan kuitenkin ymmärtää toisinkin: kuten niin sanotussa diatribityylissä on tavallista, kirjoittaja käy keskustelua kuvitellun vastustajan kanssa. 
Tällöin kysymys edustaisi vastustajan käsitystä, jonka kirjoittaja itse haluaa kumota. ${ }^{42}$

Filippuksen evankeliumi (NHK II, 2) lienee peräisin Rooman valtakunnan itäisistä osista, sillä siinä esiintyy usein viittauksia tiettyihin syyriankielisiin termeihin. Tämä teksti ei nimestään huolimatta muistuta sen enempää Uuden testamentin evankeliumeja kuin Tuomaan evankeliumiakaan, vaan siihen on koottu katkelmia useiden valentinolaisten kristittyjen opetuksista. ${ }^{43}$ Vain harvoissa tapauksissa näistä katkelmista muodostuu laajempia, samaa aihetta käsitteleviä kokonaisuuksia. Kokoelmaan on otettu myös keskenään ristiriitaisilta vaikuttavia opetuksia. ${ }^{44}$ Evankeliumissa esiintyy joka tapauksessa ajatus alemmasta luojajumalasta, joka loi maailman erehdyksessä (99), ja siinä edellytetään Irenaeuksenkin kuvaama valentinolainen oppi ylemmästä ja alemmasta Viisaudesta. Nämä piirteet eivät kuitenkaan ole keskeisellä sijalla evankeliumissa. Huomattavasti enemmän siinä kiinnitetään huomiota esimerkiksi Genesiksen alkuluvuista ja Uuden testamentin kirjoituksista esitettyihin tulkintoihin sekä kristillisiin sakramentteihin.

Filippuksen evankeliumissa mainitaan yhteensä viisi sakramenttia: kaste, voitelu, ehtoollinen, lunastus ja morsiushuone (68). Lunastus ja morsiushuone olivat nimenomaan valentinolaisten käytössä olleita sakramentteja. Morsiushuoneen sakramentin toteuttamistavasta ei ole tarkempia tietoja, mutta sen hengellistä sisältöä kuvataan Filippuksen evankeliumissa usein. Ihmiskunnan jakautumista kahteen sukupuoleen pidetään lankeemuksen seurauksena, jonka Kristus korjaa morsiushuoneen sakramentissa. Siksi kristittyjä kutsutaan evankeliumissa "morsiushuoneen lapsiksi." ${ }^{45}$ Lisäksi Filippuksen evankeliumi korostaa Johanneksen evankeliumin tavoin, että ylösnousemus on koettava jo tässä elämässä (90). Totuuden evankeliumista poiketen Filippuksen evankeliumin kristologia on selvästi dokeettista: "'Jumalani, Jumalani, miksi

\footnotetext{
${ }^{42}$ Vaihtoehdoista ja niiden vaikutuksesta ko. tekstin tulkintaan ks. Mika Hellan johdanto kokoelmassa Dunderberg \& Marjanen 2005, 161-164.

43 Johdanto ja käännös: Dunderberg \& Marjanen 2005, 173-207.

${ }^{44}$ Ks. Dunderberg \& Marjanen 2005, 175.

${ }^{45}$ Fil. ev. 78-79, 87-88.
} 
Herra hylkäsi minut?' Näin hän sanoi ristillä, sillä Herra oli lähtenyt sieltä."ํㅜ

\section{Valentinoksen koulukunta}

Jo Irenaeus puhuu "Valentinoksen koulukunnasta (didaskaleion)", ${ }^{47}$ joten tämän ryhmän voi olettaa jollain tavalla muistuttaneen antiikin filosofikoulukuntia. ${ }^{48}$ Valentinoksen koulukunnan organisaatiosta, kuten siitä, oliko heillä omia rakennuksia tätä tarkoitusta varten, ei ole säilynyt tietoja. On mahdollista, että koulukuntaan kuuluneet opettajat toimivat Rooman ja muiden suurten kaupunkien kotiseurakunnissa. Heidän sivistyksensä oli suhteellisen korkea: Valentinos pystyi kirjoittamaan runoja, Ptolemaios tunsi retoriikkaa ja Herakleon tekstien tulkinnan eri osa-alueita. Nämä ansiot epäilemättä vetosivat erityisesti varakkaisiin ja koulutettuihin kristittyihin, jotka tarjosivat kotinsa yhteisille kokoontumisille. Kotiin kutsuttu kristittyjen ryhmä oli osa "laajennettua perherakennetta". ${ }^{49}$ Perheen pää (paterfamilias) oli vastuussa yhteisten kokoontumisten järjestämisestä, mihin kuului myös vierailevien opettajien ylläpito. ${ }^{50}$ Heidän menestyksensä ratkaisi pitkälti se, millaisen vaikutuksen he onnistuivat tekemään paterfamiliakseen.

Antiikin koulukunnat poikkesivat toisistaan siinä, kuinka paljon ne sallivat poikkeamia aiemmasta traditiosta. Valentinolaiset opettajat olivat edellä esitetyn kuvauksen perusteella suhteellisen avoimia erilaisille näkemyksille. Valentinos käytti hyväkseen setiläistä traditiota, Ptolemaios puolestaan hyväksyi jossain määrin Markionin ratkaisun. Irenaeus syyttää tosin valentinolaisia usein siitä, etteivät he paljasta todellisia ajatuksiaan kuin sisäpiiriläisille. Tämä väite ei kuitenkaan sovi yhteen sen kanssa, että Irenaeus kertoo oman kuvauksensa perustuvan

\footnotetext{
${ }^{46}$ Fil. ev. 72.

${ }^{47}$ Harh. 1.11.1

${ }^{48}$ Valentinolaisista koulukuntana ks. erityisesti Markschies 1997.

${ }^{49}$ Lane 1998, 213.

${ }^{50}$ Lane 1998, 211-212.
} 
keskusteluihin, joita hän kävi valentinolaisten kanssa, sekä heidän omiin kirjoituksiinsa. Tästä voidaan päätellä, että valentinolaiset olivat valmiita keskustelemaan omista näkemyksistään myös vastustajiensa kanssa, vaikka tiesivätkin näiden olevan eri mieltä.

Toisaalta Ptolemaioksen kirje Floralle osoittaa, että valentinolaiset eivät välttämättä paljastaneet kaikkea "vasta-alkajille", vaan etenivät heille antamassaan ohjauksessa vähin erin. Vastaavanlainen käsitys esiintyy myös Filippuksen evankeliumissa: oikea opetuslapsi "näkee jokaisen ihmisen sielun tilan ja voi puhua heidän kanssaan. ... Palvelijoille hän opettaa vain alkeet, lapsille hän opettaa kaiken." ${ }^{51}$ Kahden tai useamman tason opetus ei sinänsä ollut epätavallista antiikin maailmassa, vaan sekä filosofiseen että uskonnolliseen oppineisuuteen liittyi usein esoteerisuus. Origenes ei esimerkiksi katsonut Laulujen laulun lukemisen sopivan "yksinkertaisille" kristityille. ${ }^{52}$ Yksi hermeettisten kirjoitusten kokoelmaan Corpus Hermeticum kuuluvista teksteistä puolestaan alkaa kehotuksella unohtaa kaikki aiemmin opittu! ${ }^{53}$ Uusplatonikko Plotinoksen kerrotaan vaatineen oppilailtaan vaitiololupauksen, ${ }^{54}$ ja juutalaiset rabbit keskustelivat siitä, mitkä VT:n tekstit pitää jättää kääntämättä yhteisissä synagogajumalanpalveluksissa loukkaavan sisältönsä vuoksi. ${ }^{55}$ On hyvin mahdollista, että myös valentinolaiset opettajat tarjosivat opastusta useammalla kuin yhdellä tasolla. Kyse ei välttämättä ollut erityisestä salamyhkäisyyden tavoittelusta, jos he kerta hyväksyivät Irenaeuksen keskustelukumppanikseen myös "korkeamman tason” kysymyksiä käsitellessään.

\footnotetext{
${ }^{51}$ Fil. ev. 119.

${ }^{52}$ Cant. 1.4-7; ks. Trigg 1998, 47.

${ }^{53}$ Fowden 1986, 103-104.

${ }^{54}$ Valantasis 1991, 46.

${ }^{55}$ Wewers 1975, 33-44, 204.
} 


\section{Valentinolaisten myöhemmät vaiheet}

Esimerkiksi Roomassa valentinolaiset saivat opettaa suhteellisen kauan kenenkään puuttumatta sen kummemmin asiaan. Kotikirkot olivat suhteellisen itsenäisiä yksiköitä eivätkä ne tavallisesti aktiivisesti tuominneet toisten ryhmien näkemyksiä. Justinoksen hyökkäys valentinolaisia ja muita harhaoppisia vastaan näyttää olleen pikemminkin poikkeus kuin sääntö. Poikkeus oli myös Markionin erottaminen Rooman kristillisestä kirkosta; suurimpana syynä oli todennäköisesti Markionin oma ehdottomuus. ${ }^{56}$ Edes Irenaeuksen teos valentinolaisia vastaan ei johtanut välittömästi toimenpiteisiin. Rooman ensimmäisellä monarkkipiispalla, Victorilla (189-199), oli vielä tukenaan valentinolainen presbyteeri Florinos. Irenaeus joutui erikseen vaatimaan, että Victor tutustuisi Florinoksen kirjoituksiin ja tuhoaisi ne. ${ }^{57}$

Osa valentinolaisista alkoi erkaantua jo 200-luvun taitteessa omaksi kirkkokunnakseen. Irenaeus kuvaa laajasti valentinolaisen Markoksen ryhmää, jonka hän tunsi sekä Vähästä-Aasiasta että Lyonin ympäristöstä. Markoksen seuraajat erottautuivat ilmeisesti jo varhain muita valentinolaisia selkeämmin omaksi ryhmäkseen, joilla oli oma ehtoollisrituaali sekä muita sakramentteja kuten lunastukseksi kutsuttu toimitus, jonka yhteydessä kuolevat voideltiin öljyllä. Samalla heille paljastettiin salaiset vastaukset, jotka heidän tulee kertoa tuonpuoleisuuden portinvartijoille ja itselleen demiurgille; näin he pääsevät näiden käsistä täydelliseen pelastukseen. ${ }^{58}$ Raja markolaisten ja muiden kristittyjen välillä oli ainakin Irenaeuksen kuvauksen perusteella selvä. Markolaisista ryhmistä palanneet kristityt joutuivat muun muassa tunnustamaan seurakunnan kokouksissa julkisesti osallistuneensa ryhmän toimintaan. Jo 200-luvun alussa markolaisilla oli ainakin Roomassa jo oma piispa, jonka tehtävänä

\footnotetext{
${ }^{56}$ Lampe 1989, 323-330.

${ }^{57}$ Irenaeus, Frg. syr. 28. Florinoksesta ks. myös Eusebios, Kirkkohistoria 5.20.4; Lampe 1989, 327-328.

${ }^{58}$ Irenaeus, Harh. 1.21.5.
} 
oli paljastaa edellä mainitut vastaukset; ${ }^{59}$ Irenaeuksen vastaavassa kuvauksessa piispaa ei vielä mainita.

Valentinolaisia oli Rooman valtakunnassa vielä 300-luvulla, mutta heidän asemansa heikkeni tuntuvasti konstantiaanisen käänteen seurauksena, kun oikeaoppiset kristityt saivat harhaoppien vastaisessa taistelussa taakseen keisarin arvovallan ja taloudellisen tuen. Konstantinuksen harhaoppisia koskevassa laissa vuodelta 326 harhaoppisilta, valentinolaiset mukaan lukien, kiellettiin jumalanpalveluskäyttöön tarkoitettujen tilojen omistaminen, ja Theodosiuksen laeissa kiellettiin ei-katolisten uskonnollisten ryhmien kokoontumiset. ${ }^{60}$ Harhaoppisten tekstit joutuivat kiellettyjen kirjojen listoille. Tämä selittää, miksi valentinolaisten kirjoituksia on säilynyt vain poikkeustapauksissa.

Harhaoppisten omistusoikeuteen liittyviä rajoituksia ei aina noudatettu käytännössä, mutta heidän oikeusturvansa Rooman valtakunnassa oli heikko. Kun areiolaiset ja valentinolaiset kiistelivät keskenään 300-luvun puolivälissä, keisari Julianus Apostaatti rankaisi areiolaisia ottamalla itselleen heidän kirkkonsa koko omaisuuden. Pari vuosikymmentä myöhemmältä ajalta, vuodelta 388 , on säilynyt Milanon piispa Ambrosiuksen ja keisari Theodosius I:n kirjeenvaihto, jossa mainitaan ohimennen myös valentinolaisten kirkko. Kirjeiden varsinaisena aiheena oli Theodosiuksen päätös, että kirkon on korvattava kristittyjen polttaman juutalaisen synagogan jälleenrakennustyöt. Ambrosius kuitenkin valitti kitkerään sävyyn päätöksestä. Hän vetoaa siihen, että samalla periaatteella pitäisi korvata myös kiivastuneiden munkkien aiemmin polttama valentinolainen kirkko. Tämä on kuitenkin Ambrosiuksen mukaan mahdottomuus, sillä eihän kirkon varoilla voi tukea harhaoppisia. Ambrosiuksen vetoomus tehosi, ja Theodosius pyörsi päätöksensä. ${ }^{61}$ Oikeaoppisen kristinuskon kannattajien huliganismista huolimatta valentinolaiset onnistuivat pitämään

\footnotetext{
${ }^{59}$ Hippolytos, Ref. 6.41.4-5. Markoksen ryhmästä ks. erityisesti Förster 1999.

${ }^{60}$ Eusebios, Vit. Const. 3.64-65; Cod. Theod. 16.5.6 (Koschorke 1981, 124-125, 134-135).

${ }^{61}$ Ambrosius, Ep. 40-41 (Koschorke 1981, 124, 133).
} 
pintansa Rooman valtakunnassa yllättävän pitkään; viimeisin heitä koskeva tieto on vuodelta $692 .^{62}$

62 Valentinolaiset mainitaan vielä Trullan toisen synodin (692) kaanonissa 95, ja on todennäköistä, että siinä esiintyvät määräykset "kohdistuvat vielä olemassa oleviin valentinolaisiin” (Koschorke 1981, 125). 


\section{Tunteet ja maailman synty}

(1998)

\section{Johdanto}

Myytillä Viisauden (Sofia) lankeemuksesta on keskeinen asema gnostilaisina pidetyissä kuvauksissa maailman synnystä. Myytin perusajatus on, että jumalallisessa todellisuudessa asuu itsenäisen persoonan piirteitä saava Viisaus, jonka toiminta johtaa lopulta maailman luomiseen. Juutalaisen viisauskirjallisuuden tavoin Viisauden ajatellaan toimivan eräänlaisena välittäjänä jumalallisen ja inhimillisen maailman välillä. Viisaudella ei kuitenkaan ole "gnostilaisissa" myyteissä samaa asemaa kuin juutalaisessa viisauskirjallisuudessa, jossa hänet kuvataan Jumalan ensimmäiseksi luomisteoksi ja auttajaksi luomistyössä. " "Gnostilaisissa" kuvauksissa maailman synnystä Viisauden kuvataan yleensä toimineen omin päin ja aiheuttaneen näin tragedian, joka järkyttää jumalallisen todellisuuden sisäistä järjestystä ja vaatii erityisiä toimenpiteitä tämän järjestyksen palauttamiseksi. Maailman luomista pidetään välillisenä seurauksena siitä epäharmoniasta, johon jumalallinen todellisuus Viisauden omapäisen toiminnan vuoksi joutui.

Uusimman tutkimuksen valossa "gnostilaisuutta" on ongelmallista lähestyä yhtenäisenä uskonnollisena virtauksena, siksi monenlaisia ryh-

\footnotetext{
${ }^{1}$ Klassisia kuvauksia näistä Viisauden ominaisuuksista ovat mm. Sananl. 8:22-31; Siir. 24; Viis. 24:1-9. Sananlaskujen kirjan luvuissa 1-9 ja sittemmin erityisesti hellenistijuutalaisissa kirjoituksissa esiintyvästä juutalaisesta viisausteologiasta ks. esim. Mack 1973; Sandelin 1986; Sollamo 1992.
} 
miä ja ajattelutapoja tämän termin alle on sijoitettu. ${ }^{2}$ Turvallisempi lähtökohta on oletus, että ensimmäisillä kristillisillä vuosisadoilla oli erilaisia ryhmiä, joille yhteistä oli samansuuntainen tapa tulkita Vanhan testamentin luomiskertomuksia. Luonteenomaista näille tulkinnoille oli oletus, että maailman on luonut korkeimman Jumalan sijasta alempi luojajumala, demiurgi (tai muut luojaolennot). ${ }^{3}$ Lisäksi luojajumalan yleensä ajateltiin luoneen maailman tietämättömyyden vallassa, vailla tietoa korkeimmasta Jumalasta. ${ }^{4}$

Gnostilaisuuden nykytutkimuksessa toisistaan erotetaan tavallisesti kaksi pääuomaa, niin sanottu setiläinen gnostilaisuus ja valentinolainen kristillisyys. ${ }^{5}$ Viisaus-myytti kuuluu näiden "gnostilaisen" ajattelun kahden pääuoman yhteiseen aineistoon. Setiläistä luomismyyttiä ja kertomusta Viisauden lankeemuksesta sen osana on käsitelty jo aiemmin Teologisen Aikakauskirjan palstoilla, ${ }^{6}$ joten keskityn tässä artikkelissa kuvaamaan valentinolaisten kristittyjen tulkintaa Viisaus-myytistä.

Viisaus-myytin valentinolaista versiota on tutkittu suhteellisen paljon kahdesta näkökulmasta. Kirkkoisien toisistaan poikkeavien kuvausten perusteella on ensinnäkin pyritty paljastamaan myytin "alkupe-

${ }^{2}$ Termi "gnostilaisuus" voi antaa harhaanjohtavan yhtenäisen kuvan näistä ajattelumalleista. Muistutuksena termin käyttöön sisältyvistä ongelmista varustan sanan "gnostilaisuus" ja sen johdannaiset tässä artikkelissa lainausmerkeillä.

3 Näin Williams 1996. Williams itse asiassa ehdottaa luopumista termin "gnostilaisuus" käytöstä ja sen korvaamista termillä "raamatulliset demiurgitraditiot" (biblical demiurgical traditions).

${ }^{4}$ Tämä piirre erottaa "gnostilaisen" maailmankatsomuksen platonistisesta traditiosta, jonka se muuten epäilemättä edellyttää. (Esim. Dillon (1977, 384-389), käsittelee tässä artikkelissa kuvattua valentinolaista järjestelmää yhtenä esimerkkinä "platonistisesta alamaailmasta".) Jo Platon kutsuu maailman luonutta jumalaa demiurgiksi (eli "käsityöläiseksi”) ja kuvaa tämän luoneen maailman täydellisestä todellisuudesta saadun esikuvan perusteella. Platon kuitenkin olettaa demiurgin luoneen "parhaan mahdollisen maailman": "Sillä kaikesta mitä on syntynyt, maailmankaikkeus on kauneinta ja sen luoja on kaikkien syiden joukossa paras." (Platon, Timaios 29a; suom. A. M. Anttila.). Platonin demiurgikäsityksistä ks. esim. Knuuttila 1982, 365.

${ }^{5}$ Ajatus setiläisen gnostilaisuuden keskeisestä asemasta varhaisten gnostilaisten järjestelmien joukossa on peräisin Hans-Martin Schenkeltä, saksalaiselta Nag Hammadi -tutkijalta, joka kiinnitti huomionsa useissa Nag Hammadin kirjoituksissa toistuviin yhteisiin piirteisiin (ks. esim. Schenke 1981). Nimitys on peräisin siitä, että osassa näitä kirjoituksia Setillä, Aadamin ja Eevan pojalla, on erityisasema. Schenken oletus setiläisen gnostilaisuuden keskeisistä tuntomerkeistä on laajalti vakiintunut tutkimuksessa.

${ }^{6}$ Marjanen 1991. 
räinen" valentinolainen versio, joka mahdollisesti voisi olla peräisin jo Valentinokselta, koulukunnan perustajalta. ${ }^{7}$ Toinen usein esillä pidetty näkökulma on ollut valentinolaisen Viisaus-myytin (tai sen eri versioiden) suhde muihin "gnostilaisiin" järjestelmiin. ${ }^{8}$ Lisäksi "gnostilaisen" Viisaus-myytin uskonnonhistorialliseen taustaan yleensä on kiinnitetty suhteellisen paljon huomiota; myytin juuria on etsitty juutalaisen viisauskirjallisuuden ohella niin egyptiläisestä Isis-traditiosta kuin assyrialaisista Ištar-jumalattareen liittyvistä käsityksistäkin. ${ }^{?}$

Viisaus-myytin ja antiikin filosofisten virtausten suhdetta on sen sijaan tutkittu vähänlaisesti. Valentinolaisessa Viisaus-myytissä on kuitenkin piirteitä, jotka voidaan ymmärtää ensi sijassa tätä taustaa vasten. Yksi valentinolaisen Viisaus-myytin erityispiirteistä on Viisauden haital-

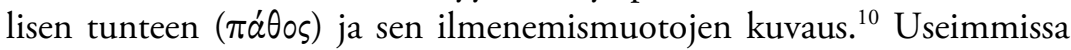
setiläisistä gnostilaisuutta kuvaavissa lähteissä tällaista kuvausta ei esiinny Viisaus-myytin yhteydessä. ${ }^{11}$ Tunteiden kuvaukseen valentino-

\footnotetext{
7 Tätä lähestymistapaa edustavat mm. Stead 1969; Quispel 1996. Valentinoksen opetuksista säilyneiden suorien lainausten perusteella on kuitenkin epävarmaa, millaisen luomismyytin hän edellytti. (Valentinoksen omien opetusten suhteen kirkkoisien kuvaamiin valentinolaisiin järjestelmiin problematisoi Markschies 1992.) Yhden katkelman perusteella on päätelty, että Valentinos itsekin puhui sekä Viisaudesta että demiurgista (näin esim. Stead 1969, 95). Varmaa tämä kuitenkaan ei ole, sillä kohta, johon tässä yhteydessä vedotaan (Clemens, Strom. 4.90.2), ei ole lainaus Valentinokselta vaan Clemensin näkemys aiemmin esitetyn katkelman tulkinnasta (ks. Markschies 1992, 171-173).

8 Valentinolaisen ja setiläisen viisaus-myytin keskinäisiin suhteisiin kiinnittää huomiota erityisesti Scholten 1987, 262-267; vrt. myös Logan 1996, 127-128.

9 Viisaus-myytin suhteesta egyptiläiseen uskontoon ks. Parrott 1987 ja mahdollisista yhteyksistä assyrialaisiin kuvauksiin Ištarin laskeutumisesta tuonelaan Parpola 1997, xxxixxxvi. Viisaus-myytin uskonnonhistoriallisen taustan täsmällistä määrittelyä vaikeuttaa se, että egyptiläisten ja assyrialaisten käsitysten oletetaan vaikuttaneen myös juutalaiseen viisausteologiaan (ks. esim. Mack 1973, 34-56), joten näiden vaikutus "gnostilaiseen" Viisausmyyttiin voi ainakin periaatteessa olla myös välillistä. Tässä yhteydessä ei ole mahdollista puuttua tarkemmin siihen kysymykseen, mitkä egyptiläisen tai assyrialaisen uskonnon piirteet voisivat heijastua suoraan "gnostilaisessa" Viisaus-myytissä.

${ }^{10}$ Käytän jatkossa yksinkertaisuuden vuoksi kreikan $\pi \alpha ́ \theta 0 \varsigma$-sanan käännöksenä sanaa "tunne", vaikka se ei tavoita läheskään kaikkia kreikkalaiseen termin vivahteita ("haitallinen tunne", "kärsimys" jne.). Monikolla "tunteet" viittaan em. pathoksen erilaisiin ilmenemismuotoihin.

${ }^{11}$ Scholten 1987, 262-263.
} 
laisessa myytissä ei kuitenkaan ole kiinnitetty kovinkaan suurta huomiota. $^{12}$

Viisauden tunteiden kuvaus ei ole valentinolaisessa luomismyytissä vähäpätöinen yksityiskohta. Siihen kiinnitetään itse lähdeteksteissä suhteellisen paljon huomiota. Lisäksi aihe on sikäli tärkeä, että antiikin filosofisissa koulukunnissa tunteista esitetyt näkemykset olivat keskeinen pohdinnan aihe. Näiden koulukuntien näkemykset ovat voineet vaikuttaa myös valentinolaisten kristittyjen käsityksiin. Filosofisissa koulukunnissa tunteiden määrittelyllä ja luokittelulla oli yleensä käytännöllinen päämäärä: tavoitteena pidettiin tunteista "parantumista". ${ }^{13}$ Koulukunnasta riippuen ihanteena saatettiin pitää joko tunteiden hallintaa ja kohtuullista ilmaisemista $(\mu \varepsilon \tau \rho ı \pi a ́ \theta \varepsilon ı \alpha)$ tai täydellistä vapautumista niistä $(\dot{\alpha} \pi \dot{\theta} \theta \varepsilon ı))^{14}$

Tunteiden kuvauksen keskeisen aseman valentinolaisessa Viisausmyytissä voi nähdäkseni parhaiten ymmärtä näistä filosofisissa koulukunnissa esitetyistä tunneteorioista käsin. Viisaus-myyttiä voidaan lukea jopa valentinolaisena kannanottona kysymykseen, miten haitallisena pidetystä tunteesta yleensä voidaan parantua.

\section{Valentinolaisen myytin pääversiot}

Valentinolainen luomismyytti maailman synnystä tunnettiin pitkään lähinnä kolmen kirkkoisiltä peräisin olevan kuvauksen perusteella. Näiden kuvauksien välillä on kuitenkin niin merkittäviä eroja, että

\footnotetext{
${ }^{12}$ Esimerkiksi François Sagnardin laajan Valentinoksen koulukuntaa käsittelevän tutkimuksen (Sagnard 1947) indeksistä ei löydy termiä $\pi \dot{\theta} \theta$ os lainkaan, vaikka sana esiintyy usein itse lähdeteksteissä.

13 Tunteista käydyn keskustelun keskeisyydestä antiikin filosofisissa koulukunnissa ja niiden näkemyksistä siitä, millä edellytyksillä ja miten tunteita voidaan "parantaa", ks. Nussbaum 1994. Aristoteleen emootioteoriasta, joka näkyi useimpien koulukuntien teorioiden taustalla, ks. Sihvola 1994, 206-214. Käytössäni on lisäksi ollut tätä artikkelia kirjoittaessani Simo Knuuttilan antiikin emootioteorioita käsittelevä käsikirjoitus [julkaistu: Knuuttila 2004] sekä osia Petri Järveläisen kristillisiä tunneteorioita käsittelevästä väitöskirjakäsikirjoituksesta [julkaistu: Järveläinen 2000], mistä sydämellinen kiitos molemmille.

14 Näiden kahden ihanteen välisestä eroa ja niistä käytyä keskustelua kreikkalaisessa filosofiassa kuvaa esim. Dillon 1990, 508-517.
} 
niiden katsotaan yleensä edustavan eri versioita. Tutkimuksessa erotetaan toisistaan tavallisesti versiot A ja B, joista A kuvaa Irenaeuksen päälähdettä (Harh. 1.1-8), B puolestaan Hippolytoksen Irenaeuksen kuvauksesta poikkeavaa versiota (Refutatio, 6.29-37). ${ }^{15}$ Näiden kahden version tarkkaa erottelua toisistaan vaikeuttaa tosin se, että kumpikin kirkkoisä näyttää oman päälähteensä lisäksi tunteneen myös yksityiskohtia toisesta pääversiosta. ${ }^{16}$ Näiden lähteiden ohella Clemens Aleksandrialaisen kokoelmassa Katkelmia Theodotokselta on pitkähkö valentinolaista luomismyyttiä kuvaava jakso (Exc. Theod. 42-65). Mikään mainituista lähteistä ei ole suoraan peräisin Valentinokselta, vaan tämän myöhemmiltä oppilailta.

Irenaeus kertoo lähteidensä alkuperästä, mutta hänen antamansa tiedot ovat jossain määrin ristiriitaisia. Yhden kohdan mukaan hän on yksinkertaisesti kuvannut Ptolemaioksen, Valentinoksen oppilaan, käsityksiä ("Näin Ptolemaios", Harh. 1.8.5), mutta kirjansa johdannossa hän ilmoittaa saaneensa tietonsa Ptolemaioksen oppilailta ja näiden kirjoituksista (Harh. 1, johdanto). Joka tapauksessa Irenaeus ei edes omien sanojensa mukaan kuvaa Valentinoksen koulukunnan varhaisimpia käsityksiä, vaan hänen esityksensä perustuu vasta koulun "kolmannelta sukupolvelta" saatuihin tietoihin. ${ }^{17}$

Nag Hammadin kirjaston valentinolaisissa kirjoituksissa luomismyyttiin viitataan usein, mutta vain kahdessa niistä itse myyttiä kuvataan tarkemmin. Laajahkon Kolmiosaisen tutkielman (NHK I, 5) luomismyytin erityispiirre on se, että siinä ei puhuta Viisauden, vaan toisen jumalallisessa maailmassa olleen hahmon, Sanan (Logos), lankeemuk-

\footnotetext{
15 Jako valentinolaisen myytin A- ja B-versioon on yleisesti hyväksytty; esim. Foerster 1928, 47-48; Sagnard 1947, 142-144 (yksityiskohtainen vertailu versioiden välillä, 146-198). Scholten 1987; Stead 1969, 77-78; Pagels 1990.

${ }^{16}$ Ks. Stead 1969, 77-79. Hippolytoksen kohdalla versioiden päällekkäisyyden selittää osaltaan se, että hänellä oli Irenaeuksen kuvaus jo käytössään.

${ }^{17}$ Irenaeus mainitsee Valentinoksen vasta kuvatessaan Ptolemaioksen (tai tämän oppilaiden) järjestelmistä poikkeavia käsityksiä (Harh. 1.11). Lisäksi Markschies, 1992, 364-379, osoittaa, että tämän kuvauksen suhde Valentinoksen fragmenteista saatuun kuvaan on hyvin ongelmallinen.
} 
sesta. ${ }^{18}$ Toinen Nag Hammadin valentinolaisista kirjoituksista, joissa luomismyyttiä kuvataan laajemmin, on Valentinolainen kirjoitus (NHK XI, 2). Tämä teksti on valitettavasti säilynyt hyvin fragmentaarisena, joten päätelmät sen sisällöstä jäävät epävarmoiksi. Tunnistettavien tekstikohtien perusteella tekstin edustama luomismyytti kuitenkin muistuttaa pääpiirteissään edellä mainittua valentinolaisen järjestelmän versiota B. ${ }^{19}$ Myös tässä kirjoituksessa Viisauden kokemat tunteet yhdistetään maailman luomiseen (Val. kirj. 35.30-38). Näin teksti fragmentaarisuudestaan huolimatta vahvistaa ensi käden lähteenä sen, että tunteiden kuvauksella todella oli keskeinen asema valentinolaisissa tulkinnoissa Viisaus-myytistä.

\section{Ylempi ja alempi Viisaus (versio A)}

Irenaeuksen kuvaamassa versiossa ${ }^{20}$ Viisauden lankeemus on kahden tason draama: toisaalta se tapahtuu ja hoidetaan jumalalallisen täyteyden eli pleroman sisäisenä asiana, toisaalta sen seuraukset ulottuvat pleroman ulkopuolelle ja johtavat lopulta maailman syntyyn. Pleroma koostuu 30 jumalallisesta olemuksesta, aioneista ("ikuisuuksista" tai "ikuisista olennoista"). Aionit jakautuvat maskuliinisiin ja feminiinisiin, joista kullakin on vastakkaista "sukupuolta" edustava kumppani, syzygos.

Irenaeuksen versiossa kaikki on alun perin lähtöisin alkuparista, toisin sanoen Alkuisästä, joka on näkymätön ja käsittämätön, sekä tämän feminiinisestä kumppanista, Ajatuksesta tai Hiljaisuudesta. Tästä parista saavat alkunsa asteittain muut aionit.

Viisaus on aioneista viimeisin ja nuorin; samalla hän on kauimpana Alkuisästä. Viisaus ei siis tässä mallissa ole Jumalan lähin työtoveri

\footnotetext{
${ }^{18}$ Sofian vaihtuminen Logokseksi ei ole täysin poikkeuksellinen piirre, sillä myös Filon antaa jumalalliselle Logokselle perinteisesti Viisauteen liitettyjä ominaisuuksia. (Mack 1973, 141154.) Käyttämäni Nag Hammadin kirjoitusten suomalaiset nimet ja lyhenteet perustuvat hiljattain uudistettuun luetteloon (Marjanen 1997, 150-151).

${ }^{19}$ Pagels 1990, 103-105.

${ }^{20}$ Olen kuvannut tämän version pääpiirteitä jo aiemmin (Dunderberg 1997a, 148); tässä yhteydessä kiinnitän tarkempaa huomiota myytin yksityiskohtiin.
} 
kuten juutalaisessa viisauskirjallisuudessa - ja ilmeisesti myös eräissä "gnostilaisissa" järjestelmissä - vaan hänet on etäännytetty mahdollisimman kauas kaikkeuden Isästä, jumalallisen todellisuuden reunalle. Pleroman rauhan järkyttää se, että Viisaus alkaa ilman maskuliinisen parinsa suostumusta etsiä kaikkeuden Isää ja haluaa ymmärtää hänen suuruutensa (Harh. 1.2.2). Koska Isä kuitenkin on ja pysyy käsittämättömänä, Viisauden pyrkimykset tuottavat vain pettymystä ja epätoivoa. Jotta Viisaus ei tuhoutuisi pyrkiessään kohti Isää, 'Rajaksi' kutsuttu voima vahvistaa häntä niin, että hän pystyy luopumaan pyrkimyksestään ja palaa omalle paikalleen pleromassa.

Myytti korostaa sitä, ettei Isää voi käsittää. Tämä apofaattinen perusvire on yllättävä ainakin siinä mielessä, että "gnostilaisuuden" tunnuspiirteenä on usein pidetty ajatusta tiedon $(\gamma \nu \tilde{\omega} \sigma \iota \varsigma)$ pelastavasta asemasta. Irenaeuksen kuvaamassa myytissä kaikkeuden Isä, olemassaolon syvyys on kuitenkin kaiken käsityskyvyn tuolla puolen. Se joka pyrkii liian lähelle häntä, on vaarassa tuhoutua. Apofaattisen korostuksen rinnalla myytissä kuitenkin korostetaan myös sitä, että salattu Isä on kaikkien olioiden kiinnostuksen ja kaipauksen kohde jo pleromassa. Itse asiassa ei ainoastaan Sofia, vaan kaikki aionit toivoivat oppivansa tuntemaan Isän: "Samoin muut aionit hiljaa toivoivat näkevänsä nähdä sen, joka oli heidän siemenensä alkuperä, ja tuntea juuren, jolla ei ollut alkua." (Harh. 1.2.1). Viisaus poikkeaa muista aioneista ainoastaan siinä, että hän alkaa toimia tämän yhteisen toiveen toteuttamiseksi.

Viisaus-myytissä on aiheellisesti nähty viitteitä Vanhan testamentin syntiinlankeemuskertomukseen (1. Moos. 3:1-24). Myyttiä voidaan jopa pitää Genesiksen kertomuksen jumalalliseen maailman siirrettynä toisintona. ${ }^{21}$ Yhdistäviä tekijöitä ovat erityisesti seuraavat kaksi piirrettä. Ensinnäkin Viisaus toimii ilman puolisonsa suostumusta kuten Eeva syntiinlankeemuskertomuksessa (1. Moos. 3:1-6, 12). Toiseksi Viisauden toiminnan motiivi on samankaltainen kuin Eevan. Eevaa houkutte-

${ }^{21}$ MacRae 1970, 100. Nämä piirteet soveltuvat yhtä hyvin setiläisen Johanneksen salaisen kirjan luomismyytissä kuvattuun Viisaus-hahmoon; ks. Marjanen 1991, 430. 
li mahdollisuus tulla Jumalan kaltaiseksi (1. Moos. 3:5), Viisaus halusi oppia tuntemaan kaikkeuden Isän.

Syntiinlankeemuskertomus ei kuitenkaan selitä tunteiden kuvauksen keskeistä osuutta valentinolaisessa Viisaus-myytissä. Genesiksen kertomuksessa Eevan tunteita ennen syntiinlankeemusta ei pohdita lainkaan, ja lankeemuksen jälkeenkin ainoa nimeltä mainittu tunne on ensimmäisten ihmisten alastomuutensa takia tuntema pelko (1. Moos. 3:10). ${ }^{22}$ Valentinolaisessa kuvauksessa koko Viisauden lankeemusta kuvaava jakso sen sijaan alkaa toteamuksella: "Viimeisin ja nuorin aioni kahdentoista aionin ryhmästä eli Viisaus koki tunteen ( $\left.\varepsilon^{\prime} \pi \dot{\alpha} \theta \varepsilon \pi \dot{\alpha} \theta \circ \varsigma\right)$ ilman yhteyttä puolisoonsa." Viisauden kokeman tunteen sisällöksi määritellään Isän etsiminen. Viisauden halu oppia tuntemaan Isä on todellisuudessa röyhkeyttä $(\tau o ́ \lambda \mu \eta)$, mutta sen sanotaan tapahtuneen rakkauden varjolla ( $\pi \rho \circ \phi a ́ \sigma \varepsilon ı ~ a ́ \gamma a ́ \pi \eta \varsigma)$. Viisauden tunnetta Isää kohtaan kuvataan myös sanalla, jota usein käytetään perheenjäsenten (yleensä vanhempien ja lasten) välisestä rakkaudesta ( $\sigma \circ \rho \gamma \eta ́)$. Isän suuruuden ja tutkimattomuuden havaitseminen puolestaan suistaa Viisauden epätoivoon $\left(\dot{\alpha} \gamma \omega^{\prime} \nu\right){ }^{23}$

Kaikki Viisauden kokemat tunteet tulkitaan osoitukseksi heikkouden tilaan joutumisesta, sillä niiden seurauksena Rajan täytyy tukea ja vahvistaa häntä. Silloinkin Viisaus pystyy "vain vaivoin kääntymään takaisin itsensä ja hylkäämään ajatuksensa ja siitä seuranneen tunteen ( $\pi a ́ \theta$ os)." Myyttiä voidaan lukea kuvauksena siitä, kuinka taivaallinen Viisaus vapautuu epätoivoon ja ahdistukseen johtaneesta tunteesta. Myytissä näkyy se, että ihanteellisena tilana pidetään tunteista eroon pääsemistä. Jo myytin tässä vaiheessa paljastuu myös tunteista parantumisen metodi: tunteesta vapautuminen edellyttää toisaalta jumalallista apua, toisaalta sen, että tunteen valtaan joutunut tekee kääntymyksen.

\footnotetext{
${ }^{22}$ Filonin edustamassa hellenistijuutalaisessa tulkintatraditiossa "sielun tunteiden/kärsimysten" ( $\pi \dot{\theta} \theta \eta \tau \tilde{\eta} \varsigma \psi u \chi \tilde{\eta} \varsigma)$ tosin katsottiin henkilöityvän Eevaan (Leg. All. 2.5-6). Tämä heijasti antiikin maailmassa laajemminkin tunnettua ajatusta, että tunteet olivat feminiinisiä ominaisuuksia, kun taas järkeä pidettiin maskuliinisena piirteenä; aiheesta tarkemmin ks. Gemünden 1997.

${ }^{23}$ Sanan merkityksestä ks. Lampe 1961, s.v.
} 
Draaman toisella, alemmalla tasolla kuvataan jumalallisessa todellisuudessa syntyneen epäjärjestyksen seurauksia pleroman ulkopuolella. Tällä tasolla toistuu monessa suhteessa se, mitä jumalallisessa maailmas-

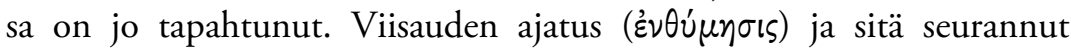
tunne yhdistävät toisiinsa ylemmän ja alemman tason. Nämä ominaisuudet eivät raukea tyhjiin, vaan jatkavat elämäänsä täyteyden ulkopuolella, varjojen ja pimeyden keskellä, vaikka järjestys on jo palautettu täyteyden sisällä.

Täyteyden ulkopuolelle rajatuista Viisauden ominaisuuksista syntyy uusi hahmo, "toinen Viisaus", jota kutsutaan myös Akhamotiksi. Nimi viittaa juutalaiseen viisauskirjallisuuteen, jossa personoidusta Jumalan Viisaudesta käytetään usein heprean viisautta merkitsevän sanan (håkma) monikollista muotoa (håkmot) (Sananl. 1:20; 9:1; 14:1; 24:7). Akhamot-nimen käyttöön onkin alun perin saattanut johtaa polemiikki juutalaista viisausteologiaa kohtaan: viisauskirjallisuudessa kuvattu, luomistyöhön osallistunut Viisaus tulkitaan valentinolaisessa myytissä alemmaksi olennoksi, jolla on ainoastaan jumalallisen Viisauden heikoimmat ominaisuudet. ${ }^{24}$

Ajatus kahdesta erillisestä Viisaus-hahmosta on Irenaeuksen Aversion ominaispiirre. Jako esiintyy ainoastaan valentinolaista kristillisyyttä kuvaavissa lähteissä eikä edes kaikissa niissä; monet valentinolaiset tekstit (muun muassa Clemensin Katkelmia Theodotokselta) edellyttävät vain yhden Viisaus-hahmon. ${ }^{25}$ Irenaeuksen kuvaamalle jaolle löytyy tukea Nag Hammadin kirjastoon kuuluvasta valentinolaisesta kirjoituksesta, 1. Jaakobin ilmestyksestä (NHK V, 3). Tässä tekstissä erotetaan toisistaan Sofia, "katoamaton tieto" ja hänestä syntyisin oleva Akhamot,

\footnotetext{
24 Hellenistijuutalainen viisausteologia on kuitenkin osaltaan voinut vaikuttaa myös valentinolaiseen jakoon "ylemmän" ja "alemman" Viisauden välillä. Mack erottaa hellenistijuutalaisissa lähteissä "salatun", "lähellä olevan" ja "kadonneen" viisauden; näistä nimenomaan "lähellä oleva viisaus" "on Jumalan luomus, hallitsee kosmosta ja asuu ihmisten keskellä" (Mack 1967, 29). Sama jako näkyy myös Filonilla, jonka kirjoituksissa ”Logos on ottanut lähellä olevan viisauden funktion" (Mack 1967, 153).

${ }^{25}$ Vrt. Stead 1969, 84-89.
} 
jolla ei ole isää eikä puolisoa (1. Jaak. ilm. 35.6-17). ${ }^{26}$ Kirjoitus vahvistaa Irenaeuksen kuvauksen siltä osin, että valentinolaiset käyttivät Viisaudesta seemiläisperäistä nimeä Akhamot. Kirjoituksen perusteella valentinolaiset tunsivat myös Akhamot-nimen seemiläisperäisen etymologian, sillä tässä tekstissä nimi on suoraan käännetty "Viisaudeksi" (1. Jaak. ilm. 36.5-6).

Akhamot-nimeen viitataan myös Filippuksen evankeliumissa (NHK II, 3), jossa nimi tosin esiintyy muodossa 'Ekhamot'. Ei ole kuitenkaan selvää, että nimi tässä yhteydessä kuvaisi "alempaa Viisautta" kuten Irenaeuksella ja 1. Jaakobin ilmestyksessä. Ekhamot näyttää Filippuksen evankeliumissa pikemminkin tarkoittavan "ylempää Viisautta", sillä hänet erotetaan alemmasta viisaus-hahmosta, Ekhmotista eli 'kuoleman kaltaisesta'.

Ekhamot ja Ekhmot ovat kaksi eri asiaa. Ekhamot on varsinainen viisaus, Ekhmot puolestaan kuoleman viisaus eli se ... joka tuntee kuoleman. Tätä viisautta kutsutaan myös 'pieneksi viisaudeksi' eli 'kuoleman kaltaiseksi'. (Fil. ev. $60, \$ 39) .^{27}$

Irenaeuksen kuvaamassa myytissä myös pleroman ulkopuolelle joutuneen Akhamotin kohtalona oli joutua haitallisen tunteen eri ilmenemismuotojen heiteltäväksi: "Hän tunsi tuskaa $(\lambda u ́ \pi \eta)$, koska ei voinut ymmärtää, pelkoa ( $\phi o ́ \beta o \varsigma)$ että menettäisi elämäänsä, ja neuvottomuutta (åmopía)."28 Neljäntenä "tunteena" tässä yhteydessä mainitaan

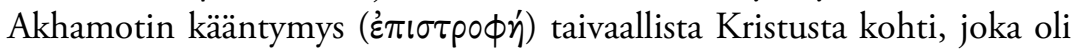
antanut hänelle muodon (Harh. 1.4.1).

Akhamotin tunteen ilmenemismuodoista saa alkunsa maailma. Sielut ovat peräisin hänen katumuksestaan, kaikki muu pelosta ja surusta (Harh. 1.4.2). Tällä selitetään se, että sieluihin on sisäänrakennettuna

\footnotetext{
${ }^{26}$ Olen aiemmassa artikkelissani (Dunderberg 1997a, 147) esittänyt käännöksinä katkelmia tästä tekstistä sekä sen rinnakkaiskohdasta, jota Irenaeuksen mukaan markolaiset käyttivät kuolinrituaalin yhteydessä (Harh. 1.21.5);

${ }^{27}$ Käännös Dunderberg 1997b, 305.

${ }^{28}$ Sanan à Topía käännös perustuu Lampen (1961, s.v.) antamiin merkityksiin ("dismay, disturbance").
} 
katumisen mahdollisuus. Luomismyytissä kuvataan lisäksi, kuinka Akhamotin mielenliikkeet ovat näkyvän maailman taustalla. Hänen kyyneleistään syntyy kosteus, hänen ilostaan valoisuus ja surusta aineellinen todellisuus. Näihin valentinolaisen luomismyytin ilmeisen poeettisiin piirteisiin Irenaeus vastaa karkeahkolla parodialla: ${ }^{29}$

Koska olen havainnut, että toisaalta on makeita vesiä kuten lähteet, joet, sadevesi ja muut näiden kaltaiset ja että toisaalta merissä on suolaista vettä, kaikki vedet eivät mielestäni voi olla peräisin hänen (Akhamotin) kyyneleistään. Kyyneleen ominaispiirre on suolaisuus, joten on selvää, että mainitut suolaiset vedet ovat peräisin hänen kyyneleistään. Kuitenkin ollessaan suuren tuskan ja hämmennyksen vallassa hän todennäköisesti myös hikoili. Näin heidän teoriansa perusteella pitää olettaa, että purot ja joet ja kaikki muut makeat vedet ovat peräisin hänen hiestään. Ei nimittäin ole lainkaan uskottavaa, että kyyneleistä, joilla on yksi ominaispiirre, syntyisivät sekä suolaiset että makeat vedet. Paljon uskottavampaa on, että toiset ovat peräisin kyyneleistä, toiset taas hiestä. Lisäksi maailmassa on kuumia ja kitkeriä vesiä - arvaa vain, mitä hän silloin teki ja mistä elimestä ne ovat peräisin! (Harh. 1.4.4)

Valentinolaisen luomismyytin toisessakin vaiheessa haitallisesta tunteesta vapautuminen on keskeinen päämäärä ja myös tähän tavoitteeseen johtava prosessi on pitkälti samankaltainen kuin draaman ylemmällä tasolla. Akhamot kääntyy taivaallisen valon, Kristuksen puoleen, joka yhdessä muiden aionien kanssa lähettää Akhamotin luokse Pelastajan. Pelastajan tehtävänä on parantaa Akhamotin tunteet ottamalla ne hänestä pois (Harh. 1.4.5). Akhamotin tunteista Pelastaja loi ei-materiaalisen olemuksen, joka näkyy maailmassa sekä pahuutena että kärsimyksenä ja josta demiurgi sittemmin luo materiaalisen maailman.

Käsitykselle Vapahtajasta, joka luo tunteista maailman perustuksen, löytyy tukea myös valentinolaisten omista kirjoituksista. Vastaava näkemys on ilmaistu Valentinolaisessa kirjoituksessa seuraavasti:

${ }^{29}$ Irenaeuksen tavasta parodioida vastustajiensa käsityksiä ja muista retorisista tehokeinoista, joille löytyy vastineensa antiikin retoriikan käsikirjoista, ks. Perkins 1976, 193-197. 


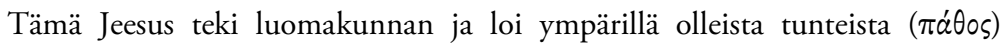
siemenet. Hän erotti tunteet toisistaan. Hyvät tunteet hän liitti henkeen, huonot taas lihalliseen olemukseen. Ensimmäiset näistä tunteista... ${ }^{30}$ (Val. kirj. 35.30-38)

Irenaeuksen kuvaamassa versiossa Akhamotille haitallisista tunteista vapautuminen merkitsee mahdollisuutta ilon täyttämänä katsella Pelastajan mukanaan tuomaa valoa. Tästä ilosta Akhamot synnyttää itselleen hengellisiä jälkeläisiä. Akhamotista erotetut tunteet jatkavat itsenäistä elämää kuten aiemmin taivaallisen Viisauden kokemat tunteet. Materiaalinen todellisuus perustuu Akhamotin tunteeseen ( $\pi \dot{\alpha} \theta 0 \varsigma)$,

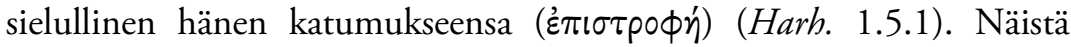
aineksista, tunteesta ja katumuksesta, demiurgi, Akhamotin jälkeläinen, luo maailman.

Kaksinkertainen kertomus Viisauden lankeemuksesta ja kääntymyksestä edellyttää, että tunteita pidetään maailmankaikkeuden keskeisenä osana, koko maailman synnyn alkusyynä. Myytti on tässä suhteessa aitiologinen, mutta sillä on epäilemättä myös ja ennen kaikkea paradigmaattinen funktio. Viisauden kaksinkertainen kääntymys esitetään myytissä toivotun inhimillisen käyttäytymisen mallina. Kertomus Viisauden lankeemuksesta on myyttiseen aikaan siirretty kuvaus siitä, miten haitallisesta tunteesta yleensä voidaan vapautua.

\section{Neljä ensimmäistä tunnetta (versio B)}

Rinnakkainen, pääasiassa Hippolytokselta peräisin oleva kuvaus valentinolaisesta järjestelmästä poikkeaa Irenaeuksen kuvaamasta mallista monissa yksityiskohdissa. Merkittävin ero on tämän järjestelmän monistinen luonne: kaiken lähtökohtana ei ole alkuisän ja syvyyden muodostama pari kuten Irenaeuksen kuvauksessa, vaan kaikkeuden Isä yksin.

30 Teksti katkeaa tässä kohti. Alun perin teksti jatkui seuraavalla sivulla, mutta sen ensimmäiset rivit puuttuvat kokonaan. 
Viisauden asema on tässä järjestelmässä sikäli samankaltainen kuin Irenaeuksella, että Viisaus kuvataan viimeisimmäksi aioniksi. ${ }^{31}$ Poikkeava sen sijaan on Viisauden lankeemuksen syyn kuvaus. Lankeemuksen tämän version mukaan aiheuttaa se, että Viisaus halusi Isän tavoin luoda yksin, ${ }^{32}$ ei siis Viisauden yritys oppia tuntemaan Isä kuten versiossa A. Koska Viisaudella ei kuitenkaan ollut samaa voimaa kuin Isällä, hän onnistuu synnyttämään ainoastaan muodottoman olennon, jonka piilottamiseksi pleromaan täytyy luoda kaksi uutta aionia. Edellä jo todettiin, ettei tässä versiossa ei tehdä jakoa taivaalliseen Viisauteen ja hänestä erotettuun Akhamotiin, vaan Viisaus itse joutuu täyteyden ulkopuolelle.

Kahta toisistaan muuten poikkeavaa versiota valentinolaisesta luomismyytistä yhdistää Viisauden tunteiden kuvaus. Versiossa B Viisauden sanotaan olleen "neljän ensimmäisen tunteen vallassa", joita

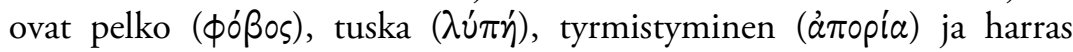

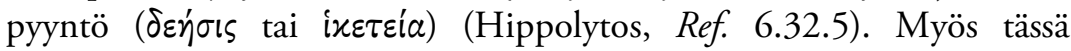
versiossa tunteiden tuottamasta ahdistuksesta vapauttaa kääntyminen: Viisaus rukoilee taivaallista Kristusta, joka yhdessä muiden aionien kanssa lähettää Viisauden luokse uuden jumalallisen hahmon, "pleroman yhteisen hedelmän" eli Jeesuksen. Tämä hahmo korjaa Viisauden hairahduksen vapauttamalla hänet tunteista.

Tämänkin version mukaan Viisauden emootioista luodaan maailmankaikkeuden perusta. Tunteet ja niistä luodut ominaisuudet eritellään vain tarkemmin kuin Irenaeuksella: pelosta luodaan psyykkinen olemus, surusta materiaalinen, tyrmistyksestä demoninen ja hartaiden pyyntöjen ilmaisemasta kääntymyksestä "ylös vievä tie ja psyykkisen olemuksen parantaminen" (Ref. 6.32.6).

Irenaeus tuntee oman päälähteensä ohella myös B-versiota muistuttavan selostuksen Viisauden lankeemuksen syistä (halu luoda

\footnotetext{
${ }^{31}$ Aionien lukumäärä tosin poikkeaa Irenaeuksen kuvauksesta: niitä on alun perin 28 (Irenaeuksella 30).

${ }^{32}$ Se että tämä motiivi esiintyy myös valentinolaisten kirjoitusten ulkopuolella, setiläisissä kirjoituksissa (esim. Joh. sal. II 9.25-35 parr.; Hall. olem. 94.5-8), viittaa mahdollisesti siihen, että versio $\mathrm{B}$ on valentinolaisen myytin traditiohistoriallisesti varhaisempi ja vähemmän kehittynyt versio kuin Irenaeuksen kuvaama versio A.
} 
yksin) ja seurauksista (Viisauden luoma muodoton olento) (Harh. 1.2.3). Tässäkin kuvauksessa kuvataan tarkoin Viisauden tunteita: hän tunsi surua havaittuaan synnyttämänsä olennon epätäydellisyyden, pelkoa ettei hänelle itselleen kävisi samoin sekä hämmennystä ja neuvottomuutta, jotka lopulta johtavat siihen, että hän yrittää piilottaa luomuksensa. Hippolytoksen tavoin Irenaeus määrittelee tässä yhteydessä tarkemmin tunteet, joista materia sai alkunsa. Näitä ovat tietämät-

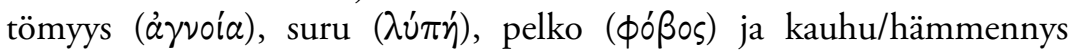
$\left(\xi^{\prime \prime} x \pi \lambda \eta \xi เ \varsigma\right)$.

\section{Apaattinen Viisaus (Katkelmia Theodotokselta)}

Clemensin teoksessa Katkelmia Theodotokselta Viisauden lankeemusta kuvataan pitkälti samaan tapaan kuin Hippolytoksella ja Irenaeuksella. Tässä versiossa Viisauden tunteet ottaa pois taivaallinen Kristus itse,

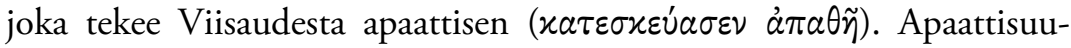
teen ei tässä yhteydessä liity samaa negatiivista mielleyhtymää kuin meidän aikanamme, vaan pathoksesta eroon pääsemistä pidettiin tavoiteltavana tilana. ${ }^{33}$ Viisauden apaattisuutta kuvataankin "parantumiseksi tunteista" (' $a \sigma \nu$ $\tau \tilde{\omega} \nu$ r $\pi \alpha \theta \tilde{\omega} \nu$ ) (Exc. Theod. 45.1-2). Irenaeuksen kuvaaman järjestelmän tavoin tässäkin mallissa kuvataan, kuinka Vapahtaja teki Viisauden tunteista muodottoman aineen (Exc. Theod. 46.1-2), josta luojajumala puolestaan loi maailman (Exc. Theod. 48.2$3)$.

Katkelmia Theodotokselta tukee osaltaan ajatusta, että myytti Viisauden lankeemuksesta ja siihen liittyneistä tunteista on luonteeltaan esikuvallinen. Myytti ei kuvaa vain Viisauden kohtaloa, vaan myös yleisemmin sitä, miten haitallisista tunteista voi päästä eroon. Valentinolainen Theodotos nimittäin rinnastaa toisiinsa sen näkemyksen, että maailma on alkuisin Viisauden emootioista, ja sen, että Herra tuli

${ }^{33}$ Vastaava "apatian" ihanne esiintyy esimerkiksi aleksandrialaisilla kirkkoisillä, Clemensillä ja Origeneella (Järveläinen 2000). 
vapauttamaan meidät emootioista (Exc. Theod. 67.4). Emootioista vapautumisen edellytyksenä on Vapahtajan kärsimys ( $\pi \dot{a} \theta \circ \varsigma)$, joka pelastaa meidät kärsimykseltä.

Katkelmia Theodotokselta osoittaa, että tunteista vapautumiseen ajateltiin liittyvän myös vapautumisen tähtien ohjaamasta kohtalosta

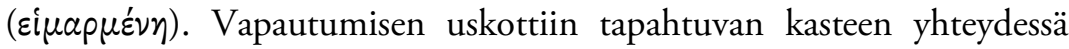
(Exc. Theod. 76.1). Kastettu ei ole tämän tekstin mukaan enää kohtalon armoilla, vaan on päässyt sen ohjausvallan ulottumattomiin. Tässä mielessä maailma koetaan uhkaavaksi paikaksi ainoastaan kasteeseen saakka, ei siitä eteenpäin. Ajatus tunteista vapautumisesta näkyy siinä, miten tässä kokoelmassa tulkitaan ylösnousemusta. Kuoleman jälkeen Vapahtaja, jonka ajateltiin jättäneen maallisen Jeesuksen ennen kuolemaa, "tuhosi kuoleman ja herätti kuolleen ruumiin, joka oli hylännyt tunteet $(\pi \dot{\theta} \theta \eta)$ " (Exc. Theod. 61.7). Ylösnousemuksen tulkitaan siis kuvaavan samaa esikuvallista ihannetta kuin Viisauden lankeemuksesta ja kääntymyksestä kertovan luomismyytin.

\section{Valentinolainen Viisaus-myytti ja tunteiden terapia}

Emootioiden asema on valentinolaisen viisaus-myytin eri versioissa niin keskeinen, ettei kyse voi olla vain esteettisesti viehättävästä yksityiskohdasta tai kirjallisesta tehokeinosta, jonka päämääränä olisi herättää lukijoiden/kuulijoiden myötätunto Viisauden kärsimyksiä kohtaan. Seuraavat kolme piirrettä viittaavat nähdäkseni selvästi siihen, että myytti viittaa antiikin filosofisissa koulukunnissa käytyyn keskustelun emootioista: (1) Viisauden emootiot jaetaan neljään perustunteeseen; (2) emootioita pidetään (kääntymystä lukuun ottamatta) haitallisina; (3) myytissä kuvataan Viisauden emootioiden parantamista.

(1) Useimpia antiikin filosofisia koulukuntia yhdisti se näkemys, ettei tunteita pidetty suorina reaktioita ulkoisiin tapahtumiin, vaan niiden katsottiin heräävän vasta silloin, kun joku asia arvioidaan 
tärkeäksi. ${ }^{34}$ Näin tunteita voitiin luokitella niihin liittyvien uskomusten perusteella.

Valentinolaisia kuvauksia yhdisti toisiinsa se ajatus, että Viisauden kokema haitallinen tunne ilmenee neljällä eri tavalla. Hippolytoksella on tässä yhteydessä säilynyt jopa maininta "neljästä ensimmäisestä tunteesta". Ajatus haitallisen tunteen neljästä ilmenemismuodosta oli ilmeisen vakiintunut valentinolaisissa piireissä, sillä se esiintyy muissakin valentinolaisissa lähteissä. Neljän tunteen luettelo esiintyy Irenaeuksella sekä version A yhteydessä (tuska, pelko, tyrmistyminen ja kääntymys, Harh. 1.4.2) että B-versiota muistuttavassa kuvauksessa Viisauden kokemista tunteista (tietämättömyys, tuska, pelko, tyrmistyminen, Harh. 1.2.3).

Valentinolainen emootioiden nelijako muistuttaa erityisesti stoalaisten filosofien käsitystä haitallisesta pathoksesta, jonka ajateltiin ilmenevän seuraavilla neljällä tavalla: ${ }^{35}$

- mielihyvä ( $\dot{\delta} \delta o v \eta ́)$ on arvio siitä, että jokin jo saavutettu on hyvää ja säilyttämisen arvoista.

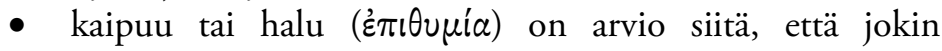
tulevaisuudessa oleva on hyvää ja tavoittelemisen arvoista.

- $\quad$ tuska $(\lambda \cup ́ \pi \eta)$ on arvio siitä, että jokin nyt käsillä oleva asia on pahaa.

- pelko (фóßos) on arvio siitä, että jokin tulevaisuudessa oleva asia on pahaa.

Valentinolaisissa lähteissä näistä pathoksen ilmenemismuodoista kaksi

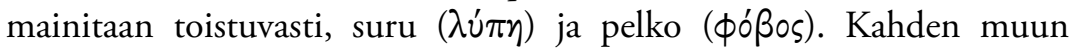
ilmenemismuodon osalta valentinolaiset käsitykset poikkeavat

\footnotetext{
${ }^{34}$ Ks. esim. Nussbaum 1994, 369-372.

${ }^{35}$ Jako esiintyy esim. seuraavissa kokoelman Stoicorum Veterum Fragmenta III kohdissa: 378 (Stobaeus, Ecl. 88.10 - kohdassa näistä puhutaan Hippolytoksen tavoin "neljänä tämän lajin ensimmäisenä edustajana"); 386 (Aspasius, In Aristot. Eth. Nicom. 45.16); 391 (Ps.Andronikos, Peri Pathōn 1); 394 (Stobaeus, Ecl. 2.90.7). Vrt. Forschner 1981, 121; Nussbaum 1994, 386. Vastaavankaltainen nelijako tosin esiintyy antiikin filosofiassa Aristoteleesta alkaen (Knuuttila 2004, 17).
} 
toisistaan. Kiinnostavaa on se, että vakiona pysyvät juuri ne piirteet, jotka kuuluvat stoalaiseen määritelmään pathoksen ilmenemismuodoista. Variaatioita sen sijaan esiintyy juuri niiden piirteiden kohdalla, jotka poikkeavat stoalaisesta listasta.

Myös tapa, jolla valentinolaiset lähteet kuvaavat Viisauden kokemaa tuskaa ja pelkoa, vastaa pitkälti edellä mainittuja stoalaisia määritelmiä. Versiossa A Akhamotin tuskan aiheutti käsillä oleva tilanne (hän ei voinut ymmärtää), kun taas hänen pelkonsa liittyi tulevaisuuteen (hän pelkäsi menettävänsä elämänsä) (Harh. 1.4.1). Myös toisessa versiossa Viisauden tuska liittyy jo tapahtuneeseen - sen herättää havainto Viisauden luoman olennon epätäydellisyydestä - ja pelko tulevaisuuteen, sillä Viisaus pelkää, että hänelle tulee käymään samoin kuin hänen luomukselleen (Harh. 1.2.3).

(2 ja 3) Useimmissa antiikin filosofisissa koulukunnissa emootioita pidettiin haitallisina. Siksi näissä koulukunnissa tavoitteena pidettiin "parantumista" tunteista. Ajatus tunteiden parantamisesta liittyi edellä mainittuun ajatukseen tunteisiin kuuluvasta kognitiivisesta elementistä. Tunteiden terapia perustui siihen, että tunteeseen liittyvään arvioon tai uskomukseen uskottiin voitavan vaikuttaa. Etenkin stoalaisessa filosofiassa tunteita pidettiin yksipuolisesti haitallisina, joten niissä pyrittiin pääsemään kokonaan eroon. Päämääränä oli korvata irrationaalisina pidetyt tunteet niitä vastaavilla rationaalisilla pyrkimyksillä $(\varepsilon \dot{\pi} \pi a ́ \theta \varepsilon ı \iota) .{ }^{36}$ Stoalaisen filosofisen terapian tavoitteena oli ihminen, joka säilyttää tyyneytensä ja mielenrauhansa kaikissa ulkoisissa olosuhteissa.

\section{Johtopäätös: tunteiden uskonnollinen terapia}

Antiikin filosofiin terapiamalleihin ja erityisesti stoalaiseen näkemykseen verrattuna valentinolaisen Viisaus-myytin voi katsoa edustavan tunteiden terapian uskonnollista versiota. Tässä uskonnollisessa versiossakin arviolla tai uskomuksella tunteen kohteesta on epäilemättä oma

\footnotetext{
${ }^{36}$ Forschner 1981, 139-140.
} 
asemansa. Myytin eri versioissa kuvataan Viisauden tekemää virheellistä arviota, joka johtaa kielteisiin tunteisiin. Tässäkin mallissa arvio jonkin asian tavoittelemisen hyödyllisyydestä esitetään siis pathoksen lähtökoh-

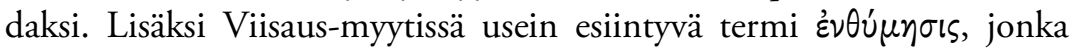
usein ymmärretään tarkoittavan Viisauden "halua" tai "pyrkimystä", voi kuvata myös "ajatusta" tai "arviota".

Myytissä esiin tuleva tunteista vapautumisen ihanne vastaa pitkälti stoalaisten filosofien esittämää päämäärää. Valentinolaisissa lähteissä tämä päämäärä ei liity vain Viisauden kohtaloon, vaan voidaan yleistää myös ihmisiin, joiden tunteet Kristus tuli parantamaan. ${ }^{37}$ Filosofisista terapiamalleista valentinolainen "emootioiden uskonnollinen terapia" poikkeaa ennen kaikkea siinä, ettei siinä ole "arvion" tai "uskomuksen" kriittisellä tarkastelulla keskeistä asemaa. Tämän piirteen korvaa toisaalta ajatus jumalallisen voiman välittämästä tuesta emootioiden valtaan joutuneelle, toisaalta taas kääntymyksen keskeisyys. Vasta jumalallisen voiman tukemana emootioiden valtaan joutunut voi kääntyä, ja vasta kääntymystä seuraa luopuminen väärästä uskomuksesta ja siihen liittyvästä tunteesta.

Valentinolaisissa lähteissä esiintyvät poikkeamat stoalaisesta tunteen ilmenemismuotojen listasta ovat tässä suhteessa merkittäviä. Valentinolaisista lähteistä puuttuu stoalaisen emootiolistan kaksi piirrettä, mielihyvä ja halu. Näiden sijasta korostetaan vaihtelevasti toisaalta tietämättömyyttä, neuvottomuutta ja tyrmistymistä (áyvoía,

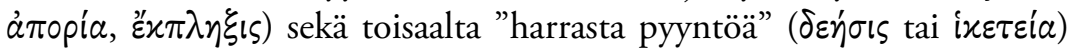

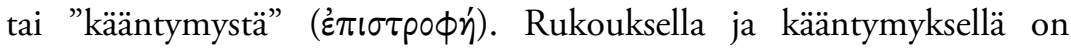
valentinolaisessa ajattelussa on selvästi positiivinen sisältö. Se että tällaisia piirteitä pidetään yhtenä neljästä perustunteesta, erottaa valentinolaisen emootioteorian stoalaisesta, jossa kaikkia tunteen ilmentymismuotoja pidettiin haitallisina. Rukouksen ja kääntymyksen sisällyttäminen neljän perustunteen joukkoon on merkittävä piirre

\footnotetext{
37 Tässä suhteessa valentinolaisuus ei edusta tyystin omaperäistä linjaa oman aikansa kristillisyydessä. Ajatus, että Kristus tuli parantamaan meidät tunteista, esiintyy useissa patristisissa lähteissä (esim. Justinus, 2. Apol. 13.4; Clemens, Paed. 1.1, 2). Ks. Lampe 1961, s.v. $\pi \dot{\theta} \theta 0 s$ II 10.
} 
valentinolaisen maailmankuvan kannalta. Koska Viisauden emootioista luotiin maailmankaikkeuden perusta, ne näkyvät myös nykyisessä maailmassa. Näin myytti Viisauden tunteista heijastaa valentinolaista käsitystä maailmasta, joka tosin on pääasiassa haitallisen pathoksen varassa, mutta johon on sisäänrakennettuna myös mahdollisuus vapautua pathoksesta kääntymyksen, hartaan rukouksen ja pyyntöjen avulla.

"Ensimmäisten tunteiden" yhdistäminen Viisauden lankeemukseen on, kuten edellä todettiin, ainoastaan valentinolaisissa lähteissä esiintyvä erityispiirre. Kuitenkin tunteisiin viitataan muissakin "gnostilaisissa" luomismyyteissä. Erityisen kiinnostava tässä suhteessa on Johanneksen salainen kirjan kuvaus luojajumalan, Jaldabaothin, alaisten henkiolentojen päämiehistä. Tämän kuvauksen yhteys stoalaiseen filosofiaan on vielä suorempi kuin valentinolaisissa kirjoituksissa, sillä siinä luetellaan kaikki neljä stoalaisittain määritellyn tunteen ilmenemismuotoa.

Nämä neljä ovat henkiolentojen päämiehet: Efememfi, joka edustaa nautintoa ( $\dot{\eta} \delta \circ \nu \eta)$, Joko, joka edustaa intohimoa ( $\left(\dot{\pi} \pi \imath u \mu \dot{i}^{\prime} \alpha\right)$, Nenentofni, joka edustaa surua $(\lambda \dot{v} \pi \eta)$, sekä Blaomen, joka edustaa pelkoa (nōhe). Näiden kaikkien äiti on Esthensisoukepiptoe. Näistä neljästä ovat lähtöisin kärsimykset. Surusta ovat peräisin pahansuopuus, kateus, tuska, ahdistus, kipu, katumattomuus, huolet, valitus ja muut vastaavat. Nautinnon tavoittelusta saavat alkunsa kaikenlainen pahuus, tyhjä ylpeys ja muut näiden kaltaiset. Himosta ovat peräisin viha, raivo, katkeruus, katkera intohimo ja muut näiden kaltaiset. Pelosta ovat alkuisin kauhu, liehittely, levottomuus ja häpeä. (Joh. sal. II 18.14-31) ${ }^{38}$

Kohdan perusteella voidaan päätellä, että stoalaiselle koulukunnalle ominainen tapa luokitella tunteita vaikutti "gnostilaisiin" luomismyytteihin eri tavoin. Johanneksen salaisen kirjan yhteydet stoalaiseen emootioteoriaan ovat varsin läheisiä. Kirjoituksessa ei ainoastaan mainita pathoksen neljää osa-aluetta, vaan kuvataan myös näistä osaalueista seuraavia tunteita samoin kuin stoalaisissa lähteissä. ${ }^{39}$

\footnotetext{
${ }^{38}$ Kohdan suomennos on peräisin työryhmän Dunderberg, Marjanen \& Salmenkivi tekeillä olevasta Johanneksen salaisen kirjan käännöksestä [sittemmin julkaistu: Dunderberg \& Marjanen 2005, 39-71].

39 Tämän osoittavan erityisesti Pseudo-Andronikoksen teoksessa Peri Pathōn esiintyvät listat, joissa yksilöidään kunkin stoalaisen perustunteen ilmentymistavat. Kiinnostavaa on, että tässä
} 
Johanneksen salaisen kirjan suhteesta valentinolaiseen järjestelmään on käyty viime aikoina vilkasta keskustelua, jonka perusteella ei ole täysin mahdotonta olettaa, että valentinolainen kristillisyys olisi voinut vaikuttaa Johanneksen salaisen kirjan tiettyihin yksityiskohtiin. ${ }^{40}$ Tunteiden kuvaus kosmogonian osana näyttää tässä kirjoituksessa kuitenkin edustavan itsenäistä, valentinolaisesta luomismyytistä poikkeavaa perimätietoa, sillä tunteiden kuvaus sijoittuu myytin eri osaan. Lisäksi luettelo muistuttaa suoraan stoalaisia esikuvia eikä edellytä niiden "valentinolaista" muunnelmaa.

Sekä käytössämme olevat lähteet valentinolaisesta ajattelusta että Johanneksen salainen kirja osoittavat, että tunteiden kuvauksella oli tärkeä asema eri "gnostilaisia" koulukuntia edustavissa luomismyyteissä. ${ }^{41}$ Yhtäläisyydet erityisesti stoalaisessa koulukunnassa esitettyihin käsityksiin tunteista ovat molemmissa tapauksissa niin läheisiä, että niiden perusteella voidaan hyvin olettaa "gnostilaisten" ryhmittymien olleen tietoisia oman aikansa filosofisesta keskustelusta. Kaikesta päätellen he - muualta saamiensa vaikutteiden ohella - omaksuivat filosofisten koulukuntien käsityksiä ja sovelsivat niitä maailmankatsomuksensa osaksi.

On mahdotonta vastata varmuudella kysymykseen, tulkitaanko "gnostilaisissa" lähteissä uskonnollista traditiota filosofisesti vai antavatko ne filosofisille ajatuksille ainoastaan kevyen uskonnollisen kuorrutuksen. Raja uskonnollisen ja filosofisen diskurssin välillä on näissä lähteissä varsin liukuva. On todennäköistä, ettei niissä edes erotettu toisistaan "uskonnollista" ja "filosofista" tapaa hahmottaa maailmaa ja

kirjoituksessa perustunteet luetellaan samassa järjestyksessä kuin yllä lainatussa Johanneksen apokryfin kohdassa; ks. Ps.-Andronikos, Peri Pathōn 2 (suru; SVF III 414) 3 (pelko; SVF III 409); 4 (intohimo; SVF III 397); 5 (nautinto; SVF III 401). Huomioni Johanneksen salaisen kirjan kyseisen jakson läheisiin yhtäläisyyksiin Pseudo-Andronikoksen tunneluetteloiden on kiinnittänyt Simo Knuuttila suullisesti [vrt. Knuuttila 2004, 113 n. 11].

${ }^{40}$ Tähän suuntaan argumentoi Logan 1996.

${ }^{41}$ On syytä huomauttaa, ettei Johanneksen salaisessa kirjassa luomismyytin osana esitettyä tunneluetteloa voi pitää koko setiläisen gnostilaisuuden kannalta edustavana esimerkkinä. Sille ei löydy rinnakkaiskohtia muista setiläisistä kirjoituksista, ei myöskään kahdesta Johanneksen salaisen kirjan lyhyempää versiota edustavasta käsikirjoituksesta (tekstin eri versioiden suhteesta ks. Marjanen 1991, 426). 
argumentoida yhtä selkeästi kuin nykyaikana. Joka tapauksessa näyttää siltä, ettei "gnostilaisissa" piireissä kehitetty erillistä, uskonnollisesta vakaumuksesta irrallaan olevaa tunteiden teoriaa. Käytettävissä olevien lähteiden perusteella tavallisin "gnostilainen" tapa soveltaa antiikin filosofikoulukunnista omaksuttuja näkemyksiä oli se, että ne integroitiin luomismyytin osaksi. 


\section{0. "Te olette alusta asti kuolemattomia"}

(1997)

\section{Valentinoksen neljäs fragmentti}

Te olette alusta asti kuolemattomia, te olette ikuisen elämän lapsia ja te tahdoitte jakaa kuoleman keskenänne kuluttaaksenne sen loppuun ja tuhotaksenne sen, jotta kuolema kuolisi teissä ja teidän avullanne. Sillä kun te teette tyhjäksi maailman tuhoutumatta kuitenkaan itse, te hallitsette luomakuntaa ja koko katoavaisuutta. ${ }^{1}$

Tämä lainaus on peräisin 100-luvun puolivälissä Roomassa vaikuttaneelta kristilliseltä opettajalta, Valentinokselta. Kirkkoisät pitävät Valentinosta toisen vuosisadan ehkä merkittävimmän kristillis-gnostilaisen koulukunnan perustajana. Silti Valentinoksen omasta opetuksesta tiedetään hyvin vähän. Valentinolaisen ajattelun tärkeimpänä lähteenä on totuttu pitämään kirkkoisä Irenaeuksen laajaa referaattia Valentinoksen koulukunnan oppijärjestelmästä teoksessa Harhaoppeja vastaan (Adversus haereses). ${ }^{2}$ Teoksen ensimmäisen osan esipuheen perusteella Irenaeus ei kuitenkaan kuvaa suoranaisesti Valentinoksen käsityksiä, vaan 'kolmannen polven' valentinolaisuutta. Irenaeus nimittäin kertoo

${ }^{1}$ Clemens Aleksandrialainen, Strom. 4.89.1-3.

${ }^{2}$ Harh. 1.1-8. 
kuvaavansa "Ptolemaioksen oppilaiden" ajattelua (Harh. 1, praef. 3); Ptolemaios puolestaan oli ehkä tunnetuin Valentinoksen oppilaista. ${ }^{4}$ Luotettavimman tiedon Valentinoksen omista näkemyksistä antavat niin sanotut Valentinoksen fragmentit eli kirkkoisien kirjoituksissa säilyneet lyhyet lainaukset hänen opetuksistaan. ${ }^{5}$ Katkelmia Valentinoksen omista kirjoituksia on valitettavasti säilynyt vain muutama, mutta niiden perusteella on hiljattain kyseenalaistettu se, voidaanko Valentinosta yleensä pitää 'gnostikkona', ja pohdittu, mikä todella oli Valentinoksen suhde myöhempään 'valentinolaisuuteen', jota Irenaeus kuvaa. ${ }^{6}$

\section{Vaihtoehtoisia tulkintoja}

Valentinoksen kuolemattomuutta käsittelevä katkelma on monella tapaa vaikeaselkoinen. Yksi syy tähän on se, ettei katkelman alkuperäistä kontekstia tunneta. Clemens Aleksandrialainen, jonka tekstissä fragmentti on säilynyt, esittää sen kristillistä marttyyrikuolemaa käsittelevän jakson yhteydessä. Juuri ennen Valentinos-sitaattiaan Clemens esittelee Valentinoksen oppilaana pidetyn Herakleonin sekä Basilideen, toisen

\footnotetext{
${ }^{3}$ Kuvaavaa on, että Irenaeus esittelee ensin laajasti 'valentinolaisen' järjestelmän ja kuvaa tämän jälkeen, miten Valentinoksen 'omat' näkemykset poikkeavat tästä järjestelmästä (Harh. 1.11.1).

${ }^{4}$ Ptolemaioksen koulukunnan näkemyksiä kuvaavaan jakson lopussa Irenaeus tosin päättää sanoihin, joiden suhde hänen teoksensa johdantoon on jännitteinen: "Näin siis Ptolemaios" (Harh. 1.8.5). Ptolemaioksen kirjoituksista on säilynyt yksi kokonainen dokumentti, sillä kirkkoisä Epifanios lainaa hänen Flora-nimiselle naiselle osoitetun opetuskirjeensä, jonka aiheena on Vanhan testamentin lain alkuperä (Panarion 33.3-7).

${ }^{5}$ Clemens Aleksandrialainen, Strom. 2.36.2-4 (1); 2.114.3-6 (2); 3.59 .3 (3); 4.89.1-3 (4; yllä); 4.89.6-90.1 (5); 6.52.3-53.1 (6); Hippolytos, Refutatio 6.42.2 (7); 6.37.6-8 (8); Ps.Anthimus, De sancta ecclesia 9 (9); Photius, Cod. 230 (10); Hippolytos, Refutatio 10.13.4 (11). Valentinoksen fragmenttien numerointi (edellä suluissa) perustuu lähdekokoelmaan Völker 1932, 57-60. Völkerin kokoelmasta puuttuu frg. 10, koska sitä pidetään yleensä epäaitona. Fragmentin 11 lisää luetteloon vasta Markschies 1992, 276-290.

${ }^{6}$ Markschies 1992, 392-407. Gilles Quispel kritisoi tosin Markschiesin tuloksia ja toteaa mm.: "Juuri lahkon perustajalta itseltään [=Valentinokselta] hänen oppilaansa saivat gnostilaiset ajatuksensa” (Quispel 1992, 2). Quispel ei kuitenkaan esitä näkemyksensä tueksi muuta kuin Irenaeuksen ja Tertullianuksen ylimalkaiset toteamukset Valentinoksen koulun ja 'gnostikkojen' suhteista (Irenaeus, Harh. 1.30.15; Tertullianus, Val. 4.2).
} 
tärkeän kristillis-gnostilaisen koulun perustajan näkemyksiä marttyyrikuoleman arvosta. ${ }^{7}$ Itse fragmentissa ei kuitenkaan sisälly suoraa viitettä tähän aihepiiriin.

Fragmentti on myös itsessään ongelmallinen. Keskustelua on viime aikoina herättänyt erityisesti se, miten katkelman alkuosan ja lopun välinen suhde tulisi ymmärtää. Katkelman alussa todetaan, että ne, joille Valentinos sanansa osoittaa, ovat kuolemattomia "alusta asti". Miten tähän väitteeseen liittyy katkelman jatkossa mainitut kuoleman jakaminen, loppuun kuluttaminen ja tuhoaminen, joiden päämääränä Valentinoksen mukaan on, että "kuolema kuolisi teissä ja teidän avullanne"?

Hiljattain kaksikin tutkijaa on esittänyt, että katkelmassa asetetaan vastakkain ihmisen alkuperäinen kuolemattomuus ja jatkossa mainitut yritykset tuhota kuolema. ${ }^{8}$ Jens Holzhausenin mukaan Valentinos kritisoi tietyn kirkollisen marttyyriteologian kannattajia, jotka ymmärsivät marttyyrikuoleman pelastumiseen tarvittavaksi välttämättömäksi 'kauppahinnaksi'. Valentinoksen kritiikin sisältö on Holzhausenin mukaan: "Vaikka ihmiset ovat jo kuolemattomia, he haluavat yhä uudelleen käyttää kuolemaa maksuvälineenä saavuttaakseen ikuisen elämän." Paul Schüngel ottaa lähtökohdakseen Holzhausenin tulkinnan, mutta esittää toisenlaisen tulkinnan siitä, mikä on Valentinoksen polemiikin kohde: "Valentinoksen kielenkäyttö viittaa yksiselitteisesti ehtoollisjuhlaan."10 Schüngelin mukaan voidaan asettaa vastakkain Paavali, jonka mukaan kristityt osallistumalla ehtoolliselle julistavat

\footnotetext{
7 Strom. 4.71-77, 81-88. Kysymys marttyyrikuolemasta kuuluu muutenkin Clemensin Stromateis-teoksen neljännen kirjan keskeisiin teemoihin, sillä aihe mainitaan jo koko kirjan aihepiiriä esittelevässä johdantojaksossa (Strom. 4.1.1).

${ }^{8}$ Holzhausen 1994; Schüngel 1996.

9 Holzhausen 1994, 123. Holzhausen ei käytä perustelunaan tässä yhteydessä niinkään katkelman tekstiyhteyttä Clemensin esityksessä, vaan kiinnittää huomionsa fragmentissa esiintyviin termeihin. Valentinoksen käyttämillä 'tuhoamista' kuvaavilla verbeillä (åva $\delta a \pi \alpha \nu \tilde{\nu})$ kuvataan muualla usein rahan käyttöä tiettyä tarkoitusta varten, ja verbiä $\mu \varepsilon \rho i \zeta \xi \varepsilon \nu$ voidaan käyttää rahan jakamisesta.

${ }^{10}$ Schüngel 1996, 262.
} 
Herran kuolemaa (1. Kor. 11:26), ja Valentinoksen "polemiikki", että he näin toimiessaan "jakavat kuoleman keskenään."11

Oletus, että Valentinoksen fragmentissa olisi kyse vastakkainasettelusta jonkun muun varhaiskristillisen näkemyksen kanssa, on kielellisesti mahdollinen. ${ }^{12}$ Sisällöllisesti tämä tulkinta on kuitenkin kahdestakin syystä ongelmallinen. Ensinnäkään edellä esitetyt yhteydet varhaiskristilliseen marttyyriteologiaan tai ehtoollisoppiin eivät yksiselitteisesti nouse esiin itse fragmentista. Holzhausenin tulkinnan ongelmana on, etteivät fragmentissa käytetyt verbit viittaa mitenkään selvästi kristilliseen marttyyriteologiaan. ${ }^{13}$ Schüngelin oletus ehtoollisen vastaisesta polemiikista on vielä heikommin perusteltu kuin Holzhausenin näkemys, sillä Valentinoksen sanavalinnat eivät viittaa Paavalin opetukseen ehtoollisesta sen enempää kuin kristilliseen ehtoollisenviettoon yleensäkään.

Toiseksi Holzhausenin ja Schüngelin adversatiivinen tulkinta ei tee oikeutta fragmentin sisäiselle logiikalle. Itse katkelmassa yritykset tuhota ja jakaa kuolema johtavat nimittäin lopulta myönteiseen tulokseen. Valentinos pitää kuulijoidensa tavoitteena kuoleman tuhoutumista, ja katkelman loppu viittaa siihen, että Valentinoksen mukaan he voivat todella saavuttaa tämän tavoitteen: "Kun te teette tyhjäksi $(\lambda u ́ \eta \tau \varepsilon)$ maailman tuhoutumatta kuitenkaan itse, te hallitsette luomakuntaa ja koko katoavaisuutta." Näin fragmentin alku on parhaiten ymmärrettävissä siten, että kuolemattomuudella ja katkelmassa kuvatuilla pyrki-

\footnotetext{
${ }^{11}$ Schüngel 1996.

${ }^{12}$ Katkelman aloituslause on yhdistetty jatkoon partikkelilla $\chi \alpha$, jota voidaan käyttää myös ilmaisemassa vastakohtaa. 'Tahtomista' kuvaavasta verbistä ( $\theta \varepsilon \dot{\varepsilon} \lambda \varepsilon \iota v)$ käytetty imperfektimuoto voidaan tulkita konatiiviseksi, ts. yrittämistä ilmaisevaksi; tähän merkitykseen voi puolestaan liittyä ajatus yrittämisestä, joka ei johda haluttuun lopputulokseen (esim. Luuk. 1:59). Imperfekti voi kuitenkin tässä yhteydessä yhtä hyvin olla esim. iteratiivinen, ts. kuvata menneessä ajassa toistettua tai tavanomaista toimintaa; ks. esim. Blass, Debrunner \& Rehkopf 1990, \$325-326.

13 Ainakaan niissä marttyyrikuolemaa ylistävissä teksteissä, joita Holzhausen (1994, 123 127) siteeraa, Valentinoksen fragmentissa esiintyviä verbejä ei käytetä. Ainoa konkreettinen

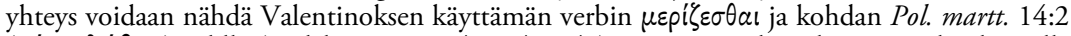
( $\mu \varepsilon ́$ pos $\lambda \alpha ́ \beta \varepsilon เ v)$ välillä (Holzhausen 1994, 124 n. 43), mutta tämäkin yhteys jää ohueksi, sillä kyse on hyvin yleisistä sanoista, joita voidaan käyttää hyvin erilaisissa yhteyksissä. Lisäksi verbien $\alpha \nu \alpha \lambda \circ \cup \tilde{\nu}$ ja $\delta a \pi \alpha \nu \tilde{\alpha} \nu$ käyttö ei rajoitu rahatalouteen, vaan kummatkin verbit kuvaavat

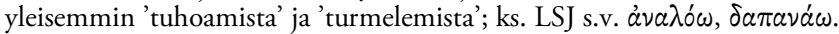


myksillä on syy-seuraussuhde. Valentinos esittää vastaanottajien alkuperäisen kuolemattomuuden perusteeksi heidän pyrkimyksilleen tuhota kuolema. Ajatus siis ei ole: "vaikka te olette kuolemattomia, te halusitte jakaa kuoleman keskenänne," vaan: "koska te olette kuolemattomia, te halusitte jakaa kuoleman keskenänne".

Katkelman alussa käytetty imperfekti verbistä $\theta \varepsilon ́ \lambda \varepsilon \iota \nu$ antaa Valentinoksen opetukselle presenttisen sävyn. Käytetyn verbimuodon perusteella Valentinoksen voidaan olettaa ajatelleen, että pyrkimys kuoleman keskinäiseen jakamiseen kuuluu jo menneisyyteen, toisin sanoen kyse on jo saavutetusta tilasta. Nyt käsillä on kuulijoiden lopullinen päämäärä, maailman tekeminen tyhjäksi tai 'tuhoaminen'. Tämä ei kuitenkaan ole viittaus kuolemassa tapahtuvaan eroon maailmasta eikä jatkossa oleva maininta "tuhoutumatta kuitenkaan itse" viittaa ainakaan ensisijaisesti ihmisen tuonpuoleiseen kuolemattomuuteen. Katkelman lopussa esiintyvää toteamusta "luomakunnan ja kaiken katoavaisuuden" hallitsemisesta on vaikea pitää viittauksena tuonpuoleisuuteen, sillä juuri tämän toteamuksen perusteella voidaan päätellä, ettei Valentinos oleta kuulijoidensa vielä päässeen lopullisesti eroon maailmasta. Pikemminkin kyse on uudesta suhteesta tämänpuoliseen todellisuuteen: 'maailman tyhjäksi tekeminen' johtaa kuulijat siihen, että he pystyvät hallitsemaan tämänpuoleista todellisuutta, joka katkelmassa määritellään 'luomakunnaksi' ja 'katoavaisuudeksi'.

\section{Kuolemattomuus - ihmisen alkuperäinen ominaisuus}

Koska katkelman alkuperäistä kontekstia ei tunneta, ei ole täyttä varmuutta siitä, mihin 'alkuun' Valentinos katkelmassa viittaa. ${ }^{14}$ Hyvällä

\footnotetext{
${ }^{14}$ Markschiesin (1992, 128-130) esittämästä neljästä tulkintavaihtoehdosta viimeisin esitellään yllä. Muut vaihtoehdot ovat: (1) Ilmaus voi viitata siihen, että ihminen saa ikuisen elämän kohdattuaan Jeesuksen; (2) Ilmaus viittaa niihin 'hengellisiin', jotka pelastuvat jumalallisen luontonsa perusteella; (3) 'Alku' voi tarkoittaa kristittynä elämisen alkua kasteen jälkeen. Kaksi ensimmäistä vaihtoehtoa liittyvät 'valentinolaiseen' oppiin kolmesta ihmisryhmästä, joista ylimpään kuuluvat, 'hengelliset', pelastuvat joka tapauksessa. Tästä opista ei
} 
syyllä voidaan olettaa, että kyse on ihmisen alkuperäisestä tilasta, mahdollisesti luomiskertomuksen tulkinnasta. Vanhan testamentin luomiskertomukseen liittyvää keskustelua ihmisen alkuperäisestä tilasta ja etenkin siihen liittyvästä kuolemattomuudesta oli käyty juutalaisissa lähteissä kuten Viisauden kirjassa ja Filonilla, ja tähän kysymyksenasetteluun on viitteitä myös muissa varhaiskristillisissä lähteissä. Itse katkelmassa luomiskertomuksen tulkintaan viittaa Valentinoksen 'alusta'

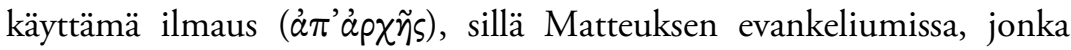
Valentinos varmasti tunsi, ${ }^{15}$ sama ilmaus viittaa niinikään Vanhan testamentin luomiskertomukseen (Matt. 19:4). Lisäksi toisen katkelman perusteella Valentinoksen tiedetään olleen kiinnostunut luomiskertomuksen tulkinnasta (frg. 1, ks. alla).

Valentinoksen näkemys, että ihmisen alkuperäiseen tilaan kuului kuolemattomuus, poikkeaa Jahvistin luomiskertomuksen intentiosta. Tässä luomiskertomuksessa "ei missään ennen Aadamin tottelemattomuutta sanota, että hän olisi ollut kuolematon, ettei hän ikinä kuolisi”. ${ }^{16}$ Jumala tosin uhkaa Aadamia kuolemalla, ettei tämä söisi hyvän ja pahan tiedon puusta (1. Moos. 2:17). Uhkauksesta ei voi kuitenkaan päätellä, että Jahvisti olisi ajatellut Aadamin olleen alun perin kuolematon. Uhkauksen sisältönä on ennenaikainen, välitön kuolema - uhkaus jota Jahve ei tosin jatkossa toteuta: "Sinä päivänä, jona siitä syöt, olet kuoleman oma."17

Valentinoksen näkemys ei kuitenkaan sanottavasti eroa juutalaisessa viisauskirjallisuudessa omaksutusta luomiskertomusten tulkinnasta. Esimerkiksi Viisauden kirjassa ${ }^{18}$ edellytetään, että kuolematto-

kuitenkaan ole säilynyt selviä jälkiä Valentinoksen omissa katkelmissa. Katkelma ei sisällä myöskään viitteitä kasteeseen.

${ }^{15}$ Valentinoksen fragmentti 2 alkaa ja päättyy viittauksella Matteuksen evankeliumiin (Matt. 19:17; 5:8); ks. Markschies 1992, 58-59.

${ }^{16}$ Barr 1993, 5. Barrin mukaan 'syntiinlankeemuskertomus' ei ole niinkään kertomus synnin ja pahuuden alkuperästä vaan "kertomus kuinka inhimillinen kuolemattomuus lähes saavutettiin, mutta todellisuudessa menetettiin" (Barr 1993, 4).

17 Barr 1993, 10-11. Näkemyksensä tueksi Barr viittaa siihen, että muuallakin Vanhassa testamentissa käytetään vastaavanlaista uhkausta ilman, että kyse olisi kuolemattomuuden menettämisestä (1. Kun. 2:37, 42).

${ }^{18}$ Viisauden kirjan ajoituksesta ks. Winston 1979, 20-25. Winston itse ajoittaa Viisauden kirjan vasta keisari Gaius Caligulan aikaan (37-41 jKr.). 
muus kuului ihmisen alkuperäiseen tilaan paratiisissa; kuolemaa pidetään syntiinlankeemuksen seurauksena: "... ei Jumala ole tehnyt kuolemaa, eikä hän iloitse elävien perikadosta" (Viis. 1:3; vrt. Hes. 33:11); "... Jumala loi ihmisen katoamattomuuteen ja teki hänet oman olemuksensa kuvaksi. Mutta perkeleen kateudesta tuli kuolema maailmaan, ja ne, jotka hänen omansa ovat, saavat sen kokea." (Viis. 2:23-24). Vastaava käsitys on taustalla myös Siirakin kirjassa, jossa kuoleman alkuperäisenä syynä pidetään Eevan lankeamista: "Naisesta on synnin alku, ja hänen tähtensä me kaikki kuolemme" (Siir. 25:24).

Vastaavan näkemyksen oli varhaiskristillisyyteen juurruttanut jo ennen Valentinosta Paavali, joka Aadam-Kristus-typologiaa hahmotellessaan edellyttää juutalaisen viisauskirjallisuuden tavoin, että vasta syntiinlankeemus aiheutti kuoleman ihmisille: "Yhden ainoan ihmisen teko toi maailmaan synnin ja synnin mukana kuoleman. Näin on kuolema saavuttanut kaikki ihmiset" (Room. 5:12; vrt. Room. 6:23; 1 . Kor. 15:21). ${ }^{19}$ Periaatteessa samanlainen käsitys ihmisen alkuperäisestä tilasta esiintyy myös Valentinoksen aikalaisella, Justinos Marttyyrillä, jonka mukaan ihmiset ovat alun perin Jumalan kuvan kaltaisia - he ovat "Jumalan tavoin vapaita kärsimyksestä ja kuolemattomia". Ihmisistä on kuitenkin tullut Aadamin ja Eevan kaltaisia ja näin "he tuottavat itselleen kuoleman” (Dial. 124.4). ${ }^{20}$ Väittäessään että ihmiset ovat "alusta alkaen kuolemattomia" Valentinos ei siis näytä opettaneen tavalla, joka olisi selvästi poikennut juutalaisesta tai muusta kristillisestä opetuksesta.

19 Paavalin juutalaisesta viisauskirjallisuudesta poikkeava erityispiirre on näkemys, että hän pitää kuoleman aiheuttajana lain 'kirjainta' (2. Kor. 3:6-7; Paavali ei tosin tarkoittane tässä yhteydessä fyysistä kuolemaa). Room. 7:10 näyttää edustavan lievempää käsitystä lain ja kuoleman suhteesta: lain tarkoitus on alun perin myönteinen, sillä sen tavoitteena on "antaa elämä”, mutta se ei lopulta pysty estämään ihmisen kuolemaa; ks. Räisänen 1983, 152-153. Paavalin näkemyksistä kielteisempi näyttää saavan jatkoa Nag Hammadista löydetyssä, yleensä 'valentinolaiseksi' luokitellussa Filippuksen evankeliumissa, jossa näkemys laista kuoleman aiheuttajana toistetaan paratiisikertomuksen allegorisena tulkintana: paratiisin puu, joka aiheutti Aadamille kuoleman, on laki (Fil. ev. $94=73.27-74.12$ ); kuoleman aiheuttajana ei tässä yhteydessä pidetä demiurgia, kuten Strutwolf $(1993,152)$ virheellisesti olettaa. Filippuksen evankeliumin esittämälle luomiskertomuksen allegoriselle tulkinnalle ei kuitenkaan löydy tukea Valentinoksen fragmenteista.

${ }^{20}$ Ks. Markschies 1992, 129. 


\section{'Presenttinen' kuolemattomuus varhaiskristillisyydessä}

Vaikka ajatus ihmisen alkuperäiseen tilaan liittyvästä kuolemattomuudesta ei ollutkaan Valentinoksen aikana - eikä myöhemminkään - epätavallinen, erikoista on se, että puhuessaan kuolemattomuudesta Va-

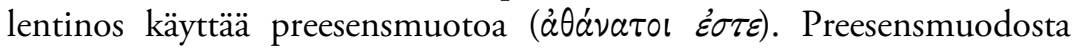
voidaan päätellä, ettei Valentinos ajatellut kuolemattomuutta syntiinlankeemuksen myötä menetettynä mahdollisuutena, vaan piti sitä ominaisuutena, joka ihmisillä edelleen on.

Jo juutalaisessa viisauskirjallisuudessa kuolemasta ja kuolemattomuudesta on esitetty samaan suuntaan johtavia näkemyksiä. Vaikka sekä Siirakin että Viisauden kirjoissa kuoleman ajatellaan toisaalta yhdistävän kaikkia ihmisiä (Siir. 14:17; 17:2; 40:1-2; Viis. 7:1), molemmissa kuolemaan ja kuolemattomuuteen yhdistetään tietty eettinen sisältö. Siirakin kirjan mukaan ihminen voi valita elämän ja kuoleman välillä (Siir. 15:17), ja Viisauden kirjassa kuolema yhdistetään nimenomaan jumalattomiin ihmisiin: he vetävät kuoleman päälleen (Viis. 1:12, 16). Viisauden kirjan kuolemattomuuskäsitys ei ole varsinaisesti 'presenttinen', sillä vanhurskasten "täynnä kuolemattomuutta" olevaan toivoon (Viis. 3:4) liittyy tuonpuoleisen kohtalon odotus: jumalattomien keskeltä temmatut vanhurskaat (Viis. 4:10-11) saavat kuolemansa jälkeen tuomita jumalattomat ja hallita yhdessä Jumalan kanssa (Viis. 4:16; 5:11). Toisaalta vanhurskaan ei ajatella varsinaisesti kuolevan lainkaan; hänen fyysistä kuolemaansa pidetään lopulta ainoastaan näennäisenä (Viis. 3:1-5). ${ }^{21}$

\footnotetext{
${ }^{21}$ Siirakin kirjan ja Viisauden kirjan kuolemakäsityksistä ja niiden välisistä eroista ks. Collins 1978, 177-192. Viisauden kirjan ja Siirakin kirjan kuolemakäsitykset eroavat selkeimmin siinä, että Siirakin kirjassa kaikesta huolimatta pidetään kiinni varhaisemmasta juutalaisesta käsityksestä, jonka mukaan sekä elämä että kuolema ovat peräisin Jumalalta (Siir. 11:14), kun taas Viisauden kirjassa Jumalan ja kuoleman välinen yhteys kiistetään selvästi (Viis. 1:3; ks. Collins 1978, 190-191). Viisauden kirjan kuolemattomuuskäsityksistä ks. myös Kolarcik (1991, 180), joka pyrkii ratkaisemaan erilaisten kuolemattomuuskäsitysten jännitteen olettamalla, että kuolemalla, joka tuli maailman "perkeleen kateudesta" (Viis. 2:24), ei viitata inhimilliseen kuolevaisuuteen yleensä, vaan "lopulliseen kuolemaan, joka erottaa ihmiset Jumalasta."
} 
Viisauskirjallisuuden eettisen näkökulman ohella 'presenttisen' kuolemattomuuskäsityksen taustalla voidaan nähdä myös varhaiskristillisiä aineksia. Paavalin ensimmäisestä kirjeestä tessalonikalaisille voidaan päätellä, että varhaisimpien kristittyjen paruusian odotukseen on täytynyt liittyä ajatus kuolemattomuudesta. Muuten tuskin voidaan ymmärtää sitä, että kuolemantapaukset olivat muodostuneet seurakunnassa ongelmaksi, johon Paavali pyrkii esittämään ratkaisun (1. Tess. 4:12-15). Alun perin vastaavanlaista odotusta heijastanee myös Jeesuksen sanojen traditiossa säilynyt lupaus: "Totisesti: tässä seisovien joukossa on muutamia, jotka eivät maista kuolemaa ennen kuin näkevät, että Jumalan valtakunta on tullut voimassaan” (Mark. 9:1).

Ensimmäisen tessalonikalaiskirjeen perusteella ajatus yleisestä ylösnousemuksesta ei ollut kuulunut Paavalin varhaisempaan julistukseen seurakunnassa. Vaikka tessalonikalaiset epäilemättä uskoivat Kristuksen ylösnousemukseen, he eivät olleet varautuneet kuolemantapausten legitimaatioon tältä perustalta. ${ }^{22}$ Paavalin vastauksesta tessalonikalaisille käy ilmi, että hän vielä oletti olevansa elossa Kristuksen palatessa. ${ }^{23}$ Kuolemantapauksia käsitellään tässä vaiheessa selvästi poikkeustapauksina. Ilmeistä on, että Paavali tässä vaiheessa ymmärsi kuolemattomuuden, joka Jeesuksen paluun myötä saavutettaisiin, tarkoittavan elämän jatkumista ikuisesti maan pääll̈.. ${ }^{24}$

Ajatukseen kuolemattomuudesta, joka voidaan saavuttaa jo nyt, on voinut vaikuttaa myös Paavalin opetus kasteesta. ${ }^{25}$ Roomalaiskirjeessä Paavali rinnastaa kasteen Kristuksen kuolemaan: "Näin meidät kasteessa annettiin kuolemaan ja haudattiin yhdessä hänen kanssaan ..." (Room.

\footnotetext{
22 Jumalhahmon kuolleista herättämiseen ei siis välttämättä liittynyt ajatus yleisestä ylösnousemuksesta tai edes näkemys, että edes herätetyn jumalhahmon hahmon kannattajat herätettäisiin kuolleista. Ks. Martin 1995, 121; Wedderburn 1987, 33-34.

${ }^{23}$ Kuten tunnettua, Paavalin kanta tässä suhteessa muuttuu hänen myöhemmissä kirjeissään; jaksossa 2. Kor. 5:1-10 ruumiin hajoamista pidetään edellytyksenä Herran luokse pääsemiselle, ja Filippiläiskirjeessä Paavali jo toivoo kuolevansa (Fil. 1:23).

${ }^{24} 1$. Tess. 4:17 mukaan elossa olevat kristityt menevät "Herraa vastaan ilmaan", kun tämä on tulossa takaisin maan päälle. 'Vastaanmeneminen' viittaa siihen, että Kristus lopulta tulee maan päälle; näin esim. Holtz 1986, 203. 1. Kor. 15 näyttää edustavan tässä suhteessa erilaista ratkaisumallia: ruumis ja veri eivät pääse Jumalan valtakuntaan, vaan ylösnousemuksen yhteydessä elossaolevatkin muuttuvat (j. 50-53; vrt. 2. Kor. 5:1-10; Fil. 3:21).

${ }^{25}$ Paavalin kastekäsityksestä ks. erityisesti Wedderburn 1987.
} 
6:14). Paavali ei vie analogiaa kasteen ja Kristuksen kuoleman ja ylösnousemuksen välillä loppuun asti, sillä hän ei väitä, että kasteen perusteella ylösnousemuksen voitaisiin ajatella jo tapahtuneen. Sen sijaan Paavali asettaa rinnakkain Kristuksen ylösnousemuksen ja kristittynä elämisen. Paavalin oppilaiden kirjeet osoittavat, että kasteen rinnastamisesta Kristuksen kuolemaan on kuitenkin vain lyhyt askel näkemykseen, että kasteessa saavutetaan myös ylösnousemus. Kolossalaiskirjeessä puhutaan jo kuolleistaherättämisestä kasteen yhteydessä (Kol. 2:12-13) ja Efesolaiskirjeessä ylösnousemuksesta jo tapahtuneena tosiasiana (Ef. 2:6; 5:14). 'Presenttisempi' tulkinta kasteessa tapahtuvasta ylösnousemuksesta on saattanut johtaa myös eräiden Paavalin oppilaiden polemisoimaan näkemykseen, että "ylösnousemus on jo tapahtunut" (2. Tim. 2:18).

Evankeliumitraditiossa Jeesuksen lupausta kuolemattomuudesta (Mark. 9:1) aletaan tulkita siten, ettei se enää viittaa fyysiseen kuolemattomuuteen. Markus sijoittaa lupauksen kirkastusvuorikertomuksen edelle (Mark. 9:2-9), ja näin tapahtumat kirkastusvuorella näyttävät jo toteuttaneen Jeesuksen opetuslapsilleen antaman lupauksen kuolemattomuudesta. Näin Jeesuksen lupaamasta kuolemattomuudesta ei tule ongelmaa, vaikka paruusia viivästyisikin. Sekä Matteus että Luukas omaksuvat saman ratkaisun. ${ }^{26}$ Johanneksen evankeliumissa Jeesuksen toisella tulemisella on vain sivuosa (Joh. 14:13). ${ }^{27}$ Tämä teema nostetaan esille evankeliumin lopussa, missä kerrotaan 'veljien keskuuteen' levinneestä käsityksestä, jonka mukaan Jeesuksen rakkain opetuslapsi ei kuole. Kertomuksessa lukijoita valistetaan, että 'veljet' olivat ymmärtäneet väärin Jeesuksen sanat Pietarille (Joh. 21:22-23): he

\footnotetext{
26 Molemmat säilyttävät Jeesuksen lupauksen kuolemattomuudesta olennaisilta osiltaan sellaisenaan (Matt. 16:28 // Luuk. 9:27). Luukkaalla ei ole mitään ongelmia käyttää tätä lausetta yhdessä kohtaa ja tehdä toisessa yhteydessä selkeä ero kuolemattomuuden ja fyysisen kuoleman välillä. Tulevaa ylösnousemusta käsittelevässä jaksossa hän lisää Markuksen varhaisempaan versioon toteamuksen, etteivät ylösnousemuksesta osalliset "voi enää kuolla" (Luuk. 20:36).

27 Tulevaisuudessa tapahtuvan paruusian odotuksen paikan näyttää Johanneksen evankeliumissa ottavan Jeesuksen paluu omiensa luokse heti kuolemansa jälkeen Puolustajan välityksellä; ks. Syreeni 1995, 158-159.
} 
eivät ymmärtäneet Jeesuksen sanojen ehdollisuutta: jääkö Jeesuksen rakkain oppilas eloon vai ei, on kokonaan kiinni Jeesuksen tahdosta. ${ }^{28}$

Se että Johanneksen evankeliumin lopussa näin selvästi korostetaan kuolemattomuuteen liittyvän lupauksen ehdollisuutta, on erikoinen piirre, kun ottaa huomioon, että juuri tässä evankeliumissa lupauksilla kuolemattomuudesta on tärkeä asema. Yksi koko evankeliumin keskeisimmistä väitteistä on, että uskovalla "on ikuinen elämä" (3:1516, 36; 5:24; 6:40, 47, 54) tai lyhyemmin ilmaistuna "elämä" (10:10; 20:31). Evankeliumissa kuvattu Jeesus julistaa, että se joka uskoo häneen "ei näe koskaan kuolemaa" (Joh. 8:51) eikä "ikinä kuole" (11:26). Johanneksen evankeliumissa lupaus kuolemattomuudesta yhdistetään tavallisesti uskomiseen ja Jeesuksen sanojen kuulemiseen, mutta Jeesuksen leipäpuheen (Joh. 6:27-58) lopussa on kuitenkin jakso, jossa lupaus kuolemattomuudesta yhdistetään toistuvasti ehtoolliseen liittyviin metaforiin (Joh. 6:51-58): "se, joka syö tätä leipää, elää ikuisesti" (j. 51, 58). Johanneksen erilaisten korostusten taustalla voi osittain olla evankeliumin syntyhistoria, sillä lukua Joh. 21 pidetään usein myöhempänä lisäyksenä. Evankeliumin lopetusta tuskin voi kuitenkaan pitää merkkinä siitä, että tämän luvun kirjoittaja olisi torjunut aikaisemmissa luvuissa esiintyvät lupaukset kuolemattomuudesta. Pikemminkin voidaan ajatella kirjoittajan halunneen torjua sen ajatuksen, että nämä lupaukset tarkoittaisivat fyysistä kuolemattomuutta; se on Jeesuksen rakkaimman opetuslapsenkin osalta korkeintaan vain yksi mahdollisuus.

Ajatuksellinen sukulaisuus Johanneksen kuolemattomuutta koskevien lauselmien ja Valentinoksen välillä vaikuttaa ilmeiseltä. ${ }^{29}$ Sekä Johanneksen evankeliumissa että Valentinoksen katkelmassa kuolemat-

\footnotetext{
${ }^{28}$ Useimmat tutkijat pitävät tätä jaksoa todisteena Jeesuksen 'rakkaimman oppilaan' historiallisuudesta, sillä jakson on katsottu viittaavan tämän oppilaan kuolemaan ja sen aiheuttamaan suruun ja epätietoisuuteen oppilaan johtamassa seurakunnassa. Tarkalleen ottaen Johanneksen lopussa ei kuitenkaan kerrota 'rakkaimman oppilaan' kuolemasta vaan kuolevaisuudesta.

${ }^{29}$ Johanneksen evankeliumi on luonnollisesti voinut vaikuttaa Valentinoksen näkemyksiin. Hänen käyttämänsä puhuttelu 'ikuisen elämän lapset' heijastaa mahdollisesti Johanneksesta omaksuttua kielenkäyttöä (Markschies 1992, 132).
} 
tomuus on todella tämänhetkinen, jo saavutettu ominaisuus. Yksi selkeä ero Johanneksen ja Valentinoksen välillä kuitenkin on: sen sijaan, että evankeliumissa Jeesuksen sanoman vastaanottajien todettaisiin olevan "alusta alkaen kuolemattomia", heistä todetaan, että he ovat "siirtyneet kuolemasta elämään” (Joh. 5:24). Johanneksen evankeliumissa ei siis esiinny ajatusta kuolemattomuudesta, jonka ihmiset (tai ainakin osa heistä) olisivat säilyttäneet itsellään "alusta alkaen".

Jeesuksen sanojen traditiossa lähimmäksi Valentinoksen katkelmassa esiintyviä ajatuksia tulee Johanneksen ohella Tuomaan evankeliumi, jossa niin ikään kuolemattomuudella on keskeinen sija. Evankeliumin ensimmäisessä lauselmassa lukijalle annetaan haluttu tulkintakehys koko kirjoitukselle: "Se, joka löytää näiden sanojen selityksen, ei ole näkevä kuolemaa" (Tuom. ev. 1). ${ }^{30}$ Valentinoksen ja Tuom. evankeliumin kuolemattomuuskäsityksiä yhdistävät seuraavat piirteet: (1) Valentinoksen tavoin Tuomaan evankeliumissa kuolemattomuus liitetään selvästi ihmisen alkuperäiseen tilaan. Valentinoksen katkelmaa selkeämmin Tuomaan evankeliumissa viitataan paratiisissa vallinneeseen alkutilaan, jonka Aadam menetti, mutta joka edelleen on niiden ulottuvilla, jotka ottavat evankeliumin sanat vakavasti: "Aadam syntyi suuresta voimasta ja valtavasta rikkaudesta, mutta hän ei ollut teidän arvoisenne. Jos hän olisi ollut, hän ei olisi nähnyt kuolemaa" (Tuom. ev. 85). "Missä on alku, siellä tulee loppukin olemaan. Autuas se, joka tavoittaa alun. Hän saa tuntea myös lopun eikä ole näkevä kuolemaa” (Tuom. ev. 18; vrt. myös Tuom. ev. 19). (2) Kuolemattomuus käsitetään myös Tuomaan evankeliumissa presenttiseksi ominaisuudeksi: "Kuollut ei elä, eikä elävä tule kuolemaan" (Tuom. ev. 11). (3) Varsin läheisesti Valentinoksen katkelmaa muistuttaa Tuomaan evankeliumin aloitusta seuraava lupaus, jossa kannustetaan etsimiseen, jonka seurauksena on

\footnotetext{
${ }^{30}$ Suomennokset Tuomaan evankeliumista: Huuhtanen, Marjanen \& Uro 1994. Lauselmassa käytetään alun perin 'maistamista' ilmaisevaa verbiä ( $d z i$-tipe; kreikankielisessä katkelmassa

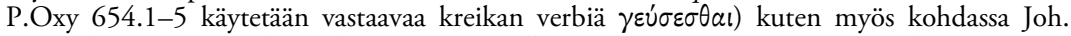
8:52. Ilmaus esiintyy kuitenkin myös muualla (4. Esra 6:26; CH 10.8; Mark. 9:1; Hepr. 2:9), joten sen esiintymisestä ei voi tehdä päätelmiä Johanneksen ja Tuomaan evankeliumin keskinäisistä suhteista; ks. Menard 1975, 77.
} 
löytäminen, hämmennys ja lopulta se, että löytäjä "hallitsee kaikkea". ${ }^{31}$ 'Hallitseminen' voi tässä yhteydessä viitata yleisesti tunnettuun ajatukseen, että 'viisas' on todellinen kuningas ja hallitsija. ${ }^{32}$

'Hallitseminen' ei tarkoita välttämättä poliittista hallitsemista, vaan kyse on oman itsensä hallitsemisesta. ${ }^{33}$ Sekä Valentinoksen ajatus "luomakunnan" ja "kaiken katoavaisuuden" hallitsemisesta että Tuomaan evankeliumissa esitetty näkemys "kaiken" hallitsemisesta voidaan hyvin ymmärtää tästä näkökulmasta käsin: ${ }^{34}$ päämääränä on, ettei maailma hallitse ihmistä, vaan että ihminen hallitsee itsensä suhteessa maailmaan. Tämä päämäärä selventää myös Valentinoksen ajatusta "kuoleman tuhoamisesta". Kyse on sisäisestä ominaisuudesta, jonka ihminen voi saavuttaa eläessään ("jotta kuolema kuolisi teissä ja teidän avullanne"). "Kuoleman tuhoaminen" viittaa tällöin ennen kaikkea elämäntapaan, jossa kuolema ja katoava maailma eivät enää hallitse ihmistä. Tällaiselle näkemykselle löytyy rinnakkaiskohtia esimerkiksi Filonilta (ks. ed.).

Sekä Johannes että Tuomaan evankeliumi osoittavat, ettei 'presenttiseen' kuolemattomuuteen välttämättä liitetty ajatusta fyysisestä kuolemattomuudesta. Tuomaan evankeliumissa ilmaistaan vielä selkeämmin kuin Johanneksessa, ettei presenttinen kuolemattomuus sulje pois fyysistä kuolemaa: "Katselkaa häntä, joka elä, katselkaa niin kauan kuin itse elätte, ettette kuolisi. Kuoltuanne te ette voi nähdä häntä, vaikka haluaisittekin" (Tuom. ev. 59).

${ }^{31}$ Tuomaan evankeliumissa 'hallitsemista' ilmaiseva verbi ( $r$-rro, $\left.\beta a \sigma \iota \lambda \varepsilon v ́ \varepsilon ı \nu\right)$ on tosin eri kuin

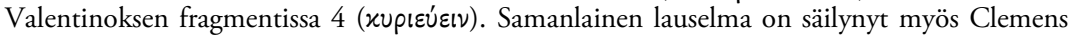
Aleksandrialaisella, joka esittää sen lainauksena Heprealaisevankeliumista (Strom. 5.14.96; käännös: Huuhtanen, Marjanen \& Uro 1994, 57 n. 4).

${ }^{32}$ Näin esim. Filon, Somn. 2.244 (selittäessään jaetta 1. Moos. 23:6): ”...viisas yksin on hallitsija ja kuningas, hyve on valta ja valtakunta, joka ei ole kenellekään alamainen”; ks. Mack 1987, 12-13. Taustalla voidaan nähdä myös Platonin ajatus siitä, että kaupunkivaltion ihanteellinen hallitsija olisi filosofi (Valtio 473d); tästä näkemyksestä ks. Thesleff 1989, 9293, 201-202.

${ }^{33}$ Esim. Platonin mukaan "jaloin ja oikeudenmukaisin" on "se joka on kuninkaallisin ja hallitsee kuninkaana itseään" (Valtio 580c-d; suom. Marja Itkonen-Kaila); tästä ja muista vastaavista esimerkeistä ks. Foucault 1992, 2.78-82.

34 Tuomaan evankeliumia on usein pidetty korostuksiltaan askeettisena tai vähintään enkraattisena; askeettinen kielenkäyttö ei ole kuitenkaan ole evankeliumissa loppuun asti johdonmukaista (Uro 1998c). 
Ajatusta fyysisestäkään kuolemattomuudesta ei tosin voida pitää täysin poissuljettuna mahdollisuutena ensimmäisellä kristillisellä vuosisadalla. Hyvin realistista kuolemattomuusoppia näyttävät edustaneen Menandros ja hänen oppilaansa. ${ }^{35}$ Irenaeus kertoo, että Menandroksen oppilaat uskoivat saavansa kuolemattomuuden kasteen yhteydessä: "Hänen oppilaansa saivat ylösnousemuksen, kun heidät kastettiin häneen, eivätkä he enää voi kuolla vaan he säilyvät vanhentumattomina ja kuolemattomina” (Harh. 1.23.5). Irenaeuksen kuvauksen perusteella näyttäisi siltä, ettei ajatus kasteen välittämästä fyysisestä kuolemattomuudesta olisi ollut mahdoton ensimmäisellä kristillisellä vuosisadalla. ${ }^{36}$

Ei ole perusteltua olettaa, että Valentinoksen (tai Johanneksen kirjoittajien) käsitys kuolemattomuudesta olisi ollut samanlainen kuin Menandroksen. ${ }^{37}$ Todennäköistä on, että Valentinoksen käsitys 'presenttisestä’ kuolemattomuudesta tulee ymmärtää samoin kuin Johanneksen nykymuodossa ja Tuomaan evankeliumissa: 'kuolemattomuus' ei tarkoita sitä, että ihminen välttäisi fyysisen kuoleman, vaan liittyy tietynlaiseen elämäntapaan. Ajatus presenttisestä kuolemattomuudesta näyttää olevan siis ennen kaikkea kvalitatiivinen, elämäntapaan liittyvä määre kuten juutalaisessa viisauskirjallisuudessakin tai Filonilla. Tältä

\footnotetext{
${ }^{35}$ Menandroksen kuolemattomuuskäsityksiin kiinnittää huomiota A. Marjanen, "Gnostilaisuus ja eskatologia" (esitelmä Raamattuteologisilla neuvottelupäivillä, Kirkon koulutuskeskus, Järvenpää 17.11.1993). Menandroksen ajoittaminen on olemassa olevien lähteiden perusteella epävarmaa. Sekä Irenaeus (Harh. 1.23.5) että jo aiemmin Justinus (1. Apol. 26.4) pitävät häntä Simon Maguksen, gnostilaisuuden 'kantaisän' oppilaana. Tässä tapauksessa Menandros olisi vaikuttanut jo ensimmäisellä vuosisadalla jKr., sillä Luukas kuvaa Simon Maguksen eläneen jo apostolien aikana (Ap.t. 8:9-24). Kirkkoisien esittämät 'hereetikkojen sukupuut' eivät kuitenkaan ole välttämättä historiallisesti luotettavia; kyse on pikemminkin yrityksestä 'paljastaa' erilaisten 'hereetikkojen' yhteinen (ja häpeällinen) tausta.

36 Irenaeuksen kuvaukseen Menandroksesta on suhtauduttava tietyin varauksin, sillä Justinoksen varhaisemmasta Menandrosta koskevasta maininnasta puuttuu Irenaeuksen kuvauksen konkreettisin piirre, ikuisen nuoruuden takaava kaste. Silti Justinoksenkaan kuvausta on vaikea ymmärtää muuten kuin että Menandros todella lupasi seuraajilleen fyysisen kuolemattomuuden: "Hän uskotteli seuraajilleen, etteivät he edes ( $\left.\mu \eta \delta \delta^{\prime}\right)$ kuole" (1. Apol. 26.4). Menandroksen mainitsee myös Tertullianus, jonka mukaan Menandroksen oppilaat uskoivat, etteivät he kuole lainkaan, sillä Menandroksen kaste tekee heistä kuolemattomia ja turmeltumattomia (De Anima 50). Tertullianuksen kuvausta Menandroksen ryhmästä ei kuitenkaan voi pitää itsenäisenä lähteenä, sillä se perustuu mitä ilmeisimmin suoraan Irenaeuksen teokseen.

${ }^{37}$ Markschies 1992, 130-131.
} 
pohjalta voidaan tulkita sekä Johannes (kuolemattomuus = usko), Tuomaan evankeliumi (kuolemattomuus = Jeesuksen sanojen oikea ymmärtäminen) ja Valentinoksen katkelma. Tällaisena 'presenttinen' kuolemattomuus ei kerro paljoakaan tuonpuoleisuuskäsityksistä; taustalle voi kätkeytyä erilaisia käsityksiä.

\section{Sisäinen ja ulkoinen ihminen}

Valentinoksen katkelmaa tulkitessa on otettava huomioon, että sen taustalla on todennäköisesti jako sisäiseen, kuolemattomaan ihmiseen ja ulkoiseen ihmiseen, ruumiiseen. Tällaiseen jakoon viittaa Valentinoksen ensimmäinen, ihmisen luomista käsittelevä fragmentti, jossa kuvataan ensimmäisen ihmisen aiheuttamaa hämmennystä luojaenkelien keskuudessa:

Ja kuten enkelit valtasi pelko tuon luomuksen takia, kun se puhui kovalla äänellä suurempia kuin sen luominen edellytti hänen takiaan, joka oli näkymättömästi antanut häneen ylhältä olevan olemuksen siemenen ja joka puhuu vapaasti, samoin maallisten ihmisten sukukunnissa ihmisten teot kuten patsaat, jumalankuvat ja kaikki se mitä kädet Jumalan nimessä valmistavat, herättivät tekijöissään pelkoa. Sillä ihmiskunnan edustajaksi luotu Aadam synnytti pelon aiemmin ollutta ihmistä kohtaan, joka hänessä olikin, ja enkelit kauhistuivat ja piilottivat (tai: turmelivat) nopeasti työnsä. ${ }^{38}$

Jako 'sisäisen' ja 'ulkoisen' ihmisen välillä oli Valentinoksen aikana ilmeisen yleinen. Tällaisen jaon edellyttää muun muassa juutalainen keskiplatonisti Filon, jonka mukaan ihmisen näkyvä osa on kuolevainen, näkymätön taas kuolematon; ihminen on näin "kuolevan ja kuolemattoman luonnon välinen raja-alue" (Opif. 135). Ihmisessä

${ }^{38}$ Clemens, Strom. 2.36.2-4. 
oleva Jumalan kaltaisuus koskee Filonin mukaan ainoastaan näkymätöntä luontoa (Opif. 69). ${ }^{39}$

Myös Filon pitää mahdollisena 'presenttistä' kuolemattomuutta, joka seuraa "taivaallisten asioiden katselusta". Tämä "filosofia" tekee kuolevaisesta ihmisestä kuolemattoman (Opif. 77). "Ikuinen elämä" liittyy Filonilla tietoon Jumalasta; jumalattomat ovat sielultaan kuolleita, kun taas ne jotka ovat elävän Jumalan palvelijoita "elävät kuolematonta elämää" (Spec. leg. 1.345). Siihen että ihminen voi elää kuolematonta elämää jo nyt, liittyy Filonilla ajatus keskittymisestä kontemploivaan elämäntapaan: "...ne sielut jotka harrastavat tosi filosofiaa, opettelevat alusta loppuun asti kuolemaan ruumiillisen elämän suhteen" (Gig. 14). Se miten Filon ymmärtää tämän ajatuksen käytännössä, ilmenee hänen ihannoivasta tavastaan kuvata terapeuttien ryhmää. Filonin kuvauksen perusteella terapeutit olivat askeettinen juutalainen lahko, jonka jäsenet olivat vetäytyneet suurista kaupungeista ja jättäneet perheensä, sukunsa ja isänmaansa (Vit. cont. 18-20). ${ }^{40}$ Filon toteaa terapeuteista, että he "ajattelevat jo päättäneensä kuolevan

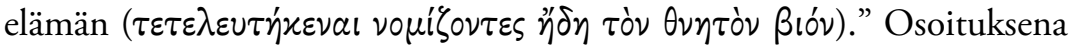
tästä he jättävät maallisen omaisuutensa lapsilleen, muille sukulaisilleen tai ystävilleen (Vit. cont. 13).

Sekä Filonin käsitykset kuolemattomuuden perusteista että hänen kuvauksensa terapeuteista valaisevat Valentinoksen katkelmaa. Ilmeistä on ensinnäkin, että sekä Filon että Valentinos liittävät kuolemattomuuden käsitykseen ihmisessä olevasta 'kahdesta tasosta', 'näkyvästä' ja 'näkymättömästä'. Toiseksi myös Filonin kuvaus terapeuteista osoittaa, ettei 'presenttinen' kuolemattomuus tarkoita fyysisen kuoleman välttämistä, vaan tiettyä elämäntapaa, jossa näkyvien asioiden sijasta

\footnotetext{
39 Lyhyen yhteenvedon Filonin kuolemakäsityksistä esittää Cavallin 1974, 135-140. Vastaavanlainen jako tehdään myös mm. hermeettisissä kirjoituksissa (esim. Askl. 22; Holzhausen 1994, 117-118.

${ }^{40}$ Terapeuteista ja heidän mahdollisista yhteyksistään essealaisiin ks. Vermes \& Goodman 1989, 15-17. Vermesin ja Goodmanin arvio on seuraava: "Kaiken kaikkiaan saatavilla oleva todistusaineisto ei oikeuta täysin yhdistämään toisiinsa terapeutteja ja essealaisia/Qumranin lahkolaisia. Todennäköisin päätelmä on, että edelliset muodostivat essealaisten palestiinalaisen askeesiliikkeen egyptiläisen haaran” (s. 17).
} 
annetaan etusija näkymättömille arvoille. ${ }^{41}$ Kolmanneksi Filonilta löytyy tukea näkemykselle ihmisen alkuperäisestä kuolemattomuudesta. Filonilla tähän näkemykseen sisältyy ajatus paluusta alkuperäiseen tilaan. Filon puhuu sieluista, jotka ovat laskeutuneet ihmisruumiisiin; osa näistä sieluista tuhoutuu maallisen elämän pyörteissä, mutta osa palaa "sinne mistä olivat lähtöisin" (Gig. 13). ${ }^{42}$

\section{Kuolemattomuus ja rituaali}

Edellä on jo käynyt ilmi kuolemattomuuden ja sakramenttien läheinen yhteys varhaiskristillisyydessä. Tämä yhteys näkyi erityisesti Paavalin oppilaiden kastekäsityksissä ja Johanneksen evankeliumissa tavassa, jolla ehtoolliseen liittyviä metaforia käytetään. Näihin esimerkkeihin voidaan lisätä Ignatios Antiokialaisen ajatus, että ehtoollisleipä on "kuolemattomuuden lääke” (Ign. Ef. 20:2).

Valentinoksen sakramenttikäsityksistä ei ole säilynyt tietoa. Sen sijaan tiedetään, että myöhemmän polven valentinolaisten piirissä kehittyi erityinen kuolemaan liittyvä riitti, jonka tavoitteena oli taata kuolemattomuus tuonpuoleisuudessa. Irenaeuksen mukaan tällainen riitti oli käytössä Markoksen ryhmän piirissä. ${ }^{43}$ Irenaeuksen suhde Markoksen ryhmään on tosin erittäin poleeminen eikä hänen tietojaan voi pitää täysin luotettavina. Kuvatessaan ryhmän kuoleville suorittamaa viimeistä voitelua Irenaeus kuitenkin kertoo esittävänsä suoria lainauksia ryhmän jäseniltä (Harh. 1.21.5), ja tältä osin muut lähteet vahvistavat Irenaeuksen luotettavuuden historiallisena lähteenä.

Irenaeuksen kuvauksen perusteella osalla Markoksen ryhmästä oli tapana voidella kuolevan pää vedellä ja öljyllä. Ihmisen kuoltua ruumis maatuu, mutta sielun ajateltiin jatkavan matkaansa luojajumalan,

\footnotetext{
${ }^{41}$ Tässä suhteessa Filon liittyy läheisesti Platonin käsityksiin filosofin tehtävästä (esim. Faidon 67e, 114de); ks. Goodenough 1946, 93, 106.

${ }^{42}$ Samanlainen käsitys esiintyy Filonilla muuallakin, esim. Conf. 78 (Goodenough 1946, 100).

43 Irenaeus kuvaa Markoksen ryhmän opetuksia ja rituaaleja varsin laajasti, itse asiassa yksityiskohtaisimmin kaikista valentinolaisista ryhmistä (Harh. 1.13-21).
} 
Demiurgin, luokse. ${ }^{44}$ Ensin vainaja joutuu kuitenkin kohtaamaan tuonpuoleiset voimat, joista hän pääsee eroon sanomalla seuraavat sanat: ${ }^{45}$

Minä olen lapsi, joka on Isästä peräisin, ennalta olevasta Isästä, lapsi ennalta olevassa. Tulin nähdäkseni kaiken, sekä sen mikä on omaa että sen mikä on vierasta (se ei tosin ole kokonaan vierasta, vaan se kuuluu Akhamotille, joka on naispuolinen ja joka teki tämän itseään varten; hän veti alas suvun, joka on lähtöisin ennalta olevasta) ja palaan omaan paikkaani josta olen tullut.

Päästyään eroon 'voimista' vainaja joutuu kohtaamaan Demiurgin

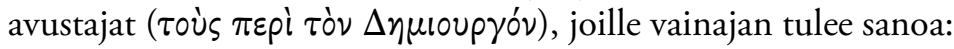

Minä olen paljon arvokkaampi astia kuin nainen, joka teki teidät. Jos teidän äitinne olikin tietämätön omasta alkuperästään, minä tunnen itseni ja tiedän, mistä olen peräisin. Minä kutsun avukseni turmeltumatonta Viisautta, joka on Isässä ja teidän äitinne äiti. Teidän äidillänne ei ole isää eikä puolisona miestä. Hän, naisesta syntynyt nainen, teki teidät tuntematta äitiään ja kuvitellen olevansa yksin. Mutta minä kutsun avukseni hänen äitiään.

Kun vainaja kertoo Demiurgin avustajille edellä mainitut sanat, avustajat hämmentyvät kuullessaan häpeällisestä alkuperästään ja kiirehtivät tuomitsemaan sen; samalla vainaja irrottautuu häntä kahlinneesta sielusta (sic! sielukaan ei pelastu täyteyteen) ja pääsee alkuperäiseen paikkaansa, mistä oli lähtöisin.

Irenaeuksen kuvausta Markoksen ryhmässä käytetyistä ohjeista tuonpuoleisuutta varten voidaan pitää luotettavana, sillä yhdessä Nag Hammadin kirjaston kirjoituksista, Ensimmäisessä Jaakobin ilmestyksessä (NHK V, 3) on läheinen rinnakkaiskohta Irenaeuksen esittämälle lainaukselle (1. Jaak. ilm. 33.11-34.20): ${ }^{46}$

\footnotetext{
${ }^{44}$ Demiurgi on luojajumala, jota gnostilaisissa järjestelmissä pidetään alempiarvoisena kuin korkeinta, näkymätöntä Jumalaa.

45 Tämän ja seuraavan jakson käännös perustuu Epifanioksen säilyttämään kreikankieliseen lainaukseen Irenaeukselta (Panarion 36.3.1-6). Epifanioksen mukaan tämä opetus on peräisin Markoksen oppilaan, Herakleonin, ryhmältä (Panarion 36.2).

46 Saman tekstin välitön jatko on niin ikään rinnakkainen Irenaeuksen jälkimmäiselle sitaatille (1. Jaak. ilm. 34.26-35.26).
} 
Kun joudut heidän käsiinsä, yksi heistä, heidän vartijansa kysyy sinulta: "Kuka olet tai mistä olet peräisin?". Sinun pitää vastata hänelle: "Minä olen lapsi, Isästä lähtöisin." Hän kysyy sinulta: "Millainen lapsi olet ja kuka oikein on isäsi?" Sinun pitää vastata hänelle: "Minä olen lähtöisin ennalta olleessa Isästä; olen lapsi hänessä joka on ollut ennalta." [Kun hän kysyy] sinulta [...], sinun pitää [vastata hänelle ...] (s. 34) ... mitkä ovat vieraita?” Sinun pitää vastata hänelle: "Ne eivät ole täysin vieraita, vaan ne ovat peräisin Akhamotilta, joka on nainen. Hän loi ne, kun hän veti tämän suvun alas Ennalta olevan luota. $\mathrm{Ne}$ eivät siis ole vieraita, vaan ne kuuluvat meille. Ne todellakin ovat meidän, sillä niiden hallitsijatar on peräisin Ennalta olevasta. Toisaalta ne ovat vieraita, koska Ennalta oleva ei yhtynyt häneen, kun hän oli luova ne.

Kun hän sitten kysyy sinulta: "Minne sinä olet menossa?", sinun pitää vastata: "Palaan sinne, mistä olen lähtenyt." Jos vastaat näin, pääset pakoon heidän hyökkäyksiltään.

Ajatus tuonpuoleisuudessa tapahtuvista kuulusteluista, jonka 'vartijat' suorittavat, tunnetaan etenkin egyptiläisestä Kuolleiden kirjasta, mutta myös orfilaisista hautakirjoituksista. ${ }^{47}$ Orfilaisissa teksteissä tuonelaan joutuneen tuli esitellä itsensä vartijoille "maan ja tähtitaivaan lapsena", jonka "suku on kuitenkin taivaasta". ${ }^{48}$ Markoksen ryhmässä kuoleville annetut ohjeet ja Ensimmäisessä Jaakobin ilmestyksessä esiintyvä teksti ovat kuitenkin läheisempää sukua toisilleen kuin useimmat rinnakkaiskohdat. Molemmat tekstit edellyttävät Irenaeuksen kuvaamaan 'valentinolaisen' myytin maailman luomisesta, jonka erityispiirre on ajatus kahdesta Viisaudesta. ${ }^{49}$ Ajatus liittyy monimutkaiseen prosessiin, jonka katsottiin johtaneen näkyvän maailman syntyyn.

Lyhyesti kuvattuna prosessi on seuraava (Harh. 1.1-5): Jumalallinen todellisuus, täyteys (pleroma), koostuu 12 jumalallisten 'aionien' parista. Viimeisin jumalallisista aioneista, Viisaus lankeaa ja joutuu täy-

\footnotetext{
${ }^{47}$ Lyhyesti näitä tekstejä referoi DeConick 1996, 50-51.

48 Maininnat ovat peräisin Thessalista löydetystä kultalehdestä; tekstin käännöksestä ks. Meyer 1987, 101. Orfilaisissa hymneissä epiteettiä "maan ja tähtitaivaan lapsi" käytetään myös Kronos-jumalasta (Meyer 1987, 102-103). Toisen sisällöltään hyvin samantyyppisen orfilaisen kirjoituksen, joka on löydetty vuonna 1969 Hipponionista, esittelee Burkert 1985, 293.

49 Tämä erottaa nämä tekstit myös muista gnostilaisista rinnakkaiskohdista, joissa käytetään samanlaisia kysymyksiä ja vastauksia (Marian ev. 15-17; Paav. apok. 22.30-24.1); vrt. myös Tuom. ev. 50.
} 
teyden ulkopuolelle. Hänet otetaan lopulta takaisin täyteyteen, mutta hänen 'kärsimyksensä' jäävät ulkopuolelle. Näitä kärsimyksiä kutsutaan 'alemmaksi Viisaudeksi' tai 'Akhamotiksi'. ${ }^{50}$ Vaikka Akhamotilla on aavistus jumalallisesta todellisuudesta, hän ei varsinaisesti tunne sitä. Materiaalisen todellisuuden luoja, Demiurgi on peräisin Akhamotista, mutta hänkään ei tunne äitiään, vaan kuvittelee olevansa ainoa jumala. Demiurgi yhdistetään juutalaisten Jumalaan, jonka tietämättömyyden erityisenä osoituksena pidetään hänen sanojaan: "Minä olen Jumala ... ei ole muuta jumalaa kuin minä" (Harh. 1.5.4; vrt. Jes. 45:5; 46:9).

Valentinosta voidaan pitää korkeintaan markolaisten etäisenä henkisenä esi-isänä, eikä hänen fragmenteissaan ole säilynyt selviä viitteitä Irenaeuksen kuvaamaan monimutkaiseen kosmogoniaan. Valentinoksen fragmentit eivät sisällä ajatusta kahdesta Viisaudesta, ylemmästä Sofiasta ja alemmasta Akhamotista, eikä niissä myöskään mainita Demiurgia. Markoksen ryhmä osoittaa korkeintaan, mihin suuntaan Valentinoksen koulu saattoi Valentinoksen jälkeisenä aikana kehittyä. Ei ole perusteltua olettaa, että tämä olisi ollut ainoa mahdollinen kehityssuunta; jopa Irenaeuksen kuvauksen perusteella Markoksen ryhmä näyttää olleen hyvin erikoinen valentinolaisen koulukunnan haara.

Yksi yhteinen tekijä Valentinoksen koulun 'ääripäiden', itse Valentinoksen ja Markoksen ryhmän välillä kuitenkin on: ihmisen ajatellaan olevan tekijänsä/tekijöidensä yläpuolella; hän parempaa syntyperää kuin maailman luoneet olennot. Valentinos ei tosin ilmeisesti puhunut Demiurgista, vaan oletti, että maailman ja ihmisen olivat luoneet luojaenkelit. Hänenkin mukaansa ihminen oli kuitenkin ylempi hahmo kuin hänet luoneet enkelit ja sai heidät kovaäänisellä puheellaan hämmennyksiin. Vastaavasti Markoksen ryhmän kuolevalle opettamien vastausten tarkoitus on saada Demiurgin palvelijat hämmennyksiin, tuomitsemaan oman syntyperänsä ja päästämään kuoleva tuonpuoleisuudessa vapaaksi.

\footnotetext{
${ }^{50}$ Nimi viittaa heprean 'viisautta' merkitsevään sanaan (håkma; monikko håkmot esiintyy Sananl. 1:20; 9:1; 24:7).
} 


\section{Yhteenveto}

On todennäköistä, että Valentinos ymmärsi presenttisen kuolemattomuuden, johon sisältyy kuoleman "tuhoaminen" ja "katoavaisuuden hallitseminen" tarkoittavan tietynlaista elämäntapaa, jossa ihminen pystyy hallitsemaan suhdettaan maailmaan. Tällaista kuolemattomuuskäsitystä voidaan monessa suhteessa pitää varhaiskristillisen ajattelun jatkeena, mutta sille löytyy vertailukohtia myös esimerkiksi Platonilta, juutalaisesta viisauskirjallisuudesta ja Filonilta. Viimeksi mainitun edustamasta keskiplatonismista Valentinos on hyvin voinut saada vaikutteita Aleksandriassa, Filonin kotikaupungissa. Ainakin myöhempinä vuosisatoina Valentinoksen ajateltiin olevan kotoisin Egyptistä ja saaneen kasvatuksensa Aleksandriassa. ${ }^{51}$

Erityisen lähelle Valentinoksen käsityksiä kuolemattomuudesta tulevat Johanneksen ja Tuomaan evankeliumit. Läheinen sukulaisuus Johanneksen evankeliumiin selittynee evankeliumin tekemällä vaikutuksella Valentinokseen. Päätelmät Valentinoksen ja Tuomaan evankeliumin suhteesta ovat sen sijaan epävarmempia. Pitäisikö yhteyksien perusteella olettaa, että Valentinos tunsi Tuomaan evankeliumin? ${ }^{52}$ Vai onko Valentinos tai hänen koulukuntansa vaikuttanut Tuomaan evankeliumiin? Vai onko taustalla ainoastaan samantyylinen, toisen vuosisadan kristillisyys, jossa korostettiin samanlaisia teemoja?

Joka tapauksessa olisi ennenaikaista leimata Valentinoksen ja Tuomaan evankeliumin välisiä yhteyksiä osoitukseksi näiden näkemysten erityisestä 'gnostilaisesta' luonteesta. Mikäli Valentinos säilyneiden fragmenttien perusteella halutaan välttämättä luonnehtia 'gnostikoksi', tällainen arvio ei voi perustua niinkään hänen kuolemattomuuskäsitykseensä kuin hänen näkemykseensä ihmisen luomisesta. Kaikkine eroavaisuuksineenkin juuri Valentinoksen luomiskäsitys on perustaltaan samankaltainen kuin myöhemmän valentinolaisuuden piirissä esitetyt näkemykset.

${ }^{51}$ Näin Epifanios, Panarion 31.2.2-3; Epifanios tosin pitää näitä tietoja vain kuulopuheina. Evidenssiin liittyvästä epävarmuudesta muistuttaa Markschies 1992, 314-331.

52 Näin Layton 1987, 220. 



\section{Kirjallisuus}

Aejmelaeus, Lars

1991 "Taivasten valtakunnan eunukit (Matt 19:12)." TAik 96, 18-27.

Attridge, Harold W. \& Elaine H. Pagels

1985 "The Tripartite Tractate: I, 5: 51.1-138.27." Sivut 159-337 kirjassa Nag Hammadi Codex I (The Jung Codex): Introductions, Texts, Translations, Indices. Toim. Harold W. Attridge. NHS 22. Leiden: Brill.

Baigent, Michael, Richard Leigh \& Henry Lincoln

1983 Holy Blood, Holy Grail. New York: Dell.

Baker, A.

1965 "One Thing Necessary." Catholical Biblical Quarterly 27, 127-137.

Barr, James

1993 The Garden of Eden and the Hope of Immortality. Minneapolis: Fortress.

Barrett, C. K.

1978 The Gospel According to St. John: An Introduction with Commentary and Notes on the Greek Text. 2. painos. London: SPCK.

1992 "The Place of John and the Synoptics within the Early History of Christian Thought." Sivut 63-79 kirjassa Denaux (toim.) 1992.

Becker, Jürgen

1979-81 (1991) Das Evangelium nach Johannes. 2 osaa. Ökumenischer Taschenbuchkommentar zum Neuen Testament 4. Gütersloh: Gütersloher Verlag.

1986 "Das Johannesevangelium im Streit des Methoden (1980-1984)." TR 51, $1-78$.

1993 Das Urchristentum als gegliederte Epoche. Stuttgarter Bibelstudien 155. Stuttgart: Katholisches Bibelwerk.

1996 Jesus von Nazareth. Berlin: de Gruyter.

Benedict, Hans-Jürgen

2003 "Die grössere Diakonie: Versuch einer Neubestimmung im Anschluss an John N. Collins." Sivut 127-135 kirjassa Hermann, Merz \& Schmidt (toim.) 2003. 
Benko, Stephen

1984 Pagan Rome and the Early Christians. Bloomington: Indiana University Press.

Beyer, Hermann Wolfgang

1935 "diakoneō, diakonia, diakonos." Theologisches Wörterbuch zum Neuen Testament 2.81-93.

Bianchi, Ugo (toim.)

1967 The Origins of Gnosticism. Studies in the History of Religions 12. Leiden: Brill.

Billerbeck, Paul

1983 Das Evangelium nach Markus, Lukas und Johannes und die Apostelgeschichte. Kommentar zum Neuen Testament aus Talmud und Midrasch II. 8. painos. München: Beck.

Blass, Friedrich, Albert Debrunner \& Friedrich Rehkopf

1990 Grammatik des neutestamentlichen Griechisch. 17. painos. Göttingen: Vandenhoeck \& Ruprecht.

Blinzler, Joseph

1965 Johannes und die Synoptiker: Ein Forschungsbericht. SBS 6. Stuttgart: Katholisches Bibelwerk.

Boer, Esther de

2000 "Mary Magdalene and the Disciple Jesus Loved." Lectio diffcilior 1/2000. http://www.lectio.unibe.ch/00_1/m-forum.htm\#_ftn 1 .

Boismard, M.-É. \& A. Lamouille (\& G. Rochais)

1977 L'Évangile de Jean. Synopse des quatre évangiles en français 3. Paris: Cerf.

Borg, Marcus

1986 "A Temperate Case for a Non-Eschatological Jesus." Forum 2/3, 81-102.

1992 "Jesus: The Teaching of Jesus Christ." The Anchor Bible Dictionary 3.804812.

Borgen, Peder

1958/59 "John and the Synoptics in the Passion Narrative." NTS 5, 246-259.

Bornkamm, Günther

1983 Jesus von Nazareth. 13. Painos. Urban-Taschenbücher 19. Stuttgart: Kohlhammer.

Boyarin, Daniel

1999 Dying for God: Martyrdom and the Making of Christianity and Judaism. Stanford, CA: Stanford University Press.

Brandenburg, Egon

1984 Markus 13 und die Apokalyptik. Forschungen zur Religion und Literatur des Alten und Neuen Testaments 134. Göttingen: Vandenhoeck \& Ruprecht. 
Brakke, David

2011 "Scriptural Practices in Early Christianity: Towards a New History of the New Testament Canon." Sivut 263-280 kirjassa Invention, Rewriting, Usurpation: Discursive Fights over Religious Traditions in Antiquity. Toim. Jörg Ulrich, Anders-Christian Jacobsen \& David Brakke. Early Christianity in the Context of Antiquity 11. Frankfurt am Main: Lang.

Brodie, Thomas L.

1993 The Quest for the Origin of John's Gospel: A Source-Oriented Approach. Oxford: Oxford University Press.

Brown, Dan

2004 Da Vinci-koodi. Suom. Pirkko Biström. Helsinki: WSOY.

Brown, Raymond E.

1966-70 The Gospel According to John: Introduction, Translation, and Notes. Anchor Bible. 2 osaa. Garden City, New York: Doubleday.

1975 "Roles of Women in the Fourth Gospel." Theological Studies 36, 688-699. Julkaistu myös kirjassa The Community of the Beloved Disciple. Appendix II, 183-198. New York, New York 1979 (siteerattu tämän mukaan).

Brutscheck, Jutta

1986 Die Maria-Marta-Erzählung: Eine redaktionskritische Untersuchung zu Luuk. 10, 38-42. BBB 64. Frankfurt: Hanstein.

Buch-Hansen, Gitte

2010 "It Is the Spirit that Gives Life": A Stoic Understanding of Pneuma in John's Gospel. BZNW 173. Berlin: de Gruyter.

Buell, Denise Kimber

2005 Why This New Race: Ethnic Reasoning in Early Christianity. New York: Columbia University Press.

Bultmann, Rudolf

1970 Die Geschichte der synoptischen Tradition. 8. painos. Göttingen: Vandenhoeck \& Ruprecht.

1986 Das Evangelium des Johannes. KEK 2. 21. painos. Göttingen: Vandenhoeck \& Ruprecht.

Burkert, Walter

1995 Greek Religion. Käänt. J. Raffan. Cambridge, MS: Harvard University Press.

Busse, Ulrich

1992 "Johannes und Lukas: Die Lazarusperikope Frucht eines Kommunikationsprozesses." Sivut 281-306 kirjassa Denaux (toim.) 1992.

Böcher, O.

1992 "geenna: Gehenna, Hölle." Exegetisches Wörterbuch zum Neuen Testament $1.574-575$. 
Carlson, Stephen C.

2005 The Gospel Hoax: Morton Smith's Invention of Secret Mark. Waco, Texas: Baylor University Press.

Carroll, Robert P.

1986 Jeremiah: A Commentary. Old Testament Library. London: SCM.

Cartlidge, David R.

1990 "Combien d'unités avez-vous de trois à quatre? What Do We Mean by Intertextuality in Early Church Studies." SBLSPS 29, 400-411.

Casey, Robert P. (toim.)

1934 The Excerpta ex Theodoto of Clement Alexandria. London: Christophers.

Cavallin, H. C. C.

1974 Life After Death: Paul's Argument for the Resurrection of the Death in 1 Cor 15, Part 1: An Enquiry into the Jewish Background. CBNT Series 7:1. Lund: Gleerup.

Collins, John J.

1978 "The Root of Immortality: Death in the Context of Jewish Wisdom." HTR 71, 177-192.

1992 "Apocalypticism: Early Jewish Apocalypticism." The Anchor Bible Dictionary 1, 282-288.

1997 Apocalypticism in the Dead Sea Scrolls. London/New York: Routledge.

Collins, John N.

1974 "Georgi's 'Envoys' in 2 Cor 11:23.” JBL 93: 88-96.

1990 Diakonia: Re-interpreting the Ancient Sources. Oxford: Oxford University Press.

Conzelmann, Hans \& Andreas Lindemann

1987 Grundriß der Theologie des Neuen Testaments. 4. painos. Tübingen: Mohr.

Copenhaver, Brian P. (käänt.)

1992 Hermetica: The Greek Corpus Hermeticum and the Latin Asclepius in a New English Translation, with Notes and Introduction. Cambridge: Cambridge University Press (paperback 1995).

Cover, Robin C.

1992 "Sin, Sinners (Old Testament)." Anchor Bible Dictionary 6.31-40.

Crossan, John D.

1991 The Historical Jesus: The Life of a Mediterranean Peasant. Edinburgh: T \& T Clark.

Culianu, Ioan P.

1984 "The Gnostic Revenge: Gnosticism and Romantic Literature." Sivut 290306 kirjassa Religionstheorie und politische Theologie, osa 2: Gnosis und Politik. Toim. J. Taubes. München: Fink. 
Czachesz, István

2010 "Rewriting and Textual Fluidity in Antiquity: Exploring the Socio-Cultural and Psychological Context of Earliest Christian Literacy." Sivut 426-441 kirjassa Myths, Martyrs, and Modernity: Studies in the History of Religions in Honour of Jan N. Bremmer. Toim. J. Dijkstra, J. Kroesen \& Y. Kuiper. Leiden: Brill.

Dauer, Anton

1972 Die Passionsgeschichte im Johannesevangelium: Eine traditionsgeschichtliche und theologische Untersuchung zu Joh. 18,1-19,30. SANT 30. München: Kosel.

1984 Johannes und Lukas: Untersuchungen $z u$ den johanneisch-lukanischen Parallelperikopen Joh. 4,46-54/Lk 7,1-10 - Joh. 12,1-8/Lk 7,36-50; 10,38-42 - Joh. 20,19-29/Lk 24,36-49. FzB 50. Würzburg: Echter.

DeConick, April D.

1996 Seek to See Him: Ascent and Vision Mysticism in the Gospel of Thomas. VigChrSup 33. Leiden: Brill.

Denaux, Adelbert

1992 "Introduction." Sivut xiii-xxii kirjassa Denaux (toim.) 1992.

Denaux, Adelbert (toim.)

1992 John and the Synoptics. BETL 101. Leuven: Peeters.

Desjardins, Michel R.

1990 Sin in Valentinianism. SBLDS 108. Atlanta, GA: Scholars Press.

Dietzel, Stefan

2003 "Zur Entstehung des Diakonats im Urchristentum: Eine Auseinandersetzung mit den Positionen von Wilhelm Brandt, Wolfgang Hermann Beyer und John N. Collins." Sivut 136-170 kirjassa Hermann, Merz \& Schmidt (toim.) 2003.

Dillon, John

1990 The Golden Chain: Studies in the Development of Platonism and Christianity. Hampshire: Variorum.

1996 The Middle Platonists 80 B. C. to A. D. 220. 2. painos. Ithaca, NY: Cornell University Press.

1999 "Monotheism in the Gnostic Tradition." Sivut 60-79 kirjassa Pagan Monotheism in Late Antiquity. Toim. P. Athanassiadi \& M. Frede. Oxford: Clarendon.

Dodd, C. H.

1961 The Parables of Kingdom. London: Collins (orig. 1935).

1963 Historical Tradition in the Fourth Gospel. Cambridge: Cambridge University Press. 
Dunderberg, Ismo

1987 "Lasaruksen kuolleistaherättäminen: Kirjallisuuskriittinen analyysi Jh 11:146:sta." Uuden testamentin eksegetiikan pro gradu -tutkielma. Helsingin yliopiston teologinen tiedekunta.

1992 "Zur Literarkritik von Joh. 12,1-11." Sivut 558-570 kirjassa Denaux (toim.) 1992.

1993 Johannes, synoptikot ja Ockhamin partaveitsi. TAik 98, 102-112.

1994 Johannes und die Synoptiker: Studien zu Joh 1-9. AASF B Diss. 69. Helsinki.

1995 "Uusia näkökulmia Johannes-tutkimuksen perinteisiin ongelmiin." TAik 100, 357-366.

1997a "'Te olette alusta asti kuolemattomia': Näkökulmia Valentinoksen käsitykseen kuolemattomuudesta," TAik 102, 138-149.

1997b "Filippuksen evankeliumi (NHK II, 3): Johdanto, käännös ja selitykset." TAik 102, 299-315.

1997c "Johanneksen evankeliumi." Sivut 270-319 kirjassa Varhaiskristilliset evankeliumit. Toim. Matti Myllykoski \& Arto Järvinen. Helsinki: Yliopistopaino.

1998a "Tunteet ja maailman synty: Valentinolainen myytti Viisaudesta." TAik 103, 387-398.

1998b "Viimeiset tapahtumat ja Jeesuksen sanojen perimätieto." Sivut 11-58 kirjassa Dunderberg et alii, Aikojen taite: Kirkko kolmannen vuosisadan vaihteessa. Helsinki: Kirjapaja.

1999 "Mitä on gnostilaisuus?" TAik 104, 243-253.

2002 "Valentinoksen koulukunta." TAik 107, 568-579.

2003 "Vermittlung statt karitativer Tätigkeit? Überlegungen zu John N. Collins' Interpretation von diakonia." Sivut 171-183 kirjassa Hermann, Merz \& Schmidt 2003.

2005a "Nag Hammadin löytö ja gnostilaisuus." Sivut 11-32 kirjassa Dunderberg \& Marjanen (toim.) 2005.

2005b "Jälkisanat: Dan Brownin Da Vinci -koodi ja Nag Hammadin kirjasto." Sivut 469-476 kirjassa Dunderberg \& Marjanen (toim.) 2005.

2005c "Keskustelua herättävä kirja." Vartija 117, 3-10.

2006 The Beloved Disciple in Conflict?: Revisiting the Gospels of John and Thomas. Oxford: Oxford University Press.

2008 Beyond Gnosticism: Myth, Lifestyle and Society in the School of Valentinus. New York: Columbia University Press.

2013 "Johannine Traditions and Apocryphal Gospels." Sivut 67-93 kirjassa The Apocryphal Gospels within the Context of Early Christian Theology. Toim. Jens Schröter. BETL 260. Leuven: Peeters.

2015 Gnostic Morality Revisited. WUNT 347. Tübingen: Mohr Siebeck. 
Dunderberg, Ismo \& Marjanen, Antti (toim.)

2005 Nag Hammadin kätketty viisaus: Gnostilaisia ja muita varhaiskristillisiä tekstejä. 2., laajennettu painos. Helsinki: WSOY.

Engberg-Pedersen, Troels

2004 "The Concept of Paraenesis." Sivut 47-72 kirjassa Early Christian Paraenesis in Context. Toim. James M. Starr \& Troels Engberg-Pedersen. BZNW 125. Berlin: de Gruyter.

Eskola, Timo

2011 Evil Gods and Reckless Saviors: Adaptation and Appropriation in Late Twentieth Century Jesus-Novels. Iustitia Supplement Series. Helsinki.

Fischer, Ulrich

1978 Eschatologie und Jenseitserwartung im hellenistischen Diasporajudentum. BZNW 44. Berlin: de Gruyter.

Fitzmyer, Joseph A.

1981 The Gospel According to Luke (X-XXIV): Introduction, Translation, and Notes. Anchor Bible. Garden City, New York: Doubleday.

Foerster, Walter

1928 Von Valentin zu Herakleon: Untersuchungen über die Quellen und die Entwicklung der valentinianischen Gnosis. BZNW 7. Gießen: Alfred Töpelmann.

Forschner, Maximilian

1981 Die stoische Ethik: Über den Zusammenhang von Natur-, Sprach- und Moralphilosophie im altstoischen System. Darmstadt: Wissenschaftliche Buchgesellschaft (repr. 1995).

Fortna, Robert T.

1970 The Gospel of Signs: A Reconstruction of the Narrative Source Underlying the Fourth Gospel. MSSNTS 11. Cambridge: Cambridge University Press.

1988 The Fourth Gospel and Its Predecessor: From Narrative Source to Present Gospel. Edinburgh: T \& T Clark.

1992 "Diachronic/Synchronic: Reading John 21 and Luke 5." Sivut 387-399 kirjassa Denaux (toim.) 1992.

Fossum, Jan

1985 The Name of God and the Angel of the Lord: Samaritan and Jewish Concepts of Intermediation and the Origin of Gnosticism. WUNT 36. Tübingen: Mohr.

Foucault, Michel

1992 The Use of Pleasure: The History of Sexuality. Käänt. R. Hurley. London: Penguin.

Fowden, Garth

1986 The Egyptian Hermes: A Historical Approach to the Late Pagan Mind. Princeton, NJ: Princeton University Press. 
Frend, W. H. C.

1965 Martyrdom and Persecution in the Early Church: A Study of a Conflict from the Maccabees to Donatus. Oxford: Blackwell.

Funk, Robert W. \& Robert W. Hoover (toim.)

1993 The Five Gospels: The Search for the Authentic Words of Jesus. New York: Macmillan.

Förster, Niclas

1999 Marcus Magus: Kult, Lehre und Gemeindeleben einer valentinianischen Gnostikergruppe: Sammlung der Quellen und Kommentar. WUNT 114. Tübingen: Mohr Siebeck.

Gardner-Smith, Percival

1938 Saint John and the Synoptic Gospels. Cambridge: Cambridge University Press.

Gemünden, Petra von

1997 "La femme passionelle et l'homme rationnel? Un chapître de psychologie historique." Bibl 78, 457-480.

Georgi, Dieter

1964 Die Gegner des Paulus im 2. Korintherbrief. WMANT 11. Neukirchen: Neukirchener Verlag.

Gnilka, Joachim

1978-79 Das Evangelium nach Markus. 2 osaa. EKK 2. Zürich: Benziger/ Neukirchen-Vluyn: Neukirchener.

Goodenough, E. R.

1946 "Philo on Immortality." HTR 39, 85-108.

Gowan, Andrew

1994 "Eating People: Accusations of Cannibalism against Christians in the Second Century." JECS 2, 413-442.

Gregory, A. F. \& C. M. Tuckett (toim.)

2005 The Reception of the New Testament in the Apostolic Fathers. Oxford: Oxford University Press.

Griffith, Terry

1998 "A Non-Polemical Reading of 1 John: Sin, Christology and the Limits of Johannine Christianity." Tyndale Bulletin 49.2, 253-276.

Gräßer, Erich

1960 Das Problem der Parusieverzögerung in den synoptischen Evangelien und in der Apostelgeschichte. 2. painos. BZNW 22. Berlin: de Gruyter.

Haenchen, Ernst

1965 Gott und Mensch: Gesammelte Aufsätze. Tübingen: Mohr Siebeck.

1980 Das Johannesevangelium: Ein Kommentar aus den nachgelassenen Manuskripten. Toim. Ulrich Busse. Tübingen: Mohr Siebeck. 
Hahn, Horst

2009 Tradition und Neuinterpretation im ersten Johannesbrief. Zürich: Theologischer Verlag.

Hakola, Raimo

2005 Identity Matters: John, the Jews and Jewishness. NovTSup 118. Leiden: Brill. Hall, Stuart G.

1978 "Aloger." Theologische Realenzyklopädie 2, 290-295.

Halme, Lasse

2005 "Naisen asema, uskonto ja seksuaalisuus: Mikä Da Vinci -koodissa kiinnostaa?" Vartija 117, 20-23.

Hendriksen, William

1983 Exposition of the Gospel According to Luke: New Testament Commentary. 3. painos. Grand Rapids, Michigan.

Hengel, Martin

1990 The Johannine Question. Käänt. John Bowden. London: SCM.

1993 Die johanneische Frage: Ein Lösungsversuch. WUNT 67. Tübingen: Mohr Siebeck.

Hermann, Volker, Rainer Merz \& Heinz Schmidt (toim.)

2003 Diakonische Konturen: Theologie im Kontext Sozialer Arbeit. Veröffentlichungen des Diakoniewissenschaftlichen Instituts 18. Heidelberg: Universitätsverlag Winter.

Hill, Charles E.

2004 The Johannine Corpus in the Early Church. Oxford: Oxford University Press.

Holopainen, Taina M.

1991 William Ockham's Theory of the Foundations of Ethics. Publications of Luther-Agricola-Society B 20. Helsinki: Luther-Agricola-Society.

Holtz, Traugott

1986 Der erste Brief an die Thessalonicher. EKK 13. Zürich: Benzinger/ Neukirchen-Vluyn: Neukirchener.

Holzhausen, Jens

1994 "Gnosis und Martyrium: Zu Valentins viertem Fragment." ZNW 85, 116131.

Horst, P. W. van der

1994 "Jewish Poetical Tomb Inscriptions." Sivut 129-147 kirjassa Studies in Early Jewish Epigraphy. Toim. J. W. van Henten \& P. W. van der Horst. AGJU 21. Leiden: Brill.

Huuhtanen, Pauli

1989 Jerusalem ja Rooma. Helsinki: Kirjapaja. 
Huuhtanen, Pauli, Antti Marjanen \& Risto Uro (toim., suom.)

1994 Jeesuksen salaiset sanat: Tuomaan evankeliumi. 2. painos. Helsinki: Yliopistopaino.

Jervell, Jakob

1983 "Die Töchter Abrahams: Die Frau in der Apostelgeschichte." Sivut 77-93 kirjassa Glaube und Gerechtigkeit. Toim. Jarmo Kiilunen, Vilho Riekkinen \& Heikki Räisänen. SESJ 38. Helsinki: Suomen Eksegeettinen Seura.

Juntunen, Viljo

1997 "Jumalasta syntynyt ei tee syntiä:" Kristitty ja synti 1. Johanneksen kirjeessä. SESJ 68. Helsinki: Suomen Eksegeettinen Seura.

Järveläinen, Petri

2000 A Study on Religious Emotions. SLAG 47. Helsinki: Luther-Agricola Society. Kelber, Walter $\mathrm{H}$.

1983 The Oral and the Written Gospel: The Hermeneutics of Speaking and Writing in the Synoptic Tradition, Mark, Paul and Q. Philadelphia: Fortress.

Kieffer, René

1992 "Jean et Marc: convergences dans la structure et dans les détails." Sivut 109-125 kirjassa Denaux (toim.) 1992.

Kiilunen, Jarmo

1992 "Sanoma kääntymyksestä - Luukkaan toimintaohjelma kirkolle." Sivut 103-124 kirjassa Aimo annos eksegetiikkaa: Piispa Aimo T. Nikolaisen jublakirja. Toim. Lars Aejmelaeus. Helsinki: Kirjapaja.

King, Karen L.

1987 "Kingdom in the Gospel of Thomas." Foundations and Facets Forum 3.1, 48-97.

1995 Revelation of the Unknowable God with Text, Translation, and Notes to NHC XI,3 Allogenes. Santa Rosa, California: Poleridge.

2003a The Gospel of Mary of Magdala: Jesus and the First Woman Apostle. Santa Rosa, CA: Polebridge Press.

2003b What is Gnosticism? Cambridge, MS: Harvard University Press.

Kloppenborg, John S.

1987a The Formation of Q: Trajectories in Ancient Wisdom Collections. Studies in Antiquity and Christianity. Philadelphia: Fortress.

1987b "Symbolic Eschatology and the Apocalypticism of Q." HTR 80, 287-306.

Knust, Jennifer Wright

2006 Abandoned to Lust: Sexual Slander and Ancient Christianity. New York: Columbia University Press.

Knuuttila, Simo

1982 "Esittelyjä ja selityksiä: Timaios." Platon, Teokset, osa 5: Sofisti, Valtiomies, Timaios, Kritias, Filebos. Suom. M. Itkonen-Kaila, A. M. Anttila \& Marianna Tyni. Helsinki: Otava, 363-381. 
2004 Emotions in Ancient and Medieval Philosophy. Oxford: Oxford University Press.

Koch, Dieter-Alex

1992 ”Der Täufer als Zeuge des Offenbarers: Das Täuferbild von Joh. 1,19-34 auf dem Hintergrund von Mk 1,2-11." Sivut 1963-1984 kirjassa The Four Gospels 1992. Toim. F. Van Segbroeck, C. M. Tuckett, G. Van Belle \& J. Verheyden. BETL 100. 3 osaa. Leuven: Peeters.

Kolarcik, Michael

1991 The Ambiguity of Death in the Book of Wisdom 1-6: A Study of Literary Structure and Interpretation. AnBib 127. Roma: Pontificio Istituto Biblico.

Konings, J.

1988 "The Pre-Markan Sequence in Jn., VI: A Critical Re-Examination." Sivut 147-178 kirjassa L'Évangile selon Marc: Tradition et rédaction. Toim. Maurits Sabbe. 2. painos. BETL 34. Leuven: Peeters.

Koschorke, Klaus

1981 "Patristische Materialien zur Spätgeschichte der valentinianischen Gnosis." Sivut 120-139 kirjassa Gnosis and Gnosticism. Toim. Martin Krause. NHS 17. Leiden: Brill.

Kotila, Markku

1988 "Aika tulee ja on jo: Eskatologinen tuomio Johanneksen evankeliumissa." Sivut 83-93 kirjassa Lopun ajat eilen ja tänään. Toim. Risto Saarinen \& Risto Uro. Kirkon tutkimuskeskus A 48. Pieksämäki: Kirkon tutkimuskeskus.

Kümmel, Werner G.

1965a "Die Anfänge der christlichen Theologie." Sivut 2.82-104 kirjassa Exegetische Versuche und Besinnungen. 2. painos. Göttingen: Vandenhoeck \& Ruprecht.

1965b "Zum Thema der urchristlichen Apokalyptik." Sivut 2.105-131 kirjassa Exegetische Versuche und Besinnungen. 2. painos. Göttingen: Vandenhoeck \& Ruprecht.

1983 Einleitung in das Neue Testament. Heidelberg: Quelle \& Meyer.

Lampe, G. W. H. (toim.)

1961 A Patristic Greek Lexicon. Oxford: Clarendon Press (repr. 1991).

Lampe, Peter

1989 Die stadtrömischen Christen in den ersten beiden Jahrhunderten: Untersuchungen zur Sozialgeschichte. 2. painos. WUNT 2/18. Tübingen: Mohr Siebeck.

Lane, William L.

1986 "Social Perspectives on Roman Christianity during the Formative Years from Nero to Nerva: Romans, Hebrews, 1 Clement." Sivut 196-244 kirjassa Judaism and Christianity in First-Century Rome. Toim. K. P. Donfried \& P. Richardson. Grand Rapids, Michigan: Eerdmans. 
Lane Fox, Robin

1986 Pagans and Christians. London: Penguin.

Lauha, Risto

1987a "Klemens Aleksandrialaisen kirje ja Markuksen salainen evankeliumi." TAik 92, 205-210.

1987b "Markuksen salaisen evankeliumin suhde kanonisiin evankeliumeihin." TAik 92, 401-408.

Layton, Bentley

1987 The Gnostic Scriptures: A New Translation with Annotations and Introductions. New York: Doubleday.

1995 "Prolegomena to the Study of Ancient Gnosticism." Sivut 334-350 kirjassa The Social World of the First Christians: Essays in Honor of Wayne A. Meeks. Toim. L. M. White \& O. L. Yarbrough. Minneapolis MN: Fortress.

Lehtipuu, Outi

2015 "I Have Not Yet Ascended to the Father': On Resurrection, Bodies, and Resurrection Bodies." Kirjassa Noli me tangere in Interdisciplinary Perspective: Textual, Iconographic and Contemporary Interpretations. Toim. R. Bieringer, B. Baert \& K. Demasure. BETL. Leuven: Peeters. (painossa)

Lewis, Theodore J.

1992 "Death, Abode of the." The Anchor Bible Dictionary 2.101-105.

Lieu, Judith M.

2008 I, II, \& III John: A Commentary. The New Testament Library. Louisville: Westminster John Knox Press.

Logan, Alastair H. B.

1996 Gnostic Truth and Christian Heresy: A Study in the History of Gnosticism. Edinburgh: T \& T Clark.

Lührmann, Dieter

1987 Das Markusevangelium. HNT 3. Tübingen: Mohr Siebeck.

Luz, Ulrich

1990 Das Evangelium nach Matthäus, osa 2: Mt 8-17. Evangelisch-katholischer Kommentar zum Neuen Testament I/2. Zürich: Benzinger/NeukirchenVluyn: Neukirchener.

1997 Das Evangelium nach Matthäus, osa 3: Mt 18-25. Zürich: Benzinger/ Neukirchen-Vluyn: Neukirchener.

Löhr, Winrich A.

1993 "Epiphanes' Schrift Peri dikaiosynēs (= Clemens Alexandrinus, Str. III,1,6,1-9,3)." Sivut 12-29 kirjassa Logos: Festschrift für Luise Abramowski. Toim. Hanns Christof Beinecke, Enrst Ludwig Grasmück \& Christoph Markschies. BZNW 67. Berlin: de Gruyter.

1995 Basilides und seine Schule. WUNT 83. Tübingen: Mohr Siebeck. 
Mack, Burton

1973 Logos und Sophia: Untersuchungen zur Weisheitstheologie im hellenistischen Judentum. SUNT 10. Göttingen: Vandenhoeck \& Ruprecht.

1987 "The Kingdom Sayings in Mark." Forum 3, 3-47.

1993 The Lost Gospel: The Book of $Q$ and Christian Origins. San Fransisco: Harper.

MacRae, George W.

1970 "The Jewish Background of the Gnostic Sophia Myth." NovT 12, 86-101. Marjanen, Antti

1991 "Maailman synnystä gnostilaisuudessa: Luomismyytti Johanneksen apokryfin mukaan." TAik 96, 426-432.

1996 The Woman Jesus Loved: Mary Magdalene in the Nag Hammadi and Related Documents. Nag Hammadi and Manichean Studies 40. Leiden: Brill.

1997 "Nag Hammadin tekstilöytö ja Uuden testamentin tutkimus." Sivut 136153 kirjassa Raamatuntutkimuksen undet tuulet. Toim. Raimo Hakola \& Petri Merenlahti. Helsinki: Yliopistopaino.

2002 "The Mother of Jesus or the Magdalene? The Identity of Mary in the socalled Gnostic Christian Texts." Sivut 31-42 kirjassa Which Mary? The Marys of Early Christian Tradition. Toim. F. Stanley Jones. SBL Symposium Series, 19. Atlanta: Society of Biblical Literature.

2005 "Marian evankeliumi (BG 7.1-19.5): Johdanto, käännös ja selitykset." Sivut 435-442 kirjassa Dunderberg \& Marjanen (toim.) 2005.

Markschies, Christoph

1992 Valentinus Gnosticus? Untersuchungen zur valentinianischen Gnosis mit einem Kommentar zu den Fragmenten Valentin. WUNT 65. Tübingen: Mohr Siebeck.

1997 "Valentinian Gnosticism: Toward the Anatomy of a School." Sivut 401438 kirjassa The Nag Hammadi Library After Fifty Years. Toim. John D. Turner \& Anne McGuire. NHMS 44. Leiden: Brill.

Martin, Dale B.

1995 The Corinthian Body. New Haven, CT: Yale University Press.

2006 "Sex and the Single Savior." Sivut 393-410 kirjassa Sacred Marriages: The Divine-Human Sexual Metaphor from Sumer to Early Christianity. Toim. Martti Nissinen \& Risto Uro. Winona Lake: Eisenbrauns.

May, Gerhard

1994 Creatio ex Nibilo: The Doctrine of "Creation out of Nothing" in Early Christian Thought. Käänt. A. S. Worrall. Edinburgh: T \&T Clark.

Meeks, Wayne A.

1983 "Social Functions of Apocalyptic Language in Pauline Christianity." Sivut 687-705 kirjassa Apocalypticism in the Mediterranean Writings and the Near East. Toim. David Hellholm. Tübingen: Mohr. 
Menard, J.-É.

1975 L'évangile selon Thomas. NHS 5. Leiden: Brill.

Merkel, Helmut

1971 Die Widersprüche zwischen den Evangelien: Ihre polemische und apologetische Behandlung in der Alten Kirche bis zu Augustin. WUNT 13. Tübingen: Mohr Siebeck.

Meyer, Marvin (toim.)

1987 The Ancient Mysteries: A Sourcebook, Sacred Texts of the Mystery Religions of the Ancient Mediterranean World. San Francisco: HarperCollins.

Musurillo, Herbert (toim.)

1972 The Acts of the Christian Martyrs. Oxford: Clarendon Press.

Myllykoski, Matti

1987 ”Jeesus ja Ihmisen Poika - ikuinen arvoitus?” TAik 92, 498-502.

1991 Die letzten Tage Jesu I: Markus und Johannes, ihre Traditionen und die historische Frage. AASF B 256. Helsinki: Suomalainen Tiedeakatemia.

1991b "The Material Common to Luke and John: A Sketch." Sivut 116-156 kirjassa Luke-Acts: Scandinavian Perspectives. Toim. Petri Luomanen. SESJ 54. Helsinki: Suomen Eksegeettinen Seura.

2002 "Kerinthos." TAik 107, 521-533.

2005a "Cerinthus." Sivut 213-246 kirjassa A Companion to Second-Century Christian "Heretics." Toim. Antti Marjanen \& Petri Luomanen. VigChrSup 76. Leiden: Brill.

2005b "Salaliittoteoriat." Vartija 117, 1-2.

Nagel, Titus

2000 Die Rezeption des Johannesevangeliums im 2. Jahrhundert: Studien zu vorirenäischen Aneignung und Auslegung des vierten Evangeliums in christlicher und christlich-gnostischer Literature. ABG 2. Berlin: Evangelische Verlagsanstalt.

Neirynck, Frans

1982 Evangelica: Gospel Studies - Études d'évangile. BETL 60. Leuven: Peeters.

1991 Evangelica II: 1982-1991: Collected Essays. Toim. F. van Segbroeck. BETL 99. Leuven: Peeters.

1992 "John and the Synoptics: 1975-1990." Sivut 3-62 kirjassa Denaux (toim.) 1992.

Nickelsburg, George W. E.

1972 Resurrection, Immortality and Eternal Life in Intertestamental Judaism. HTS 26. Cambridge, Mass.: Harvard University Press.

Nikolainen, Aimo T.

1980 Luukkaan evankeliumi. Suomalainen Uuden testamentin selitys 3. 3. painos. Helsinki: Kirjapaja. 
Nussbaum, Martha

1994 The Therapy of Desire: Theory and Practice in Hellenistic Ethics. Princeton: Princeton University Press.

Oepke, Albrecht

1933 "gynē." Theologisches Wörterbuch zum Neuen Testament 1, 776-790.

Pagels, Elaine

1990 "Introduction: NHC XI,2: A Valentinian Exposition 22,1-39,39." Sivut 89-105 kirjassa Nag Hammadi Codices XI, XII, XIII. Toim. Charles W. Hedrick. NHS 28. Leiden: Brill.

2003 Beyond Belief: The Secret Gospel of Thomas. New York: Random House.

Parpola, Simo

1997 Assyrian Prophecies. Helsinki: Helsinki University Press.

Parrott, Douglas M.

1987 "Gnosticism and Egyptian Religion." NovT 29, 73-93.

Pearson, Birger A.

1990 Gnosticism, Judaism, and Egyptian Christianity. Minneapolis, MN: Fortress.

Perkins, Pheme

1976 "Ireneus and the Gnostics: Rhetoric and Composition in Adversus haereses Book One." VigChr 30, 193-200.

Petersen, Silke

1999 "Zerstört die Werke der Weiblichkeit:" Maria Magdalena, Salome \& andere Jüngerinnen Jesu in christlich-gnostischen Schriften. NHMS 48. Leiden: Brill.

Pétrement, Simone

1990 A Separate God: The Origins and Teachings of Gnosticism. Käänt. Carol Harrison. San Francisco: HarperSanFrancisco.

Quispel, Gilles

1996 "Valentinus and the Gnostikoi." VigChr 50, 1-4.

Rasimus, Tuomas (toim.)

2010 The Legacy of John: Second-Century Reception of the Fourth Gospel. NovTSupp 132. Leiden: Brill.

Reim, Günther

1974 Studien zum altentestamentlichen Hintergrund des Johannesevangeliums. MSSNTS 22. Cambridge: Cambridge University Press.

Remus, Harold

2002 "Persecution." Sivut 431-452 kirjassa Handbook of Early Christianity: Social Science Approaches. Toim. Anthony J. Blasi, Jean Duhaime \& P.-A. Turcotte. Walnut Creek, CA: Altamira Press.

Riley, Gregory J.

1995 Resurrection Reconsidered: Thomas and John in Controversy. Minneapolis, $\mathrm{MN}$ : Fortress. 
1996 "Introduction to VII, 2: Second Treatise of the Great Seth." Sivut 129-144 kirjassa Nag Hammadi Codex VII. Toim. Birger A. Pearson. NHMS 30. Leiden: Brill.

Rochais, Gérard

1981 Les récits de résurrection des morts dans le Nouveau Testament. MSSNTS 40. Cambridge: Cambridge University Press.

Roukema, Riemer

1999 Gnosis and Faith in Early Christianity: An Introduction to Gnosticism. Käänt. John Bowden. London: SCM Press.

Rudolph, Kurt

1996 Gnosis und Spätantike Religionsgeschichte: Gesammelte Aufsätze. NHMS 42. Leiden: Brill.

Räisänen, Heikki

1983 Paul and the Law. Philadelphia: Fortress [repr. 1987]

1992 "Nikolaiitat: Kahden kulttuurikäsityksen yhteentörmäys Ilmestyskirjassa." Sivut 239-256 kirjassa Aimo annos eksegetiikkaa: Piispa Aimo T. Nikolaisen jublakirja. Toim. Lars Aejmelaeus. Helsinki: Kirjapaja.

1994 "Jesus in Context: E. P. Sanders' The Historical Figure of Jesus." Reviews in Religion and Theology 1994/2, 9-18.

1996 "Exorcisms and the Kingdom: Is Q 11:20 a Saying of the Historical Jesus?" Sivut 119-142 kirjassa Symbols and Strata: Essays on the Sayings Gospel Q. Toim. Risto Uro. SESJ 65. Helsinki: Suomen Eksegeettinen Seura.

1997 "Jeesus-tutkimuksen kaksi vuosisataa." Sivut 8-27 kirjassa Uro \& Lehtipuu (toim.) 1997.

2001 Challenges to Biblical Interpretation: Collected Essays 1991-2001. BibIntSup 59. Leiden: Brill.

2011 Mitä varhaiset kristityt uskoivat? Helsinki: WSOY.

Sabbe, Maurits

1977 "The Arrest of Jesus and Its Relation to the Synoptic Gospels: A Critical Evaluation of A. Dauers Hypothesis." Sivut 203-234 kirjassa L'Évangile de Jean: Sources, redaction, théologie. Toim. Marinus de Jonge. BETL 44. Leuven: Peeters.

1992 "The Trial of Jesus before Pilate in John and Its Relation to the Synoptic Gospels." Sivut 341-385 kirjassa Denaux (toim.) 1992.

Sagnard, F.

1947 La gnose valentinienne et le témoignane de Saint Irénée. Études de Philosophie Médiévale 36. Paris: J. Vrin.

Salmesvuori, Päivi

2005 "Magdalan Marian arvoitus." Vartija 117, 11-19. 
Sandelin, Karl-Gustav

1986 Wisdom as Nourisher: A Study of an Old Testament Theme, Its Development within Early Judaism and Its Impact on Early Christianity. Acta Academicae Aboensis A 64/3. Åbo: Åbo Akademi.

Sanders, E. P.

1985 Jesus and Judaism. London: SCM.

1992 Judaism: Practice and Belief 63 BCE-66 CE. London: SCM.

1993 The Historical Figure of Jesus. London: Penguin Books.

Sanders, E. P. \& Margaret Davies

1989 Studying the Synoptic Gospels. London: SCM Press.

Schenke, Hans-Martin

1981 "The Phenomenon and Significance of Gnostic Sethianism." Sivut 2.588616 kirjassa The Rediscovery of Gnosticism. Toim. Bentley Layton. NumenSup 41. Leiden: Brill.

Schmid, Hansjörg

2002 Gegner im 1. Johannesbrief: Zu Konstruktion und Selbstreferenz im johanneischen Sinnsystem. BWANT 159. Stuttgart: Kohlhammer.

Schnackenburg, Rudolf

1981-84 Das Johannesevangelium. HThK 4. Freiburg: Herder.

Schneiders, Sandra M.

1987 "Death in the Community of Eternal Life: History, Theology, and Spirituality in John 11." Interpretation 41, 44-56.

Schniewind, Julius

1914 Die Parallelperikopen bei Lukas und Johannes. Leipzig: Brandstetter (repr. 1958: Hildesheim).

Scholten, Clemens

1987 Martyrium und Sophiamythos im Gnostizismus nach den Texten von Nag Hammadi. JAC, Ergänzungsband 14. Münster: Aschendorffsche Verlagsbuchhandlung.

Schüngel, Paul

1996 "Gnostische kontra neutestamentliche Soteriologie: $\mathrm{Zu}$ Valentins viertem Fragment." VigChr 50, 257-265.

Schwartz, Eduard

1907-8 "Aporien im vierten Evangelium 1-4." NGWG.PH 1907, 342-372; 1908, 115-148, 149-188, 497-567.

Seim, Turid Karlsen

1987 "Roles of Women in the Gospel of John." Sivut 56-73 kirjassa Aspects on the Johannine Literature. Toim. Lars Hartman \& Birger Olsson. CB New Testament Series 18. Uppsala. 
Sihvola, Juha

1994 Hyvän elämän politiikka: Näkökulmia Aristoteleen poliittiseen filosofiaan. Helsinki: Tutkijaliitto.

Silvola, Kalevi

1987 "Vain yksikö on tarpeen? Luuk. 10:42a:n tekstin tarkastelua." TAik 92, 235-238.

1989 Nardusvoide ja suudelma: Traditio- ja redaktiohistoriallinen tutkimus evankeliumien voitelukertomuksista. SESJ 50. Helsinki: Suomen Eksegeettinen Seura.

Smith, D. Moody

1987 Johannine Christianity: Essays on its Setting, Sources, and Theology. Edinburgh: T \& T Clark.

1992 John among the Gospels: The Relationship in Twentieth-Century Research. Minneapolis: Fortress.

Smith, Morton

1973a Clement of Alexandria and a Secret Gospel of Mark. Cambridge: Harvard University Press.

1973b The Secret Gospel: The Discovery and Interpretation of the Secret Gospel According to Mark. New York: Harper \& Row.

Smith, Richard

1988 "Afterword: The Modern Relevance of Gnosticism." Sivut 532-549 kirjassa The Nag Hammadi Library in English. Toim. James A. Robinson. 3. painos. Leiden: Brill.

Snyder, Gregory H.

2000 Teachers and Texts in the Ancient World: Philosophers, Jews and Christians. London: Routledge.

Sollamo, Raija

1992 "Naiseksi personoitu viisaus Sananlaskujen kirjassa." Sivut 7-22 kirjassa Naisia Raamatussa: Viisaus ja rakkaus. Toim. Raija Sollamo \& Ismo Dunderberg. Helsinki: Yliopistopaino.

Sordi, Martha

1983 The Christians and the Roman Empire. Käänt. A. Bedini. London: Groom Helm.

Spitta, Friedrich

1910 Das Johannes-Evangelium als Quelle der Geschichte Jesu. Göttingen: Vandenhoeck \& Ruprecht.

Stark, Rodney

1997 The Rise of Christianity. San Francisco: HarperSanFrancisco.

Starnitzke, Dierk

2003 "Die Bedeutung von diakonos im frühen Christentum." Sivut 184-212 kirjassa Hermann, Merz \& Schmidt (toim.) 2003. 
Stead, C. G.

1969 "The Valentinian Myth of Sophia." JTS 20, 75-104.

Streett, Daniel C.

2011 They Went Out From Us: The Identity of the Opponents in First John. BZNW 177. Berlin: de Gruyter.

Strutwolf, Holger

1993 Gnosis als System: Zur Rezeption der valentinianischen Gnosis bei Origenes. FKDG 56. Göttingen: Vandenhoeck \& Ruprecht.

Syreeni, Kari

1995 Uusi testamentti ja hermeneutiikka: Tulkinnan fragmentteja. SESJ 61. Helsinki: Suomen Eksegeettinen Seura.

Talbert, Charles H.

2005 Reading John: A Literary and Theological Commentary on the Fourth Gospel and the Johannine Epistles. Uudistettu laitos. Macon, GA: Smyth \& Helwys.

Taylor, Vincent

1952 The Gospel According to St. Mark: The Greek Text with Introduction, Notes, and Indexes. London: Macmillan.

Thesleff, Holger

1989 Platon. Helsinki: Otava.

Thompson, Leonard

1990 The Book of Revelation: Apocalypse and Empire. Oxford: Oxford University Press.

Thyen, Hartwig

1988 "Johannesevangelium." Theologische Realenzyklopädie 17, 200-225.

1992a "Die Erzählung von den bethanischen Geschwistern (Joh. 11,1-12,19) als 'Palimpsest' über synoptischen Texten." Sivut 2021-2050 kirjassa The Four Gospels 1992. Toim. F. Van Segbroeck, C. M. Tuckett, G. Van Belle \& J. Verheyden. 3 osaa. BETL 100. Leuven: Peeters.

1992b ”ohannes und die Synoptiker: Auf der Suche nach einem neuen Paradigma zur Beschreibung ihrer Beziehungen anhand von Beobachtungen an Passions- und Ostererzählungen.” Sivut 81-107 kirjassa Denaux (toim.) 1992.

Tilborg, Sjef van

1993 Imaginative Love in John. Biblical Interpretation Series 2. Leiden: Brill.

Trigg, Joseph W.

1998 Origen. The Early Church Fathers. London: Routledge.

Trumbower, Jeffrey A.

1992 Born from Above: The Antropology of the Gospel of John. HUT 29. Tübingen: Mohr Siebeck. 
Tuckett, Christopher

2007 The Gospel of Mary. Oxford Early Christian Gospel Texts. Oxford: Oxford University Press.

Uro, Risto

1988 "Alkukristillisyys apokalyptisenä liikkeenä." Sivut 29-46 kirjassa Lopun ajat eilen ja tänään. Toim. Risto Saarinen \& Risto Uro. Kirkon tutkimuskeskus A 48. Tampere: Kirkon tutkimuskeskus.

1993 Jeesus-liikkeestä kristinuskoksi. Helsinki: Yliopistopaino.

1996 "Apocalyptic Symbolism and Social Identity in Q." Sivut 67-118 kirjassa Symbols and Strata: Essays on the Sayings Gospel Q. Toim. Risto Uro. SESJ 65. Helsinki: Suomen Eksegeettinen Seura.

1997 "Johannes Kastaja ja Jeesus-liike." Sivut 106-145 kirjassa Uro \& Lehtipuu (toim.) 1997.

1998a "Puhtaus ja saastaisuus Uuden testamentin maailmassa." TAik 103, 399407.

1998b "Thomas and Oral Gospel Tradition." Sivut 8-32 kirjassa Uro (toim.) 1998.

1998c "Is Thomas an Encratite Gospel?" Sivut 140-182 kirjassa Uro (toim.) 1998.

Uro, Risto (toim.)

1998 Thomas at the Crossroads: Essays on the Gospel of Thomas. Edinburgh: T \& T Clark.

Uro Risto \& Outi Lehtipuu (toim.)

1997 Nasaretilaisen historia. Helsinki: Kirjapaja.

Valantasis, Richard

1991 Spiritual Guides of the Third Century: A Semiotic Study of the Guide-Disciple Relationship in Christianity, Neoplatonism, Hermetism, and Gnosticism. HDR 27. Minneapolis, MN: Fortress.

Van Seters, John

1975 Abraham in History and Tradition. New Haven/London: Yale University Press.

Wedderburn, A. J. M.

1987 Baptism and Resurrection: Studies in Pauline Theology against Its GraecoRoman Background. WUNT 44. Tübingen: Mohr Siebeck.

Veijola, Timo

1988 Dekalogi: Raamatullisen etiikan perusteita. SESJ 49. Helsinki: Suomen Eksegeettinen Seura.

Wellhausen, Julius

1908 Das Evangelium des Johannis. Berlin: Reimer.

Verheyden, Josef

1992 "P. Gardner-Smith and 'The Turn of the Tide."' Sivut 423-452 kirjassa Denaux (toim.) 1992. 
Westbrook, Raymond

1992 "Punishments and Crimes." Anchor Bible Dictionary 5, 546-556.

Vermes, Geza \& Martin D. Goodman (toim.)

1989 The Essenes According to Classical Sources. Sheffield: JSOT Press.

Wewers, G. A.

1975 Geheimnis und Geheimhaltung im rabbinischen Judentum. RVV 35. Berlin: de Gruyter.

Williams, Michael

1996 Rethinking "Gnosticism": An Argument for Dismantling a Dubious Category. Princeton: Princeton University Press.

Windisch, Hans

1926 Johannes und die Synoptiker: Wollte der vierte Evangelist die älteren Evangelien ergänzen oder ersetzen? UNT 12. Leipzig: Hinrichs.

Winston, David

1979 The Wisdom of Solomon: A New Translation with Introduction and Commentary. AncB 43. New York: Doubleday 1979.

Wißmann, Hans

1982 "Eschatologie, I: Religionsgeschichtlich." Theologische Realenzyklopädie 10, 254-256.

Witherington, Ben

1984 Women in the Ministry of Jesus: A Study of Jesus' Attitudes to Women and Their Roles as Reflected in His Earthly Life. MSSNTS 51. Cambridge: Cambridge University Press.

Vouga, François

1992 "Le quatrième évangile comme interprète de la tradition synoptique: Jean 6." Sivut 261-279 kirjassa Denaux (toim.) 1992.

Wright, N. T.

1992 "Quest for the Historical Jesus." Anchor Bible Dictionary 3, 796-802.

Wucherpfennig, Ansgar

2002 Heracleon Philologus: Gnostische Johannesexegese im zweiten Jahrhundert. WUNT 142. Tübingen: Mohr Siebeck.

Würthwein, Ernst

1984 Die Bücher der Könige: 1. Kön. 17-2. Kön. 25. ATD 11, 2. Göttingen: Vandenhoeck \& Ruprecht.

Völker, Walter (toim.)

1932 Quellen zur Geschichte der christlichen Gnosis. SAKDQ 5. Tübingen: Mohr. Yarbro Collins, Adela

1996 Cosmology and Eschatology in Jewish and Christian Apocalypticism. Leiden: Brill. 


\section{Zager, Werner}

1996 Gottesherrschaft und Endgericht in der Verkündigung Jesu: Eine Untersuchung zur markinischen Jesusüberlieferung einschließlich der Q-Parallelen. BZNW 82. Berlin: de Guyter. 